


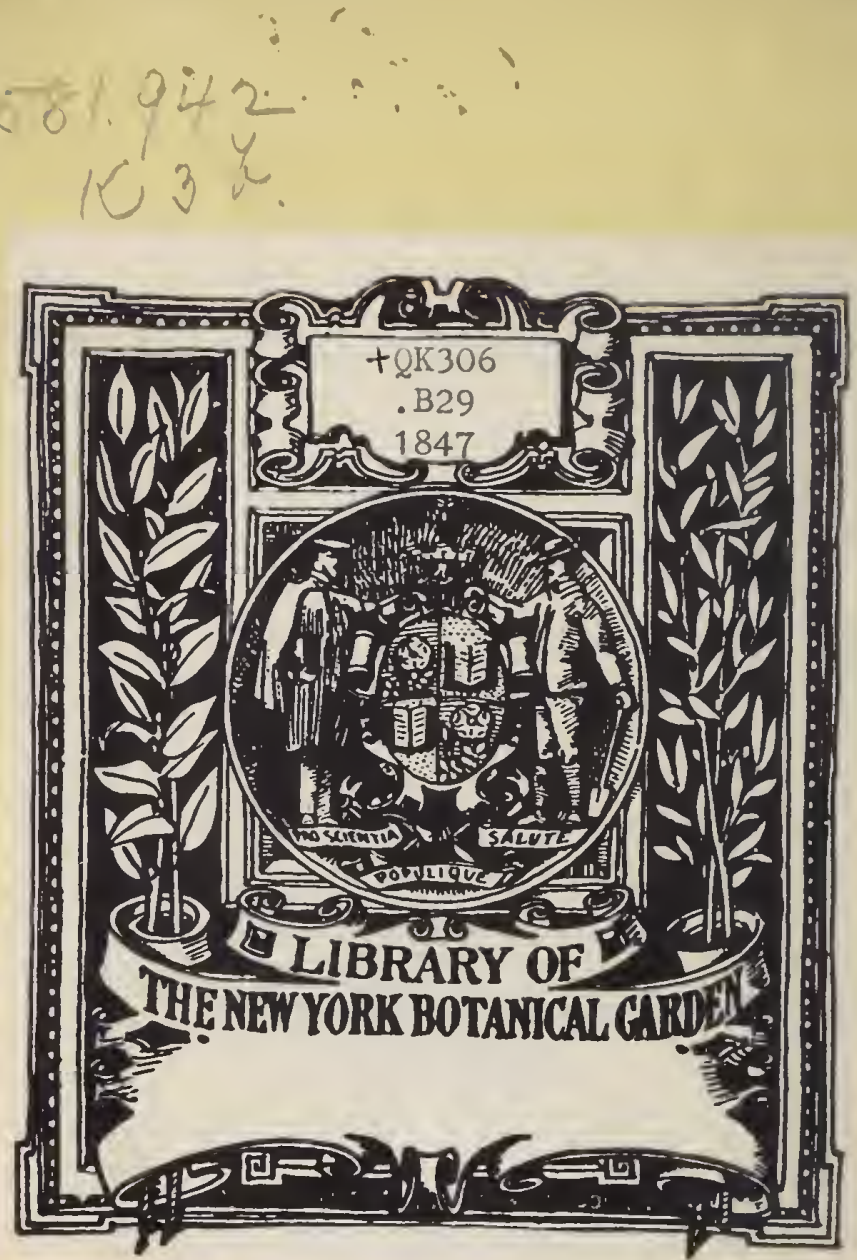

Pres, ol columpla college, 1804-180y.

and

Mrs. M. M. Barnard. 
C.P. Selby 
Digitized by the Internet Archive in 2015 


\section{A N U A L}

$$
\text { OF }
$$

\section{B R I T I S H BOTANY.}




$$
\begin{gathered}
+Q \times 306 \\
.229 \\
1847
\end{gathered}
$$

PRINTED BY R. AND J. E. TAYLOR, RED LION COURT, PLEET STRERT. 


\section{P R E F A C E.}

In this work it has becn the Author's wish to adopt in all cases those names which have the claim of priority, unless good cause could be shown for a contrary proceeding, and with this object he has carefully examined nearly all the best European Floras, comparing our plants with the descriptions contained in them, and in very many cases with foreign specimens of undoubted authenticity. In the adoption of genera and species an endeavour has been made, by the examination of the plants themselves, to detcrmine what are to be considered as truly distinct, thus, it is hoped, taking Nature as a guide, and not depending upon the atlthority of any name, however distinguished. Still let it not be supposed that any claim is made to peculiar accuracy, nor that the Author considers himself qualified to dictate to any student of botany, for he is well aware that there are many points upon which persons who have carefully studied the subject may form different conclusions from those to which he has been led.

The present volume being intended to form a field-book

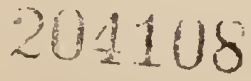


or travelling companion for botanists, it was advisable to restrict the space allotted to each species as much as possible, and accordingly it will be found that the characters and observations are only such as appeared to be necessary for their accurate discrimination. Synonyms have been almost wholly omitted, but at least one British and one German figure of each plant is quoted in all cases in which it could be done with accuracy. Localities are only given for new or rare plants, the cxistence of so complete a work as Mr. Watson's New Botanist's Guide having made it unnecessary inconveniently to swell the present rolume by their introduction; but in order to convey some idea of the distribution of plants throughout the United Kingdom, the letters E., S., and I. have been appended to the descriptions of such specics as have, it is beliered, been only found in England, Scotland, or Ireland respectively, - all plants without such an addition having been observed in each of them. An 0 . has been appended to a very few plants which only occur in the Chamel Islands, or which, although included in our lists, there is reason to suppose have never been really detected in Britain, thus pointing out that they hare little or no right to be considered as natives or even denizens. The descriptions of a considerable number of doubtful species which have been added to our Flora by previous writers, or which, although decidedly naturalized, have very slender claims to be considered as aboriginal natives, are included within [ ], and notices of a few plants concerning which more accurate information is requisite arc distinguished in a similar manner. A very concise Synopsis of the genera, according to the Linnæan method, is given for the convenience of those botanists who may not be quite familiar with the Natural Orders.

Dr. Lindley's valuable Vegetable Kingdom being accessible to ncarly all the readers of this little work, it has not been 
considered advisable to introduce detailed descriptions of the Orders; but in the preparation of the short distinctive characters the author has availed himself of that work, of Dr. Arnott's elaborate treatise contained in the Encyclop. Britan. (ed. 7. vol. v. pp. 30-141), of Endlicher's Genera Plantarum and Koch's Synopsis Flora Germanica. To the latter work, which may be considered as the model of the present publieation, he has pleasure in acknowledging himself to be peculiarly indebted.

To Prof. Balfour, W. Borrer, Esq., E. Forster, Esq., Prof. Heuslow, the Rev. W. A. Lcighton, and his other botanical fricnds and correspondents too numerous to record here, he takes this opportunity of returning most sincere thanks for the great assistance that they have rendered to him by the communication of valuable suggestions, observations, and specimens.

To the present edition a condensed Synopsis of the Natural Orders is added, and the whole work has been carefully revised, so as, if possible, to keep pace with the rapidly advancing knowledge of British plants.

The portability of the rolume being one of its most valuable qualities, it has been found impossible to accord to the wishes of some young botanists by prefixing to it a short Introduction to Botany, or a Glossary of botanical terms; since sufficient space could not have been afforded to them to admit of their possessing that fullness and detail without which they would be worse than useless. Students are recommended to make themselves well acquainted with the contents of some good introduetory work, such as Lindley's Introduction, Henfrey's Outlines, A. Gray's Botanical TextBook, or especially the Botanique of $M$. A. de Jussieu. A good Glossary is expected from the pen of Dr. Lindley.

It is hoped that those who use this book will farour the author with information of any (eren the slightest) addi- 
tion, correction or alteration that may appear to be necessary, in order that it may be employed in the preparation of a future edition, as it is only through such assistance that the Flora of an extcnsive country can attain to even a moderatc degree of perfection.

St. John's College, Cambridge, April 21, 1847. 


\section{ABBREVIATIONS.}

In the descriptions.

anth. ... anthers.

caps. ... capisule.

carp. ... carpel.

cor. ... corolla.

fl. ... flower.

fr. ... fruit.

in. ... inches.

inv. ... involucre.

L. $l$. ... leaves.

leafl. ... leaflets.

ped. ... peduncle.

pet. ... petals.

sep. ... sepals.

st. $\quad$... stem.

stam. ... stamens.

stigm. ... stigmas.

stip. ... stipules.

Books.

A. N.H. ... Annals of Natural History.

E. B. ... Englislı Botany.

E. B. S.... Supplement to E. B.

G. F. G. ... Nees von Esenbeck's

Genera Plantarum Floræ Germanica.

H. ... Hoppe's Caricologia Germanica, in Sturm's Deutsel1lands Flora.

N. ... Newman's History of British Ferms, ed. 2.

R. $\quad$... Reichenbach's Icones Floræ Germanicx.

R. I. ... Reichenbach's Iconographia Botanica.

Schk. ... Schkuhr's Riedgräser.

St. $\quad$... Sturm's Deutschlands Flora.

I. II. III. \&c. represent the montlis of flowering, viz. Jan., Feb., March, \&e.
A. ... Annual.

B. ... Biennial.

P. ... Percnnial.

Sh. ... Shrub.

T. ... Tree.

Native country.

E. ... England.

S. ... Scotland.

I. ... Ireland.

O. ... Not certainly known to have been found in either of the three.
$†$... Possibly introduced but now having the appearance of being a true native.

* ... Certainly naturalized.

(n)




\section{NATURAL ORDERS OF BRITISH PLANTS.}

\section{Class I. Dicotyledones.}

\section{Subclass I. EXOGENA.}

Subdivision I. THALAMIFLORE.

Order I. RANUNCULACEA.

II. BERBERIDEE.

III. NYMPHAEACEA.

IV. PAPAVERACEE.

V. FUMARIACEA.

VI. CRUCIFERTE.

VII. RESEDACEZE.

VIII. CISTINEA.

IX. VIOLACEA.

$\mathrm{X}$. 1)ROSERACE更。

II. POLTGALE.E.

XII. TAMARISCINEZ.

XIII. FRANKENIACEA.

XIV. ELATINEAE.

XV. CARYOPHYLLER.

XVI. MALVACEA.

XVII. TILIACEA.

XVIII. HYPERICINEA.

XIX. ACERINEA.

XX. GERANIACER.

XX1. LINE.

XXII. BALSAMINEA.

XXIII. OXALIDEZ.

Subl. II. CAL YCIFLORE.

XXIV. CELASTRINEZE.

XXV. RHAAINEZE.

XXVI. LEGUMINOSE.

XXVII. IROSACEE.

XXVIII. LYTHRARIERE.

XXIX. CERATOPHYLLEX

XXX. ONAGRARIE.

XXXI. HALOIRAGEE.

XXXII. CUCURIITACE.E.

XXXIII. POR'TULACEF.

XXXIV. PARONICHIACER.

XXXV. CRASSULACEA.

XXXVI. GROSSULARIEA.

XXXVII. SAXIFIRAGACE.E.

XXXVIII. UMBELLIFER .

XXXIX. ARALIACEE.

XL. CORNE.E.

Subd. III. COROLLIFLORE.

XLI, I,ORAN'THACEX.

XLII. CAPRIFOLIACE.E.

XLIII. IUUBIACEA.

XLIV. VALERIANACER.

XLV. DIPSACEA.

XLVI. CONIPOSITA.

XLVI1. CAMIPANULACEA.

XLVIII. ERICINEAE.

XLIX. ILICINETE.

I. OLEACER

II. APOCYNIE.

LII. GENTIANACEA.
Order LIII. POLEMONIACE F.

LIV. CONVOLVULACER.

LV. BORAGINEA.

LVI. SOIANACEX.

I,VII. OROBANCHEIE.

LVIII. SCROPHULARINEIE.

LIX. LABIATA.

LX. VERBENACEF.

LXI. LENTIBULARIACE

LXII. PRIMULACEX.

LXIII. PLUMIBAGINEF.

LXIV. PLANTAGINE.E.

Subd. IV. MONOCHLAMYDEA:

LXV. AMARANTHACE.E.

LXVI, CHENOPODIACE AE.

LXVII, POLYGONIACEA.

LXVIII. ELAAGNER.

LXIX. THYMELER.

LXX. SANTALACEA.

LXXI. ARISTOLOCHIACEE.

LXXII. EMPETRER.

LXXIII. EUPHORBIACEA.

LXXIV. URTICACEE.

LXXV. A I EN'TACEA.

Subclass II. GYMNOGENE.

LXXVI. CONIFERÆ.

Class II. Monocotyledones.

Subclass I. DICTYOGENE.

1,XXVII. TRILLIACEZE.

LXXVIII. TANEA.

Subclass II. ENDOGENAE.

Subdivision I. FLORIDE.

LXXIX. HYDROCHARIDEA.

LXXX. ORCHIDEE.

LXXXI. IRIDEXE.

LXXXII. AMARYLLIDEAE.

LXXXIII. ASPARAGER.

LXXXIV. LILIACEAE.

LXXXV. COLCHICACEF.

LXXXVI. FRIOCAULACEA:.

LXXXVII. JUNCACEAE.

LXXXVIII. ALISMIACEF.

LXXXIX. AIROIDE.E.

XC. POTAMOGETONEA.

Subd. II. GLUMACEE.

XCI. CYPERACER.

XCII. GRAMINEA.

\section{Class III. Cryptogamea.}

XCIII. EQUISETACEZE.

XCIV. FILICES.

XCV. MARSILEACEF.

XCVI. LYCOPODIACE.E. 


\section{S Y N O P S I S}

OF THE

\section{NATURAL ORDERS OF BRITISH PLANTS.}

The number prefixed to each Order indicates the page where the description of the Genera will be found.

\section{PHANEROGAMEAE or FLOWERING PLAN'TS.}

\section{Class I. DICOTYLEDONES.}

Wool of stem youngest at the circumference. Cotyledons " or more.

\section{Subclass I. EXOGENS.}

Seeds inclosed in seed-vessels.

Subdivision I. Fl. with a calyx and corolla, polypetalous, inferior.

1. Oraries numerous, distinct or united, each bearing a style ; or solitary with 1 lateral placenta.

I. Corolla regular.

a. Sepals distinct. Stam. hypogynous.

1. Ranunculaces. Anth. opening by 2 longitudinal clefts.

10. Berberidex. Antl. opening by a valve from the bottom to the top.

b. Sepals more or less combined below.

122. Crassulacez. Stam. as many as, or twice the number of, the pet., on the base of the calyx.

87. Rosace. Stam. 20 or more, on the calyx.

II. Corolla irregular.

32. Resedacex. Cal. persistent. Ovary 3-lobed, 1-celled, open at the cud. Stam. $10-24$.

70. Leguminos.s. Ovary 1-celled, closed. Fr, a pod. Stam. $10,1-2$-adelphous. 
B. Ovary one ; placentas 2 or more, parietal or on the dissepiments, not forming a central axis.

I. Corolla regular. Pet. 4.

12. Papaveracee. Sepals 2. Stam. numerous.

15. Crucifera. Sepals 4. Stam. tetradynamous.

II. Corolla regular. Pet. 5 .

33. Cistinea. Sep. 5, distinct, imbricate. Seeds without an arillus.

39. Tamariscinez. Sep. 5, combined below. Seels comose.

111. Corolla regular. Pet. numerous.

11. Nympireacez. Pet. gradually passing into the stamens.

IV. Corolla irregular.

14. Fumariaceж. Sep. 2 or 0 . Stam. 6, in two bundles.

34. Violaceж. Sep. 5. Stam. 5, filaments free at the base.

C. Ovary 1 ; placentas central.

I. Estivation of calyx valvate or with distant lobes.

56. Malvace现. Stam. monadelphons.

58. Trliaceze. Stam. distinet, hypogynous.

69. Rhamnes. Stam. distinet, opposite the pet. and equalling them in number, perigynous.

12. Lythrariez. Stam. distinct, alternating with the pet. or twice as many.

11. Estivation of calyx imbricate. Cal, and cor. irregular.

67. Balsaminez.

11I. Estivation of gamosepalous calyx imbricate. Cor. regular.

87. Rosaceæ (Tr. Amygdalex). Fruit a drupe. Stam, epigynous.

41. Caryophyleede (Tr. Silenex). Fr. a capsule. Stam. hypogynous.

IV. Estivation of cal. imbricate; sep. distinct or slightly connected below. Cor, regular.

A. Ovary 1-celled.

119. Portulacee. Sep. 2. Stam. opposite the petals.

41. Caryophyllea (Tr. Alsinex), Sep. 3-5. Stam. 10 or fewer, opposite the sepals. Stipules 0 , or rarely scarious.

120. Paronychice site the sepals. Stipules present. 
B. Ovary many-eelled. Stam. polyadelphons.

59. IIYPERICINEA.

C. Ovary many-eelled. Stam. monadelphous.

66. Linese. Ovary with $4-5$ eomplete and $4-5$ ineomplete dissepiments.

68. OxALIDE丸. Ovary 5-eelled; eells many-seeded.

62. Geraniace 2 . Ovary 5-celled; eells l-seeded.

D. Ovary many-eelled. Stam. free. Style 1.

62. Acerineж. Stam. usually 8. Pet. 5. Fr. winged, separating into 2 capsules.

279. Fupetrez. Stam. 3. Pet. 3. Fr. fleshy.

39. Frankeniacez. Stam. 5 or mole. Pet. 5 . Caps. 3valved.

68. Celastrinez. Stam. and pet. 4-5, inserted in an hypogynous disk.

203. Ericacea (Tr. Pyrolex and Monotroper). Stanı. 10. IIypogynous disk 0 .

E. Ovary many-celled. Stam. free. Styles 3-5.

40. Elatineж. Pet. $3-5$. Stam. $3-5$ or $6-8$.

Subdivision II. Fl, with a ealyx and corolla, polypetalous, superior.

A. Ovary l-eelled; placentas parietal.

125. Grossularies. Stam. and pet. 4-5, altermating.

B. Ovary 2-many-eelled; plaeentas central.

a. Stamens numerous.

89. Rosaces (Tr. Pomea). Fr. a $1-5$-celled pome.

b. Stam. as many as, and alternating with, the petals, or twice as many.

130. Umbellifera. Styles 2, from a bifid epigynous disk. Fr. of 2 carpels pendulous from a eommon axis and adliering by their face.

148. Araliaceze. Pet. valvate in æstivation. Fr. a berrv.

149. Corne . Pet. valvate in astivation. Fr. a drupe.

113. Onagrariz. Pet. imbrieate or twisted in estivation. Style 1.

126. Saxifragea. Pet. imbricate in restivation. Styles 2 or more. (Fl. sometimes inferior.) . Caps, 2-valverl.

117. If loragede (in part). Pet. imbricate in æstivation. Styles 4. Caps. not bursting. 
C. Stam. as many as, and opposite to, the petals.

150. Loranthacex. Filaments or anthers adnate to the petals.

Subdivision III. Fl. with a calyx and corolla, gamopetalous, superior.

A. Stam. inserted in an epigynous disk.

204. Ericacese (Tr. Vaccineæ).

B. Stam. inserted with the corolla.

199. Campanulaces. Filaments frec.

119. Cucurbitacez. Stam. 5, triadelphous.

C. Stam. inserted on the tube of the corolla or between its lobes.

160. Сомpositж. Anthers syngenesious. Fl. capitate.

152. Ruвiд сеж. Stam. free. Ovary usually didymous, 2-celled, with 2 ovules. Cal. simple.

156. Valerianacez. Stam. free. Ovary with 1 perfect cell and 1 ovule. Cal. simple.

150. Caprifoliaces. Stam. free. Ovary 3-5-celled. Cal. simple.

158. Dipsaceж. Stam. free. Cal. double.

Subdivision IV. Fl, with a calyx and corolla, gamopetalous, inferior:

A. Ovary 4-parted, 4-seeded. Style 1. Fr. of 4 nuts. 216. Boragine.E. Stam. 5.

240. Labiate. Stam. 4, didynamous, or 2.

B. Ovary simple, 1-celled, 1-seeded.

260. Plumbagine.e. Stam. 5.

C. Ovary simple, l-celled, many-seeded; placenta central, free, simple.

254. Lentibulariaces. Cor. irregular. Stam. 2.

256. Primulaces. Cor. regular. Stam. 4-5, opposite to the segments of the cor.

D. Orary simple, l-celled, many-seeded; placenta central, frec, winged.

262. Plantaginee. Cor. 4-fid, scarious. Stam. 4.

E. Ovary simple, 2- or more-celled, with central placentas; 1-celled with a parietal placenta ; or 2 ovaries with parietal placentas.

I. Stam. hypogynous, scarcely attached to the corolla, distinct. 203. Ericaces (Tr. Arbuteæ and Ericer). 
II. Stan. on the corolla, filaments connected.

38. Polygalex. Filaments monadelphous, separating into 2 bundles above.

III. Stam. on the corolla, distinct.

a. Stam. 2. Cor. regular.

210. Oleacede.

b. Stam. 2 , or 4 and didynamous. Cor. regular.

226. Orobanchex. Ovary 1-celled, with 2 or more parietal placentas, in a fleshy disk.

229. Scrophularinea. Ovary 2-celled, placentas central.

254. Verbenacez. Ovary 2-4-celled. Carpel dividing into 4 nuts.

c. Stam. 4-5, not didynamous. Cells of the ovary with $1-2$ ovules.

209. Ilicine As. Cor. 4-6-parted. Hypogynous disk 0. Fr. flesliy, not bursting.

215. Convolvulace e. Cor. 4-5-lobed. An hypogynons disk surrounding the ovary. Fr. a capsule, bursting.

d. Stam. 4-5, not didynamous. Cells of the ovary with many ovules.

214. Polemoniaceж. Ovary 3-celled. Caps. 3-valved.

211. Gentianacez. Ovary 1-2-celled. Caps. 2-valved.

223. Solanacea. Ovary 2-celled.

2]0. Aросynea. Ovaries 2, 1-celled.

Subdivision V. Perianth single or none.

A. Flowers not in catkins, superior.

278. Aristolochiaces. Stam. 6 or 12, cpigynous. Ovary 3-6-celled.

117. Halorage (in part). Stam. 1. Perianth very minute. 277. Santalaceze. Stam. 4-5. Ovary 1-celled.

B. Flowers not in catkins, inferior.

I. Fr. separating into several carpels.

117. HalorageA (in part). Fr. separating into 4 carpels.

279. EuphoRbiACEA. Fr. separating into 3, rarely 2, carpels.

II. Fruit indeliscent.

a. Leaves with stipules.

270. Polygonaceæ. Stipules (ochreæ) connceted quite round the stem. 
87. Rosacese (part of Tr. Dryadeæ). Stipules adnate to the petiole.

283. URticacez. Stipules free, deciduous.

b. Stipules 0. Fl. monocious. Perigone 0.

113. Ceratophyllez.

c. Stipules 0. Fl. hermaphrodite or polygamous. Embryo straight.

277. Thy meles. Fr. a nut or drupe. Radicle superior.

276. EldAAGNEA. Fr. clothed with the berry-like perigone. Radicle inferior.

d. Stipules 0. Fl. hermaphrodite or polygamous. Embryo curved or spiral.

120. Paronychiace⿸ (Scleranthus). Fr. inclosed in the lardened calyx-tube.

264. Chenopodiace E. Cal. not hardened. Stam. from the base of the perianth.

263. Amaranthacede. Cal. not hardened. Stam. hypogynous.

C. Male flowers always in catkins.

286. Amentaceж.

\section{Subclass Il. GYMNOGENS.}

Seeds quite nakerl.

301. Coniferæ.

\section{Class II. MONOCOTYLEDONES.}

Wood of stem youngest at the centre. Cotyledon single.

\section{Subclass I. DICTYOGENS.}

Leaves net-reined, deciduous.

304. Trillacez. Perianth inferior.

304. Tамеж. Perianth superior.

\section{Subclass H. ENDOGENS.}

Leaves parallel-veined, persistent.

Subdivision I. Floridz. Floral enrelopes whorled.

A. Ovaries several, cach bearing a style or stigma.

335. Alismaces. Perianth 6-parted. Caps. not bursting. 
341. Potamogetonez. Perianth 4-parted.

327. Colciucacex. Periunth 6-7-parted. Caps. opening at the inner edge.

B. Ovary 1, inferior.

306. Orchides. Stam. aud style united in a central column. 305. Hydrocilaridex. Stam. free. Sep. 3. Pet. 3.

316. Iridex. Stam. frec, 3. Antl. bursting outwards. Perianth coloured.

318. Amaryldides. Stam. free, 6. Anth. bursting inwards. Perianth coloured. Fr. a 3-valved capsule.

\section{Ovary 1, superior.}

I. Perianth like a corolla of 6 petals.

321. Liliace.s. Fr. dry, bursting with 3 valves.

319. Asparagez. Fr. succulent, not bursting.

II. Perianth more or less glumaeeous, like a calyx, or partly coloured.

328. Juncace.s. Perianth 6-parted. Stam. 6. Fl. hermaphrodite.

328. Eriocaulaces. Perianth 4-5-parted. Stam. 2-6. Fl. monnecious.

338. AROIDE.E. Fl. mostly unisexual, on a spadix or in dense spikes; or monœcious in a membranous spath.

341. Potamogetonex (Zostera). Perianth 0. Fl. in 2 rows upon one side of a spadix.

Subdivision II. Glumacese. Floral envelopes imbricated.

346. Cyperacese. Leaves with entire sheaths. Anth. entire at the end.

370. Gramines. Leaves with split sheaths. Anth. notehed at both ends.

\section{CRYPTOGAMEE or FLOWERLESS PLANTS.}

\section{Class III. CRYPTOGAMEA DUCTULOSA.}

403. Equisetace※. Leafless branched plants with a striated fistular stem, with sheaths at the articulations.

406. Filices. Leafy plants. Theex from the veins on the underside or at the end of the leaves.

417. Lycopodiaces. Leafy plants. Thecæ axillary, sessile. 
** Fl. inferior, monopetalous, regular. Perianth double.

210. Ligustrum. Cor. 4-eleft. Berry with 2 cells and 4 seeds. 210. Fraxinus. Cor. 4-cleft or 0. Caps. compressed, 2-celled, 2 -seeded.

*** Fl. inferior, monopetalous, irregular. Perianth double.

$$
\text { Carp. simple. }
$$

255. Pinguicula. Cal. 5-fid. Cor. ringent. Caps. 1-cclled. 255. Utricularia. Cal. of 2 scpals. Cor. ringent. Caps. 1celled.

237. Veronica. Cor. 4-cleft, rotate. Caps. 2-cclled.

**** Fl. inferior, monopetalous, irregular. Perianth double. Carp. 4-lobed.

245. Lycopus. Filaments simple. Anthers 2-celled.

245. Salvia. Filaments bifid; I branch barren. Anth. 1-celled. ***** Fl. superior. Perianth double.

116. Circiea. Cal. of 2 sepals connected below. Cor. of 2 petals.

(Pet. 0. Salicornia, Nat. Ord. 66. Fraxinus, N. 0.50. Rhynchospora, N. O. 90.)

(Pet. 4. Lepidium and Senebiera, N. O. 6.)

\section{Order II. DIGYNIA.}

278. Anthoxanthum. Perianth glumaccous. A grass.

\section{Class III. TRIANDRIA.}

\section{Order I. MONOGYNIA.}

* Fl. superior, with calyx and corolla.

156. Nat. Order 44. VAlerianaces.

** Fl. superior. Perianth single, petaloid.

316. Nat. Order 81. Inidex.

$$
\text { *** Fl. inferior, glumaceous, chaffy. }
$$

346. Nat. Order 91. Cyperaces (in part). Sheaths of the leaves entire. Stem angular. Cor. 0 .

378. Nardus. Cor. of 2 valves. Cal. 0. A grass.

(Juncus, N. O. 86.)

\section{Order II. DIGYNIA.}

370. Nat. Order 92. Graminez. Fl. glumaceous. Grasses. 


\section{Order III. TRIGYNIA.}

119. Mostra. Cal. of 2 leaves. Cor. of 1 petal. Caps. 3ralved, 3-seederl.

121. Polycarpos. Cal. of 5 leaves. Pet. 5. Caps.1-celled, 3-valved.

51. Holostevi. Cal. of 5 leares. Pet. 5. Caps. I-eelled, opening with 6 tecth at the end.

(Tillaca, N. O. 35.)

\section{Class IV. TETR ANDRIA.}

\section{Order I. MONOG III.}

* Perianth double. Cal. double, inner adnate to the fr. Cor. monopetalous.

158. Nat. Order 45. Dirsacex.

** Perianth double. Cal. single. Cor. monopetalous, inferior. 262. Plaxtago. Segments of eor. reflexed. Stam. very long. 213. Cicesidid. Cor. salvershaped, spreading. Stam. includect. Caps. opening at the top by two valses.

259. Centusculus. Cor.tubular, spreading. Stam. included. Caps. bursting transrersely.

(Gentiana, X. O. 52.)

*** Perianth double. Cal. single. Cor. monopetalous, superior.

152. Nat. Oriler 43. Rubiaces. Limb of the eal. often obsolete.

$$
\text { **** Perianth double. Pet. } 4 .
$$

11. Fipinedua. Cor. inferior.

149. Coksics. Cor. superior.

(Cardamine, N. O.6. Senebiera, N. O.6. Euonymus, No. 24.)

***** Perianth single.

320. Maiantilemuar. Periantl petaloil, 4-parted, inferior.

92. Alcinesillad. Perianth a ealyx, inferior, 8-parted: 4 larger and 4 smaller.

92. Savgcisoriz. Perianth a ealyx, inferior, 4-parterl. Stam. iuserted on a ring closing the tube.

283. Parietaria. P'erianth inferior, 4-parted, bellshaped. Stam. at its base.

116. Issandia. Perianth superior, 4-parted, persistent. 


\section{Order II. DIGYNIA.}

47. Buffonia. Cal. of 4 persistent sepals.

(Cuscuta, N. O. 54.)

\section{Order III. TETRAGYNIA.}

209. Ilex. Cal.4-toothed. Cor. rotate. Berry with 4 l-seeded nuts.

54. Moenchia. Pet. 4. Caps. 1-celled, opening at the top with 8 teeth.

47. Sagina. Pet. 4. Caps. 1-celled, opening with 4 valves.

67. Ra brola. Cal. 4-fid: lobes 2-3-fid. Pet. 4. Caps, with 8 cells and 8 valves.

122. Tillea. Cal. 3-4-parted. Caps. several, each 2-seeded. 341. Potamogetox. Perianth single, of 4 scales. Drupes 4. (Cerastium, N. O. 15.)

\section{Class V. PENTANDRIA.}

\section{Order I. MONOGYNIA.}

* Cor. monopetalous, inferior. Ovary 4-lobed. Fr. 4 nuts. 216. Nat. Order 55. Boragines.

** Cor. monopetalous, inferior. Caps. 1-celled. Stam.opposite to the segments of the corolla.

256. Nat. Order 62. Primulace (in part).

*** Cor. monopetalous, inferior. Stam. and cor.-segments alternate.

211. Nat, Order 52. Gentianeze (in part). Fr. l-or imperfectly 2-celled, many-seeded.

223. Nat. Order 56. Solanacex. Fr. 2-celled, many-secded. Stam. inserted on the corolla.

215. Polemonium. Fr. 3-celled. Stam. inserted on the tube of the corolla.

215. Nat. Order 54. Coxvolvulaces. Fr. 2-3-celled, mostly few-seeded. Stam. inserted on the base of the corolla.

207. Azalea. Fr. 2-3-celled. Stam. inserted on the receptacle.

210. VINcA. Fr. consisting of 2 follicles.

**** Cor. monopetalous, superior.

199. Nat. Order 47. Campanulacezs. Stam. separate from the corolla. Fr. a capsule. 
151. Lovicera. Stam. on the urregular cor. Fr. a berry.

260. SAmolus. Stam. on the half-inferior bellshaped cor. and opposite to its segments, 5 scales (barren stam.) above. Fr. a capsulc.

$$
\text { ***** Cor. of } 4 \text { or } 5 \text { petals, inferior. }
$$

67. Impatiess. Fl. irregular. Scp. 3, uncqual, deciduous. Pet. 3.

35. Vrola. Fl. irregular. Sep. 5, persistent. Pct. 5.

69. Rifanus. Fl. regular. Stam. opposite to the petals.

69. Euoxyucs. Fl. regular. Stam. alternate with the petals.

$$
\text { ****** Petals distinct, superior. }
$$

125. Rines. Pet. and stam. on the limb of the calyx. Pet. clawed.

149. HedErA. Pet. and stam. below the margin of an epiggnous disk. Pet. sessile with a broad basc.

******* Perianth single.

260. Glaux. Perianth inferior, bellshaped, coloured.

277. Thesiua. Perianth superior, persistent.

(Illecebrum and Herniaria, N. O. 34.)

\section{Order II. DIGYNIA.}

* Perianth single or pet. resembling abortive stamens.

284. Uluus. Caps, compressed, winged all round. L. with stipules.

264. Nat. Order 66. Cirexopodiace (in part). Caps. not winged. Stip. 0.

120. IIerviaria. Cal. 5-cleft; segments plano-concave. Pet. (or abortivc stam.) 5, sctaccous.

12I. Illece BRUM. Cal. of 5 thick laterally compressed hooded leaves. Pet. (or abortive stam.) 5, subulate.

** Perianth double. Cor. monopetalous, inferior.

212. Gextiana. Caps. 1-celled, 2-valved. Cor. without nectariferous pores.

216. Cuscuta. Caps. 2-celled, bursting transverscly. Cor. bellshaped.

*** Perianth double, superior. Cal.-limb often obsolete. Pet. 5. 130. Nat. Order 38. Unbellifere. 


\section{Order III. TRIGYNIA.}

69. Stapiylea. Pet. 5 , inferior. Caps. 2 or 3 , inflated.

39. Tamarix. Pet. 5, inferior. Caps. 1-eelled, 3-valved. Secds numerous.

120. Corrigiola. Pet. 5, inferior. Caps. 1-seeded, not opening.

151. Viburnum. Cor. superior. Berry 1 -seeded.

151. Sambucus. Cor. superior. Berry 3-seeded.

(Polycarpon, N. O. 34.)

\section{Order IV. TETRAGYNIA.}

38. Parnassia. Nectaries 5, heartshaped, fringed with stalked glands.

\section{Order V. PENTAGYNIA.}

66. Linum. Ovary 1,10 -eelled.

93. Sibbaldia. Ovaries 5 , free.

260. Statice. Ovary 1, l-seeded. Fl. in loose panicles.

261. Armeria. Ovary 1, 1-seeded. Fl. capitate.

(Cerastium and Spergula, N. O. 15.)

\section{Order VI. IIEXAGYNIA.}

37. Drosera. Ovary 1, 1-eelled, many-seeded.

\section{Order VII. POLYGYNIA.}

4. Myosurus. Ovaries many, 1-seeded, on a very long reeeptaele.

\section{Class VI. HEXANDRIA.}

\section{Order I. MONOGYNIA.}

* Fl. with calyx and corolla.

10. Berberis. Cal. inferior, 6-leaved. Pet. 6.

40. Frankenia. Cal. inferior, 5-parted. Pet. 5. Caps. 1celled.

113. Peplis. Cal. inferior, 6-jarted. Pet. 6. Caps. 2-eelled. (Lythrum, N. O. 28.)

$$
\text { ** Perianth single, coloured, superior. }
$$

318. Nat. Order 82. Amaryllidez. 
*** Perianth single, coloured, inferior, 6-parted.

320. Convaliaria. Perianth bellshaped. Fr. a berry.

327. Agrapins. Periantl tubular-bellshaped. Fr. a eapsule.

327. Muscal1. Periantl globose or eylindrieal, contracted at the mouth.

**** Perianth single, coloured, inferior, of 6 leaves.

† Style trificl.

320. Asparagus. Perianth tubular below, persistent. Fr. succulent.

322. Fritillaria. L. of perianth each with a neetariferous eavity at the base. Fr. dry.

†† Style entire or 0 . Stigma obtuse or 3-lobed.

323. GaGEa. Anth. ereet, their base attaehed to the end of the filament.

Anthers incumbent.

323. Limum. L. of perianth with a longitudinal neetariferous furrow below.

323. LLOYDiA. L. of perianth with a transverse neetariferous fold below.

Nectary none.

324. Allium. Umbel inelosed in a spath before flowering.

329. Narthecium. Spath 0. Filaments bearded. Style trigonous.

323. Ornithogalum. Spath 0 . Filaments inserted on the receptacle. Style trigonous.-Fl. white or yellow.

324. Scilla. Spath 0. Filaments at the base of the perianth. Style trigonous. - Fl. never white or yellow.

322. Tulipa. Spath 0. Style 0. Stigma 3-lobed.

340. Acorus. Spath 0. Style 0. Stigma obseurely 3-lobed. Fl. on a spadix.

***** Perianth single, glumaceous, inferior.

328. Juncus. Caps. 3-celled, 3-valved. Seeds numerous.

334. Luzula. Caps. 3-eelled, 3-valved. Seeds 3.

\section{Order II. DIGYNIA.}

273. Oxyria. Periantl 4-leaved. 
112. Lythrum. Cal. tubular, inferior, with 10 teeth. Pet. 6. Style 1.

92. Agrimonia. Cal, turbinate, with hooked bristles. Pet. 5. Styles 2.

33. Reseda. Pet. irregular. Styles 3. Caps. open at the end. 124. Sempervivum. Pet. and styles 12 or more.

(Styles 3. Euphorbia, N. O. 73.)

(Styles 4. Potentilla, N. O. 27.)

\section{Class XII. ICOSANDRIA.}

86. Nat. Order 27. RosAce (in part).

\section{Class XIII. POLYANDRIA.}

\section{Order I. MONOGYNIA.}

12. Nat. Order 4. Papaveraceas. Sep. 2. Pet. 4.

10. Aст дa. Sep. 4 . Pet. 4.

33. Helianthemum. Fistivation of eal. twisted. Pet. 5. 58. Tilia. Estivation of cal. valvate. Pet. 5.

11. Nat. Order 3. Nymphancex. Pet. numerous.

Order II. DI- POLY- GYNIA.

1. Nat. Order 1. Ranunculacez. Cal. and cor. inferior. (Reseda, N. 0. 7.)

\section{Class XIV. DID YNAMIA.}

\section{Order I. GYMNOSPERMIA.}

[Fr. deeply 4-lobed, resembling 4 seeds.]

240. Nat. Order 59. Labiata.

(Verbena, N. O. 60.)

\section{Order II. ANGIOSPERMIA.}

[Seeds in a distinet capsule.]

226. Nat. Order 57. Orobanches. Caps. 1-celled, manysceded. Placentas parietal.

234. Limosella. Caps. 1-celled (exeept at the bottom). Placentas central, free. 
2.29. Nat. Order 58. Scropilularinez (in part). Caps. 2eclled.

152. Linnea. Ovary 3-eelled. Fr. 1-seeded.

254. Verbena. Ovary 4-eelled. Seeds $2-4$, periearp evanescent.

\section{Class XV. TETRADYNAMIA.}

15. Nat. Order 6. Cruciferx.

Class XVI. MONADELPHIA.

Order I. PENT- DEC- ANDRIA.

[Stam. 5-10.]

63. Nat. Order 20. Geraniacez.

(Lysimachia, N. O. 62. Linum, N. O. 21. Oxalis, N. O. 23. Part of Leguminose, N. O. 26.)

\section{Order II. POLYANDRIA.}

56. Nat. Order 16. Malvacez.

\section{Class XVII. DIADELPHIA.}

14. Nat. Order 5. Fumariacex. Stam. 6. 38. Nat. Order 11. Polygales. Stam. 8. 70. Nat. Order 26. Leguminose. Stam. 10.

\section{Class XVIII. POLYADELPHIA.}

59. Nat. Order 18. Hypericines. Stam. numerous.

\section{Class XIX. SYNGENESIA.}

160. Nat. Order 46. СомровIтж.

Class XX. GYNANDRIA.

306. Nat. Order 78. Orchidex. Stam. 1 or 2. 278. Aristo lochia. Stam. 6 . Stigma with 6 lobes. 


\section{Class XXI. MONGECL.}

\section{Order I. MONANDRIA.}

[Stam. 1.]

280. Euphorbia. Involucre bellshaped, inclosing numerous male fl. and 1 female flower. Cor. and eal. wanting.

340. ARUM. Spath of 1 sheathing leaf, inclosing numerous female fl. and numerous male fl. above them. Cal, and cor. wanting.

118. Callitriche. Bracts 2 petaloid, or 0 . Involucre, spath, cal. and cor. wanting.

346. Zaxicheldia. Involucre 0. Male fl. without cal. or cor. Fem. fl. with a perianth of 1 lcaf. Nuts 4, stalked. Stigma peltate.

346. Zostera. Fl. aggregate in 2 rows on one side of a spadix. Spath cnding in a leaf.

- Order II. DIANDRIA.

(Callitriche, N. O. 31. Carex, N. 0. 90.)

\section{Order III. TRIANDRIA.}

339. Trpha. Spikes male and female, cylindrical. Ovary surrounded with bristles. Perianth 0 .

339. Sparganium. Spikes male and female, globose. Perianth single, 3-leaved.

355. CAREX. Fl. in 1 or more imbricated sealy spikes. Perianth 0. Perigone urceolate.

354. Kobresia. Fl. in a compound spike. Perianth and perigone 0 .

\section{Order IV. TETRANDRIA.}

263. Littorella. Cor. of male fl. with a cylindrical tube and 4-parted limb. Stam, very long.

280. Buxus. Cor. of male fl. of 2 petals, fem. of 3 pet. Caps. with 3 beaks.

284. Urtica. Perianth 4-leaved. Perigone 2-leared. Stam. cqualling the periantl.

300. Anvus. Fl. in inbricated cathins. Scales of male fl. 3lobed, 3-flowered. Pcrianth 4-fid. Perigone 0. 


\section{Order V. PENT-POLY-ANDRIA.}

* Fl. not in catkins, with cal. and cor.

117. Myriopirylus. Pet. of male fl. 4, deciduous. Stam. 8. Germ. inferior.

337. Sagrttaria. Pet.3. Stam. about 24. Carp. numerous upon a globose receptacle.

119. Bryoxia. Cal. with 5 teeth. Cor. 5 -eleft. Filaments 3. Antl. 5. lir. an inferior berry.

$$
\text { ** } F l \text {, not in catkins, imperfect. }
$$

199. Xastrnu. Involucre of male many-leaved, witl a 5toothed periantlı; of female l-kaved, inclosing 2 flowers.

11:3. Ceratopiylues. Perianth many-leared. Stam. 16-20). Nut ending in a spine.

32s. Eriocallox. Periantli 4-6-cleft. Stam.4-6. Caps. 2-3-lobed, 2-3-eclled.

264. Imarantules. Perianth 3-4-leaved. Stam..3 or 5. Caps. opening all round.

9.2. Poterics. Perianth 4-cleft. Fr. 2 nuts, invested with the hardened quadrangular tube of the perigone.

$$
\text { *** Fl. in catkins. }
$$

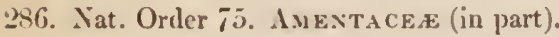

\section{Order VI. MONADELPIIA.}

[Filaments of stan. united below into oue set.]

303. P'ixes. Male $\mathrm{fl}$. in racemose eatkins. Fr. in concs.

\section{Class XXII. DICECI.}

287. Salrx. Periantlı 0. Stan, and pistils with 1 or 2 gland. at the base. Inth. 1-5, usually 2 .

279. Empetrum. Cal. 3-parted. Pet. 3. Stam. 3.

321. Resces. Sej. 6. Pet. 0. Stam. 3.

277. Il IP POPIIA 5 . Male $\mathrm{fl}$, with a perianth of 2 deep roundish lobes. Stain. 4 . Fem. fl. with a tubular bifid perianth. Stigna elongate.

150. Viscè. Cor. 4-parted. Cal. of male fl. (0, of fem. fl. an obscure free unargin. Stam. 4. Stigma obtuse, sessile.

299. Mrrica. Fl. in catkins, Perianth 0. Stam. 4, at the base of the seales.

281. Hewcius. Fcmale fl. in a catkin formed of large persistent seales. Stam. 5 . 
305. Tamus. Perianth 6-parted, superior. Stam. 6. 298. Populus. Fl. in imbricated catkins. Stam. 8. 282. Mercurialis. Perianth single, 3-parted. Stam. 9. 305. Iy drocharis. Cal. 3-parted, superior. Pet. 3. Stam. 9. 306. Stratiotes. Cal. 3-parted, supcrior. Stam. 12. 302. Junilerus. Stam. 5, combincl. Fl. in catkins. Fem. fl. 3 , scales ultimately fleslyy and united.

302. Taxus. Stam. 5, combined. Fl. in catkins. Fem. fl. 1, scaly below. Perigone ultimately fleshy, cupshaped. (Stam.3. Valeriana, N. O.44. Stam.4. Rhamnus, N. O. 25. Urtica, N. O. 74. Stam.8. Sedum, N. O.35. Stam. 12. Stratiotes, N. O. 77.)

\section{Class XXIII. POLYGAMIA.}

268. Atriplex. Perigone 2-lobed or 2-parted. Pericarp free. Testa crustaceous.

270. Halimus. Perigone 2-lobed. Pcricarp adhering to the perigone. Testa membranous.

\section{Class XXIV. CRYPTOGAMIA.}

403. Nat. Order 93. Equis Etace ж. Leafless branched plants with sheathed articulations. Fructification in terminal catkins.

406. Nat. Order 94. Filices. Leafy plants. Fructification attached to the veins, either on the back or edge of the leaves.

417. Nat. Order 95. Marsileacex. Creeping plants with slender leaves. Fructification consisting of globular nearly sessile coriaceous 3-4-celled capsules.

417. Nat. Order 96. Lycopodiaces. Plants with imbricated leaves. Capsules axillary, solitary. 


\section{MANUAL \\ OF \\ B R ITISH BOTA NY.}

\section{FLOWERING PLANTS.}

Substance composed of cellular tissue, woody fibre and spiral ressels. Epidermis with stomata. Embryo with cotyledons.

\section{Class I. DICO'TYLEDONES.}

Stems formed of bark, wood and pith. The wood furnished with medullary rays and increasing by the addition of concentric layers externally. Leaves mostly with reticulated reins. Cotyledons 2 or more, opposite or whorled.

\section{Subclass I. EXOGENS.}

Plants with an ovary, style and stigma. Seeds inclosed in a seed-ressel.

\section{Subdivision I. THALAMIFLOR E.}

Petals distinct (rarely 0), and as well as the stamens hypogynous.

\section{Order I. RANUNCULACEA.}

Sep. 3-6. Pet. 5 or more, rarely 0. Stam. indefinite: anth. adnate, opening longitudinally. Carp. numerous, distinet, or rarely united into a single pistil. Seeds erect or pendulous. 
* Anthers extrorse.

Tribe I. CLEMATIDE E. Fruit 1-secded with a feathery awn. Seerl pendulous. Listivation valvate or induplicate. Leaves opposite.

1. Crematis. Cal. of 4 or 5 sepals. Pet. 0. Carp. not bursting, awned.

Tr. II. ANEHONEAE. Fr. 1-seeded. Seed pendulous. Estivation imbricate. Leaves radical or alternate.

2. Thalictrum. Cal, of 4 or 5 sepals. Pet. 0. Carp. not bursting, without awns.

3. Anemone. Cal. petaloid, sep. 5-9. Pet. 0. Carp. not burstiug, tipped with the persistent sometimes feathery styles, inserted upon a thickened hemispherieal or conical receptacle.

4. Adonis. Cal. of 5 sepals. Pet. 5-10, without a nectary. Carp. not bu'sting, without awns.

Tr. III. RANUNCULEAE. Fr. 1-seerled. Seed ereet (except in Myosurus). Fstivation imbricate. Pet. with a nectariferous pore at their base.

5. Myosurus. Cal. of 5 scpals, prolongerl into a spur at the base. Pet. 5, with a filiform tubular claw. Carp, not bursting, closely imbricated upon a long filiform receptacle. Seed pendulous. Embryo inverted with the radiele superior.

6. Ranunculus. Cal. of 5, rarely 3, sepals. Pet. 5, rarely numerous: nectariferous pore naked or covered by a seale. Carp. not bursting, collected into a globular or elliptical head.

Tr. IV. HEILLBOREAE. Fr. many-seeded, bursting. Estivation imbricate.

7. Caltha. Cal. of 5 petaloid deeiduous sepals. Pet. 0. Caps. 5-10, many-seeded.

8. Trollius. Cal. of 5 or many petaloid deciduous sepals. Pet. small, linear, flat, clawed. Caps. numerous, sessile.

[9. Erantuis. Cal, of 5-8 petaloid deeiduous sepals. Pet. small, tubular, with a long claw, 2-lipped, inner lip very short. Caps. numerous, stalked.]

10. IIellebonus. Cal. of 5 petaloid persistent sepals. Pet. small, tubular, 2-lipped, elawed. Caps. 3-10 sessile.

11. Aavilegia. Cal, of 5 petaloid deeiduous sepals. Pet.5, funnel-shaped, with a long hornlike spur. Caps. 5. 
12. Delphinium. Cal. of 5 petaloid deciduons scpals, superior sep. with a long spur at the base. Pet. 4, 2 upper ones with spurs included in the spurred sepal, or all combined into one spurred petal. Caps. 1, 3 or 5.

13. Aconitum. Cal. of 5 petaloid sepals, npper one helmetshiped. Two upper pet. tubular, on long stalks, concealed in the helmet-shaped sepal. Caps. 3-5.

** Anthers introrse.

Tr. V. PAONIEA or spurious Ranunculacex.

14. Астжа. Cal. of 4 petaloil deciduous sepals. Pet. 4. Carp. 1, baccate, indehiscent, many-sceded.

15. l'AoNia. Cal. of 5 persistent sepals. Pet. 5 or more. Follicles 2-5, many-seeded, bursting inwards, crowned with the bilaminated stigmas.

\section{Tribe I. Clematidea.}

\section{Clematis Linn.}

1. C. Vitalba (L.); st. climbing, 1. pinnate, leaflets ovate acuminate entire coarsely scrrate or inciso-lobate rounded or cordate below, petioles twining, sep. oblong downy on both sides, fr. with long fenthery awns.-E.B. 612. R. 4667.-St. woody, angular, branched. Petioles acting as tendrils. The form witl nearly cntire scarcely lobed leaves with a rounded not cordate base, is jrobably C. scandens Borkh.-Hedges and thickets on a calcarcous soil. Sh. VI. Traveller's Joy.-E.S.

\section{Tribe II. Anemonea.}

\section{Thalictrum Limn.}

1. T. alpinum (L.); st. perfectly simple and almost naked, cluster terminal simple, fruitstalks reficxed, carp. shortly stalked tipped with the hooked stylc.-E.B.262. R. 4625.-St. 3-6 in. high, quite smooth. L. mostly radical, upon long stalks, twice ternate.-Higher parts of mountains. P. VI. VII.

2. T. minus (L.) ; st. zigzag striated branched solid leafless at the base, 1. 2-3-pinnate, leafl. ternate 3-cleft glaucous, petioles with angular ascending branches, $f l$. panicled drooping, carp . fusiform 8-rizbed subcompressed.-E.B. 11. R. 4627.-St. l-2 ft. high.- [T. flexuosum $R .4628$, Fries, is leafy at the base and has oblong-attenuated 10-ribbed carpels. It is probably a native.]Stony pastures. P. VI. VII.

[A plant from the rocks near Twll Dû near Llanberis, N. Wales, is probably T. Kochii (Fries), but is too imperfect for determination.] 
3. T. majus (Crantz?); st. zigzag angular branched hollow, l. 3-pinnate, leafl. ternate 3-cleft broal glaucous, petioles with angular branches springing at right-angles, fl. subumbellate drooping. -E.B.611.-St. 3-6 feet ligh. Leafl. very broad, lobes acute; uppermost often entire and ovate. A very doubtful plant.Busly hills in the south of Scotland and north of England. P. VI. VII.

E. S.

4. T. flavum (L.); st. crect furrowel, l. bipinnate, leafl. oroadly obovate or wedgc-shaped trificl, panicle compaet corymbose, fl. erect.-E.B. 367 .-L. ratler paler beneath. Root rreeping. The lower subdivisions of the petiole with stipules and the root creeping; or, no partial stipules and a fibrous root; cliaracterize the T. flavum and T. rufinerve of Koeh's Synopsis, but these characters do not appear to be permanent. In the fens of Cambridgeshire the plant las an extensively creeping root aud partial stipules.-In wet fields. P. VI. VII. Common Meadow Rue.

\section{Anemone Linn.}

I. A. Pulsatilla (L.); fl. solitary erect, involuere sessile in deep linear scgments, l. doubly pinnate, leaflets pinnatifid: lobes linear, carp. with feathery tails.-E.B. 51.-Fl, violet-purple, extcrnally silky. Involuere silky, close to the flower, but, by the elongation of the stalk, distant from the fruit.-Open ehalky pastures. P. IV. V. Pasque flower.

2. A. nemorosa (L.) ; fl. solitary, sep. 6 elliptical, involuere of 3 ternate or quinate stalked leaves with lobed and cut leaflets, l. similar, carp. pubescent keeled.-E.B. 355. R. 4644.-Fl. white or purplish. Carp. with a beak of nearly their own length but not tailed. Root (rhizoma) horizontal. Sep. glabrous on both sides.-In groves and thickets; common, P. III.-V. Wood Anemone.

*3. A. apennina (L.); fl. solitary, sep. numerous lanceolate, involucre of 3 ternate stalked deeply eut leaves, l. similar, "carp. pointed without tails."-E.B. I062. R. 4645,-Fl. bright blue. Root similar to the last.-Scarcely naturalized. P. IV. E.

*? 4. A. ranunculoides (L.); fl. solitary or in pairs, sep. 5 elliptical, involucre of 3 nearly sessile ternate deeply cut leaves, 1. similar often quinate, carp. pointed downy without tails.-E.B. 1484. R. 4643.-Fl. bright yellow. Sep. externally pubeseent. Root similar to the last. $-A$ very doubtful native. P. IV. E.

\section{Adonis Linn.}

†1. A. autumnalis (L.); eal. glabrous patent, pet. connivent, carp. without teeth collected into an ovate head and tipped with a straight beak.-E.B. 308. R. 4621.-Fl. searlet, black at the 
base. L. triply and eopiously pinnatifid, segments lincar.Coru fich, rare. A. VII. Corn Pheasant's Eye. E. S.

\section{Tribe III. Ranunculea.}

\section{Mrosurus Limn. Mousetail.}

l. M. minimus (L.).-E. B.435. R.4569.-St. sinple, leafless, siugle-flowered, $2-5$ in. ligh. Receptacle rery long, with numerous oblong carpels. L. linear. The sced being attached to the upper part of the calp. makes it pendulons with the ralicle pointing upwarls; this difference from the true Ranunculi is only apparent, and is caused by the singular point of attachment of the seed, the rarlicle being in fact inferior.-In damp plaees in fields. A. V. VI. E.

\section{Ranunculus Linn.}

* Carp. transversely wrinkled, nectary naked, fi. white. $B_{\mathrm{A}-}$ TrACHUM Fries.

† Reeptacle setose.

1. R. aquatilis (L.); st. floating, submersed 1. divided into eapillary segments spreading in all directions, floating l. reniform 3-5-parted lobed, carp. unequally ovate with an obtuse subterminal point.-E. B. 101. R. 4576.-L. all more or less stalkerl. Fl. white, varying greatly in size. Upper stip. adnate nearly throughout. Style straight.-Probably two or more speeics are confounded under this name, viz. B. heterophyllus (Fries); floating 1. witl dentate or eut lobes, fl. from the axils of the submersed or floating leaves; or B. peltatus (Fries); floating l. subpeltate with a eordate or truncate base and erenate lobes, fl. from the axils of the floating 1 . alone. Often the floating 1 . are wanting in the former; never in fertile plants of the latter.--Ponds and ditches. P. V. VI. Water Crowfoot.

2. $R$. circinatus (Sibth.); st. submersed aseending, l. all submersed divided into numerous eapillary 2-4 times forked rigid segments spreading in one plane, earp. semi-ovate laterally tipped with the long acute incurved style.-E.B.S.2869. R. 4575.R. divaricatus, Koch.-L. with sheathing not auricled stalks, always small remarkably flat and rigid with a circular outline. Fl. white.-In ponds and ditehes, not eonfined to stagnant water. P. VI.-VIII.

E. S.

3. R. fuitans (Lam.); st. floating, lcaves all submersed repeatedly 2-3-chotomous : segments elongated setaceous parallel, carp. obovate with a short obtuse straight lateral point.-E.B.S. 2570. R. 4577.-L. remarkably long and upon very long stalks, together often $\mathrm{l}$ foot or more in length. Fl. large, white. Cpper 
stip. broad alnate nearly throughout. Very rarely a few terminal "subtrifid truncate" floating leaves are found. See $A, N . H$. iii. 225.-In rivers and brooks, but not confined to running water. P. VI. VII.

E. S.

†† Receptacle not setose.

4. R. hederaceus (L.); st. creeping, $l$. all roundish reniform with 3-5 rounded lobes, carp. obtuse laterally tipped with the style, stam. 5-10.-E. B.2003. R. 4573.-Pet. narrow and scarcely so long as the calyx. Stip. narrower than in the next species, adnate nearly throughout. Distinguished from the 3 preceding by its few stamens and truly creeping stem without any capillary divided leaves.-In wet places. P. VI.-VIII. Ivy Crowfoot,

5. R. Lenormandi (F. W. Schultz); st. crecping, l. all cordatesubrotund suhpeltate $3-5$-lobed : each lobe with 2 or 3 notches, carp. obovate tipped with the terminal style.-E. B. S, 2930. ined. Coss, et Germ. Atl. Fl. Par. t. l. f. 3. 4. R. hel. $\beta$. grandiflorus $B a b$. - Pet. longer than the calyx. Stip. very broad, scarcely adnate. L. not always keeply lobed as statcd by Schultz.-On water, probably common. P. VI.-VIII.

E.

** Carp. not transversely wrinkled, nectary with a small scale (except in R. alpestris).

$\dagger$ L. divided, fl. white, nectary naked.

6. R. alpestris (L.) ; root fibrous, l. smooth, radical l. somewhat heart-shaped deeply 3-5-lobed: lobes inciso-crenate at the extremity, stem l. 1 "or 2 " simple linear "or trifid with linear lobes," fl. almost solitary, pechuncle furrowed, calyx glabrous, car'). obovate with a straight beak hooked at the end.E. B. 2390.-Pet. obcordatc, white, nectary naked. St. $4-5$ in. high. The figure in $E . B$. represents the leares of this plant as much more acutely lobed and the lobes more decidedly separated than is the case in my foreign specimens or in $R .4581$. Can the Clova plant be $R$. Traunfellneri (IIoppe), a specimen of which (from Croatia) in my Herb. is well represented by the E. B. figure? - In moist places on the Clova mountains. Mr. G, Don. P. Y.

†† L. undivided, fl. yellow.

[7. R. gramineus (L.); root fibrous, the fibres thickening towards the end, l. linear-lanceolate striated entire, st. and ped. glabrous few-flowered, carp. obliquely obovate rugose with a short revolute point, nectary tubular.-E. B. 2306. R. 4594.-Reported to have been found in N. Wales. P. V. VI.] E.?

8. R. Flammula (L.); root fibrous, l. ovate- or linear-lanccolate 
nearly entire stalked, stem reclining at the base and rooting, carp. obovate minutely pitted with a short point.-E. B. 387. R. 45.95 . -Stems 6-18 in. ligh. I. sometimes serrated, hairy or glitbrous.- $\beta$. reptans; st. procumbent filiform rooting, 1. linear. R. reptans (L.), Lightf. Fl. Scot. t. 1.- In wet places. P. VI. -VlIl. Lesser Spearwort.

9. R. ophioglossifolius (Vill.); root fibrous, lower 7 . cordateovate stalked, upper l. oblong sessile amplexicaule, stem erect hollow, carp. obliquely ovate margined tuberculated with a short terminal point. - E. B. S.2833. R. 4613.-Glabrous. N1. small. St. about 1 foot ligh, branched, many-flowered, tapering below, throwing out whorls of fibrous roots from its lower joints.-St. Peter's Marsh, Jersey. A. VI.

10. R. Lingua (L.); root fibrous, $l$. elongatc-lanceolate acute somewhat seluated sessile amplexicaule, stem erect, carp. margined minutely pitted with a broad sword-shaped beak.-E. B. 100. R. 45.97.-Fl. largc. St. 2-3 fect high, throwing out whorls of fibrous roots from its lower joints. St. and l. glabrous or with adpressed hairs.-In marshy places, rather rare. P. VI. VII. Great Spearwort.

11. R. Ficaria (L.); root with fasciculated tubers, l. cordate stalked angular or crenate, st. leafy single-flowered, sep. usually 3, carp. smooth blunt.-E.B. 584. R. 4572.-Pet. usually 8, but varying from 6 to 11 . (Hag. Nat. Hist. vii. 375.) St. $3-8$ ill. long, weak, often producing bulbs in the axils of its leaves.Damp sharly places, common. P. IV. V. Pilewort.

†† L. divided, fl. yellow, carp. smooth.

12. R. auricomus (L.) ; root fibrous, radical $l$. reniform 3-7partite with crenate or cut lobes, petioles sheathing below, stem 1. sessile digitate with linear or lanceolate more or less toothed segments, peduncles round, calyx pubescent, carp. downy ventricose : beak slender looked.-E. B. 624. R. 4599.-Pet. ofterl wanting. Sep. yellow. St. about one foot high.- Woods and thickets, common. P.IV. V. Wood Crowfoot.

13. R. acris (L.) ; root fibrous, radical l. palmately tripartite: segments trifid and deeply cut, uppermost stem 1. tripartite witl linear segments, peduncles round, calyx pubescent erecto-patent, carp. oval glabrous margined: beak short marginal recurved, receptacle ylabrous.-E.B.652. R. 4606.-Hairy. St. 2-3 feet high. Beak about $\frac{1}{4}$ the length of the carpel. $-\beta$. pumilus (Wahl.) ; dwarf, 1-flowered.-Mearlows and pastures, common; mountains. $\beta$. alpine. P.VI. VII. Upright Crowfoot.

14. R: repens (L.); scions creeping, 1. with 3 stalked leaflets which are 3-lobed : lobes 3-fid and cut, peduncles furrowed, calyx 
pubescent erecto-patent, carp. oral glabrons margined minutely pitted : beak longish slightly curved, receptacle hairy.-E. $B$. 516. R. 4610.-Primary stem erect, 10-12 in. high.-Meadows and pastures, commou. P. V.-Vlll. Creeping Crowfoot.

15. R. bulbosus (L.); stem bulblike at the base, radical l. with 3 stalked leaflets which are tripartite: segments trifid and cut, peduncles furrowed, calyx hairy reflexed, carp. round margined smooth: beak short, receptacle liairy.-E. B.515. R.4611.St. about 1 foot high. Upper l. cut into narrow segments.Meadows and pastures. P.V. Bulbous Crowfoot.

t+十 L. divided, fl. yellow, carp. rugose or tubercular.

16. R. hirsutus (Curt.); root fibrous, radical 1. with 3 stalked trifid and cut leaflets, peduncles furrowed, calyx reflexed, carp. round margined with a series of tubercles near the margin: beak short curved, receptacle hairy--E. B. 1504. R. 4617. R. Philonotis (Ehrh.) Koch.-St. 4-18 in. high ; the smaller specimens are $\boldsymbol{R}$. parvulus $\mathbf{L}$. Upper $\mathbf{l}$. in narrow acute segments. Fl. pale yellow.-Waste land and corn-fields, rare. A. VI.-X. E. S.

17. R. sceleratus (L.); root fibrous, lower 1. stalked tripartite : segments blunt crenate, upper l. trifid linear entive or incisodentate, calyx reflexed, heads of fr. oblong, carp. minute wrinkled. - E. B. 681. R. 4598.-Fl. very small, pale yellow. Lower l. broad, glabrous, shining. Stem $1-2$ feet high, throwing ont whorls of fibrous roots from its lower joints.-By ditches and ponds. A. Vl.-1X. Celery-leaved Crowfoot.

†18. $R$. arvensis (L.); root fibrous, radical 1. 3-cleft dentate, stem l. once or twice ternate witl linear-lanceolate segments, calyx erecto-patent, carp. margiued beaked and spinous.-E.B. 135. R. 4614.-Fl. pale yellow. Known by its spinous fruit.Corn-fields. A. VI. Corn Crowfoot.

19. R. parviflorus (L.); root fibrous, stems prostrate, 1. roundish-cordate 3-5-lobed cut, upper l. oblong undivided or 3-lobed, calyx at first erect afterwards reflexed, carp. orbicular muricated. -E. B. 120. R. 4616.-Peduncles opposite the leaves. St. spreading. Pet. narrow.-Corn-fields aud dry banks, rare. A. V. Vl.

E. I.

\section{Tribe IV. Helleborea.}

\section{Caltha Linn.}

1. C. palustris (L.); st. ascending, l. heart-shaped rounded crenate.-E. B. 506. R. 4712.-Fl. large. Sep. roundish-ovate, bright yellow.- $\beta$. minor (DC.); smaller in all its parts and with the l. considerably shorter in proportion, but the posterior lobes 
greatly produeed.-Marsly plaees, common, $\beta$. in more mountainous situations. P. III. IV. Marsh Marigold.

2. C. radicans (Forst.); st. creepiny, l, triangular somewhat heart-shaped serrate-erenate.-E.B.2175. Forst. in Linn. Truns. viii. $t$. 17.-Fl. half the size of those of $C$. palustris, sep. narrower, the hinder angles of the leaves seareely at all produeed so that the leaf is almost triangular. I have only seen eultivated specineus.- "In a diteh that runs from the farm-house ealled Haltoun, on the estate of C. Gray, Esq. of Carse, Forfarshire. 1790." Mr. G. Don; all the other stations probably belong to C. palustris $\beta$. minor. P. V. VI.

\section{Trollius Linn.}

1. T. europeus (L.); sep. $10-15$ concave eonverging into a globe, pet. 10 about as long as the stam., 1. palmately 5-parted : segments rhomboid 3-partite ineiso-serrate--E.B.28. R.4713. - Fl. bright yellow. Pet. ligulate. St. $1-2 \frac{1}{2}$ feet high.-Damp mountain pastures. P. VI. VII. Globe Flower.

\section{Eranthis Salist.}

[*1. E. hyemalis (Salisb.); sep. 6-8 oblong.-R. 4714. Helleborus Linn.-Radieal 1. upon long stalks, 5-7-1parted, deeply eut into linear-oblong segments. St. $4-6$ in. high, with 2 opposite sessile 1 . just below the solitary yellow $\mathrm{fl}$. Root (rhizoma) tuberous. - Naturalized in thiekets in the south of England. P. II. III. Winter Aconite.]

E. S.?

\section{Helleborus $\operatorname{Linn}$.}

1. H. viridis (L.); radieal $l$. digitate stalked, stem l. sessile at the ramifieations, st. few-flowered, calyx spreading.-E. B. 200. R.47I8.-Veins of the l. prominent beneath. Stigma ereet. St. I foot high, annual. Fl. greenish-yellow.-Thickets on a caleareous soil. P. III. IV. Green Hellebore.

†2. H. fotidus (L.); l. pedate stalked, upper 1. gradually becoming ovate bracts, st. leafy many-flowered, calyx converging.E. B.613. R. 4715.-Upper 1. gradually eontraeting and their petioles widening until they become braets. St. 2 feet high. Fl. globose, drooping, greenish tipped with purple.-Thiekets, but usually near houses. P. III. IV. Stinking Hellebore. E. S.

\section{Aquilegia Linn.}

1. A. vulgaris (L.); spur of the pet. ineurved, limb obtuse rather shorter than the stamens, I. biternate, leaflets 3-lobed crenate.-E. B. 297. R. 4729.-St. 2-3 feet high, slightly leafy. Caps. hairy. Inner stam. frequently imperfeet.-Woods and thickets. P. V. VI. Columbine. 


\section{Delphinium Linn.}

†1.D. Consolida (L.) ; st. erect branched, racemes few-flowered, spur longer than the calyx, pet. combined.-E. B. 1839. R. 4669 . D. pubescens, DC.-Pedicels usually longer than the bracts. Caps. downy. Fl. of a vivid and permanent blue, rarely red, pink or white. L. decply multifid.-Sandy or chalky corn-fields; not noticed by Ray. $\Lambda$. VI. VII. Field Larkspur. E. S.

\section{Aconitum $\operatorname{Linn}$.}

†1. A. Napellus (L.); nectaries horizontal upon curved stalks: spurs bent down, fl. racemose, young carpels diverging.-E. $B$. S. 2730. R. 4700.-Filaments slightly hairy, with cuspidate wings. Nectary inflated above, its lip broad. Helnet open, hemispherical. Pedicels erect, downy,-Banks of rivers and brooks, rare. VI. VII. Monk's-hood. E. S.

\section{Tribe V. Pconiea.}

\section{ACtálinn.}

1. A. spicata (L.); raceme simple elongated, pet. as long as the stamens, bcries oval.-E.B.918. R. 4739.-L. stalked, 2tcrnate : leaflets ovate, trifil, deeply cut. St. $1-2$ feet high..Nountainous limestone tracts in the north. P. V. E. S.

\section{Peinonia Linn.}

* 1. P. corallina (Retz.); 1. 2-ternate, leaflets ovate entire glaucous beneath, caps. dlowny recurved from the base.-E. $B$. 1513. R. 4745.-Root fleshy, knobbed. Herb 2 feet high. Fl. large, crimson with yellow anthers.-On the Steep Holmes Island in the Severn. P. V. VI.

\section{Order II. BERBERIDER.}

Sep. 3,4 or 6 , in a louble row. Pet. the same number. Stam, the same number as, and opposite to the petals. Anth. opening by valves from the bottom to the top. Carpel 1, 1celled, seeds attached to the bottom.

1. Berberis. Cal. of 6 deciduous sepals. Pet. 6 , each with 2 glands at the basc within. Berry two-seeded.

[2. Epimediun. Cal. of 4 deciduous sepals. Pet. 4. Nectaries 4, cup-shaped. Caps. podlike, many-seeded.]

\section{Berberis Linn. Barberry.}

1. B. vulgaris (L.); spines 3-parted, 1. obovate ciliate-serrate, racemes pendulous many-flowered, petals entire.-E. B. 49 . 
R. 4486.-Fl. yellow. Berries red, oblong, slightly eurved. Filaments euriously elastie.-Iledges and thickets. S. V. VI.

\section{LHMEDIUM Linn.}

[1. F. alpinum (L.) ; root leaves 0, stem 1. twiee ternateE. B. 438. R. 4485,-Leatlets heartshaped, serrate. Pauicle shorter than the leaf and appearing to grow from the petiole. Fl. red with yellow neetaries.-Subalpine woods. It has very slender elaims to be eonsidered as a native. P. V.] E. S.

\section{Order III. NYMPHAACEA.}

Sep. 4-6, passing gradually into the petals, and these into the numerous stamens, all inserted on a fleshy disk more or less completely surrounding the ovary. Stig. simple. Fruit manycelled: seeds numerous, attached to the spongy dissepiments. Embryo in a bag on the outside of the base of the albumen.

1. Nympндa. Cal. of 4 sepals. Pet. numerous, inserted together with the stamens upon a fleslyy disk enveloping the germen. Berry many-eelled, many-seeded. Stigma sessile, of numerous rays.

2. Nuphar. Cal. of 5 sepals. Pet. numerous, inserted together with the stamens upon the reeeptaele. Berry manyeelled, many-seeded. Stigma sessile, of numerous rays.

\section{NумРнжA Linn.}

l. N. alba (L.); 1. roundish deeply eordate entire with approximate lobes even beneath, stigma of $12-20$ rays. $-E$. $B$. 160. R. vii. f. 117.-Fl. large, white, floating. Stigmas yellow. Ovary eovered with the stamens almost to its summit. Caps. dissolving away into a mass of pulp. Tubes in the ped. hairy within, in the petioles naked. Noteh in the leaves with parallel sides.-Slow rivers, lakes and elear ditehes. P. VII. White Water Lily.

\section{Nuphar $S m$.}

1. N. lntea (Sm.); 1. oblong eordate, sep. 5, stigma with $10-$ 20 rays not extending to the entire margin, anthers linear.-E. B. 159. Fl.Lond.n.s. 141. R. vii. f. 113.-Fl. yellow, with a smell like brandy. Caps. bursting irregularly,-Lakes and ditehes. P. VII. Yellow Water Lily.

2. N. pumila (DC.); 1. ovate deeply eordate with distant lobes, sep. 5, stigma with 8-10 rays extending to the margin and forming acute teeth, anth. subquadrale.-E. B. 2292. R. vii. f. 115. Fl. Lond. n.s. 170.-Fl. yellow, small. Caps. furrowed upwards. Anth. not twiee as long as broad. Whole plant mueh 
smaller than N. lutea.-Iu small highland lakes. P. VII. VlIl.

\section{Order IV. PAPAVERACEA.}

Sep. 2. Cor. rcgular, of 4 petals. Stam. generally numerous, free. Ovary free, placcutas parietal, seeds numerous. Stigmas as many as the placentas, simple or lobed, the lobes of adjoining stigmas combining thus appearing (falsely) to be opposite to the placentas.

\section{* Seeds not crested.}

1. Papaver. Pet. 4. Stam. numerous. Style 0. Stigmas 4-20, radiating, sessile. Caps. obovate, opeuiug by pores beneath the stigma.

2. Meconopsis. Pet. 4. Stam. numerous. Style short. Stigmas 5-6, radiating, free. Caps, obovate, opening by pores beneath the apex.

3. Roemeria. Pet. 4. Stam. numerous. Stigmas 2-4, sessile. Caps. elongaterl, 2-4-valved, ]-celled, placentas distinct.

4. Glaucium. Pet. 4. Stam. numerous. Stigmas 2, sessile. Caps. elongated, 2-valved, placentas connected by a spongy dissepiment.

\section{** Seeds crested.}

5. Chelddonium. Pet. 4. Stam. numerous. Stigmas 2. Caps. elongated, 2-valved, l-celled, placentas distinct.

\section{Papaver Linn.}

†1. P. Argemone (L.); filaments dilated upwards, caps. clavate hispid with erect hristles, stem leafy many-flowered, 1. bipinnatifid.-E. B. $643 . R .4475$.-Fl. small. Pet, pale scarlet, black at the base. Bristles sometimes spreading.-In corn-fields, rather rare. A. VI. VII.

2. P. hybridum (L.); filaments dilated upwards, caps. ovate hispid with patent bristles, stem leafy many-flowered, 1. bipinnatifid.-E.B. 43. R.4476.-Fl. small. Pet. purplish, often with a dark spot at the base.-Sandy fields, rare. A. VI. VII. E. I.

3. P. Rhœas (L.); filaments subulate, caps. nearly globular smooth, margin of the stigma with incumbent lobes, stem hispid many-flowered, 1. pinnatifid cut.-E. B. 645. R. 4479.-Fl. large. Pet. deep scarlet, often nearly black at the base. Pcduncles with spreading hairs, or ( $\beta$, strigosum Boenningh.) with adpressed hairs.-In corn-fields, common. A. VI. VII. Common red Poppy.

4. P. dubium (L.); filaments subulate, caps. clavate smooth, 
margin of the stigma with distinct erenatmres, stcm hispid manyflowered, 1. pimnatifid.-E. B. 644. R. 4477.-Fl, large. Pet. light scarlet. Peduncles with adpressed hairs.-Corn-ficlds, common. A, VI, VII.

†5. P. somniferum (L.); filaments dilated upwards, caps. truly globular smooth as well as the calyx and stem, l. oblong unequally toothed anplexicaule.-E. B. 2145. R. 4481.-Fl. large. Pet. bluish white with a violet spot at the base. Whole herb smooth, except sometimes a few rigid spreading bristly hairs upon the flower-stalk and a bristle tipjing many of the teeth of the leaves, in which case it probably is the $P$. setigerum DC. -On sandy ground near the sea, and in the fens. A. VIl.

\section{Meconopsis Vig.}

1. M. cambrica (Vig.); caps. smooth, 1. stalked.-E. B. 66 . -Caps. oblong, beaked. Stem many-flowered, about 1 foot high. L. pinnate, cut, glaucous beneath. Fl. large, orangeyellow, on long stalks.-Rocky shady places, rare. P. VI.

\section{Roemeria Cand.}

† 1. R. hybrida (DC.); pod 3-valved erect with a few rigid liairs at its extremity.-E. B. 201.-Pod 2-3 in. long. L. twice or thrice pinnatifid with linear nearly smooth bristle-pointed segments. St. about 1 foot high, usually slightly hairy. Fl. violetblue. Pet. falling off before noon.-Chalky corn-fields in Cambridgeshire and Norfolk. A. VI.

E.

\section{Glaucium Tourn.}

1. G. luteum (Scop.); st. smooth, stem 1. amplexicaule sinnate, pod minutely tubercular-scabrous.-E. B. 8.-Glaucous. St. $1-3$ feet high, glabrous or slightly hairy. Root 1. stalked, lyrate, lobed and cut, hairy. Fl. large, golden yellow. Pods 6 -12 in. long, curved, glabrous.- Sandy sea-shores. B. VI.v1Il. Yellow Horned Poppy.

[2. G. phœniceum (Crantz); st. pilose, stem l. pinnatifid cut, pod hispid.-E. B. 1433.-Fl. scarlet with a black spot at the base.-Said to have been found in Norfolk. A. VI. V11.] E.

\section{Chemidonium Linn.}

1. C. majus (L.); peduncles umbellate, l. deeply pinnatifid: segments rounded and bluntly lobed.-E. B. 1581.-Fl. yellow, small. Pod long. St. 1-2 feet high. All parts fill of an orange juice.- [ $\beta$. laciniatum; segments of the leaves deeply pinnatifid: lobes inciso-serrate. C. laciniatum DC.]-Waste places and old walls. $\beta$, a very doubtful native. P. V,-VIII. 


\section{Order V. FUMARIACE.}

Sep. 2 or 0 . Cor. irregular, of 4 prarallel petals, one or both of the two outcr saceate at the basc. Stam. 6 , in 2 bundles opposite to the outer petals : lateral stam. in each bundle 1-celled. Ovary frec, 1-celled. Style filiform. Stigma with 2 or more points.

1. Corydalis. Cal. of 2 sepals or wanting. Pet. 4, the upper one spurred at the base. Stam. diadelphous. Pod 2-ralved, many-seeded, compressed.

2. Fumaria. Cal. of 2 sepals. Pet. 4, the upper one spurred at the base. Stam. diadelphous. Fruit a nut, indebiscent, 1 -seeded.

\section{Corydalis Cand.}

*? 1. C. solida (Hook.); root tuberous solid, l. biternate cut, lowest petiole a leafless scalc, bracts palmate.-E. B. 1471.Lobes of the l. obtuse. Fl. purplish. St. a span high. $-A$ very doubtful uative. P. IV. V.

E. S.

*2. C. lutea (DC.); root fibrous, l. triternate, bracts mimute oblong cuspidatc, secds shining granulate-rugose with a patent denticulated crest.-E. B. 588. - Leaflets obovate, trifid. Bracts shorter than the pedicels. Fl. yellow. St. about a foot high, brittle.-Naturalized on old walls. P. V.-VIIl. Yellow Fumitory.

E. S.

3. C. claviculata (DC.); root fibrous, leaves pinnate: pinnx ternate, footstalks ending in tendrils, bracts obloug acuminate.E. B. 103,-Leaflets entire, elliptical. Bracts rather longer than the pedicels. Fl. small, pale yellow or nearly white. St. slender, elimbing, $1-4$ fect long.-Busliy places in billy districts. A. V1. VI1. White Climbing Fumitory.

\section{Fumaria Linn.}

1. F. capreolata (L.); sep. ovate acute toothed as broad as the cor. and half its length, fr. globose very obtuse, bracts about $\frac{1}{3}$ shorter than the fruitstalks.-E. B. 943. R. 4456. Koch in St. 62. 13.-Sep. sometimes entirc. Fruitstalks patent or reflexed. Rarely the bracts are equal to, or longer than, the fruitstalks. Fl. cream-coloured, tipped with red ; lower pet. linear, green and boatshaped towards the end but not dilated, sides inflexed ; lateral pet. linear truncate apiculate with a narrow boatshaped wing at the back. Fr. smooth, longer than broad. St. climbing by means of the twisting petioles. $-\beta$. Leightonii; sep. broader and $\frac{1}{3}$ shorter than the cor., fr. rather broader than long.-Common. A. VI.IX. Rampant Fumitory.

2. F. officinalis (L.); sep. ovate-lanceolate acute toothed nar- 
rower and $\frac{2}{3}$ shorter than the cor. broader than the pedicel, fr. globose trmucate slightly emarginate, bracts 2 or 3 tinnes shorter thian the fruitstalks.- E. B. 589. R. 445\%. Koch in St. 62. 14. - rl. rose-coloured ; lower pet. spathulate, limb flat, green centre boatshaped, elaw with inliexed sides; lateral pet. nearly linear trumeate apieulate with a broad prominent rounded wing on their back towards the end. Fr. tuberenlar. St. erect, much branched. -Common. A. V.-IX. Common Fumitory.

3. F. micrantha (Lag.) ; sep. orbicular dentate broader than and nenrly half as long as the cor., fi. glohose not apiculate, bracts longer than the fruitstalks.-Arn. in Hook. Icon. Pl. $t$. 363. E. B. S. 2876. F. calycina Bab.-Fl. pale purple, in dense spikes. L. in numcrons linear scgments. Stems much branched.-Edinburgh, Fife, Dover, Guildford. A. VI.-IX. E. S.

4. F. parviflora (Lam.); sep. ovate cut as broad as and $\frac{2}{3}$ shorter than the cor., fr. globose pointed, bracts as long as the fruitstalks. -E. B. 590? R.! 445I. Koch in St. 62. 16.-I am but little acquainted with this species. Found at Woldliam in Kent by Mr. J. Rayer. A. "VIII. IX."

E.

5. F. Vaillantii (Lois.); sep. narrower than the pedicels many times shorter than the cor., fr. globose, bracts about as long as the pediccls.-E. B. S. 2877. R. 4452. Koch in St. 62. I5.Fl. white with a purple tip, or pale purple. St. slender, much branched, spreading. Leaftets in almost capillary segments.Common. A, VI.- IX.

\section{Order VI. CRUCIFER R.}

Sep. 4. Cor. cruciform of 4 petals. Stam. 6:4 longer in pairs opposite the anterior and posterior sepals and the stigmas, 2 shorter opposite the lateral petals. Ovary free, with parietal placentas meeting in the middle. Stigmas 2, opposite to the placentas (or rather, alternate with them, lobed and combining). Fruit a silique or silicle.

\section{Suborder I. SILIQUOSE.}

Pod (silique) linear or linear-lanceolate, opening by 2 valres.

Tribe I. ARABIDE $E$. Cotylerlons accumbent parallel to the dissepiment, radicle lateral, seed compressecl.

1. Matthiola. Pod round or compressed. Stigma 2-lobed: lobes erect gibbous or horned at the back.

2. Cheiranthus. Pod compressed or 2-edged, with an elevated longitudinal nerve upon each valve. Stigma 2-lobed: lobes patent. Seeds in a single row in each cell. 
3. Nasturtium. Pod nearly cylindrical, short: valves convex, almost nerveless. Stigma capitate. Seeds irregularly in 2 rows.-The short-podded species (N.amphibium) is scarcely distinguishable generically from Armoracia.

4. Barbarea. Pod terete: valves convex with a prominent longitudinal nerve. Stigma capitate. Secds in a single row.

5. Turritis. Pod compressed: valves slightly convex with a prominent longitudinal nerve. Stigma capitate. Seeds in 2 rows.

6. Arabis. Pod compressed : valves nearly flat with a prominent longitudinal nerve, or rarely ncrveless with numerous longitudinal veins. Stigma obtuse. Seeds in a single row,

7. CARdamine. Pol compressed: valves flat, nerveless. Stigma capitate. Sceds in a single row : funiculus simple, filifor'm.

8. Dentaria. Pod lanceolate, compressed : valves flat, nerveless. Stigma capitate. Sceds in a single row : funiculus dilated, winged.

Tr. II. SISYMBREAE. Cotyledons incumbent contrary to the disscpiment, radicle dorsal, seed compressed.

9. Hesperis. Pod quadrangular or subcompressed: valves keeled, somewhat 3-nerved. Stigma of 2 closely converging erect elliptical obtuse lobes. Seeds in a single row.

10. Sisymbrium. Pod terete, or rarcly tetragonal: valves convex, with 3 longitudinal nerves. Stigma entire. Sceds in a single row, smooth: funiculus filiform. - S. thalianum has its pod tetragonal with the valves angularly keeled and the lateral ncrves very slender.

11. Alliaria. Pod terete: valves convex, with 3 longitudinal nerves, the middle onc prominent and strong, the : lateral slender and branching. Stigma entire. Seeds in a single row, striated: funiculus flattened, winged.

12. ERYsimum. Pod tetragonal : valves prominently keeled, with 1 longitudinal nerve. Stigma obtuse, entire or slightly emarginate. Secls in a single row : funiculus filiform.

Tr. III. BRASSICEAE. Cotyledons conduplicate longitudinally folded in the middlc: radicle dorsal, within the fold.

13. Brassica. Pod terete : valves convex with one straight dorsal nerve, lateral nerves none or represented by a few anastomosing veins. Secds globose, in a singlc row. 
14. Sinapis. Pod terete : valves convex with 3 or 5 straight strong nerves. Secls globose, in a single row.

15. Frucastrum. Porl terete: valves convex with l straight dorsal nerve. Seeds oval or oblong, in a single row.

16. Diplotaxis, Porl eompressed : valves subconvex with 1 straight nerve. Seeds oval or oblong, in 2 rows.

\section{Suborkler II. LATISEPTE.}

Pouch (silicle) short, opening with two valves : dissepiment in its broulest diameter.

Tr. IV. ALYSSINEAE. Cotyledons accumbent.

17. Alyssum. Pouch roundish or oval, compressed. Sceds 2-4 in eaeh cell. Filaments usually toothed or the shorter ones with a gland or subulate process on eaeh side at the base.

18. Koniga. Pouch oval, compressed. Seeds $1-2$ in each cell. Filaments simple. Hypogynous glands 8. Carpophorum 0.

19. Draba. Pouch oval or oblong, slightly convex. Seeds many in each cell, not inarginel, in two rows. Filaments simple.

20. Cochlearia. Ponch globose: valves very convex, dorsal nerve prominent. Seeds numerous. Filaments simple.

21. Armoracia. Pouch globose: valves very convex, without a nerve. 'Seeds numerous. Filaments simple.

[Tr. V. CAMELINE E. Cotyledons incumbent.

22. Camelina. Pouch subovate: valves ventrieose with a lincar prolongation at the end whieh is eonfluent with the persistent style.]

[Tr. VI. VELLE E. Cotylerlons conduplieate.

23. Vella. Pouch ovate with a dilated winged leafy flat style longer than the convex valves.]

\section{Suborder III. ANGUSTISEPTE.}

Pouch (silicle) short, laterally eompresserl, opening with 2 boatshaped valves keeled and winged on the back: dissepiment narrow, linear, or lanceolate.

Tr. VII. THLASPIDEAE. Cotyledons aeeumbent.

24. Thlaspi. Poueh roundish, notched: valves boatshaped, winged at the baek. Seeds numerous. Pet. equal. Filaments simple. 
25. II utchinsia. Pouch elliptical, entire : valves boatshaped, keeled not winged at tlic back. Sceds 2 in each cell. Pct. equal. Filaments simple.

26. Teespalia. Ponch roundish notched: valves boatshaped, thicir back keeled below narrowly winged above. Sceds 2 in eacli ccll. Pet. cqual or 2 onter ones larger. Filaments with a little scale at the base of each within.

27. IBERIS. Pouch ovate or roundish, notched : valves boatshaped, winged at the back. Seeds 1 in each cell. Pet. unequal, 2 outer ones much larger. Filaments simple.

\section{Tr. VIII. LEPIDINERE. Cotyledons incumbent.}

28. LEPIDIUM. Ponch roundish or oblong, entire or notched : valves compressed, kecled or winged at the back. Sceds I in each cell. Filaments simple.

29. Capsella. Ponch triangular-obeordate: valves compressed, keeled but not winged. Seeds numerous. Filameuts simple.

Tr. IX. SUBULARIE E. Cotyledons incumbent, long, linear, curved back above their base. Cells many-seeded.

30. Subularia. Pouch oval-oblong, laterally compressed : valves boatshaped.

Tr. X. SENEBIERE $A$. Cotyledons incumbent, long, linear, curved back above their base. Cells one-seeded.

31. Senebiera. Pouch somewhat kidney-sliaped, entire at the end, or noteherl above and bclow and almost 2-lober, not burstiug. Cells l-secded.

\section{Suborder IV. NUCUMENTACEA.}

Pouch (silicle) scarcely dchiscent, often 1-celled owing to the absence of the dissepiment.

Tr. XI. ISATIDEA. Cotyledons incumbent.

32. Isatrs. Pouch laterally compressed, l-celled, l-seeded : valves keelerl, eventually separating. Cotyl. slightly channcled.

\section{Suborder V. LOMENTACEE.}

Silicle or silique dividing transversely in single-seeded cells, the true silique ofteu barren, all the seeds being in the beak.

Tr. III. CAKILINE $E$. Cotylerlons accumbent.

33. CAKILE. Silicle angular, of two l-seeded indehiscent 
joints, upper joint deciduous with an ereet seed, lower persistent secdless or witl a peulent seed.

Tr. XIII. RAPHANEAE. Cotylelons conduplicate.

34. Cranne. Silicle 2-jointed, ulper joint globose with 1 seed pendent from a long curver funiculus springing from the bottom of the cell, lower joint barren pedicelliform.

35. Rapranus. Silique linear or oblong, tapering upwarls, smooth and indchiscent, or nouiliform and dividing transversely into l-seeled eclls, lower'most cell barren imperfeetly 2 -ralved resenbling a pedicel.

\section{Suborder I. Siliquosa. Tribe I. Arabidea.}

\section{Matthiola $R$. Br.}

1. MI. incana (R. Br.); st. shrubby upright branched, l. lanceolate entire loary, pods "cylindrical without glands." $-E$. $B$. I935. R. 4354.-Fl. dull pale red.-Cliffs in the Isle of Wight. P. V. VI. Hoary Stock.

2. M. sinuata (R. Br.); st. herbaceous diffuse, l. oblong downy, lower l. sinuated, pods compressed muricated with glands. -E. B. 462. R. 4350.-Fl. pruple.-Sandy sea-coasts of Wales, Cornwall and Jersey. B. VI.-VIII. Sea Stock. E. I.

\section{Cheiranthus Iinn.}

†I. C. Cheiri(L.); st. slrubby, l, lanceolate acute entire with bipartite adpressed liairs, pods tetragonal.-E. B. 1934. R. 4347. -Fl. yellow or tinged with red. A variety with very narrow petals is found upon the walls of the Abbey of Bury St. Edmonds. -Old walls. P. IV. V. Common Wallflower.

\section{Nasturtium R. Br.}

I. N. officinale (R. Br.) ; pods linear about as long as their pedicels, l. pinnate, leaflets ovate or oblong subcordate sinuatedentate.-E. B. 855. R. 4359.-Fl. white. Pods patent. Very variable in size and in the form and size of its leaves. When growing out of water it is slender with small leaves and is N. microphyllum (R. 4360); when remarkably luxuriant, many fcet in length, the stem often nearly an inch thick and the leaves very large and resembling those of a Sium, it is N. siifolium $(R$. 4361).-Brooks and ditches. P. VI. VII. Water Cress.

2. N. amphibium (R. Br.); pods elliptical much shorter than their pedicels, $l$.oblong-lanceolate attenuated at both ends sessilc serrated or pinnatifil, pet. longer than the calyx.-E. B. 1840. R. 4363. a. $\beta$. $\gamma .-F l$. yellow. Submersed 1. pectinate-pinna- 
tifid. Pod erecto-patent. Should not this plant be referred to Armoracia, as is done by Meyer? It differs from our other Nasturtia by its very short porls with remarkably convex valves : the only character which sejarates Armoracia from Nasturtium. Its habit is that of $A$. rusticana. Watery places. P. VI.VIII.

3. N. anceps (Reich.); pods linear-oblong half as long as their pedicels, l. lyrate-pinnatifid, upper l. ollong inciso-dentate or piunatifid: segments oblong-lanceolate toothed, pet, twice as long as the calyx.-R. 4364.-Fl. yellow. Fruitstalks patent, pods asecnding.-River-sides. Bcrwick upon Tweed, Worcester, Newcastle upon Tyne, \&c. P. VII. VIII.

4. N. sylvestre (R. Br.); pods linear as long as their pedicels, all the $l$. deeply pinnatifid: segments oblong-lanceolate toothed, pet. twice as long as the calyx.-E. B. 2324. R, 4365, 4368.Fl. yellow. Pods patent or ascending.-River-sides and wet places. P. VI.-VIIII.

5. N. palustre (DC.); pods oblong turgid as long as their pedicels, lower l. lyrate, upper 1. deeply pinnatifid: segments oblong toothed, pet. as long as the calyx. $-R .4362$. N. terrestre Sm., E. B. I747.-Fl. yellow, small. Pods ascending, fruitstalks patent or even deflexed.-Wet places. P. VI.-IX.

\section{Barbarea $R . B r$.}

1. B. vulgaris (R. Br.); lower l. Iyrate : upper pair of lobes as broad as the large roundish subcordate terminal lobe, uppermost 1. undivided toothed, young pods obliquely erect.-E. B. 443. R. 4356.-Pct. twice as long as the calyx. Flowering raceme lax. Pods straight. Style about as long as the breadth of the ripe pod. $\beta$. arcuata; young pods patent upon nearly horizontal pedicels. $-B$. arcuata Reich. in St. xi. 43.-In damp places, B.? V.-VIII. Yellow Rocket.

2. B. stricta (Andrzj.); lower l. lyrate : upper pair of lobes small much narrower than the large oblong-ovate terminal lobe, uppermost 1 . undivided toothed, pods adpressed, styles slender. -R. 4355. B. parviflora Fies.-Pet. half as long again as the calyx. Flowering raceme close. Fl. much smaller than in the 2 preceding species. Pods straight. Lateral lobes of the lowermost 1. very small, often obsoletc.-Between Sheffield and Halifax aud between Weedon and Blisworth, plentufully. Mr. Borrer. York. B.? V.-VIII.

L.

3. B. $\operatorname{pracox}(\mathrm{R} . \mathrm{Br}$.); lower l. imparipinnate with large lobes : upper pair as broad as the subcordate terminal lobe, uppermost l. pinnatifid with linear-oblong entire lobes, styles short and thick.-E. B. II29. R. 4358.-Fl. moderate. Raceme closc. 
Porls patent. Lower l. usually interruptedly pinnate.-South of Eingland. B. V.-VII.

\section{Turritis $\operatorname{Linn}$.}

1. T. glabra (L.); radical l. toothed liairy, stem l. glabrous entire amplexicanle with a sagittate base, pods straight erect.E. B. 77\% R. R346.-Plant very ercet and straight. Fl. whitislyellow.-Banks, particularly in Norf. and Suff. Cliffs in Glen Deron, Scotland. B. VI. VIII.

E.

\section{Arabis Linn.}

1. A. hirsuta (R. Br.); l. hispid dentate, stem l. cordate-amplexicaule, pods erect narrow linear straight.-E. B. $587 .-\mathrm{St}$. I foot high, clothed with spreading mostly simple hairs and numerous erect leaves. Sometimes the hairs on the stem are adpressed and branched. Root 1. narrowed into a footstalk. Koch and Reich. divide this into two or more species which $I$ have not been able to determine.-Walls and banks. B. VI.-VIII.

2. A. ciliata (R. Br.); l. glabrous cihated somewhat toothed nearly sessile, stem $l$. sessile with a rounded base, pods erect narrow linear straight. $-E . B .1746$. R. 4338.-St. glabrous, erect. Seeds witlout wings.- Rocks by the sea, Cunnamara, Ireland. Glen Esk, Scotland. B. VII. VIII. S. I.

3. A. stricta (Huds.); l. hispid and ciliated with simple or forked bristles deeply sinuate-dentate narrowed into a footstalk, stem $l$. sessile, pods few distant crecto-patent straight. $-E$. $B$. 614. R. 4337.-St. crect, glabrous, hispid below, $6-8$ in. high. Fl. rather large. "Seeds with a narrow margin and winged at the apex."-Limestone cliffs near Bristol. P. IV. V. E. I.

4. A. petrca (Lam.); l. glabrous or with forked hairs lyratepinnatifid or oblong-orate nearly entire with long stalks, stem $l$. narrow nearly entire stalked, pods spreading slender straight.E. B. 469. A. Crantziana R. 4323. - St. erect or decumbent, 3-8 in. long, glabrous. Fl. large, white tinged with purple. Seeds oblong with a narrow margin and slight wing at the end. -Alpine rocks in England and Scotland. Ben Bulben, Ireland. Mr. Wynne. P. VII. VIII.

*5. A. Turrita (L.); 1. elothed with short forked hairs dentate elliptical narrowed into a stalk, stem l. deeply cordate amplexicaule elongated, pods flat with a thickened margin recurved from an crect stalk, seeds with a membranous margin.-E. B. 178. R. 4345. - St. 1 foot high, erect, hairy. Fl. yellowish. Pods 3-4 in. long, without any central nerve but with numerous prominent longitudinal anastomosing veins.-On walls at Oxford, Cambridge, and Cleish Castle Kinross. B. V. E. S. 


\section{Cardamine Limon.}

I. C. impatiens (L.); l. pinnate, leaflets of the lower l. orate 3-fid, of the npper l. oblong-lanceolate toothed or cntire, petioles of the stem $l$. with slender auricles, pet. linear or wanting.E. B. 80, R. 4302.-Pet. crect, whitc. Distinguished from the other British species by having auricles at the base of its petioles. -Hilly districts, preferring limestone. A. VII. VIII. E.

2. C. sylvatica (Link); 1. pinnate, leaflets of the lower $l$. roundish angled or toothed, of the upper l. narrower, pet. twice as long as the calyx, pods crect ipon patcnt pediccls, stam. 6 , style long.-R. 4303. St. 45. 13. C. flexuosa With.-Fl, small. Pet. ercet, white. St. flexuose, morc leafy than in C. birsuta.Common, especially in woody places, A IV.-IX. E. S.

3. C. hirsuta (L.) ; l. pinnate, leaflets of the lowcr 1. ronndish angled or toothed, of the upper l. narrower, pet. twice as long as the calyx, porls and perlicals erect, stam. 4, style short.-R. 4304. St. 45. 14.-Fl. small. Pet. erect, white. St. nearly straight, rather leafy.-Common in damp places. A. IV.-VIII.

4. C. pratensis (L.); I. pinnate, lcaflets of the lower 1. roundish slightly anglcd, of the upper l. linear-lanceolate entire, pet. 3 times as long as the calyx spreading, stam. half the length of the petals, st. terete.-E. B. 776. R. 4308.-Fl. large, lilac. Anth. yellow. Style short. - $\beta$. dentata (Koch); leatlets of the lower l. and those of the lower part of the stem acutely angular. $C$. dentata (Schnlt.) R. 4308. B. Reich. in St. 45. 15. -Noist meadows, common. $\beta$. near Cambridge. P. IV. Common Bittercress.

5. C. amara (L.); 1. pinnate, leaflets of the lower 1. roundishwate, of the upper l. oblong, all angular, pet. 3 times as long as the calrx crect, stam. nearly as long as the petals, st. angular.E. B. 1000. R. 4305.-Fl. large, wlite. Anthers purple. Style long, slender. Stigma small. St. rooting below.--Moist meadows near streams, rare. P. V. VI.

[C. bellidifolia (L.) which has simple entire l. has been erroneously considered as a native of Britain. E. B. 2355.]

\section{Dentaria Linn.}

1. D. bulbifera (L.) ; st. simple, l. alternate, lower l. pinnate, upper l. simple, axils of the l. producing bulbs. - E. B. 309. R. 4318.-Rlizoma thick, creeping, with fleshy toothlike knobs. St. $1-1 \frac{1}{2}$ foot high. Leaflets lanceolate, serrated or entire. Fl. large, rose-coloured or purple.-Woods and shady places, rare. Toubridge Wells, \&c. P. V. VI. Coralwort.

E. 


\section{Tribe II. Sisymbrere.}

\section{IIesperis Linn.}

†1. H. matronalis (L.); st. crect branched above, l. oratelanceolate acuminate toothed, pedicels alont as long as the calyx, pet. obovate obtuse with an apienlus, pods erect from a patent pedicel teretc torulose.-E. B. 731. R. 4378 and 4377?.-Fl. lilac, "fragrant," large and liandsome. H. inodora does not appear to differ from the cultivated plant more than would be caused by difference of situation.- Hilly pastures, very rare. B. V. VI. Dame's Violet.

[Halcolmia maritima (R. Br.), which has a terete pod and a conical stigma of 2 connate acutc lobes, is said to have been found wild, escaped from cultivation?, in Kient.]

\section{Sisymbirium Linn.}

1. S. officinale (Scop.); pods subulate adpressed to the stem, l. runcinate-pinnatifid with 2 or 3 pairs of oblong dentate lobes and a large liastate terminal lobe.-E. B. 735. R. 4401.St. 1-2 feet high with divaricated branches, upper part leafless. Fl. small, pale yellow. Pods on very short adjuressed stalks, solitary, pubescent sometimes glabrous.-Common. A. VI. TII. Hedge Mustard.

[*2. S. polyceratium (L.); pods subulate spreading sessile axillary about 3 together, l. lanceolate repando-dentate or subhastatc.-R. 4403.-St. leafy throughout, branched, "prostrate." Fl. small.-In the outskirts of Bury St. Edmonds but certainly an escape from cultivation. A. VII. VIII.] E.

3. S. Irio (L.); pods terete 4 times as long as their pedicels erecto-patent, the young pods exceeding the $\mathrm{H}$., seeds oblong, 1 . runcinate-pinnatifid : lobes dentate oblong the terminal lobe angular, lobes of the upper l. lanceolate with the terminal hastate. -E. B. 1631 . R. 4408.-St. erect, branched, and as well as the l. glabrons. Fl. yellow. Pods narrow, linear. Pedicels slender. -In the neighbourhood of old towns, rare. A. VII. VIII. London Rocket.

4. S. Sophia (L.); pods terete 3 times as long as their pedicels erecto-patent, seeds oblong, $l$. doubly or trebly pinnate: segments linear or linear-lanceolate-E E. B. 963. R. 4405.-St. erect, branched, and as well as the l. slightly downy. Fl. yellow. Pet. short. Pods linear, narrow. Pedicels slendcr.-Waste places, not common. A. VI.-VIII. Flixweed.

5. S. thatianum (Gaul.); pods 4-angular linear ascending twice as long as their patent pedicels, seeds oblong not striated, l. oblong-lanceolate undivided toothed.-Arabis Sm., E. B. 901. 
Conringia $R .4380$.- St. ereet, slender, mueh branehed, with few leaves whieh are ncarly all radieal. Fl. small, white. Pods angular on the back of the valves (tetragonous), not eonvex as in the other spceies (terete), nor with the lateral longitudinal nerves so strongly marked.--On walls and banks. A. IV. V. and IX. X.

\section{Aldiaria Adans.}

1. A. officinalis (Andrzj.); l. lieartshaped the lower ones reniform eoarsely repando-erenate or sinuate-dentate all stalked, porls erecto-patent mueh longer than their stalks, seeds oblong subeylindrieal striated,-E. B. 796. R. 4379. Sisymbrium Alliaria Sm., Koch.-St. ereet, $1-2$ feet high, slightly branched. L. large, thin, veined, smelling like garlie when bruised. Fl. white.-Hedgebanks. B. V. VI. Jack-by-the-Hedge. Saucealone.

\section{Erysimum Linn.}

1. E. cheiranthoides (L.); l. oblong-lanceolate slightly toothed with stellate-tripartite hairs, all narrowed into a slight footstalk, pedieels longer than the calyx, 2 or 3 times shorter than the pods, pods patent aseending, seeds small numerous. $-E$. B. 942 . $R$. 4383.--Seeds very small, so numerous in the pod as to be nearly 2-rowed. Fl. small. Pods always diverging from the stem.Cultivated ground. Wild in the Fens. B. VI.-VIII. E. I.

$[E$. virgatum is not now to be found, it was probably introduced accidentally at Bath.]

†2. E. orientale (R. Br.); l. elliptical heartshaped obtuse clasping the stem, radieal l. obovate, all smooth glaueous undivided entire.-E. B. 1804. Conringia orientalis $R$. 4382.--Fl. white or eream-eoloured.- "Fields and eliffs near the sea." Dingle, Kerry (in flax ficlds). A. V.-VII.

\section{Tribe III. Brassicea.}

\section{Brassica Linn.}

1. B. oleracea (L.); l. glabrous glaucous waved and lobed, lower l. lyrate, upper l. oblong sessile.-E. B. 637. R. 4438.L. thick and somewhat fleshy. Stam. all ereet. Fl. large, ereamcoloured. Raeeme elongated before the $\mathrm{fl}$. expand. Cal. ereet, adpressed. The wild state of the garden Cabbage.-Cliffs by the sea. B. VI.-VIII. Wild Cabbage.

2. B. campestris (L.); lower l. lyrate dentate somewhat hispid, upper l. ovate aeuminatc deeply cordate amplexicaule glabrous. E. B. 2234. R. 4434.-" Raceme elose, the open fl. rising above the buds." Fl. yellow. $-\beta$. Rapa; rout caulescent fleshy. 
B. Rapa Limn. E. B. 2176. R. 4437.-Borders of fields. A. or 13. VI. VII. Wild Navew. $\beta$. Turnip.

3. B. Napus (L.) ; lower 1. lyrate dentate glabrous, upper $l$. oblong somewhat narroved below with a dilated cordate semiamplexieaule brse.-E. B. 2146. R. 4435.—" Raceme elongated at the time when the fl. expand. Shorter stam. patent, ascendiug." Fl. yellow. It is difficult to find any character by which to distinguish this plant from the preceding.-Borders of fields. A. or B. V. VI. Rape, or Coleseed.

4. B. nigra (Koch); l, all stalked, lower l. lyrate tootherl: the terminal lobe large and lobed, upper l. lanceolate entire, calyx spreading liorizontally, pods adpressed to the stem.-Sinapis Sm., E. B. 369 . R. 4427.- Porls quadrangular. Fl. yellow. Lower 1. large, rough.-Hedgebauks aud waste places. A. VI. -VIII. Black Mustard.

\section{Sinapis Linn.}

1. S. arvensis (L.); pods subeylindrical knotty longer than the conical compressed beak, valves 3-nerverl, l. ovate the lowermost sublyrate stalked, upper l. sessile, ealyx spreading horizontally.-E: B. 1748. R. 4425.-Fl. large, yellow. Whole plant scabrous. Pods glabrous or rough with deflexed bristles; beak oecasionally with 1 seed; valves with faint intermediate nerves. Stem $1-1 \frac{1}{2}$ foot high.-Corn-fields. A. VI. VIII. Charlock.

2. S. alba (L.); pods eylindrical knotty shorter than the swordshaped beak, "valves 5-nerved," l. lyrate pinnatifid irregularly lobed, calyx spreading horizontally.-E. B. 1677. R. 4424.Fl. large, yellow. Pools hispid. St. 1-2 feet high.-Cultivated and waste land. A. VII. White Mustard.

3. S. monensis (Bab.); pods slightly tetragonous, valves 3-nerverl, beak 1-3-seeded, 1. glabrous stalkerl all deeply pinnatifid and mostly radieal: lobes oblong unequally toothed in the upper l. linear, calyx erect closed, st. glabrous.-E. B.962. Brassica $\mathrm{Sm}$., Hook.-St. usually prostrate. Fl. yellow.-On the western coasts. B. or P.? VIII. $\quad$ E. S.

4.? S. Cheiranthus (Koch); pods eylindrical, valves 3-nerved, beak 1-3-seeded, 1, hispid stalked all deeply pinnatifid : lobes oval-oblong unequally toothed in the upper l. linear, calyx erect closed, st. hispid below.-E, B. S. 2821. R. 4432. 4433.-St. l-3 feet high, erect, leafy. Fl. yellow. A doubtful speeies. "The bristles vary much in quantity on Merthyr Tydfil specimens, and are entircly wanting on those from Gower. They usually abound on the petioles and are not always absolutely wanting on the stems of S. monensis. Lobes of the leaves variable in form." Borr.-Sea-side burrows in Gower, and on cin- 
ders, \&c. by Carliff roal at Mertlyy Tylfil, S. Wales. Mr. Borrer. St. Aubin's Bay, Jersey. B. or P. VI.-VIII.

F.

\section{Erucastrum Schimper and Spenner.}

1. E. incanum (Koch); pods adpressed turgid with a short 1 -sceded beak, l. lyrate hispid, stem l. linear-lanceolate, st. much branched.-E. B.S. 2843. R.4423.-St. 1-3 feet high, branches divaricated with few very small leaves. Pods very short, glabrous or hairy, often searcely longer than their glabrous beak. Sandy places in Jersey and Aldcrney. B. VII. VIII.

O.

\section{Diplotaxis Cand.}

1. D. tenuifolia (DC.); st. shrubby below branched glabrous leafy, l. glancous linear-lanceolate very acute sinuate-dentate or pinnatifid: segments linear remotely dentate, pet. roundishovate with a short claw.-E.B.525. R.4420.-Sinapis Sm.Pedicels usually twice as long as the large yellow flowers. St. 1 $-1 \frac{1}{2}$ foot high. Plant foetil._Old walls. P. VII.-IX.-E. S.

2. D. muralis (DC.); st, herbaceous simple hispid and leafy at the base, l. almost glabrous ovate-lanceolate sinuate-dentate or pinnatifid, pet. roundish ovate with a short elaw,-E. B. 1090. R. 4417. Sinapis Sm.-Pedicels as long as the flowers. L. often blunt, never very acute, all collected about the base of the stem. Branches all springing from the base.-Dry banks and old walls, rare. A. VIII. IX.

\section{Suborder II. Latisepta. Tribe IV. Alyssinea.}

\section{Alyssum Limn.}

1. A. calycinum (L.); herbaceous hoary with starry pubescence, l. obovate-lanceolate attenuated below, porls orbicular stellate-pubescent, calyx persistent, filaments all toothless, shorter ones from between 2 setaceous processes.-E. B. S. 2853. R. 4269.-Cells of the pod 2-sceled. Pet. yellow, becoming at length white.-Grassy commons, S.; ploughed land, E. See Phytol. ii. 284. A. V. VI.

E. S.

[Farsetia incana (R. Br.); seeds 6 or more in each cell, pods pubescent subventricose; was observed for several years on old mearlow land recently broken up near Lewes by Mr. Borrer, and is said to have occurred similarly near Weymouth.]

\section{Koniga Adans., R. Br.}

*1. K. maritima (R. Br.): procumbent, liairs bipartite, l. linear-lanceolate acute, pods oval pointed glabrous.-E. B. 1729. R. 4266. Alyssum Sm. Lobularia Koch.-St. rather woody 
below. Fl. white, swect-secntel. Shonld the name Koniga be given up from its resemblance to Koenigia, this genus inust be called Lobularia after Desvaux, not Glyce with Liudley.-Naturalized near the sea. P. VIII. IX.

\section{Draba Linn.}

1. D. aizoides (L.); Scape lcafless glabrous, l. linear rigid acute keeled glabrous ciliated, stam. as long as the slightly notched petals, style as long as thic breadth of thic pouch. - E. B. 1271 . R. 4254.-l'l. bright ycllow. L. fringed with rigid hairs, densely collected into cushion-like tufts. - On rocks and walls at Pennard Castle near Swansea. P. III. IV.

E.

2. D. rupestris (R. Br.); scape leafless or with I or 2 leaves pubescent, l. lanceolate flat stellately pubescent, stam. shorter than the slightly notched petals, style short.-E.B.1338. R. 4245. D. hirta Sm.-Pouch oblong-oval, slightly hairy. St. very short, branched, each branch bearing a dense tuft of leaves and 1 -3 short scapes. Fl. small. L. mostly entire.-Tops of the highland mountains, rare. P. VII.

S. 1 .

3. D. incana (L.); stem l. several, l. lanccolate stellately pubescent toothed, pet. twice as long as the calyx entirc, pouch longer than its pedicel twisted, style short slender.-E. B.388. R. 4249.-Pouch nearly or quite glabrous, erect, lanceolate-oblong. St. 4-I2 in. ligh, simple or branched. Fl. white-Mountains. Sand hills by the sea in Islay, S. P. VI. VII.

4. D. muralis (R. Br.); st. leafy branched, 1. ovate amplexicaule toothed hairy, pet. "entire," pedicels spreading horizontally rather longer than the glabrous pouch.-E. B. 9I2. R. 4235.-Pouch elliptical. St. 5-12 in. high. Fl. white. Pubescence branched. : Root 1. attenuated below.-Limestone mountains. A. IV. V.

5. D. verna (L.); scape leafless glabrous above, l. lanceolate acute attenuatel below liairy, pet. deeply cloven, pouch oblong shorter than its pedicel.-E. B. 586. R. 4234.-Pouch compressed, acute or rounded at the end. Fl. white. L. entire or toothed. Scape sometimes rather pilose.- $\beta$. inflata (IIook.); pouch inflated. Probably D. spathulata (Lang.) Hoppe in St. 65. I. D. precox Reich. 4233 , in which the pouches when transversely cut present a nearly circular section.-Very common on walls, banks, \&c. $\beta$; Ben Lawers. A. III.-V. Common Whitlow-grass.

\section{Cochlearia Limn.}

1. C. officinalis (L.); radical l. cordate-reniform stalked, c 2 
stem l. sessile oblong sinuated scmiamplcxicaule, pouch globose or obovate-obtuse.-E. B.551. R. 4260.-Petioles long. Lower 1. entire or simuated. Secls large. Style short. St. occasionally rooting and proliferous. $-\beta$. alpina; pouch obovate, leaves smaller. C. groenlandica Sm., E. B. 2403.--Sca-coast, mostly in muddy places. $\beta$. on the higher parts of mountains. 13.? Vİ. -VIII. Common Scurry-grass.

2. C.danica (L.); l. stalked, radical l. cordate somewhat lobed, stem 1. 3-5-lobed subdeltoid uppermost subsessile, pouch ovate. -E. B. 696. R. 4257.- Petioles of the root l. very long, gradually shortening as they become more distant from the root. Sceds small. Style short.-Sca-coast. A. V.-VIII.

3. C. anglica,(L.) ; radical l. stalked ovate-oblong entire, stem 1. oblong entire or toothel mostly sessile the upper ones amplexicaule, pouch oval-oblong with net-like veins.-E.B.552.R. 4258.-Pouch twice as large as that of $C$. officinalis, much compressed laterally. Seeds large. Style ratler long. Lower 1. rounded below or narrowed into a footstalk. Fl. large.-Seasliores. A. V. English Scurvy-grass.

\section{Armoracia Fl. Wett.}

1. A. rusticana (Fl. Wett.); radical l. oblong crenate-serrate on long stalks, stem l. elongate-lanceolate inciso-serrate or entire subsessile, pouch oval "4-seeded."-Cochlearia Armoracia (L.) E. B. 2323. R. 4262.-St. 2-3 feet high. Roots long and thick, running deep into the ground.-Wastes and pastures near Swansea, abundant. Mr. Borrer. Elsewhere, scarcely wild. P. V. Horse Radish.

\section{Tribe V. Camelinece.}

\section{Camelina Crantz. Gold-of-pleasure.}

[1. C. sativa (Cr.); pouches pearshaped, intermediate stem $\mathbf{l}$. lanccolate sagittate at the base entire or denticulate.-E. $B$. 1254. R. 4292.-Pouches large, on long stalks. Fl. small, yellow.-In flax fields; not even naturalized. A. VI. VII.]

[C. dentata (Pcrs.) R. 4294, las equal claims to be almitted into our list, althongh deciledly not a native plant. It is distinguished by its sinuate-dentate or pinnatifid l. attenuated below but still sagittate at the base; its secds are stated to be twice as large as those of C. sativa, in company with which it occurs.]

Tribe VI. Vellea.

\section{Velua Linn.}

[1. V. annua (L.); "l. doubly pinnatifid, pouches deflexerl." 
- E. B. 1442.-Found in the time of Ray on Salisbury Plain, but las not since been noticel. A. VI.] E.

\section{Suborder III. Angustisepta. Tribe VII. Thlaspidea.}

\section{Thlaspi Iinn.}

1. T. arvense (L.); fruithearing raceme elongated, pouches orbicular with a broad longitudinal wing, seeds concentrically rugose and striated, stem l. oblong sagittate toothed.-E. B. 1659. R. 4181.-Cells above 6-seeded. Poucl very large with remarkably broad wings. Stigma subsessile. St. of ten a foot high. T. alliaceum (L.) differs from this by having a narrower wing to the pouch and foreolate-reticulate seeds.-Fields and road-sides. A. V.-VII. Penny Cress.

2. T. perfoliatum (L.); fruitbearing raceme elongated, pouches obcordate, style included within the notch, sceds $3-4$ in each cell smooth, stem l. cordate-oblong.-E. B. 2354. R.4183.Ahout 6 in. high.-Limestone pastures in Oxfordshire and Gloucestershire. A. V.

3. T. alpestre (L.); fruitbearing racemes elongated, pouches triangular-obcordate, style exserted, seeds numcrous, stem l. oblong-cordate--E.B. 81.-Stam. as long as the petals. St. simple, several from the same root, $6-12 \mathrm{in.} \mathrm{long.-Limestone}$ mountain pastures. P. VI.-VIll.

E. S.

\section{Hutchinsia $R$. $B r$.}

1. H. petrea (R. Br.); 1. pinnate, st. branched leafy, pet. scarcely longer than the calyx, pouches obtuse at both ends.-E. B. 111. R. 4190.-A small plant, $2-4$ in. high, with small flowers. Differs from Teesdalia by wanting the scales at the base of the filaments; from Noccea (R.), by its accumbent cotyledons.-Limestone rocks, rare. A. III.-V.

\section{Teesdalia $R$. Br.}

1. T. nudicaulis (R. Br.); petals unequal.-E. B. 327. R. 4189.-L. numerous, spreading on the ground, lyrate-pinnatifid, rarely orbicular-spathulate and entire. St. 2-4 in. ligh, solitary or several from the crown of the root, sometimes bearing 1 or 2 small leaves. Stam. with remarkable scales within. Pouch emarginate.-Sandy and gravelly places. A. V. VI. E. S.

\section{IBERIS $\operatorname{Linn}$.}

1. I. amara (L.); herbaceous, 1. lanceolate somewhat toothed, pouches racemose orbicular notched : lobes triangular porrect.E. B. 52. R. 4197.-L. usually with $1-3$ obtuse teeth on each side. St. often 1 foot high, diffuse, branched. Fl. at first co- 
rymbose, afterwards in lengthened clusters. Outer pet. radiant. Chalky fields. A. VII. Bitter Candytuft.

\section{Tribe VIII. Lepidinea.}

\section{LEPIDIUM Linn.}

* Po 1 ch cordate with turgid valves, style filiform.

* I. L. Draba (L.) ; l. oblong entire or toothed lower ones narrowed into a footstalk, stem l. sagittate and amplexicaule, style as long as the dissepiment.-E. B. S. 2683. R. 42II.One foot or more in height, branched, producing a somewhat umbellate corymb of uumerous small white flowers upon long pedicels.-In Kent; uear Swansea; and other places. Introduced. P. V. VI.

** Pouch oval or somewhat orbicular winged notched.

† Siyle manifest.

2. L. campestre (R. Br.); l, downy toothel lower ones oblong narrowed into a footstalk, stem l. lanceolate sagittate and amplexicaule, pouch ovate rough with minute scales notched and rounded at the end, style scarcely longer than the notch.-E.B. I385. R.4214. - Scales on the pouch only minute globular blisters when fiesh. St. upright, about a foot high, branched in the upper part. Smith mentions a rar. with the l. nearly glabrous, and one with a few hairs on the pouch.-Dry gravelly soil. A. VI.-VIIII.

3. L. Smithii (Ilook.); l. hairy toothed lower ones obcordate stalked, stem l. lanceolate-sagittate amplexicaule, pouch ovate glabrous notched and rounded at the end, style twice as long as the notch.-L. hirtum Sm., E. B. 1803.--Seeds $\frac{1}{2}$ as long as in $L$. campestre. Pouch sometimes with a few scales, never liairy as in L. hirtum (R.4213.) which has the lobes of the pouch acute. - Iledge-banks. P. VII. VIII.

$$
\dagger \text { Scarcely any style. }
$$

[L. sativum (L.); lower 1. lobed pinnate or bipinnate, upper 1. sessile limear cntire, pouch roumdish oval, obtuse.-R. 4212.Escaped from cultivation in many places.]

*** Pouch oval or roundish notched, scarcely any style.

4. L. ruderale (L.); lower l. pinnatifid, upper l. linear entire, pouch roundish-oval notched patent, fl. diandrous without petals. -E. B. 1595. R. 4215.--Pouch with a very uarrow wing at the end. St. branched, often a foot high. Radicle dorsal.-Waste places near the sca. $\Lambda, \mathrm{V}$.

***** Pouch oval or roundish scarcely notched wingless, scarcely any style.

5. L. latifolium (L.); l. ovate-lanceolate serrate or entire undivided, pouch oval entire downy.-E. B. 182, R. 4219.-Fl. 
mumerons, small, in compound leafy panicled clusters. St. 3 feet ligh, erect, branched. L. large, the lower ones spon long stalks, the upper nearly sessile and narrower.-In salt marshes and sandy places near the sea.-P. VII. VIII.

\section{Capselua Vent.}

I. C. Bursa-pastoris (DC.); radical l. lanecolate pinnatifil or undivided toothed, upper l. undivided, ponch triangnlar'-obcordate. -Thlaspi Sm., E. B. I485. R. 4229.-Varying greatly in the form and divisions of its leaves but easily known by its pecnliar pouches.-A common weed. A. III.-X. Shepherd's Purse.

\section{Tribe IX. Subulariea.}

\section{Subularia Linn. Awl-wort.}

1. S. aquatica (L.)-E. B. 732. R. 4232. Hook. Lond. I35.Cotyledons only once folded, but they are in a continuous straight line with the radicle and then curved back upon themselves above ther base, therefore incumbent not bicrures. Plant small, subaqueons. L. linear-subulate, radical. Root of numerous long white fibres. Fl. small, often perfected uuder water.-Margins of alpiue lakes. P. VII.

\section{Tribe X. Senebierea. \\ 31. Senebiera Cand.}

I. S. Coronopus (Poiret); pouch undivided reniform crested with little sharp points, style prominent, 1. pinnatifid.-E. B. 1660. R. 4210 . St. much branched, prostrate. Fl. small, white, in lateral clusters. Pouches large, in dense clusters. Cotyledons in this and the following species forming a slight angle with the radicle, then curved back upon themselves and afterwards their points parallcl to the radicle; therefore the bend is above the base of the cotyledous, uot at their base as is usual in Cruciferce. - Waste ground, common. A. VI.-IX.

2. S. didyma (Pers.); pouch notched of two wrinkled lobes, style extremely short, l. pinnatifid.-E. B. 248. R. 4209.-St. spreading, prostrate, a foot or more in Iength. Fl. small white in long slender lax clusters.-Waste ground near the sea in the south and south-west. A. VII.-IX.

E. I.

\section{Suborder IV. Nucumentacea. Tribe XI. Isatidea.}

\section{Isatis Linn.}

†1. I. tinctoria (L.); "radical leaves copiously crenate, those of the stem entire, pouch abrupt smooth thrice as long as broad." 
- E. B. 97. R. 4177.- "In cultivated fields in the east of England, but rare. B. VII." Dyer's Woad.

\section{Suborder V. Lomentacea. Tribe XII. Cakilinea.}

\section{Cakile Gaert.}

1. C. maritima (Scop.); joints of the pouch 2-edged, the upper one with 2 tecth at the base, 1 . fleshy pinnatifis or somewhat toothed.-E. B. 231. R. 4158.-Fl. purplish. Pouches an inch long, ercet, with 4 sharp angles, swordshaped in the upper part. -Sandy sea-shores. A. VI. VII. Purple Sea-Rocket.

\section{Tribe XIII. Raphanea.}

\section{Crambe Linn. Sea-kale.}

1. C. maritima (L.); longer filaments forked at the end, pouch without a style, l. roundish sinuatel wary toothed glaucous and as well as the st. glabrous.-E. B. 924. R. 4164.-Root thick, fleshy, St. 2 fect high. Fl, white.-Sandy sea-shores. P. VI.

\section{Raphanus Linn.}

1. R. Raphanistrum (L.); pods moniliform striated shorter than the very long beak, l. simply lyrate.-E. B. 856.R. $4172 .-$ Lobes of the leaves quite distinct.-Corn-fields. A. VI. VII. Jointed Charlock.

2. R. maritimus (Sm.); pods moniliform striated beak shorter, radical l. interruptedly pinnate.-E. B. 1643. R. 4174.-Lobes of the l. usually so close as to overlap each other.-Sea-coasts, rarc. B.? VI.-VIII. Sea Radish.

The fruit of Raphanus, Cakile, and Crambe consists of a very small 2-celled pedicelliform usually sterile pod with a long moniliform beak bearing the seeds and dividing transversely into as many indehiscent cells as there are seeds. See Prim. Fl. Sarn. 10. This is the true structure of the Siliqua lomentacea.

\section{Order VII. RESEDACEA.}

Sep. 4 or 5 or 6 , persistent. Cor. irregular, pet. $4-6$ entire or lacerated. Stam. 10-24, filaments variously united, inserted on a glandular irregular l-sided disk. Ovary 3-lobed, l-celled, with 3 parictal placentas. Fruit opening early at the end. Embryo curverl.

1. Resedi. Cal. many-parted. Pet. entire or variously cut, unequal. Stam. numerous. Fruit of one cell opening at the top. Styles $3-6$. 


\section{Reseda Linn.}

1. R. lutea (L.); sep. 6 lincar, pet. 6 very unequal as long as the sepals, l. 3-cleft or pinnatifid.-E. B. 32L. R. 44-46.-L. very variable. Two upper pet, with 2 winglike lobes, lateral pet. witls a siugle wing, lower oncs nearly entirc. Fl. yellow. Fr. oblong, wrinkled. St. 2 feet high, branched, smooth.-Waste plaecs in chalky and limestone districts. B. VI.-VIII.

†2. R. fruticulosa (L.); scp. 5 linear-lanceolate, pet. 5 nearly equal 3-fid longer than the calyx, $l$. all pinnatifid: scgments lincar acute sometimes wavy.-E. B. S. 26228. R. 4449.-Fl. white. l'r. oblong, wrimkled. St. $1 \frac{1}{2}-2$ feet high, rather shrubby below. This plant is sometimes found with 6 sep. and pet. when it appears to be $R$. alba (L.).-Waste sandy places near the sea, rare. B. or P. V'II. VIII.

3. R. Luteola (L.); sep. 4 , pet. 4 or 5 very unequal longer than the calyx, $l$. elongate-lanceolate undivided. $-E . B .320 . R$. 4442.-Pet. usually 4, upper onc 3-, 4-, or 5-cleft, 2 lateral 3cleft : segments linear, lower one (or 2 ) linear entire. Fr. broad, depressed. St. 2 fect high.-Waste places, particularly on chalk or limestone. B. VII. VIII. Weld.

\section{Order VIII. CISTINEE.}

Sep. 5 , two outer smaller sometimes wanting, 3 inner with a twisted æstivation. Pet. 5, corrugated and twisted in æstivation the contrary way to the sepals. Stam. numerous. Ovary l- or many-celled. Style and stigma simple. Fruit capsular, with 3, 5 or 10 valves. Embryo spiral or curved, in the midst of the albumeu.

1. He Lianthemum. Cal. of 5 scpals, the two exterior smaller or wauting. Pet. 5, deciduous. Stam. numerous. Caps. with 3 valves.

\section{Helianthemun Gaert.}

1. H. guttatum (Mill.); erect herbaceous, l. oblong-lanceolate or linear, lower l. opposite without stipules, upper alternate with or without them, racemes without bracts, stigma subsessile.-E.B. 544. R. 4526.-Upper l. usually with sinall stipules. Fruitstalks patent. Pubescence of long simple hairs intermixed with short stellate oues. Fl. yellow, usually with a deep red spot at the base of each petal. "Anth. not emarginate at the apex."-Very rare. Three-Castle Head, Cork. Miss H. Townsend. Jersey. A. VI.-VIII.

I.

2. H. Breweri (Planchon); erect herbaceous, $l$, obovate obtuse rosulate without stip., upper l. linear with or without stip., racemes with bracts. -Lond. Journ. of Bot. iï. 618, $t$. 21.-St. single in 
wild specimens ("branching from the basc," Plan.). Pct. narrow, yellow not spotted. Fruitstalks ercet-patent. Pubescence as in II. guttatum.-Very rarc. Ilolyhead Mountain and near Amlwel, Anglesca. A. VI.-VIII.

3. H. canum (Dum.); shrubby, without stipules, l. oppositc ovatc or oblong stalked flat loary bencath, racemes terminal bracteated, "style twisted at the base reflexed, at the apex inflexed."-Cistus marifolius Sm., E. B. 396. C. anglicus and C. canus L.-Fl. yellow, small. St. dccumbent. L. lioary beneath, hairy abovc. "Anth. cmarginate at both ends. Style longer than the stigma."-On alpine limestone, rare. P. V.-VII. E.

†4. H. ledifolium (Willd.); herbaceous, with stipules, downy, l. lanceolate opposite the upper ones alternate nearly sessile pubescent, peduncles solitary opposite to the leaves shorter than the calyx, styles straight.- E. B. 24I4.-I am only acquainted with this plant from the figurc and descriptions, it appears to be more correctly C. niloticus than C. ledifolius of Linn., but the two plants are only varictics of one specics.-Brent Downs, Somerset, not found for many years. A. VI. VII.

E.

5. H. vulgare (Gaert.); procumbent, shrubby, with stipules, 1. oval or linear-oblong opposite nearly flat green above hoary beneath, racemes bracteated, style longer than the ovarium bent at the base, inner sep. obtuse apiculate.-Cistus Helianthemum (L.) E. B. 1321. R. 4547. 4548.-Fruitstalks contortel and deflexed. Varying much in the size and shapc of its lcaves and the amount of hoariness and pubescence. $\mathrm{Fl}$. yellow.-C. tomentosus E. B. 2208. does not appear to differ in any essential point from this plant. I have never seen the "stipules hoary."-C. surrejanus E. B. 2207. (from a garden specimen of Mr. Dickson's) is not the Croydon plant (Dill. Hort. Elth. $t$. 145.) which was again found there by the late Mr. Cliristy and is a monstrosity of H.vulgaris. -Common on dry lilly places. P. VII.-IX. Common Rockrose.

6. H. polifolium (Amott); hoary with stellate pubescence, shrubby, procumbent, with stipules, $l$. opposite ovate-oblong or oblong-linear morc or less revolute hoary on both sides, racemes bracteated, style bent at the base longer than the germen, inner sep. obtuse.-E. B. 1322. H. apenninum DC. $-F l$. white. Distinguished from the H. polifolium(DC.) by the hoary upper surfaces of the leaves and stellate pubescence.-Very rare. Brean Downs, Som.; and Torquay, Devon. P. VII. VIII.

E.

\section{Order IX. VIOLACEE.}

Sep. 5, imbricate. Pet.5, regular or irregular. Stam. 5, filaments dilated, connective elongated beyond the anthers into a 
flat menbrane. Ovary l-celled with 3 parictal placentas. Style with a hooded stigma. Caps. with 3 valves. Embryo straight, in fleshy albumen.

1. Vrous. Sep. 5, cxtended at the base. Pet. 5, unequal, the lower one prodncel into a hollow spur bchind. Stam. 5 . Anth. combined into a cylinder, 2 lower ones spurred behind.

\section{VIOLA Limn.}

\section{* Stemless or nearly so.}

1.V. palustris (L.); anth.-cells nearly parallel, anth.-spurs short thick rounded, spur of the cor. very short obtuse, $l$. reniform-cordate glabrous.-E. B. 444. R. 4491.-Antherine spur concave below, convex above; anth.-cells slightly separated below. Fl. pale lilac with purple streaks. Sometimes the petioles are slightly hairy but usually glabrous.- $[$ In V. uliginosa (Schr.) which is closely allicl to this the anth.-spur is longer, much less curved and more narrowed at the end and the stipules adnate.] Bogs in mountainous districts. P. IV.-VI. Marsh Violet.

[I have reason to think that an imperfect specimen of Viola from the island of N. Uist, S., is the $V$. epipsia (Led.) Fries, which has short ped., longer free stip. and cordate adpresseddentate lcaves.]

2. V. odorata (L.); anth.-cells diverging below, anth.-spurs lancet-shaped decurved blunt, spur of the cor. obtuse straight, lateral pet. entire lower one emarginatc, 1. cordate, scions creeping.-E. B. 619. R. 4498.-Anth.-spurs narrowed to an obtuse point. Spurs of the pet. inflated towarks the end, slightly channeled above. Fl. purple, often white, sweet-scented. Bracts above the midllle of the flowerstalk. Petioles with deflexed hairs. Lateral pet. with a hairy line which is sometimes wanting when the plant becomes $V$. imberbis Leight. Caps. globose downy,Common. P. III. IV. Sweet Violet.

3. V. hirta (L.); anth.-cells diverying below, anth.-spurs nearly linear obtuse, spur of the cor. obtuse hooked at the end, pet. entire or slightly emarginate, l. corlate, scions wanting.-E. $B$. 894. R. 4493.-Sep. obtuse. Anth.-spur's scarcely broarler at the base than at the apex. Spur of the petals compressed, not channeled. Fl. pale blue, sometimes white, scentless. Lateral pet. usually with a hairy line. Bracts below the middle of the Howerstalk. Stip. not hispid at the margin. Petioles with spreading hairs. Caps. globose, downy.- $\beta$. calcarea (Bab.); fl. smaller, pel. much longer than the leaves, sep. oblong-ovate obtuse.-Common on limestone. $\beta$. Gogmagog Hills, Cambridge. P. IV. V. Hairy Violet. 
**With an evident stem.

4. V. sylvatica (Fries); anth.-cells parallel, anth.-spurs lancetshaped acute, spur of the cor. cylindrical obtuse, l. cordate more or less acute, stip. ${ }^{1}$ lanceolate-attenuated fimbriate-ciliate much shorter than the petioles, primary st. short and barren witlı accessary flowering branches, caps. oblong acute glabrous.- - R. 4503 . R. riviniana $R .4504$ ? V. sylvestris Koch.-Fl. blue or rarely white, scentless.-Commou? P. IV. V.

E. S.

5. V. canina (L.); anth.-cells parallel, anth.-spurs lancetshaped acute, spur of the cor. obtuse, l. cordate-orate or -oblong, stip. lanceolate entire ciliate or dentate, primary st. elongated, caps. truncate-obtuse apiculate glabrous.-E. B. 620.-Spurs of the pet. inflated in their lower half, slightly channcled above. Fl. blue or rarely white, scentless. L. acutc. Stip. usually oblonglanceolate.- $\beta$. pusilla; 1 . roundish-cordate rather acute small, $\mathrm{fl}$. large, base of the stems woody. V.flavicornis Sm., E. B.S. 27.36. $\rightarrow \gamma$. montana; similar to $\beta$. but with the l. cordate-oblong. $V$. montana Linn.- $\delta$. Ruppii; l. cordate-ovate subattenuated above and slightly narrowed into the petiole, stip. large incised, base of the stem woody.-Common. P. IV. V. Dog Violet.

6. V. lactea $(\mathbf{S m}$.); antl.-cells parallel, anth.-spurs lanectshaped acutc, spur of the cor. obtuse, l. ovate-lanceolate-attenuate rounded below and narrowed into the petiole: lowermost corlate, stip. linear-lanceolate inciso-serrate shorter than the petioles, caps. oblong acute glabrous.-E. B. 445.-St. ercet, sinple. Fl. pale, scentless. L. equally attenuated to an acute point. To be carefully distinguished from V. canina, $\delta$. Ruppii which is often taken for it and has probably given rise to the opinion that this plaut chauges into $V$. canina. See Fries Mant. iii. 118-127.-Boggy heatls. P. IV.-VI. E.

7. V. lutea (IIuds.); anth.-cells nearly parallel, anth.-spurs elongated filiform, spur of the cor. as long or longer than the calycine appcudages, sep. acute, 1 . crenate-serrate lower ones ovatecordate, upper l. ovate or lanceolate, stip. palmate-pinnatifid: terminal lobe linear or linear-lanceolate entire, st. ascending.E. B. 721. R. 4519.-Fl. wholly yellow, yellow with the 2 upper petals purple or wholly purple, varying greatly in size. Caps. globose. All the lobes of the stip. of nearly equal size, lateral ones (usually 3 ou onc side and 1 on the other) all springing from near the base of the stip., the terminal lobe narrow and always quite entire but sometimes considerably larger than the others. - $\beta$. Curtisii; stems angular rough, lower part of the stip.

1 The stipules on about the middle of the stem should always bc examined in determining the species of Viola, the others are variable in form.-See Aun. Nat. IIist. x. 100.-Trans. Bot. Soc. Edin. i. 75. 
somewhat clongated so as slightly to separate the lateral lobes. V. Curtisii E. B. S. 26.93.-Mountainous pastures. $\beta$. Sands near the sca. P. VI. VII.

8. V.tricolor (L.); anth.-cells diverging below, anth.-spurs elougate subclavate-filiform, spur of the cololla about equalling the ealycine appendages, 1 . crenate-serrate lower ones ovatecordate, 1)per 1. ovate or ovate-lanceolate, stip. lyrate-pinnatifid: terminal lobe spathulate crenate, st. ascending.-E. B. 1287. R. 4517. V. Curtisii (Mack.) from Portmarnock.-Fl. witl the upper pet. purple, lateral ones bluish, lower one yellow. Caps. orate. I liave never found the terminal Iobe of the stip. quite entirc, although it often las only one tooth on cach side.$\beta$. arvensis; pet. shorter than the calyx whitish, caps, nearly globular. V. arvensis E. B. S. 2712.-Common. A. V.-IX. Heartsease, Pansy.

\section{Order X. DROSERACEA.}

Sep. 5, imbricate. Pet. 5, regular. Stam. 5 or 10 , free. Styles 3 or 5. Ovary free. Caps. 3-5-valved. Seeds without an arillus. Embryo straight, iu fleshy albumen.-L. with a circinate velnatioll.

1. Drosera. Cal. deeply 5-cleft. Pet. 5. Stam. 5. Styles $3-5$, deeply bifid. Caps. 1-celled with $3-5$ valves, manysceded.

2. Parnassia. Cal, decply 5-cleft. Pet. 5. Stam. 5, with 5 scales finged with glandular setre interposed. Stigmas 4 , scssile. Caps. 1-celled, with 4 valves.-Differs from this Order by wanting the circinate veruation, and is referred by Lindley to Saxifragee and by Don to Hypericinea.

\section{Drosera Linn. Sundew.}

1. D. rotundifolia (L.) ; 1. orbicular spreading, petioles hairy, peduncles erect, seels with a loose chaffy coat. $-E . B .867 . R$. 4522.-Flowering stalks 2-6 in. high. "Stigmas white, clubbed, entirc. Anth. white." Borr. L. covered, as in all our species, with hairs terminating in large glands secreting a viscid fluid which retains insects that settle upon them.-Common in boggy places. P. VII. VIII. Round-leaved Sundew.

2. D. longifolia (L.); 1. spathulate obtuse erect, petioles glabrous, peduncles arcuate or decumbent at the base, sceds with a close rough not chaffy coat.--E. B.868. D. intermedia $R .4523$., Koch, Fries._"Stig. pink, bifid. Antl. yellow." Borr. A variety with shorter leaves and the flowering stalks shorter than the leaves is found in Ireland and Scotland.-Commou in boggy places. P. VII. VIII. 
3. D. anglica (Huds.); l. obovate-lanceolate obtuse erect, petioles glabrous, peduncles erect, seeds with a loose chaffy coat. -E. B.869. D. longifolia R. 4524., Koch. Fries.-Much larger and taller than the last. $A$ variety is common in Scotland with broader leaves and the styles often, though not always, emarginate. It is D. obovata (M. and K.) R. 4525.-In bogs, rather riure, common in Ireland. P. VII. VIII.

\section{Parnassia Limu.}

1. P. palustris (L.) ; filaments of the petaloid scales $9-13$, pet. with a short claw, radical l. cordate stalkel, stem l. amplexicaule.-E. B. 82. R. 4520.-Pet. white, veinerl. Glands of the scales yellow. L. mostly radical.-Wet and boggy places, particularly in the north. P. VIII-X.

\section{Order XI. POLYGALEN.}

Sep. 5, imbricate, irregular, 2 interior much larger petaloid. Pet. unequal, usually 3, 1 anterior and larger than the rest. Stam. monadelphous, separating above into 2 equal opposite bundles. Anth. l-celled, opening by a pore at their apex. Caps. 1-3-cclled, with placentas in the axis. Seeds pendulous, usually with an arillus at the base.

1. Polygala. Sep. 5, persistent, 2 inner (wings) broader and often petaloid. Cor. irregular. Pet. $3-5$, connected together, the lower one keelshaper. Caps. compressed, of 2 cells and 2 valves. Secds solitary, with a 3 -pointed basal arillus.

\section{Polygala Linn. Milkwort.}

1. P. vulgaris (L.); lower l. smaller oblong, upper l. linearlanceolate, fl. crested, wings of the cal. obovate mucronate: the lateral nerves branched and anastomosing with an oblique branch of the central nerve, caps. orbicular-oblong-obcordate sessile, lateral bracts shorter than the pedicels.-E. B. 76.-All the nerves of the wings branched (the middle one least) and anastomosing, the lateral ones not reaching to the extremity of the wing but joining a branch of the central one, never ( $I$ believe) the central one itself. Fl. blue, pink or white. Arillus forming a kind of helmet.-P. oxyptera (Reich.) E. B. S. 2827. is only a variety with narrower calyx-wings and sccund $\mathrm{fl}$. and fruit. $-\mathbf{A}$ plant from Ben Bulben, Sligo, which is probably distinet, has the lower leaves oblong and rather small, upper lanceolate and large, wings of the cal. elliptical apiculate, their lateral nerves rejoining the central nerve near the apex and with numerous anastomosing branches externally, central nerve usually quite simple. L. much larger and fl. deep blue.-Dry pastures. P. VI.-IX. 
2. P. calcarea (Schultz); l. chiefly in an irregular terminal tuft large obovate obtuse, 1 . of flowering shoot smaller lanceolate, fl. crested, wings of the calyx obloug : the lateral nerves distinct from the central nerve at the apex all branched, caps. obcordateorbicular sessile, lateral bracts shorter than the perlicels.- $P$. amara (Don) E. B. S. 2746. R. exsic. 749. 1'. amarella Coss. et Germ. Atl. Fl. Par. t.7. On the wings the branclies are sometimes slightly confluent but the lateral nerves never rejoin the central one althongh very rarely they anastomose with an oblique branch of it. Fl. blue.-Chalk hills of the south-east of England. P. V.

L.

\section{Order XII. TAMARISCINEF.}

Cal. 4-5-partcd, persistent, xstivation imbricate. Pet. 4-5, withering, regular, restivation imbricate. Stan. equal or twice as many as the petals, distinct or monadclphous. Caps. 1-celled, 3-valveil, many-seeded, loculicidal; placentas often only at the base. Sceds ascending, comose.

1. TAmarix. Cal. 4-5-parted. Pet. 4-5. Stam. 4-5 or 8-10, inscrted in a hypogynous ring. Styles 3, patent. Sceds affixed at the base of the capsule : coma or down of simple pappiform hairs arising from the apex.

\section{Tamarix Linn. Tamarisk.}

†1. T. anglica (Webb); l. glabrous somewhat narrowed at the base spurred, hypogynous ring 5 angled narrowed into the filaments of the cordate sliortly apiculate antliers whose cells diverge below, caps. roundish trigonous at the base abruptly narrowed towards the apex.-T. gallica Sm., E. B. 1318.-St. slurubby, with slender leafy branches. L. minute with a loosc spur at the base. Spikes latcral, somewhat panicled, sfender. Fl. small, piuk.-In T.gallica the l. are broader at the base, the ring has 10 obtuse lobes with the filaments between them, the anther a much longer point and the caps. gradually narrowed foom its base. Webb in Hook. Journ. of Bot. iii. 429. tab. 15.South-west coasts of England. S. VII.

\section{Order XIII. FRANKENIACER.}

Sep. 4-5, in a furrowed tube below. Pet. 5, clawed, with appendages at the base of the limb. Stam, 5 or more, free, 2celled, opening by 2 terminal pores or longitudinally. Caps. 1celled, 3-valved, septicidal ; placentas 3, parietal. Style slender, simple or trifid. Seeds numerous, minute. Embryo in the midst of albumen.

1. Frankenia. Style 3 -fid. : lobes oblong with the stigma 
on their inner sile. Caps. 1-celled, 3-4-ralved, manyseeded.

\section{Frankenia Linn.}

1. F. lavis (L.); L. linear revolute at the unargin glabrous ciliated at the base.-E. B. 205.-St. slightly downy. Cal. slightly hispid between its prominent angles. Fl. terininal or from the forks of the stem, sessile, rose-colontred. St. prostrate, branched, wiry. L. sometimes pulverulent.-Salt marshes on the east coast. P. VIII.

E.

2. $F$. pulverulenta (L.); l. obovate retuse glabrous above pulverulent beneatl, petiole ciliated.-E. B. 2.22. - St. similar to the last.-Found by Dillenius and IIudson on the Sussex coast, epparently now lost. A. VII.

F.

\section{Order XIV. ELATINEE.}

Sep. 3-5, distinct or slightly connate. Pet. 3-5. Stam. equalling or twice as many as the pet., free. Caps. 3-5-celled, 3-5-valved, loculicidal, with central placentas. Styles 3-5, stigmas capitate. Seeds numerous, albumen 0, cmbryo curved with the seed.-L. without stipules, opposite.

1. Elatine. Cal. 3-4-partel. Pet. 3-4. Stam. 3-4 or 6-8. Styles 3-4. Caps, 3-4-celled, many-seeded. Seeds cylindrical, terete, straight or bent.

\section{Elatine Linn.}

1. E. hexandra (DC.); l. opposite longer than their petioles, fl. slightly stalked with 6 stam. and 3 obovate pet., caps. turbinate concare at the summit 3-celled, seeds nearly straight ascending 8-12 in cach cell. $-R$. I. f. 599. E. Hydropiper $E$. B. 955. E. tripetala Sm.-Plant minute, procumbent. Fl. alternate, axillary. Cal. 3-fid.-Forming small matted tufts under water, rare. A. VIII.

2. E. Hydropiper (L.) ; l. opposite shorter than their petioles, fl. stalked or nearly sessile witl 8 stam. and 4 ovate pet., caps. roundish depressed 4-celled, seeds bent almost double pendulous 4 in each cell.-E. B. S. 2670. E. Schkuhriana (Hayne) Reich. -Fl. quite sessile in our plant. Cal. 4-fid.-Very rare, growing under water. Fransham Ponds, Surrey. Mr.W.W. Reeves, Llyn Coron, Anglesea. Newry and at the Lough Neagh outlet of the Lagan Canal, Ireland. A. VIII.

E. I.

\section{Order XV. CARYOPHYLLEÆ.}

Scp. 5 or 4 , distinct or connected in a tube. Pet. 5 or 4 , clawed. Stam. usually twice as many as, sometimes equalling, 
the petals, free or comnected at the base. Anth. opening longitulinally. Orary one, often stalked. Stigmas 2-5, sessile, filiforn. Caps. l-or imperfectly 2-5-celled, opening by twice as many tecth as stigmas, sometimes valvular. Placenta central. Limbryo generally curved round mealy albumen.-L. witlout (rarely with) stiputes, opposite.

\section{Suborke I. SILENEAE.}

Sep. counected into a tube. Stam. connected below into a tube which is connate with the stalk (carpophore) of the ovary. Caps. stalkerl.

1. Dianthus. Cal. 5-toothed, with 2 or more imbricated opposite scales at the base (except in D.prolifer). Pet. 5, clawed. Stam. 10. Styles 2. Caps. I-celled, many-sceded, opening at the top with 4 valves. Seerls peltate, convex above, concave beneath and more or less keelerl.

2. Saponaria. Cal. 5-toothed, naked at the base. Pet. 5, clawed. Stam. 10. Stytes 2. Caps. 1-celled, opening at the top with 4 valves. Seeds globular or reniform.

[3. Cucubalus. Cal. 5-toothed, naked. Pet. 5, clarred. Stam. 10. Styles 3. Caps. a globose 1-celled berry. Seeds reniform.]

4. Silene. Cal.5-toothed, naked. Pet. 5, clawed. Stam. 10. Styles 3. Caps. more or less completely 3-celled, opening at the top with 6 valves. Seeds reniform.

5. Lychris. Cal. 5-toothed, naked. Pet. 5, clawed. Stam. 10. Styles 5. Caps. 1- or half 5-celled, opening at the top with 5 or 10 teeth.

\section{Suborder II. ALSINEA.}

Sep. distinct. Stam. free, inserted into a more or less evident hypogynous ring. Caps. sessile.

* Valves of caps, the same number as the styles.

[6. Buffonia. Sep. 4. Pet. 4, entire. Stam.4. Styles 2. Caps. flattened, 2-valved, 2-seeded.]

7. Sagina. Sep., entire pet., styles and valves of caps. 4-5. Seeds reniform, wingless.

8. Spergula. Sep., entire pet., styles and valves 5. Seeds orbicular, margined.

9. Alsine. Sep. and pet. 5 or 4 . Styles and ralves 3 (or 4 ). Seeds numerous (in $A$. peploides few) with a naked hilum.

10. Cherleria. Sep. 5. Pet. 0 or 5. Stam. 10, outer ones 
opposite to the sep. and springing from an oblong emarginate glandular base. Styles and valves 3.

**Valves of the caps. twice as many as the styles.

11. Moemringia. Sep. 5. Pet $4-5$, entire or slightly emarginate. Stam. 8 or 10. Styles 2-3. Caps. opening with 4 or 6 valves. Seeds numerous, with an appendage at the hilum.

12. Arenaria. Sep. 5. Pet. 5, entire, or slightly emarginate. Stam. 10. Styles 3. Caps. opening with 6 valves. Sceds numerous, with a naked hilum.

13. Holostevm. Sep. 5. Pet. 5, toothed at the end. Stam. 5 or 3 or 4 . Styles 3 . Capss. subcylindrieal, many-secded, opening at the end with 6 teeth.

14. Stellaria. Sep. 5. Pet. 5, bifid. Stam. 10. Styles 3. Caps. opening with 6 valves or teeth, many-seeded.

15. Moencina. Sep. 4, erect. Pet. 4, entire. Stam. 4. Caps. many-seeded, opening at the end with 8 or 10 teetl.

16. Malachium. Sep. 5. Pet. 5, bifid or entire. Stam. 10. Styles 5. Caps, opening with 5 bifid valves.

17. Cenrastivm. Sep. 5. Pet. 5, bifid. Stam. 10 or 5 or 4 . Styles 5 or 4 . Caps. tubular, opening at the end with 10 teetl.

\section{Suborder 1. Silener. \\ 1. Dianthus Linu. \\ * Fl. capitate or clusiered.}

1. D. prolifer (L.); fl. in a clustered head, involucral scales membranous pellucid the 2 outer ones shorter mueronate, inner ones obtuse about as long as the ealyx, st. glabrous, l. all linear, seeds boatshaped with a longitudinal membrane in the hollow rougl pointed at one end.-E. B. 956. R. 5009.-St. l- $1 \frac{1}{2} \mathrm{ft}$. high, crect, usually simple. Fl. expanding one at a time, small. Pet. rose-coloured, obeordate. Ilead quite inelosed by brown dry seales.-D.diminutus (L.) is only a dwarf l-flowered state of this plant.-Sandy and gravelly places, rare. A. V11.

2. D. Armeria (L.); fl. aggregate tufted, involucral scales and bracts lanceolate-subulate downy herbaceous ribbed as long as the tube, st. downy, l. linear downy, seeds nearly flat one side slightly hollowed and with a longitudinal keel in its middle rough pointed at one end.-E. B. 317. R. 5011.-St. 1-2 feet high, ereet, branched. Pet. rose-eoloured, speekled with white dots, crenate.-Waste places, rare. A. VII. VIII. Deptford Pink. E. 
** Fl. solitary or panicled.

†3. D. plumarius (L.); st. 2-5-flowered, A. solitary, involucral scales roumdish-ovate shortly mucronate 4 times shorter than the tube, $l$. rough at the margin lincar-subulate, pet. digitate-multifid as far as the middle with the central entirc part obovate downy, barren st. proeumbent rooting much branched, seeds flat orbicular with a point on one sidc. - R.5030. Leight. Shrop. p. 188. - Flowering stems $6-12$ in. high. Calyx tecth ciliated at the inargin, slightly shorter than the capsulc. Fl. pale pink, sometinnes white, fragrant.-Old walls and ruins. P. VI. E.

†4. D. Caryophyllus (L.); fl. solitary, involucral scales broadly obovate pointed 4 times shorter than the tube, $l$. with smooth margins lincar, pet. crenate-dentate ovate glabrous, barren st. elongated proeumbent branching, scells pyriform nearly flat. -E. B.2l4. R. 5051.-Fl. stems $12-18$ in. high. Calyx teeth not ciliated, longer than the capsulc. Fl, pale pink, fragrant. Seeds half the size of those of the preceding.-Old walls, Kent, Norwich (?). P. VII. VIII. Clove Pink.

5. D. casius (Sm.); st. mostly single-flowered, involucral scales adpressed ovate obtuse shortly pointed 4 times shorter than the tubc, l. with rough margins linear, pet. obovate crenatelycut bearded, barren stems elongated procumbent branching, secds ovate pointed at one end.-E. B.62. R.5044.-Flowering stem $6-8$ in. high. Calyx teeth ciliated. Fl. pale rose-colour, fragrant.-On limestone cliffs at Cheddar, Som. P, VI. VII. Cheddar Pink.

6. D. deltoides (L.); fl. solitary, involucral scales usually 2 ovate aristate $\frac{1}{2}$ the length of the tube, l. linear-lanceolate the lower ones obtuse rough at the edges and keel, stem l. acute and as well as the st. pubescent-scabrous, pet. obovate dentate, barren st. short procumbent simple (?), seeds obovate flat reticulaterugose.-E. B. 61. R. 5040.-Flowering-stems 6-12 in. high, branched. Calyx tecth lanceolate, minutely ciliated. FI. rosecoloured, with a darker circle round the mouth, scentless. $-\beta$. glaucus; 1 . glaucous, involucral scales usually 4 , fl. ncarly white with a purple circle. D. glaucus Linn.-Hilly pastures. $\beta$. said to have been found in the King's Park, Edinburgh. P. VI.IX. Maiden Pink.

\section{SAPONARIa Linn.}

†1. S. officinalis (L.); fl. fasciculate-corymbose, cal. cylindrical slightly downy, pet. retuse crowned, l. elliptic-lanceolate ribbed, st. erect.-E, B. 1060. R. 4995. St. 6. 10.-St, 1-2 feet high, stout, leafy. Fl. flesh-coloured or pale pink, large, landsome. - . hybrida (L.); some of the upper l. combined and shcathing, 
pet. combined.-Roadsides and hedges, mostly near villages. $\beta$. Northamptonshire and Liverpool. P. VIII. Soapwort.

\section{Cucubalus Linn.}

[1. C. bacciferus (L.); st. branched spreading, l. ovate acute, cal. campanulate, pet. distant.-E. B. 1577.-Finit fleshy.-Isle of Dogs near London, scarcely native. P. VIII.] E.

\section{Silene Linn.}

1. S. anglica (L.); racemes terminal, fl. alternate, cal. hairy with sctaceous teeth ovate when in fruit, pet. slightly cloven or cntire obovate, 1. lanceolate lower ones spathulate.-E. B. 1178. - St. 6-18 in. high, simple or branched. L. oblong, the lower I. obovate obtuse apiculate. Fl. white or tinged with red. Whole plant hairy and viscid.- $\beta$. quinquevulner $a$ (Koch); fl. white with a large crimson spot upon the disk of each usually cntire petal, whole plant hairy. S. quinquevulnera (L.) E.B.86.-Sandy and gravelly fields. $\beta$. Duppas Hill, Surrey, and Wrotham, Kent. A. VI. VII. English Catchfly.

2. S. nutans (L.); pubescent, glandular-viscid above, panicle secund with drooping trichotomous opposite 3-7-flowered branches, cal. ventricose with acute teeth, pet. bifid crowned: segments linear, Iower l. spathulate, sten 1. sessile lanceolate, teeth of the caps. reflexed.-E. B. 465.-St. $1 \frac{1}{2}$ foot high. Carpophore scarcely half as long as the capsule. Fl. white, most expanded and sweetest in the evening.- $\beta$. paradoxa (Sm.); l. broader.-On limestone and chalky places. $\beta$. Dover Cliffs. P. VI. VII. Nottingham Catchly.

E. S.

[3. S. italica (Pers.) ; pubescent, panicle nearly erect with opposite trichotomous viscid branches, cal. long clavate with obtnse teeth, pet. bifil not crowned: segments broad, lower l. lanceolatespathnlate, stem l. linear-lanceolate, teeth of the capsule reflexed (?).-S. patens (Peete) E. B. S.2748.-St. about 2 feet high. Carpophore as long as the capsule.-An escape from cultivation. Sce Comp. Bot. Mlag. i. 327. P. VI. VII.] E. S.

4 S. Otites (Sm.); panicle elongate with opposite tufted rerticillate-racemose branches, whorls many-flowered, peduncles glabrous, cal. faintly nerved smooth with obtuse teetl, pet. linear undivided not crowned, l. lanceolate-spathulate, stem l. small linear crect.-E. B. 85.-Fl. imperfectly diocious, small, yellowish. Caps. sessile. St. viscid at about the unidlle, 1 foot high. - Sandy and gravelly places in the east of England. P. VI. E.

5. S. inflata (Sm.); panicle terminal, fl. numerous drooping, cal. inflated bladdery reticulated with acute tceth, pet. deeply 
cloven seareely ever crowned: segments narrow, 1. ellipticallanceolate, stem erect (young seeds white),-E. B. I64. R.5120. - Glal)rous, smooth. St. 2-; feet high. Inflorescence between corymbose and panicled. Pet. white. Cal. often tinged with purple, glabrous.- $\beta$. hirsuta (Leight.) ; st. and l. rough with hairs. "Cal. downy." Hooker-Fields and roadsides. $\beta$. rarer. P. VI.-VIII. Bladder Campion.

6. S. maritima (Witlı.); panicle terminal, fl. few usually solitary erect, cal. inflated bladdery reticulated with acute tectl, pet. slightly cloven crowned: segments broad, l. lanceolate or ovatelanceolate, st. spreading decumbent, fl. shoots ascending, (young seeds purple).-E. B.957.- Sandy and stony sen-shores, also by alpine rills. P. VI.-VIII. Sea Bladder Campion.

7. S. conica (L.) st. erect forked, fl. from the forks or terminal, cal. with 30 furrows conical in fruit umbilicate below: teeth subulate acute, pet. obcordate crowned, l. linear-subulate downy, caps. oblong-ovate-E. B.922. S. conoidea R.5061.-St. 312 in. high, simple or branched. Cal. of the flowers conicaltubular, rounded below, of the fruit very broad at the base. Carpophore very short. Fl. reddish.-In sandy fields, rare. A. V.-VII.

8. S. noctiflora (L.); st. erect repeatedly forked, fl. from the forks or terminal, cal. veined and with $\mathrm{I} 0$ hairy glandular ribs in fruit elliptic-oblong: teeth long subnlate, pet. deeply bificl crowned, 1. lanceolate lower ones obovate, caps. ovate.-E.B. 29I. St. 3. 10.-L. much like those of S. inflata but longer. St. about I foot high, downy and glandular. Carpophore very short. 1\%. reddish-white, rather large, sweet-scented in the evening, peduncles glandular.-Sandy and gravelly fields. A. VII. VIII.

[9. S. Armeria (L.); "panicles forked many-flowered leveltopped, pet. cloven each with a double awlshaped scale, cal. and l. smooth, caps. not longer than its stalk." Sm.-E. B. 1398. St. 21. 4.-Half a mile below Chester on the banks of the Dee, now lost. Yalding, Kent. Mr. E. Edwards. A. VII.] E.

[I0. S. alpestris (Jacq.); cal. topshaped short, st. dichotomous, fl. axillary and terminal, calyx-teeth ovate-obtuse, pet. crowned : limb with 4 teeth, caps. oblong twice as long as the calyx, seeds cristate-clliate, 1. lanceolate.-A specimen of this plant, gathered by the late Mr. G. Don "on a rock on a monntain to the east of Clova, Angus-shire," is in Mr. Borrer's Herbarinm.]

11. S. acaulis (L.); st. densely tufted and mnch branched, $f$. solitary, peduncles and cal. glabrous, cal. bellshaped with 10 
strix : teeth ovate-obtuse, pet. slightly notched crowned, l. linear ciliated below.-E. B. 1081 . R. 5084 .-Forming broad dense tufts $2-3$ in. high. Fl. purple or white, upon longish solitary stalks, sometimes nearly sessile. Caps. twice as long as the calyx. Plauts somewhat diocious.-Summits of the higher mountains. P. VII. VIII. Moss Campion.

\section{LYCHNIS Limn.}

1. L. Viscaria (L.); jet. cmarginate crowned, st. glabrous viscid below the joints, l. lanceolate glabrous the margins woolly at the base, fl. raccmose-panicled somewhat whorled, carpophore $\frac{1}{2}$ the length of the capsule.-E. B.788. R.5131.-St. simple, 1 foot high. Fl. large, rose-coloured. Caps. 5-celled when young. Seeds reniform, minute, acutely tubercled.-Dry rocks, rare. P. VI.

E. S.

2. L. alpina (L.); pet. cloven scarcely crowned, st. glabrous not at all viscid, l. linear-lanceolate glabrous sometimes minutely ciliated at the base, fl. corymbose, carpophore $\frac{1}{3}$ of the length of the capsule.-E. B.2254. R. 5130. St.51. 10.-St. simple, 5-6 in. high. Fl. small, rosc-coloured, crown scarcely more than 2 small tubercles upon each petal. Caps. 5-celled when young. Seeds reniform, minute, bluntly tubercled.-Momtains. Glen Isla, Forfar. (3200 ft.). Hobearton Fell, Cumb. (2000 ft.). Mr. R. Mathews. P. VI. VII.

E. S.

3. L. Flos-cuculi (L.) ; pet. deeply 4-cleft crowned : segments linear palmately diverging, cal. with short teeth, st. with deffexed hairs, l. lanceolate the lower ones uarrowed below, $\mathrm{fl}$. loosely panicled, caps 1-celled : teeth 5 , carpophore very short.-E. $\dot{B}$. 573. R.5129.-St. viscid and brownish above, $1-2$ feet high. Pet. rose-coloured, the crown bipartite : segments subulate erect and usually with an acute tooth on the middle of the onter margin. Cal. 10-ribbed.-Moist meadows. P. V. VI. Ragged Robin.

4. L. vespertina (Sibth.); pet. half bifid crowned, st. villose, 1. peduncles and cal. hairy, l. ovate-lanceolate, fl. dichotomonsly panicled diocions, calyx-teeth of the fertile fl. linear-lanceolate elongated, caps. conical: teeth 10 erect.-Hoppe in St. 23. 9. R.5125. L. dioica B. (L.) E.B. $1580 .-F$ l. white, very rarely reddish. Calyx-teeth of fertile fl. twice as long as those of $L$. diurna.-Hedgebanks. B. (?) VI.-IX. IThite Campion.

5. L. diurna (Sibth.); pet. half bifid crowned, st. l. and calyces villose, 1 . ovate acute, fi. dichotomously panicled, dicecious, caly $x$ teeth of the fertile fl. triangular, caps. nearly globular: teeth 10 reflexed.-Hoppe in St. 23. 8. R.5126. L. dioica $\alpha$. (L.) E.B. [579.-Fl. red, very rarely nearly white. Certainly distinct from 
the preceding. In the E. B. figmes due attention was not paid to the form of the ealyx-teeth. Both sometimes have perfect fl. and both vary in eolonr from red to white and white to red.1)amp liedgebanks. 13. (?) V. V1. Red Campion.

6. L. Githago (Lam.); pet. entire crownless, ealyx-teeth longer than the tube and also the petals, H. solitary upon long stalks.Agrostemma (L.) E. B. 741. St. 5. 6.-Fi. large, purple. St. diehotomons, 2-3 feet high. Cal. coriaceons, ribbed, with 5 linear-lanceolate eonstantly crecto-patent very long segments.

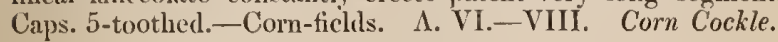

\section{Suborder II. Alsinea.}

\section{Buffonia Linn.}

[1. B. annua (DC.); "st. loosely panicled from the base, branches sprealing short firm, strix on the calyx straight parallel, caps. searcely as loug as the ealyx, l. subulate spreading at the basc." DC.-B. tenuifolia Sm., E. B. 1313.- Said to have been found near Boston, Lincolnshire, and upon Hounslow Heath; probably a mistake. A. VI.]

E.

\section{Sagina Linn.}

* Sep., pet., stam., styles and valves of caps. 4.

1. S. proeumbens (L.); st. very short, branehes elongated procumbent, $l$. linear mucronate glabrous, sep. blint much longer than the petals and slightly shorter than the eapsule, apex of the peduncles reflexed after flowering ultimately erect.-E.B. 880. R. 4959. St. 30. 3.-Central st. very short, barren and creet. The branches elongated, procumbent, often rooting. Pet. blunt, often wanting. A fiftl part is occasionally added to the $\mathrm{fl}$. in which ease it is distinguished from S. saxatilis by its cal. spreading when in fruit and styles reflexed during flowering. Mr. Borrer found, at Pulborough, Sussex, a eurious variety with nearly sessile flowers.- $\beta$. spinosa (Gibs.); l. longer and narrower very minutely spinose-ciliated on the edges.-Waste ground. A. V.IX. Procumbent Pearlwort.

2. S. maritima (Don); st. elongated forked, branches aseending, l. fleshy blunt rounded at the back glabrous, pet. 0 , sep. blunt slightly longer than the capsulc, peduncles always erect.-E. B. 2195. R. 4960. S. stricta (Frics) Sv. Bot. 562. 2.-The central stem produces flowers and is erect, or in luxuriant plants more or less procumbent. Caps. sometimes longer than the calyx. Specimens of $S$. proeumbens which have beeome more fleshy fiom growing near the sea are often mistaken for this plant.-O On the sea-shore. (Fries states that his plant sometimes occurs upon mountains in Norway.) A. V.-IX. Sea Pearlwort. 
3. S. apetala (Hard.); st. elongated forked, branehes ascending, l. linear mucronate, sep. blunt much longer than the petals and shorter than the eapsule, pedineles always ereet.-E.B.88I. $R .4958$.- Plant pale green, the upper part of the stem, peduneles and calyx more or less clothed with glandular hairs. 'The eentral stein clongated and bearing flowers. Branches often quite erect, sometimes prostrate. Pet. very minute, inversely welgeshaped and trumcate. L. eiliated. Tubereles on the sceds acute. S. ciliata Fries (Sv. Bot. 562. 1.) has the outer sep, acute, not blunt with a muero as in our plant.- $\beta$. glabra (Bab.); l. glabrous, tubercles on the sceds blunt, outer sep. obtuse but often mueronate. $-\gamma$. lavis (Gibs.); smooth in every part.- $\delta$. prostrata (Gibs.); plant dark green hairy, stem and branches short all prostrate hairy, l. short. For this I am indebted to Mr. S. Gibson. See Phytol. i. 177. Walls and dry plaees. A. V.-IX.

** Sep., pet., styles and valves 5. Stam. I0. Spergelda, Reich.

4. S. saxatilis (Wimm.); l. linear mucronate smooth, st. peduncles and cal. glabrous, pet. shorter caps. longer than the ealyx. - Spergula saginoides Sm., E. B. 2105. R. 4962.-St. prostrate, slightly rooting, numerous, peduncles long, their apices reflexed after flowering ultimately erect. Caps. rather longer than the calyx, sometimes twice the length when it becomes S.macrocarpa R. 4963. b. Closely resembling $S$. procumbens but distingnished by the valves of its capsule being much more narrowed upwards, the sep. adpressed and namower, pet. longer, styles not reflexed. -IIighland mountains. P. VI.-VIII.

5. S. subulata (Wimm.); l. awned linear often ciliated, peduncles and calyx glandular hairy, pet. about as long eaps. longer than the calyx.-Spergula Sn., E. B. I082. R. 4963.-St. procumbent. Perluncles very long, the apex slightly reflexed after flowering ultimately erect.-Dry gravelly and sandy plaees. P. VI.-VIII.

6. S. nodosa (E. Mever); 1. subulate glabrous, upper l. shorter fasciculate, pet. mucli longer than the calyx, peduneles always erect.-Spergula Sm., E. B.694. R. 4965.-Primary stem abbreviated, not flowering; lateral stems proeumbent at the base then ascending, 2-6 in. long. Fl. terminal 1, 2 or 3 together, white, eonspicuous. Whole plant often quite glabrous. Sometimes ( $\beta$. pubescens. S. glandulosa Bess.) the upper parts of the stem, the connecting membrane of the leaves and the base of the ealyx are glandular-hairy.-Wet and sandy plaecs. P. VII. VIII. Knotted Spurrey.

\section{Spergula Linn.}

1. S. arvensis (L.); $l$, linear convex above furrowed beneath, f. panieled, fruitstalks deflexed, seeds slightly eompressed tu- 
bercled or papillose with a narrow margin.-E.B. 1535.-St. 6-12 in. high. L. long, slender. Sceds black, covered with minute elevated points. S. sativa Bocmingh. S. arvensis $R . I$. t. 511.- 3 . vulgaris (Koch); sceds covered with white or brown clubshaperl papilla. S. vulgaris Bocningh., R. I. t. 512.-On cultivated ground. A. VI.-VIlI. Corn Spurrey.

2. ? S. pentandra (L.); l. linear subterete convex beneath, fl. panicled, seeds much compressed smooth with a broad membranous margin.-E. B. 1536?-I have not seen specimens of this plant, which appears to differ from $S$. arvensis only by having the under side of its leaves not hollowed into a furrow but convex. -Sail to liave been found in Ircland. A. VII. ?

I. ?

\section{Alsine $I^{T} a h l$.}

* Leares with stipules. Caps. nerveless. Seeds roundish-pyriform with or without a wing. LEPIGONUM Fries, Koch.

1. A. rubra (Wahl.); st. round, seeds angular rough mostly wingless, $l$. flat linear pointed, scp. obtuse obscurely 3-nerved scarcely shorter than the capsule.-Arenaria Sm., E. B. 852.St. procumbent, the end and the ped. and cal. covered with fine glaudular hairs. Seeds rongh all over, triangular-pyriform, small. - $\beta$. media; 1 . fleshy rather convex beneath, seedls mostly wingless with a thickened rough border, a few winged, caps. a little longer than the calyx. $\quad L$. medium Fries.-Sandy fields. $\beta$. In damp places and near the sea. A. VI.-IX.

2. A. marina (M. and K.); st. compressed, seeds roundish nearly smooth mostly winged, $l$. fleshy blunt, sep. obtusc obscurely 3-nerved shorter than the capsulc.-Arenaria Sm., E. B.958.St. smooth or downy. Seeds nearly all winged. - Fruitstalks reflexed thickened at the end, sep. ovate half as long as the terete turgid capsules. L. marinum l'ries.- $\beta$. marginata; fruitstalks not thickenel, $\mathrm{t}$. half the size, sep. but little shorter than the subtrigonous capsule. L. salinum Fries.-Sea-coast. P.? B. A. VI.-VIII.

\section{** Stipules none.}

$\dagger$ Leaves elliptical or ovate; calyx valves broad, nerved; sceds few. Haliantius Fries, Koch.

3. A. peploides (Wahl.); l. sessile ovate acute fleshy glabrous l-nerved, pet. obovate, sep. ovate obtuse l-nerved shorter than the petals.-Arenaria E. B. 189. Honckenya $R$. 3670.-St. dichotomous, procumbent, often much buried in the sand. Fl. from the forks of the stem, frequently diœcious.-Sandy seacoasts. P. VI.-IX. 
†† Leaves narrow linear or subulate.

4. A. stricta (Wahl.); $l$. filiform nerveless, fl--shoots ercet naked above, pet. equalling the eal. oblong-oval attenuated below, sep. ovate-laneeolate acute 3-nerved (wlien dry), ped. terminal l-3 very long.-Aren. uliginosa E. B. S.2890. Alsinanthe R. 4935.-St. prostrate, exspitose.-Teesdale moors, very rare. Mr. J. Backhouse. P. VI.

5. A. verna (Jacq.) ; 1. linear-subulate acute 3-nerved, pet. longer than the calyx rounded-obovate attenuated below, sep. ovate-laneeolate aente 3 -nerved with a membranous margin, peduneles 1- or many-flowered.-Arenaria Sm., E. B. 512. Tripliane $R .4929$.-L. usually not adpressed and mostly with a minute point.- $\beta$. Gerardi; l. subulate bluntish not apieulate, pet. elliptieal shortly clawed seareely longer thau the ealyx. T. Gerarli $R$. 4928. The 1 . being usually pressed close to the stem gives this plant a peculiar appearanee, but the only eharacters which I ean deteet by whieh to distinguish it from $A$. verna are the bluntish, not apieulated, leaves and the form of the petals. -Rocky places in mountainous districts. $\beta$. On the hills above Kynance Cove near the Lizard Point, Cornwall. P. V.-IX.

6. A. rubella (Wahl.); 7. linear-subulate blunt 3-nerved, pet. obovate atteuuated below shorter than the calyx, sep. ovate-laneeolate aeute 3-nerved with a membranous margin, peduneles 1-flowered.-E, B. S. 2638. Wahl. Lap. t. 6.-St. numerous. Flowering shoots terminal, downy, nearly always single-flowered, about an ineh long, with $1-3$ pairs of leaves. Ped. longer than the ealyx, petals shorter. The number of styles and valves of the eapsule varies from $3-5$, thereby showing the very artificial eharacter of these genera. - Summits of the Seoteh mountains, very rare. P. VII. VIII.

7. A.tenuifolia (Wahl.); 1. subulate acute 3-nerved, pet. ovate attenuated below shorter than the calyx, sep. laneeclate-subulate 3-nerved with a membranous margin.-Arenaria Sm., E. B. 219. Sabulina R. 4916.-St. slender, $4-6$ in. high, mueh branehed, diehotomous, with flowers from the axils. Glabrous.-Sandy and ehalky places. A. V. VI.

8. A. fastigiata ; 1. subulate acute 3-nerved, pet. oblong obtuse half the length of the calyx, sep. laneeolate acute equal (white) with 2 central (green) ribs.-Arenaria Sm., E. B. 1744. Minuartia R. 4919. - "Mountains of Fifeshire an! on the mountains to the westward of Clova." Mr. G. Don. A. VI.

\section{Cherleria Linn.}

I. C. sedoides (L.).-E. B. 1212.-Pet. generally wanting. Fl. solitary, on short stalks. St. very numerous, forming a dense 
mass elose to the ground. L. very numerous, linear-subulate, fuely ciliated.-Sumnits of mountains. P. VI.-VIIl. S.

\section{Moemringia Linn.}

l. M. trinervia (Clairv.); l. ovate aente stalked 3-5-nerved the 11 p)er ones sessile, pet. shortcr than the ealyx, sep. lanceolate acute 3 -ribbed the intermediate rib strongest and rough.- $R$. 4943. Arenaria Sin., E. B. 1483.-St. about a foot high, weak, brancherl, downy. Fl. solitary from the forks of the stem and axils of the upper leaves. Ped. ultimately sprcading and eurved just below the fruit. Lateral nerves of the sep. often obsolete. Distinguished from Arenaria and Alsine by the appendage to the hilum of its seeds.-Damp slady places. A. V. Vl.

\section{Arenaria Linn.}

1. A. serpyllifolia (L.); l. ovate acute subseabrous sessile, pet. shorter than the calyx, sep. lanceolate acute 3-ribbed hairy.E. B. 923. R. 4941.-St. prostrate or aseending dielotomous. Fl. from the forks of the stem or the axils of the upper leaves. Pet. narrowly ovate, narrowed below. Clothed all over with minute lairs which are sometimes glandular. Aecording to IIooker (Br. Fl. 53.) Wilson finds a plant at Bangor witl 5 stam., the pet. only $\frac{1}{4}$ as long as the cal. and the sep. with prominent ribs.- $\beta$. tenuior (Koch); stems much more slender, $\mathrm{fl}$. and fr. of half the size.-Dry places and walls. A. VI.-VIII.

2. A. ciliata (L.) ; l. spathulate ciliated, pet. longer than the calyx, sep. ovatc-lanceolate with 3 prominent ribs. - E. B. 1745. R. 4942.-St. much branched, ascending, rough. Fl. $1-5$, terminal, somewliat panielerl. Pet. ovate, slightly clawed. Distinguished from $A$. multicaulis by its keeled sepals. In the foreign plant the leaves are usually eiliated only ncar the base.-On limestonc cliffs on Ben Bulben, \&e., Sligo. P. VI. VIl.

I.

3. A. norvegica (Gunn.) ; l. spathulate obovate fleshy not ciliated, pet. longer than the ealyx, sep. ovate acute obscurely 3-ribbed glabrous.-E. B. S. 2852.--St. much branched, proeumbent, nearly smooth. Fl. $1-3$, terminal. Pet. ovate, slightly elawerl. Seed dark brown, tuberculated. Distinguished from A. ciliata by its fleshy not ciliated 1 . whieh are less narrowed below, and the shorter point and obseure ribs of its sepals; in A. multicaulis the point of the sep. is longer than that of A. ciliata.- On Serpentine Hill, Unst, Shetland. P. VII. VIII.

S.

\section{Holosteum Linn.}

1. H. umbellatum (L.) ; fl. umbellate, perluneles pubeseent viseid, pedicels reflexed after flowering, I. elliptieal or elongate 
acute.-E. B. 27. R. 4901.--On old walls and dry places at Norwich, Bury, Eye and Yarmouth. A. IV.

\section{Stellaria Linn.}

* Capsule opening with entire teeth at the apex, columella linear-elongate, DIсHоDоN Reich.

1. S. cerastoides $\left(\mathbf{L}_{\text {. }}\right)$; st. terete decumbent with an alternate hairy line, l. sessile elliptic-oblong rather acute glabrous, lower 1. blunter, perhuncles pubescent, pet. cloven nearly twice as long as the ealyx which is downy beneath.-E. B. 911. Koch in St. 64. 1. R. 4915. Cerastium trigynum Fries.-Resembling Cerastium alpinum. St. slender, $2-4$ iu. long, leafless below and greatly branched. L. light green, glabrous, or with a few hairs on the margin at their base. Fl. large, white. Number of the styles and the teeth of the capsule variable.- $\beta$. nivale; l. clothed with rather numerous long hairs. Cerastium nivale Don.Iighland monntains. P. VII. VIII.

S. I.

** Caps. opening with entire valves of about half its length, columella linear-elongate.

2. S. nemorum (L.); st. ascending dlowny above, l. stalked heartshaped, upper l. ovate sessile, panicle dichotomous, perluncles alternately pubescent, pet. deeply bifid twice as long as the lanceolate scpals, caps. longer than the calyx.-E. B.92, R. 4906.-St. $1-1_{2}^{\frac{1}{2}}$ foot high. L. large, rough on the upper surface, ciliated. Sep. with narrow scarions margins.-Damp woods. P. V. VI. IVood Stitchwort.

*** Caps, opening with entire valves of not less than half its length, rounded below or scarcely if at all narrowed: columella very short.

3. S. media (Wither.); st. procumbent and ascending with an alternate hairy line, l. ovate shortly pointed stalked, upper $l$. sessile, $\mathrm{fl}$. axillary and terminal, pet. deeply bifis not longer than the ovate-lanecolate single-ribbed glandular-pilose sepals, caps. oblong longer thau the (alyx. $-E . B .537 . R$. 4504.- Very variable in length of stems, size of leaves, number of stamens (3-10), and length of internorles. Sep. with a narrow scarious margin, glabrous or with loug hairs. Pct. sometimes wanting. Fruitstalks reflexed. I. glabrous with broal ciliated petioles.$\beta$. major (Koch); l. larger with longer stalks, upper l. sessile and subcordate slightly amplexicaule, stam. 10. S. neglecta R. $4905 .-\gamma$. umbrosa; l. narrowed gradually into long points, cal. more narrowerl below, sep. lanceolate acute glabrous but tubercular, valves of the caps. uarrower, seeds witl prominent acute tubereles.-St. much branched, slender. S. grandiftora (Ten.) according to Mr. Wools. S. umbrosa (Opjitz!) R. Fl. 
Exsic. 895. (but that specimen has hairs on the calyx). Not figured in R. lcon. $\mathrm{kl}$. Germ.-Common. $\gamma$. Sussex. A. 111. -XI. Common Chickweed.

4. S. Holostea (L.); st. ascending tetragonal with the angles rough, $l$. lanceolate-attenuated acute with a rough margin and kecl all sessile, H. in a forked panicle, pet. half bifil twice as long as the lanecolate ncrveless sepals, caps. globose about as long as the calyx, bracts lerbaceous.-E. B. 511. R. 4\%08.-St. 1 -2 fect high, slender and procumbent at the base, thicker upwards. L. gradially narrowing from a little above the base to the very acute point. l'l. large, white, few in number in a leafy panicle. -Woods and hedges. P. IV.-YI. Greater Stitchwort.

5. S. glauca (Withcr.); st. crect weak quadrangular smooth, l. linear-lanceolate acute quite smooth sessile, lower l. broader, f. solitary or in a few-flowered lax corymb, pet. bipartitc longer than the lanceolate 3-nerved sepals, caps. oblong-ovate about as long as the calyx, bracts with scarions and glabrous margins.E. B. 825. R. 4909.-Glancous. St. 6-12 in. high, leafy. Pet. deeply bifid : segments linear, white, sometimes considerably longer than the calyx.-Marshy places. P. V.-VII.

6. S.graminea (L.); st. diffuse quadrangular smooth, $l$. linearlanceolate acute quite smooth ciliated below sessile, fl. in a dichotomous panicle, pet. bipartite as long or longer than the 3-nerved sepals, caps. oblong longer than the calyx, bracts scarious ciliated. -E. B. 803. - St. 1-2 feet high. Fi. smaller than those of the last 2, white. Shorter or longer pet. accompany an imperfection of the stam. or germen. L. "gradually tapering from the base to the point." Deakin.-I have not seen S, Babingtonii (Deak.) which has its 1. " linear with a lanceolate point" not at all ciliated, "darker and more wrinkled seeds, and caps. and pet. scarcely longer than the calyx." Flor. Brit. ii. 643. f. 735. I loubt its being a distinct species; it is found "in the Swann pool near Lincoln." - [S. longifolia (Fr.), S. Friesiana (Koch), differs fiom $S$.graminea by having the upper part of its stem and the edges and keel of its leaves scabrous.]-Dry licathy and bushy places. P. V.-VIII. Lesser Stitchwort.

7. S. scapigera (Willd.); st. shorter than the perluncles erect, 1. linear-lanceolate slightly pubescent on the margins, peduncles long rising far above the leaves slender glabrous simple or once forked, pet. deeply divided equalling the lanceolate acute slightly fringed 3-ribbed sepals.-E. B. 1269. 1. much broader than in my cultivated specimen.-Caps. pyramidal obtuse divided halfway down. I liave not seen any wild specimens except those gathered by Mr. Don.-By the sides of rivulets to the north of Dunkeld and about Loch Nevis, Scotland. Mr. G. Don. P. VI. 
**** Caps. opening with 6 entire valves of not less than half its length, attenuated below, hence the cal. has a funnelshaped base. Larbrea St. Hil. not Ser.

8. S. uliginosa (Murr.); st. diffise quadrangular glabrous, $l$. oblong-lanceolate acute with a callous tip glabrous slightly ciliated below sessile, fl. irregularly panicled lateral and terminal, pet. bipartite shorter than the lanceolate 3 -ncrved sepals, caps. ovate nicarly as long as the calyx, bracts scarious with glabrous margins.-E. B. 1074. Larbrea R. I. $t .226$. L. aquatica St. Hit. - Very variable in size, usually abont a foot long. Fl. in small panicles mostly axillary. On the summits of the Clova mountains ( 3200 fcet) it is about 2 in. long, with minute leaves and usually solitary flowers.-In damp places. A. V. VI.

\section{Moenchia Ehrh.}

I. M. erecta (Sm.) ; stam. 4.-E. B. 609. R. 4953.-St. usually 2 -flowered, crect, glabrous, $1-4$ in. ligh. L. opposite, linearlanceolate, acute, rigid. Sep. with broad white membranous margins, acute. The whole plant glaucous.-Dry gravelly and sandy places. A. V. VI.

E.

\section{I6. Malachium Fries.}

1. M. aquaticum (Fr.); st. decumbent and ascending angular covered with glandular hairs, 1 . cordate-ovate acuminate sessile, the lowest one stalked, fl. scattered solitary in the forks of the stem, pet. bipartite rather longer than the calyx, caps. longer than the calyx.-R. 4967. Cerastium Sm., E. B. 538. Larbrea Ser.-Closely resembling Stellaria nemorum.-In wet places. P. VII. VIII. Water Chickweed.

\section{Cerastium Linn.}

* Root fibrous scarcely more than annual. Pet. not longer than the calyx.

$\dagger$ Caps. curved, pet. about as long as the calyx.

1. C. glomeratum (Thuil.); l. ovate, sep. lanceolate acute with a narrow membranous margin and as well as the herbaceous bracts hairy throughout, caps. cylindrical ascending twice as long as the calyx, fruitstalks about as long as the calyx.--Koch in St. 63. 13. C. vulgatum Sm., E. B. 789. R. 4970. C. viscosum Fries, Gaud.-St. erect. Fl. aggregated or in dichotomous panicles, longer than their stalks.- $\beta$. apetalum; pet. 0. C. apetalum (Dum.) Koch.-Fields and banks. $\beta$. Reigate, Surr. MIr. Borrer. A. IV.-IX.

2. C. triviale (Link); l. oblong-lanceolate, sep. oblong-ovate bluntish and as well as the bracts membranous at their margins 
and glabrous apices, caps. cylindrical ascending twice as long as the calyx, finitstalks at least as loug as the calyx.- $R$. 49.9:2. Koch in St. 63. 8. C. viscosum Sm., E. B. 790. C. vulgatum Fries.-St. mostly procumbent. Fl. larger than those of the last, in small terminal panicles the branches of which become much elongated as the fruit advances to maturity.- $\beta$. holosteoides (Fries); glabrous, the sides of the stem altcrnately pubescent. St. 63. 9.-In fields. $\beta$. Red IIeugh, Gateshearl. Mr. Robertson. Newcastle on Tyne. Mr. Storey. Kinfauns, Perth. Mr. J. Gorrie. A. IV.-IX.

†† Caps. ncarly straight, pet. mostly shorter than the calyx.

3. C. semidecandrum (L.); l. broadly ovate, sep. lanceolate broadly membranous at their margins and apices, bracts with their upper half membranous, caps. cylindrical slightly inflated erect longer than the calyx, fruitstalks longer than the calyx at first reflexed afterwards erect.-E. B. 1630. R. 4968.-St. erect or dccumbent, downy, sometimes viscid. Distinguished by its lialf membranous bracts.-Common in dry places. A. IV. V.

4. C. atrovirens (Bab.); l. ovate or oblong slightly pointed, sep. lanceolate acute with their apex and margins narrowly membranous, bracts herbaceous with a very narrow membranous margin, caps. longer than the calyx, fruitstalks longer than the calyx erect or ascending.-Bab. in Mag. Zool. Bot. ii. t. 9 . C. tetrandrum Sm. not Curt. Sag. cerastoides E. B. 166. ?-Pet. scarcely shorter than the calyx or half as long. Fruitstalks twice, or 3-4 times, as long as the calyx, sometimes divaricated. St. repeatedly forked, bearing a flower in each fork. The membranous margin of the bracts is sometimes scarcely distinguishable even in the living plant. Nearly allied to C. obscurum Chaub. (Fl. Agen.), but French specimens of that plant have the fruitstalks mostly bent just under the calyx, which is not the case in our much more branched plant. C. tetrandrum (Koch) St. 64.15 . is probably C. atrovirens. - On sandy places and rocks near the sea. A. V.-VII.

5. C. pumilum (Curt.); l. ovate-lanceolate, sep. lanceolate acute with the apex and margins narrowly membranous, bracts herbaceous with an extremely narrow membranous margin, caps. slightly curved upwards longer than the calyx, fruitstalks scarcely longer than the calyx reflexed.-Curt. Lond. ii.92.-St. branched at the root, afterwards nearly simple, prostratc, or ascending. $\mathrm{Fl}$. in small terminal dichotomous corymbs. Distinguished by its reflexed fruit, short fruitstalks and membranous apex of the sepals. It is possible that this and the preceding and C.obscurum (Chaub.) may prove to be forms of one species, but I am not yet convinced that such is the fact. Their difference from $C$. semi- 
lecandrum will be at once seen.-Near Croydon, Surrey. Mr. Dickson! A. V.?

6. C. tetrandrum (Curt.); l. elliptical-oblong uppermost l. and bracts ovate or nearly orbicular blunt, sep. lanceolate very acute attenuated 11pwards their sides broadly membranous and apex with a central nearly excurrent herbaceons line, caps. a little longer than the calyx straight, fruitstalks elongated reflexed.Curt. Lond. ii. 93.-Fl. large, from the forks of the stem. Bracts broad round and herbaceous. Distinguished by its reflexed fruit, broad round bracts, and oblong 1 . the lowest narrowed into a long stalk.-Tynemouth and Shetland. A. V. E. S.

** Root truly perennial, with prostrate leafy shoots. Pet. longer than the calyx.

7. C.alpinum (L.); hairy, st. ascending, l. ovate ovate-oblong or lanceolate, fl. few, sep. bluntish with membranous margins, bracts herbaceous their margins often narrowly membranous, caps. nearly cylindrical curved at the end, seed small acutely tubercled, fruitstalks obliquely patent.-E. B. 472. Koch in St. 64. 3.-Pubescence long, silky. St. mostly simple, elongated, prostrate or ascending. Fl. I, 2 or 3 together, in a forked panicle, shorter than their stalks. Bracts with slightly membranous margins. (See Watson in Phytol. ii. 93.)-Alpine parts of Scotland and the north of England. P. VI.-VIII. E. S.

8. C. latifolium (L.); pubescence short, st.prostrate crespitose, 1. elliptical or lanceolate, fl. I-3, sep. blunt with membranous margins, bracts lierbaceous, caps. slightly narrowing straight, seeds large rugose, frnitstalks obliquely patent.-E. B. 473. $R$. 4975.-Barren shoots usually long. L. rariable in shape.- $\beta$. glaciale; l. roundish-ovate dark green, ped. short, fl. large, st. short densely leafy. Koch in St.64. I5.-Alpine parts of Wales and Scotland. $\beta$. Unst, Shetland. Mr. T. Edmondston. P. V. E. S.

9. C. arvense (L.); st. ascending prostrate below, l. linearlanceolate, fl. numerous, sep. and bracts lanceolate shightly acute with membranous margins and apices, caps. at last longer than the calyx, seeds small acutely tubercled.-E. B. 93.-St. long. Fl. 7-I4, in dichotomous panicles. Fruitstalks erect, bent just under the calyx.- $\beta$. strictum; st. and l. glabrous.-In gravelly and chalky places. $\beta$. Arran, Ireland. Mr. Andrews. P. IV.-VIII.

\section{Order XVI. MALVACEE.}

Sep. 5 or 3 or 4 , more or less connected below, often double, restivation valvate. Pet. as many as the sepals, xstivation twisted. Stam. monadelphous, indefinite; anth. l-celled, reniform, 
bursting transversely. Ovary formed by the union of screral carpels round a common axis. Carp. l- or mauy-seeded. Einbryo curved with twisted or doubled cotyledons, albuucu variable iu quatity.-L. alternate, with stipules.

1. Malva. Styles numcrous. Cal. double, outer 3-leaved, iuncr 5-fid. Caps. orbienlar, many-celled: cells I-seeded and cureularly arrauged.

2. Altirka. Styles numerous. Cal. double, outer 6-9-fid, inuer 5-fid. Caps. orbicular, many-celled: cells 1 -sceded and circularly arranged.

3. Lavatera. Styles numcrous. Cal. double, outer 3-lobed, inner 5-fid. Caps. orbicular, many-celled: cells l-seeded and circularly arranged.

\section{Malva Linn.}

1. M. moschata (L.); st. erect, l. kidneyshaped with 5 or 7 deep pinnatifid lobes, lower 1 . inciso-crenate, stipules lanceolate acute, fruitstalks erect, outer sep. linear-lanceolate, fruit hairy. -E. B. 754. R. 484l.-Fl. large, rose-coloured, on axillary single-flowered peduncles, crowded at the extremity of the stem and branches. Cal. hairy. St. $1-2$ feet high.-Gravelly places. P. VII. VIII. Musk Mallow.

2. M. sylvestris (L.); st. erect, l. kidneyshaped with 5-7 deep crenate lobes, stipules lanceolate, fruitstalks erect, outer sep. lanceolate, fruit glabrous reticulate-rugose.-E. B. 671.R. 4840 . -Fl. large. Pet. much longer than the hairy calyx, purple, on axillary aggregated peduncles. St. $2-4$ feet high.-Road-sides and waste places. P. VI.-IX. Common Mallow.

3. M. rotundifolia (L.); st. decumbent, l. roundish-heartshaped with 5 shallow acutely crenate lobes, stipules ovate-acute, fruitstalks decurved, outer sepals liuear-lanceolate shorter than the ovate-acuminate stellately hairy inner ones, pet. 2 or 3 times longer' than the calyx, fruit pubesceut, carp. rounded on the edge smooth. -E. B. 1092. M. vulgaris Fries.-Fl. small, purple. Carp. meeting each other with a straight line. Central disk of the fr. rather large.-Waste places. P.? VI.-IX. Dwarf Mallow.

4. M. borealis (Wallm.); st. decumbent, l. roundish-heartshaped with 5 rather shallow crenate-dentate lobes, stipules lanceolate, fruitstalks deflexed, outer sep. linear as long as the ovate-acnte glabrous but strongly ciliated inner ones, pet. about as long as the calyx, fr. pubescent, carp. margined reticulaterugose.-M. pusilla Sm. E. B. 241. M. rotundifolia Fries, R.! 4835.-Fl. very small. Carpels meeting each other with a toothed edge. Central disk half as large as in the preceding plant.-Hythe, Kent. Huds. A. VII.? 
*? 5. M. verticillata (L.); st. erect, 1. cordate with 5 decp) crenate-dentate triaugular acute lobes, $\mathrm{Al}$. axillary clustered nearly sessile, outer sep. linear half as long as the reticulated diaphanous pilose enlarged inner ones, pet. about as long as the calyx, fr. glabrous, carp. rounded on the edge reticulated.-Fl. small. Carpels separated by a deep furrow into which the elevato-reticulated surface extends. Central disk very small. Stem quite erect like a little holyoak. Petioles several times longer than the clisters. I name this on Sir W. Hooker's anthority.-Near Llanelly, S. Wales. Mr. Jas. Motley. A.

E.

\section{2. Ацтижа Linn.}

1. A. officinalis (L.); 1. soft on both sides crenate or crenateserrate cordate or ovate $3-5$-lobcd, peduncles axillary manyflowered shorter than the leaves, st. downy.-E.B.147.R. 4849. -St. 2-3 feet high. Covered with soft velvety pubescence.Marshes, particularly near the sea. P. VIII. IX. Marsh Mallow.

†2. A. hirsuta (L.); 1. hispid, lower l. reniform obtusely 5 -lobed, upper 1. palınate with 5 or 3 acute lobes, peduncles axillary single-flowcred longer than the leaves, st. lispid.E. B. S. 2674. R. 4846.-Remarkably hispid on its stem leaves and calyx.-Between Cobham aud Cuxton, Kent. A. VI.VII.-E.

\section{Lavatera Linn. Tree-Mallow.}

1. $L$. arborea (L.); st. woody, l. 7-angled plaited velvety, ped. axillary aggregated $l$-flowered shorter than the petioles.-E. $B$. 1841. R. 4857.-Fl. much like those of Malva sylvestris, purplish rose-coloured with darker veins. St. 6-8 feet high.-On maritime rocks, rare. B. VII.-IX.

\section{Order XVII. TILIACEA.}

Sep. 4-5, xstivation valvate. Pet. $4-5$. Stam. distinet, indefinite, or (in exotics) polyadelphons; anth. 2-celled, bursting longitudinally. Glands $4-5$ at the base of the petals. Carp. t-10-celled, several seeds in each cell or by abortion 1-celled l-seeded. Embryo erect in the axis of fleshy albumen; cotyledons flat, leafy.-L. alternate, with stipules.

1. Tilia. Sep. 5, deciduous. Pet. 5 , witl or without a scale on the outside. Stam. indefinite, free, or polyadelphous. Ovary 5 -celled, cells 2 -seeded. Style 1. Fr. 1-celled, with 1 or 2 seeds.

\section{Trlia Linn. Lime Tree.}

*1. T. europea $($ L. $)$; $l$. obliquely cordate glabrous except a 
woolly tuft at the origin of each nerve bencath, peduncles manyHowered, fruit nearly smooth coriaceous downy.-E. B. 610.Fl. in a naked cyme springing from a lanceolate leafy bract. $I$. twice the length of their petioles. The staninodium does not occur in cither of our species.--In many old plantations. T. VIl.

2. T. parvifolia (Ehrh.); l. obliquely cordate glabrous except a woolly tuft at the origin of cach nerve beneath, peduncles many-flowered, fruit angular thin and brittle. - E. B. 1705.- L . usually scarcely longer than their petioles, by which and by its thin, not coriaccous fruit it is distinguished from the preceding. Lobes of the stigma ultimately spreading horizontally.--In woods. Probably the only truly native species. T. VIII.

*3. T. grandifolia (Ehrh.); l. obliquely cordate downy beneath with a woolly tuft at the origin of each nerve beneath, peduncles mostly 3-flowered, fruit with 5 prominent angles woody downy turbiuate.-E. B. S. 2720.-Young shoots hairy. L. longer than their petioles. Lobes of the stigma erect.-T. rubra (Lindl. Syn.) is stated to have globose and smooth fiuit and to be the $T$. corallina Sm. I have not seen it. Reichenbach places it in a section in which the bract extends to the base of the peduncle and refers E. B.S. 2720 to it. That plate represents the bract as not extending to the base, but, judging from my specimens of T. grandifolia, that character is not to be depended upon. -In old plantations. T. VI. VII.

E. I.

\section{Order XVIII. IIYPERICINEE.}

Sep. 4-5, distinct or cohering, persistent, with glandular dots, imbricate. Pet. 4-5, twisted in rstivation. Stam. indefinite, polyadelphous, connected in 3 or 4 bundles at the base. Anthers versatile. Styles several, rarely connate. Fruit a dry or fleshy capsule of many cells and many valves, the valves curved inwards. Seeds minute, indefinite, on a central axis or the turned margins of the valves, embryo straight with no albumen.-L. mostly opposite, with pellucid dots. Fl, yellow.

1. Hypericum. Cal. 5-parted or of 5 sepals. Pet. 5. Styles 3 (in nearly all our plants) or 5 . Caps. more or less perfectly 3-celled.-Fl. yellow.

1. Hypericum Linn. St. John's Wort.

* Styles 5 .

*1. H. calycinum (L.); st. shrubby square, 1. oblong, fl. solitary, sep. unequal obovate obtuse, pet. often lobed on one side. -E. B. 2017.-Fl. very large.-Naturalized in bushy places in 
Wicklow and Cork, also in Scotland, but I fear not an original natirc. P. Vll.-IX.

** Styles 3, sep. without glandular serratures.

2. H. Androsamum (L.); st. shrubby compressed 2-edged, 1. corlate-ovatc, eymes trichotomous few-flowered, sep. nneqnal subcordate-ovate, pet. oval obtusc, caps. finally pulpy imperfectly 3-celled.-E. B. 1225. Androsamum officinale R. 5192.-St. 2 feet high. L. large, having a strong aromatic smell when rnbbed. Fl. large in terminal cymes. Styles mnch shorter than the black fleshy capsule.-Woods and thickets. P. VII. VIII. Tutsan.

[H. grandifolium (Chois.) which has mnch longer styles and stam. than $H$. Androscmum is stated by Reich. (Icon. $\dot{F}$. G. vi. 70.f. 5193.) to grow in Arran, Scotland.]

3. H. quadrangulum (L.); st. erect with 4 wings, l. oval-oblong or elliptical with pellncid dots, sep. erect lanceolate acuminate entire, pet. lanceolate, styles half the lengtl of the capsnle. -E. B. 370. H. tetrapterum Fries, Koch, R. 5179.-St. $1-2$ feet high. Fl. in terminal forked close many-flowered cymes. Linnæens quotes Hort. Cliff. 380. No.5. as the original anthority for his $H$. quadrangulum, of which he there sars "folıa calycina subnlata," it therefore is the present plant.- - ln wet places. P. VII.

4. H. maculatum (Crantz); st. erect 4-angnlar, 1. ellipticalovate obtuse with a few pellucid dots, sep. reflexed ovate-lanceolate minutely denticulate obtuse mucronate with pellucid streaks; pet. elliptical obtuse with purple streaks and dots beneath, styles half the length of the capsule.- $H$. delphinense Vill.! $H$. quadrangulum Fries, Leight. - St. $1-2$ feet ligh. Fl. in forked terminal cymes.-Moist places by ditches, rivers, \&e. P. VII. E.

5. H. dubium (Leers); st. erect obscurcly qnadrangular, l. elliptical obtuse with a few pellucid dots, sep. reflexed broad elliptical obtuse quite entire with numerous black dots on the outside, pet. elliptical with many black dots, styles half the length of the capsule.-E. B. 296. H. quadrangulum I'l. Silcs., R. !-St. l-2 feet high. Sec Trans. Edin. Bot. Soc. i. 88.-In mountainous places, rare. P. VII. VIII.

E. S.

6. H. perforatum (L.); st. erect 2-edged, l. elliptic-oblong or linear-oblong with pcllncid dots, sep. erect lanceolate acute, pet. obliqnely oblong, styles as long as the capsule.-E. B. 295. R. 5177. - St. 1-2 fect high. The l. vary much in form. The number and size of the pellucid dots are very variable. Under side of the l. and pet. with black dots. Sep. longer than the ovary, usnally denticulate near the apex.- $\beta$. angustifolium; 1 . linearol)long, sep. lanceolate acnte denticulate (not "entire") rather 
longer than the ovary. II. veromense (Schr.) Koch Syn.ed.2. 440.?-Woods, hedgebanks, \&e. I'. VII. VIII.

7. H. humifusum (L.) ; st. prostrate somewhat 2-edgerl, l. ovaloblong obtuse minutely pellucid-pmetate the margins with blaek dots bencatli, fl. subcrmose, sep. nucqual, 3 oblong obtuse mucronate, 2 laneeolate, all cutire or glandular-serrate and having a few black dots beneath, stan. not more than 15 , styles very short. -E. B. 1226. R. 5176.-St. procumbent, slender, 3-6 in. long. The presenee or absence of the glandular serratures on the sepals makes it uncertain to which section this plant ought to be referred.-Gravelly and heathy places. P. VII.

*** Styles 3, sep. with glandular serratures.

8. H. linariifolium (Valll); st. erect or ascending terete, 1. linear obtuse with revolute margins, fl. cymose, sep. rather unequal lanceolate acute with glandular serratures and numerous black dots beneath, stam. about 30, styles half as long as the capsule.-E. B. S. 2851.-St. cither wholly erect or procumbent at the base. Fl. larger than in the last.-Jersey. Cape Cornwall. Banks of the Teign, Devon. P. VII.

E.

9. H. barbatum (Jacq.); st. erect slightly 2-edged, l. oblonglanceolate with revolute margins and scattered black dots on both sides and pellneid punetures, sep. lanceolate fringed: the hairs minutely glandular at the end and as long as the diameter of the sepals which lave numerous black dots beneath, pet. obovate minutely ciliated and eopiously dotted.-E. B. 1986.-I have seen a speeinen from Mr. G. Don and drawn the eharaeter from that and Smith's figure and deseription.- "Abcrdalgy in Strathearn, Perthshire." $3 / r$. G. Don. P. IX. X.

S.

10. H. hirsutum (L.); st. erect round hairy, l. oval-oblong slightly stalked pellucid-punctate pubescent, sep. lanceolate acute fringed with shortly stalked glands, pet. linear oblong tipped with stalked glands, strles deciduous.-E. B. 1156.R. 5189. -St. about 2 feet high, nearly simple. Fl. in axillary and terminal forked panicles. "Sceds longitudinally papillose." Leight._ Woods and thickets. P. VII. VIII.

11. H. montanum (L.); st. erect round glabrous, l, ovate-oblong sessile pellucid-punctate with glandular dots near the margin, sep. lanceolate acute fringed with shortly stalked glands, pet. elliptical entire without dots or glands, styles half the lengtl of the capsule.-E. B. 371. R. 5187.- St. two feet high, simple. FI. in terminal dense panicles. Seeds with longitudinal crenate ridges.-Bushy limestone hills. P. VII. VIII.

E.

12. H. pulchrum (L.); st. erect round glabrous, l. cordate amplexicaule pellueid-punctate glabrous, sep. broadly ovate obtuse 
fringed with sessile glands, pet. ovate-lanceolate fringed with glands. - E. B. 1227.-St. $12-18$ in. high, nearly simple. Fl. in loose, axillary, opposite, and terminal panicles. Buds tipped with red. Antl. red.-Dry heaths, banks, woods. P. Vl. V11.

13. $H$. elodes (L.); st. ascending round shaggy rooting below, l. roundish-ovate sessile pellucil-punctate shaggy, sep. ovate bluntish glabrous fringed with shortly stalked glands, pet. ovate entire, styles nearly as long as the capsules.-E. B. 109. Elodes palustris $R .5182$.- St. prostrate below, then ascending and leafy. Fl. in terminal and axillary few-flowered panicles. "Seeds longitudinally furrowed." Leight. Spongy bogs. P. VII. VIII.

\section{Order XIX. ACERINEA.}

Cal. 5-, rarely 4-9-parted, imbricated. Pet. the same number, inserted round a hypogynous disk. Stam. generally 8 , inserted on the lypogynous disk. Ovary 2-lobed, 2-celled. Style 1. Stigmas 2. Fruit winged, separating into 2 indehiscent nuts each with 1 cell and $1-2$ seeds. Embryo curved, albumen 0.Trees with opposite leaves.

1. Acen. Fl. polygamous. Calyx 5-parted. Pet. 5. Stam. usually 8 , longer in the male flowers.

\section{ACER Linn.}

1. A. campestre (L.) ; 1. 5-lobed: lobes entire or slightly eut, corymbs erect, sep. and pet. linear hairy, wings of the fruit horizontally diverging, ovary downy, stam. of the male flowers as long as the corolla.-E. B.304. R. 4825.-A small tree with corky bark full of fissures.-Woods and hedges. T. V. VI. Maple.

*2. A. Pseudo-platanus (L.) ; 1. 5-lobed unequally serrated, racemes pendulous, ovary downy with spreading wings, stam. of the male flowers twice as long as the corolla.- E. B.303. R. 4829.-A large handsome trce.- - In hedges and plantations. T. V. VI. Sycamore.

\section{Order XX. GERANIACEÆ.}

Sep. 5, persistent, imbricated. Pet. 5, clawed, twisted in restivation. Stam. generally monadelphous, 2 or 3 times as many as the petals, some often abortive. Fruit of 5 shells cohering round a long beaked torus, each terminated by an indurated style whieh finally twists up, separating from the torus, and earrying with it the pericarp. Seeds solitary, without albumen. Cotyledons eonvolıte, plaited.

1. Geranium. Sep. 5. Pet. 5. Stam. 10, monarlelphous, 
alternately larger and with glands at their base. Fruit beaked, separating into $5 \mathrm{l}$-seeded carpels, cach with a long ultimatcly recurved awn glabrous internally.

2. Eropium. Scp. 5. Pet. 5. Stam. mouadelphous, 5 sterile 5 fertile witl glands at their base. Fruit beaked, separating into 51 -seeded carpels, each with a long ultimately spirally twisted awn bearled internally.

\section{Geranium Linn. Cranesbill.}

* Root consisting of long fibres springing from a premorse rhizoma, perennial.

1. G. phoum (L.); peduncles 2 -flowered, pet. roundish wedgeshaped rather longer than the mucronate sepals, "carp. hairy below transversely wrinkled above, seeds punctate-striate." - E.B. 322. R. 4891.-St. erect, 2 feet high. L. 5-lobed: lobes acute, cut, serrated. Fl. purplish-black.-In woods and thickets, rare. "With white fl. on the sands of Barrie near Dundee." Hooker. P. V. VI.

E. S.

[2. G. nodosum (L.); peduncles 2-flowered, pet. obcordate twice as long as the awned sepals, carp. even downy, 1. 3-5lobed: lobes ovate acuninate scrrate-E.B.1091.-St. 18 in. high, slender, erect. Fl. pale purple. I have seen no specimens.-In Cumberland and Hertfordshire. Very rare. P. V. -VIII.]

3. G. sylvaticum (L.); peduncles 2-flowered, pet. obovate slightly notched twice as long as the awned sepals, carp. even liairy : hairs spreading glandular, seeds dotted, l. palmate 7-lobed : lobes cut and serrated, st. erect glandular-hairy above, filaments of the stam. subulate, fruitstalks erect.-E.B. 121.-St. erect, 2-3 feet high. Fl. purplish-blue, claws of the petals bearded, filaments hairy half way up. A specimen from Dr. Greville (found at Dollar) with pale rose-coloured flowers, smaller and nearly entire petals and a more decidedly hairy stem, is probably the var. $\beta$. fastigiatum (Fries) Nov. 211.-Woods and thickets, rare. P. VI. VII.

4. G. pratense (L.); peduncles 2-flowered, pet. obovate entire or slightly notched twice as long as the awned sepals, carp. even hairy : hairs spreading glandular, seeds "minutely reticulated," 1. palmate 7-lobed: lobes cut and serrated, st. diffuse glandular hairy above: hairs deflexed, flaments of the stam. filiform with a triangular-ovate base, fruitstalks deflexed.-E.B.404. R. 4883. -St. $1-2$ feet high. Fl. large, purple, claw of the pet. ciliated not bearded. Filaments slightly hairy at their base.-Moist pastures. P. VI.-VIII. 
5. G. sanguineum (L.); peduneles mostly single-flowered, pet. obeordate twiee as long as the awned sepals, earp. "smooth crowned with a few bristles, seeds minutely wrinkled and dotted," 1. nearly orbienlar 7-lobed: lobes deeply :3-fid and eut, st. diffuse hairy: hairs spreading horizontally.-E. B.272. R. 4894.Fl. large purple, filaments dilated at the base. $-\beta$. prostratum; st. dwarf tufted nearly simple deeumbent, $\mathrm{t}$. flesh-eoloured. $G$. prostratum Lindl. G. laneastriense With.-In dry plaees. $\beta$. Sands in Walney Island, Laneashire. P. VII.

\section{** Root fusiform, rhizoma wanting, perennial.}

6. G. pyrenaieum (L.); peduneles 2-flowered, fruitstalks deflexed, pet. obeordate twice as long as the mueronate sep.: elaws densely eiliated, earp. smooth with adpressed hairs, seeds smooth, 1. reniform 7-9-lobed: lobes oblong obtuse trifid and toothed at the end, st. ereet villose.-E. B. 405. R.4881.-Fl. light purple or nearly white. Claws of the pet. with a dense tuft of hairs on each side. Hypogynous ring $\frac{1}{3}$ less than the whorl of earps. ; lobes bluntly rounded, rather longer than broad. Fertile anth. I0. Segments of the upper leaves more aeute. St. spreading, $1-3$ feet high, elothed with dense short down and long hairs intermixed.--Roadsides and pastures. P. VI. VII.

\section{*** Root fusiform anmual.}

7. G. pusillum (L.); peduneles 2-flowerel, pedieels deflexed after flowering, pet. bifid about as long as the mucronate sepals: elaws slightly eiliated, earp. smooth with adpressed hairs, seeds smooth, 1. reniform palmate with $5-7$ trifid lobes, st. diffuse downy.-E. B. 385. R.4877. G. rotundifolium Fries.-St. prostrate, elothed only with short down. Fl. small, bluish-purple. Claws of the pet. only slightly ciliated. "Hypog. ring $\frac{1}{2}$ less than whorl of ear'ss.; lobes blunt oblong." "Fertile anth. 5. Peduneles shorter than the leaves.-Waste places. A. VI.IX.

8. G. dissectum (L.); peduncles 2-flowered, pet. bifid seareely longer than the awned sepals: claws slightly eiliated, earp. smooth with ereet hairs, seeds retieulated, l. in 5-7 deep laciniated segments with linear lobes, st. diffuse hairy.-E. B. 753 . R. 4876.-Fl. small, bhuish-purple. IIypog. ring $\frac{1}{3}$ less than whorl. of earps.; lobes eorlate. L. divided almost to the base, longer than the peduneles.-Waste plaees. A. VI.-VIII.

9. G. eolumbinum (L.); pedumeles 2-flowered, pet. obovate emarginate with a short obtuse tooth in the notch about as long as the awned sepals : elaws eiliated, earp. smooth with a few minute seattered hairs, seeds retieulated, 1 . in 5-7 deep laciniated segments, st. diffuse with adpressed hairs.-E. B. 259. R.4875.Fl. small, rose-eoloured. L. divided almost to their base. $P e$ - 
duncles longer than the leaves, with very long pedicels.-On gravelly and limestone soils. $\Lambda$. VI. VII.

10. G. rotundifolium (L.); perluncles 2 -flowered, pet. spathulate entire obtuse rather longer than the shortly awned sepals : claws glabrous, carp. smooth with spreading hairs, seeds reticulated, 1. reniform in 5-7 broadly werlge-shaped inciso-erenate segments, st. diffuse pulbesecnt.-E. B. 157. R. 4878.-l'l. small, Hesli-eolonred. Pedmeles shorter than the leaves.-Old walls and waste places, rare. $\Lambda$. VI. VII.

11. G. molle (L.) ; perluncles 2-flowered, pet. oblong decply bifid scarcely longer than the mucronate sepals : claws ciliated, carp. transversely wrinkled glabrous, seeds smooth, l. roundishreniform in 7-9) deep wedge-shaped segments trifid at the end, st. diffise pubescent.-E.B.778. R.4879,-Fl. small, purple. IIypog. ring rather less than the whorl of earp.; lobes narrow, acute. Pubescence very soft.- $\beta$. ? aquale; carp. withont wrinkles, hypog. ring at the base of the axis as broad as the whorl of carps. : lobes very broad.-Dry plaees. $\beta$. near Leamington (1845). Mr. J.J. Murcott. A. IV.-VIII.

12. G. lucidum (L.); peduneles 2-flowered, pet. obovate entire: claws glabrous very long nearly equalling the transversely rugose pyramidal calyx, carp. reticulated triply keeled glandularhairy at the summit, seeds smooth, l. reniform in 5 obtise incisoerenate mncronate segments, st. spreading ascending.-E. B. 75 . R. 4872.-Fl. small, rose-eoloured. St. and l. glabrous and shining, often strongly tinged with red.-Lindley considers his G. Raii as most allicd to this species; it differs, he says, by its "shaggy calyx and simply keeled fruit," and occurs on the south coast of England.-Walls and hedge-banks. A. V.-VIII.

13. G. robertianum (L.); peduncles 2-flowered, pet. obovate entire or slightly emarginate: claws glabrous very long nearly equalling the long-awned hairy and slightly glandular sepals, carp. transversely wrinkled downy, seeds smooth, l. ternate or quinate, leaflets stalked trifid inciso-pinnatifid, st. spreading erect.-E. B. 1486. R. 4871.-Fl. purple, sometimes white. Cal. with a very few glandular hairs, not transversely rugose.- $\beta$. purpureum; pet. narrower, sep. glandular-hairy, carp. glabrons and more wrinkled, 1. in narrower segments. G. purpureum Forst. E. B. S. 2640.-Hedge-banks. ß3. Southern sea-coast. A. V. -IX.

\section{Erodium L'Ierit.}

1. E. cicutarium (Sm.); st. procumbent hairy, peduncles many-flowered, perfect stam. dilated not toothed below glabrous, beak hairy, I. pinnate, leaflets sessile pinnatifid eut.-E. B. 1768 . 
- Very hairy. Fl. purplish or white. Leaflets very deeply divided, their segments lanccolate or linear, acute. In specimens from Pennard Sands near Swansca the peduncles are mostly 3 flowered and the scgments of the leaves much shorter finer and more spreading. In Jersey specimens the 1 . are ovate and short, and their segments short broad and bluntish.- $[E$. pimpinellefolium which has a glabrous beak and entire cotyledons ought to be found in England.] - Waste ground. A. VI.-IX.

2. E. moschatum (Sm.); st. procumbent hairy, peduncles many-flowered, perfect stam. toothed at the base glabrous, beak downy, l. pinnate leaflets nearly sessile ovate unequally cut.E. B.902.-Much larger than the preceding and diffusing a strong musky scent when handled.-Waste places, rather rare. A. VI. VII.

3. E. maritimum (Sm.); st. prostrate slightly hairy, peduncles 1-2-flowered, pet. very minute, 1 . simple ovate-cordate stalked lobed and crenate.-E. B. 646.-St. often very fleshy. Fl. very small and inconspicuous. Pet. pale red, very minute, of ten wanting.-Sandy and gravelly places, particularly near the sea, rare. P. V.-IX.

\section{Order XXI. LINEÆ.}

Sep. 3-5, persistent, imbricatc. Pet. 3-5, twisted in astivation, clawed, fugitive. Stam. as many as the pet., connected into a hypogynous ring with intermediate teeth (abortive stamens). Ovary with about as many cells and styles as the sepals, stigmas capitate. Caps. generally tipped with the hardened base of the styles, with 4-5 complete dissepiments (of 2 membranes), and $4-5$ incomplete dissepiments. Seeds I in each spurious cell, pendulous, with albumen.-L. without stipules, alternate.

I. Linum. Cal. of 5 sepals. Pet. 5. Stam. 5. Caps, with 10 cells and 10 valves.

2. Radiola. Cal. of 4 sepaIs, connected below, deeply trifid. Pet. 4. Stam. 4. Caps. with 8 cells and 8 valves.

\section{Linum Linn.}

* Leaves scattered. Margins of the sep. not glandular.

I. L. angustifolium (IIuds.); sep. elliptical pointed ciliated, I. linear-lanceolate, st. numerous.-E. B. 381.- Fl. pale blue. St. 1-2 feet high.-Sandy and chalky places. P. VII. E. I.

*2. L. usitutissimum (L.); sep. ovate pointed ciliated, l. Ianceolate, st. solitary.-E. B. 1357. St. 26. I2.-Fl. blue. St. I-I $\frac{1}{2}$ foot ligh. Scp. 3-nerved.- $\beta$. crepitans (Schub.); smaller 
and inore branched, caps, opening with elastieity, seeds paler.In eultivated fiekls. $\Lambda$. VII. Common. Flax.

3. L. perenne (L.); sep. obovate obtuse obscurely 5-nerved glabrous, l. linear-lauceolite, st. numerous, fruitstalks erect.E. B. 40.-l'l. blue.-St. ereet or deemubent.-Chalky places. P. VI. VII.

\section{** Leaves opposite.}

4. L. catharticum (L.); sep. elliptical pointed, l. opposite obovate-laneeolate. - E. B. 382.-l'l, white, small ; sep. serrated ; pet. acute. St. one or more, slender. Paniele forked, spreading. -In dry pastures. A. VI.-VIII.

\section{Radiola Gmel.}

1. R. millegrana (Sm.).-E. B. 893. R. linoides DC., Koeh. -St. 1-2 in. high, repeatedly forked, with solitary $\mathrm{Al}$. in the axils as well as at the extremities of the branehes. Fl. minute, white. Sep. deeply and acutely 3-(cleft, eonnected below into a tube.-Danp sandy places. A. VII. VIII.

\section{Order XXII. BALSAMINEA.}

Sep. 5 (2 upper usually wanting), irregular, deeiduous, lower spurred, imbrieate in xstivation. Pet. 5, irregular, united in pairs. Stan. 5. Anth. 2-eelled, opening at the apex by a longitudinal fissure, more or less eonnecter. Ovary 5-eelled. Fr. capsular with 5 elastie valves. Seels solitary or numerous, pendulous, albumen $0 .-\mathrm{L}$. without stipules. Plant sueeulent.

1. Impatiens. Sej. 3, the lower one eueullate with a spur. Pet. 3, upper one symmetrieal, lateral unequally 2-lobed or each formed of 2 combined. Anth. eohering. Caps. of 5 elastie valves, at length spirally rolled inwards.

\section{Inpatiens Linn.}

1. I. Noli-me-tangere (L.) ; l. ovate eoarsely serrate, perluneles many-flowered solitary, spur loosely recurved not emarginate. -E. B. 937. R. v. $t$. 198. b. St.5. 15.-Fl. large, yellow spotted with orange. Serratures of the leaves not glandular. St. $1-2$ feet high, tumid at the joints.-Damp woody places in mountainous distriets. A. VII.-IX. Yellow Balsam.

*2. I. fulva (Nutt.); l. ovate coarsely serrated, peduneles about 4-flowered solitary, spur closely reflexed emarginate.E. B. S. 2794.-Fl. orange-yellow spotted with red. Serratures of the l. with a reflexed glandular tooth. St. $2-3$ feet high with tumid joints.-An Ameriean plant now quite naturalized by the river Wey in Surrey. A. VIII. 


\section{Order XXIII. OXALIDEF.}

Scp. 5, equal, persistent, imbricate in astivation. Pet. 5, cqual, often cohering at the base, twisted in astivation. Stam. 10, more or less monadelphous, those opposite to the pet. longer than the other's. Antli. 2-celled, not connected. Ovary 5-celled. Styles 5. Caps. 5-10-valved. Seeds several; testa fleshy, bursting elastically. Embryo straight, in cartilaginous albuinen.

1. Oxalis. Sep. 5, connccted below. Pet. 5, often connected below. Stam. 10, monadelphous, 5 outer ones shorter. Styles 5. Caps. ollong.

\section{Oxalis Linn.}

1. O. Acetosella (L.); stemless, rhizoma creeping toothed, l. ternatc, leaflets obcordate hairy, peduncles longer than the leaves with 2 scaly bracts at about the middle-E. B. 762. R. 4898. -Fl. white with purple veins or rarely purple or blue. Cor. about 4 times as long as the calyx.-W Woods and shady places. P. V. Wood Sorrel.

2. O. corniculata (L.); st. diffuse with procumbent branches pubescent, l. ternate, leaflets obcordate, stipules ablong united to the base of the petioles, peduncles about 2-flowered sliorter than the leaves, partial fruitstalks reflexed, root fibrous without scions. -E. B. 1726.-Fl. yellow. L. mostly in pairs.-Waste ground in Devon and Cornwall. A. VI.-IX.

E.

[3. O. stricta (L.); st. erect, stipules 0 , peduncles 2-8flowered longer than the l., fruitstalks erect, root with underground scions.- R. 4895.- Naturalized at Penzance, Corn.; and Ilsington, Devon. B. VII. VIII.]

E.

\section{Subdivision II. CALYCIFLOR E.}

Pet. distinct. Stam. perigynous.

\section{Order XXIV. CELASTRINEE.}

Sep. 4-5, æstivation imbricate. Pet. 4-5, inserted into the margin of a lypogynous fleshy disk. Stam. alternate with the petals, inserted in the disk. Ovary sunk in the disk, more or less connected with it, 3-4-celled ; cells 1-2-seeded; ovules erect. Embryo straight.

[1. Staphylea. Cal. 5-parted, coloured; disk urceolate. Pet. 5, Stam. 5, inserted round the disk. Styles 2-3. Caps. membranous, 2-3-celled, dehiscing internally. Seeds few, bony, truncate at the hilum.-Leaves compound.] 
2. Euonymus. Cal. flat, 4-5-lobed; disk peltate. Pet. $4-5$, inserted in the margin of the disk. Stan. 4-5, inserted in the disk. Style 1. Capss. 3-5-eelled, 3-5angled, lehiscenee loeulieidal. Seeds solitary in each eell, with a fleshy arillus, not truncate at the lilum.-Leaves simple.

\section{Staphylea Limn. Bladder-nut.}

[1. S. pinnata (L.); 1. pinnate, leaflets $5-7$, petioles without glands, fl. racemose, styles 2 , eaps. bladlery.-E. B. 1560. $R$. 4823.-Fl, yellowish-white.-A very doubtful native. S. VI.] E.

\section{Euonyuus Linn. Spindle-tree.}

1. E. europaus (L.); pet. oblong, fl. mostly 4-eleft and 4-androus, branehes tetragonal smooth and even, l. elliptie-laneeolate minutely serrate, eaps. obtusely angular not winged.--E. B. 362 . R. 5134. St. 27. 3.-Arillus inelosing the seed. Bark green. L. glabrous. Fl. few together forming a small umbel, greenishwhite. Fruit rose-eoloured.--IIedges and woods. Sh. V.

\section{Order XXV. RIIAMNEA.}

Cal. 4-5-eleft, xestivation valvate. Pet. distinet, inserted into the throat of the ealyx. Stam. opposite to the pet. and equalling them in number. Ovary wholly or in part superior, 2-34-celled, surrounded by a glandular disk. Seeds solitary, ereet. Embryo straight. Fruit fleshy or dry.

1. Rhamnus. Cal. ureeolate, $4-5$-eleft. Pet. 4 or 5 , or sometimes 0 , inserted with the stam. on the margin of the tube of the ealyx. Fruit fleshy, with $2-4$ eells and as many seeds.

\section{Rhamnus Linn.}

1. R. catharticus (L.); thol'ns terminal, $f$. 4-cleft diøeious, petioles mueh longer than the stipules, l. roundish-oval sharply toothed, fr. with 4 seeds.-E. B. 1629.-Branches opposite. Serratures of the l. ineurved, glandular. Noteh in the seeds shut. Styles 4 , united half way up.-Hedges and thiekets. Sh. V.-VII. Buckthorn.

2. R. Frangula (L.); spineless, $f$. 5 -cleft perfeet, $l$. elliptical acuminate narrowed below entire, fr. with 2 seeds, style simple.F. B. 250.-Branches alternate. I'l. in small elusters, greenishwhite, small.-Hedges and thiekets. Sh. V. VI. Alder Buckthorn.

E. I. 


\section{Order XXVI. LEGUMINOSA.}

Cal. inferior. Scp. 5, more or less combined, odd one anterior. Cor. papilionaceous (in our plants), inserted into the base of the calyx. Pet. 5, odd one superior. Stam. 10 (in our plants), monadelphous or diadelphous. Ovary free, 1-celled. Fruit a legume; placenta on the upper suture; style from the upper suture. Embryo bent over the edge of the eotyledons, or straight. -All our plants have papilionaceons flowers and 10 stamens in one bundle or in two bundles of 9 and 1 .

Tribe I. LOTE $F$. Pod contimnous. Cotyledons rising above the ground and becoming green leaves. Leaves of 1 or 3 leaflets or pinnate with an odd one.

\section{* Leaflet solitary. Stamens monadelphous.}

1. Ulex. Cal. of 2 parts, the upper with 3, the lower with 2 teeth, a bract on each side at the base. Pod turgid, fewseeded, scarcely longer than the calyx.

2. Genista. Cal. 2-lipped, upper bifid, lower trifid. Style subulate, ascending. Stigma termiual, oblique, introrsc.

\section{** Leaf of 3 leaflets. Stamens monadelphous.}

3. Sarothaunus. Cal. 2-lipped, the upper with 2, the lower with 3 teeth. Style long, curved, thickened upwards, ehanneled within. Stigma terminal, eapitate, small. Pod flat.

4. Oxonis. Cal. 5-cleft, campanulate, segments narrow, the lower ones longer. Keel beaked. Style filiform, aseending. Stigma terminal, subeapitate.

$$
\text { *** Leaf of } 3 \text { leaflets. Stamens diadelphous. }
$$

5. Medicago. Cal. with 5 nearly equal teeth. Keel obtuse. Filaments of the stamens filiform. Ovaries eurved. Pod l-eelled, falcate or spiral. Seeds 1 or numerous.

6. Melilotus. Cal, with 5 nearly equal tecth. Keel obtuse. Filaments filiform, not united with the claws of the petals. Ovary straight. Pod subglobose or ollong, l-celled, 1-4secded, longer than the calyx. Pct. distinet, deeiduous.

7. Trifolium. Cal. with 5 uncqual teeth. Keel obtuse. Filaments slightly enlarged upwards and more or less united with the elaws of the petals. Pod oval, $1-4$-seeded, included in the calyx or slightly protruding. Pet. slightly combined, persistent.-In T. ornithopodioides, seareely a true Trifolium, the pod is 8-seeded and the filaments are filiform.

8. Lotus. Cal. with 5 nearly equal teeth. Keel ascending, with a narrowed point (bcak). Wings connivent at their 
upper margin. Louger filaments dilated upwards. Style kneed at the base, filiform-subulatc. Pod linear, manyseeded, 2-valved, imperfeetly divided by transverse partitions.

**** Leaf pinnate with an odd one. Stamens monadelphous.

9. Antirlis. Cal.tubular, inflated, 5-cleft, segments unequal. Keel not beaked. Style filiform. Stigma capitate.

***** Leaf pinnate with an odd one. Stamens diadelphous.

10. Oxytropis. Cal. with 5 tecth. Keel with a narrow straight point. Pod imperfectly 2-celled, cells formed by the inflexed margin of the upper suture.

11. Astragalus. Cal. with 5 teeth. Keel obtuse. Pods imperfcetly 2-celled, cells formed by the inflexed margin of the lower suture.

Tr. II. VICIE $A$. Pod continuous. Stam. diadelphous. Cotyledons remaining under ground. L. abruptly pinnate.

12. Vicia. Cal. 5-fid or 5-toothed. Style filiform, its upper part hairy all over, or bearded on the underside and at the same time hairy or glabrous. Pods 1-cclled, 2-valved.

13. Latruyus. Cal. 5-fid or 5-toothed. Style dilated upwards, plane on the upper side, hairy beneath the stigma. Pods 1-celled, 2-valved.-L. witl tendrils (except in L. Nissolia).

14. Oroвus. Cal. 5-fid or 5-toothed. Style linear or dilated upwards, plane on the upper side, hairy beneath the stigma. Pods 1-celled, 2-valved.-L. with an herbaceous point in the place of tendrils.

Tr. III. HEDYSAREAE. Pod divided transversely into lsecded joints. L. pinnate with an odd oue.

15. Ornithopus. Cal. elongated, tubular, with 5 nearly equal teeth : 2 upper ones slightly combined and converging. Keel obtuse. Pod elongated, compressed, of many l-seeded indehiscent joints equally narrowed on both sides at the articulations. - A pex of the common peduncles bearing a small pimnate leaf just below the flowers.

16. Авти roloвium. Cal. elongated, tubular, with 5 nearly equal teetlı: 2 upper oncs combined up to their middle and straight. Keel obtuse. Pod elongated, eylindrical, of many l-seeded indehiseent joints scarcely narrowed at the articulations.-No leaf at the apex of the peduncles.

17. Hippocrepis. Cal. short, campanulate, with 5 nearly equal teeth: 2 upper oues combined up to their middle. 
Keel narrowed into a beak. Pod elongated, compressed, of many I-sccded crcscent-shaped joints, so that each pod has many notches on one side.

I8. ONoвrycuis, Cal, with 5 nearly equal subulate teeth. Keel obliquely truncate, longer than the wings. Pod l-celled, compressed, indchisecnt, l-seeded, upper suture straight, lower curved toothed winged or crested.

\section{Tribe I. Lotea.}

\section{ULEX Linn.}

1. U. europaus (L.); cal. slaggy, bracts orate lax, young l. shaggy beneath furrowed, primary spines strong terete polygonal furrowed minutely seabrons, st. hairy, fl. lateral.-E. B. $742 .-$ St. 4-6 feet high, very much branched sprearling. Fl. bright yellow, springing from both the prinary and seeondary spines. Spines branching at their base and up to abont half their length, not extending beyond the flowers. "Sceds I0." See $A$. N. H. v. 300.-Hcaths. Sh. II.-VI. Spring Furze, Whin, Gorse.

2. U. strictus (Mack.); eal. shaggy, bracts ovate lax, young 1 . shaggy beneath thin, primary spines small slender tetragonal ininutely scabrous, st. hairy, $f$. terminal. - Plant I-2 feet high, with upright branches. Fl. rarely produced : in all the speeimens that I have secn they are tcrminal, springing from the summit of the stem, not from the spines, which branch as in $U$. europaus but are peculiarly small. The pet. slightly different in form from the last. Distinguished from both the other species by its peculiar habit. Mr. Cameron of the Birningham Bot. Gard. has sown the sceds of this plant and obtained only plants exactly like the parent. (Phyt. i. 7(i.)-In Lord Londonderry's park, Down, Ireland. Sh. IV. Irish Furze.

3. U. nanus (Forst.); cal. finely downy, bracts very minute adpressed, young $l$. glabrous ciliated furrowed, primary spines slender tcrete striated smooth, st. hairy, fl. latcral and terminal. - E. B. 743.--St. procumbent. Primary spines short, slender, spreading, branched at their base only. Fl. lialf the size of those of $U$. europas, springing from the primary spines and not extending beyond them. "Sceds 5." - $\beta$. major (Bab.); st. erect or ascending $3-6$ feet high, primary spines long strong deflexed. -Heaths. Sh. VIII.-XI. Autumnal Furze.

\section{Genista Linn.}

1. G. pilosa (L.); st. procumbent without thorns, l. obovatelanceolate obtuse, stipules ovate blunt, branches peduncles calyx standard kecl and underside of the l. silky, pcduncles lateral $\dot{a} c$ - 
companied by a tuft of leaves, pods hairy.-E. B. 208.-FI. small, vellow, collected towarls the extremity of the brauches. St. inuch branched, furrowed, woody.-Diry sandy and gravelly heaths, rare. Sl. V.

IS.

2. G. tinctoria (L.); st. depressed with erect branehes without thorns, l. lanceolate or elliptical hairy at the edges, stipules minute subulate, $f$. racemose, cor. and pods glabrous.-E. B. 44.branclies ereet, $1-2$ fect high, elevato-striatc, glabrous, downy above. Il. yellow. Keel as long as the standard.- $\beta$. humifusa; st. and branches procumbent, l. ovate or oblong, porls hairy on the back of eaeh valve. G. Lumifusa Dickson MSS. in Herb. l'orst. -St. angular, $6-10 \mathrm{in}$. long.-In pastures and thickets. $\beta$. Near Kymance Cove, Cornwall. Sh. VII.-IX. Dyers-weed. Woad.

3. G. anglica (L.) ; st. aseending spinous leafless below, flowering branehes unarmed glabrous, l. ovate-laneeolate, stipules $0, f$. solitary in the axils of the upper l., corolla and pods glabrous. -E. B. 132.-St. 1 foot high, round, leafless, with short leafy branehes bearing the yellow flowers. Keel longer than the standard. -Moist peaty heatlis. Sh. V. VI. Needle Whin.

[Many species of Genista have compound leaves.]

\section{Sarothamens Wrimm. Broom.}

1. S. scoparius (Wimm.).-E. B. 1339. Spartium L., Sm., Cytisus Link.-St. 2-3 feet high, angular, glabrous. L. teruate or simple, leaflcts obovate. Fl. axillary, solitary or in pairs, shortly stalked, large, bright yellow. Pols dark brown, hairy at the edges, with numerous seeds. In Cytisus the style is subulate and stigma oblique; in Spartium the style is subulate and the stigma oblong and attached longitudinally below the apex of the style.-Dry lills and heaths. Sh. V. VI.

\section{ONonis Linn.}

1. O. arvensis (L.); st. procumbent uniformly hairy, fl. axillary solitary stalked, leaflcts broadly oblong, pods ovate ereet shorter llan the calyx.-E. B. S. 2659. O. repens Koch in St. 72. 13.Usually without spines. St. rooting at their base. Seeds tubcrcularseabrous.-Barren sandy places. P.VI.-IX.Trailing Rest-harrow.

2. O. antiquorum (L.?); st. ereet or ascending, bifariously hairy, 1. axillary solitary stalked, leaflets oblong, pods ovate erect longer than the calyx.-E. B. 682. O. spinosa Koch in St.72. 11. O. campestris Fries.-Usually spinous. St. mostly erect. Seeds tubercular-scabrous. Is this the true $O$. antiquorum L.? Koch and Reichenbach both describe and figure quite a different plant with smooth seeds. Sec St. 72. 12. R.I. 14. A. N. H. ii. 95.Barren places. P. VI.-IX. Spinous Rest-harrow. E. S. 
[O. hircina (Jacq.) differs, according to Koch, by having its tl. axillary in paurs and denscly spiked at the ends of the branches.]

3. O. reclinata (L.) ; viscid, pubescent, st. ascending, fl. axillary, pedicels l-flowered shorter than the 1 . fl. or pod without bracts, cor. about equal to the calyx, leaflets obovate-cuneate scriated at the lip, stipules ovate, pods cylindrical reflexed, seeds 14-18 tuberculated.-E. B. S. 2838.-St. 5-6 in. high, much branclied.-Sandy places. Galloway, Channel Isles. A.VII.-S.

\section{Medicago Linn.}

*1. M. sativa (L.) ; racemes nnany-flowered, pods compressed loosely spiral with 2 or 3 turns downy with adpressed hairs unarmed, pedicels shorter than the calyx or bract, leaflets obovateoblong dentate above cuarginate mucronate- $-E$. B. 1749.-St. erect, angular when young. Porls twisted into a loose open spiral. Fi. yellow or violet.-Hedge-banks and borders of fields, scarcely naturalized. P. VI. VII. Lucerne.

2. M. falcata (L.); racemes many-flowered subcorymbose, pods compressed sickle-shaped or once twisted downy unarmed, pedicels shorter than the calyx longer than the bract, leaflets obovate-oblong dentate above emarginatc mucronate.-E. B. 1016.?--St. decumbent, terete, solid, with adpressed hairs. Pods not forming a spiral. F'l. yellow or violet.-Dry banks, rare. P. VI. VII. E.

3. 11 . lupulina (L.); spikes many-flowered dense oval, pods compressed unarmed kidney-shaped with a spiral point rugged with longitudinal branched prominent veins, stip. obliquely ovate slightly toothed, leaflets roundish-obovate denticulate above emarsinate mucronate.-E. B. 971.- St. procumbent or ascending, spreading widely. Pods scarcely spiral, glabrous or slightly hairy. Fl. yellow.-Waste ground. A. V.-VIII. Black Medick.

4. M. maculata (Sibth.); peduncles 1-4-flowered, pods compactly spiral compressed consisting of 2 or 3 turns veined with 4 ridges on the edge and a central furrow, spines in 2 rows divergrent subulate curverl, leaflets triangular-obcordate, stip. toothed. -E. B. 1616.--Leaflets with a purple spot in the centre. Edge of the pods broad; spines arising from the margin and the ridge next to it on cach sile, compressed and furrowed on both sides, varying considerably in length.-On a gravelly soil. A. V.-VIII.

5. M. minima (Lam.); peduncles 1-6-flowered, pods compactly spiral consisting of 4 turns smooth with a thin edge, spines in 2 rows divergent subulate hooked, leaflets obovate, stip. nearly entire.-E. B. S. 2635.--Edge of the pods with 3 ridges, the ceutral one so prominent as to be easily taken for the true margin, no central furrow but the central ridge common to the 2 rows of spines. Sides of the pods smooth. Spines varying con- 
siderably in length and the whole plant in hairiness.-In sandy fields, rare. $\Lambda . \mathrm{V}$.

[I lave omitted $M$. nuricata, bcing convineed from personal observation that no such plant now exists "on the sea-bank at Orforl."']

6. MI. denticulata (Willd.); peduncles $1-5$-flowered, pods rather loosely spiral cousisting of 2 or 3 turns deeply reticulated witl a thin edge, spines in 2 rows divergent subulate hooked, leaflets obcordate, stip. laciniated.-E. B.S.2634.--Edge of the jods as in $M$, minima. Spines about equalling the diameter of the pool. Whole plant glabrons.- $\beta$. apiculata; spines very short without hooks, often seareely longer than their own breadth so as to appear little more than tubercles, ped. 3-10-flowered. $M$. apiculata (Willl.), Koch, DC.-On sandy ground near the sea. I. V.-VIII.

E. I.

\section{Melilotus Lam.}

1. M. officinalis (Willd.); racemes lax, cor. twice as long as the calyx, wings keel and standard equal, pods ovate acute eompressed transversely wrinkled hairy, leatlets serrate truneate narrowly ovate, stip. setaceous entirc.-E. B. 1340. M. macrorhiza Pcrs., Koch.-St. crect, $2-3$ feet high. Fl. in lateral racemes, yellow.-Waste places. B.? VI.--VIII. Melilot.

2. M. vulgaris (Willd.); racemes lax, cor. twice as long as the calyx, wings and keel equal but shorter than the standard, pods ovate obtuse mucronate reticulate-rugose glabrous, leaflets obovate the upper ones oblong serrate obtuse, stip. awlshaped entire--H. leucantha Koch in DC., E. B. S. 2689. M. alba Koch "not Lam." (Coss. et Germ.) - St. erect. Fl. white.Sandy and gravelly places ncar the sea, rare. B. VII. VIII.

\section{Trifolium Limn.}

* F7. sessile, cal. with an elevated thickened often hairy line or ring of hairs in its throat, not inflated.

1. T. pratense (L.); heads ovate dense sessile, eal. 10-nerved hairy not half so long as the eorolla: teeth setaceous ciliated, stip. ovate abruptly bristle-pointed, leaflets oval emarginate upper ones entire apiculate.-E.B. 1770. St. 15.11.-In the cultivated plant the leatlets are usually all quite entire. Teeth of the cal. 5,4 ncarly equal in length to the tube, the lower one twice as long, the mouth with a thickeued hairy ring within. Heads of H. sometimes slightly stalked. Fl. purplish, sometimes white. St. erect.- $\beta$. parvifiorum; heads stalked, calyx-teeth as long or longer than the corolla.-Mountainous pastures, ficlds. $\beta$. in dry places. P. V.-IX. Purple Clover.

2. T. medium (L.); heads subglobose lax stalked, ealyx 10-nerved glabrous not half as long as the corolla: teeth seta- 
ceous hairy, stip. linear-lanceolate acnminate, leaflets elliptical or lanceolate apicnlatc.-E. B. 190. St. 15. 13.-Four of the calyx-tectl equal in length to, or rather longer than the tube, the fiftl one-thircl longer, montlı with a thickened hairy ring within. Heads of fl. large. Fl. purplish. St. ascending, zigzag.-Dry elevated pastures. P. VI.-IX.

3. T. ochroleucum (L.); heads subglobose dense stalked solitary terminal, cal. 10-nerved pubescent about lialf as long as the corolla : teeth erect in fruit subulate lower one rather longer than the tube the others two-thisds shorter, stip. lanccolate-subulate, lcaflets clliptic-oblong the lower one emarginate or cordate.E. B. 1224. St. 15. 15.-Cal. with acnte teeth having 1 strong nerve, mouth with a thickened ring pubescent on its npper side within. St. $1 \frac{1}{2}$ foot ligh, erect. Lower l. on very long stalks. Fl. cream-coloured, at length tuming brown.-Dry gravelly soils in the east of England. P. VI. VII.

E. S.

4. T. incarnatum (L.); heads ovate at length cylindrical stalked solitary terminal, cal. 10-nerved lairy not half as long as the corolla : teeth patent in fruit lanceolate-subulate nearly equal rather longer than the tulsc and shorter than the cor., stip. ovate obtuse, leaflets obovate retuse or obcorlate, st. crect and together with the 1 . and stip. villose.-St. 16. 4.-Stip. sometimes rather acute especially the lower ones. Fl. reddish purple. Mlouth of the calyx of the fr. hairy. $-\beta$. Molinieri (R.); plant smaller, leaflets obcorlate, fl. yellow.-Naturalized in a few places. $\beta$. is "decidedly indigenons" near the Lizard Point, Cornwall. Rev. $W$. S. Hore (Pliytol. ii. 237). A. VI. VII.

†5. T. stellatum (I.); heads globose stalked terminal, calyx 10-nerved hairy : teeth snbulate from a broad base equal longer than the corolla patent in fruit 3-nerved and reticulated throat closerl with lrairs, stip, ovate rather acute denticnlated, leaflets obcordate, st. spreading and together with the l. and stip. villose. -E. B. 1545. St. 16.5.- Hl. cream-coloured, small. Calyx of the fruit remarkably large, its tecth spreading in a stellate manner. St. short.-Shingly beach near Shoreham. A. VI. V1I. E.

6. T. arvense (L.) ; heads nearly cylindrical stalked very bairy, cal. 10-nerved: teeth subulate-setaceous hairy nearly cqual nerveless longer than the cor. at length slightly sprearling, stip. ovate or lanceolate acuminate, leaflets linear-oblong.-L. B. 944. St. 16. 3.-St. erect, or in a maritime form (Ray Syn. t. 14. f. 2.) procumbent witl globose hearls, st. and l. finely hairy. Points of the lower stip. sometimes very slender. Fl. small, alinost concealed by the very liairy calyx. Seeds oval, greenish yellow, radicle not prominent. 'Throat of the calyx thickened and glabrons within.-Sandy fields. A. VII.-1X. Hare's-foot Trefoil.

7. T. striatum (L.); heads ovate or oblong sessile terminal and 
lateral solitary, calyx 10-nerved hairy: teeth subulate unequal straight mucronate about as long as the cor., tube ventricose in fruit, stip). ovate cuspidate, leaflets obcordate or obovate : veins equal and straight at the margins, $-E$. B. 1843. St. 16.6.7.St. procumbent, 4-10 in. loug and as well as the l. silky. lil. small. Seeds oval, brownish yellow, radicle not prominent. 'Throat of the calyx thickened within.- $\beta$. erectum (Leight.); st. crect, heads elongated subconical, cor. longer than the calyx. Secds (?).-Dry aud sandy places. A. VI. VII.

8. T. scabrum (L.); heads ovate sessile terminal and lateral solitary, cal. 10-nerved liairy : teeth lanceolate mucronate about as long as the cor. with 1 strong prominent nerve at lengtlı patent, tube cylindrical in fruit, stip. ovate cuspidate, leaflcts obovate: veins thickened and curved at the margins. $-E$. B. 903.-St. procumbent, spreading. Fl. small. Cal. of the fruit very rigid. Seeds oblong, reddish yellow, radicle not prominent. Throat of the cal. thickened within.-Dry sandy places. A. V.-VII.

9. T. Bocconi (Savi) ; heads oblong-ovate sessile terminal usually 2 together, cal. 10-nerved hairy: teetl lanccolate-subulate unucronate abont as long as the cor. with 1 strong prominent nerve erect: tube cylindrical in fruit, stip. oblong with a long subulate point, leaflets oblong-obovate in the lower lcaves roundish-obovate : veins equal and straight at the margins, seeds with the radicle slightly prominent.-E.B.S. 2868 . -St. $2-6 \mathrm{in.}$ ligh, crect. Fl, small, pale yellow. Seeds oval, browuish yellow. Throat of the calyx hairy within. Heads dense, somewhat conical. -Iu dry places, very rare. Cadgewith, Cornwall. A. VII. E.

10. T. maritimum (IIuds.); heads ovate-globose stalked terminal, cal. strongly ncrved: teeth ciliated at first subulate erect shorter than the cor. afterwards broad lcafy acute spreading 1-nerved the lower one longest and 3-nerved, tube hairy above obconical in fruit, stip. broadly subulate very long, leafl. oblongobovate. $-E . B .220$. - St. spreading, usually procumbent. Fl. pale red, small. Throat of the cal. with an elevated thickened ring, hairy on its upper side, within.-Mnddy salt marshes. A. VI. VII.

** Fl. sessile; throat of the calyx naked within; heads fewflowered, at length producing thick stellated fibres (abortive calyces) from thcir ccntre which ultimately fold over the fruit.

11. T. subterraneum (L.); heads 2-5-flowered erect deflexed in frnit, calyx glabrous : teeth filiform hairy nearly equal shorter than the corolla, tube iuflated in fruit and at length split longitudinally, abortive calyces numerous slender stellate with 5 points, stip. ovate pointed, leaflets obcordate.-E. B. 1048.-St. prostrate and as well as the l. hairy. Fl. white, considerably longer than the calyx. The curious abortive calyces are remarkably char acteristic of this speeies.-Dry gravelly places. A. V. VI. 
*** Fl. sessile or stalked; throat of the calyx naked within, not inflated, pods 2-4-8-sceded.

12. T. glomeratum (L.); heads glohose sessile tcrininal and axillary, calyx sessile 10-nerved: teeth ovate very acute veiny nearly cqual reflexed, stip. ovate taper-pointed, leaflets obcordate the upper ones obovate, seeds 2.-E. B. 1063.-St. procumbent. Fl. rose-coloured, stanclard persistent striated. Seeds transversely ovate-reniform, radicle prominent.-Gravelly places near the sea. $\Lambda$. VI.

13. T. strictum (L.?); heads globose axillary, calyx sessilc 10-nerved: teeth subulate nnequal somewhat spreading, stip. broad pointed scrrated, leaflets obovate the upper ones oblong, seeds 2.-Schreb. in St. 15. 4. (stip. not so acute in our plant.) T. parviflorum (Ehrh.) Koch.-St. erect, short. Ped. short. Pods slightly exserted, seeds ovate, radicle slightly prominent.Jersey. Mr. J. Woods, and (near Fabre Chapel, St. Brelades, in 1842) Rev. W. W. Newbould. A. VIII.

14. T. suffocatum (L.); heads roundish sessile axillary, cal. scssile: teeth lanceolate acute falcate recurved longer than the corolla, stip. ovate pointed, leaflets obcordate, seeds 2.-E. B. 1049. - St. short, usually buried in the sand. Fl. sinall, erect. Cal. scarcely striated. Seeds roundish, radicle prominent.Sandy sea-shores, rare. A. VI.

15. T. repens (L.); heads roundish, peduncles axillary longer than the leaves, $f$. stalked at length deflexed, calyx glabrous half as long as the corolla: teeth lanceolate unequal erect, stip. ovate abruptly cuspidate, leaflets obovate or obcordate, seeds 4 , stems creeping.-E. B. 1769. St. 15. 6.-Fl. white, standard striated. L. often with a dark spot at their base. Pod included. In damp seasons the porl is often protruded in the form of a horm or changed into a small leaf.-Meadows and pastures. P. V.-IX. Dutch or White Clover.

16. T.? ornithopodioides (L.); clusters stalked axillary of $1-$ 3 stalked $f$., calyx glabrous : teeth slender acute ncarly equal erect, stip. ovate with long taper points, leaflets obcordate, seeds 8.-E. B. 1047.-St. prostrate. Nl. small, pet. all distinet. Pod exserted, compressed, obtuse, transversely furrowed, slightly hairy, curved, longer than the calyx, opening with 2 valves. This plant is scarccly a Trifolium or Trigonella.--Dry gravelly places. 1. VI. VII.

**** Fl. sessile, throat of the calyx naked within inflated after flowering and arched above.

17. T. fragiferum (L.); heads globose, peduncles axillary longer than the leaves, involucre multifid as long as the calyx, calyx of the fruit membranous reticulated downy, stip. ovate with 
a long attenuated point, leaflets obovate emarginate muntely serrate, seeds 2.-E. B. 1050. St. 16.8.-St. creeping. I'l. purplish red. IIeads large, remarkable when in fruit for their curious ralyees. Pod inchuded.-Damp pastures. P. VII. VIII.

[18. T. resupinatum $\left(\mathrm{L}_{\text {. }}\right)$; heads hemispherieal at length globose, peduncles axillary equalling the leaves, bracts minute, ealyx of the fruit membrunous retienlated woolly, stip. subulate-lanceolate from an ovate base, leaflets obovate minutely serrate, sceds 2.-E. B. S. 2789. (had) St, I6. 9.-St. prostrate or aseending. li. sinall, resupinate. Pod included.-Below Bristol, now lost. Poole, Dorset. Belfast, Mr. Thompson. A. VII.] E. I.

***** Fl.stalked, thront of the calyx naked within not inflated, cor. persistent, standard deflexed and covering the pod.

19. T. procumbens (L.); heads oval dense with about $40 \mathrm{fl}$., ped. axillary as long or longer than the leaves, fl. at length reHexed, style much shorter than the pod, stip. ovate acute entire, leafl. obovate emarginate, central petiole longest, scerls elliptical radicle seareely prominent.-E.B.945. St. I5. 15.-Primary stem ereet, brainclies procumbent or aseending. Pod pointed at both ends. Peduneles sometimes shorter at others longer than the leaves. Fl. yellow. Radiele causing a slight irregularity in the otherwise regularly elliptical seerls. [T. patens (Sehreb.), T'. parisiense (DC.); style equal in length to the pod, seeds elliptieal : radicle forming a marked projection throughout half the length of one side, stip. half-eordate usually denticulate; will probably be found in England.] - Dry pastures. A. VI.-VIII.

20. T. minus (Sm.); heads close about 12-flowered, perluneles axillary, pedieels very short, fl. at length reflexed, standard furrowed truncate quite eovering the pod, style mueh shorter than the pod, stip. ovate, leaflets obeordate intermediate one-stalked. -E. B. I256. T. filiforme Koch.-Dry plaees. A. VI.-VIII.

2I. T. filiforme (L.); fl. few (3-5) in lax racemes, peduneles axillary, pedicels as long as the ealyx-tube, fl. at length reflexed, standard not furrowed "deeply emarginate" seareely eovering the poil.-E. B. I257. T. micranthum Koch.-Standard mueh narrower in proportion than in T. minus. See Phyt. i. 293.Dry places. $\Lambda$. VI. VII.

\section{Lotus Linn.}

I. L. corniculatus (L.); elaw of the standard obovate transversely vaulted, calyx-teeth straight in the bud subulate from a triangular base as long as their tube but shorter than the corolla : points of the 2 upper ones converging, heads 5-I0-flowered.E. B. 2090.-Glabrous or slightly hairy. St. aseending. Leaf- 
lets obovate. Stip. orate. Angle between the 2 upper calyxtecth rounded.- $\beta$. villosus (Ser.); upper part of st., l., and cal. hairy rith long spreadling hairs. - $\gamma$. crassifolius (Pers.); pilose, st. caspitose, leaflets obovate fleshy, stip. ovate.- $\delta$. tenuis (Bab.); glabrons or slightly hairy, st. filiform elongated procumbent or ascending, leaflets linear or lincar-obovate, stipules lialf-ovate. E. B. S. 2615. L. tenuis Sm.--Pastures, dry banks, \&c. P. VII. VIII.

2. L. major (Scop.); claw of the standard linear, calyx-teeth spreading like a star in the bud subulatc from a triangular base as long as their own tube but much shorter than the corolla: tuo upper ones diverging, heads 8-12-flowered, lcaflets obovate, stip. roundish-orate.- - E. B. 2091.--Hairy. St. usually erect, $1-3$ feet higl. Angle between the 2 upper calyx-teeth acute. $-\beta$. glabriusculus (Bab.); glabrous, the margins and nerves of the 1 . stip. bracts and sep. ciliated, st. ercet or procumbent.-In damp places. $\beta$. on drier spots. P. VII. VIII.

3. L. angustissimus (L.); claw of the standard linear, calyxteetl straight in the bud subulate as long as their own tube shorter than the corolla, pod linear 6 times longer than the calyx: beak straight, head about 2 -flowered.-E. B.925. L. angustissimus (L. !), L. diffusus (Ner.).-Peduncle of the fl. as long as the l. of the fr. twice as long, leaflcts and stip. ovate-lanceolate acute, st. procumbent. - $\beta$. Seringianus (Bab.); peduncle of the $\mathrm{fl}$. and fr. as long as the leaves, leaflets obovate-oblong, stip. ovate acute, st. ascending. L. angustissimus (Ser.).-South of England near the sea. A. VII. VIII.

E.

4. L. hispidus (Desf.); claw of the standard subulate, calyxteeth straight in the bud subulate longer than their own tube shorter than the corolla, pod rugose terete twice as long as the calyx : beak elongate setaceous bent downwards, heads few (3-4) flowered, leaflets obovatc-lanceolate, stip. half-cordate, st. procumbent.- E. B. S. 28:23.-Near the sea in Deron and Cornwall. A. VII. VIII.

\section{Axtryluis Linn. Lady's Fingers.}

1. A. Vulneraria (L.); herbaceous, l. pinnate, leaflets unequal, heads of $\mathrm{fl}$. in pairs, calyx of 5 ovate pointed teeth.E. B. 104. St. 49. 4. 5.--Pod scmiorbicular, long-stalked, upper suture arched outwards, l-seeded. St. 6-12 in. high, silky. Root 1. simple, oval. Fl. yellow, in terminal pairs of crowded many-flowered heads.- $\beta$. Dillenii; plant smaller, fl. red. Dill. Elth. 320.-Dry pastures. P. VI.-VIII.

\section{Oxytropis Cand.}

1. O. Halleri (Bunge); stemless, leaflets ovate acute in about 
1.2 pairs, peduncles longer than the leaves erect sitky, bracts as loug as the calyx, pods erect orate-oblong inflated silky"2-celled. - Astragalus uralensis Sm. E. B. 466.-Root, or more correctly stem, woody, branched. Pods abrupt with a very oblique acnte point. ll. bluish purple. "Pl. uraleusis ab curoprea differt." Koch.-Dry hilly pastures in Scotland. P. VII.

2. O. campestris (DC.) ; st. short procumbent, lcaflets laueeolate in abont 12 pairs, peduncles rather longer than the 1. ascending hairy, braets as long as the calyx, pods erect ovate inHatcd hairy imperfectly 2-celled.-Astrayalus Sm. E. B. 2522. St. 19. 12.-Root woody, produeing short procumbent stems. Pods narrowed upwards with a slightly oblique point. Fl. yellowish tinged with puiple.-Clova Iountains. P. VII. S.

\section{Astragalus Limn.}

1. A. lypoglottis (L.); st. prostrate, stip. combined, leaflets blunt in 8-10 pairs, spikes ovate, peduncles longer than the leaves. pods ovate hairy stalked in the calyx erect.-E. B. 274.-Stip. quite combined into one leaflet opposite to the leaves. St. a few inches long, slencler. Leaflets small. Fl. in rather large heads, ascending, purple. Orary twice as long as its stalk.-Chalky and gravelly places. P. VI. VII.

2. A. alpinus (L.); st. procumbent, stip. orate free, leaflets elliptical blunt in 10-12 pairs, spikes capitate, peduncles as long as the leaves, pods oblong hairy narrowed at both ends stalked in the calyx pendulous.-E. B.S.2717. St. 19.13.-Stip. sometimes slightly connected at the base. St. elongated, slender. Fl. few, drooping, white tipped with purple.-Lofty mountains. Glen Dolc, Clora. Little Craigindal, Braemar. P. VII. S.

3. A. glycyplyyllos (L.); st. prostrate, stip. ovate-lanceolate free, leaflets orate in $5-6$ pairs, spikes ovate, peduncles much shorter than the leaves, pods linear incurved erect glabrous.E. B. 203.-St. 2-3 fcet long, scarcely branched, nearly glabrous. 1\%. in short dense spikes, dull yellow. Pods an inch loug.-Thickets on a ehalky or gravelly soil. P. VI.

\section{Tribe II. Viciea.}

\section{Vicia Linn.}

* Upper part of the style equally hairy all over. ERvUm Peterm., Koch Syn. ed. 2. 218. note.

$\dagger$ Peduncles clongated, few-flowered; eal. not gibbous at the base on the upper side. Tares.

1. V. hirsuta (Koch); peduncles 2-6-flowered about as long E 5 
as the leares, leaflets in $6-8$ pairs linear-oblong truncate mucrouate, calyx-teeth equal as long as their tube the 2 upper ones converging, pods oblong 2-seeded hairy.-Ervum Sm., E.B.970. St. 32. 12.-Stip. 2-lobel, outer lobe trifid with setaceous segments, inner lanceolate. Fl. small, pale blue, staudard eutire. Calyx-teeth subulate. Seeds orbicular, compressed, red with Jarker spots, smootlı; liilum long linear.-MIr. Borrer found a few specimens at IIenfield with 1-2-flowered peduncles and glabrous pods in company with the usual form of the species, they are the $\beta$. angustifolia (Fries).-Corn-fields and liedges. A. VI.-VIlI. Hairy Tare.

2. V. tetrasperma (Koch); peduncles 1-2-flowered about as long as the leaves, leaflets linear-oblong blunt mucronate in 4-6 pairs, calyx-teeth unequal shorter than their tube the 2 upper ones shortest " diverging," pods linear-oblong 4-seeded glabrous. -Ervum Sm., E. B. 1223. St. 32. I4.-Stipules half-arrowshaped. Fl. small, pale blue; standard witl blue streaks, cmarginate. Calyx-teeth elongate-triangular. Seeds $3-5$, globose, dull brown, slightly rough; hilum oblong.-Fields and hedges. A. VI.-VIII. Smooth Tare.

3. V.gracilis (Lois.); peduncles I-4-flowered at length twice as long as the leares, leaflets linear acute iu $3-4$ pairs, calyxteeth unequal shorter than their tube the 2 upper ones shortest, pods linear 6-8-seeded glabrous.-Loisel. Fl.Gall.t. I2. E.B.S. 2904 . Errum Hook.-Stip. half-arrowshaped. Fl. twice as large as those of $V$. tetrasperma, pale blue; standard emarginate. Calyx-teeth elongate-triangular. Seeds globose variegated with dark brown and yellow, smooth; hilum short, oval, half as long as that of the last.-Fields and hedges. A. VI.-VIII.

+ Peduncles elongated, many-flowered; calyx gibbous at the base on the upper side.

4. I'. sylvatica (L.); peduncles longer than the leares, leaflets elliptical obtuse mucronate in about 8 pairs, stip. lunate deeply toothed at the base: teeth setaceous, calyx-teeth shorter than their tube subulate.-E. B. 79. St. 3I. 3.-St. many feet long, climbing by their branched tendrils. Fl. numerous, cream-coloured and streaked with blue. Hilum extending about half round the seed.-Woods and thickets. P. VII. VIII. Wood Vetch.

5. V. Orobus (DC.); peduncles ultimatcly longer than the leares, leaflets ovate-oblong or ovate-lanceolate mucronate in numerous $(7-10)$ pairs, stip. lialf-arrowshaped slightly toothed at the base, calyx-teeth longer than their tube, 2 upper ones triangular, the others triangular-subulate.-Orobus sylvaticus Sm., E. B. 518.-St. ascending, $\mathrm{l}-\mathrm{l} \frac{1}{2}$ foot long. Tendrils reduced 
to a short slender point. Fl. numcrous, crean-coloured streaked with purple. Pods linear-oblong. IIilum extending abont $\frac{1}{3}$ round the sced.-Rocky wookls. I'. V. VI.

** Style bearded below the stigma, in other respects glabrous or uniformly hairy all over in its upper part; calyx gibbous at the base on the upper side. VICIx GENUINA.

† Peduncles elongated, many-flowered.

6. V. Cracca (L.); leaflets lanceolate mucronate silky in about I0 pairs, stip. half-arrowshaperl entire, calyx-teeth shorter than their tube, upper pair minute, the others subnlate, standard but little longer than the keel and sinuated at about the middle of eael side, pols linear-oblong smooth.-E. B. 1168. St. 3I. 6. -St. 3-4 feet long. Fl. blue variegated with purple. "Seerls subglobose, black. Hilum linear, extending half round the seed." Upier part of the style hairy all over.-Hedges. P. VI.-VIII.

\section{†† Peduncles few-flowered.}

7. $I^{\top}$. bithynica (L.); perluncles shorter than the leaves, leaflets 4 in the lower, 2 in the upper leaves, elliptic-lanceolate mucronate or linear-lanceolate acute, stip. half-arrowshaped toothed, ealyx-teeth longer than their tube lanceolate-subulate, pods linearoblong hairy.-E. B. I842. St. 32. 5.-St. 12-18 in. long. Fl. almost always solitary, purple. "Seeds globose, speckled with black and grey; hilum oval." Upper part of the style hairy all over. 'The inland plant has broader leafl. and more eut stip. than the maritime one.--Bushy places on a gravelly soil. P. VII. VIII.

E.

8. V. sepium (L.); fl. 4-6 in small axillary nearly sessile clusters, leaflets in $4-8$ pairs ovate obtuse mucronate gradually smaller upwards on the petiole, stip. half-arrowshaped undivided or lobed, calyx-teeth unequal shorter than their tube, 2 upper ones eurved upwards, pods lincar-oblong glabrous.-E. B. I5I5. St. 3I. I6.-St. about 2 feet high. Fl. purplish. Calyx hairy. "Seerls globose, speckled witl blaek and grey; hilum lincar, extending through about $\frac{2}{3}$ of the circumference." Upper part of the style nearly or quite glabrous, bearded. L. more or less hairy. - $\boldsymbol{\beta}$. montana (Koch?); leaflets ovate-laneeolate truncate. -Woods and hedges. B. Hoy, Orkney. P. VI.-VIII.

9. $V$. lavigata (Sm.); $f$. solitary axillary, leaflets ellipticoblong rounded mueronate in 4 pairs, stip. cloven, calyx-teeth nearly equal as long as the tube subulate, standard glabrous, pods compressed oblong glabrous.-E. B. 483.-St. suberect, $3-4$ in. to I foot long. Fl. pale purple. Seerls oblong, brown, attached by one end. I have not seen speeimens.-On the pebbly beach at Weymouth. P. VII. VIII. 
10. V. lybrida (L.); fl. solitary axillary, leaflets obovatc emarginate apiculate in 5-7 pairs, stip. lialf-arrowshaped cut, calyxteeth unequal spreading subulate longer than their tube, standard hairy, pod ovate-oblong hairy.-E. B. 482. St. 32. 3.-St. ascending, 1 foot long. Fl. reddish yellow. Hairs on the pods simple. "Scels round with a slort hilım." I have seen no native specimens.-On Glastoubury Tor Ilill. P. VI. VII. E.

11. V. lutea (L.) ; fl. solitary axillary, lcaflets clliptic-lanceolate acute or rounded at the end apiculate in 5-8 pairs, stip. ovate pointed coloured simple or with one patent lobe, calyx-teeth unequal, npper ones very short and curved upwards, lower one longer than the tube, standard glabrous, porls clliptic-oblong hairy.-E. B. 481. St. 31. 13.-St. procumbent, 1-2 feet long. Fl. sulphur-coloured. Hairs on the porls with a bilbous base. Seeds round, compressed, witl a slort hilum. L. varying greatly in hairincss.-Pebbly ground near the sca. P. VI.-V111. E. S.

12. V. sativa (1.) ; fl. axillary solitary or in pairs, lcaflets in 5-7 pairs clliptic-oblong retuse or olicordate-mucronate, the upper ones narrower or linear truncate mucronatc, stip, half-arrowsliaped toothed, calyx-teeth equal lanceolate-subulate long equalling their tube, standard glabrous, pods linear slightly silky, sceds globose smooth. - Seeds slightly compressed ; lilum linear, occupying about $\frac{1}{4}$ of the circumferencc.-a. sativa (DC.); leaflets all elliptic- or obovate-oblong, the lower ones shorter and broader, fl. usually in pairs, pods erect, st. $1-1 \frac{1}{2}$ foot high. V. sativa Sm., E. B. 334. St. 31. 10.-B. angustifolia; leaflets of the upper l. linear-lanceolate, lower ones obovate retuse or obcordate, fl. solitary or in pairs, pods patent, st. slender. $V$. angustifolia Sm.,

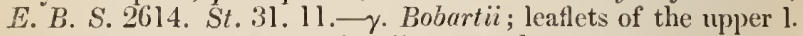
linear truncate or retuse, fl. solitary, pods patent, st. prostrate. V. Bobartii (Forst.) E. B. S. 2708.-Cultivated ground. $\beta$ and $\gamma$ in dry places. A. V. VI. Common Vetch.

*** Style bearded below the stigma; calyx not gibbous at the base.

13. V. lathyroides (L.) ; fi. axillary solitary, leaflets in $2-3$ pairs obovatc or oblong retuse mueronatc, calyx-tectl subulate straight as long as their tubc, pods linear glabrous, seeds nearly cubical tubercular, hilum short elliptical.-E. B. 30. St. 31.12. -St. procumbent, 3-5 in. long. Fl. small, purple.-Dry gravelly and sandy places. A. V. VI.

\section{Lathyrus Linn.}

1. L. Aphaca (L.); peduncles single-flowered, petioles leafless forming tendrils, stip. very large leaf-like corlate-sagittate.E. B. 1167.-St. weak, climbing. Fl. ycllow, on long stalks. 
lemarkable for its total waut of 1 . which are replaced by the large stipules. Rarely 1 or '2 laneeolate leaflets may be found. l'ods somewhat cylindrieal; seed smootl, compressed.- Sandy aud gravelly tichls, rare. A. V.-VIII.

li.

2. I, Nissolia (L,) ; peduncles 1 -2-flowcred, petioles lenflike lincar-lancolate without $l$. or tendrils, stip. mimute sululate.E. B. 112.-St. mostly erect. L closely resembling those of grasses. ll. purple, on long stalks. Pools cylindrieal; seeds tubereular, round; hiluun small, oval.-Buslıy grassy plaees, rare. 1. VI.

E.

3. L. hirsutus (L.); pedmeles 2-flowered, I. of one pair of linear-lanceolate leaflets, pols hairy, seeds globosc tubercular.E. B. 1255.-St. winged, climbine to the height of 1 or 2 feet. l'ods linear-oblong, covered with hairs having bulbous bases. Fl. sometimes solitary, pale blue with a crimson standard. Ililum oblong.-Rare. Lissex. Somerset? A. VI. VII.

E.

4. L. pratensis (L.); peduncles many-flowered, 1. of onc pair of lanceolate mucronate slightly silky leaflets, stip. arrowshaped, calyx-teeth unequal subulate, upper ones shorter converging, porls obliquely reined, seeds globose smooth,-E. B. 670.-St. 2-3 fect high, climbing, acutely angular not winged. Pods linearoblong. Fl. racemose, drooping, bright yellow. Hilum small, oblong.-Moist mealows and pastures. P. VII. VIII.

5. I. sylvestris (L.); st. winged, pednucles many-flowered, 1. of one pair of linear-lanceolate or lanceolate leaflets, stip. halfarrowshaped narrow, calyx-teeth unequal triangular-subulate, 2 upper ones short, pods reticulated with veins, seeds compressed smootl half surrounded by the hilum.-E. B. 805.- St. climbing to the heiglit of 5-6 feet. Porls linear-oblong, curred. Fl. greenish yellow variegated with purple. Broader-leaverl varieties often pass for L. latifolins.-Woods and thickets. P. VII.-IX. E. S.

[*? 6. I. latifolius (L.) ; st. winged, peduncles many-flowered, 1. of one pair of elliptical pointed leaftets, stip. half-arrowshaped triangular-ovate broad, calyx-teeth unequal, "pods reticulated with veins, seeds tubereular-rugose $\frac{1}{3}$ surrounded by the hilum." $-E, B, 1108$. - St. climbing to the height of 5 or 6 feet. "Pods linear-oblong." I'l. purplish rose-colour, large.-A very doubtful native. P. VII, VIII.]

E. S.

7. L. palustris (L.); st, winged, peduncles many-flowered, 1. of 2 or 3 pairs of linear-lanceolate acute leaflets, stip. half-arrowshaped lanceolate, calyx-teeth unequal, "porls linear-oblong. seels round compressed smooth $\frac{1}{4}$ surrounded by the hilum." E. B. 16\%.-St. 2-3 feet high. Fl. bluish purple--Boggy meadows, rare. P. VI. VII.

E. I.

8. L. maritimus (Big.); st. angular not winged, peduncles 
many-flowered, 1. of $3-8$ pairs of oval leaflets, stip. large oval cordate-hastate, calyx-teeth unequal, porls oblong obliquely reticulated, seeds globose $\frac{1}{3}$ surromiled by the hilum.--Pisum Sm., E. B. 1046.-St. prostrate. Leaflets large, obtuse but apiculate; petioles often recurved. Fl. purple, variegated.- $\beta$. acutifolius (Bab.); lcaflets elliptic-lanceolate acute, petioles straight, stems slender straggling. See Edmondston's Fl. Shetl. 31.-Pebbly sea-shores, rare. $\beta$. Burrafirth, Unst, Shetland. P. VII. VIII. Sea Pea.

\section{Orobus Linn.}

1. O. tuberosus (L.); leaflets oblong or lanceolate blunt apiculate in $2-3$ pairs, stip. half-arrowshaped broad, st. simple erect winged.-E. B. 1153. St. 21.5.-Fl. purple, variegated with red and blue. Pods linear. Root tuberous. - $\beta$. tenuifolius; 1. linear.-Woods and thickets in hilly countries. P. VI. VII.

2. O. niger (L.) ; leaflets oblong-lanceolate or oblong more or less rounded at the end and apiculate in $3-6$ pair's, stip. linearlanceolate acute the lower ones half-arrowshaped, st. branched erect angular not winged.-E. B. S. 2788.-Whole plant becomes quite hlack in drying. Fl. variegated with red blue and purple. Pods linear. Seed oblong elliptical, dark brown, perfectly smooth.--Rocky woods in Scotland, rare. P. VI. VII. S.

\section{Tribe III. Hedysarea.}

\section{Ornithopus $\operatorname{Iinn}$.}

1. O. perpusillus (L.); peduncles longer than the leaves, calyxteeth triangular acute $\frac{1}{3}$ the length of their tube, beak as long as a joint of the pod.- $E . B .369,-A$ small prostrate plant, 3-12 in. long. L. witl $5 \frac{1}{2}-12 \frac{1}{2}$ pairs of elliptical downy leaflets. Fl. small; calyx lairy, cor. white with crimson veins. Pods curved, joints beadlike wrinkled lengthwise. A minute scale at the base of each pedicel.-Dry sandy and gravelly places. A. V.-ViI. Birdsfoot.

\section{Arthrolobium Desv.}

1. A. ebracteatum (DC.); peduncles about as long as the 1 . 2-4-flowered, stip. minute distinct, 1 . pinnate with inany pairs of elliptic-oblong leaflets, the lowest pair remote from the stem. -E. B. S. 2844.-St. prostrate filiforn. Fl. small, yellow, standard red externally. Pod curved upwaris, joints cylindrical rugose. A minute scale at the base of cacl pedicel but no leafy bract.-Channel and Scilly lslands. A. VI. VII.

\section{Hippocrepis Limn. Horseshoe Veteh.}

1. H. comosa (L.); pods umbellate, their joints rough curved 
neither dilated nor bordered, articulations glabrous, perluncles longer than the leaves.-E. B. 31.-St. procumbent, often a foot long. Fl. yellow. Lcaflets 7-13, obovate, obtuse or emarginate, apiculate.-Dry cloalky banks. P. V.-VIlI.

\section{Onobrychis Gaert.}

1. O. sativa (Lan.); wings shorter than the calyx, keel about as long as the standard, st. ascending, pords with reticulated spinous elcvations on the disk and short sharp flat teeth on the lower suture.-E. B. 96. Mart. Rust. 47. St. 19. 10.-St. ofteu 2 fect long, recumbent. Fl. in long dense terminal racemes, crimson, variegated. Tube of the calyx silky, short; teeth very long. Leaffets elliptic-oblong, mucronate, cntire, glabrous above, in about $12 \frac{1}{2}$ pairs. - On chalky and limestone hills. P. VI. VII. Saintfoin.

E. S.

\section{Order XXVII. ROSACEA.}

Cal. 4-5-parted, lined with a disk below, odd lobe superior. Pet. 5, cqual. Stam. usually indefinite. Carp. several or solitary, distinct or combined with each other or with the calyx. Styles distinet, often lateral. Fruit various. Seeds nearly withont albumen, embryo straight.-L. alternate, usually compound, with stipules.

Tribe I. AMYGDALE E. Fruit a solitary drupe; sceds 1-2, pendulous. Cal. deciduous.

1. Prunus. Drupe fleshy, indehiscent. Putanen smooth or sulcated.

Tr. II. SPIR EA E. Fr. formed of sereral follicles; sceds $1-6$, suspended from the inner elges of the follicles. Cal. persistent.

2. Spirfa. Cal. 5-cleft. Stam. numcrous, inscrted along with the pet. on a disk adhering to the calyx. Follicles 1 or more, usually distinct. Seeds $2-6$.

Tr. III. DRYADE E. Fr. formed of small dry (in Rubus sueculent) muts, few, or numerous and then inserted on a fleshy or succulent receptacle. Cal. persistent.

* Attacliment of the seed distant from that of the style, radicle inferior.

3. Dryas. Cal. 8-9-cleft, in one row. Pet. 8-9. Stam. numerous. Fr, of numerous small nuts, tipped with the persistent lairy styles which are straight at the extremity, aggregated on a dry receptacle. Seed ascending.

1. Geum. Cal. 10-cleft, in 2 rows, the outer parts smaller. 
Pet. 5. Stam. numerons. Fr. of numerous small nuts, tipped with the persistent jointed styles hooked at the joint, aggregated on a dry receptacle. Seed asceuding.

\section{** Attacliment of the seed near to that of the style, radicle superior.}

5. Sanguisorba. Fl. perfect. Cal. 4-cleft, with 2 or 3 external scales at its base, tube quadrangular. Pet. 0. Stam. 4, opposite to the segments of the calyx. Nuts 2 , included in the dry tube of the calyx. Style terminal. Stig. capitate, covered with oblong spreading papilla. Seed suspended. -G. F. G. Monochl. 78.

6. Poterium. Fl. monoceious or polygamous. Cal.4-cleft, with 3 external scales at its base, tube quadrangular. Pet. 0 . Stam. 20-30. Nuts 2-3, included in the dry tube of the calyx. Style terminal. Stig. brush-shaped with filiform divisious. Seed suspended.-G. I. G. Mouochl. 79 .

7. Agrimonia. Calyx 5-cleft, without external scales; tube turbinate, armed with hooked bristles above and contracted at the throat. Pet.5. Stam. 15, inserterl with the pet. into a glandular ring in the throat of the calyx. Nuts 2, included in the dry tube of the ealyx. Style termiual. Seed suspended.

8. Alchemilia. Cal. \&-parted, the alternate parts smaller; tube obconical, contracted at the throat. Pet.0. Stam. $1-1$, inserted into a ring in the throat of the calyx and opposite to the smaller segments. Style from near the base of the nut. Seed ascending.-G. F. G. Monochl. 80 .

9. Sibialdia. Cal. concave, 10-parter, in 2 series, 5 exterior parts smaller. Pet. 5. Stam. 5. Style lateral. Fr. of 5-10 small uuts placed on a dry reeptacle. Seed ascending.

10. Potextilia. Cal, coneave, 8-10-parted, in 2 series, 5 exterior parts smaller. Pet. 4-5. Stam. numerous. Style lateral or nearly terminal. Fr. of mumerous small nuts placed upon a flattish dry receptacle. Seed peurlulous or aseending.

11. Comarum. Cal. cor. stam. and pistils as in Potentilla. Receptacle ultimately large fleshy aud spongy, persistent. Style lateral near the summit of the nut. Seed pendulous.

12. Fragaria. Cal. eor. stam. and pistils as in Potentilla. Receptacle large succulent pulpy deciduous. Style lateral near the base of the nut. Sced ascending.

13. Rubus. Cal. concave or flattish, 5-parted. Pet. 5. Stam. numerous. Styles nearly terminal. Carp. numerous, suc- 
culent, drupaceous, placed upon a hemispherical or conical spongy receptacle. Seed pemlulous.

Tr. IV. ROSAEN. F. formed of numerous small dry nuts inclosed in the fleshy tube of the calyx.

14. Rosa. Cal. urceolate, contracted at the mouth, ultimately fleshy, 5-fid. Pet. 5. Stam. numerous, inserted with the petals on the rim of the tube of the calyx.

Tr. V. POMEA. Fruit a $1-5$-celled pome.

15. Crategus. Calyx-segnents 5, acutc. Pet. 5. Styles 1-5. Fr. oval or round concealing the upper end of the 1-5 bony 1-2-secled carpets.

16. Cotoneaster. Calyx-segments 5. Pet. 5. Styles 2-5. Fr. turbinatc, its nuts adhering to the sides of the calyx but not cohering at the centre.-Stam. ercct, as long as the tceth of the calyx.

17. Mespruus. Calyx-scgments 5, leaflike. Pet. 5. Styles 2-5. Fr. turbinate with the upper end of the bony carpels exposed; disk dilated, almost as broad as the fruit.

18. PYrus. Cal, 5-toothed. Pet. 5. Styles 2-5. Fr. fleshy with 5 cartilaginous distinct 2 -secicd cells. Testa cartilaginous.

\section{Tribe I. Amygdalea.}

\section{Prunus Linn.}

1. P. spinosa (L.) ; peduncles mostly solitary glabrous, $l$. clliptical glabrous, branches spinous, fr. globose.-E. B. 842. St. 3. 2.-L. sometimes slightly downy near the lower part of the midrib bencath, gencrally appearing after the $\mathrm{H}$. but sometimes at the same time with them when it is the $\beta$. coctanea (Wimm.), P. frutieans Weihe? Yomng branches downy.-IIerges and thickets. Sh. IV. V. Black Thorn. Sloe.

2.?P. insititia (L.); peduncles usually 2 together downy, $l$. clliptical or ovate-lanceolate downy beneath, branches slightly spinous, fr. globose.-E. B.841.-L. usually very downy beneath and slightly so above, particularly when young, usually appearing at the same time with the flowers. Young branches downy. -Iedges and thickets. Sh. IV. V. Wild Bullace.

3. ? P. domestica (L.); peduncles usually 2 together glabrous, b. ovate-lanceolate hairy about the midrib beneath, branches without spines, "fr. oblong." - E. B. 1783.-L. downy when voung, afterwards glabrous execpt the lower half of the midrib 
which is densely woolly, appcaring at the same time with the Howers.-Woods and thickets. T. IV. V. Wild Plum.

4. P. Padus (L.); arborescent, 1. obovate-lanceolate finely serrate glabrous, $f l$. in pendulous racemes, fr. roundish-oblong. E. B. 1383.-A small tree. L. minutely doubly serrate. Fl. white, numerous, in a lax raceme. Fr. black, harsh and bitter, with a corrugated nut.- Woods and hedges. T. V. Bird Cherry.

5. P. Avium (L.); arborescent, $l$. drooping oblong-obovate suddenly cuspidate inciso-serrate downy beneath, calyx-tube contracted below the entire scpals, "fr. heartshaped."-E. B. 706. $-A$ tree of $20-30$ fcet high. Outer scales of the leaf-buds deflexed. Flower-buds not leafy. Fl. in umbels. Pet. bifid, with a minute claw. "Fr. firm, bitter, black or red." Borr.-Woods. T. V. Wild Cherry.

6. P. Cerasus (L.); fruticose, $l$. not drooping oblong-obovate or ovate-lanceolate doubly crenate-serrate glabrous, calyx-tube not contracted, fruit round.-E. B. S. 2863. Cerasus austera Leight. 1. 524.-An erect bushy shrub, 3-8 feet high. Umbels scattcred. Outcr scalcs of the leaf-buds erect. Inner scales of the flower-buds leafy. Scp. crenate-serrate. Pet. subemarginate, with a claw. "Fr. juiey, acid, always red."-Hedges. Sh. V.

\section{Tribe II. Spirae.}

\section{SPIrea Linn.}

†1. S. salicifolia (L.) ; shrubby, stip. 0, 1. elliptic-lanceolate unequally serrate glabrous, racemes terminal compound, stam. longer than the petals. $-E . B .1468 .-$ A shrub of $4-5$ feet high with smooth round wandlike branches. Fl. flesh-coloured, in dense erect racemes.-Damp woods in the north. Sh. VII. E. S. *I.

2. S. Ulmaria (L.) ; herbaceous, stip. rounded toothed, I. interruptedly pinnate, leaflets ovate undivided: the terminal one larger palmately 3-5-lobed, 1 . in compound proliferous cymes, caps. glabrous contorted.-E. B. 960. St. 18.8.-St. about 3 feet high, angular, branched. L. with a few large serrated leaflets and rery minute intermediate ones, downy beneath. Peduncles downy. Fl. yellowish, sweetscented. Pet. roundish.Meadows and by water. P. VI.-VIII. Meadow-sweet.

3. S. Filipendula (L.); herbaceous, stip. of the root leaves linear acute entire, thosc of the stem rounded and cut, l. interruptedly pinnate, leaflets all oblong deeply cut and serrate, $\mathrm{fl}$. in a panicled cyme, caps. hairy parallelly adpressed.-E. B. 284. St. 18. 7. - St. 1-1 $\frac{1}{2}$ foot higl, round, simple, panicled at the top. L. mostly radical, spreading; leaflets small, numerous, in- 
termediate ones mueh smaller. l'l. yellowish white tinged with red. Pet. obovate--Dry clialky and limestone pastures. P. VI. VII. Dropwort.

E. S.

\section{Tribe III. Dryadea.}

\section{Dryas Linn.}

1. D. octopetala (L.); 1. crenate-serrate obtuse, sep. 3 or 4 times as long as broad more or less pointed, base of the eal. hemispherical.-E. B. 451. St. 20.3.-1'l. large, white. Pet. 8. L. simple, white with fine dense woolly pubescenee beneath. St. prostrate, woorly. Seeds obovate-oblong apiculate.-a. Sep. acute, covered with red hairs. L. ovatc-oblong, dceply cut into large roumled lobes; under side of the petiole and midrib green, bearing minute linear pellucirl fringed scales mixed witl long Lairs, midrib and lateral ribs sparingly hairy and eonspicnous.$\beta$. pilosa (Bab.). Sep. slightly pointed, covered with nearly black hairs. L. oblong or ovate-oblong, deeply eut into large slightly acute lobes; ınder side of the petioles and midrib dark red, liairy but withont scales, midrib and lateral ribs eovered with long white hairs and inconspieuous. Awn longer and more feathery.-Alpine situations, particularly on limestone. $\beta$. County of Clarc, Ireland. P. VI. VII.

2. D. depressa (Bab.); l. crenate-serrate obtuse, sep. twiee as long as broad bhut and rounded at the end, base of the calyx truncate nearly flat.-A. N. H. x. 183. t. 7 (calyx and leaf).Fl. large (white or yellowish?). Pet. 8. L. ovate, deeply eut into large rounded lobes, white with fine dense woolly pubescence beneatli ; nnder side of the petiole and midrib green, bearing minute pellucid fringed scales mixed with long hairs. Stems prostrate, woody. I have not seen recent petals.-Ben Bulben, Sligo. P. VI. VII.

\section{GEUM Linn.}

1. G. urbanum (L.); fl. erect, pet. obovate, cal. of the fruit reflcxed, carpophore 0, lower joint of the awn much longer than the glabrous upper joint, radical l. interruptedly pinnate and lyrate, stem l. ternate, stip. large rounded lobed and cut.-E. B. 1400. St. 5. 7.-St. 2 feet high. Fl. small, bright yellow, calyx green. Upper joint of the awn with a few minute hairs at its base.Iledges and thickets. P. VI.-VIII. Wood Avens.

2. G. intermedium (Ehrh.); fl. erect or nodding, pet. roundish with a wedgeshaped claw, cal. of the fruit patent, carpophore 0 , lower joint of the awn longer than the hairy upper joint, radieal l. interrmptedly pinnate and lyrate, stem 1. 3-lobed, stipules round 
toother.-St. I-2 feet higrl. Fl. larger than those of G. urbanum less than in $G$. rivale, ycllow, ealyx purplish. Upper joint of the awn eovered with long hairs but with a rather long glabrous point.-Damp woods. P. VI. VII.

E. S.

3. G. rivale (L.) ; fl. nodding, pet broadly obovate emarginate or obeordate with a long wedgeshaped elaw, cal. of the fruit ereet, carpophore elongated, lower joint of the awn equalling the long hairy upper joint, radieal l. intermutedly pinnate and ly rate, stem 1. ternate, stip. small orate toothed.-E. B. I06. St. 3.St. about I foot high. Fl. large, purplish brown with darker veins, ealyx purplisli. IIead of fruit upon a stalk whielı is nearly as long as the ealyx. Upper joint of the awn with a short glabrous point.-Damp, woods. P. VI. VII. Water Avens.

\section{Sanguisorba Linn.}

1. S. officinalis (L.); spikes ovate-oblong, stam. about as"long as the calyx, leaflets eordate oblong.- $E . B .1312 .-$ L. pinnate glabrous; leaflets about I3, stalked, opposite, obtuse, coarsely serrate. Minute stipell $x$ are sometimes found at the base of the leaflets.- $\beta$. media; spikes elongated cylindrieal.-Damp meadows. P. VI.-VIII. Great Burnet.

\section{Poterium Lims.}

I. P. Sanguisorba (L.); herbaeeous, st. slightly angular, cal. of the fruit hardened quadrangular.-E. B. 860 ,-L. pinnate with numerous small ovate eoarsely serrate subsessile leaflets glabrous or slightly hairy beneath. Lower part of the stems and petioles often downy.-On a dry ealcareous soil. P. VI.-VIII. Lesser Burnet.

E. I.

\section{Agrimonia Lim.}

1. A. Eupatoria (L.); cal. of the fr. obconic furrowed to the base : exterior spines spreading, l. interruptedly pinnate serrate tomentose beneath.-E.B. I335. St.59.4.-St. ereet, about 2 feet high. Spikes long with distant yellow flowers. Leaflets deeply serrated.-Fields and road-sides. P. VI. VII.

2. A. odorata (Ait.); cal. of the fr. bellshaped its upper half alone furrowed : exterior spines refiexed, l. interruptedly pinnate hairy and with minute glands beneath.-Resembling the last. Spikes long. Fl. red. Leafl. deeply and sharply serrate. Cal. of the fr. seareely furrowed as far as half-way down.-Beaumont, Jersey. Rev. W: W. Newbould. P. VI. VIII.

O.

\section{Alchemilia Linn.}

I. A. vulgaris (L.); l. reniform plaited 7-9-lobed, lobes 
rounded serrated thronghont green beneath, fl. in terminal corymis.-E. B. 597. St. 2. 5.-Slightly hairy. Fl. yellowish grecu. L. large on long stalks, those on the stem sessile with a prair of large notehed eomate stipules. - $\beta$. subsericen (Koeh); st. I. and petioles silky.-Dry hilly pastures. P. VI.-VIII. Common I,ady's Mantle.

2. A. alpina (L.); radical l. digitate: divisions 5-7 separated to their base oblong obtnse closcly serrated at the end white and silky beneath, $\mathrm{tl}$. in interrupted spikes of small lateral and terminal eorymbs, st. slightly branched simple below.-E. B. 244. St. 51. 2.-St., cal. and under side of the l. beautifilly silky. Leallets rarely slightly combined, outer ones of the radical 1. usually nearly opposite to each other. Branehes usually undivided, asecndiug.-Mountains. P. VI. VII. Alpine Lady's Mantle.

3. A. conjuncta (Bab).); radical l. peltate-palmate: divisions 5-7 combined through $\frac{1}{3}$ of their length oblong obtuse elosely serrated at the end white and very silky beneath, fl. in interrupted spikes of small lateral and terminal corymbs, st. with numerous branches.-Bab.in A.N.H.x.25. A. argentea (Don) not Lam.Closely allied to $A$. alpina but usually much larger in all its parts and distinguished by its comnected leaflets which are broader and darker coloured, more silky on the under side and so placed in the radical leaves that the 2 external ones almost if not quite touch each other so as to present the appearance of a peltate leaf; st. with long alternate spreading branches, which are often again subdivided; the $f$. in small nearly simple distant corymbs, upon longel stalks, and more silky. This plant lias now retained its character's for many years in gardens, under various enlture and from seed. [It was found in the Ferrce Isles by Sir W. C. 'Trevelyan.]-Cloxa Mountains. Mr. G. Don! Glen Sannox, Arrall, Scotland. Dr. N. Tyache. P. VI. VII.

S.

4. A. arvensis (L.) ; l. palmate 3-fid wedgeslaped below hairy : lobes with 3-6 teeth at the end, fl. sessile axillary.-Aphanes (L.) E. B. 1011 .-St. prostrate, $4-5$ in. long. Fl. very small, greenish, in small hairy ineonspieuous tufts.-Dry fields on sand and giavel. A. V.- VIII. Parsley Piert.

\section{Sibbaldia Limn.}

1. S. procumbens (L.); l. ternate, leaflets wedgeslaped with 3 tecth at the end, fl. corymbose, pet. lanceolate--E. B. 897 . St. 17.5.-L. pilose on both sides. St. woody, procumbent. Pet. very small. "Pistils and stam. very variable in number. I an disposed to consider it as a Potentilla." W. Wilson.-Dry summits of Seottish mountains. P. VII. 


\section{Potentilla Linn.}

* Hairs on the receptacle shorter than the glabrous carpels.

$\dagger$ Leaves pinnate.

1. P. rupestris (L.); st. erect diehotomous, leaflets romndishovate mequally ent and serrate $5-7$ on the lower leaves, ou the nppermost 3.-E. B. 2058.-Fl. white, large. Pet. much longer than the calyx. St. 1-2 feet ligh.-On Craig Breidden, Montgoneryshire. P. V. VI.

E.

2. P. anserina (L.) ; st.creeping, l. intermptedly pinnate, leaflets numerous oblong aeutely serrate silky beneath, perluneles solitary.-E. B. 861 . St. 4. 7.-Fl. yellow, large. L. green above, white and silky beneath._ $\beta$. sericea (Koch); white and densely silky on both sides.-Roal-sides. $\beta$. Cambridge. P. VI. ViI. Silver Weed.

it Leaves digitate.

3. P. argentea (L.); st. decumbent or ascending, l. quinate, leaflets obovate-cuneate inciso-serrate downy beneath : margins revolute,-E. B. 8. St. 17. 7.-Fl. yellow, small, in terminal eorymbs.-Dry gravelly plaees. P. V'l. VIl.

4. P. opaca (L.) ; st. ascending, $l$. of 7 hairy linear-cuneate leafl. deeply serrated throughout green above and below, st. l. terriate, teeth 5 or more on eaeh side of a leaflet.-E. B. 2449 . -Fl. on long simple solitary axillary or panicled stalks, yellow. Serratures large distant, extending almost to the base of the leaflet. I have not seen speeimens.--Clova and Balquidder. P. VI.

$$
\text { S. }
$$

5. P. verna (L.); st. prostrate, lower 1. of 5-7 obovate leaflets serrated towards the end bristly on the margin and ribs beneath : tecth '2-4 on each side, lowest stipules narrowly linear.E. B.37. St. 17.8.-St. woody, abont 5 in. long. Fl. yellow, solitary or $2 \mathrm{or}^{3} 3$ together. The terminal tooth of the l. usually smallest and shortest.-Dry pastures. P. IV. V. E. S.

6. P.alpestris (Hall.); st. ascending, lower 1, quinate, leaflets obovate-cumeate somewhat hairy deeply cut in the upper half: teetl abont 4 on each side, stip, all ovate.-E.B.56l. P. salisburgensis (Haenke) St.17.10.-Larger than the preceding.Mountains. P. Vl. VII.

L. S.

7. P. reptans (L.); st. filiform procumbent rooting, $l$. quinate stalked, leaflets obovate serrated, peduneles solitary, carpels granulate-scabrous.-E. B. 862.-L. on long stalks, often with a buneh of small 1. in their axils, sometimes solitary, usually in pair's. Leaflets blunt, rough or hairy on their ribs and margins. Fl. on long stalks yellow. $\beta$. sericea; 1 . and eal. eovered with long silky hairs on both sides.- $\gamma$. acutifolia; leaflets laneeolate 
aeute deeply toothed covered with silky hairs on both sides, ealyx-segments clongated acute silky.-Roul-sides and bauks. $\beta$. Usan, lorfarshire. Mr. Lindsay Carnegie. $\gamma$. Milton, Northamptonshire. Rev. M. J. Berkeley. P. VI.-IX.

8. P. Tormentilla (Nesl.); st. proeumbent or ascending, l. ternate sessile or shortly stalked, lower l. quinate on long stalks, leaflets lanceolate inciso-serrate, carpels longitudinally wrinkled. -Tormentilla officinalis (L.) E. B. 863. St. 34. 12.-Leaflets acute, somewhat hairy. L. all nearly sessile except the lowest which often have long stalks. Stip. deeply cut. l'l. small, yellow, usually with 8 sep. and 4 pet. but varying greatly in that respect. (Mag. Nat. Hist. vi. 248.)- $\beta$. procumbens; leaflets obovate-cuneate deeply cut, l. all shortly stalked, stip. entire or trificl. Fl. usually larger. T. reptans (L.) E.B.864.-lı dry places. $\beta$. Woods and hedge-banks. P. VI.-VIII.

** Hairs on the receptacle elongated, carpels hairy at the scar or all over.

9. P. fruticosa (L.); shrubby, l. pinnate, leaflets mostly 5 oblong acute cutire hairy with revolute margins.-E. B. 88. - St. 3-4 feet high. Fl. large, yellow, terminal, somewhat aggregated. -Teesdale. Galway. Clare. Sh. VI. VII.

E. I.

[10. P. alba (L.); st. weak ascending, l. quinate, leaflets ellipticoblong narrowed below silky beneath tipped with couverging serratures, filanents and earpels glabrous except at the scar of the latter.-E. B. 1384. St. 4. 2.-Fl. white. Stem 1. ternate-Said to have been found in Wales. Huds. P. VI.] E.?

11. P. tridentata (Sol.); st. woody creeping at the base, l. ternate, leaflets oblong-cuneate with 3 teeth at the end glabrous above hairy beneath, filaments glabrous, carpels downy.-E. $B$. 2389.-Fl. white._-"Werron Hill, and East roeks Loch Brandy," Clova. Mr. G. Don. P. Vl.

I2. P. Fragariastrum (Ehrh.); st. procumbent, 1. ternate, leaflets roundish obovate serrate silky on both sides, carp. glabrous except at the scar smooth or wrinkled transversely.-E. B. 1785. -Fl. small, white.-Woods, banks. P. IV. V. Barren Strawberry.

\section{Comarum Linn.}

1. C. palustre (L.).-E.B. 172.-St. ascending, 1 foot high, reddish. L. pinnate. Leaflets 5-7, elliptic-oblong, acute, sharply serrate. Fl. several, dark purple; cal. purple within; pet. small. Differing from Potentilla, to which it perhaps ought to be joined, by its enlarged spongy receptacle.-Marshes and peaty bogs. P. VII. 


\section{Fragaria Linn.}

1. F. vesca (L.); eal. of the fruit spreading or reflexed, hairs on the peduneles spreading those of the perlicels adpressed upwards silky.-E. B.1524. E. B.S.2742.-ITairs on the pedieel of the first fl. spreading, those on the under side of the l. adpressed. Carp. smooth, glabrous. "Pet. about as long as broad, white throughout, with 2 slight notches at the end; claw indistinet." Kinight. (Phytol. i. 650.) - Woods and thiekets. P. V. VI. Wood Strawberry.

+2. F. elatior (Ehrh.); eal. of the fruit spreading or reflexed, hairs on the pedumeles and pedicels spreading and somewhat deflexed.-E.B.2197. F. moschata Lindl.-Fl. imperfeetly diœcious. "Pet. $\frac{1}{3}$ broader than long, white, encire; claw distinet, bright yellow." Knight. A larger and more hairy plant than the last.-Woods in the south, rare. P. VI.-IX. Hautboy Strawberry.

\section{Runus $\operatorname{Lin} .^{1}$ \\ A. Stems wooly. * Stens erect; leaves pinnate.}

1. R. Idaus (L.); st. ncarly erect round glabrous pruinose, prickles setaceous straight, 1. 5-nate-pinnate or temate, fl. axillary terminal corymbose pendulous, fr. woolly.-E. B.2442. R. G. 47.-St. 4-6i feet high ; prickles small, setaceous, straight, purple. L. white beneath; terminal leaflet stalked. Fl. red, or white when the priekles are pale. $-\beta$. trifoliatus; 1 . ternate, terminal leafl. stalked, st. polished.- $\gamma$. Leesii; l. termate, leafl. all sessile overlapping. - Woods and hilly places. $\gamma$. Ilford Bridges, Devon. Sh. VI. Raspberry.

$$
\begin{aligned}
& \text { ** Stems mostly suberect; leaves digitate or subpinnate; pani- } \\
& \text { cle lax. }
\end{aligned}
$$

2. R. suberectus (Anders.); st. subereet angular, priekles few small straight subulate, 1. 5-7-nate, leafl. flexible eordate-ovate acuminate, lower pair subsessile, leafl. of flowering shoot all narrowed below, panicle nearly simple, cal. reflexed from the (deep red) fruit.-E. B. 2572.-St. 3-4 feet high; prickles suddenly enlarged at the base. L. green on both sides; on the fl.-shoot ternate. Panicle usually unarmed.- $\beta$. trifoliatus; 1 . all ternate, "fr. bright red."- Boggy woods and heaths. Sh. VII. VIII.

1 In the descriptions by stem is meant the barren stem, and the shape of the leafiets is always taken from a terminal full-groun leaflet from that stem.-A more detailed itecount of the Britisls species will be found in $A$ Synopsis of British Rubi.-By R. G. the plates in Weihe and Nees's Rubi Germanici are intended. 
[R. fissus (Lindl.) is scarcely different from $R$. suberectus. The retlexed calyx is probably not constant, and $R$. suberectus $\beta$. lias "ti. bright red."']

3. R. plicutus (W. and N.); st. suberect angular, pricliles equal slightly deflexed confined to the angles of the st., $l .5$-nate plicate, leafl. cordate-ovate acuminate, lower pair subsessile, lateral leafl. of fl.-shoot dilated below, panicle ncarly simple racenose, cal. reflexed from the (black) fruit.-E.B.2714. R.G.1. R. fruticosus Arrh.-St. 3-4 feet higlı; prickles slcnder, dilated at the base. L. rarely 7-nate, green on both sides; on the fl.shoot mostly ternate, lateral lcafl. dilated or lobed on one side at the base.- $\dot{\beta}$. carinatus ; prickles looked, leatl. all elliptic-laneeolate acute at both ends keeled and strongly veined beneath, paniele simple, ped. very loug, "fr. decp red."-Damp stony plaees in the nor'tl. "Soniewhat boggy plaees in Sussex." Mr. Borrer. $\beta$. Isle of Wight. Leicestershire. Sh. VII. VIII.

4. R. fastigiatus (W. and N.?); st. decurved or procumbent angular glabrous, prickles few straight declining equal confined to the angles of the stem, $l$. 5 -nate flat, leafl. cordate acnminate, lower pair subsessile and overlapping the interm. pair, lateral leafl. of tl.-shoot dilated below, paniele nearly simple leafy corymbose at the end, eal. of fr. reflexerl.-R. G. 2.?-St. many feet long; prickles dilated at the base, distant. L. grcen on both sides, pilose above, palcr and downy beneath, flexible, large, $\mathrm{nn}$ equally dentate-serrate; petioles and midribs with strong booked prickles. Ped. simple, elongate, downy with spreading laairs, lower distant axillary, npper corymbose, terminal one short; prickles few, small, straight, declining; fl.-l. cordate-ovate, simple, few.-Dense woods in Dumfries-shire. Sh. VIII. IX. S.

5. R. nitidus (W. and N.); st. subereet angular shining smooth, prickles conical straight declining dilated at the base, $l$. 5-nate flat shining above green and pubescent beneath, leafl, ovate or roundish, lower pair stalked not overlapping the interm. pair, panicle compound leafy with spreading or divaricated branches: rachis polished pilose at the end.-R. G.4.-St. not arching bnt producing a pendulons shoot in the autnmn, glabrous or with a few seattered hairs; secondary shoot pilose at the end. Leafl. sharply and inregularly serrate, terminal one nsnally ovate. Petioles with short, generally numerons, hooked prickles. Panicle very prickly, its branehes usually nearly at right angles with the rachis.-IIedges and thickets. Sh. VII. VIII.

*** Stems arched or prostrate, rooting, angular, withont setx (on the young stems a few sete are often to be found and sometimes but rurely on the older ones), not hispid. Prickles chiefly confined to the angles of the stem, nearly equal.

6. R. Salteri (Bab.); st. proeumbent angular furrowed slightly 
hairy, prickles uniform straight declining, 1. 5-nate, leafl. oval apieulate pilose above downy beneath, lower pair shortly stalked not overlapping the interm. pair, panicle narrow leafy below with short divaricated simple or corymbose branches, cal. of the oblong fr. adpressed.-Bab. in A. N. H. xvii. 172.-St. long, green, with seattered short patent hairs; prickles from a thick base, confined to the angles of the stem. Leafl. strongly and doubly dentatc-scriatc. I'etioles with few small strong declining prickles. Panicle compound, pubescent with lax hairs, no setre, prickles few slort detlexed, term. H. sessile.-Apse-castle-wood, Isle of Wight. Sh. VII. VIII.

7. R. tenuis (Bell Salt.); st. procumbent terete glabrous, prickles deflexed equal stout, $l$. 3-nate rarcly 5 -nate subglabrous above green and downy beneath, leafl. obovate acuminate, panicle decompound, sep. lanceolate acuminate adpressed to the small (black) fr. of few large grains.-Bell Salt. in A. N. H. xv. 305. R. affinis $\delta . R, G .3 . \mathrm{b}$. (fr.)-Resembles $R$. cresius but differs by its short equal and not straight prickles and want of hairs and setre on the barren stems. Panicle with long slender declining prickles. Prickles on the petioles and midribs strongly hooked. - South of England. Sh. VII. VIII.

8. R. corylifolius (Sm.); st. decurved or procumbent roundish glabrous, prickles conical straight slender, $l$. 5-nate flat with a wavy margin rather coriaccous soft and hairy beneath, leafl. roundish ovate or cordate, lower pair subsessile overlapping the interm. pair, panicle subcorymbose, sep. ovate reftexed from the fruit.-E.B. $\$ 27$. R. corylifolius and R. affinis, Bab. ed. 1.Prickles moderate, on the petioles nearly straight. Lower branches of the panicle often clongated and sprearing. "Torus roundish-clavate. Fr. sometimes rather hany."-Hedges and thickets. Sl. VII. VIII.

9. R. cordifolius (W. and N.) ; st. arched angular nearly naked, prickles straight horizontal or declining, l. 5-nate thick coriaceous downy beneath, lcafl. ovate or nearly round or cordatecuspidate, lower pair stalked not overlapping the interm. pair, panicle compound hairy.-R.G.5. R. rhamnifolius R.G.6. E.B. 2604. Bab. ed. 1.-St. long. Leatl. variable in size, soft and green or whitish beneath, cordate roundish enspjidate in $R$. cordifolius, or ovate or roundish-ovate in $R$. rhamnifolius of the Rub. Germ. Panicle rather long; lower branches often elongated and spreading, axillary; rachis downy.-IIedges and thickets. Sh. VII. VIII.

10. R. Grabowskii (Weihe?); st. arched angular glabrous, prickles equal much declining or deftexed from a dilated base, $l$. 
i)-nate-digitate flat glabrous and opaque above ashy and douny beneath acntely dentate, leafl. cordate abruptly cuspidate, lower pair stalked overlappring the interm. pair, panicle compound leafy below with ascending branches: rachis pilose its summit and the pol. tomentose, fr. hairy. - Il eihe in Wimm. and Grab. Fl. siles. ii. 32.? Bab. in A. N. II. xix. 83. - Sceondary shoots of st. pilose. Petioles with stiong much hooked numerous prickles. Panicle narrow, not setose, very prickly throughout: prickles slender, declining or deflexed,-Near Cadeby, Leicestershire. Rev. A. Bloxam. Sh. Vill.?

11. R. discolor (W. and $\mathrm{N}$.) ; st. angular arched mostly furrowed silky, prickles straightish decurved or horizontal, 7 . 5-nate coriaccous but thin white beneath, leafl. obovate or oblong pointed, panicle long narrow nearly leafless tomentose.- $\mathrm{R}$. fruticosis $B a b$. ed. 1.-St. long, usually deeply furrower. Prickles large, strong, mumerons. Leaft. variable in shape nsually obovate and acute, sometimes ( $R$. abruptus Lindl.) cmeate-oblong abruptly truneate and cuspidate. Panicle with patent branclies, oceasionally with long axillary ones below. $-a$. discolor; st. strigose-silky, prickles declining or deflcxed, leafl. usually with deflexed margins glabrons above white and finely tomentose beneatl, branches of the racemose tomentose panicle deeomponud. R. C. 20. R. fruticosus Sm., E. B.715.- 3 . thyrsoideus; stem nearly glabrous, prickles straight, leafl. flat glabrous above greenish white or white and tomentose beneath, panicle clongate thyrs.id tomentose. R. thyrsoideus (Wimm.) Arrh. R. fruticosus R. G. T. R. discolor v. lividus Blox. Fasc. $-\gamma$. macroacanthus; st. with seattered patent hairs, prickles strong pilose nearly stıaight slightly deflexed, leafl. flat pilose above downy white and soft beneath, racemose branches of the pnbeseent panicle fewflowerel. $R$. (Y. 18.- $\delta$. argenteus; stem with patent hairs, prickles straight, leafl. flat silvery-white and downy beneath, racemose-compound branches of the pubescent panicle fewflowered. R. G. 19.-Common, the varieties less frequent. Sh. VII. VIII.

12. R. leucostachys (Sm.); st. arehed angnlar hairy, prickles equal straightish horizontal, $l$. 5-nate coriaceous that soft and tawny or white with shining hairs beneath, leafl. ovate or roundish abruptly pointed, panicle long narrow leafy shaggy or downy.E. B. 2631. R. pubescens R. G. 16.-St. long, not furrowed, often nearly ronnd; pubescence loose, weak. Prickles numerous, hairy; on fl.-shoot and panicle long and straight.- $\beta$. vestitus; st. nearly suberect, leafl. round acute mucronate-dentate pale green or whitish beneatl. $R . G .33$. R. diversifolins Lindl. Syn. ed. 1.83. R. villicaulis Leight. var. $a$. Bab. ed, $1 .-\gamma$. argenteus; pubeseence of st. dense and silvery, leafl. ronndish-obovate acu- 
minate doubly dentate white silky and shining beneath, prickles on st. and panicle very large, lower branches of panicle elongated erect-patent. R. villicaulis $\beta$. Bab. ed. I.- Herlges and thickets. $\beta$. in shady places. $\gamma$. Channel Islands. Sussex. Isle of Wight. Sh. VII. VIII.

E. I.

13. R. sylvaticus (W. and N.); st. arched slightly angular patently hairy, prickles rather unequal slender straight, $l .5$-nate soft shining and pale green beneath, leafl. cordate-ovate pointed, panicle compound leafy with short branches.-R. G. I5. R. villicaulis $\gamma$. Bab. ed. I.-St. long, not furrowed, often nearly round ; mbescence of shining patent hairs. Prickles morlerate, rather numerous, declining, hairy at the base, not quite confined to the angles of the st.; on the fl.-shoot and panicle short and slender. Leafl. serrate, thick, usually tinged with purple on the veins beneath.- $\beta$. villicaulis ; leatl. oval or roundish cuspidate, panicle with more and longer branches anil stronger prickles, st. with more equal and fewer prickles. R. G. I7.-Rather rare. Bath. Killarney. Loch Eil. Linlithgow. $\beta$. Isle of Wight. Dorset. Sh. VII. VIII.

14. R. Balfourianus; st. arched terete patently hairy, prickles slightly unequal slender straight scarcely declining, 1. 5-nate soft and pale green bencath, leafl. cordate or orate acute, lower pair nearly sessile overlapping the interm. pair, panicle corymbosediffuse downy, bracts leafike trifid, sep. ovate-lanceolate downy setose erect-patent with a leaflike or filiform attenuated point.A.N.H. xix. 86.-St. and its pubescence and prickles like those of R. sylvaticus. Panicle usually lax or diffuse. Cal. erect or clasping the hemispherical fruit.-Near Rugby, Leicestershire. Rev. A. Bloxam. Sh. VIII.?

15. R. Borreri (Bell Salt.); st. procumbent terete hairy, prickles numerous unequal long slender deflexed, l.5-nate hairy and deep green beneath, leafl. broadly obovate-lanceolate cuspidate, panicle corymbose its lower branches long and decompound, cal. of the hemispherical fr. erect-patent.-Bell Salt. in A.N.H.xv. 306.St. mostly quite prostrate, very prickly; pulbescence of patent hairs. Prickles not confined to the angles of the stem; on the hairy fi.-shoot and panicle few and slender. L. the same colour on both sides. Terminal flower usually nearly sessile. Sep. lincar-lanceolate.- " $\beta$. Wilsoni; a few aciculi on st., prickles broad at the base."-Isle of Wight. Near Rugby. Rev. A. Bloxam. " $\beta$. Buglawton, Cheshire. Mr. S. E. Wilson." Sh. VI.

16. R. Sprengelii (Weilhe); st. procumbent terete with seattered hairs, prickles hooked, l. ternate, leafl. obovate acuminate, paricle with divaricate few-flowered branches tomentose, sep. 
ovate acuminate tomentose spreading.-R.G. 10.-St. quite prostrate, nsually slemeler. Prickles suall, strongly looked. L. nearly always teruate. Fl.-shoot erect (from the grouml), with few small prickles. Ped. and cal, very hairy and shaggy. Pet. rose-pink.-Bredbury Wood, Mr. Sidebotham; and Congleton, Cheshire, Mr. S. E. Hilson. Barlon IIll, Leicestershire. Reo. A. Bloxam. Bromsgrove Liekey. Mr. Lees. Sh. VIl.? E.

17. R. Leightonianus (Bab.); st. arched slightly angular hairy, prickles rather unequal straight slightly declining, $l$. 5 -nate or ternate thin pilose above pale green and hairy beneath doubly apiculate-dentate, leaft. roundish acute, panicle leafy below with short few-flowercel ratlier distant divaricating branclies densely hairy and sctose, sepals reflexed.-Bab. in A. N.H. xvii. 240 . R. villicaulis 8 . Bab. ed. 1 .- St. long; hairs numerous, fine, sprealiug. Prickles numerous, not confined to the angles of the st., subulate from a dilated liairy base; on the very hairy fl.shoot and panicle slender straight deelining; on the very hairy petioles nearly or quite straight and slender.-Shropshire. Sussex. Little Malvern. Mr. Lees. Eccleshall Wood, Sheffield. Rev. W. W. Newbould. Sh. VI1. VIII.

E.

18. R. carpinifolius (W. and N.); st. ascending slightly angular hairy, priekles strong deflexed or declining, 1. 5-11ate rather eoriaceous sharply serrate green beneath, leafl. ovate narrow acuminate, lower pair not overlapping the interm. pair, panicle narrow with ascending branches very hairy.-E. B. 2664. R. G. 13.-St. suberect, ultimately arching; hairs fascicled, straight, spreading. Prickles numerous, equal, hairy. L. slightly hairy above, more so and palcr beneath. Panicle prickly, compract, often slightly setose; branches short, few-flowered or simple.Hedgres and thickets. Sh. VI1.-IX.

19. R. macrophyllus (W. and N.); st. arched angular hairy, prickles small straight equal few, l. 5-nate thin mueronate serrate pale green and pubesecnt beneath, leafl. elliptic-ovate, lower pair stalked not overlapping the interm. pair, panicle compound rather elongated with ascending branches.-E. B. 2625. R. G. 12.-St. long, purplish, more or less hairy. Prickles short, thiek at the base, distant; on the paniele small. L. irregularly but doubly serratc, with a long point, downy or distantly pilose beneath.$\beta$. Schlechtendalii; leafl. obovate-cuneate cuspidate irregularly doubly serrate, prickles on the barren st. larger. $R$. G. I1. $-\gamma$. amplificatus; lcafl. as in $\beta$. but often pale beneatl, panicle very long narrow leafy below with aseending branches: pubescence yellowish.-Hedges and thiekets, not eommon. Sh. VII. VIII. 
***** Stems arched or prostrate, rooting, angular, hairy, setose.

+ Stems rongh with the rigid bases of the acienli and setx. Prickles rather unequal, chiefly confined to the angles of the stem.

20. R. Balbingtonii (Bell Salt.); st. arched terete but sulcate rough glabrous (?), prickles stout short declining, setæe and acicull numerous short rigid, $l$. nostly ternate crenate-dentate-mucronate pilose and opaque above downy and pale green beneath, leafl. shortly obovate abruptly cuspidate, panicle long leafy downy prickly setose witl ascenting branches.-Bell Salt. in A. N. H. xv. 307.-A very large plant. Panicle more than $2 \mathrm{ft}$. long; pubeseence dingy; floral l. very large, simple or ternate. Cal. setose. Fr. small. Barren st. not angular; aciculi and setxe short but very thick and strong. - $\beta$. Bloxamii; st. angular with flat siles, prickles small, aciculi and setae very short, branches of the paniele short few-flowered corymbose--Sclborne, Hants. $\beta$. In a lane by Hartshill Wood, Warwiekshirc. Rev. A. Bloxam. Sh. VII.

E.

21. R. rudis (Weile); st. areher or prostrate slightly furrowed rough, prickles nearly equal strong declining mostly confined to the angles of the stem much longer than the equal aciculi setae and hairs, $l$. 5-nate doubly and coarsely serrate white beneath, panicle long leafy naked at the end with ascending corvmbose branches, sep. lanceolate prickly setose strongly reflexed from the fruit.-St. dark fuscous; prickles not passing into acieuli and setre. Panicle mneh branched; rachis usually very setose. Sep. mostly witl a leaflike point, clothed with dark sctx.-a. rudis; leafl. obovate-laneeolate. R. G. 40. R. Radula Leight var. $\gamma$. Bab. ed. 1.- $\beta$. Leightonii ; leafl. roundishobovate abruptly cuspidate rather thimner. $R$. Leightoni Lees. - . Reichenbachii; leafl. nearly roumd, st. hairy with very few aciculi and setre. R. G. 37.- $\delta$. denticulatus; leafl. quadrangular-obovate cuspidate cordate below with broad but very shallow tceth and denticulate. A.N.H. xix.87. A very curionis plant. L. broadly and obscurely dentate instead of deeply serrate; their whole margin denticulate. Panicle that of typical R. rudis. - . attenuatus; leafl. obovate with a long tapering point pale green beneath. R. echinatus Bab. ed. I. not Lindl.- Hedges in the south. $\beta$. Sliropslure. $\gamma$. Isle of Wight. $\delta$. Loxley near Sheffield. Rev. W.W. Newbould, $\epsilon$. Somerset. Shropshire. Leicestershire. Sh. VII.

22. R. Radula (Wcihe); st. arched or prostrate angular rough, prickles unequal slender from a thick base declining not eonfined to the angles of the stem mostly much longer than the unequal aciculi seta aud hairs, $l$. 5-nate unequally and finely 
serrate, leafl. acuminate, panicle long loafy naked at the end with short corymbose branches, sep. orate tomentose loosely reflexed from the frnit.- St. green or greenish purple; prickles mostly large, but a few sualler passing into aciculi and sita. l'anicle slightly brauched ; rachis rather sparingly setose. Sep. without a leaflike point, clothed with a whitish tomentum and a few setx.-a. Rudula; st. with numerous setx and few hairs, 1. glabrous with impressed veins above whitish-green and pubescent bencath, leafl. orate-acuminate variable in size. $R$. G. 39. var.

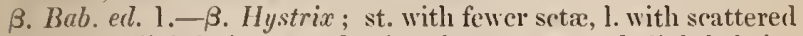
liairs and slightly impressed veins above green and slightly hairy beneath, leafl. often much narrowed below. R. G. 41.- - pyymreus; st. roundish with numerous prickles aciculi setre and hairs, l. with scattered hairs and scarcely inpressed veins above grcen and softy hairy beneath, leafl. obovate acuminate : petiole with numerous unequal shightly hooked prickles and short thick aciculi. R. G. 42.-- $\delta$. foliosus; st. slightly angular with very short aciculi setx and hairs, l. with scattered hairs above grecnishwhite soft and downy bencath, leafl. ovate-aeminate : petiole as in var. $\gamma$. R. G. 28.--Iledges and thickets, not very common. Sh. VII. VIII.

E. S.

23. ? R. Lingua (Weihe); st. procumbent or arched slightly angular rough, prickles unequal nearly straight declining aciculi setre and hairs few and short, 1.5-nate or 3-nate nearly glabrous above pale green or whitish and hairy bencath, leafl. obovate abrupt cuspidate, panicle lax with mostly l-flowered branches and large simple floral leaves, sep. ovate tomentosc cuspidate loosely reflexcrl from the fruit.-R. G. 38.- St. grcen or greenishpurple. Prickles not very numerons, moderate, fewer than in R. Radula and less decidedly larger than the aciculi. Panicle nearly simple with very long pedicels; rachis and branches clothed with an ashy tomentum, short setx, and slender prickles. Cal. greenish. Scarcely distinct from $R$. Radula.-- $\beta$. tomentosus; leafl. obovate acuminate soft and ashy-white beneath, panicle with corymbosc about 3 -flowered branches. $R$. scaber R. G. 32. ?Deion. Dumfi'ies-shire. ß.Jersey. Dorset. Sh. VII.-IX. E.S.

t† Prickles not confined to the angles of the stem and passing insensibly into setæ.

24. R. fusco-ater (Weihe); st. decumbent angular slightly hairy sctose, prickles numerous unequal straight, 1. 5-natc opraque alove palc soft shining and silky beneath, leafl. cordate-ovate acuminate wavy, lower pair overlapping the interm. pair, panicle leafy bclow downy and setose with corymbose branches, cal. of fr. patent or loosely reflexerl. $-R$. G. 26. R. Radula Leight.St. with many rather unequal moderately large prickles anck more or less numcrous unequal smaller ones eonnecting them 
with the aeiculi and setx. L. pale green beneath; lower leafl. nsually sessile; term. leafl. rather broad below. Petioles with hooked prickles. Panicle with many sloort hairs and setre and long strong prickles. - $\beta$. candicans; st. and petioles less prickly much more hairy, l. white beneatl, leatl. rather broal at the base: lower pair stalket, panicle very hairy. $-\gamma$. echinatus; st. and petioles very prickly, l. the same colour on both sides hard wrth rather rigid hairs lieneath, leafl. rather narrow at the base: lower pair stalked, panicle with long hairs longer setre and acieuli and many small sleuter prickles. R. echinatus Lindl. Syn. ed. 1. 94. Leight. Shrop. not Bab. ed. 1.- $\delta$. subglaber ; st. and petioles witl nearly equal prickles few short setæe short acieuli and very few hairs, l. apiculate-dentate glabrous above downy bencath, leafl. cordate cuspidate, panicle diffuse downy with scarcely any prominent hairs sete and aciculi short priekles long. -Isle of Wight. Dorset. Satop. Leicestershire. $\beta$. Malvern.

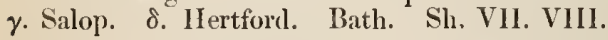

E.

25. R. Koehleri (Weihe); st. decurved or proeumbent hairy setose, prickles numerous strong very unequal mostly straight, 1. 5-nate opaque above hairy and soft beneath, leafl. obovate or elliptical acuminate, lower pair stalked not overlapping the interm. pair, panicle branched leafy below prickly setose, cal. of fr. spreailing or reflexed.-a. Koehleri; prickles very numerous unequal straight slightly declining, hairs few, leafl. obovate acuminate, panicle tomentose above with spreading corymbose branehes and numerous long straight prickles. R. G. 25. E. B. S. 2605. Barren stem almost covered with very numerous priekles aeiculi and sctæ.- $\beta$. cuspidatus; prickles short straight horizontal, hairs few, leafl. obovate cuspidate, panicle tomentose above with short spreading corymbose branches numerous seta and scattered short straight prickles. R. glandulosus Sm.$\gamma$. pallidus; prickles slender straight declining, hairs rather mumerous, leaft. obovate-elliptical acuminate, panicle subtomentose above with racemose-corymbose branches numerous setæ and rather numerous short strong declining or deflexed prickles. R. G. 29.- - . infestus; prickles rather numerous stout short strongly declining, hairs and sete and very short aciculi few, leafl. oblong acuminate pale green and downy beneath, paniele oblong with short few-flowcred branches and numerous long slender declining prickles. Prickles even hooked, short, with thick bases. —. fuscus; prickles rather few declining, aciculi setæ and hairs rather numerous, leaft. elliptical subcordate cuspidate, panicle narrow with short few-flowered corymbose branehes and short slender prickles. R. G. 27 . R. fusco-ater Leight. R. Koehleri $\beta$. fusco-ater Bab. ed. l. Paniele with long nuequal prominent setæ.-Common. $\delta$. Killarney. Sh. VII. VIII.

26. R. hirtus (W. and N.); st. "proeumbent terete" hairy 
setose, prickles small slender very unequal rather numerous straight declining, $l$. 5-nate or 3-nate green on both sides pilose above hairy heneatl, leafl. oval-cuspiclate or ovate-lanceolate, panicle very setose and tomentose or hairy prickly racemosc lenty below: sete very unequal pmple, eal. patent or loosely clasping the fr. setose.-Seta very ummerous and very unequal. Panicle with rather distant axillary branches which are somewhat corymbose and short.- a. hirtus; l. large 5-nate, leafl. oval cuspiclate, panicle tomentose. R. G. 43.- $\beta$. Menkii; l. moderate 5- or 3-nate, leafl. oval-lanceolate, panicle hairy, cal. prickly. R. G. 22.-Rare. a. Dumfries-shire. Sussex. Salop. $\beta$. Tonbridge Wells. Sh. VII. VIII.

E. S.

27. R. glondulosus (Bell.); st. arched or declining terete or slightly angula lairy sctose, prickles small slender unequal straiglit decliming, $l$. 3-nate or 5-nate green on both sides pilose above hairy beneath, leatl. oval obovate or obovate-lanceolate, panicle very sctose and hairy or tomentose prickly corymbose leafy below: sete short nearly equal purple, cal. of fr. loosely clasping or reflexed setose-—a. Bellardi; st. terete sparingly liairy very setose, prickles all small very numerous, leafl. oval cuspidate regularly and finely serrate, panicle but little divided tomentose with numerous slender straight horizontal prickles its sunmit and few long distant few-flowered branches corymbose. R. G. 44. E. B. S. 2883.- - . Lejeunii; st. slightly angular sparingly hairy and sctose, prickles mostly small a few larger, leatl. oval-cuspidate or obovate-lanecolate inequally but rather finely serrate, panicle branched densely tomentose with numerous short sunken setæ and slender declining or slightly deflexed prickles. $R . G .31 .-\gamma$. rosuceus; st. slightly angular hairy very setose, prickles very unequal, leafl. obovate or obovate-lanceolate acuminate coarsely and unequally serrate, panicle branched below (often with two principal branches) corymbose above hairy with long protruded sete and declining or slightly deflexed prickles. R. G. 36.- $\delta$. dentatus; st. slightly angular pilose setose, prickles few and small, leafl. ovate cuspidate cordate below unequally apiculate-dentate, panicle hairy with many short setæ and few slender straight declining prickles: branches few short distant divaricated few-flowered corymbose. Bab. in A. N. H.xix. 17.- Rare. a. Terrington Car, Yorkshire. Mr. Spruce. $\delta$. Twycross, Leicestershire. Rev. A. Bloxam. Sl. VII. VIII. E.

28. $R$. Güntheri (Weihe); st. arched slightly angular setose with scattered hairs, prickles numerous unequal straight declining some strong but short, l. 3-nate or 5-nate unequally dentate-serrate green on both sides glabrous above paler and pilose on the veins beneath, leafl. broadly ohovate cuspidate, panicle thyrsoid hairy lcafy below with few slender straight declining prickles and short 
setre: apex and sloort ascending many-flowered branches panicled. -R. G. 21. Bab. in A. N. H. xix. 17.-Prickles short from a thick base. L. mueh like those of $R$. glandulosus, nearly always 3 -nate. Panicle long, narrow, 3 or four lower branches axillary short.-Hartshill Wood, Warwickshire. Rev. A. Bloxam. Crowsnest Wood near Worcester. Mr. E. Lees. Sh. VIII.?

E.

29. R. humifusus (Weilıc); st. procumbent tercte hairy setose prickles ver'y slender and unequal numerous deelining, I. 3-nate or 5-nate finely and unequally serrate green on both sides paler and pilose beueath, leafl. cordate-ovate cuspidate, panicle branched leafy bclow densely covered with lax hairs prominent setæ and long slender declining prickles.-R. G. 35.-St., tl.-shoot, ped. and petioles beautifully elothed with long slender priekles and aciculi, which have a puple base and pass insensibly into very long and slender and very unequal setæ. Lower branches of the paniele elongated, ascending, 3-4-flowered; the others mostly 1-flowered. St. slender, fuscous-purple-Glen Falloch, Perthslime. Sh. VII. VIII.

30.? R. Sclleicheri (Weihe?); st. arehed or prostrate obsoletely angular nearly round with scattered hairs and seta, prickles scattered unequal straight declining, 1. 5-nate or 3-nate pilose above green soft and pubescent beneath, leafl. roundish shortly acuminate narrower below, panicle small with 3 or 4 distant veryfew-flowered short branches and a tcrminal simple corynb setose: prickles many long straight declining, cal. of fr. erect-patent.Leight. Shrop. 237.-A very donlotful plant.-Shropshire, IIampshire. Sh. VII. VIII.

31. R. Wallbergii (Arrh.); st. arched obtusely angular with few or no hairs or setæ, prickles numerons very unequal, 1.5 -nate pale green beneath, leaft. broadly ovate acuminate cordate below, on the fl.-shoot cordate broad below, panicle long leafy prickly, cal. of fr. patent, pet. obovate narrowed below, "styles green." Bell Salt. in A. N. H. xvi. 371. Prickles straight, rather declining, on the antumnal shoots and petioles lookel. Often much like $R$, corylifolius.-South of Englant. Sh. VIII. E.

32. R. nemorosus ("Hayne"); st. arched obsoletely angular hairs and setxe few, prickles numerous very uncqual, 1. 5-nate nearly glabrous above palcr and soft bencath, leaft. roundly cordate cuspidate, on the fl.-shoot ovate narrowed below, panicle nearly simple, pet. nearly round, "styles flesh-eoloured," cal. embracing the (black) fruit.-R. dimetorum R. G. 45. Bab. ed. l. - Prickles as in the preceding.-a. glabratus; 1. hairy and pale green beneath, fl.-shoots downy, st. nearly terete subgtabrous.$\beta$. pilosus; 1 . softly hairy and pale green beneath, fl.-shoots and nearly terete st. tomentose. $-\gamma$. bifrons; 1 . whitish and tomen- 
tose beneath, fl.-shoots fincly tomentose and together with the ped. aud pedicels armed with long straight strong declining prickles, st. nearly ghlabrous with similar prickles. $R$. bifrons $V$ ('st.- $\delta$. horrides; 1 . green with long soft hairs beneath, fl.shoots hairy with munerous long rather slender prickles, eal. ussually prickly, st. with numerous very unequal deelining prickles. -IIedges and thickets. Sh. VII. VIII.

33. R. cesius (L.); st. prostrate round glaueous, priekles slenler sulbulate unequal straight, l. 3-nate, leafl. rhomboidalovate acmininate, panicle simple, " pet. obovate emarginate, styles green," cal. cmbracing the glaueous fruit.-E. B. 826. R. G.46. - St. usually slender. Terminal leafl. oceasionally divided into three.-Common. Sh. VI.-VIII. Dewberry.

\section{B. Stems nearly or quite herbaecous.}

34. R. saxatilis (L.); st. slender rooting unarmed or with few very distant minute priekles, fl.-shoot ereet with a terminal corymb of flew flowers, pet. oval about as long as the ealyx, 1 . 3-nite,-E. B. 2233. R. G. 9.--Rooting st. amnual, very slender. Fl.-shoots about a span high. Fl. vellow. Fr. of I-4 large red drupes.-Stony mountains. P. VIII. VIII.

35. R. $\operatorname{arcticus}($ L. $)$; st. ereet unarmed herbaceons with alout one terminal $\mathrm{fl}$, pet. obovate twiee as long as the calyx, stam. connirent, l. 3-nate.-E. B. I585. R. G. 48.-Fl. rose-coloured. - Said to have been found in the Isle of Mull and on Ben-y-Glo. P. V.

36. R. Chamamorus (L.); st. erect unarmed I-flowered herbaceons, l. simple lobed and plaited.-E. B. 7I6. R. G. 49.True stems subterranean, ereeping, woody. Fl.-shoot (st.) 6I0 in. high. Fl. large, white, dioecious. Fr. large, red, afterwards orange-yellow. - Alpine turfy bogs. P. VI. Cloudberry.

\section{Tribe IV. Rosar.}

\section{Rosa Linn. (1) Rose.}

* Shoots setigerous, prickles scarcely curved.

\section{$\uparrow$ Braets large.}

[1. R. Dicksoni (Lindl.); "shoots setigerous," priekles seattered slender subulate, leaflets oval with coarse double serratures hoary, sep. long simple equal, fruit ovate-urceolate.-E.B.S. 2707 . - Smaller serratures of the 1 . irregular or wanting. Peduneles thiekened upwards, setose.-Probably not a native. See Mack. Fl. Hibern. Sh. VI.] I.?

1 In this genus I have availed myself of the observations of my valued friend $\mathrm{Mr}$. Borrer in Hook. Br. Fl. ed. 3 . 
[2. R. cinnamomea (L.); shoots setigerous, prickles scattered slender subnlate, leaflets lanceolate-oblong simply serrate downy and glandulose beneath, sep. long simple, fr. ovate small. Borr.E. B. 2388.- Serratures of the leaves sometimes with an intermediate tooth. Pedineles not thiekened upwards, withont seta. Sep. longer than the corolla, mostly simple, linear-laneeolate, connivent on the fruit.-Probably not a native. Sh. V.]-E.? S.?

† Bracts small or wauting.

3. R. rubella (Sm.); st, and branehes densely setigerous thronghout, prickles nearly equal few slender, leaflets simply serrated naked their disk eglandulose, fr. oblong or ureeolate pendulous.-E. B. 2521 and (fruit) 2601.-Persistent sepals mostly spreading. Fr. bright red.- Said to have been found at South Shields and Abergeldy, but a doubtful native. Sh. V.-L.? S.?

4. R. spinosissima (L.); prickles numerous crowded very unequal mostly straight subulate or setaceous intermixed with seta, leaflets simply serrated their disk without glands, sep. half as long as the eor. acuminate entire, fr. nearly globular erect.-E. B. 187.--Fr. (lark purple or black.- $\beta$. pilosa (Lindl.); "l. acute hairy on the under side."-Sandy and chalky heaths. $\beta$. Ireland. Sh. V.

5. R. libernica (Sm.); prickles scattered unequal the larger ones slightly faleate, setc few, leaflets simply serrate hairy beneath their disk without glands, sep, shorter than the eor. pinnate slightly leafy, fi. nearly globular.-E. B.2196.-Fr. somewhat ureeolate, blood-red. Fl. mostly solitary or 2 or 3 together. Leaflets sometimes smooth when growing in exposed places near the sea.-Counties of Derry and Down. Sh. V.-X.

6. R. Wilsoni (Borr.); prickles numerons crowded very unequal straight, setæ few, leaflets simply serrate hairy on both sides their disk without glands, sep. shorter than the pet. slightly leafy mostly simple, fr. ovate-urceolate.-E. B. S. 2723.-Fr. scarlet. -Banks of the Menai near Bangor. Sh. VI.

7. R. involuta (Sm.); priekles erowded very unequal straight, setæe few, leaflets donbly serrate hairy and glandular beneath, sep, nearly as long as the cor. slightly leafy mostly simple, fr. globose-ureeolate setose.-E. B.2068 and (fr.) 2601.-Fr. dark rerl. Dwarf.-IIebrides and western highlands. Sh. VI.

8. R. Sabini (Woods); prickles scattered unequal straight or nearly so, sctre few, leaftets doubly serrate hairy glandular bencath, sep. nearly as long as the eor. somewhat pinnate slightly leafy, fr. globose or slightly urceolate setose-E. B. S. 2594. -Fr. dark red.- $\beta$. doniana (Lindl.); priekles more uuinerous, 
l. very hairy, cal. almost simple. E. B. S. 2601.- $\gamma$. gracilis (13orr.); larger prickles falcate, cal. aluost simple. E. B.583 (fig. only).-Mostly in the north. Sh. VI.

** Shoots mostly without setc, leaves glandulose.

† Prickles nearly uniform, seta few or nonc.

?. R. villosa (1.); prickles uniform nearly straight, leaflets doubly scrrated downy glamdular, sep. slighilly pinnate, rootshoots struight.-E. B. 2459.-Sep. persistent, usually connivent on the ellipitical or nearly globose fruit.-Northern counties. Sl. VI. VII.

10. R. tomentosa (Sm.); prickles mostly uniform straight or curved, leaflets doubly serrated downy glandular, sep. copiously pinnate.-E. B.990 and 1896.-Root-shoots straight or arched. Sep. persistent, usually spreading on the oblong or urceolate fruit. A very variable plant.-IIedges and thickets. Sh. VI. VII.

I1. R. inodora (Fries); prickles uniform uncinate, lcaflets donlly serrated hairy glandular beneath, sep. closely pinnate mostly decirluous, ramuli without seta, fr. elliptical or nearly globular.-E. B, 2579.-L. sparingly glandular, sometimes with more numerous glands, and then the sep. are elongated and persistent. Sep. short with a short leafy point and closely-sct shortly-lanceolate often compound pinnæ.-Hedges and thickets. Sh. VI. VII.

E. I.

12. R. micrantha (Sm.); prickles uniform uncinate, leaflets doubly serrated hainy glandular beneath, sep. and pinno elongated deciduous, ramuli sparingly setigerous, fr. small elliptical and ovate.-E. B. 2490,--Distinguished by its sepals with a long leafy point and narrow lanceolate simple pinna from the last, and by its uniform prickles, its small fruit (primordial) rounded at the base and deciduous sepals from the following. Glands on the undcr side of the leaves numerous.-Hedges and thickets in the south. Sh. VII. VIII.

E. I.

If Prickles various, intermixed with setæ.

I3. R. rubiginosa (L.); prickles numerous the larger uncinate the smaller subulate, leaflets doubly serrate hairy glandulose bencath rounded at the base, sep. and pinnce elongated persistent, prinordial fruit pearshaped.-E. B.99I.-The various prickles, persistent calyx and pearshaped (primordial) fruit distinguish this from the 2 last with which it is very closely allied and has been combinerl by Lindley and Fries.-Bushy places. Sh. VI. VII. Sweet-Briar.

I4. $R$. sepium (Thuil.); prickles numerous the larger curved the smaller subulate, leafiets doubly serrated bairy glandular 
bencatl acute at the base, sep. and pinna elongated narrow, fruit (primordial) ovatc rounded at the base.-E. B.S.2653.-Pinnre of the calyx small, narrowly lanceolate, springing nearly at rightaugles from the sepals which lave a linear-lanceolate linb.Bridport, Warwickshire. IIeyford, Oxfordshire. Sh. VI. E.

*** Shrots mostly without setณ, leaves without glands.

† Styles distinct, included, or nearly so.

15. R. canina (L.); prickles uniforn looked, l. naked or slightly hairy without glands the serratures simple or compoumd, sej. pimate decirluous, styles distinct.-a.canina; leaflets naked keeled serratures simple. Leaflets narrowly elliptical, not rounded below, often with a twisted point, green or grey. $R$. canina Woods, E. B. 992,- $\beta$. sarmentacea (Borr.); leaflets naked keeled serratures compound. R. sarmentacea Woods, E. B.S. 2595. - $\gamma$. surculosa (Borr.); leatlets naked flat serratures simple. Leaflets roundish or elliptical with irregular serratures. R. surculosa Woods.- $\delta$. clumetorum (Borr.); leaflets hairy on both sides flat. Tcrminal leaflets often nearly cordate. R. dumetorum Woods, E. B.S.2610.- - . Forsteri (Borr.); leaftets more or less hairy not flat. Leaflets concave or keeled, hairy on both sides or only beneath. R. Forsteri Sm., E. B. S. 26II.-See Borrer's detailed account of this species in Hook. $\mathrm{Br}$. Fl. ed. 3.-Iledges and thickets. Sh. VI. VII. Doy Rose.

I6. R. bractescens (Woods); "calyx-tube globose, priekles hooked, leaflets simply serrated downy beneath, bracteas overtopping the fruit." Woorls.-Styles woolly. Hr. globose.-U1verston, Lancash.; Ambleside, Westm. Mr. Woods. Sh. E.

17. R. cœsia $(\mathrm{Sm}$.$) ; prickles uniform uncinate, leaflets doubly$ serrate downy without glands, sep. distantly and sparingly pinnate, fr. elliptical smooth.-E. B.2367.-Diffieult to distinguish on paper from $R$. camina but more resembling $R$. tomentosa in appearance.-In the north. Sh. VI.

†† Styles united iu a column, mostly exserted.

18. R. systyla (Bast.?); prickles uniform uncinate, leaflets simply serrate without glands, sep. sparingly pinnate deciduous, centrul germens stalked, styles hairless, stigmas forming a conical head, shoots nearly erect.-E. B. 1895.- Serratures towards the upper end of the leaflets usually converging. Germens in the centre of the calyx on stalks as long as theinselves. Column of styles variable in length. L. nearly glabrous or hairy on both sides. The strongly arehed shoots often rise to the height of 10-12 feet.-Hedges and thickets. Sh. VI. VII. E. I.

19. R. arvensis (Huds.); prickles uncinate those on the ramuli feeble, leatlets simply serrate deeiduous without glands, 
sep, sparingly pinnate decilhous all the germens sessile, styles hairless. stigmas forming " round heud, shoots trailing.-E. $B$. 1S..-IIerlges and thickets. Sh. VI. VII.

\section{Tribe V. Pomere.}

\section{Crategus Lim.}

1. C. Oryacantha (L.); spinose, l. obovate 3-4-lobed cut and serrate emeate at the base, $\mathbb{A}$. eorymbose, cal. not glandular, styles $1-3 .-E . B$. (var. $\beta$. ?) 2504.-It is not improbable that thic following varieties are distinct species. $-a$. l. lobed bluntish, peduncles and calyces glabrous, strles $1-3$, fruit oval. C. Oxyacantha L., Jacq.- -. monogyna; l. deeply loberl usually acute, peduncles and calyces villose, style 1 bent, fruit subglobose. C. monogyna Jacq., Koch.-IIelges and thickcts, $\beta$. the more common form. 'T. V. VI. Hawihorn. Whitethorn.

\section{Cotoneaster Lindl.}

l. C. vulgaris (Lindl.); l. roundish-ovate rounded at the base, flowerstalks and margins of the calyx downy.-E. B. S.2713.Pet. rose-coloured. Fr. small, penilulous.-Cliffs at the Great Orme's IIcal, Caernarvonshire. Sh. V.

Ii.

\section{Mespilus Limn.}

1. M. germanica (L.); l. lanceolate undivided downy beneath, H. solitary.-E. B. 1523.-L. cntire simply or donbly serrate. In a wild state spinons.-Iledges and thickets in Surrey, Sussex and Clicshire. 'T. V. VI. Medlar.

E.

\section{Pyrus Limn.}

1. P. communis (L.); l. simple ovate serrated, flowerstalks corymbose, fruit turbinate, styles free.-E. B. 1784.-Germen woolly. Lcaves sometimes obovate suddenly contraeted into a long very acute point.-I Hedges and woods. T. IV. V. Wild Pear tree.

2. P. Malus (L.); l. ovate aeute serrate, fl. in a sessile umbel, fr. globose, slyles combined below.-E. B. 179.—a. glabra (Koch); young branelies peduncles calyx-tube and under side of the 1 . glabrous. - $\beta$. tomentosa (Koch); the same parts pubesecnt or woolly. See Leight. Fl. Shrop. p. 527.-Woods and hedges. T. V: Crab tree.

[3. P. domestica (Snn.); l. pinnate downy beneatl serrated, f. panicled, fr. obovate.-E. B. 350.-Fr. resembling a small pear.-One tree in Wyre Forest. T. V. Service Iree.] E. 
4. P. aucuparia (Gacrt.); 1. pinnate downy beneath scrrated, fl. corymbose, fr. (small red) globose.-E. B. 337.-Hilly woods and on mountains. 'T. V. Vl. Rowan tree. Mountain Ash.

5. P. pinnatificla (Ehrl..); l. oblong doubly serrate near the apex pinnatifid below: pinna lanceolate oblong serrated the 2 lowermost distinct, under side white and downy, fl. corymbose.E. B. 2331. Sorbus hybrida L.-Fr. scarlet. Lower part of the 1. usually truly pinnate, the lobes becoming more and nore combincl as they approach the extremity of the leaf which is only deeply and donbly serrate.-Mountains in the northern part of the Isle of Arran. T. V.

6. P. Aria (Sm.); l. oval or oblong unequally and doubly serrate or slightly lobed towards the apex nearly entire below under side white and downy, fl. corymbose.-E.B. 1858.-Fr. scarlet. Veins of the l. numerous.- $\beta$. intermedia (Sm.); 1 . oblong doubly serrate and lobed : lobes deepest towards the middle of each side of the leaf, lateral nerves much fewer.-Hilly and mountain woods. $\beta$. Castle Dinas Bran. T. V. White Beam tree.

7. P. torminalis (Sm.); l. ovate or cordate lobed glabrous: lobes triangular acute serrated the lower ones larger and spreading, fl. corymbose.-E. B. 298.-Fr. oval, brown.-Woods and hedges elicfly in the south. T. IV. V. Wild Service tree. E.

\section{Order XXVIII. LYTHRARIE}

Cal. tubular, lobed: lobes valvate or distant in restivation, sometimes witl intermediate teeth. Pet. between the lobes of the calyx, very deciduous. Stam. inserted in the tube of the cal. below the pet. and equalling them or 2,3 or 4 times as many. Ovary free, $2-4$-celled. Caps. membranaccous, usually (by abortion) l-celled, with numcrous seeds and a central placenta, covered by the calyx. Embryo straight.

1. Lythrum. Cal. tubular, cylindrical, with 8-12 teeth; 4-6 broader, erect; altermate tecth subulate, opposite to the petals. Pet. 4-6. Stam. inserted at the middle or base of the calyx, as many as, or twice the number of the petals. Style filiform. Caps. 2-cellerl, many-seederl.

2. Pepurs. Cal. campanulate with 12 teeth of which 6 are broader and erect, the others subulate. Pet. 6 , minute, fugacious. Stam. 6, opposite to the broader teeth of the calyx. Style very short. Caps. 2-celled, many-sected.

\section{LyThRUM Lim.}

1. L. Salicaria (L.); l. lanceolate from a cordate base opposite 
or whorled, fl. in whorled lenfy spilies, bracts 0, subulate calyxteeth twice as long as the others, stam. 12.-E. B. 106i.Whorls of $\mathrm{t}$. in a more or less leafy spike, upuer l. usually very small, shorter than the flowers; but sometimes ( $\beta$. verticillatum) so large as totally to destroy the spiked appearance and give quite a different aspeet to the plant. St. $2-4$ feet high and 1. nearly glabrous, or $(\gamma$. canescens) downy with erisped hairs. Fl. large, purple or criunson.-Ditch-banks and damp places. P. VII. VIII. Purple Loosestrife.

2. I. Hyssopifolia (L.); l. alternate linear-lanceolate blunt, A. axillary solitary, bracts 2 mimute subulate, calyx-teeth all short, stam. 6.-E. B. 292.-St, procumbent, spreading, simple or branched. Fl. small, light purple. Whole plant glabrous.-Damp places wherc water has stagnated, rare. A. VI.-X. E. I.

\section{Peplis Linn. Water Purslane.}

1. P. Portula (L.); l. opposite obovatc stalked, fl. axillary solitary sessilc.-E. B. 1211. St. 1.7.-Pet. often wanting. St. 4-6 iu. long, prostrate, crecping.-Damp places. A. VII. VIII.

\section{Order XXIX. CERATOPHYLLEE.}

Fl. monocious. Perianth single, frec, in many divisions. Anth. 12-20, sessile, 2-celled, 2-pointed, "cells again partially divided." - Perigone none. Ovary free, 1 -celled, with 1 pendulous seed. Fubryo straight; cotyledons 4, alternately smaller.

1. Ceratophyluu Linn. The only genus.-G. F. G. Monochl. 1.

1. C. demersum (L.); calyx-segments notched at the end, fruit with 2 spines near the base and terminated by the curved subulate style.-E. B.947.-L. 2-4 times forked : segments linearfiliform, dark green, those of the uppermost l. broader and more rigid. Basal spines sometimes scarcely distinguishable,-Ponds and ditches. P. VII.

2. C. submersum (L.); calyx-segments "acute and entire," fr. destitute of spines and terminated by the short curved style.E. B. 679,-Segments of the pale green l. capillary.-Ponds and ditches, rare. P. VI.

E. S.

\section{Order XXX. ONAGRARIE.}

Cal. tubular, adnate to the ovary wholly or in part, with $2-4$ lobes valvate in astivation. Pet. as many as the calyx-lobes, twisted in astivation, inserted at the top of the tube. Stam. 2, 4 or 8 , inscrted with the petals. Ovary of several cells, with a 
central placenta. Style 1, filiform, stigma capitate or lobed. Fr. a beny or capsule with 4 cells. Albumen 0.-L. alternate or opposite not dotted.

1. Epilonium. Cal. 4-cleft. Pet.4. Stam. 8. Style filiform with a clavate or cruciform stigma. Caps. linear, of 4 cclls, witl 4 valves. Seeds numerous, bearded.

2. (Exothera. Secds not bearded. In other respects like Epilobium.

3. Isina rdia. Limb of the cal. 4 -cleft. Pet. 4 or 0 . Stam. 4. Style filiform, deciluons, stigma capitate. Caps.obovate, 4valied, 4-cclled, many-sected, with a loculicidal dehiscence.

4. Circasa. Limb of the cal.2-cleft, its tube closed by a cupshaped disk. Pet. 2, obcorlate. Stam. 2, altcrnate with the petals. Style simple; stigma emarginate. Caps. 1 or 2-celled, cells l-seeded, seerls erect.

\section{Epilobium Linn. Willow Herbs.}

* Style and stamens at length declining, leaves scattered, cal. without any separate tube. CHAM ENeriox Fries.

1. E. angustifolium (L.); 1. lanceolate callose-denticulate veined, pet. clawed obovate, sep. linear-lanceolate acute equalling or slightly longer than the pet., eaps. lincar straight.-E. $B$. 1947.- a. macrocarpum; l. lanceolate, f.-buds obovate narrowed at the base and suddenly contracted into a point at the apex, caps. elongate crect. L. broadest at about their middlc. St. 3-4 feet high. E. macrocarpum (Steph.) A. N. H. viii. 170.-B. brachycarpum; l. narrowly lanceolate, $\mathrm{fl}$. buds oblong-lanceolate obliqucly acute, caps. short spreading.-L. gradually uarrowing upwards from below the middle. E. brachycarpun (Leight.) A. N. H. viii. 401.-Damp shady places. P. VII.

** Style erect, leaves alternate the lower ones opposite, cal. with a short tube.

$\dagger$ Stem without elevated lines.

2. E. hirsutum (L.); woolly, l. opposite clasping slightly decurrent oblong-lanceolate denticulatc-serrate upper ones alternate, stigmas 4-cleft, buds mucronate, root stoloniferous.-E. $B$. 838. - St. 4-5 feet high, branched. L. most hairy upon the nerves. Fl. large. A very villose form is the E. intermedium Merat.-Wet places by rivers and ditelies P. VII. VIII. Great IVillow-herb.

3. E. parviflorum (Schreb.) ; lowny, l. sessile lanceolate denticulate lower ones opposite and sliglitly stalked, stigmas 4-cleft, buds obtuse, root fibrous, no scions.-E. B. 795.-St. 1-2 feet 
high, nearly simple. L. uniformly luiry. I'l. small. $\Lambda$ dwarf woolly forni with ovate obtuse leaves occurs in Jersey. $-\beta$. rivulare; subglibrous. L. rivulare Wahl., IR. I. f. 301.-In wet plices. P. VII. VIII.

4. E.montanum (L.) ; l. ovate-oblongrounded at the base toothed shortly stulked, upper ones subsessile, st. round pubeseent, stigma t-cleft, no scions.- E. B. 1I77. St. 72. 7.-Bise of the st. decumbent and rooting but not creeping. Margins and veins of the leaves pubeseent. St. l-2 feet high, slightly brancherl; or, in $\beta$. rumosissimum, $6-18 \mathrm{in}$. high, greatly branched, leaves ovate; in $\gamma$. lumile, st. 3-6 in. ligh deeumbent below, l. small ovate; in $\delta$. verticillatum, 1. in threes;- $\epsilon$. lanceolatum (Kioch); l. laneeolate with a wedgeshaped base all stalked. St. 1 foot high, scenrecly branched but with tufts of leaves or abbreviated shoots in the axils of nearly all the leaves. Koch in St. 72.9. E. lanceolutum seb. and Mauri Fl. Roun. t. I. f. 2., Bert. Bertoloni siry's that the Italian plaut is different from that of Koch, yet my specimens agree exactly with both the figures.-In hilly places. $\gamma$. on mountains. $\delta$. Jersey. P. VI. VII.

5. E. palustre (L.) ; l. narrowly lanceolate with a wedgeshaped base entire or denticulate sessile, st. round, stigma undivided, seel obovate : testa prolonged into a point at the summit, scions filiforn.-E. B.346."-L. usually quite entire, very narrow. St. (j-Is in. high, pubescence often collected into 2 deeurent lines but the stem itself is truly terete. Buds nodding.-In boggy places. P. VII. VIII.

†† Stem with elevaterl lines.

6. E. virgatum (Fries); $l$. laneeolate uarrowing upwards sessile denticulate not decurrent, st. with 2 or 4 elevated lines, stigma undivided or slightly patent or 4-ficl, seeds oblong-obovate not prointed, scions filiform.-Florig. Brit. f. 624.-St. I, 2 or eren 3 fect high, often decumbent and rooting, elevated lines often faint. L. not decurrent, lower 1. narrowed to their base. Buds erect. Scions from the lower joints of the stem, very slender, not teminating in a rose-shaped tuft of leaves.-Deep ditehes in peat-bogs. P. VII. VIII.

7. E.tetragonum (L.); l.oblong-lanceolate narrowing upwards from a rounded base sessile denticulate, intermediate $l$. shortly decurrent, st. with 2 or 4 elevated decurrent lines, stigma undivided, seeds oblong-obovate not pointed, root somewhat ereeping.-E. B. 1948.-The intermediate 1. are truly decmrrent and often eombine so as to produce one line on each side of the stem cominon to both of them. St. $1-2$ feet high. Buds erect. Scious short, and terminating in rose-shaped tufts of leaves.Damp places. P. VII. VIII. 
8. E. roseum (Schreb.); l. stalked ovate toothed, st. with 2 or 4 elerated lines, stigma undivided, root fibrous, seions wanting. -E. B. 693.-St. l-2 feet ligh, branching. L. upon rather long stalks. Stigma sometimes slightly lobed.-Wet places, rare. P. VII. VIII.

9. E. alsinifolium (Vill.); l, ovate slightly stalked repandodenticulate acuminate glabrous, st. simple with 2 elcvated hairy lines, stigina undivided, stoloniferous.-E. B. 2000.-St. mostly decumbent, nearly simple, 6-12 in. long, produciug elongate scions with scattered leaves. L. narrowed but also rounded at the base. Fl. rather large.-Damp places on mountains. P. VII.

E. S.

I0. E. alpinum (L.); l. ovate-oblong or oblong-lanccolate obtuse entire or obsoletely toothed attenuated below, st. simple with 2 elevated hairy lines, stigma undivided, stoloniferous.E. B. 2001 .-St. decumbent or aseending, simple, 3 or $4 \mathrm{in}$. long. L. narrowed and not rounded at the base. Hl. small. Buds nodding. Scions short, with a rose-like tuft of leaves.On the ligher mountains. P. VII.

\section{Enothera Linn.}

*? I. $G$. biennis (L.); l. ovate-lanceolate flat toothed, st. rough rather hairy, pet. longer than the stam. and about half as long as the tube of the calyx.-E. B. 1534. St. 5. 5.-Fl. large, numerous, bright yellow. Caps. short, hairy. St. $2-3$ feet high, leafy.-Sandy coast of Lancashire. Often an outcast from gardens. B. VİI.-IX. Evening Primrose.

\section{ISNARDIA Limn.}

1. I. palustris (L.); st. procumbent rooting glabrous, 1. opposite ovate acute narrowed into a petiole, $\mathrm{fl}$. axillary solitary sessile, pet. wanting.--E. B. S. 2593. St. 22.3.-St. 6-8 in. long, round, branching, often redidish. Fl. with 2 smail braets at the base. Caps. ovate, obtusely quadrangular with the persistent calyx spreading horizontally.-Pools aud marshes. Buxted, Suss. Petersfield and Brokenluirst, Hants. Jersey. A. VI. E.

\section{Circexa Linn.}

I. C. lutetiana (L.); l. ovate or slightly cordate below repandodenticulate opaque, petioles subterete, bracteoles 0 , pet. deeply emarginate : lobes broadly obovate, cal. hairy, ovary ¿2-celled.E. B. 1056. St. 23. 1.-Usually pubescent. Pet. as long as the herbaceous sepals, broal below. Fr. persistent.-Woods and hedge-bauks. P. VI.--VIII. Enchanter's Nightshade.

2. C. alpina (L.); l. cordate acuminate repando-dentate shining, 
petioles flat with membranous wings, bracteoles setaceous, pet. hificl : lobes oblong, cal. glalorons, "ovary l-celled."-L. B. 1057. St. 23. 2.-Usually glabrous. l'et. shorter than the membranous sepals, narrow below. Fr. soon falling. Bracteoles deciduons.- $\beta$. intermedia (1)C.); fl. larger, sep. less membranous equalling the petals. Whole plant nuch larger. C. intermedia (Ehrlı.) Koch.-Woods and thickets in mountainous districts. l. VII. VIII.

\section{Order XXXI. HALORAGEA.}

Cal. adnate with the ovary, limb minutc. Pet. minute, from the throat of the ealyx or 0 . Stam. $1-8$ inserted with the petals. Ovary of 1 or more cells. Styles equal in number to the cells. Frnit dry, not bursting, usually erowned with the rim of the ealyx. Seed pendulous with a small quantity of albumen.

1. Myriophylum. Monocious. Cal. 4-parted. Pet. 4, fugitive, longer than the calyx in the male, small and reflexed or 0 in the female. Stam. 8. Styles 4, villose. Fr. tetragonal, separable into 4 hard nuts.-G. F. G. Monochl. 3.

2. Ilipuris. Calyx-limb very minute, obsoletely 2-lobed. l'et. 0. Stam. 1. Style filiform, lying in a channel of the anther. Stigma simple, acute. Fruit a I-cellednut.-G.F.G. Monochl. 2.

3. CAllitriche. Fl, witlont eal. or eor., usually with 2 bracts at the base. Stan. 1. Ovaries 2, each of 2 lobes and imperfectly 2-celled. Styles 2, suluulate. Fr. dry, scparating into 4 inclehiscent carpels.-Kützing figures and describes a fugacious inferior 2-parted minute calyx as sometimes found. R. Icon. $t$. 890.-G. F. G. Monoehl. 4.

\section{Myriophyllum Linn. Water Milfoil.}

1. M. verticillatum (L.) ; fl. all axillary whorled, bracts pinnatifid.-E. B. 218.-L. whorled pinnatifidly divided into setaeeous segrnents. Bracts longer than the flowers, pinnatifid or peetimate.-Ponds and ditehes, rare. P. VII. VIII.

2. M. spicatum (L.); $A$. whorled forming a leafless spike, bracts small entire, spike erect when in bul.-E. B. 83.-L. 4 in a whorl, snbmersel.--Ponds and ditehes. P. VI. VII.

3. II. alterniflorum (DC.); sterile fl. alternate about 6 forming a leafless spike, spike nodding when in bud afterwards ereet, fertile $f$. about 3 together in axillary whorls at the base of the 
spike.-E. B. S. 2854 .-L. 3 or 4 in a whorl, submersed.Ponds and ditches. P. VII. VIII.

E. S.

\section{IIrpuris Limn. Mare's Tail.}

1. H. vulgaris (L.); l. linear $6-12$ in a whorl with a callous point.-E. B. 763. St. 44. 1.-St. simple, or sonnctimes branching at the base, ereet. FI. in the axil of each of the up'pcr leaves, often without stamens. In decp water the submersed leaves are elongated flaccid pellucid and not callous at the end.--In stagnant water and slow streans. P'. VI. VII.

\section{Callitriche Lim.}

1. C. verna (L.); fr. nearly sessile: lobes parallel in pairs bluntly keeled on the back, styles constantly erect, bracts falcate. - E. B.722. R. I. t. 881. R. 4746 . Fr. small "lobes converging at the back." Floating l. spathulate rarely linear, submersed 1. linear, "invariably commate." Bracts crossing each other over the germen, slorter than the fruit.-Common in stagnant water and slow strenms. A, or P. IV.-IX. Water Starwort.

2. C. platycarpa (Kütz.); fi. nearly sessile: lobes parallel in pairs slightly winged at the back, styles crect in the flower refleaed closely over the fruit, bracts falcate.-E. B. S. 2864. R. I. t. 883 -889. R. 4748.-Fr. twice as large as that of C.verna, pale when dry. L. all ovate or spatluulate in all the British specimens that I have seen.- [C. stagnalis (Scop.) Kütz. only differs from this by having the lobes of its fr. all diverging in a stellate manner.]-Common on mud or in shallow water, rarely in deep water, throughont Britain. A. or P. V.-IX.

3. C. pedunculata (DC.); fr. stalked or nearly sessile, lobes parallel in pairs obtusely keeled at the back, styles divaricate in the $\mathrm{fl}$. reflexed over the fruit, bracts $0 .-$ E. B. S, 2606.-L. linear, upper ones broader in the middle. Fr. stalked, small, the size of that of C. verna.-B. sessilis (Bab.); l. linenr, upper l. (floating) ovate-spathulate, fr. sessile. I consider this to be the C. tenuifolia Pers., Fries, but not having seen specimens of their plant do not venture to adopt that name. $-[$ C. hamulata (Kütz.) closely resembles var. $\beta$. but has always large faleate braets.] - In marshes. $\beta$. lakes. A. or P. VI.-IX.

4. C. autumnalis (L.); fr. nearly sessile: lobes diverging in a stellate form broadly and acutely winged at the back, styles spreading, loracts 0,1 . all linear and broadest at the base.-E. $B . S$. 2732. R. 4749 . b.-Fr. 4 times as large as that of C. verna, dark brown, 1 or 2 of the lobes often abortive. L. dark green, all submerged, abrupt at the end.-Rare. Anglesea. Loch of Cluny, Forfar. Islay. Cong, Mayo, A. or P. YI.-IX. 


\section{Order XXXII. CUCURBITACEA.}

(al. 5-tootled, tulse adnate with the ovary. Cor. 5-eleft. often searcely distinguisliable from the ealyx, with reticulated veins. Stam. 5, more or less cohering. Anth. sinuose. Ovary 3-5-celled or spuriously l-eelled, placentas parietal. Style slort. Stigmas lobed. ir. more or less suceulent. Seeds fiat, in an arillus, embryo flat, albumen 0.-Plants succulent, climbing with tendrils.

1. Bryonis. Cal. 5-tontherl. Cor. 5-cleft. Male. Stam.5 in 3 bundles. licm. Strle 3-ficl. Fruit a globose 3-loeular berry. Scerls oval, compressed, more or less bordered.

\section{Bryonia Limn. Red Bryony.}

1. B. dioica (L.); st. climbing, 1. palmate 5-lobed dentate rough on both sides with callous points, fl. dioccions, cal. of the fertile $\mathrm{fl}$. lialf as long as the corolla.-E. B. 439.-Tendrils simple. Fr. red.- $[B$. alba (L.), which has not yet beeu found in England, has the fertilc cal. as long as the cor. and black fruit. It is sail to be monocious.] -Hedges and thickets. P. V.-IX. E.

\section{Order XXXIII. PORTULACEA.}

Scp, 2 , rarely 3 or 5 , cohering at the base, rstivation imbricatc. Pet. usually 5, from the base of the calyx. Stam. indefinite, inscrted with the petals, flaments distinct, often opposite to the petals. Ovary l-celled. Style 0. Stigmas several. Caps. opening transversely or by 3 valves, placenta central. Embryo curved round the alkumen.

1. Movtia. Cal. of 2 sepals, persistent. Cor. 5-parted, with 3 segments smaller than the others, tube split to the base in front. Stam. 3, inserted in the throat and opposite to the smaller segments of the corolla. Ovary turbinate. Style very short. Stigmas 3, downy. Caps. of 1 cell with 3 valves and 3 seeds.

\section{Montia Linn.}

1. 11. fontana (L.).--E. B. 1206. St. 11. 1.-L. opposite, spathulate, cntire. Pednncles often forked, axillary or terminal. Seeds subreniform, reticulate-scabrous rather opaque in $M$. minor (Gm.), or simply reticulate and shining in $M$. rivularis $(\mathrm{Gm}$.). Valves of the caps. rolled longitudinally inwards after the seeds have fallen. St. short, ascending, rigid, or (M. rivularis) flaccid and elougated.- Watery places. A. IV.-VIII. 


\section{Order XXXIV. PARONYCHIACEA.}

Cal. 5-parted, rarely 4 or 3 , xstivation imbricate. Pet. minute and resembling abortive stam. or 0 . Sitam. indefinite, opposite the sep. (when the same number), filanents distinct or rarely united below. Ovary free. Styles 2 or 3. Fr. dhy, 3-valved or indehiscent, placenta central. Embryo more or less curved. Albumen farinaceous.

1. Corrigiola. Sep. 5, slightly cohering at the base. Pet. 5, equalling the sepals. Stam, 5. Stigmas 3, sessile. Fr. 1-seeded, indehiscent. Seed suspended by its cord which arises from the base of the capsulc.-Pet. as long as the sep. inserterl upon an obscurely perigynous ring at the bottom of the calyx.

2. Herniaria. Sep. 5, slightly cohering at the base. Pet. 5, filiform, inserted with the 5 stam. on a perigynous ring. Stignas 2, nearly sessile. Fr. 1-seeded, indehiscent, membranaceous.

3. Illecebrum. Sep, 5, slightly colhcring at the base, thiekened, horned at the back. Pet, 0 or 5, subulate, inserted with the 5 stam. on a perigynous ring. Stigmas 2. Fr. 1-celled, l-seeded, furrowed, bursting along the 5 furrows.

4. Polycarpox. Sep, slightly cohering at the base. Pet.5, emarginate. Stam. 3-5. Styles 3, short. Fr. 1-celled, 3-valvel, many-seeded.

5. Scleranthus. Tube of the cal. ureeolate, contracted at the mouth by a glandular ring; limb 5-fid. Pet. 0. Stam. 10 rarely 5 , inserted in the throut of the calyx. Styles 2. Fr. membranous, 1-seeded, indeliscent, included in the hardened calyx.-G. F. G. Monoehl. 77.

\section{Corrigrola Linn.}

1. C. littoralis (L.) ; st. leafy on the part that bears the flowers. -E. B. 668.-Fl. stalked, white, small, in small clusters from the axils of the upper leaves. Stem l. oblong, narrow below. St. numerons from the crown of the root, prostrate, slender.-Sandy shores. Slapton Sands and near the Start Point, Deron. Helston, Cornwall. A. VII. VIII.

E.

\section{IIerniaria Linn.}

1. H. glabra (L.); st. herbaceous prostrate clothed with minute decurted hairs, l. oval-oblong, clusters of sessile fl. axillary coalesciug on the lateral branches into a slightly leafy spike.E. B. 206.-St. procumbent or subterranean, rooting extensively. Lateral branches resembling leafy spikes from the dense aggre- 
gation of the chnsters. Cal. glabrons or with a very few hairs. L. glibrous.- - $\beta$. subciliata (Bab.); l. more or less ciliated. Quite distinct from the following.-Very rare. Snffolk. West of Kerry. Mr. II. Andrews. Ruan Winor, Corn. Mr. Borrer. Vilsforil, Lincoln. I)r. K. Latham. P. VII. E. I.

2. II. ciliatu (Bab.); st. herlueeous prostrate clothed with mimute decurverl hairs, l. orbicular-ovate ciliated, clusters of sessile A. axillery upon the latcral branches and distinct.-E. B.S. $285 \%$ - - lioot strong, woody. St. spreading extensively from the crown of the root but scarcely rooting. Clusters l-3 together in small distinct bunches. Sep. tipjed with a strong bristle. Very different in halsit from $H$. glabra.-Very rare. Lizard Point, Cornwall. Guemsey. P. VII. VIII.

[3. H. hirsuta (L.); st. herbaceous prostrate clothed with straight spreading hairs, l. oval-oblong, chusters of sessile fl. axillary ilistinet.-E. B. I379.-Cal. hairy, resembling a minute bur. - I very doubtful native. The Finehley Common plant was H. glabra, as I learn from a specimen gathered by the late Mr. Dickson. P. VII.]

E. ?

\section{Illecebrum Linn.}

1. I. verticillatum (L.).-E. B. 895.-St. proeumbent. Fl. whorled, axillary, minute, white. L. roundish, variable in size, shorter or longer than the flowers.-Boggy ground in Devon and Cornwall. P. V'II.

E.

\section{Polycarion Linn.}

1. P. tetraphyllum (L.); triandrous, pet. cmarginate, stem l. in fours, l. on the branehes opposite.-E. B. I031.-In young plants the 1 . are often all opposite.-Coasts of the south-west of England, A. VI. VII.

E.

\section{Scleranthus Limn.}

1. S. annuus (L.); subdeeandrous, segments of the calyx of the fr. patent acute with a very narrow membranous margin, as long as their tube.-E. B. 35I.- Styles longer than the stamens. St. repeatedly dichotomous, green. Fl, green, often solitary in the forks of the stem, or densely eorymbose.-Sandy fields. A. VI. VII.

2. S. perennis (L.); decandrous, segments of the ealyx of the fi. connivent obtuse rounded with a broad membranous margin. -E. B. 352.-Styles usually shorter than the stamens. St. nearly simple or irregularly branched, proeumbent, glaucous, at length reddish. Fl. variegated with green and white. L. ercet, direetell to one side.-Sandy fields in Norfolk and Suffolk. P. VI.-VIII.

E. 


\section{Order XXXV. CRASSULACER.}

Sep. 3-20, more or less united at the base. Pet. the same number, regular, free or slightly connected, inserterl at the base of the calyx. Stam. inserted with the pet. and the samc or twice their number. Hypogynous scale (abortive stamen) l at the base of each carpel or obsolete. Carpels the same number as and opposite to the pet., fice or slightly connceted, l-celled. Fr. of several follicles opening on their face, with slightly albuminous seeds on the inner suture.

1. TILldea. Sep., pet., anil stam. 3-4. Carp. 3-4, constricted in the midlle and 2-seeded. IIypogynous scales 0.

2. Sedum. Sep. and pet. 5 , rarely 6 . Stam. 10 or 12 . Hypogynous scales entire. Carp. 5 or 6 , many-seeded.- $S$. Rhodiola has 4 sep., 4 pet., 8 stam., 4 carp., and is subdioccious.

[3. Sempervivum. Sep. 6-20. Pet. the same. Stam. twice as many as the pet. Hypogynous scales laciniated. Carp. as many as the petals.]

4. Cotyledon. Sep. 5. Pet. cohering in a tubular 5-cleft corolla. Stam. 10, inserted on the coralla. Hypogynous scales 5. Carp. 5.

\section{Tillea Linn.}

1. T. muscosa (L.); st. branched and decumbent at the base, fl. axillary sessile trifid.-E. B. 116. R. Icon. $t$. 191.-Very minute, about 1 in. long, reddlish. L. opposite, oblong, obtuse, concave above, connate. Sep. ovate or lanceolate, acute, bristlepointed. Pet. nearly subulate, white tipperl with red.-On barren sandy lieaths. A. VI. VII.

\section{Sedum Linn.}

* Root thick, many-headed. Leaves flat.

$\dagger$ Flowers yellow. RHodiola Linn.

1. S. Rhodiola (DC.); root flesliy, l. oblong dentate smooth, f. dicecious by abortion, usually divided in fours.-E. B. 508 . Rhodiola rosea Sm.-Fl. in a compact terminal cyme. L. acuminate, with numerous parallel nerves in the place of a midrib, branching and anastomosing so as to cover the whole surface with a network of slender nerves. Root (rhizoma) large, having a remarkable smell. St. $6-8$ in. high, simple.-Wet alpine rocks. P. VI. VII. Rose-root.

†† Flowers white or purple.

2. S.Telephium(L.); uppermost l. oval-oblong dentate rounded 
at the base and sessile, lower l. obovate or oblong narrowed below, corrmb lense.-E. B.1319. R.I.968. S. purpurasecns Koch, St. 8:3.8. - St. 1-2 feet high. L. large and broad. " Back of the ovaries furrowed." [In anl allicel species (?) (S. maximum Sut., R. I. 969. St. 8.3. 7.) the lower 1. are broal and the uppermost cordute at the base, and the hack of the ovaries convex.] -Ilergebanks on a gravelly soil. P. VII. VIH. Orpine. Iive-long.

3. S. purpureum (Tausch); l. dentate oblong-lanceolate or lniccolate all attcuuated below, corymb densc.- Tausch Ann. Sc. Nat. 1835. 55. S. Fabaria Koch, St.83, 9,-Resembling $S$. Telephium but the l. very different. "Back of the ovaries not furrowed." The character derived from the insertion of the stam. scems incoustant.-IHertfordshire. Rev. W. H. Coleman. Westminrclaud. Mr. Borrer. P. VIII.

E.

** Root small, weak, without any rooting shoots. L. subterete.

4. S. villosum (L.); st. erect, l. linear obtuse flat above not produced at the basc, pet. ovate acute, stem l. and panicle glandnlar-pubescent.-E. B. 394. St. 6. 12.-Pet, rose-coloured with a purple streak. St. 3-4 in. high.-Wet mountain pastures. P. (Sm.) B. (Koch) A. (DC.) VI. VII. E. S.

*** Root small, producing rooting shoots.

$\dagger$ Flowers white.

5. S. album (L.); flowering st. erect, barren st. procumbent rooting, $l$. oblong cylindrical obtuse spreading, pet. lanccolate, panicle much branched glabrous.-E. B. 1578.-Pet. white. St. $4-5$ in. high, purplish, leafy. $-\beta$. turgidum (DC.); l. oblongovate terete gibbous beneath. Perhaps a distinct species. S. turgidum Ram.--Rocks and walls, not common. P. VII. VIII.

6. S. dasyphyllum (L.); flowering and balren st. procumbent, l. ovate obtusc fleshy gibbous sessile, pet. and sep. ovate obtnse, panicle small glandular-pubescent.-E. B. 656.-Pet. white. sep., pet., and carp. often in sixes. L. very thick, glaucous, often tinged with red, crowded and opposite on the barren shoots. Flowcring st. 3-4 in. long.-Rocks and walls, rare. P.? VI. VII.

7. S. anglicum (Huds.); st. procumbent at the base ascending, l. orate fleshy gibbous spurred at the base, pet. lanceolate acute, sep. ovate bluntish, cyme bifid smooth.-E. B. I71.-Pet. white spotted with red. L. mostly alternate. Flowering st. 3-6 iu. loug.-Sandy and rocky places. A. VII. VIII.

†† Flowers yellow.

8. S. acre (L.); l. ovate thick tumid spurred at the base, pct. 
lanceolate acute, sep. ovatc obiuse gibbous at the base, cyme trifid smooth.-E. B. 8.3\%.-I. closely imbricated on the barren shoots, very acrid.-Walls, rocks and sandy ground. P. VI. VII. Wall Pepper.

9. S. sexangulare (L.); l. linear obtuse terete spurred at the base, pet. Ianceolate acute, sep. lanceolate acute not gibbous, cyme trifid smooth.-E. B. I946.-L. much longer than in the last, arranged in 6 rows on the barren sloots. I have seen no British specimens.-On ohl walls, very rare. P. VII. E. S.

10. S. reflexum (L.); l. subulate scattered spumed at the base convex on both sides the lowermost recmrvel, $\mathrm{fl}$. cymose, scp. ovate rather acute, pet. lanceolate obtuse.-E. B. 695.-Barren st. Iong; 1. numerous patent or reflexed. Cyme nearly level-topped, its outer branches spreading or recurved.- $\beta$. glaucum; 1. more slender glaucous not recurved. S. glaucum Sm., E. B. 2477.Walls, common. $\beta$. Dry hills, rare. P. VII. VIII.

I1. S. rupestre (L.?); l. linear-lanceolate spurred at the base flattened, fl. imperfectly cymose, sep. elliptical obtnse, pet. lanceolate.-E. B. 170. S. elegans Lej., Kocl._Barren st. short with densely imbricated adpressed leaves. FI. more corymbose than cymose.-On limestone rocks. Bristol. Cheddar. Orme's Head, \&c. P. VI, VII.

I2. S. Forsterianum (Sin.); 1. lanceolate spurred at the base flattened, eyme round-topped compact, sep. clliptical, pet. Ianreolate.-E. B. I802.-Barren st. short, erect, lensely leafy, l. forming small roselike tufts. Fl. truly cymose. Very different from the last in general appearance but difficult to distinguish on paper.-Rocks in Wales and Shropshire. P. VI. VII. E.

\section{Sempervivum Limn.}

[1. S. tectorum (L.); 1. glabrous ciliated, pet. 12 or more entire at the margins, hypogynous scales short convex resembling glands.-E. B. 1320.-L. succulent, forming Iarge roselike tufts. -Walls and roofs (planted). P. VII. Houseleek.]

\section{Cotyledon Linn.}

I. C. Umbilicus (L.); lower 1. peltate concave orbicular, bracts entire, fl, pendulous.-E. B. 325.-Racemc usually simple. St. 6-I2 in. high, leaves mostly collecter at its base. Fl. greenish-ycllow.-Rocks and walls in the west. P. VI.-VIII.

[2. C. lutea (Inds.); lower 1, somewhat peltate, upper 1. crenate or toothed, bracts toothed, fl. erect.-E. B. 1522.-Fl. bright ycllow.-Probably not a native, P. VII.] E.? 


\section{Order XXXVI. GROSSULARIEA:}

Cal. superior, 4-5-eleft, resular. Pet. 4-5, small, inserted at the month of the tube and alternating with the stanens. Ovary l-celled, with 2 opposite parictal placentas. Style 2-4-cleft. lBerry many'-seeded; cell filled with pulp. Albumen horny.

1. Rines. Cal. 5-cleft. Pet. and stamens inserted at the mouth of the tube. Berry many-seeded, crowned with the persistent calyx.

\section{Rines Linn.}

\section{* Peduncles 1-3-flowered. Stems spinous.}

†1. R. Grossularia (L.); pedıneles 1-2 or rarely 3-flowered with 2 mimutc bracts, eal. bellshaped, sep. reflexed ololong, pet. orate.-E. B. 1292 and 2057. St. 4. 4. and 44. 13.-Thorns $1-3$ at the basc of the young branches. Germen and fruit smootl or pubescent or glandnlar. L. rounded 3-5-lobed and cnt, glabrons or liairy.- Iredges and thickets, doubtfully native. Sh. IV. V. Gooseberry.

\section{** Flouers racemose. Spines none.}

2. R. alpinum (L.); racemes upright both in flower and fruit glandular-pilose, bracts longer than the pedicels lanceolate, cal. glabrous, l. shining beneath. - E. B.704. St.51.6.-Male raceme densc, of many flowers; fem. of $2-5 \mathrm{f}$. Limb of the calyx nearly Hat. Berries scarlct. L. with 3 acute deeply serrate lobes.-Woods in the north, rare. Sh. IV.V.

E. S.

3. $R$. nigrum (L.); racemes pendulous downy with a simple pedicel at the base of each, bracts subulate shorter than the pedicels, cal. pubescent, l. glandular-punctate beneath.-E. B. 1291. -Raccmes lax. Calyx-limb bellshaped. Berries large, black. L. with 3-5 acute serrated lobes.-In damp and swampy places. Sh. IV. V. Black Currant.

4. R. rubrum (L.); racemes mostly glabrous and pendulous, bracts shorter than the pedicels ovate, cal. nearly flat glabrous, 1. obtusely 5-lobed.-a. sylvestre; stam. very short erect crutchshaped, filament shorter than the breadth of the anther, cells distant, connective very broad and short, fl. tinged with brown or purple, fr. pale red.- $\beta$. sativum; stam. rather connivent, filament about as long as the brealth of the anther, cells near together prominent, connective narrow, $H$. greenish, fr. red. $-E$. $B$. 128.). (Phytol. ii. 517.) - $\gamma$. petrcum (Hook.); racemes slightly downy, in flower upright, in fruit pendulous, anth.-cells near together. R. petrcum Sm., E. B. 705., not Wulf.-ס. spicatum (Hook.); raeemes erect both in flower and fruit, " $\mathrm{fl}$. nearly ses- 
sile," antli.-cclls ncar together. R. spicatum Robs., E. B. 1290. - R. petrcum (Wulf.) has a bellshaped coloured caly $\mathbf{x}$ ciliated at the margin, and leaves decply divided into somewhat triangular acute lobes.-Woods. $\beta$. is the plant usually cultivated. $\gamma$. Nortl of L., S. $\delta$. Richmond, Yorkshire. Sh. IV. V. Red Currant.

\section{Order XXXVII. SAXIFRAGEA.}

Cal. 4-5-cleft, supcrior or inferior. Pet. 4-5, rarely 0 . Stam. 5-10, free, perigynous or hypogynous. Glandular disk present or wanting. Ovary of 2 carpels cohering by the inflexed sides or margins. Styles 2, persistent. Seeds numerous. Albumen fleshy.

I. Saxifraga. Cal. 5-fid or 5-parted, more or less adnate to the ovary or frec. Cor. of 5 petals. Stam. 10. Styles 2 , persistent. Caps. 2-celled, with 2 bcaks, opening by a pore between the beaks.

2. Cinrsosplenium. Cal. 4-fid, half superior. Cor. 0. Stam. 8, rarely 10. Styles 2. Caps. 1-celled, with 2 beaks, opening into the form of a cup.

\section{Saxifraga Linn.}

Sec. 1. With decumbent barren shoots at the base.

* Cal. reflexed inferior, fl. panicled, flowering stems leafless.

$\dagger$ Filaments enlarged upwards. RoBertsonia Haw.

1. S. umbrosa (L.); l. obovate with cartilaginous crenatures or sharp notches tapering at the base into dilated flat footstalks, panicle racemose, caps. superior-a. crenata; l. bluntly crenate spreading. E. B. 663.-B. crenato-serrata (Bab.); l. acutely crenate or subserrate spreading. $-\gamma$. punctata (Don); l. nearly round acutely serrate erect. S. punctata (IIaw.) R. I. $t .622$, 623.- $\delta$. serratifolia (Mack.); l, oblong acutely serrate erect. E. B. S. 2891, S. serratifolia (Mack.) R. I. t. 624.-a. Yorkshirc. All the forms are found in the west of Ireland. P. VI. London Pride. St. Patrick's Cabbage.

E. I.

2. S. elegans (Mack.); l. round smooth shining acutely serrate, footstalks broad flat above convex beneath, panicle racemose, caps. superior.-E. B. S. 2892. R. I. t. 625.-L. not tapering into the footstalks. - Very rare. Top of Turk Mountain, Killarney. P. VI.

3. S. hirsuta (L.); l. oval sharply serrate, footstalks linear semicylindrical channeled hairy, panicle racemose, caps. superior. -E. B. 2322. R. Icon. t. 621.-Footstalks slightly tapering up- 
wards. L. longer than broad.- Very rare. Gap of Dumloe and Connor IIill, Kerry. Hnngry IIill, Cork. P. VI. I.

4. S. Geum (L.); l. transversely oval or reniform crenate or dentate, footstalks semicylindrical channeled hairy, janicle racemose, eaps. superior. - E. B. 1561 . E. B. S. 2893.- L. always rather broader than loug, nsually hairy, sometimes glabrous, often beantifully reticulated with purple beneath.-West of lreland. Naturalized near Lìlinburgh. P. Vl.

(*S.) I.

†† Filaments subulate. Spatularia Haw.

5. S. stellaris (L.); l. oblong-wedgeshaped dentate-serrate narrowed below scarcely stalked, panicle corymbose of few flowers. -E. B. 167. St. 35. 3. - Stems tufted. Fl. stalks 1-5 in. high, naked. Pet. ovate, clawerl, white witl 2 transverse yellow spots on their lower lialf. - $\beta$. integrifolia (Hook.); l. quite entire.Damp rocks on mountains. $\beta$. Ben Nevis. P. VII.

** Cal. at length reflexed inferior, st. leafy, l. undivided.

6. S. Hirculus (L.) ; st. ereet, barren shoots prostrate filiforn, l. alternate lanceolate flat entire, root-l. narrowed into a footstalk, sep. obtuse fringed at the margin, pet. obtuse with 2 callous points near the base.-E. B. I009. St. 35. 8.-Fl. few or solitary, terminal. Pet. obovate spreading, yellow dotted with red. St. $4-8 \mathrm{in}$. high, downy in the upper part.-Wet moors, rare. P. V11I.

*** Cal. erect or spreading half inferior, st. leafy, $l$. simple toothed or with rigid jointless cilia.

7. S. aizoides (L.); st. decumbent below, 1. alternate linearoblong mueronate eiliated entire flat above convex beneath, sep. blunt. - E. B. 39. St. 35. 9.-Fl. in a leafy panicle, with glutinous downy stalks. Pet. bright yellow often spotted witl searlet. St. 3-6 in. long. L. rigilly ciliated. $-\beta$. dentata, l, witl several strong teeth.- Wet places on mountains. P. VIl.-IX.

**** Cal. erect or spreading superior or half inferior, st. more or less leafy, l. lobed, cilia all jointed.

8. S. muscoides (Wulf.); "radical 1. erowded linear obtuse entire or trifid, st. nearly naked few-flowered, pet. oblong obtuse a little longer than the superior calyx." Hooker.- "Pet. nearly linear, cal. almost naked." Sm.- $\beta$. pygmea, "Pet. obovate, cal. glandular." Sm. E. B. 2314.- Said to have been found in Westmoreland. $\beta$. Hlighlands of Scotland. P. V.

9. S. caspitosa (L.); radical $l$. crowded 3-5-eleft obtuse reined fringed, fl. $1-5$, pet. rounded 3-nerved, cal. half inferior, sep. obtuse.-E. B. 794.-Germen broad and rounded below. Common base of the 1. not furrowed.- $\beta$. decipiens (Sm.); larger 
and with more numerous flowers. $-E$. B. 455.- $\gamma$. incurvifolia (Mack.) ; stem l. more mumerous with ineurved lobes. E. B.S. 2909. S. incurvifolia D. Don,-Caernarvonshire. Aberdcenshire. Kerry. P. V. VI.

10. S. lirta (Sm.); l. crowded 3-5-clcft: lobes lanceolate pointed fringed, fl. few (usually 3) loosely panicled, pet. obovate 3-nerved, cal. half inferior, sep. ovate acute.-E. B. 2291. (good) -L. on the barren shoots as well as the radical 1. 3-clcft, the lateral lobes often divided half way down, lobes diverging. St. $3-6$ or $8 \mathrm{in}$. long, weak, ascending, hairy, glandular, bearing 2 or 3 decply 3 -lobed leaves and a few simple linear bracts. Laterąl peduncles ultimately much overtopping the intermediate one. -On the summit of Brandon Moumtain, Kerry ; and Galty-more, Tipperary. West of Scotland. Mr. G. Don. P. VII. S. I.

11. S. affinis (Don); 1. of the trailing shoots 3-5-lobed with a very broal base fringed : lobes linear acute, fl. few (2-4), pet. oblong 3-ncrved inflexed at the sides, cal. half inferior deeply divided into subulate aeute sepals.-E. B. S. 2903.-The 5-cleft l. few; lobes of the others nearly parallel or slightly spreading. St. 1-3 in. high, erect, with a few linear simple leaves, glandular.-I have examined this plant and S. hirta upon Brandon Mountain and consider them as distinct from S. hypnoides.Summit of Brandon Mountain, Kerry. P. VII.

12. S. hypnoides (L.); radical 1.3-5-cleft, those of the trailing shoots undivided or 3-cleft: lobes all acute bristle-pointed and fringed, calyx half inferior, sep. ovate aeute.-E. B. 454. S. platypetala (E. B. 2276.), hypnoides, elongella (E. B.2277.), leptophylla, and denudata of Smith.--a. l. of the trailing shoots undivided. - $\beta$. l. of the trailing shoots 3-cleft, lobes broad. $-\gamma$. as $\beta$. with linear lanceolate wilely spreading lobes.-These varieties are scarcely worth notice. In all of them the lobes of the $l$. are gradually narrowed from just above the midlle to an acute point. "Pctiole inflated-semiterete bencath."-Mountains, P.V.-VII.

13. S. latevirens (D. Don); trailing shoots procumbent elongated, 1. 5- or 3-parted : lobes linear aeute, calyx-segments lanceolate mucronate, pet. spathulate emarginate. Don. - "The recorved points of the scgments of the l. may possibly distinguish this as a species." $W$. Witson. I know nothing of this plant.Monntains. Angus, Aberdeen, and north of Loch Lomond. P. VI.

14. S. pedatifida (Sm.); radieal l. and also those of the short sterile shoots upon very long stalks divided into 3 deep linearlanceolate aeute lotes, lateral lobes deeply bificl, calyx almost superior, sep. linear-lanceolate as long as the eapsule shorter than the germen.-E. B. 2278.-Fl. in a cymose paniele, numerous, 
white. St. a foot high, solitary. Peducles, germens and eal. downy and viscid. Caps. not tubereular. S. ladanifera, which is eovifounded with this by Seringe, has oblong sepals about half as long as the tuber'enlar caps. in my Pyrenean speeimen.-Clova Moumtains. G. Don. Isle of Aehill, 1. Mr. Wynne. P. V. S. I.

Sec. 2. Without barren shoots at the base.

$$
\text { * Stem leafy. }
$$

15. S. tridactylites (L.); st. panieled ereet leafy, l. wedgeshaped :3-5-fid with a flat petiole, lowermost often simple and spathulate, peduncles 1-flowered mueh longer than the fruit with 2 bracts at the base, eal. superior,-E. B. 501. St. 33. 15.Whole plant viscill, 2-4 in. high. Fl. seattered, numerous, small, white.-Walls and dry banks. A. IV.-VII.

16. S. granulata (L.); st. ereet slightly leafy, radical l. reniform crenately lobed with ehanneled petioles, stem l. nearly sessile 3-5-fid, fl. in a cymose panicle, cal. half inferior, pet. obovateoblong 2 or 3 times as long as the sepals, roots granulated.E. B. 500 ,- Root bearing numerous small round downy bulbs. St. (-12 in. high. Fl. large, white.-Gravelly banks. P. V

17. S. cernua (L.); st. erect simple 1-flowered leafy, radical l. reniform palmately lobed stalked, upper l. nearly sessile subtrificl, uppermost entire, axils bearing bulbs, cal. quite inferior.-E. B. 664.-Rarely flowering; fl. replaced by reddish bulbs. St. 3-6 in. high.-On the highest summits of the Breadalbane Mountains, rare. P. VI.-VIII.

18. S. rivularis (L.); st. ascending branched few-flowered leafy, radieal l. subreniform stalked with $3-5$ rounded lobes, uppermost 1. lanecolate entire, eal. half inferior.-E. B. 2275.-St. 1--2 in. long. Fl. few, stalked, white.-Wet places on the highest summits of mountains. P. VIII.

\section{** Stem leafless.}

19. S. nivalis (L.); st. ereet leafless, $l$. all radical roundish-oboxate dentate-serrate narrowed into a footstalk, fl. capitate, cal. half inferior, pet. longer than the calyx.-E. B. 440 . St. 35.4 . -St. 3-6 in. high, usually simple, sometimes with 1 braneh. Fl, in a dense eluster, white.-Alpine rocks. P. VII.

Sec. 3. Stems procumbent with opposite l. and terminal flowers.

20. S. oppositifolia (L.) ; st. procumbent, l. opposite oblong obtuse fringed, sep. eiliatel without glands, pet. ovate.-E. $\vec{B}$. 9.-Very different from our other speeies. Fl. large, purple.Damp alpine rocks. P. IV. V. 


\section{Chrysosplenium Linn. Golden Saxifrage.}

1. C. alternifolinm (L.); l. alternate, lower l. subreniform hairy crenate upou long stalks.-E. B. 54. St. 12,-Crenatures of the lower l. emarginate, upper 1. glabrous with the crenatures often rather acute. St. erect, $4-5 \mathrm{in}$. high, branching only near the top. Nl. umbellate, nearly sessile, deep yellow. Stam. usually 8.-The anthers of this genus have only 1 cell and perhaps ought to be considcred as 4 or 5 divided to the base of their filaments.-Boggy places. P. IV.

2. C.oppositifolium (L.); l. opposite, lower l. roundisl-cordate shortly stakked wavy.-E. B. 490. St. 4. 6.-St. branching from the base, 4-6 in. long, decumbent, straggling. Fl. paler and more seattered than in the last. L. usually glabrous, sometimes slightly haury. Stam. usually 8.-Damp shady places. P. IV. V.

\section{Order XXXVIII. UMBELLIFERA.}

Cal. 5-toothed or entire, alherent to the ovary, limb often obsolete. Pet. 5, usually inflexed at the point. Stam. 5, inserted with the pet. on the mouth of the calyx. Ovary 2-celled, crowned with a double fleshy disk (stylopode). Styles 2 . Fr. consisting of 2 carpels (mericarps) adhering by theu face (commissure) to a common axis from which they ultimately separate and become pendulous. Scerl solitary pendulous. Albumen horny.Inflorescence umbellate.-Each mericarp has 5 primary ridges and often 4 intermediate secondary ones with channels between, and in the substance of the pericarp are usually linear receptacles of oil (vittæ) under the channcls or rarely the ridges. These parts are sometimes either wanting or only slightly apparent.

\section{Suborder I. ORTHOSPERMA.}

Seed or albumen not furrowed in front.

$$
\text { * Umbels imperfect or simple. }
$$

Tribe I. HYDROCOTYLEAE. Fr. laterally compressed, its back even or acute.

1. IIy drocotyle. Cal. ${ }^{1}$ obsolcte. Pet. ovate, entire, acute, plane at the end. Fr. of 2 flat nearly orbicular mericarps or carpels, each with 5 filiform ridges, of which the dorsal and 2 lateral arc often obsolete, the 2 intermediate ones arched. Vittæ 0. Commissure linear.

Tr. II. SANICULEAE. Transverse section of the fi. nearly round.

2. Sanicula. Cal, of 5 leaflike teeth. Pet, crect, obovate, with

'By calyx, throughout this Order, the free margin is intended. 
a long inflexed connivent point. Fr. subglobose, covered with hooked spines, rilges 0, vittie numerons.

3. Astrantia. Cal. of 5 leaflike teeth. Pet. erect, comnivent, witl a long inflexed point. Fr. with 5 plicate-dentate ridges, vitta 0 .

4. Errygivm. Cal of 5 leaflike teeth. Pet. erect, oblong, with a long inflexed point. Fr. obovate, covered with chaffy scales without ridges or vittae.

** With perfect or compound umbels.

+ With primary ridges only.

Tr. III. AMIIINEAE. Fr. laterally eompressed or didymous.

5. Cicuts. Cal. of 5 leaflike teeth. Pet. obcordate with an inflexed point. Fr. subdidymous. Carp. with 5 equal broad flattened ridges, the lateral marginal ; interstices witl single vittre.

6. Liıu. Cal. obsolete. Pet. roundish entire with a small involute point. Fr. roundish ovate, didymous. Carp. with 5 filiform equal ridges witl single vittæ in the interstices.Involucre 0 .

7. Petroselinum. Cal. obsolete. Pet. roundish entire with a narrow incurved point. Fr. ovate. Carp. with 5 filiform equal rilges with siugle vitta in the interstiees. Carpophore bipartite.-Involucre, partial of many, general of few leaves.

8. Trinia. Cal. obsolete. Pet. of the barren fl. lanceolate with the point inflexed, of the fertile $f$. ovate with a short inflexed point. Fr. ovate. Carp. with 5 filiform prominent equal ridges with a single vitta beneath each of them. Interstices without vittre.

9. Helosciadium. Cal. of 5 teeth or obsolete. Pet. ovate entire witl a straight or incurved apiculus. Fr. ovate or oblong. Carp. with 5 filiform prominent equal rirlges. Interstices with single vitta. Carpophore entire.

10. Sison. Cal. obsolete. Pet. broadly obcordate, deeply emarginate with an inflexed point. Fr. ovate. Carp. with 5 filiform equal ridges. Interstices with single abbreviated clavate vitta.

11. Egopodium. Cal. obsolete. Pet. obovate, emarginate with an inflexed point. Fr. oblong. Carp. with 5 filiform ridges. Interstices without vitta. Stylopode conical.

12. Carum. Cal. obsolete. Pet. obcordate with a narrow: acute inflexed point. Fr. oblong. Carpels with 5 filiform ridges. Interstices with single vittæ. Stylopode depressed. 
13. Bunium. Cal. olssolete. Pet. obcordate with a broad obtuse inflexed point. Ir. oblong. Carp, with 5 filiform equal ridges. Interstices with 1 or 3 vittr. Stylopode conical.

14. Pimpinella. Cal. obsolete. Pet. obcordate with an inHexed point. Fr. ovate. Carp. with 5 filiform equal ridges. Interstices with 3 or more vitta. Stylopode tumid. Styles of the fr. divaricated or recurved.-Invol. 0 (rarcly of 1 leaf).

15. Sivm. Cal. of 5 small teeth. Pet. obcordate with an inflexed point. Fr. ovate or subdidymous. Carp. with 5 filiform equal obtuse ridges. Interstices with 3 or more vittæ. Stylopode depressed or shortly conical. Styles of the fr. divaricated or recurved.-Involucres both universal and partial.

16. Bupleurum. Cal.obsolete. Pet. roundish, entire with a closely involute broad retuse point. Fr. subdidymous. Carp. with equal, winged, or filiform and sharp, or obsolete ridges. Interstices with or without vittx. Styloporle depressed.

Tr. IV. SESELINE $A$. Section of the fr. rounded or roundish.

17. CEnanthe. Cal. of 5 lanceolatc teetl. Pet. obcordate with an inflexcl point. Fr. ovate-cylindrical or subturbinate, crowned with the long erect styles. Carpels more or less corky, with 5 blunt convex ridges. Interstices with single vittre.

18. Exinusa. Cal. obsolete. Pet. obcordate with an acute inflexed point. Fr. shortly ovate crowned with the reflexed styles. Carp. with 5 thick acutely-keeled ridges. Intcrstices with single vittx.

19. Foniculum. Cal. obsolete. Pet. roundish, entire with a broad obtuse inflexed lobe. Fr. oblong. Carp. with 5 promincut obtusely-keeled ridges. Interstices with single vittæ. Styloporle conical.

20. Liвалотіs. Cal. with elongate linear deciduous teeth. Pet. obcordate with a broad inflexed lobe. Fr. ovate, slightly dorsally compressed. Carp, with 5 thick blunt ridges. Interstices witl single vittae. Stylopode conical, 2 or 3 times shorter than the reflexed styles.

21. Ligusticun. Cal. of 5 small teeth, sometimes obsolete. Pet.ovate acutely emarginate with an inflexed lobe and short claw. Fr. elliptical terete or slightly dorsally compressed. Carp. with 5 shary somewhat winged ridges. Interstices and commissure with many vittx. 
22. Silaus. Cal. obsolete. Pet.ovate-oblong entire or slightly emarginate with an inflexed lobe, sessile trucate or appendaged at the base. Fr, as in Ligusticum.

23. Meum. Cal. obsolete. Pet. entire, elliptieal, acute at both ends, with an ineurvel point. Fr. as in Ligusticum.

24. Critrmum. Cal, obsolete. Pet. elliptical, entire, involute. Fr. clliptieal, terete. Carp. with 5 elevated sharp, slightly winged rillges. Seed free, with numerous vittc.

Tr. V. ANGEIICEAE. Fr. much and dorsally eompressed, with a clouble wing on caels side.

25. ANGELICA. Cal. obsolete. Pet. laneeolate, entire, aenminate, inenuved. Fr. solid. Carp. with 3 dorsal elevated filiform ridges and 2 marginal ridges dilated into broad wings. Interstices with single vitta.

[26. Archangelica. Cal. minutely 5-tootled. Pet. ovate, entire, acuminate, ineurverl. Fr. nucleated. Carp. with 3 dorsal elevated thick ridges, and 2 marginal ridges dilated into broad wings. Interstices without vitta. Seed free, with numerous vittce.]

Tr. VI. PEUCEDANEAE. Fr. mueh and dorsally eompressed, with a single wing on each side whieh is flat or thickenerl towards the erlge.

27. Peucedanum. Cal. of 5 teeth or obsolete. Pet. oborate or obeordate with an inflexerl point. Fr. with a dilaterl thin that nurgin. Carp. with equidistant ridges, 3 dorsal filiform, 2 lateral close to the base of the dilated margin obsolete. Interstices with single vitta.

28. Pastinaca. Cal. of 5 very small or nearly obsolete teeth. Pet. roundish, entire, involute with an acute point. Fr. with a dilated flat margin. Carj), with slender ridges, 3 ilorsal equidistant, 2 lateral distant near the outer edge of the dilated margin. Interstices with single linear vitta.

29. II eracleus. Cal. of 5 minute teetl. Pet. obcordate with an inflexed point, outer ones radiant. Fr. as in Pastinaca. Vitte abbreviated clubshaped.

30. Tordylium. Cal. of 5 awlshaped teeth. Pet. obeordate witl an inflexed lobe, outer ones radiant. Fr. with a thickened wrinkled margin. Carp. with slender ridges, 3 dorsal equidistant, 2 lateral distant close to the thickened margin. Interstices with $1-3$ vittæ.

†† With primary and secondary ridges.

Tr. VII. DAUCINEAE. Fr. somewhat dorsally eompressed. 
Carp. with 5 primary ridges, the latcral ones on the inner face; and 4 secondary forming rows of prickles.

31. Daucus. Cal. of 5 teetl. Pet. obcordate with an inflexed lobe, exterior usually radiant and bifid. Fr. dorsally compressed. Carp. with bristly primary ridges ; secondary ridges equal winged with 1 row of spines.

\section{Suborder II. CAMPYLOSPERMA.}

Seed inflexed at the margin or deeply furrowed in front.

Tr. VIII. CAUCALINEAE. Fr. contracted or rounded. Carp. with the lateral primary ridges on the inncr face; 4 secondary more prominent, prickly.

32. Caucalis. Cal. of 5 teeth. Pet. obcordate with an inflexed point, outer ones radiant and bifid. Fr. slightly laterally compressed. Carp. with filiform bristly primary, and more or less prominent secondary ridges, all bearing I-3 rows of prickles.

33. Torilis. Cal. of 5 tecth. Pet. obcordate with an inflexed point, outer ones radiant and bifid. Fr. slightly laterally compressed. Carp. with bristly primary ridges; the secondary lidden by the numerous prickles which occupy the interstices.

Tr. IX. SCANDICINEAE. Fr. compressed or contracted on the sides, often beaked. Carpels with primary ridges only.

34. Scandix. Cal. obsolete. Pet. obovate with an inflexed point. Fr, with a very long beak. Carp. with 5 obtuse ridges.

35. Axthriscus. Cal. obsolete. Pet. obcordate with an inflexed short point. Fr. with a short beak. Carp. without ridges : beak with 5 ridges.

36. Cheropityluum. Cal, obsolete. Pet, obcordate with an inflexed point. Fr. not beaked. Carp. with 5 equal obtuse ridges. Interstices with single vittr.

37. Myrrisis. Cal. obsolete. Pet. obcordate with an inflexed point. Fr. not beaked. Carp. with a double membrane: the outer with elevated keeled ridges hollow within, inner close to the seed. Vittæ 0 .

Tr. X. SMYRNEAE. Fr. turgid compressed or contracted at the sides. Carp. with primary rilges only.

38. Echinophora. Cal. of 5 teeth. Pet. obcordate with an inflexed point, the exterior larger and bifid. Fl. of the ray sterile on long stalks, fertile central and solitary. Fr. ovate, 
terete, imbediled in the enlarged reecptacle. Carp. witl 5 depressed equal striated wavy ridges. Interstices with single vitta covered by a cobweblike membrane.

39. Conivu. Cal. obsolete. Pet. obcordate with a short inflexed point. lir. ovate, laterally compressed. Carp. with 5 prominent wavy or crenate ridges, the lateral margiual. Interstices striated : vittix 0 .

40. Physospermum. Cal, of 5 teeth. Pet. obcordate with an infexed point. Fr. laterally eompressed. Carp. reniformglobose, didymous, with 5 filiform slender equal ridges, the lateral within the margin. Interstices with single vitto.

4I. Suyrnium. Cal. obsoletc. Pet. laneeolate or elliptical, entire, with an inflexed point. Fr. laterally compressed. Carp. reniform-oblong, didymous, with 3 dorsal prominent sharp ridges and 2 lateral marginal nearly obsolete ones. Interstices with many vitta.

\section{Suborder III. COELOSPERMA.}

Seed with the base and apex curved inwards in front.

'Tr. XI. CORIANDREA. Fr. globose or didymons. Primary rilges of the carp. often obsolete, seeondary more prominent, all apterous.

42. Coriandrum. Cal. of 5 teetl. Pet. obcordate with an inflexed point, outer ones radiant and bifid. Fr. globose. Carp. with the primary ridges obsolete, the 4 secondary conspieuons prominent keeled. Interstices without vitta. Commissure with 2 vitta.

\section{Suborder I. Orthosperma. Tribe I. Hydrocotylea.}

\section{Hyorocotyle Linn.}

1. H. vulgaris (L.) ; 1. peltate orbicular doubly erenate, umbels eapitate of $5 \mathrm{fl}$. often proliferous, fr. emarginate below.E. B. 751.-Fl. and fr. almost sessile. Umbels or rather heads often proliferous in the centre and bearing a seeond head. St. creeping extensively. L. springing from the joints of the stem, upon stalks which are considerably longer than the peduneles.Bogs and marshy places. P. V.-VIII. Penny-wort.

\section{Tribe II. Saniculea.}

\section{Sanicula Linn.}

1. S. europcea (L.) ; lower 1. palmate 3-5-lobed: lobes trifid unequally serrate, fertile $\mathrm{fl}$. sessile, barren $\mathrm{fl}$. slightly stalked.- 
E. B. 98.-Umbels numerous, eapitate, in an irregular slightly umbellate panicle. Styles persistent, reflexed. St. ascending, about a foot high.-Woods and thickets. P. VI. VII.

\section{Astrantia Linn.}

†1. A. major (L.); lower 1. palmately 5-7-fid: lobes oblong acute unequally inciso-serrate involucral l. cntirc, cal.-teeth orate-lanceolate narrowed to an acute point.-St. 29. 8.-Involucre as long as the umbel, usually straw-coloured.-Woods in hilly distriets. Between Whitbourne and Malvern. Above Stokesay Castle, near Ludlow. Mr. Borrer has seen it in the latter place and considers it to have been introduced "ages ago." P. VI,-VIII.

E.

\section{Eryngium Limn.}

I. E. maritimum (L.); radical $l$. roundish plaited spinous stalked, upper l. amplexicaule palmatcly lobed, involucral l. 3lobed spinous longer than the heads, seales of the receptacle 3lobed.-E. B. 7 I8. - St. I foot or more in licight, branched, leafy. Fl. in heads rather than umbels, pet. blue.-Sandy sea-shores. P. VII. VIII. Sea Holly.

2. E. campestre(L.) ; radicall. 2 or 3 times pinnatifid spinous stalked, st. l. amplexicaule bipinnatifid, involucral l. lanceolate spinous longer than the heads, scales of the recptacle undivided. - E. B. 57.-More bushy and slender than the last. Pet. purplish. Petioles thick, semiterete, channeled.-I am indebted to Mr. Jas. Storey of Neweastle upon Tyne for specimens from Friar's Goose which are referable to this species,-On waste ground, very rare. P. VII. VIII.

E. S.

\section{Tribe III. Amminea.}

\section{Cicuta Limn.}

1. C. virosa (L.); fibres of the root filiform, 1. tripartite, leaflets linear-lanceolate acute serrate decurrent.-E. B. 479.St. 3-4 feet high, rery thick round and hollow below. Lower 1. on long stalks; leaflets I-2 in. long. Umbels large; general inv. 0 , or of 1 or 2 slender leaflets; partial of numerous subulate leaflets. Fl. white. II crb poisonous.-Ponds and ditches, not common. P. VI.-VIII. Water Hemlock. Cowbane.

\section{Apium Linn.}

1. A. graveolens (L.); glabrous, l. pinnate or ternate, leaftets of the upper l. werlgeshaperl and notehed at the end. $-E$. $B$. 1210.-St. I-2 feet high, branched, furrowerl, leafy. Umbels terminal or lateral, frequently almost scssile, accompanied by I 
or 2 trinate leaves. l'l. sinall, white-Marshes and ditches, especially near the sen. I', VI.-VIII. Celery.

\section{Petroselinum $I I o f m$.}

†1. P. sativum (IIoffm.); l. tripinnate shining, leaflets of the lower l. ovate-cuneate trifil and toothed, of the upper l. termate lanceolate cutire.-E. B. S. 2793.-Partial involucres filiform. L. grecnish.-Rocks and old walls. B. VI.-VIII. Parsley.

2. P. segetum (Koch); lower $l$. pinnate : lcaflets nearly sessile ovate lobed and scrrate, upper l. entire or trifid.-Sison Sm., E. B. 228.-Umbels very irregular. General inv. of $1-2$ lcaves. Fl. whitish. St. erect, roundish, nearly leafless above, $1-1 \frac{1}{2}$ foot high.-Damp fields on a calcareous soil. B. VIII. IX.

\section{Trinia $H o f f m$.}

1. T. vulgaris (DC.); glabrous, involucres wanting or of 1 leaf, ridges of the fr. obtuse.-Pimpinella dioica Sin., E. B. 120.9.-L. tripinnate, glaucous-green ; leaflets linear or filiform. Root crowned with the remnants of former leaves. St. branched, erect, $6-8$ in. high. Plants usually dioccious.-Dry limestone hills, rare. P. V. VI.

E.

\section{Helosciadium Koch.}

I. H. nodiflorum (Koch); st. procumbent at the base ancl rooting, l. pinuatc, leaflets ovate or ovate-lanceolate unequally obtusely serrate, umbels opposite to the l. longer than their peluncles ol ncarly sessile.-Sium Sm., E. B. 639.-St. 1-2 feet long.-Banks of ditches and brooks. P. VIII.

2. H. repens (Koch); st. prostrate creeping, l. pinnate, leaflets roundish-ovate unequally and acutely inciso-serrate, umbels shorter than the peduncles.-Sium Sm., E. B. 1431.-Scarcely more than a variety of the preceding. St. quite prostrate.-Boggy meadows, rare. P. VII. VIII.

3. H. inundatum (Koch); st. creeping, l. pinnate, leaflets of the lower $l$. divided into capillary segments, of the upper l. wedgeshaped and trifid, umbels generally with 2 rays.-Sium Sm., E. B. 227.-Usually wholly submersed cxcept a few of the upper 1. and the fl. which rise above the water. Partial umbels very small.-Ponds. P. VI. VII.

\section{Sison Linn.}

1. S. Amomum (L.).-E. B. 954.-St. erect, paniclerl, 2-3 feet high. Lower l. pinnate : leafl. oblong lobed cut and serrate; upper l. divided into narrow segments. Partial umbels and $\mathrm{H}$. small.-Dampish places on a calcareous soil. B. VIII. E. S. 


\section{Rgopodum Linn.}

1. E. Podagraria (L.).-E. B.940.-St. 1-2 feet high, ereet, furrowed. L. 2 or 3 times ternate; leaflets ovate-acuminate, unequal at the base, acutely serrate. Root creeping.-Damp places. P. VI. VII. Gout Weed.

\section{Carum Linn.}

†1. C. Carui (L.); partial involucre 0 , general 0 or of 1 leaf, 1. bipinnate, leaflets eut into linear segments.-E. B. 1503.-St. $1-2$ feet high. Root fusiform. Carp. aromatic.-Meadows and pastures. B. VI. Caraway.

2. C. verticillatum (Koch); general and partial involucres of many leaves small, 1. pinnate, leaflets divided to the base into eapillary sprearling segments.-Sium Sm., E. B. 395.-St. 1-1 $\frac{1}{2}$ foot ligh. Root fascicled. Segments of the leaflets spreading so as to appear whorled and quite surrounding the petiole. L. nearly all radical.-Damp hilly pastures, rare. P. VIII.

\section{BuNIUM Linn.}

1. B. flexuosum (With.); general involucre of $1-3$ leaves, partial more numerous, $f r$. oval narrowing upwards erowned with the elongated stylopode and erect styles, interstices with 3 vitta. -E.B.988. B. denudatum DC.-Involueres sometimes altogether wanting. Root a solitary tuber. St. a foot or more high, very slender below, bearing a few l. with linear segments. Radieal l. triternate with long footstalks tapcring downwards.-Sandy and gravelly pastures. P. V. VI. Pig-nut.

2. B. Bulbocastanum (L.); general and partial involucres of numerous leaves, fr. oblong erowned with the short stylopode and reflexed styles, interstiees with single vittre.-E. B. S. 2862. Carum Koeh, DC.-Involucres always present. Root a tubcr. St. about 2 feet high, slightly narrowed below. Lower l. bipinnate, with a triangular outline, rather numerous near the base of the stem, rarely 1 or 2 radical upon long footstalks tapering downwards.-Chalky fields in Cambridgeshire and Ilerts. Rev. W. H. Coleman. P. VI. VII.

\section{Pimpinella Linn.}

1. P. magna (L.); 1. pinnatc, leaflets all ovate serrate somewhat cut the terminal one 3 -lobel, st. angularly striate. $-E . B$. 408. - St. 1-2 feet high, leafy. Latcral leafl. sometines 3-lobed. Styles longer than the ovary, as long or longer than the oval fruit.-Under hedges. P. VII. VIII.

E. I.

2. P. Saxifraga (L.); l. pinnatc, leaflets of the lower 1. roundish-ovate serrated somewhat cut, tlose of the stem l. bipin- 
natifid with linear segments, st. terete, ped. glabrous.- E. B. 407. - St. 1-2 fect high, naked above. Styles shorter than the ovary. L. sometimes all pinuatificl. $-[$ P. nigra (Willd.) Koch has "densely pubeseent peduncles." ]-Dry pastures. P. VII.IX.

\section{Sivm Linn.}

* Stylopocle depressed. Carp. with the lateral ridges marginal. Interstices with 3 superficially placed vitta. Albumen very convex, flattened on the inner side. SIUm Koch.

1. S. latifolium (L.); root stoloniferous fibrous, l. pinnate, leafiets oblong-lanceolate equally serrate pointed, involucres of many lanceolate leaves. $-E, B .204$.- Ridges of the carp. obtuse roundel. St. 3-5 feet high, angnlar, furrowel. Lcaflets very large, listant, $4 \frac{1}{2}-6 \frac{1}{2}$ pairs on a leaf.-Ditches and rivers, rare. P. VII. VIII.

** Stylopode shortly conical. Carp. with the lateral ridges not marginal. Interstices with 3 or more deeply seated vitta. Albumen terete. BERULA Koch.

2. S. angustifolium (L.); root stoloniferous, l. pinnate, leaflets unequally lobed and cut ovate, of the stem l. lanceolate, inv. of many lanceolate entire or cut leaves.-E. B. 139.-Ridges of the carp. but slightly prominent. St. $1-3$ feet high, round, striated. Leafl. often very decply cut and lobed.-Ditches. P. VIII.

\section{Bupleurum Linn.}

* Fruit granulated.

I. B. tenuissimum (L.); st. branched, 1. linear acute, umbels lateral and terminal minute, partial umbels of 3-5 flower's usually overtopped by their involucres, carp. granulated between the 5 ridges.-E. B. 478.-St. very slender, wiry, 6-12 in. long.Murldy salt marshes. A. VIIII. IX.

F.

** Fruit not granulated.

2. B. aristatum (Bartl.); st. branched, 1 . lincar-lanceolate acuninate 3-nervel, 1 . of the partial involucres elliptic-lanceolate cuspidate somewhat awned with branching nerves, pedicels slort equal.-B. Odontites Sm., E. B. 2468, not Linn.-St. $1-6$ in. high.-Torquay, Devon. Channel Islands. A. VII. E.

3. B. falcatum (L.); st. brancherl, 1. 5-7-nerved, lower $l$. elliptical-oblong on long stalks, upper $l$. linear-lanceolate acute sessile, partial involucre of 5 lanceolate pointed $\mathrm{l}$. as long as the flowers.-E. B. S. 2763.-Pedicels as long as the fruit. St. $1-4$ feet high.-Near Ongar, Essex. P. VIII.

F.

4. B. rotundifolium (L.); st. branched above, l. oval perfoliate. 
fr. with the interstices striate.-E. B.99.-General involucre 0 . Partial involucre connirent.-Corn-fields on a calcareous soil. A. VII. Thorow-wax. Hare's ear.

E.

\section{Tribe IV. Seselinea.}

\section{Enanthe Linn.}

* Root fasciculated, fibres more or less thickened or tuberous.

1. E. fistulosa (L.); root tuberous stoloniferous, st. and petioles fistulose, root 1. 2-3-pinnate with 3-fid leaflets, stem $l$. simply piunate shorter than their petioles : leaflets linear, fr. angular turbinate.-E. B.363.- St. 1-3 feet high, remarkably fistulose. Stem l. distant, with very long stalks. Scions with simply pinnate leaves. Umbels small, globose in fruit; geueral involuere 0 . Fruit tiped with the long slightly diverging rigid styles.-By ponds and ditches. P. VII.-IX. E. I.

2. E. pimpinelloides (L.); root of long fibres bearing round or oval knobs beyond their middle, root l. bipinnate: leaft. acutely inciso-dentate or trifid, st.-l. pinnate uppermost simple : leafl. linear aeute, radiant pet. obeordate divided to the middle, $f r$. subcylindrical with an enlarged callous base.-Jacq. Aust. $t$. 394.-St. $\frac{1}{2}-3 \mathrm{ft}$. high, alternatcly branched. General inv. 0 -6-lcaved : 1. setaceous; partial of many l., about as long as the barren fl. Purtial umbels close together forming one compact flat-topped umbel. Fr. ncarly cylindrical, rather longer than the slightly diverging styles.-Gloucestershire. Weymouth. Isle of Wight. P. VII.- IX.

E.

3. E. Lachenalii (Gmel.); root of elongate-subclavate fleshy fibres tapcring at both ends, root l. bipinnate: leafl.oblong entire or wedgeshaped and bluntly 2-3-lobed, lower stem 1. 2-3-pinnate upper simply pinnate: leafl. linear acute, radiant pet. divided to the midlle, fr. oblong not thickened below. $-\mathrm{OE}$. pimpinelloides Sm., E. B. 347.-St. 1 -3 feet high, slightly branched. General inv. of many leaves, sometimes wanting; partial of many leaves, shorter than the barren flowers. Onter fl. on long stalks, mostly barren; inner fl. fertile, nearly sessile. Radiant pet. roundishobcordate with a short narrow claw. Partial umbels distinct, spherical. Fr. crowned with the rigid nearly erect styles. Root leaves very evanescent.-Salt marshes, rarely near fresh water. P. VII.-IX.

4. E. peucedanifolia (Poll.); root of elliptical-oblong knobs, radical l. bipinnate, stem 1 . pinnate, lenflets all linear acute, fr. "oblong attenuated downwards contracted below the cal." E. B. 348.-St. 2-3 feet high, slightly branched. Radiant pet. obcordate with an attenuated base, noteh $\frac{1}{3}$ their length. I have not seeu the ripe fruit of British specimens. General involucre 0, 
partial of many leaves shorter than the flowers. Distinguished from the preceding by its pet., miform lentlets, and want of a general iuvolucre.-Miny authors refer the linglish plant to $\mathrm{OE}$. siluifolia (Bicb.) which has an enlarged (allons base to its fr. aceording to Koel and Grischach. The nomenclature cannot be settled without ripe fruit of the Finglish plant.-In freshwater marshes. P. VI.

5. (E. crocata (L.); root of large fusiform tubers, radieal l. 2-3-pimnate, stem 1. pimnatitid, leaflets stalked roundish or obloug-wedgeshaped variously eut those of the upjer 1, narrower, $f i$. cylindrical oblong striated longer than its pediecl.-E. $B$. 2313. - St. 3-5 feet ligh, much branelied. I. large, leaflets broad. Involueres various in number and shape.-[E. apiifolia has narrower ant more divided upper 1 . aceording to a Corsican specimeu.] - Wet places. P. VII.

$$
\text { ** Root of whorls of slender fibres. }
$$

6. E. Phellandriun (L.); st. erect: base fusiform, 1. tripinnate, leaflets ovate pimmatifid eut sprealing, of the submersed $l$. multifid with capillary diverging segments, unbels lateral opposite to the leaves, fr. ovate.-E.B.684.-St. 2-3 feet ligh, very thick below, stoloniferons. Segments of the 1. numerous, fine, acute, pale green; submersed l. dark green. Probably, as suggested lyy Koch, the flowering root dies each year, but the plant is continued by the offsets.-In the water of ditehes and ponds. B.? $\beta$. P.? VII. -IX.

7. E. fluviatilis (Colem.); st. floating, 1. bipinnate, leaft. sinple or pinnatifid, of the submersed $l$. cuneate cut pellucid with many parallel nerves, umbels lateral opposite to tlie l., fi: broally elliptical. $-A$. N. H. xi. 188. $t$. 3.-A decumbeut floating plant well marked by the leafl. of its submersed l. being divided into fingerlike acute broadly linear parallel segments deepiy incised at the end. Leafl. of the upper l. broader than those of $Q E$. Phellandrium.-Streams in chalky distriets. Cambridge. Essex. Winchester. Hertford. B. or P. VII.-IX.

E.

18. Frriusa Linn. Fools' Parsley.

1. E. Cynapium (L.); partial involucre of 3 leaves longer than their umbel, 1 . all doubly pinnate: leaflets lanecolate decurrent pinnatificl.-E. B. $1192 .-$ St. about a foot high. L. dark green, luril, stinking. General involucre 0; partial oue long, uarrow, pendulous. Herb poisonous. The vittæ appear to me to eonverge below until they meet without deseending to the base of the earpel.- $\beta$. pygmeea (Koch); umbels mostly lateral nearly sessile, partial involueres short, lower 1 . 3-fid with obtuse segments eut at the end, upper ones ternate. St. 4-6 in. high. E. segetalis Boenningh,-Cultivated land. A. VII. VIII. 


\section{Føniculum IIoffm. Fennel.}

I. F, officinale (All.); st. terete below, l. decomposite: segments all capillary elongate in the upper l. flaccid, unbels of many rays concave.-Meum Sin., E. B. 1208.?-Involneres 0. St. 3-4 feet ligh, uswally filled with pith, branehing. Umbels large. Fl. ycllow. Whole herb aromatic. Scgments of 1. channeled.-IIooker says "segments of the l. awlshaped," which I do not find to be the case in the wild (Clutlleigh, Devon; Tenby, S. Wales; Hythe, Kent;) plant. The fig. and deseription in $E$. $B$. also appear's to be erroneons in this point. Is not the cultivated plant often a different species?-Rocks and walls, particularly near the sea. P. VII. VIII.

E. I.

[*?2. F. piperatum (Ten.); st. terete below, segments of the upper $l$. subulate thick short rigid, umbels of few $(6-12)$ rays. Inv. 0. St. $3 \mathrm{ft}$. lighl (?), filler with pith. Umbels rather small. Fl. yellow. Upper leaves with very short and rigirl channeled seginents.-St. Anbiu's bay, Jersey. Rev. W. W. Newbould. P. VII. VIII.]

\section{Libanotis Crantz.}

1. I. montana (Crantz); l. doubly pinnate cut: segments lanceolate mucronate, the lowermost leaflets crossing, general involucre of many lcaves, fr. hairy.-Athumanta Sm., E. B. I38. - St. 1-3 feet ligh, covered at the base with the fibrons remains of decayed petioles. Umbels terminal, convex, with numerons downy rays.-Bertoloni (Fl. Ital. iii. 450) aseribes 2 vittæ to each interstice and 4 to the commissure. I only find 1 in the former case and 2 in the latter. This genus is very near in structure but differs in habit from Seseli.-Chalk hills of Cambridgeshire and Sussex. P. VII. VIII.

E.

\section{Ligusticum Linn.}

1. I. scoticum (L.) ; l. twicc tcrnate, leaflcts ovate somewhat rhomboilal dentate-serrate opaque, involnere of $5-7$ linearlaneeolatc leaves, cal. 5-toothed.-E. B. 1207 . IIaloscias Fr.St. herbaceons, nearly simple, striated, tinged with reel, $\mathrm{I}-\mathrm{l}_{\frac{1}{2}}$ foot high. Leafl. large, lobed and cut. Interstices with 3 , commissure with 6 vittx. Seed free.-Roeks on the sea-coast of Scotland and Nortlumberland. P. VII. Scottish Lovage. E. S.

\section{Silaus Besser.}

1. S. pratensis (Bess.); st. angular, radical 1. 3-4 times pinnate, leaflets lanceolate cntire or bifid, terminal trijartite, involincre of 1-2 leaves, involneels of many leaves.-Cridium Silaus Sm., E. B. 2142. -St. I-2 feet high. I. mostly radical, stem 1. decreasing upwards. Fl. pale ycllow.-Damp meadows and pastures. P. VI.-IX. 


\section{Meum Tourn.}

1. M. athananticum (Jacq.); 1. bipinnate, leaflets multipartite, segments threarlshaped acute.-E. B. 2249.-St. 1-2 feet high, rome, elothed at the base with the fibrous remains of the deenyed petioles. Fl. numerous, whitish-yellow. General involucre of 2 or 3 leaves, partial more numcrous. Highly aromatic.-Dry inountainous pastures. P. VI. VII. Bald-money. E.S.

\section{Crithmum Linn.}

1. C. maritimum (L.).-E. B. 819.-St. 6-12 in. long. L. fleshy, 2-3-pinnate: leaflets lanceolate, narrowed at both ends, few. lnvolucre of many lanceolate acute leaves. Fl. whitish. -On rocky sea-coasts. P. VIII. Samphire.

\section{Tribe V. Angelicece. \\ 25. Axgeidica Linn.}

1. A. sylvestris (L.); leaflets equal ovate-lanceolate or ovate inciso-scrrate not decurrent, lateral ones rather unequal at the basc.-E. B. I128.-St. 2-3 feet high, slightly downy above, purplish. Fl. pinkish-white. Involucre of about 3 leaves, deciduous. Leaflets often subcordate at the base.-In wet places. P. VII. VIII.

\section{Archangelica Hoffm.}

[1. A. officinalis (IIoffm.); leaflets ovate-lanceolate all sessile partly decurrent, terminal one trifil.-E. B. 2561.-St. 3-5 feet high. Foliage, stalks and even fl. bright green. L. $2-3$ fect wile. Petioles much dilated at the base. $-A$ very doubtful native. Watery places. P. VII.-IX.] E. S.

\section{Tribe VI. Peucedanea.}

\section{Peucedanum Linn.}

I. P. officinale (L.); $l .5$ times tripartite: leaflets linear acute flaccid, general involucre 3 -leaved deciduous, pedicels much longer than the fruit.-E. B. 1767.-Leaflets very long, narrow. Fl. ycllow. St. terete, striated, Vittæ of the commissure superficial. - Salt marshes, very rare. P. VII.-IX.

2. P. palnstre (Moench); l. 3-pinnate, leaflets pinnatifid with linear-lanceolate acuminate segments, general involucre of many persistent lanceolate deflexed leaves, st. furrowed.-Thysselinum Koch. Selinum Sm., E. B. 229.-St. erect, 3-5 feet ligh. Fl. white. "Vittæ of the commissure deeply seated."-Marshy and fenny places, rare. P. VII. VIII. 
† 3. P. Ostruihium (Koeh); l. biternate, leaflets broadly ovate lobed cut and serrated, sheaths very large, general involucre 0 , cal.-segments obsolete- $-E$. B. 1380.--St. $1-2$ feet high. Fl. white.-Moist mearlows in Scotlaud. P. VI. Mastervort.-S.

\section{Pastinaca Linn. Parsnep.}

1. P. sativa (L.); st. angular furrowed, l. pinnate downy beneath, leatlets ovate-oblong crenate-serrate often witl a lateral lobe at the base, inv. 0 , fr. oval. - E. B. 556.-St. 2 - 3 feet ligh. Fl. yellow. L. generally shiming above, downy beneath. In a Guernsey speeimen the lower $l$. have cordate ovate deeply eut and aeutely serrate leafl., and the stem l. laneeolate lobed and aeute leafl. with the lobes lanceolate and serrated.-IIedge-banks on a caleareous soil. B. VH.

\section{Heracleum Linn.}

1. H. Sphondylium (L.); l. pinnate, leaflets lobed or pinnatifid cut and serrated, fr. at length glabrous.-E. B. 939.-St. 4 feet ligh. Lower l. very large. Umbels large, flattish. Fl. white or rerldish, outer fl. radiant.- $\beta$. angustifolium; leaflets deeply pinnatifid : lobes laneeolate, lower ones elongated and spreading. -Hedge-banks. B. VII. Cow Parsnep. Hog-weed.

\section{Tordylium Linn.}

1. T. maximum (L.); outermost pet. radiant with 2 equal lobes, partial involucres linear shorter than the umbel, fr. hispid the thickened margin slightly erenate- $-E$. B. 1173.-St. $2-4$ feet high. Fl, reddish. - Waste ground, very rare. A. VII. E.

[2. T. officinale (L.); two outermost pet. radiant each with 2 very unequal lobes, partial involucres laneeolate about as long as the umbel, fr. rough with the thiekened margin beautifully erenate.-E. B. 2410.-Near London. A. VHl.] E.

\section{Tribe VII. Daucinea.}

\section{Daucus Linn.}

1. D. Carota (L.); bristles of the fr. slender subulate distinct about equalling the breadth of the fr., l. bipinnate, leafl. ineisodentate: segments acute, of the upper l. linear-laneeolate, of the lower laneeolate, leafl. of general inv. pinnatifid with linear ancl narrowly membranously winged stalks, of the partial similarly winged linear entire or trifid. $-E, B .1174$.-St. $2-3 \mathrm{ft}$. high, hispid. Inv. variable in length. Central fi. red. Umbel of fr. eoneave.-Roadsides and helge-banks. B. VII.VIH. Carrot.

[A plant eharaeterized as follows is probably distinet and seems 
to be D. Gingillum (L.); bristles of the fr. subulate distinct equalling the breath of the fr. or slightly shorter, l. bijinnate, leafl. inciso-dentate, seginents bluntish mucronate, leafl. of the general inv. linear-pimatifil witl broadly membranonsly winged stalks, of the partial inv. lanceolate sinilarly winged.-L. dark green, rather fleshy. St. variable in height, hispid. Central $\mathrm{fl}$. white. Unbel of fi. convex.-Sonthern sea-coasts. Kent. Cornwall. Jersey. B. VII. VIII.-Further study of the living plant is required.]

2. D. maritimus (Witlı.); bristles of the fr. flattened dilated and confluent below shorter than the breadth of the fr., lower 1 . bipimnate with inciso-dentate leafl.: seyments blunt ovate-muerounte, leatl. of the general inv. pinnatifid with linear segments and narrowly membranously winged stalks, of the partial inv. lanceolate sinple or trifid with broad white membranous wings. $-E$. B. 2560.-Distingnished by the peeuliar comblike secondary ridges of its fr. with short teeth which, although differing considerably in length, are always much shorter than the diameter of the fr. St. about $18 \mathrm{in}$. high, densely hairy below. Leafl. broad, shining above, somewhat fleslyy. Central fl. white. Umbels of fr. generally convex.-Southern sea-coasts. Cornwall. Devon. B. VII. Viil.

\section{Suborder II. Campylosperma. Tribe VIII. Caucalinea.}

\section{Caucalis IIoffim.}

1. C.daucoides (L.); l. bipinnate, leaflets pinnatifid with linearaeute segments, general involucre 0 , partial umbels of few $f$. with involucres of $3-5$ leaves, secondary ridges of the fr. each with one row of glabrous hooked prickles.-E. B. 197.-St. 6-12 in. ligh, furrowed, hairy at the joints. General umbels 3-cleft; partial bearing about 3 large oblong very prickly fruits. Fl. sinall, redlish.-Corn-fields on a chalky soil. A. VI.

E.

†2. C. latifolia (L.); l. pinnate, leaflets lanceolate decurrent coarsely serrate, involueres oblong membranous, secondary ridges of the fr. with retrorsely seabrous prickles.-E. B. 198. Turgenia Koch.—St. 1-2 feet high, seabrous. General umbels about 3-cleft; partial bearing about 5 large oblong very prickly fruits. Fl. large, pink.-Corn-fields, mostly on a chalky soil, very rare. A. VII.

E.

\section{Toritis Adans.}

1. T. Anthriscus (Gaert.); 1. bipinnate, leaflets ovate-oblong inciso-serrate, umbels stalked terminal, general involucre of many leaves, fr. with subulate incurved not hooked seabrous prickles. -E. B. 987.-St. ereet, 1-3 feet high. Umbels on long stalks. 
Fr. densely priekly. Fl. small, white or reddish.-Iledges and hanks. A. VII. ViII.

2. T. infesta (Spr.); 1. bipinnate, leaflets ovate-lanccolate in('iso-serrate, umbels stalked terminal, general involucre of one leaf or $0, f r$, with sprealing hooked retrorsely scabrous prickles.E. B. 1314. T. helvetica Koch.-St. erect, more branched than in the last, 6-18 in. high. Umbels on long stalks. Fr. densely prickly, the primary ridges witl adpressed prickles. Fl. small, reddish. Styles scarcely twice as long as the stylopode.-Fields and waste places. A. VII. VIII.

3. T. nodosa (Gaert.); lower l. bipinnate, upper pinnate, leaflets deeply narrowly and unformly pinnated, umbels nearly sessile dense lateral, outer carpels with hooked bristles inner often warted.-E. B. 199.-St. diffuse. Umbels very small, nearly globular.-Banks and dry places. A. V.-VII.

\section{Tribe IX, Scandicinea.}

\section{Scandix Linn.}

1. S. Pecten-veneris (L.); fr. roughish : bcak 3 times as long as the earpels dorsally compressed glabrous with bristly edges, leaflets of partial involueres entire or bifid longer than the pedicels.-E. B. 1397.-St. often a foot high. L. light green, triply pinnate; segments short, linear. Umbels $1-2$ together, small. 11. often slightly radiant. Fr. remarkable for its very long ( $1-2$ in.) beak. Styles always straight. Stylopode purple. Partial involucres sometimes mueh divided.-Cultivated land. A. VI.-IX. Shepherd's Needle.

\section{Anthriscus Hoffm.}

1. A. sylvestris (Hoffm.); st. hairy bclow glabrous above slightly swollen below the joints, umbels terminal stalked, l. bipinnate, leaflets pinnatifid, fr. linear glabrous with a short beak. -Charophyllum Sm., E. B. 752.-St. 3 feet high, ereet, leafy, furrowed, branched. Partial involucre of several ovate-lanceolate ciliated lcaflets. Umbels at first drooping.-Hedges and banks. P. IV.-VI. Wild Chervil.

†2. A. Cerefolium (Hoffm.); st. hairy above the joints only, umbels lateral sessile, l. tripinnate, leaflets ovate pinnatifid, fr. linear smooth about twice as long as its beak.-Chcerophyllum sativum Sm., E. B. 1268.-St. l-3 feet ligh, slender, striated, much branched. Partial involucre of 3 unilateral linear-laneeolate leaflets. Peduncles downy.-Waste ground. Probably an eseape from eultivation. A. V. VI. Garden Chervil.

3. A. vulgaris (Pers.); st. glabrous, umbels lateral stalked, 
l. tripinnate, leaflets pinnatifid, fr. ovate lispid about twiee as long as its glabrons beak.-E. B. 818.-St, erect, 2 feet high, branched. L. slightly hairy. Umbels on rather short stalks. Partial involucres of few ciliated leaflets.-Waste plaees. $\mathbf{\Lambda}$.V.VI.

\section{Cirarowitulum Linn.}

1. C. tenulum (L.); st. swelling beneath the joints rough, 1. bipinmate, leaflets ovate-oblong pinnatificl with obtuse mueronate segments, pet. glabrous, styles equalling the stylopode.-Myrrhis temulenta Sm., E. B. 1521.-St. 3-4 feet high, round, spotted, seabrous below, hairy near the summit. Umbels at first nodding. -IIedge-banks. P. VI. VII.

*2. C. aureum (L.); st. somewhat thiekened below the joints, 1. tripinnate, leaflets attenuated very acute ineiso-pinnatifid, pet. glabious, styles longer than the stylopode.-Myrrhis Sm., E. B. 2103.-St. 3 feet high, angular, striated. Partial involueres with ovate-lanceolate mueh attenuated leaflets.-Between Arbroath and Montrose and at Costorphine. Mr.G. Don. A very doubtful native. P. VI.

S. ?

†3. C. aromaticam (L.); st. slightly thickened below the joints, 1. subternately bipinnate, leaflets undivided broad oblong aeuminate sharply serrate hairy beneath, styles longer than the stylopode.Myrrhis Sm., E. B. S. 2636.-St. 2-3 feet high, furowed, angular, rough with bristly hairs and spotted below.-Near Guthrie between Forfar and Arbroath. Mr. G. Don. P. VI.

\section{Myrris Scop. Sweet Cicely.}

1. M. odorata (Seop.) ; 1. downy beneath, leaflets of the partial involueres lanceolate-neuminate.-E. B.697.-St. $2-3$ feet high, round, leafy, hollow. L. very large, tripinnate. Leaflets ovatelaneeolate, pinnatifid. Umbels terminal. Fl. numerous, white. Fr. large, nearly an ineh long, dark brown. Whole plant highly aromatie.-Pastures in lilly distriets. P. V. VI.

\section{Tribe X. Smyrnea.}

\section{Echinophora Linn.}

1. E. spinosa (L.); 1. pinnate, leaflets pinnatifid with spinous awlshaped entire segments.-E.B.2413.- Sandy sea-shores, probably now lost. Laneashire and Kent. P. VII.

E.

\section{Conium Linn.}

1. C. maculatum (L.); leaflets of the partial involueres unilateral ovate-laneeolate with an attenuated point shorter than the umbels.-E. B. 1191.-St. 3-5 feet high, ereet, round, hollow, 
glaucous, spotted with purple, branched. L. tripinnate; leaflets lanceolate, pinnatifid with acutc cut segments. Readily distinguished by its foctil smell, spotted stem, unilateral partial involucres and wavy crenate ridges of the fruit. IIighly poisonous. -Hedge-banks and waste places. B. VI. VII. Hemlock.

\section{Pinsospermum Cusson.}

1. P. cornubiense (DC.); radical 1. triternate, leaflets werlgeshaped cut or deeply 3-lobel with acnte segments, stem l. ternate lanceolate entirc. - E. B. 683.-St. $1-3$ feet high, erect, round, striated, minutely scabrous, bearing a few small ternate leaves with lincar lanceolate segments, the upperinost represented by a barren lanccolate acute sheath. Umbels terminal. Carp. longer than broad ; the coat loose. Seed free.-Hooker refers $P$. aquilegifolium (Koch) to this; on the contrary, Bertoloni, with Hooker's observations before him, states that they are quite different.-Devon and Cornwall, rare. P. VII. VIIII.

E.

\section{Smyrnium Linn.}

1. S. Olusatrum (L.); st. terete, stem 1. ternate stalked serrate.-E. B. 230.-St. 3-4 feet high, stout, branched, leafy, furrowed. Radical l. very large, all with large membranous sheaths and large ovate shining cut and serrated leaflets. Fl. greenish-yellow in dense rounded umbels. Fr. nearly black, aromatic. -Waste ground and near ruins. B.? V. VI. Alexanders.

\section{Suborder III. Colosperma. Tribe XI. Coriandrea.}

\section{Cormandrum Linn.}

*1. C. sativum (L.).-E. B. 67.-St. 12-18 in. high, leafy, round, striated. L. bipinnatc, cut; upper ones more divided into linear segments. Fl. white.-Ficlds and waste places, an escape from cultivation. A. VI. Coriander.

\section{Order XXXIX. ARALIACEE.}

Cal. 4-5-toothed, adnate to the ovary. Pet. 5-16 rarely wanting, xstivation valvate. Stam. as many as the pet. and alternate with them or twice as many, inserted below the margin of an epigynous disk. Ovary with more than 2 cells. Styles as many as the cells. Fr. succulent or dry, of several cells each with 1 pendulous sced, endocarl crustaceous. Albumen fleshy. Embryo minute (not so in our Hedera).-L. alternate without stipules.

1. Adoxa. Cal. half inferior, limb trifid. Cor. superior, 4-5-cleft, rotate with a short tube contracted at the throat. 
Stam. 8-10, in pairs alternate with the petals, anthers 1cellerl. Berry 4-5-celled; eells l-seeded.

2. IIedera. Cal. superior, limb of 5 teeth. Pet. $5-10$, not adhering at the apex. Stam. 5-10. Styles 5-10, connivent, or combined into one. Berry 5 -celled and 5 -seeded, erowned with the ealyx.-Closely allied by its embryo to Cornea.

\section{- 1. Adoxa Linn.}

1. A. Moschatellina (L.).-E. B.453.-Rhizoma white, fleshy, toothed, stoloniferons. St. solitary, creet, simple, $3-4$ in. high, witl 2 opposite leaves, and a head of 4 whorled and I terminal flowers. Stam. often more or less combined, showing their number to be normally 4 . Fl. with a musky smell. Terminal A. usually divided in fours, the others in fives, but the numbers rary.-WWoods and shaly hedge-banks. P. IV. V.

\section{Hedera $\operatorname{Lin}$.}

1. H. Helix (L.) ; 1. coriaceous ovate or cordate and 5-lobed : lobes angular, umbels simple downy erect. $-E . B .1267 .-$ Clinnbing by means of rootlike fibres. $L$. of the flowering branches ovate-oblong, acute, entire. Berries black.-Rocks, old walls, hedges. Sh. X. Xl. Ivy.

\section{Order XL. CORNEE.}

Cal. 4-lobed. Pet. 4, oblong, broad at the base, inserted at the top of the calyx-tube, xstivation valvate. Stam. 4. Ovary 2-celled. Style filiform. Fruit a drupe, erowned with the remains of the calyx; endoearp thick and bony. Albumen fleshy. Seeds pendulous, solitary.-Leaves opposite.

1. Cornus. Calyx-limb superior, of 4 tecth. Pet. 4. Stam. 4. Style 1. Drupe with a 2-celled and 2-seeded nut.

\section{Cornus Linn.}

1. C. sanguinea (L.); arborescent, branehes straight, l. ovate cuspidate green on both sides, cymes flat without an involucre. - E. B. 249. St. 52. 3. - Shrub 5-6 feet high. Old bark reddish. Fl. numerous, white, in terminal cymes. Fr. dark purple. L. mostly opposite, strongly nerved, acutely cuspidate, rounded below.-Hedges and thickets. Sh. VI. Dog-wood.

2. C. suecica (L.); herbaceous, l. all opposite scssile ovate: nerves separate almost to the base, $\mathrm{fl}$. umbellate shorter than the 4-leaved petaloid involucre.-E. B. 310. St. 52. 1.-Flowering shoots about 6 in. high, annual, springing from the procumbent or subterranean creeping woody leafless stems. Fl. dark purple with yellow stamens, in a small solitary terminal umbel with an 
involucre of 4 ovate yellow leaves tipped with purple. Fr. red. -Moist alpine pastures. P. VII.

E. S.

\section{Subdivision III. COROLLIFLOR E.}

Pet. united bearing the stamens.

\section{Order XLI. LORANTHACEF.}

Cal. adnate to the ovary, with 2 bracts at its base, limb entire or lobed. Cor. of $4-8$ nore or less united petals. Stam. as many as and opposite to the petals and the filaments more or less combined with them, antlı. sometimes adnate to the petals. Ovary 1, l-celled with 1 ercet ovule. Style filiform or 0 . Stigma capitate. Fr. sucenlent. Albumen fleshy.-Parasitical plants with entire, mostly opposite leaves.

1. Vrscum. Diocious. Male: Cal. 0. Pet. 4, ovate, flesliy, united at the base. Anth. arlnate to the petals, many-celled. Fem.: Cal. an obscure entire superior margin. Pet. 4, erect, somewhat triangular, minute. Stigma scssile, obtuse. Berry 1-seeded, crowned with the calyx.

\section{Vrscum Linn.}

1. V. album (L.); st. repeatedly dichotomously branched, branches tercte, l. ovate-lanceolate obtuse, $\mathrm{fl}$. in the forks of the stem sessile clustered.-E. B. 1470. St. 8.-Evergreen, parasitical, yellow, succulent. Male fl. about 3 together, female about 5 , yellowish. Berries white, pellucid, globular, viscid.-For an excellent deseription of this plant see Leight. Shrop. 491. Sec also Loudon's Mag. Nat. Hist. vi. 500, and Ann. Nat. Hist. vii. 185.-Parasitical on various trees. P. III.-IV. Mistletoe. E.

\section{Order XLII. CAPRIFOLIACEA.}

Cal. adnate with the ovary, usually with bracts at the base, limb 4-5-lobed. Cor. regular or irregular, 4-5-cleft. Stam. free, on the corolla, $4-5$, alternate with the lobes. Ovary $3-5$ celled, cells with one or more pendulous ovnles. Stigmas 1-3. Fruit indehiscent, 1 - or more celled, usually fleshy. Albumen fleshy.-L. oppositc.

1. Sambucus. Cal.-limb 5-cleft. Cor. rotate, 5-lobed, at length reflexed. Stam. 5. Stigmas 3, sessile. Fr. 3-4seeded.

2. Viburnum. Cal.-limb 5-cleft. Cor. campanulate or funnelshaped, 5-lobed. Stam. 5. Stigmas 3, sessile. Fruit 1sceded.

3. Lonicera. Cal.-limb small, 5-cleft. Cor. tubular or 
funnclshaped, usually saceate at the base, limb 5 -fid or irregular. Stam. 5. Style filiform. Stigma capitate. Fruit [-3-eelled, few-seeded.

4. Linnsa. Cal.-limb 5-eleft, with lanceolate subulate equal deciduous segments. Cor. between turbinate and eampanillatc, 5-lobel. Stam. 4, rarcly 5, 2 longer. Style filiform, stigma eapitate. Fr, dry, 3-celled; 2 eclls barren, 1 singleseeded.-'Two large and 2 mimute bracts at the base of the fruit.

\section{Sambucus Linn.}

1. S. Ebulus (L.); herbaceous, st. furrowed, stip. leafy ovate serrate, 1. pimmate, leaflets lanceolate serrate, eyme with 3 principal branches.-E. B. 475.-St. 2-4 feet ligh. Cymes terminal. Il. white, reddislı externally, anth. purple. Fr. reddishblaek.-Hedge-banks. P. VIII. Dwarf Elder. Danewort.

2. S. nigra (L.); arborescent, stip. obsolete, l. pinnate, leaflets ovate cuspidate serrate, cymes with 5 principal branehes. $-E . B$. 476. $\Lambda$ small tree. Cymes large, terminal. Fl. eream-colourel. Fr. black, rarely green or white.- $\beta$. laciniata ; $1.2-3-$ pinnate, pinmules laciniated.- $\gamma$. rotundifolia (DC.); leafl. usually 3 quite round.-Woods and hedges. $\beta$. near Ayr. Hooker. Endcrby, Leicestershire. Rev. N. P. Small. $\gamma$. Isle of Wight. T. VI. Elder.

\section{Viburnum Linn.}

1. V. Lantana (L.); l. elliptical with a cordate base finely denticulate-serrate downy beneath, pubescence stellate.-E. $B$. 331.-A small tree with romd mealy branches. Young shoots, petioles, and under sides of the l. densely, upper side more sparingly, covered with stellate down. Cymes terminal. Fl. white, not radiant. Fr. black.-Hedges and thickets on a calcarcous soil. T. V. Mealy Guelder-rose. Wayfaring tree. E. S.

2. V. Opulns (L.); l. 3-5-lobed: lobes aeuminate and dentate, petioles glandular.-E. B. 332. St.27.6.-Branches glabrous, tetragonal when young. L. slightly downy beneath. Cymes large, with linear braets; $f$. white, inncr ones fertile, outer barren and radiant. Fr. red.-IIedges and thiekets. T. VI. VII. Common Guelder-rose.

\section{Lonicera Linn.}

† 1. L. Caprifolium (L.) ; fl. ringent whorled terminal sessile, 1. deeiduous glabrous on both sides obtuse, upper $l$. connate-perfoliate, style glabrous.-E. B. 799.-St. twining. Fl. white or purplish. Fr. orange. Upper pairs of leaves connate, the rest distinct.-Thiekets. Sh. V. VI.

E. S. 
2. L. Periclymenum (L.); fl. ringent capitate terminal, heads stalked, l. all distinct deciduous oval, st. twining.-E. B.800.Fl. pale yellow, externally red. Fr. red. L. sometimes downy bencath, rarely lobed. - Woods and hedges. Sh. VI.-IX. Honeysuckle. Woodbine.

3. L. Xylosteum (L.); peduncles 2-flowered downy as long as the flowers, calyx-limb deciduous, berries slightly connected at the base, l. oval downy, st. erect.-E.B.916.-Fl. pale yellow. L., bracts, cal., cor. externally, filaments, and style downy. Fr. scarlet, ncarly distinct.-Thickets, very rare. Truly wild in Sussex. Sh. V.

E. S. ?

\section{LinnaA Gronov.}

1. L. borealis (Gron.).-E. B. 433.-St. trailing and creeping. L. opposite, broally ovate, stalked, dark green above, paler beneatl. Peduncles long, erect, 2-flowered, from short lateral branches with 2-4 leaves. Fl. pcndulous, flcsh-coloured, purple within.-Woods, cliefly of fir, in the north. P. VII. E. S.

\section{Order XLIII. RUBIACEA.}

Cal. superior, 4-5-6-lobed or obsolete. Cor. regular, 4-5-6-loberl. Stam. 4-5, alternate with the lobes of the corolla. Ovary 1, 2-celled, with solitary erect ovules. Style 1, often bifid. Stigmas 2. Fr. a didymous indehiscent pericarp. Embryo straight in horny albumen.

1. Sherardia. Cor. funnelshaped. Fr. crowned with the 6-toothed calyx, dry.

2. Asperula. Cor. funnelshaped, Fr, dry, not crowned with the limb of the calyx.

3. Galium. Cor. rotate. Fr. dry, not crowned with the calyx.

4. RuBiA. Cor. rotate or campanulate. Fr. succulent, 2-lobed.

\section{Sherardia Linn.}

1. S. arvensis (L.).-E. B. 891.-St. mostly decumbent, branched, square, leafy. L. 6 in a whorl, obovate-lanceolate, acute. Fl. blue, in a small sessile terminal umbel. Cal. of 4 segments, 2 of them bifid.-Cultivated land on a gravelly soil. A. V.-VII.

\section{Asperula Linn.}

[1. A. arvensis (L.); l. 6-10 in a whorl linear-lanceolate obtuse, fl. aggregate terminal surrounded lyy long ciliated bracts, fr. glabrous. - E. B. S. 2792.-Closcly resembling Sherardia arvensis. St. ascending, square. Lowermost l. opposite or 4 
togretlier, roundisl-oborate. St. and margins of the l. rough. Fl. brighit blue.-Oceasionally introducerl. Devonport. $\mathbf{A}$. VI.]

[* A.taurina (L.) ; 1.4 in a whorl elliptieal acuminate 3 -nerved, fl. eorymbose, tube much longer than the limb of the cor., fr. punetulate seabrous. - Naturalized. Cadcby, Leicestershire. Rev. A. Bloxam. Casterton Woods, Westmoreland. Rev. $R$. Blunt.]

2. A. cynanchica (L.); $l .4$ in a whorl linear, uppermost 1. very unequal, $\mathrm{fl}$. eorynbose, bracts laneeolate mueronate, eor. scabrous, "fr. granular-scabrous."-E. B. 33.-Root fusiforn. Stems many diffise or ascending branched. Fl. generally lilac. -Dry banks in limestone districts. P. VI. VII.

3. A. odorata (L.); $l$. 6-8 in a whorl lanceolate, margins scabrous, fl. in stalked terminal corymbs, fr. hispid.-E. B. 755. -St. erect, abont 6 in. lighl. Fl. white. L. broad. Whole plant fragrant.-Woods. P. T. VI. Woodruff.

\section{Galium Linn.}

1. G. cruciatum (With.); $l .4$ in a whorl elliptic-oblong hairy 3-nerved, flowerstalks lateral corymbose bracteated, terminal $f$. fertile, lateral mostly male, fruitstalks deflexed, fr. smooth.E. B. 143. - St. simple above, $1-2$ feet high, hairy. Fl. small, about $\&$ together in small axillary corymbs, yellow.-" $\beta$. lavipes; peduncles and pedieels glabrous."-Hedges and thickets. P. V. VI. Crosswort.

2. G. palustre (L.); l. 4 in a whorl linear-oblong broader 11)wards obtuse, paniele diffuse, fl. perfect, fruitstalks straight spreading at right angles, fr. smooth.-E. B. 1857.-St. I-4 feet high, weak, branched or simple. Lowest l. usually 6 in a whorl, the rest in fours, 2 often much smaller. Fl. small, white. St. and branclies nearly smooth. - $\beta$. Witheringii (Hook.); angles of the stem and margins and under sides of the l. rough with deflexed bristles. E. B. 2206. G. Witheringii Sm.-These varieties are scarcely distinguishable exeept in their extreme states. - Wet places by ditches and rivers. P. VII. VIII.

3. G. erectum (Huds.); $l$. about 8 in a whorl lanceolate mucronate the margins rough with prickles all pointing forwards, midrib slender, branches of the panicle all ascending, fruitstalks divaricated, fr. oval smooth, pet. taper-pointed.-E. B. 2067.St. weak, glabrous or hairy, ascending. L. lanceolate, scarecly at all obovate; margins with 2 rows of prickles pointing forwards; midrib beneath rather slender, smooth.- $\beta$. cinereum; 1. $6-8$ in a whorl linear, fruitstalks........-G. cinereum Sm., E. B. S. 2783, seems to be only a narrow-leaved variety.- 
G. lucidum Bert., Koch, Reich., differs from this by the very broad midrib upon the under side of its leaves and the horizontally patent lower branches of its panicle, both of which character's are very conspicuous in foreign specimens. G. cinereum from Corsica has very glaucous slender 1 . and a few of the marginal prickles decurved, but in other respects agrees with $G$. $l u$ cidum and is very different from Smith's plant.-Hedges aud pastures. P. VI. VII.

4. G. aristatum (L.); $l .6$ in a whorl lanceolatc bristle-pointed with minutc marginal prickles pointing forwards, branches of the panicle all (?) ascending, fruitstalks......, fr. smooth separating into 2 kidncyshapel carpels, pet. taper-pointed.-E. B. S. 2784. -St. a foot high, very smooth, branching. Midrib of the 1 . smooth.-I know nothing of this plaut except from the figure and description.-Angusshire. Mr. G, Don. P. VII. VIII. S.

5. G. Mollugo (L.); l. about 8 in a whorl lanceolate-obovate or obovate-oblong cuspidate the margins rough with prickles pointing forwards, midrib slender, branches of the panicle manyHowered lower ones spreading horizontally or deflexed, fruitstalks divaricated, fr. glabrous, pet. taper-pointed.-E. B. 1673.-St. ascending, square, thickened at the joints, glabrous, or in $\beta$. scabrum (Sm.) as well as the l. hairy.- - $\gamma$. insubricum; 1 . about 6 in a whorl obovate abruptly cuspidate, branches of the panicle fewflowered terminating in trichotomous umbels, floral l. large, bracts large usually solitary. G. insubricum Gaud., Koch, DC. \&c.-Hedges and thickets. $\gamma$. Winauder Mere. Rev. C. A. Stevens. P. VII. VIII.

6. G. verum (L.); l. about 8 in a whorl linear-setaceous with revolute margins channeled above downy beneath, panicles numerous small densely flowered subtermiual, frnitstalks patent, fruit smooth, pet. obtuse and apiculate.-E. B. 660.-St. erect, slightly branched, somewhat woody, with numcrous whorls of narrow deflexed leaves. Fl. golden yellow, rarely greeu or strawcoloured, usually in numerous small dense panicles collected into a kind of terminal spike. St. and upper surface of the l. sometimes downy or scabrous. On loose sands the st. are much more branched and the $\mathrm{fl}$. sometimes solitary but agreeing in all other respects with this species.-Dry and sandy places. P. VII. VIII.

7. G. saxatile (L.); l. about 6 in a whorl obovate pointed, panicles corymbose small, flowerstalks and fruitstalks erectpatent, fr. granulated, pet. acute.-E. B.815.-St. numerous, procumbent, much branched. L. obovate and suddenly narrowed to a point, smooth, with a few marginal ascending prickles. -IIeaths. P. VII. VIII.

8. G. pusillum (L.); l. about 8 in a whorl linear-lanceolate mucronate without marginal prickles, panicle few-flowered, flower- 
stalks and fruitstalks erect-patent, fr. olssoletely granulated, pet. acute-- E. B. 74. G. sylvestre Koch.-St. nimerous, slender, square, branched, loosely spreading. L. often nearly glabrous or with marginal hairs not prickles spreading or deflexed never ascending. Lower part of the stem aud leaves sometimes densely covered with patent hairs. Fr. very minutely grannlated.Limestone lills, rare. P. VII. VIII.

9. G. uliginosum (L.); $l$. 6-8 in a whorl linear-lanceolate bristle-pointed with margins rough like the angles of the stem with prickles pointing backwards, panicles small axillary fow-flowered trichotomous the branches patent 3-ficl, fruitstalks straight, fruit granulated.-E. B. 197\%.-Stems slender, brittle, about a foot ligh, wcak. L. usually 6 in a whorl, discoloured at the tip, and terininating in a transparent bristle. Branches of the small panicles erect-patent. Fr. dark brown.-Wet plaees. P. VII. VIII.

10. G. anglicum (Huds.); l. about 6 in a whorl linear-lanceolate bristle-pointed the margins rough with prickles pointing forwards, st. rongh with decurved prickles, panicles small axillary dichotomous : branehes divaricated bifid, fr. granulated.-E. B. 384.St. 6-8 in. high, spreading, slender, brittle. L. usually 6 in a whorl, the lowermost sometimes in fours. Branches of the small panicles often spreading nearly at right angles with their stalk. Fr. ncarly black. Differs from G. parisiense ouly by liaving no hooked bristles upon the fruit.-Old walls and dry sandy places. A.? VI. VII.

* 11. G. saccharatum (All.) ; 1. about 6 in a whorl linear-lanccolate with marginal prickles pointing forwards, st. rough with decurred priekles, peduncles axillary 3-flowered, lateral fl. barren, fr. warted reflexed.-E. B.2173.-St. procumbent, spreading. Fl. small, pale yellow. Fr. large, a double globe, quite eovered with large pyramidal tubercles. - Carse of Gowrie and near Forfar. Malton, Yorkshire. A. VI.-VIII.

12. G. tricorne (With.) ; 1.6-8 in a whorl linear-lanceolate with marginal prickles pointing backwards, st. rough with deflexed prickles, peduncles axillary 3-flowered, $f r$. granulated reflexed. -E. B. 1641.- St. procumbent, spreading. Fl. small, all 3 usually perfect in structure but seldom more than the middle one fertile. Fr. large, a double globe, covered with small granulations.-Dry ealcareous fields. A. VI.-IX.

E.

13. G. Aparine (L.) ; 1. $6-8$ in a whorl linear-lanceolate with marginal priekles pointing backwards, st. rough with deflexed prickles, peduncles axillary few- (about 3) flowered, fruitstalks divaricated straight, fruit eovered with short hooked bristles.E. B. 816.-St. straggling amongst bushes, $3-4$ feet long. The marginal priekles near the extremity of the l. point forwards, the 
rest backwards. Fr. small. Peduncles or rather flowering branches with several leaves at the primary divisions. Fr. large--Common. A. VI.-VIII. Goose-grass. Cleavers.

14. G. spurium (L.) ; l. 6-8 in a whorl lincar-lanceolate with marginal prickles pointing backwards, st. rough with deflexed prickles, peduncles axillary with 3-9 flowers, fruitstalks divaricated straight, fr. smooth or hispirl.-E. B. 1871.-Closely resembling the preceding and perhaps only a variety of it; distinguished by its more numerous flowers, floral lcaves solitary ("or in nairs"), and fruit of about half the size, in the typical plant smooth.- $\beta$. Vaillantii; fruit hispid as in G. Aparine. G. Vaillantii DC.-Forfar. $\beta$. not uncommon. A. VII. E. S.

15. G. boreale (L.); $l .4$ in a whorl lanceolate 3-nerved, st. erect panicled, corymbs terminal contracted, fruitstalks patent, fr. covered with hooked bristles.-E. B. 105.-St. about 18 in. high, with many leafy branches. Fl. white in compact terminal corymbs. Fr. hispid in the British plant.-Moist rocky places. P. VII. VIII.

\section{Rubia Linn.}

1. R. peregrina (L.); l. 4 in a whorl elliptic or lanceolate shining smooth above without veins the margin and keel rough with reflexed bristles.-E. B. 851.-St. spreading, square. L. rigid, persistent. Cor. rather rotate than campanulate, 5-cleft : lobes oval suddenly narrowed into a slender point.-Stony and sandy thickets in the south. P. VI.-VIII. Wild Madder. E. I.

\section{Order XLIV. VALERIANACEÆ.}

Cal. superior, limb various, toothed, obsolete or involute and ultimately resembling a pappus. Cor. tubular, $3-5$-lobed, unequal or irregular often spurred or gibbous at the base. Stam. $1-5$, inserted in the tube, free. Ovary with 1 perfect cell and often 2 abortive cells, ovule solitary pendulous. Fr. dry.

1. Centranthus. Cor regular, 5-lobed, with a spur. Stam. 1. Fr. l-celled, indehiscent, crowned with the limb of the calyx cxpanded into a feathery pappus.

2. VALERIANA. Cor. regular, 5-lobed, gibbous but without a spur. Stam.3. Fr. 1-celled, indehiscent, crowned with the limb of the calyx expanded into a feathery papjus.

3. Valerianella. Cor. regular, 5-lobed, without a spur. Stam. 3. Fr. 3-celled, indehiscent, crowned with the erect unequally toothed limb of the calyx, 2 of the cells usually empty inflated or filiform. 


\section{Centranthus Cand.}

†1. C. ruber (DC.); l. ovate-lanceolate, spur much shorter than the tube of the corolla and twice as long as the germen.I'aleriana Sm., E. B. 1531.-St. I-2 fect light. Fl. purple or white.-Chalk-pits and old walls. P. VI.-IX. Red Valerian.

[C. Calcitrapa (Dufr.); radical 1. ovate entire, stem l. pimatifisl, spur very short, is naturalized at Eltham in Kent.]

\section{Valeriana Linn.}

1. V. officinalis (L.); $l$. all pinnate, leafl. in $7-10$ pairs lanceolate dentate-serrate terminal one not larger than the others, st. sulcatc solitary, fr. glabrous.-E. B. 698. St.9.-St. 2-4 feet high. Fl. flesh-coloured. Radical 1. on long stalks. Tube of the corolla funnelshaped about as long or longer than the limb. l'r. narrowed upwards. Root with scions.-Ditches and damp chalky places. P. VI. VII. Valerian.

2. V. sambucifolia ("Mikan."); l. all pinnate, leafl. dentateserrate in $4-5$ pairs, of the radical 1 . ovate acute, of the stem $l$. oblong-lanceolate, teminal leafl. not larger than the otlicrs, st. sulcatc solitary, fr. glabrous.-Root with scions. A species universally adopted on the continent. "E seminibus educta, characteres indicatos bene servat, quare ut speciem agnoseere cogimur." Fries Mant. iii. 2. My specimens exactly accord with Bohemian ones from Tausch.-Damp places. P. V́I. VII. E. S.

+3. V. pyrenaica (L.); l. heartshaped serrate stalked, upjer 1. with 1-2 pairs of small lanceolate leaflets.-E. B. 1591.-St. 2-3 feet ligh, furrowed. Fl. light rose-coloured.-Woods in Scotland. P. VI. VII.

4. $V$. dioica (L.); $A$. imperfectly diœcious, radical $l$. ovate stalkel, stem l. pinnatifid with a large terminal lobe, fr. glabrous. - E. B. 628. St. 9.-St. 6-12 in. high, simple. Fl. flesh. coloured; rather large with protruded stam., barren; or small with included stamens and forming a closer corymb, fertile. Root creeping.-Boggy places. P. V. VI.

E. S.

\section{Valerianelda Moench.}

* Fruit with 2 barren cells.

1. V. olitoria (Moench); fr. compressed oblique, fertile cell corky on the back, barren cells without furrows : dissepiment incomplete, bracts ciliated.-E. B. 8II. St. 2. 3. R. Icon. t. 60. Fedia Sm.-L. ovate-spathulate, upper ones narrower. Fl. in terminal dense cymes with oblong linear opposite bracts. Fr. 3-celled; I fertile with its back formed of a thick gibbous mass of spongy cellular tissue which is usually traversed by a single 
furrow and separated from the 2 barren eells by a groove on each side; the 2 barren cells separated by an ineomplete dissepiment, each witl a slender rib on its side and their jumction marked by a slight furrow.-Corn-fields and banks. A. V. VI. Corn Salad.

2. V. carinata (Loisel.); fr. oblong boatshaped crowned with I straight tooth, cells nearly equal cach with a single rib on the back, barren cells contignons in their whole length and with a (lecp furrow between them, fl. in dense cymes.-Fedia E. B.S. 2810. R. Icon. t. 61.-Fl. pale blue. Root leaves spathulate, those of the stem oblong. Bracts ciliated. Section of the fr. reseent-sliaped.--IIedge-banks, rare. A. IV.-VI. Lambs' Lettuce.

E. S.

3. V. Auricula (DC.); fr. subglobose crowned with 1 erect membranous leaf, barren cells larger than the fertile one infated contignons having a narrow furrow between them, fl. scattered. -Fedia E. B. S. 2809. V. dentata DC. Prod. iv. 627.-Fl. distant, in the forks of a repeatedly dichotomous cyme. Lower $l$. obovate attenuate downwards, upper l. oblong. Bracts ciliated. Section of the fruit nearly rouml. Crown of one oblong obtuse obliquely truncate tooth, sometimes with a minute tooth on each side, or ( $\beta$. tridentata) of 3 acnte teeth, of which one is much the longest and often 3-pointed.-Cultivated land. A. VII. VIII.

\section{** Barren cells 0 , or reduced to a rib.}

4. V. dentata (Deitr.); fr. oval crowned with the small oblique equally 4-toothed caly $x$ flat in front with an oblong space inclosed between 2 elevated curved ribs (barren cells) convex behind, cyme lax spreading: branches long divaricated.-Fedia Sm., E. B. 1370. V. Morisonii DC. Prod. iv. 627.-Tecth of the crown spreading or all incurved except the largest. Fr. smooth or hairy $(\beta$. mixta). Fl. corymbose.-Com-fields and banks. A. VI. VII.

5. V. eriocarpa (Desv.); fr. oral cromned with the large oblique open unequally 5-7-toothed calyx flat in front with an oval space inclosed between 2 elevated curved ribs (barren cells) convex behind, cyme condensed : branches short.-Very different in habit from the preceding but searcely affording any specific charaeter. It may be a varicty.-Great Orme's Hearl, $\mathbf{X}$. Wales. A. VI.

\section{Order XLV. DIPSACEE.}

Fl. capitate. Cal. supcrior, surromded by an involucel which closely invests the ripe fruit. Cor. $4-5$-fid with unequal lobes. 
Stam. 4, inserted in the tube, free, filaments not jointed. Style 1. Stigma simple. Ovary l-celled with a pendulous ovule. I'r. erowned with the pappis-like calyx. Linbryo in fleshy albumen.

1. Dipsacus. Calyx eupshaped. Involneel forming a thiekened margin to the germen. Cor. 4-ficl. Receptacle with spinous scales shorter than the involuere. Fr. with 4 sides and 8 little depressions.

2. Knavtia. Calyx eupslaped witl radiant tecth. Involueel terminating in 4 small teetl. Receptacle hairy: scalcs 0 . lir. with 4 sides and 4 little depressions.

3. Scabiosa. Calyx of 5 bristles. Involneel membranons and plaited. Receptacle scaly. Fr. nearly eylindrical with 8 excavations.

\section{Dipsacus Limn.}

1. D. sylvestris (L.); l. opposite undivided sessile, stem 1 . connate, scales of the receptacle straiglt at the end longer than the flowers, involucres curved upwards.-E. B. 1032.- St. 5-6 feet high, prickly, leafy, hranched. IIcads of tl. large, conical, overtopped by the slender ascending involucre.-Hedges and roadsiles. B. VIII. IX. Wild Tcasel.

*2. D. Fullonum (L.); 1. opposite undivided sessile, stem 1. commate, scales of the receptacle looked at the cnd as long as the flowers, involucres reflexed.-E, B. 2080.-St. 5-6 feet high, prickly, leafy, bramched. IIeads of $\mathrm{fl}$. obtuse, conical, abont as long as the spinous spreading involucre.-West of England, seareely wild. B. VIII. IX. Teasel.

E.

3. D. pilosus (L.); l. stalked with latcral lcaflets, seales of the receptacle obovate-cuspidate straight, involueres deflexed.- $E$. $B$. 877. - St. 3-4 feet high, branched, rough, leafy. Heads of $\mathrm{fl}$. small, globose, longer than the involueres.-Moist shady places. B. VIII.

\section{Knautia Coult.}

1. K. arvensis (Coult.); lower 1 , simple, stem l. pinnatifid, st. luistly, calyx with 8-16 somewhat awned tecth.-E. B. 659. -St. 2-3 feet high, slightly branched, with few leaves. Radical 1. numerous, sometimes piunately lobed. Fl. purple, in large convex long-stalked heads, outer ones usually unequal and radiant. Involıeres bluntish._Fields. P. VII. Field Scabious.

\section{Scabiosa Limn.}

1. S. succisa (L.); root abrupt, heads of $\mathrm{fl}$. and fi. nearly globose, involucel hairy 4-fid herbaceous: lobes ovate acute, calyx of 5 bristles, cor.'4-cleft, l. oblong entire, upper l. narrower mostly 
entire.-E. $\dot{B} .878 .-$ St. $1-2$ feet high. Kadical 1. numerous, stem l. few. Fl. purplish-blue, rarely white. St. and both sides of the l. hairy or glabrous.-Mearlow's and pastures. P. VII.$\mathrm{X}$. Devil's bit.

2. S. Columbaria (L.); heads of fr. globose, involucel membranous plaited notched, calyx of 5 nerveless bristles, cor. 5 -cleft, radical l. oblong stalked crenate entire or lyrate, uppermost 1 . pinnatifid witl linear segments.-E. B. 1311.-St, 12-18 in. high. Radical l. obtusc, or, rarely, lanccolate and acute, on long stalks. Fl. purplish. Involucres narrow,-Common on a calcareous soil. P. VII. VIII.

E. S.

\section{Order XLVI. COMPOSITA.}

Fl. capitate. Cal. supcrior ; limb olsolete or forming a toothed bristly or feathery pappus. Cor. tubular or ligulate. Stam. 5, inserted in the tube, anthers united, syngenœcious. Fr. an indehiscent dry pericarp with an erect seed without albumen.

The following arrangement of the genera is nearly that of Jussieu, as being morc simple than that of DeCandolle, which is followel in the arrangement of the species.

\section{Suborder I. CORYMBIFERE.}

Florets of the disk tubular forming a level top ; marginal florets often ligulate. Stigma not jointed to the style.

\section{* Pappus more or less hairy.}

(1.) 1. Еupatorium. Ileads few-flowered. Involucre imbricate oblong. Receptacle naked. Florets tubular-funnelshaped, hermaphrodite. Antl. included. Branches of the stylc exserted, cylindrical obtuse.

(2.) 2. Petasites. Heads many-flowered, subdiocious. Fem. florets filiform, obliquely truncate. in many rows in the fem. heads, in 1 row in the herm. heads. IIerm. florets tubular, few and central in the fem. heads, occupying the whole disk in the herm. heads. Receptaclc nakcl. Involucre in one row.

(3.) 3. Tussilago. Heads many-flowercd, heterogamous. Fem. florets marginal, in many rows, narrowly ligulate. Male florets discoidal, tubular, 5-cleft. Receptacle naked. Involucre of one row of scales with nembranous margins.

(4.) 25. Senecio. I'lorets of the ray ligulate, fem., rarely 0 ; of the disk herm., tubular. Involucre cylindrical or conical 
of 1 row of equal scales not membranous at the margin, and several smaller seales at its base. Pappus pilose.

(5.) 24. Cineraria. Involuere of 1 row of equal seales only. Otherwise like Senecio.

(6.) 23. Doronicum. Florets of the ray ligulate, fem.; of the disk herm., tubular. Involucre hemispherical of 2 or 3 rows of equal scales. Pappus pilose, wanting in the ray.

(7.) 8. Chrysocoma. Heads not radiant. Florets all herm., tubular. Receptacle naked, alveolate (alveoles with elevated dentate margins in our plant). Involuere imbricated. Pappus pilose. Fr. compressed, silky.

(8.) 4. Asten. Ileals radiant. Florets of the ray fem., ligulate, in 1 row ; of the disk herm., tubular. Receptacle naked, alveolate. Involucre imbricated and a few scales on the pedumcle. Pappus pilose, in many rows. Fr. eompressed.

(9.) 5. Erigeron. IIeads radiant. Florets of the ray fem., ligulate, in many rows; of the disk mostly herm., tubular. Receptacle naked, foveolate. Involucre imbricated. Pappus pilose, in many rows. Fr. compressed.

(10.) 7. Solidago. Pappus pilose, in 1 row. Fr. terete. Otlierwise like Aster.

(11.) 9. Inula. Heads radiant. Florets of the ray fem., ligulate, rarely subtubular; of the disk herm., tubular. Auth. with 2 bristles at the base. Receptacle naked. Involucre imbricated in many rows. Pappus pilose, uniform, in 1 row.

(12.) 10. Pulicaria. Involucre laxly imbrieated in few rows. Pappus in 2 rows, onter short euplike membranous toothed, imer pilose. Otherwise like Inula.

(13.) 21. Gnaphalium. Outer florets fem., eentral herm., all tubular. Pappus capillary. Reeptacle flat, naked. Involucre hemispherical, imbricated; the scales equalling the florets but not intermixed with them.-Cor. of the fem. florets often obsolete.

(14.) 20. Filatgo. Outer florets fem., filiform, in several rows, outermost ones intermixed with the inner scales of the involucre or palex; central florets few, herm., tubular. Papjus capillary. Receptacle conical, scaly at the margin. Involucre subconieal, imbricated, seales lanceolate longer than the florets.

(15.) 22. Antennaria. Heads subdiceions. Male florets 
tubular, style almost simple, pappus clavate. Fem. florets filiform, pappus capillary. Receptacle convex. Involucre hemisplicrical, imbricated, scales coloured at the end.

** Pappus 0, membranous, or of 2-3 bristles.

† Receptacle without scales. Ileads heterogamous, radiant. Fl. of the ray fem., ligulate, in 1 row ; of the disk herm., tubular.

(16.) 6. BeLLIS. Involucre of 2 rows of equal obtuse scales. Receptacle conical. Fr. compressed. Pappus 0.

(17.) 15. Chrysanthemum. Involucre hemispherical. Receptacle plane or convex. Fr. terete, without wings, or sliglitly angular and somewhat winged. Pappus 0 or of 3 minutc teeth.

(18.) 16. Pyretinum. Involucre hemispherical. Receptacle planc or convex. Fr. angular, not winged. Pappus an elevated membranous border.

(19.) 17. Matricaria. Involucre nearly flat. Receptacle elongate-conical. Fr. angular, not winged. Pappus 0 , or a slight inembranous border.

\section{†† Receptacle scaly. Pappus 0.}

(20.) 12. Antuemis. Hcads heterogamous, radiant. Florets of the ray fem., or nciter, ligulate, in 1 row; of the disk herm., tubular. Receptacle convex or conical. Involucre imbricated, of few rows. Fr. terete, or obtusely tctragonal, without pappus, but with a more or less prominent margin.

[Anacycuus. Fr. compressed, winged at the erges. Otherwisc like Anthemis.]

(21.) 13. Acrillea. Ileads hetcrogamous, radiant. Florets of the ray fem., lignlate, short; of the disk herm., tubnlar: tube plano-compressed 2-winged. Receptacle narrow, slightly elcrated. Involucre ovate or oblong, imbricated. Fr. compressed, without pappus.

(22.) 14. Diotis. IIcads homogamous, discoidal. Florets herm., tubular : tube compresscel with 2 auricles at the basc. Recptacle convex, with concave downy-topped scalcs. Involucre bellshaped, imbricated. Fr. compressed, crowned with the persistent auricled tube of the cor., pappus 0 .

†† Receptacle without scalcs. IIcads discoidal.

(23.) 18. Artemisia. Florets of the disk herm., of the ray 
fem. slender in 1 row; or all herm, and tubular. Involuere roundish, imbricated. Receptacle naked or hairy. Fr. obovate, witl a small cpigynous disk, without papjons.

(24.) 19. Tanacetum, Florets as in Artemisia. Involucre hemispherieal imbrieated. Receptacle naked. Fr. oblong, angular, with a large epigynous disk (as broad as the fruit), crowned with a slight membianous border.

$\dagger+\uparrow \dagger$ Receptacle sealy. Pappus of $2-5$ stiff bristles.

(25.) 11. Brinews. Heads homogamous, discoidal, sometimes radiant. Florets (of the ray neuter, ligulate;) of the disk lierm., tubular. Receptaele flat, lnvolucre of 2 rows, outer row spreading. Branches of the style surmounterl by short cones. Fr. compressed, angular, rough at the edges, the angles terminating in $2-5$ stiff retrorsely hispid bristles.

\section{Suborder Il. CYNAROCEPHALEA.}

Florets all tubular forming a convex or hemispherical top. Stigma jointed to the style.

* Pappus in 1-2 rows, not surrounded by an elevated margin.

26. Saussurea. Florets all herm., tubular. Anth. with ciliated setæ at the base. Involucre imbrieated, unarmed. Receptacle scaly. Pappus in 2 rows, outer of short rough bristles, inner feathery.

27. Carlina. Florets all herm., tubular. Anthers with eiliated appendages at the base. Involucre imbrieated, outer scales lax leaflike spiuose, inner linear membranous coloured and resembling a ray. Reeptacle with cleft scales. Pappus in 1 row, branched and feathery, connected into at ring below.

** Pappus in many rows of different lengths: second row longest, placed within the margin which surrounds the epigynous disk, rarely 0 .

28. Centaurea. Anthers with papillose filaments, involucre imbrieated. Receptacle ehaffy. Fr. attached laterally above the base to the receptacle. Pappus pilose, rarely 0.

*** Pappus in many rows not surrounded by a prominent margin.

29. Arctium. Involucre globose imbrieated with scales ter- 
minating in hocked points. Receptacle flat, with rigid subulate scales. Fr. compressed, oblong. Pappus short, pilose, distinct.

30. Onopordum. Receptacle loney-combed. lir. 4-ribbed. Pappus rough. Otherwise like Carduus.

31. Carduus. Involucre imbricated with simple spinous pointed scales. Receptacle witl fimbriated scales. Fr. compressed, oblong, with a somewhat fleshy terminal areola. Pappus long, pilose or plumose, united into a ring at the base and deciduous.-Includes Cnicus Linn. and Cirsium DC.

**** Pappus in many rows. Filaments monadelphous.

32. Sily в им. Involucre imbricated : scales leaflike at the basc, narrowed into a long spreading spinous point. Receptacle scaly. Fr. compressed, its terminal areola surrounded by a papillose ring. Pappus pilose, united into a ring at the base, deciduous.

***** Pappus in many rows of different lengths: inner row longest, surrounded by a margin.

33. Serratula. IIeads diøecious by abortion. Involucre imbricated with sharp unarmed scales. Scales of the receptacle split longitudinally into linear bristles. Fr. compressed, not beakcd, basal areola oblique. Pappus persistent.

\section{Suborder III. CICHORACEE.}

Florets all ligulate and perfect.

* Receptacles without scales. Pappus 0 .

34. LA PSANA. IIeads 8-12-flowercl. Involucre with 1 row of erect scales and $4-5$ short bracts at the base. Fr. compressed, striated, deciduous, not cnveloped in the scales of the involucre.

** Receptacle without scales. Pappus like a crown or of many entire broad scales.

35. Arvoseris. IIcads many-flowered. Involucre of 1 row of about 12 keeled linear-lanceolate at length converging scales and a few sinall bracts at the base. Fr. angular crowned with a short elevated entire margin.

36. Cichorium. IIcads many-flowered. Involucre in 2 rows; outer of about 5 lax shortish scales; inncr of 8-10 longer 
ones, converging, at length reflexed. Receptacle sometimes slightly pilose. Fr. obovate compressed striated. P'appus of 2 rows of minute erect chaffy scales.

\section{*** Receptacle scaly. Pappus feathery.}

37. HYPoc11 ER1s. IIeads many-flowerel. Involucre oblong, imbricated. Fr. glabrous, nuricated, often beaked. Pappus in 2 rows, outer short and setaceous, inner long and feathery.

38. Achyrophorus. Pappus in 1 row, feathery. Otherwise like Hypocharis.

**** Receptacle without scales. Pappus feathery, or on the exterior fruits scaly.

39. Turincia. Involucre oblong, in 1 row, with a few additional scales at the base. Receptacle punctured. Fr. leaked. Pappus in 2 rows; onter setaceous, decidnous; inner longer, feathery, dilated at the base. Marginal row of fruits enveloped in the scales of the involucre, scarcely beaked and with a short crownlike fimbriated pappus.

40. Leontodon. Involucre subinbricatcd, exterior scales much smaller in 1-3 rows. Reccptacle punctured. Fr. uniform, slightly beaked. Pappus of all the fr. in 2 rows; outer setaceous, persistent ; inner longer, feathery, dilated at the base.

41. Oporivis. Involnce subimbricated, exterior scales much sinaller in several rows. Reccptacle puncturer. Fr. attenuated, uniform. Pappus of all the fr. in 1 row, feathery, dilated at the base.

42. Tragopogon. Involucre simple, of $8-10$ scales connected at the base. Receptacle punctured. Fr. longitudinally striated, with a long beak, areola lateral. Pappus in many rows, feathery, interwoven in the ray.

43. Picris. Involucre of 1 row of equal scales, with unequal linear often spreading scales at the base. Receptacle dotted. $F r$, terete, transversely striated, constricted or slightly beaked above, areola terminal. Pappus in 2 rows, feathery, external row subpilose.

44. Hemuintuia. Involucre in 1 row of equal scales, surrounded by 3-5 leaflike loose bracts. Receptacle dotted. Fr. compressed, transversely rugose, rounded at the end and with a slender beak longer than itself. Pappus in several rows, feathery. 
***** Receptacle generally without scales. Pappus filiform, very soft, deciduous, never feathery nor dilated at the base, silvery.

45. Lactuca. Heads few-flowered. Involucre imbricated in 2-4 rows, outer row shorter, scales witl a membranous margin. Fr. plano-compressed, contracted and produced into a filiform beak which is not crowned nor muricated at the basc.

46. Taraxacum. IIcads many-flowered. Involucre double; inner of 1 row, ercet; outer of few short lax or adpressed imbricated scales. Fr. subcompressed, muricated and suddenly contracted above, produced into a filiform beak.

47. Crepis. IIeads many-flowered. Involucre double, inner of 1 row, outer of short lax scales. Fr. terete, narrowed upwards or beaked.

48. Sonchus. Ileads many-flowered. Involucre imbricated with 2 or 3 rows of unequal seales. Fr. plano-compressed, truncate above not beaked.

49. Mulgedium. IIeads many-flowered. Involucre double, inner of 1 row, outer of short lax imbricated scales. Fr. compressed constricted above and terminating in a ciliated disk. Outer rows of the pappus rigid and brittle.

****** Pappus rigid, brittle, at length brownish or yellowish. Otherwise like the preceding section.

50. IIIfracium. Heads many-flowered. Involuere imbricated with many oblong scales. Fr. terete, angular, furrowed, truncatc above not bcaked, with a very short crenulated margin.

\section{Anomalous Genus. Order Ambrosiacez Link.}

51. Xanthium. Heads monocious. Male. Involucre of 1 row of free scales, many-flowered. Receptacle scaly. Cor. funnelshaped, 5-cleft. Antl. free. Stigma obtuse, entire.Fem. fl. 2, inclosed within the involucre which is terminated by $1-2$ beaks and covered with hooked spines and at length hardened over the fruit. Cor. filiform. Stam. 0. Stigmas 2, diverging, linear. Fr. compressed each occupying a cell in the involucre. 
* TUBULIFLORAE. IIerm. florets tubular, regular, teetl 4 or 5 .

\section{Tribe I. Eupatoriacece.}

Style of the liermaphrodite florets eylindrieal witl elongated slighitly clavate branches which arc downy above; stigmatic lines but little prominent often not extending as far as the middle of the branches.

Section 1. EUPATORIEAE. IIcals lomogamous (florets all hermiphrodite).—Pippus pilose and rough.

\section{Eupatorium Limn.}

I. E. cunnabinum (L.) ; 1 . in 3 or 5 deep laneeolate serrated segments the middle one longest.-E. B. 428.-St. herbaceous, erect, striated, scabrous, $2-3$ feet high. IIends in a fastigiate corymb, 5-6-flowered; involueral seales about $10: 5$ exterior short obtuse. Florets reddish-purple. L. downy. IIerb slightly aromatic.-Banks of streams. P. VIII. IX. Hemp-Agrimony.

Section 2. TUSSILAGINEA. Heads heterogamous or subdiocious.

\section{Petasites Gaert.}

1. P. vulgaris (Desf.); 1. roundish-eordate unequally toothed downy beneath : basal lobes approximate, stigmas of the hermaphrodite florets short ovate.-Tussilago Petasites Sm., E. B. 43I and 430. St. 2. I3.-Thyrsus long and lax in the female plant, ovate and dense in the male. Root thick, creeping extensively. Fl. appearing before the l, on stout erect stalks which are clothed with eoncave tumid petioles either leafless or with a small limb. L. very large, radical, ultimately often 3 feet broad, glabrous above.-In marshy places. P.IV. Butter-bur.

\section{Tussilago Linn.}

I. T. Farfara (L.) - E. B. 429. St. 2. 10.--Root creeping extensively. Fl. appearing before the 1 , in bright yellow solitary hearls, erect in blossom and seed, drooping before and after flowering, their stalls elothed with sealelike smooth bracts. L. roundish-eordate, angular, toothed, downy beneath.-Moist chalky and elay soils. P. III. IV. Coltsfoot.

\section{Tribe II. Asteroidea.}

Style of the hermaphroditeflorets cylindrieal with linear branches which are flat and equally and minutely downy on the outer surface and have narrow prominent stigmatic lines throughout. 
Section 1. ASTEREAE. Heads never dicecious, mostly radiant. Anth. without appendages. L. alternate.

\section{4. (8.) Aster Linn.}

1. A. Tripolium (L.); st. glabrous eorymbose, l. linear-lanceolate fleshy sinooth, involuere imbricate: seales obtuse membranous the inner ones longer.-E. B. 87. Tripolium vulgare DC.-St. l-2 feet high, erect, hollow, leafy, many-flowered. IIeads large with a yellow disk and bright blue rays; rays often wanting.-Muldy salt marshes. P. VIII. 1X.

\section{5. (9.) Erigeron Linn.}

*1. E. canadensis (L.); st. much branched hairy panicled many-flowered, 1. linear-lanceolate ciliated.-E. B. 2019.-St. erect, $1-2$ feet high. Heads numerons, small, yellowish. lnvolucres cylindrical, scareely shorter than the florets of the ray, finally spreading.-Waste ground, rare. A. VIII. 1X. E.

2. E. acris (L.); st. corymbose, branches alternate bearing single heads, l. linear-lanceolate entire spreading, lower 1. narrowed below, rayerect scarcely longer thun the disk, inner female florets filiform numerous.-E. B. 1158.-St. erect, 6-18 in. high, simple below, branching in a corymbose manner above. Fl. yellow, the ray pale blue.-Dry gravelly places. B. V11. Vili. Fleabane.

3. E. alpinus (L.); st. mostly with a single head, l. laneeolate, lower 1. narrowed below, ray spreading twice as long as the disk, "inner female florets tubular-filiform numerous."-E. B. 464. St. 38. 11.-St. 4-8 in. high, usually terminating in a solitary head with a yellow disk and light purple ray. Involucre hairy. $-\beta$ ? unifiorus; "involuere woolly, female florets all ligulate." E. uniflorus Sin., E. B. 24l6.-Highlanıl mountains. P. VII. VIIl.

\section{6. (16.) Bellis Linn.}

1. B. perennis (L.); l. obovate-spathulate single-ribbed erenate-dentate.-E. B. 424.-St. a short procumbent rhizoma producing l. only at its extremity. Flowerstalks sinple, each bearing a single head. Sometimes all the florets are ligulate, rarely all are tubular.-Banks and pastures. P. 111.-X.

Daisy.

\section{7. (10.) Solidago Linn.}

1. S. Virgaurea (L.); st. erect slightly angular, l. laneeolate narrowed at botl ends, lower l. elliptical stalked serrated, raceme erect simple or compound, involucral scales lanceolate aeute, fr. downy.-E. B. 301. St. 9.-St. usually 1-3 feet high, leafy, nearly simple, terminating in a long cluster of yellow heads.$\beta$. angustifolia (Koeh); 1. all lanceolate. $-\gamma$. cambrica (Sm.); 
st. 2-6 in. high, l. ovate-laneeolate, heads larger. S. cambrica Ilnds. - Woods and thickets. $\beta$. on mountains. P. VII.IX. Golden Rod.

\section{8. (7.) Cirrvocoma Linn.}

1. C. Linosyris (L.); herbaceous, 1. linear glabrous, heads corymbose, involucres lax.-E. B. 2505. Linosyris vulgaris DC., Koeh.-St. I2-18 in. high, simple, leafy. L. single-ribbed, smooth or scabrous, very numerous, more or less punctate. Fl. yellow.-Limestone eliffis, rare. P. VIII. IX.

E.

Section 2. INULE E. IIeads never diceious, rarely homogannons or discoid, generally heterogamous and radiant. Female Horets ligulate. Anth. with appendages. Reeeptaeles without scales. L. alternate.

\section{9. (11.) InULA Linn.}

1. I. Helenium (L.); outer scales of the involucre ovate, inner obovate, 1. unequally dentate domny beneath cordate-ovate acute clasping, root !. stalked elliptic-oblong, fr. quadrangular glabrous. -E. B. 1546.-St. 3-4 feet high, round, furrowed, solid, leafy, branched above. IIeals few together or solitary, terminal, very large; florets bright yellow. Involueral seales reflexed.-Moist pastures. P. VII. VIII. Elecampane.

2. I. Conyza (DC.); scales of the involucre all linear, l. ovateIanceolate downy dentieulate, lower 1 . narrowed into a footstalk, florets of the ray subligulate, fr. terete.-Conyza squarrosa Sm., E. B. 1195.- St. I-2 feet high, leafy. IJeads eorymbose. Inv. seales reflexed, leafy. Fl. yellow, those of the cireumference between tubular and ligulate, deeply divided on the inner side.Caleareous soils. P. VII.-IX. Plowman's Spikenard. E.

3. I. crithmoides (L.); scales of the involucre linear taperpointed, l. fleshy linear obtuse or with 3 points.-E. B. 68.St. about a foot high, slightly branched near the top, each branch terminating in a solitary head with an orange-eoloured chisk and yellow rays.-On rocks and in muddy salt marshes by the sea. P. VII. VIII. Golden Samphire.

\section{0. (I2.) Pulicaria Gaert.}

1. P. vulgaris (Gaert.); l. lanceolate wavy narrow at the base and somewhat elasping, st. much branched downy, heads lateral and terminal hemispherieal with very short rays.-Inula Pulicaria Sm., E. B. 1196.-St. 6-12 in. ligh, leafy. Heads small, florets yellow. Outer pappus setulose-laciniate.-Moist sandy heaths. A. VIII. IX. 
2. P. dysenterica (Gaert.); l. oblong cordate at the base clasping obsoletely toothed downy beneath, st. panieled woolly, heads axillary and terminal corymlose, rays much longer than the disk. -Inula Sm., E. B. 1115.-St. 12-18 in. high, leafy. Heads larger than those of the last, florets bright yellow. Outer pappus cuplike, erenulate.-Damp places. IP. ViII. IX. Fleabane.

\section{Tribe III. Senecioidec.}

Style of the hermaphrodite florets cylindrieal with long linear branches terminated by a bunch of hairs or sometimes extending beyond the lairs into a short cone or elongated appendage. Stigmatic lines broad and prominent and extending as far as the bairs.

Scetion 1. HELIANTHEA. Heads usually heterogamous and radiant, or lomogamous and discoid. Anth. without appendages. Reeeptacle palcaceous throughout or only near the margin. Cor. of the hermaphrodite florets with thickeued lobes. Pappus aristate in our plants.

\section{1. (25.) Broens Iinn.}

1. B. tripartita (L.); l. stalked 3-partite: segments lanceolate serrate, fr, obovate-euneate usually with 2 bristles.-E. B. 1113. -St. 1-3 feet ligh, with opposite branches. L. narrowed into winged footstalks, sometimes undivided, sometimes pinnate-5-fid. Heads terminal, solitary, slightly drooping. Florcts brownishvellow.- $\beta$. radiata ; with radiant 3 -toothed marginal florets.Mlarshy places. A. V11I. IX.

2. B. cernua (L.); l. sessile comnate laneeolate undivided serrate, fr. cuncate usually with $3-4$ bristles. - E.B.1114.-St. 1-3 feet high, with opposite branches. L. simple, narrowed below but not stalked. Heads terminal, solitary, drooping. Florets brownish-yellow. $-\beta$. radiata; with radiant marginal florets. Coreopsis Bidens (L.) St. 1. 16.-Watery places. A. VIII. IX.

Section 2. ANTHEMIDE $A$. IIearls usually heterogamous, ray female or neuter. Anth. without appendages. Branches of the style truncate, bearded, very rarcly terminated by a cone. Pappus often wanting or erownlike, rarcly formed of seales or capillary hairs.

\section{2. (20.) Anтнгмrs Linn.}

* Scales of the receptacle lanceolate or oblong terminating in an acute rigid point.

1. A. arvensis (L.); receptacle conical, fr. tetragonal, 1. bipin- 
natifid hairy, segments linear-lanecolate.-E. B. 602. St. 27. 16. -St. 1 - 2 feet high, striated, downy, much branched. Segments of the l. paraltel aud at length converging. IIcads on long stalks, solitary, terminal, disk convex bright yellow, ray white. Seales just appraring above the therets of the disk, lanceolate, acute with a rigrid point. Onier fr, erowned with a tumid plicate-rugose ring, imer with an acute margin.-Borders of eultivated fields, rare. A. VI. VII. Corn Chamomile.

2. A. tinctoria (L.); receptacle hemispherical, fr. tetragonal crowned with a membranous undivided border, l. bipinnatifid downy bencath, segnents parallel decurent scrrated, ray shorter than the brealtl of the disk.-E. B..1472.-St. $1-2$ feet high, much branched, cottony. L. green, rough or hairy above, cottony and white bencath. Ileads on long stalks, solitary terminal, disk and rays bright yellow. Scales not protruding.-Fields and stony places, rare. B.? VII. VIII. E. S.

3. A. anglica (Spr.); receptacle flat, fr. crowned with a very narrow entire jorder, l. pimnatifis somewhat hairy, lobes incisoscrrate acnte bristle-pointed rather fleshy.-A. marilima Sm., E. B. 2370.-St. prostrate, branched, downy. Involuere downy. Disk yellow, ray white. Scales of the receptacle shorter than the opened flowers, subulate; in which it differs from $A$. altissima. (See DC. Proul. vi. 10.) Very different from A. maritima (I.) which has glabrous fleshy punctured pinnatifid l. with lanceolate scnrcely acute lobes either quite entire or with 2 or 3 teeth at their apcx.-Sen-shore. Sunderland. Mr. Robson. Also Mr. James Backhouse, 1844! (Mr. Wilson's Bearhaven plant is Anacyclus radiatus.) A. VII.

** Scales of the receptacle linear-setaceous acute. Maruta Cass.

4. A. Cotula (L.); receptacle elongate-conical, fir. terete tubercular-striated crowned with a crenulated margin surrounding a slightly convex disk, l. bipinnatifid nearly glabrous : lobes limear acute inostly entire.-E. B. 1772.-St. 1-2 feet high, branched, angnlar, furrowed. Heads solitary, on long terminal stalks; disk yellow, ray white. Tube of cor. 2-winged. Involucral scales obtuse, witl white membranous margins. Whole plant fetid and acrid.-Fields and waste places. A. VII.-IX.

\section{*** Scales of the receptacle thin membranous obtuse.}

5. A.nobilis (L.); receptacle conical, fr. " subtrigonous smooth crowned with an obsolete margin," I. bipinnate, leaflets linearsubulate slightly downy rather fleshy acute.-E. B, 980. St. 27. 15.-St. procumbent, 1 foot long, much branched. IIearls solitary, terminal, disk yellow, ray white. Whole plant pleasantly aromatic.-Gravelly places. P. VII. VIII. Chamomile. E. I. 
[Anacyclus radiatus (Lois.); l. bipinnatifid rather woolly: lobes hinear-subulate, outer inv.-scales liairy on the back, inner ones obtuse dilated and diaphanous above.-Heads solitary, ray yellow.-Dunboy Quay, Bearhaven, Cork. Mr.W.Wilson. A. VII.]

\section{3. (21.) Achillea Linn.}

1. A. Ptarmica (L.); l. shining linear-lanceolate attenuated acute glabrous smootl uniformly and finely serrate, serratures adpressed mucronate minutely scabrous at the margin, ray 8-12. flowered as long as the involucre, corymb compound.-E. B. 757. St. 10.-St. about 2 feet high, slightly branched above, erect, leafy, angular, smooth. Involucral seales with a dark brown membranous margin. Limb of the radiant florets longer than broad, white. Disk broad, white. L. sometimes very narrow; the serratures closely adpressed and the lower ones not deeper than the others.-MIoist meadows and thickets. P. VII. VIII. Sneezewort.

2. A. decolorans (Schrad.); l. opaque linear-lanceolate bluntish downy thickly punctured coarsely and doubly serrate with spreading serratures laciniate and radiating at the base, ray 5-or 6 flowered about as long as the involucre, corymb compound.- $A$. serrata Sm., E. B. 2531. not Retz. See DC. Prod. vi. 22 and 27. -St. simple, erect, leafy, with axillary leafy tufts, downy. Involueral seales witl a reddish-yellow membranous margin. Limb of the radiant florets pale yellow, broader than long. Disk darker yellow. L. not at all attenuated and very different in shape, consistency and sculpture from those of the preceding.-Near Matlock. E. B. Temple Cloud, Som. Mr. T.B. Flower. P. IX. E.

3. A.tomentosa (L.); l. with a linear-lanceolate outline pinnatifid woolly: lobes crowded linear acute, trifid in the lowermost leaves, $2-3$-fid in the intermediate, uppermost simple, corymb repeatedly compound, ray about half as long as the involucre.E. B. 2532. St. 59. 15.-St. 10-12 in. ligh, decumbent at the base, woolly, simple. Scales of the involucre woolly, edged with brown. Disk and rays golden yellow.-Afflunchart, Bamffshire. Rev. W. Little. Near Newcastlc, Co. Down. Miss Keown. P. VII. VIII.

S. I.

4. A. Millefolium (L.); $l$. with a lanceolate outline bipinnatifid woolly or nearly glabrous: lobes cut with linear segments, rachis entire or subdentate with entire teeth, corymb dense, rays about half as long as the involucre.-E. B. 758. St. 10.-St. erect, f-18 in. high, nearly glabrous or woolly. Scales of the involucre nearly glabrous with a brown margin. Heads small. Florets white, oceasionally reddish or purple.-Pastures and waste ground. P. VI.-VIII. Yarrow. Nillefoil. 
5. A. tanacetifolia (All.); stem l. with an oblong outline bipinnatifid woolly or ncarly glabrous : rachis winged serrate, pinnce pinnules and teeth of the rachis inciso-serrate, corymb dense, rays about lialf as long as the involucre.-St. 3-4 feet high, erect, woolly. Radical 1 . stalked, with a lanceolate outline; raehis with large inciso-serrate tecth esjecially just under the pinnx. Pinne and pimules broad. Rachis of the st.-l. and the upper part of the radical l. broadly winged. Il. yellowish. St.-l. sometimes pimatifid only.-. " $\Lambda$ rough hilly bank near Ringing Low near Sheffielı, and Cromford Moor, Derbyshire." Mr. John Hardy. P. VII.

E.

\section{4. (22.) Diотіs Desf.}

I. D. maritima (Cass.).-E. B. 141.-Whole plant densely cottony and white. St. about a foot high, recumbent below, densely leafy, corymbose ahove. L. sessile, oblong, obtuse, flat, crenate, pcrsistent. Ileals in terminal corymbose tufts. Involuere cottony. Florets yellow.-Sandy sea-shores, rare. P. VIII. IX.

\section{5. (17.) Cirrysanthemum Linn.}

1. C. Leucanthemum (L.); lower 1. obovate stalked, stem l. oblong obtuse cut sessile pinnatifid at the base, involucral scales lanceolate obtuse $u$ ith a narrow membranous margin, florets of the ray white, fr. without a border.-E. B.60I. St.2. 11.-St. erect, $1-2$ feet high, simple, striated. Lower 1 . narrowing into a winged and auricled stalk. Hleads solitary, terminal, large, disk yellow.-Fields. P. VI.-VilI. Ox-eye.

2. C. segetum (L.); l. glabrous toothesl dilated outwards and lobed, upper l. clasping, involucral scales ovate obtuse with a broad membranous margin, florets of the ray yellow.- E. B. 540 . - St. a foot high, altcrnately branched, angular. L. inciso-serrate or lobed in the upper part, simply toothed below. Heads solitary, terminal.-Corn-fields. A. VI.-VIII. Corn Marigold.

\section{6. (18.) Pyrethrum $S m$.}

1. P. Parthenium (Sm.); l. stalked pinnate, segments ovate or oblong pinnatifid : lobes cut, st. branched, heads corymbose, involucral scales linear obtuse, fr. crowned with a short jagged membrane.-E. B. 1231--St. erect, 2 feet high, branched, furrowed, panicled. Heads in small corymbs terminating the stem and branches, disk yellow, ray white.-Waste places, not very common. P. VIl. Vill. Feverfew.

2. P. inodorum (Sm.); l. sessile pinnatifid in numerous capillary pointed segments, st. branched, heads solitary, involucral seales lanceolate obtuse, $f r$. rugose and with 2 round glandular 
dots on the external face just below the elevated entire border.E. B. 676. Matricaria DC.-St. erect, I2-18 in. high, smooth, angular. L. in very narrow elongated mostly alternate segments "furrowed beneatlı." IIcads solitary, terminating the branches, ray white, disk yellow. Fr. with 3 prominent smootl ribs, the intermediate spaces rugose, 2 of them narrow and internal, 1 broad and external. $-\Lambda$ maritime form of this is often taken for the next species.-Fields and waste places. $\Lambda$. VII. VIII.

3. P. maritimum (Sm.); l. sessile doubly pinnate, segments fleshy linear entire bluntish convex above, principal ribs keeled beneath, st. branched diffuse, heads solitary, involucral scales lanceolate obtuse, $f r$. slightly rugose and with 2 elongated glandular spots on the external face just below the lobed elevated border.-E. B.979.-St. mostly procumbent, reddish. L. with short crowded mostly opposite segments. Heads as in $P$. inodorum. Fr. with 3 prominent smooth ribs with a narrow intermediate rugose space externally but the 2 intcrnal spaces reduced to simple lines separating the ribs.-Sea-shores. P. VI1. VIIl.

\section{7. (19.) Matricaria Linn.}

1. M. Chamomilla (L.); l. bipinnate smooth, scgments capillary simple or divided, hearls solitary, receptacle hollow, involucral scales linear obtuse.-E. B. 1232.- St. crect, I foot high, branched. Heads on long naked stalks, disk ycllow, ray white.-Cultivated and waste ground. A. VI. VI1. Wild Chamomile.

\section{8. (23.) Artemisia Linn.}

\section{* Receptacle hairy.}

1. A. Absinthium (L.); heads drooping hemispherical heterogamous, l. silky in many decp lanceolate obtuse segments, outer involueral scales linear silky, inner roundish searious.-E. $B$. 1230. - St. bushy, I-2 feet high. Heads in erect aggregate leafy panicles. Floral $\mathrm{l}$. simple. Florets dull yellow, the outer row fernalc.-Waste ground. P. VII. VIII. Wormwood.

\section{** Receptacle naked.}

2. A. campestris (L.) ; heads drooping ovate glabrous heterogamous, $l$. silky with many linear-lanceolate mucronate scgments, stem l. once or twice pinnate with limear segments, st. wandlike procumbent before flowering, inv. scales ovate glabrous with $a$ scarious margin.-E. B. 338.-Barreu st. cxspitose. Flowering st. slender, $1-2$ feet long, ascending when the flowers appear, leafy, smooth. Florets yellow, involucre purplish.- Sandy heaths in Norf. and Suff., rare. P. V11I. IX.

3. A. vulgaris (L.); heads ovate heterogamous, $l$. woolly and 
white beneath pinnatifid with lanceolate acuminatecut and serrated segments, inv. scales woolly.-E. B. 978.-St. 2-3 fect high, creet, lenfy. Clusters leafy, nearly simple, erect. I'l. few, redelish or brownish yellow.-Waste ground. P. VII.-IX. Mugwort.

4. A. maritima (I.); heads oblong, florets few all perfect, $l$. downy pinnatifid with linear obtuse segments, involucral seales oblong onter woolly inner scarions.-E. B. 1706.-St. recumbent or ascending, woolly, mueh brancher. Florets reddish-yellow. Raccmes drooping. - $\beta$. gatlica; racemes more dense, heads creet. E. B. 1001.- - . salina; racemes unilateral, heads drooping.-Salt marshes. P. VIII. IX.

[5. A. ccrulescens (L.); hcads oblong, florets few all perfect, l. lioary lanecolate undivided, those of the barren shoots pinnatifid.-E. B. 2426.-Boston and Isle of Wight. Not found for many ycars. P. VIII. IX.]

\section{9. (24.) Tanacetum Linn. Tansy.}

1. T. vulgare (L.) ; l. bipinnatifid, leaflets serrated.-E. B. 1229. St.20.- Hearls in a terminal corymb. Fl. golden-yellow. r. with an entirc crown. St. $2-3$ feet high.-Way-sides. P. VIII.

Section 3. GNAPHALIEAE. Heads homogamous or heteroganous, discoid. Anthers with appendages. Branches of the styles of the hermaphrodite florets truncate. Pappus pilose or sctaceous, rarely 0 .

\section{0. (14.) Filago Linn.}

1. F. germanica (L.); cottony, st. proliferous at the summit, 1. lanceolate wavy, heads in axillary and tcrminal globose clusters not surrounded and orertopped by leaves, involucral scales cuspidate cottony with glabrous points.-E. B. 946. St. 12. Gnaphatium Sm.-St. erect or ascending, 4-12 in. long, bearing a solitary terminal cluster of heads, afterwards producing from just bclow the cluster 2 or more ascending branches which are again proliferous. Interm. inv.-scales linear and longitudinally folded not inclosing the fruits. Florets yellow.- $[$ F. Jussiai (Coss, et Germ.) las its clusters surrounded and overtopped by leaves; inv. silky; heads larger and fewer in each cluster. Interm. inv.-scales boatsliaped, not inclosing the fruit.] -The Rev. G. E. Smith distinguishes a plant found in Yorkshire as F. apiculata (Phytol. ii. 575.) which has broader, greener, blunt, and apiculate 1. ; and red tops to the inv.-scales, but I am unable to separate it from $F$. germanica.-Dry sandy and gravelly fields. A. VII.-IX. Common Cudweed.

2. F. minima (Fries); st. dichotomously branched, l. linear-lan- 
ceolate acute flat adpresserl, hearls eonical in lateral and terminal clusters longer than the leaves, inv.-scales bluntish cottony with glabrous points.-E. B. 1I57. Gnaphalium Sin,-St, slender, mostly erect, 2-6 in. high, branched, the branehes dichotomous. Fl. yellowish in very small heads. Whole plant cottony, grayish. - Dry sandy and gravelly places. A. VI.-IX.

3. F. gallica (L.); st. dichotomously branched, $l$. linear acute revolute, heads conical in axillary terminal clusters shorter than the leaves, outer involucral scales cottony with bluntish glabrous points gibbous at the base and inclosing the marginal fr.-E. $B$. 2369. Gnaphalium Sm.-St. 6-8 in. ligh, slender. L. narrowing upwarls from the base.-Dry gravelly places, very rare. Bere Churel, Essex. Rev. W. L. P. Garnons, 1842. A. VII.IX.

\section{1. (13.) Gnaphalium Linn.}

E.

1. G. luten-album (L.); st. simple branched at the base slightly eorymbose above, heads densely clusterel leafless, l. linear-oblong wavy woolly on both sides half clasping, lower 1 . broader at the end and obtuse, upper l. narrowing and acute.-E. B. 1002.Woolly. St. 3-12 in. high, decumbent below, then erect or ascending. IIeads aggregated at the extremities of the stem, involucre straw-coloured, florets tinged with red.-Sandy fields, very rare. † Belfast. Mr. W. Thompson. A. VII. VIII. E. I.

2. G, uliginosum (L.); st. diffuse much branched, heads in terminal dense clusters shorter than the leaves, l. linear-lanceolate cottony on both sides. $-E$. B. I194.-St. 3-5 in. high, much branelied, decumbent or ascending. Heads aggregated at the cxtremity of the st. and branches, involucre yellowish-brown.Wet sandy places. A. VII. VIII.

3. G. sylvaticum (L.); st. simple nearly erect, heads in axillary clusters forming a leafy spike, l. lineal-lanceolate upper ones narrower.-E. B.9I3.-St. 3 in. to $1 \frac{1}{2}$ or 2 feet high, the upper part forming a simple or slightly branched leafy interrupted spike. Varies with the leaves silky or cottony on both sides and the spike shorter (G. sylvaticum Sm., G. Norvegicum Retz.) or nearly if not quite glabrous above and the spike elongated (G. rectum Sm., E. B. 124. G. sylvaticum $K o c h)$. If these plants are distinct I must confess myself unacquainted with the true $G$. norvegicum, as figured by Hoppe in $S t .38 .5$, for I believe that the G。 rectum (Sm.) is the G. sylvaticum (Linn.).-Thickets and pastures, rare.- "G. sylvaticum ou the IIighland mountains." Sm. P. VII.-IX.

4. G. supinum (L.); caspitose, st. decumbent, flowering st. erect, heads solitary I-5 distant, 1 . linear downy on both siles mostly radical._Lightf. Scot. t. 20. f. 2. (good). E. B. 1193. G. pusillum Haenke.-IIeight $2-3$ in. Cæspitose, very leafy 
at the root. I'lowering st. with few leaves and often only a single hend. L. downy on both sides. - Shuttleworth separates from this as the true (r. supinum a plant which is not caspitose and has a sort of capitate spike. 1 doubt its distinetness but have scen no specimens. (Mag. Zool. Bot. ii. 192.)-Highland mountains. l?. VII. s.

\section{2. (15.) Antennaria $R, B r$.}

1. A. dioica (Gacrt.); shoots procumbent, flowering st. simple erect, corrmb dense terminal, involucral seales oblong dilated upwarls obtuse colourcd, radical l. obovate-spathulate glabrons above cottony beneath, stem 1 . nearly equal linear-lanceolate adpressel.-E. B.267. Gnaphalium Sm.-Root of long simple fibres. St. prostrate, woody, terminating in a tuft of numerons l. and producing prostrate leafy scions. Flowering st. $4-8$ in. high, quite simple, cottony. II eads $4-5$, crect, slightly stalked. Inv.-scales white or rosc-colour. - $\beta$. hyperborea; 1 . cottony on both sides. E. B. S. 2640.-Mountain heaths. P. VI. VII.

†2. A. margaritacea (R. Br.); st. erect branched above corymbose leafy, $l$. linear-lanceolate acute cottony below, heads in level-topped corymbs.-E. B. 2018.-St. 2-3 feet high, cottony. I. alternate, slightly cottony above, densely beneath. Inv. white. Fl. yellowish.-Moist meadows, rare. P. VIII.

Section 4. SENECIONEAE. Heals homogamous or heterogamous, discoid or radiant. Anth. without appendages. Pappus pilose or setaceous, rarely 0 .

\section{3. (6.) Doronicum Linn.}

†1. D. Pardalianches (L.) ; l. cordate denticulate, lowermost l. on long stalks, intermediate with clasping auricles at the base of the stalk, uppermost sessile clasping, root creeping tuberous. -E. B. S. 2654.-St. 2-3 feet high, erect, solitary, hollow, hairy. L. hairy, minutely toothed, soft, blunt, the uppermost acutc. Petioles except the lowest winged or auricled. Heads screral, involucral scales lanceolate-subulate. Florets yellow. The earlier heads overtopped by the latter ones. Fr. oblong, furrowed.-Damp and hilly woods and pastures, rare. P. V.-VII.

+2. D. plantagineum (L.?); l. ovate denticulate, radical on long stalks rounded or subcordate produced at the base, stem $l$. sessile clasping the lowermost with a winged and auricled stalk. root......-E. B. 630. (excl. leaf.) - Crown of the root woolly. St. 2-3 feet high. Stem 1. narrowed in their lower half but sessilc, uppermost with a long taper point. Heads usually solitary, or, if more, the lateral ones not overtopping the terminal onc. Involucral scales subulate. Florets yellow.-Damp places, rare. P. VI. VII. E. S. 


\section{4. (5.) Cineraria Linn.}

1. C. palustris (L.); shaggy, st. much branched and corymbose above, $l$. broadly lanceolite half-clasping, lower 1 . sinuatedentate.-E. B. 15l. Senecio DC.-St. 3 feet high, thick, hollow, leafy. Heads ercet. Florets bright yellow.-Fen ditches, now become very scarce. P. VI. VII.

E.

2. C. campestris (Retz.); shaggy, st. simple, root oblong nearly entire narrowed below, stem l. lanceolate, heads corymbose, involucre woolly below nearly glabrous in the upper half, fr. hispid. -C. integrifolia Sm., E. B. 152. Senecio DC.-St. 6-8 in. high, with small leaves. Heads erect, $1-6$, in a simple corymb. lnvolucre often almost glabrous, pale. Florets yellow.-ln very wet seasons (Mag. Nat. Hist. v. 88.) and near the sea this plant is often thrice as large with numerous larger heads and the lower 1. dentate, when it is the $\beta$. maritima of authol's.-Chalk downs; $\beta$. ou maritime rocks ncar Holyhead. P.? VI.

E.

\section{5. (1.) Senecio Linn.}

* Florets all tubular, or the marginal ones ligulate but revolute.

1. S. vulgaris (L.); l. half-clasping pinnatifid: segments distant oblong obtuse and together with the rachis and auricles acutely and unequally toothed, lower l. narrowed into a stalk, heads in clustercd racemes, outer involucral scales very short adpressed with black points, ray 0.-E. B. 747.-Smooth or woolly. St. 6-12 in. high, branching. Heads small ; involucre oblongeonical glabrous, florets yellow, fr. with silky hairs. - $\beta$. radiatus (Koch); with a single row of ligulate minute revolute marginal florets.-Common. A. 1.-XIl. Groundsel.

2. S. viscosus (L.); l. dceply pinnatifid viscid glandular-hairy: segments oblong unequally toothed and lobed, heads in an irregular corymb, involucre viscid outer scales half the length of the inner, ray small revolute, fr. glabrous.-E. B. 32. - St. 1 -2 feet high, much branched, spreading, viscid. Heads on long stalks, inv. cylindrical, fl. yellow.-Waste ground, rare. A. VII.--IX.

3. S. sylvaticus (L.); l. deeply pinnatifid downy, segments oblong unequally toothed, heads corymbose, involucre downy outer scales very short, ray small revolute, fr. silky.-E. B. 748.St. $1-2$ feet high, erect, more or less branched, hairy. L. narrower than in the last. Involucres conical, florets yellow.B. lividus; upper l. distinctly auricled and clasping. E. B. 2515. -Dry and gravelly hills. A. VII.-IX.

** Heads with spreading rays.

*4. S. squalidus (L.); l. pinnatifid glabrous: segments linear or oblong distant toothed irregular, heads loosely corymbose, in- 
voluere glalsrons, outer scales few and small, fr. silky.- E. R. 600. S. elirysanthemifolius DC.-St. muleh branched, leafy, smooth. L. sessile, often anricled, deeply and irregularly lobed. IIeads few, brond. Onter iuvolucral seales very small and sometimes very few. Many awlshaped seattered bracts below the heads. Plorets yellow,-Walls. Oxford. Bicleford, Deron. $\Lambda$. VI. $-X$.

5. S. erucifolius (L.); l. pinnatifid margins somewhat revolute downy bencatl the lower ones stalked, segments linear the lowermost smallest entire and clasping the stem, outer involucral scales half as long as the imuer, fr, all silky.-E. B.574. S. tenuifolins Sin.-Root crecping. St. ereet, 2 feet ligh, angular, furrowerl, somewhat cottony, simple. Lower I. oblong-ovate deeply pinnatifil, the segments often linear downy on both suffaces but particularly beneath. F'r. all equally provided with persistent pappus. Florets yellow. $\Lambda$ state witl its 1 . divided into very narrow segments is S. tenuifolius Jacq.-Calcareons soils. P. VII. VIII.

6. S. Jacobcea (L.); lower l. oblong-obovate attenuated below lyrate-pinnatifid stalked, stem 1 . sessile bipinnatifid: segments spreading oblong deeply aud irregularly toothed and cut lowermost mueh divided clasjing, outer involucral scales seattered few lax fr. hairy those of the ray glabious.-E. B. 1130.-Root flcshy. St. 2-3 feet high, sniooth, striated, branched, lcafy. Corymb with ercet branclies. L. glabrous. Fr. of the ray quite glalorous, the pappus deciduous. Florets yellow. Ray sometimes wanting.- Wraste ground. P. VII.-IX. Raguort.

7. S. aquaticus (Huds.); lower l. stalked crenate or dentate obovate or oblong slightly produced at the base undivided or sublyrate obtuse, upper 1 . lyrate or pinnately eut : segments oblong or linear, st. round eorymbosely branched, fr. all glabrous "submurieate."-E.B. 1131.-St. ereet, 1-4 feet high, simple or branehed in the upper half, branehes ascending. Terminal lobe of the lower l. rounded below and narrowed into its stalk.$\beta$. major; l. lyrate, terminal lobe truncate or subcordate below, segments subspathulate, fr. all glabrous and smooth. St. erect, with numerous branches. Terminal lobe of the lower l. remarkably truncate and scarcely decurrent at the base. S. erraticus Bert.?-In marshy places. P. VII. VIII.

8. S. paludosus (L.); l. sessile elongate-laneeolate tapering sharply serrate cottony beneath, st. straight hollow, eorymbs terminal.-E. B. 650. - St. 4-6 feet high, somewhat woolly. Florets yellow, of the ray uarrow $13-16$. - Fen ditches, very rare. P. V.-VII.

9. S. saraccnicus (L.); $l$. sessile laneeolate aeute glabrous irre- 
gularly serrate: teeth small incurved, st. straight solid, corymbs terminal, ray of $6-7$ Horets. $-E . B .2211$ - $-5 t$ t. 3-5 feet high, smooth. L. broad. Corymb many-headed. l'lorets yellow.Watery places, local. P. VIII.

\section{Tribe IV. Cynarea.}

Style of the hermaphrodite florets nodosely thickened above and often with a bunch of hairs at the knot; its branches united or free, downy externally. Stigmatic lines reaching to the apex of the branches and there confluent.

Section 1. CARLINEAE. IIearls many-flowered, never diacious. Involucral scalcs in many rows, distinct, often spinous. Filaments distinct, naked. Fr. mostly villose. Pappus in $1-2$ rows, not surrounded by an elevated margin.

\section{Saussurea Cand.}

1. S. alpina (DC.); 1. nearly glabrous above cottony beneath, lower ones ovate lanceolate, upper sessile lanceolate, all distantly toothed, heads few in a dense corymb, involucre subcylindrical with adpressed hairy scalcs.-Serratula Sm., E. B. 599.-St. 3-12 in. ligh, crect, downy, simple, terminating in a small corymb of heads with pinkish florets and purple anthers. Fr. glabrous.-In alpine situations. P. VIII.

\section{Carlina Linn.}

1. C. vulgaris (L.); st. corymbose 1-inany-headed, l. oblonglanceolate sinuate spinous, outer scales of the involucre bipinnatifid spinous, inner lincar-lanceolate attcnuated acute ciliated in the lower half, bracts shorter than the heads.-E. B. 1144.St. 6-12 in. high, usually cottony, leafy. Root l. lanceolate or linear-lanceolate. Under side of the 1 . and involucral scales often cottony. Heads large, inner involucral scales cream-coloured, florets red, anth. yellow.-Dry sandy heaths. B. VII.-X.

[C. racemosa (L.); l. lanceolate sinuate spinose, heads in the axils of the dichotomous st. or terminal, imner inv.-scales radiant yellow, bracts longer than the heads. - A single specimen found in the isle of Arran, I. Mr. Andrews. Lond. Journ. Bot. iv. 570.]

Section 2. CENTAUREAE. Heads many-flowered, discoidal, outer row of florets usually barren enlarged and irregular. Involucre of many rows. Filaments distinct. Pappus in many rows of different lengths, second row longest, setaceo-pilose, placed within the margin which surrounds the epigynous disk, rarely 0 . 


\section{Centaurea Limn.}

* Involucral scales with a scarious pectinated not decurrent appendage.

1. C. Jacea (L.); involncral appendages torn the outcr oncs pinnatifid quite covering the inv., heads radiant, pappus 0,1 . linear-lanceolate lower ones broader and toothed.-E. B. 1678. -Lower 1. ovate-lanceolate, stalked, toothed. Involucre pale brown, few outermost seales with appendages decply jagged in a pimnatifid mamer, few innermost entire, the rest irregularly jarged. I have secn no native specinens.-Very rare. Sussex. Borrer. Angusshire and Belfast. Hooker. P. VIII. IX.

2. C. nigra (L.); involucral appendages erect ovate-attenuate pectinated quite covering the inv.: teeth divaricated capillary twice as long as the breadth of the apjendage, pappus very short tufted, l. limecolate simuate-dentatc.-E. B. 278 . - St. $1-2$ feet ligh. L. scabrous. Inv.-scales light brown or yellow : appendages dark, of the outermost smaller and narrower than the others; of the innermost roundish, dark brown, membranous, jagged but not pectinated; all contracted just below the appendage; the upper ones crowded. IIcads not radiant, florets all fertile purple or rarely whitc. $-\beta$. radiata; outer row of florets barren and radiant.-Mcadows and pastures. P. VIII. IX. Black Knapweed.

3. C. nigrescens ("Willd.," Koch); involucral appendages erect ovate pectinated about 3 innermost rows separated from the rest and exposing the scales: teeth ascending capillary at least as long as the breadth of the appendage, pappus almost wanting, 1. linear-lanccolate lower ones ovate sinuate-clentate or lyratcsinuate.-Resembles C. nigra but, I think, listinct. Involucral seales palc: appendages dark, of the outcrmost small, of succeeding rows broader and broader, of ahout the 3 inncrnost rows roundish and jagged irregularly. Heads usually radiant.-Meadows and pastures in the West of England. P. VI.-IX. E.

** Involucral scales lanceolate, their upper half with a somewhat scarious deeply toothed or fringed decurrent margin.

4. C. Cyanus (L.); involucral scales crect adpressed deeply toothed, pappus as long as the fruit, l. linear-lanceolate, the lowermost toothed or pinnatifid.-E. B. 277.-St. I-3 feet high, loosely cottony, leafy. L. slightly cottony above, densely beneath. Involucre greenish-ycllow, scales often tinged with purple in their upper half, margins brown decurrent with whitish teeth. Heads with large radiant blue flowers, disk purple.-Corn-fields. A. VI.-VIII. Corn Bluebottle.

5. C. Scabiosa (L.); involucral scales ercet adpressed pectiuated: teeth ascending setaceous, pappus as long as the fruit, $l$. 
pinnatiful roughish, segments lobed with eallous points.-E. B. 56.-St. 2-3 feet high, rough, furnowed. L. lispid, lobes of the upper ones entire. Ilearls on long naked stalks, solitary. Involucres usually rather woolly; scales pale, blunt, with dark acute membrauons pectinated decurrent appendages, teeth pale. Florets purple, outer row radiant or 0 .- Fields and liedges. P. VII.-IX. Great Knapweed.

\section{*** Involucral scales horny at the end with palmate or pinnate spines.}

*6. C. solstitialis (L.); involucral scales woolly palmately spinous, central spine of the intermediate seales very long needleshapel, inner ones with a roundish searious appendage, heads terminal solitary, st. winged with the decurrent bases of the linear-lanceolate entire hoary leaves, root l. lyrate.-E. B. 243. -St. 1-2 feet high, branched, spreading. Involucres sometimes glabrous. Flurets ycllow.-Cultivated land, probably introduced. A. VII.-IX. Tellow Star-thistle.

E.

7. C. Calcitrapa (L.); inv.-scales glabrous palmately spinous, central spine strong channeled, innermost scales with a searious obtuse appendage, heads lateral sessile solitary, pappus obsolete, $l$. deeply pinnatifid, lobes of the root 1 . lanceolate toothed, of the stem l. linear.-E. B. I25, - St. furrowed, slightly hairy, branclsed, spreading, about a foot high. Fl. purplish.-Gravelly and sandy plaees. A. VII. VIII. Common Star-thistle.

8. C. Isnardi (L.); inv.-scales palmately spinous, spines nearly equal 3-5, innermost scales with a scarious obtuse lanceolate or slightly spathulate appendagc, heads terminal solitary, pappus of all the fr. in several rows, $l$. linear coarsely toothed narrowed below sessile rough, lower ones (and those of the primary stem?) broader inciso-dentate with clasping auricles.-E. B. 2256.-St. procumbent, with long slender simple leafy branches each terminated by a solitary head. L. mostly linear, slightly toothed or entire.-Fl. purple.-Distinguished from C. aspera only by its simple upper leaves.-Guernsey. P. VII. VIII.

Scetion 3. CARDUINE $E$. Ileads many-flowered, florets all tubular. Involucre in many rows of distinct spinous scales. Filaments distinct. Pappus in many rows, not surrounded by a prominent margin.

\section{Arctium Linn.}

1. A. majus (Schkuhr); heads subcorymbose, involucres nearly glabrous with the inner seales subulate gradually attenuated into a mueronate point longer than the florets.-A. Lappa Sm.-St. much branched, 3-4 feet high, Ieafy. L. cordate ovate, the lowermost very large. Involucral scales all yellowish-green; a 
few of the innermost narrowed very gralually into a slort rigid struight point, the margins searious. Scarcely ary trace of a web unless on the very youngest licals. -There is some eonfusion in the figures in $L$. B.- Waste plaees, not very common. b. VII. VIII. Great Burdock.

2. A. minus (Schluhr); heads racemose, involucral seales eonnected by a eobwcb-like down, inner ones coloured subulate rather abruptly mucronate shorter than the florets.-Lappa Koeh. -L. rather smaller than in the last. Ileads smaller; involncral scales nearly all tinged with purple, many of the inner ones without hooks but narrowed rather suddenly into an almost straight rigid point. Web often very slight.-Waste plaees. B. VII. VIII. Lesser Burdock.

\section{ONOPORdum Linn.}

1. O. Acanthium (L.) ; st. ereet many-headed, 1. elliptie-oblong woolly on both sides sinuate spinous decurrent, outer involucral seales laneeolate-subulate recurved and sprearling.- $E$. B. 977.- St. 4-5 feet high, woolly, with broal spinous wings, branehed. Involucre nearly globose, large, somewhat eottony; scales fringed with ninute spinons teeth. Florets purple.Waste ground. B. VIII. Cotton Thistle. E. S.

\section{Carduus Linn. Thistle.}

[Many hybrids oeeur in this genms.]

* Pappus rough. CARDuus Sm., DC., Koch.

1. C. nutans (L.); l. deeurrent spinous laneeolate sinuated, heads solitary drooping hemispherieal, involucral scales lanceolate cottony outer ones reflexed.-E. B. 1112.-St. 2 feet high, ereet, angular, furrowed, eottony, winged. L. hairy on both sides, woolly on the veins beneath, pinnatifid with 3 -lobed wavy spinoseciliated segments terminated by strong spines. Heads large, f. purple. Interm. inv.-scales eontracted above the base and then lanceolatc.-Dr. Hooker informs me that the eommon C. nutans of England is C. onopordioides (Fiseh.) and that the true C. nutans is to be found near Exeter. I have not seen the latter nor Fiseher's plant and eannot determine them from the descriptions. -Waste ground. B. V.-VIII.

2. C. acanthoides (L.); l. deeurrent spinose-eiliated laneeolate glabrous or eottony beneatl deeply pinnatifid: lobes trifid and dentate, heads solitary or aggregated roundish, involucral scales linear-subulate ereet or aseending.-E. B. 973.-St. about 3 feet high. L. broadly laneeolate nearly glabrous bencath, heads usually solitary and stalked. C. acanthoides L.- $\beta$. crispus; 1. narrower woolly beneath, heads usually aggregate. C. crispus L.I find no permanent character by whieh to separate these plants. 
-Dry banks and waste places. $\beta$. is the more common plant. B. ? VI.-VIII.

3. C. tenuiflorus (Curt.); l. decurrent sinuate spinous broadly lauceolate cottony beneath : segments ovatc lobed, heads numerous aggregatc sessile subcylindrical, involucral scales ovate-lanccolate attenuated.-E. B. 4l2. - St. about 3 feet high, slightly branched, with broad deeply lobed spinous wings. L. dceply sinuate or pinnatifid. Involucres nearly glabrous. Florets pink. - Sandy places ncar the sea. B.? VI.-VIII.

** Pappusfeathery. Cxicus Linn., Sm. Cirsium Koch, DC. † L. spinous-hairy above, fl. purple.

4. C. lanceolatus (L.); l. decurrent white and cottony beneath pinnatifid : lobes bifid with lanceolate entire seginents cach terminated by a strong spiue, inrolucres ovate shaggy, scales lanceolate spinous sprealing.-E. B. 107.-St. 3-4 feet high, erect, furrowed, hairy, with strong spinous wings. Ilcads terminal, solitary or 2 or 3 together, large ; florets purple.-Waste ground. B. VII. VIII. Spear Thistle.

5. C. criophorus (L.); l. half-clasping not decurrent white and cottony beneath deeply pinnatifid : lobes bifid the segments lanceolate cntire alternatcly pointing upwards and downwards and each terminated by a strong spine, imvolucres globose shaggy, scales lanceolate with a long linear spiuous-tipped reflexed point.E. B. 386.-St. 3-4 feet high, much brancherl, furrowed, hairy. Root 1. 1-2 feet long, lincar with long divergent lobes which form double rows in a very regular manner. Stem 1 . similar but smaller. Heads very large ; involucre covered with a densc white web; florets purple. A remarkably conspicuous plant.-Waste ground on a limestone soil. IB. ViII. Woolly-headed Thistle.

†† Leaves not spinous-hairy above.

a. Limb of the cor. 5-parted to its base. BREEA Less.

6. C. arvensis (Curt.); heads subdicecious, $l$. subsessile oblonglanceolate pinnatifid spinous wavy, involucres ovatc subglabrous : scales broadly lanceolate adpressed terminating in a short spreading spine, root creeping.-E. B. 975. - St. erect, 3-4 feet high, leafy, angular, corymbose above. L. very spinous, sessile or very slightly decurrent.- $\beta$. latifolius; l. glabrous oblong broad sinuately lobcd slightly wavy decurrent with an intcrupted wavy spinous wing, uppermost nearly sessile, lobes obtuse fringed with strong equal spines, in other respects like the type. A remarkable variety? Is it distinct?-† $\gamma$. setosus; l. lanceolate flat entire or slightly lobed. Cirs. setosum M. B.-Fields and road-sides. $\beta$. Croxall, Derbyshire. $\gamma$. Culross, S. Dr, Dewar. P. VII. $\beta$. IX. Creeping Thistle. 
b. Limb of the cor. 5-parted to its middle.

7. C. palustris (L.) ; l. decurrent lanceolate decply pinnatifid spinose, involucres ovate clustered: scales ovate-lanceolate adpressed mucronate. - E. B. 974.-St, solitary, erect, 3-5 feet high, wandlike, with wavy spinose wings throughout, slightly branched. Ileads in a terminal clnster. Ilorets purple or white. Under side of the I. usually cottony. Involuere with a slight web.-Wet meadows. A. VII. VIII.

8.? C. Forsteri; $l$, slightly decurrent lanceolate all pinnatifid spinose cottony bencath : lobes bifid or slightly palmate, involueres 2 or 3 togetlicr ovate terminating the stem and branches slightly cottony: scales lanceolate attenuated adpressed mucronatc, caspitose.-Cnicus Forsteri Sm.-I believe this is a hybrid plant.-st. 3-4 feet ligh, nearly simple or panicled above, angular, furrowed, not winged, slightly cottony, several togetler from the crown of the root, not stoloniferous. L. half-clasping, lower tapering into a footstalk; intermediate narrowed downwards, sessile, a little decurrent; upper gradually smaller; all cottony bencath and slightly pilose above, their lobes witl prominent lanceolatc segments often accompanied by several smaller ones, or shallow with 2 rather prominent points. In a specimen from the county of Mayo the l, are not at all decurrent.-Boggy places. P. VII. VIII.

E. I.

9. C. pratensis (IIuds.); l. mostly radical lanceolate wavy or lobed pilose above cottony beneath fringed with minute prickles, stem $l$. not decurrent few elasping, involucres globose solitary terminal slightly cottony: scales lanceolate-attenuated adpressed mueronate, root stoloniferous. - E. B. 177.-St. $1-2$ feet high, cottony, usually quite simple and single-headed, leafless in the upper half with a few scaly bracts, springing singly from the suckers. L. broad, soft, sinuate-dentate, rarcly with small 2-3-fid lobes, fringed with small but unequal prickles, lower 1. stalked. Occasionally there are 2 or $3 \mathrm{fl}$. on a stem, but the stem 1 . are always soft and wavy at the edges, not pimnatifid as in the preceding.-This is the Cir. anglicum (Lam.) DC., Koch, but Iludson appears to have been its first describer in modern times.-Boggy meadows. P. VI.-VIII.

I0. C. tuberosus (L.); l. lanceolate dceply pinnatifid pilose above hairy or slightly cottony bencath fringed with minute prickles, stem $l$. sessile not decurrent : lobes 2-3-fid, involucres ovate terminal I-3 together slightly cottony : scales lanceolate mucronate alpressed, root of elliptical tapering fleshy fibres.E. B. 2562. Cir. bulbosum DC., Koch.-St. 2 feet high, erect, round, hairy, leafless above the middle with a few minute bracts. Lower 1. stalked, stem 1. nearly or quite sessile.-Great-ridge Wood near Boyton, Wilts. P. VIII. IX. 
11. C. acaulis (L.); l. glabrous radical laneeolate pinnatifid: lobes subtrifid spinose, iuvoluere ovate glabrous nearly sessile mostly solitary : outer seales ovate inner ones gradually longer adpressed, root with filiform fibres.-E. B. 161. St. 24. 16.-St. generally wanting, sometimes $3-4$ in. long, leafy, woolly. L. all stalkel, glabrous except a few hairs upon the ribs bencath. lleads very large, $f$. crimson. $-\beta$. dubius (Willd.); st. much branehed woolly a foot or more in lieight. C. dubius Willd. I'l. Berol. f. 11. C. Roseni Vill. Delph.t. 21.-Dry calcarcous pastures. $\beta$. Saffron Walden, Essex. Mr.G.S.Gibson. P. VII.-IX.

12. C. heterophyllus (L.); l. clasping not decurrent glabrous above white and downy beneath laneeolate serrated fringed with minute prickles, root l. with long stalks clasping at the base, involucres ovate slightly downy : seales ovate or lanceolate aeuminate adpressed.-E. B. 675.-Root ereeping. St. 3-4 feet high, furrowed, eottony, slightly branched above. IIcads large and handsome. L. very large, undivided.-Moist mountain pastures. P. VII. VIII.

E. S.

Seetion 4. SILYBEAE. Filaments monadelphous. Pappus in many rows.

\section{Silybum Gaert. Milk Thistle.}

1. S. marianum (Gaert.).-Carduus Sm., E. B. 976.-St. 3-4 feet high, ribbed and furrowed. L. very large, oblong-lanceolate, wavy, clasping; radical l. pimnatifid, usually variegated with green and milk-white. IIearls large, globose. Involucral seales closely arlpresserl below. Florets purple, their tube very long.-Waste places. 13. Vl. VII.

Seetion 5. SERRATULEAE. Hearls many-flowered; florets all tubular, hermaphrodite or diccious, the external row sometimes female. Involucre of many rows of distinct scales. Filaments distinct. Pappus in many rows of different lengtlis, inner row longest, pilose or plumose, surrounded by a margin.

\section{Serratula Linn.}

1. S. tinctoria (L.); l. with bristly scrratures pinnatifid somewhat lyrate, heads oblong corymbose, involucral seales orate adpressed, inner ones linear coloured,-E. B. 38. St. 3. I6.St. 2-3 feet high, straight, erect, angular, branched above. L. variously pinnatifid or lyrate. Florets purple.-Groves and thickets. P. VIII. Saw-wort.

E. S. 
** LIGULIFLORA. All the florets hermaphrodite, ligulate.

\section{Tribe V. Cichoracere.}

Style crlindrical alove and, with its long obtuse branches, equally pribescent. Stigmatic lines prominent, narrow, terminating below the midclle of the branclies.

Section 1. LAPSANEA. Recptacle without scales. Pappus nonc.

\section{LAPSANA Linn.}

1. L. communis (L.); l. dentate or lobed stalked, lower l. lyrate, involncres glabrons angular, st. panicled.-E. B. 844.-St. and l. hispir or nearly glabrous. St. 1-3 fect high, branched above. Heads small, with yellow florets, in terminal panicles with small subnlate bracts at the subdivisions. Involucre of the fruit erect. - Waste and cultivated land. A. VII. VIII. Nipplewort.

Section 2. HYOSERIDEE. Receptacle without scales. Pappus like a crown, of many entire broad scales.

\section{Arnoseris Gaert.}

1. A. pusilla (Gaert.),-Lapsana Sm., E. B. 95.-St.3-8 in. high, swelling and hollow upwards, leafless, with a minute bract at the base of each branch. Each successive branch overtopping its predecessor and gradually thickening up to the solitary small terminal head of yellow florets. Involucre connivent over the fruit when its scales become remarkably keeled. Rcceptacle alveolate towards the margins. Fr. small obovate, attenuated below, with 5 angles. L. radical, oblong, toothed.-Gravelly places, rare. A. VI.-VIII.

E. S.

\section{Cichorium $\operatorname{Linn}$.}

1. C. Intybus (L.) ; lower l. runcinate hispid on the keel, upper 1. oblong or lanceolate clasping entire, heads axillary in pairs ncarly sessile.- E. B. 539. St. 6. 15. - St. 2-3 feet high, bristly, alternately branched. Heads numerous, of bright blue handsome florets. Floral l. lanceolate from a broad clasping base.-Banks on a gravelly or chalky soil. P. VII. VIII. Succory. Chicory.

Section 3. HYPOCHCERIDEA. Receptacle scaly. Pappus feathery.

\section{Hypocharis Linn.}

1. H. glabra (L.); st. branched leafless glabrous, l. oblong dentate-sinuate, involucre glabrous equalling the florets.- $E . B$. 575.-St. 3-10 in. high, branched, scaly, each branch termi- 
nating in a small solitary head. L. spreading in a circle on the grouml, glabrons, except a few scattered liairs. Outer row of fruits destitute of a beak, the rest with a long beak.- $\beta$. Balbisii (Bab.); all the frnits with long beaks. H. Balbisii (Lois.) $D C$. -The beak of the outer row of fruits is variable.-Sandy and gravelly places. $\beta$. in Kent and Salop. $\Lambda$. VII. VIII. E. S.

2. H. radicata (L.); st. branchel leafless glabrous, l. runcinate obtuse, involucre shorter than the florets.-E.B. 831.-St. about a foot ligh, branched, scaly, each branch terminating in a rather largc solitary head. L. spreading upon the ground, scabrous. Stalks slightly thekened beneath the heads. Fr. all beaked.Waste ground. P.? VII.

\section{AсHyrophorus Scop.}

1. A. maculatus (Scop.); st. simple or slightly branched almost leafless, l. ovate-oblong undivided toothed pilose, involueral seales bristly on the back.-Hypocheris Sm., E. B. 225.-St. about a foot high, stout, slightly hairy. L. often all radical. Hearls large, florets deepyellow.-Chalky and limestone hills. P.VII.VIII. E.

Section 4. SCORZONEREA. Receptacle without scales. Pappus feathery or on the exterior fruits scaly.

\section{Thrincia Roth.}

1. T. hirta (DC.); l. lanccolate sinuate-dentate or entire lispid or hairy with forked or simple hairs, stalks simple pilose below, involucre glabrous. - E. B. 555 . - L. all radical, sometimes nearly or quite entire, occasionally runcinatc. Stalks quite simple, longer than the leaves, somewhat hairy in thcir lower half. Involucral scales downy on the margins at the apex or hairy. Root premorse.-Gravelly places. P. VII.-IX.

\section{Leontodon Linn.}

1. L. hispidum (L.); l. radical oblong-lanceolate runcinate hispid with forked hairs, stalks simple nakel or with 1 or 2 minute scales thickened upwards hispid, involucre hairy.-Apargia Sm., E. B. 554. L. hastilis Koch.-L. all radical with regular spreading or reflexed narrow teeth. Stalks erect, longer than the leaves. Head drooping in bud afterwards erect. Florets glandular at the end. Fr. muricated.-Mr. J. Ball found a plant upon the "mountains south of Glen Crec, Wicklow," which appeared to be closely allicd to the L. alpinum (Jacq.). A. N. H. ii. 29.-Meadows and pastures. P. VI.-IX.

\section{Oporivia Don.}

1. O. autumnalis (Don); l. radical linear-lanceolate toothed or 
pinnatifid nearly glabrous, stalk branched sealy and thickened upwarls, involnere glabrous or hairy.-Apargia Sin., L. B. 8.30. Leontodon Koch. - L. all radieal, tajering at the base, often with long linear sprendiug scgments, usually somewhat lairy particularly on the nidrib beneatl. Involuere nearly always hairy. Papjus browuish.— $\beta$. Taraxaci; l. glabrous, stalk mostly simple, involucre shacrgy with greenish-black hairs. Apargia Taraxaci

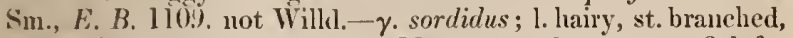
iuv, as in $\beta$, plaut very large.-Meadows and pastures. $\beta$. lofty mountaius. $\gamma$. lighland glens, S. P. VIII.

\section{Tragopogon Linn.}

1. T. minor (Fries); involucre about twice as long as the florets, peduncles slightly thickened at the very summit, l. tapering into a loug slcuder poiut from a dilated base.-T. major Ilook. not Jacq.-St. 2 feet high, branched, ereet. L. clasping the stem, gradually tapering into a very long aeuninated point. Involuere 8 -leaved in 2 rows. Florets yellow, truneate, 5-toothed. Fr. of the margiual florets angular and striated, the angles squamosely toothed, the interstiees tubercular.-Meadows and pastures. 13.? VI. VII. Smaller Goat's-beard. E. S.

2. T. pratensis (L.); involucre equalling or shorter than the florets, pedinncles slightly thiekened at the very summit, l. linear kecled dilated at the base.-E. B. 434.-St. $1 \frac{1}{2}-2$ feet high, brancher, erect. L. elasping the stem, narrowing upwards and terminating in a very long linear-acuminate point. Involuere 8leaverl in 2 rows. Florets yellow, truncate, with 5 teeth. There are 2 forms of this plant; (a) with the involuere equalling the florets, and the fruit of the marginal florets obsoletely striated and squamosely-scabrous throughout; the other (b) with the involuere rather shorter than the florets and the marginal fruits (in my specimen) yellow slightly furrowed and quite smooth.Meadows and pastures, less frequent than the preediug. B.? VI, Field Gout's-beard.

†3. T. porrifolius (L.); involucre longer than the florets, peduncles much thickened upwards, 1 . tapering slightly dilated just above the base.-E. B. 638.-St. 3- 4 feet high, erect, branched. L. slightly broader just above the base theu gradually narrowing to an acute point. Heads twice as large as in the two preceding. Involucres usually $\frac{1}{3}$ longer than the florets, but sometimes only equalling them. Florets purple. Marginal fruits squamoscly-tubereular throughout but partieularly on the ribs. - T. major is probably only a yellow-flowered variety of this, as stated by Fries, but it has not been found in Britain.-Moist pastures near rivers. B. VI. Salsify. 


\section{Picris Linn.}

1. P. hieracioides (L.); rough with forked and hooked bristles, 1. lanceolate dentate or sinuated, upyer 1. somewhat clasping, hearls solitary terminating the stem and branches, outer involncral scales lax oblong bristly on the kecl glabrous on the margin, fr. constricted just below the pappus. - E. B. 196.-St. 1-3 fect high, branched above, rather corymbose, very rough. Florets yellow.-Dry banks. B. VII.-IX.

E. I.

\section{Irmmintiita Juss. Ox-tongue.}

I. H. echioides (Gaert.); hispid with rigid 3-fid and hooked hairs from tubereular bases, st. erect, involucral bracts 5 ovatecordate.-E. B.972.-St. 2-3 feet high, branched, covered, as well as the leaves and involucre, with strong prickles springing from white tubercles and with 3 minute hooks at the apex (glochidate). L. elasping.-Dry banks. A. VII.-IX.

Section 5. LACTUCE A. Reeeptacle generally without seales. Pappus filiform, very soft, deciduous, never feathery nor dilated at the base, silvery.

\section{Lactuca Linn. \\ * Beak elongated.}

1. L. saligna (L.); 1. with a prickly keel, upper 1. hinear entire acuminate with a sagittate base, lower 1 . pinnatifid, beak white twice as long as the fruit.-E. B. 707.-St. 2 feet high, slender, wavy, slightly branched. Heads in small alternate tufts forming long clusters. Florets yellow.-Chalky plaees and near the sea. B. VII. VIII. Least Listuce.

E.

2. L. virosa (L.); l. with a prickly keel horizontal oblong auricled and clasping mucronate-dentate or sinuated, beak white equalling the black fruit.-E. B. 1957.-St. 2-4 feet high, leafy, branelied above, panicled. IIeads scattered with numerous cordate acute bracts. Plant full of acrid milky juice.-Dry banks. B. VII. VIII. Acrid Lettuce.

E. S.

3. L. Scariola (L.) ; 7. with a prickly keel perpendicular arrowsliaped at the base and clasping sinuate, beak white equalling the pale fruit.-E. B. 268.-St. 2-5 feet high, leafy, panicled. Heads scattered with numerous heartshaped bracts. Juice rather less acrid than in the preceding. Waste plaees, rare. B. VII. VIII. Prickly Lettuce.

E. ** Beak short.

4. L. muralis (DC.) ; florets 5,1 . with a smooth keel lyrateruncinate angled and toothed clasping: terminal lobe largest angled, beak much shorter than the fruit, lieads panicled.-Pre- 
nanthes Sm., E. B. 457.-St. crect, a foot high, smooth, round, hollow, Florets bright vellow. Hnit black.-lianks and old walls. A.? (I'.Sm.) VII.

E. I.

\section{6. 'Taraxacum Juss.}

1. T. officinale (Wigg.) ; 1. muncinate toothed, fr. lincar-obovate blunt and squiniosely murieated at the summit longiturlinally striated with a long beak.-Stalks simgle-headed, radical. llorets yellow. L. all radical, very variable, glabrous or slightly hispicl. 'The following varieties may be noticel since tliey aro cousidered as speries by DeCandolle, but they are quite connected by intermediate forms.- I. Outer involucral scales reflexed or patent.-a. genuinnm; outer scales linear deflexed, fr. yellow its upper half muricated, glabrous or woolly at the crown of the root, 1. nuncinatc broal. Leontodon taraxacum Sm., E. B. 510.B. T. levigatum (DC.); outer scales erecto-patent ovate, fr. reddish-ycllow muricated at the summit, beak with a thickened and coloured base, l. runcinate-pinnatificl with unequal teeth. $\rightarrow \gamma$. T. erythrospermum (DC.); outer scales lanceolate adpressed or patent, fr. bright red muricated at the summit, beak with a thickened and coloured base, l. runcinatc-pinnatifil with unequal teeth and intermediate smaller ones. T. lavigatum Bab. Lowermost l. somctimes obovate and dentate not runcinate when it becomes T. obovatum DC. - II. Outer scales adpressed. $-\delta$. L. palustre (Sm.); outer scales ovate-acuminate, fr. pale yellow or brown muricnted at the summit, l. oblong and cutire sinuatedentate or runcinate; or outer seales ovate-lanceolate or ( $L$. leptocephalum R.) lanceolate. E. B. 553.-Very common, $\gamma$. in dry places, $\delta$. in bogs. P. III.-X. Dandelion.

\section{Crepis Linn.}

* Fruit gradually contracted into a long beak. BARKHaUsia Mloencl.

1. C. taraxacifolia (Thuil.); 1. rongh runcinate-pinnatifid, heads erect, involucre bristly and downy covering half the pappus its outer scales ovate-lanceolate with a membranous margin, bracts herbaccous, $f r$. all equally beaked.-Root fusiform. St. I-2 feet high, hispid, angular, furrowed, purple below, at length branched, corymbose. L. mostly radical lyrate-runcinate with retrorse teeth, or deeply pinnatifid with the terminal lobe large. Stem l. few, sessile, clasping, deeply pinnatifid and toothed. Florets ycllow, purple beneath. Fr. narrowing very gradially into a setaceous beak of about its own length, ribs rongh.Limestone districts. B. VI. VII.

E.

[2. C. setosa (IIall.); l. runcinate-dentate or lyrate-runcinate, st.-1. sagittate entire or inciso-dentate below, heads erect, inv. 
about covering the pappus, margin of the outcr laneeolate acute scales and the bracts the back of the inner scalcs and the ped. hispid with rigid simple bristles.-DC. Icon. Gall. $t$. 19.-Plant 1-2 fect high. Stem 1. large, ratler strapshaped, clasping.Cultivated land. Introdueed with seed. Essex, IIerts., IIants., Fife. A. VII. VIII.]

E. S.

3. C. fretida (L.); 1. hairy runcinate-pimuatifid, unopened heads nodding, involucre hairy and downy as long as the greatly protruded pappus its outer scales lanceolate acnte downy, marginal fr. slightly beaked shorter than the involucre, central ones with long beaks equalling it. - E. B.406.-Root slender, fusiform. St. 6-12 in. high, hairy, round, branched. L. mostly radical, stem l. few small lanceolate dceply tootherl at the base sessile. IIeads solitary, terminal, on long simple stalks. Midrib of the involucral scales at length much thickened and hardened. Ribs of the fr. rough.-Chalky plaees, rare. B. VI. VII.

E.

** Fruit narrowed upwards or obscurely beaked.

4. C. pulchra (L.); outer involucral scales ovate short adpressed, l. downy toothed, stem 1. arrowshaped clasping; paniele eorymbose, fr. about as long as the pappus obsoletely striated slightly attenuated upwards.-E. B. 23:5.--St. erect, downy. Lower 1. obovate runcinately toothed, stem l. small. Ileads small, florets yellow, involncre at length thickencd. Outer row of fruits often apparently without pappus.- "Hill of Turin near Forfar." Mr. G. Don. A. VI.-IX.

5. C. virens (L.); outer involucral scales adpressed linear inner ones glabrous within, l. lanceolate rcmotcly dentate runcinate or pinnatifid, uppermost $l$. linear-arrowshajed clasping with flat margins, st. subcorymbose, fr. shorter than the pappus oblong slightly attennated ipwards with smooth ribs.-C. tectorum Sm., not Linn., E. B. 1111 .-St. $1-3$ feet high. L. very variable. Florets yellow. The trme C. tectorum (L.) has revolute margins to its upper l., the inner side of the involucral scales downy, its fr. somewhat beaked and with scabrous ribs. It has not been found in Bitain.-Common. A. VI.-IX.

6. C. biennis (L.); outer involucral scales oblong-linear lax inner downy within, l. runcinate-pinnatifid hispid, uppermost l. lauccolate clasping dentate-pinnatifid, st. subcorymbose, fr. oblong slightly attemated npwards with smooth ribs and about as long as the pappus.- E. B. 149 ? (exeluding the fruit.)-St. $1-3$ feet high, hispid, nearly leafless above, branched in a corymbose manner. IJeads large, florets yellow. Angles of fr. often rough. L. radical and extending lialf-way up the stem.-Chalky places, rare? B. VI. VII. 
7. C. succisefolia (Tausch); involucral scales lanceolate-atlenuated outer ones very short adpressed, l. entice nearly glabrons oblong obtuse lower ones narrowed into a footstalk, upper $l$. sessile and somewhat clasping, st. corymbosc, peduncles and involueres glandular-liairy, fr. much striated sliglitly narrowed upwards as fong as the pajpus which is shorter than the involucre. -Hieraciun molle Sm., E. B. 2210.-St. crect, with few leaves, simple below. Heads few, florets yellow.-Woods in the north. P. VII. V'll1.

E. S.

8. C. paludosa (Mocneh); involueral scales laneeolate mueh attemated glandular-pilose outer ones short, l. ovate-oblong taper-pointed runcinate-clentate narrowed into a footstalk glabrous, upper $l$. ovate-lanccolate cordate and clasping acute entire or dentate, st. subcorymbose, fr. striated scarcely narrowed upwards.-Hieracium Sm., E. B.I094.—St. 2 feet high, leafy, simple, angular. L. large. 'Florets yellow. Scparated from this genus, with which it does not agree well in habit, by many authors, and named Aracium (Ncck.), bceause of its I-rowed rather rigid brittle pappus.-Damp woods and shady places. P. VII.-IX.

\section{Soxchus $\operatorname{Linn}$.}

I. S. oleraceus (L.); I. undivided or pinnatifid toothed clasping: auricles spreading arrowshaped, fr. transversely rugose and longitudinally ribbed, st. branched, heads subumbellate, involucres glabrous.- E. B. 843.-St. 2-3 feet high. Florets yellow.Common. A. VI.-VIII. Sowthistle.

2. S. asper (Hoffm.); l. undivided or pinnatifid sharply toothed elasping: auricles rounded, $f r$. longitudinally ribbed smooth, st. branehed, heads subumbellate, involucres glabrous.-E. B.S. 2765,2766 . - St. 2-3 feet high. Florets yellow.-Common. A. VI.-VIII. Sowthistle.

3. S. arvensis (L.); 1. lanceolate runcinate finely toothed eordate at the base, uppermost l. entire, st. simple, heads corymbose, involucre and peduncles glandular-hairy, fr. with transversely rugose ribs, root ereeping, - E. B. 674.-St. 3-4 feet high, leafy. L. long, acute. IIeads large, florets yellow.-Fields. P. VIII. IX. Corn Sowthistle.

4. S. pahustris (L.); l. linear-lanceolate "lower runcinate," upper l. simple, all arrowshaped spinosely-ciliated: auricles acute, st. simple, heads corymbose, involucre and peduncles glandular-hairy, fr. with finely-rugose ribs, root without scions.E. B. 935.-St. $4-6$ fcet high, leafy. Florets lemon-coloured. -Marshes, very rare. P. VII. VIII. 


\section{Mulgedium Cass.}

I. H. alpinum (Less.); 1. glabrous lyrate arrowslaped at the basc: terminal lobe large triangular-liastate acute, st. simple, hearls raccmose, bracts peduncles and involucres glandlular-liairy, fr. oblong not attcmuated with many ribs.-Sonclus creruleus Sm., E. B. 2425.-St. 3 feet high, glabrons below, leafy. I. gradually sinaller upwards, cordate on the barren shoots. II cads small, numerous. llorets bluc. A remarkably liandsome plant, and very distinct genus.-Clova Mountains. P. VIII.

Scction 6. HIERACE E. Receptacle generally without scales. Pappus filiform, rigid, brittle, never featlery nor dilated at the base, at length brownish or yellowish.

\section{Hieracium Linn.}

\section{* Piloscllæ. Stem resembling a scape. Root premorse.}

I. H. Pilosella (L.); st. leafless single-healed, scions creeping, l. elliptic-lanceolate or lanceolate entire hairy above hoary beneath, involucral scales linear-lanceolate, $-E, B . \mathrm{I} 093,-$ Florets pale lemon-coloured with a red stripe on the back. Involucral seales in 2 rows, outer short, inner longer acuminate.$\beta$. Peleterianum (Gaud.); scions short, l. and involucres clothed with long silky hairs, 1. lanceolate-Dry banks. $\beta$. dry elevated hills. P. V.-VIII. Mouse-ear Hawkweed.

[2. H. dubium (L.?); "l. elliptic-lanceolate obtuse nearly entire besprinkled with coarsc hairs rather glaucous beneath, scions creeping elongated, stalks nearly smooth loosely corymbose, cal. bristly." Smith.-E. B. 2332.- "Stalk radical, 3-4-flowered." -Mount Fairfield, near Rydal, Westmoreland. Hudson. P. VII.]

[3. H. Auricula (L.?); "l. lanccolate acute ncarly entire coarsely hairy green on both sides, scions scarcely so long as the leaves, stalks downy and hairy corymbose, cal. sliaggy." Smith. -E. B. 2368.-Dalc Head, Grassmere, Westmoreland. Huds. P. VII.-It will be time enough to determine the correct nomenclature of this plant and the preceding when either of them is found in Britain.]

† 4. H. aurantiacum (L.); st. slightly leafy below clothed with long slender hairs upper part and corymb with black glandular hairs intermixed with the slender simple ones, scions creeping, 1. ovate-oblong acute entire with simple not stellate pubescence green bencatlı.-E. B. 1469.-Corymb dense, 2-I0-flowered, thickly covered with black lairs and glands.-Hilly woods; a doubtful native, common in gardens. P. VI. VII. 
** I'ulmonarex. Stem more or less leafy. Root not premorse nor creeping. Radical leaves present at the time of flowering.

5. H. alpinum (L.); st. usually single-headled, l. lanceolate or clliptical narrowed into a footstalk entire or tootlied, stem l. one or more, involucre covered with long white silky hairs with a black base aud a few black seta: scales scurcely at all membranous at the edges linear-attemuated, florets exterually laairy.-E. B. 1110. - St. simple in the British plant, clothed with stellate pubeseence and long slender laaits black at the base. L. obovate-spathnlate; steu l. linear or linear-lanceolate. Involucral scales acute, outer oues lax. Florets bright yellow. In the branched forms the ped. scparate at an acute angle and are nearly straight.$\beta$. Halleri (IIook.); larger, radical 1. toothed oblong-lanceolate or lanceolate, hairs on the involucre much less white. H. villosum E. B. 2379 . (bad.) - Alpine locks; $\beta$. the more common form. P. VII. VIII.

E. S.

6. H. nigrescens (Willd.); st. usually single-headed, radical $l$. broadly ovate stalked coarsely toothed, stem-l. one lanccolate, inv. covered with nuuncrous black setæ having longer whitepointed hairs interspersed : scales linear-attenuated, fl. externally hairy.-II. pulmonarium E. B.2307.?-St. nearly al ways simple in British specimens. Closely resembling $H$. alpinum with which it agrees in having, when branched, acute-angled subdivisions. In cultivation it becomes many-headed but retains its characters in otlicr respects. - Mlpine rocks on the Grampian mountains. P. VII. VIII.

7. H. villosum (L.); st. with 1 or few heads, l. oblong-lanceolate attenuated below, stem l. sessile, upper l. ovate half-clasping, involucre covered with long silky hairs: scales attenuate from an oxate base outer ones lax.-L. st. and involueres with long silky yellowish hairs, mixed on the perluncles only, with stellate pubescence. St. simple or divided, with erect peduncles, and several leares. H. villosum E. B. is H. alpinum $\beta$.- "Rocks near Loch Callater, north of Clova. Mr. T. Drummond." Sm. Herb.! "Loch na Gar." Herb. Dalton, in York Museum. P.-S.

8. H. murorum (L.); st. bearing a single leaf, radical l. numerous persistent ovate or cordate with retroflexed teeth at the base rounded obtuse or attenuated at the extremity hairy beneath stalked, heads corymbose, inv. and ped, with white stellate pubescence and many black setæ.-E. B.2082.-St. erect, 12-18 in. high, rarely with morc than one leaf, often none. L. green, usually thin ; margins and under side hairy. Heads rather small. Ped. curved at their base.-L. often spotted above; or cæsioglaucous beneath.-Rocks, walls, woods. P. VI.-VIII.

9. H. Schmidtii (Tausch); st. bearing about one leaf, l. casioК 2 
glaucous oblong-lanecolate narrowed into a footstalk toothed: tecth all pointing upwards, st.-l. subsessile, heads corymbose, inv. and ped. white with stellate pulsescence with black setre and black-based lairs interspersed.-H. diaphanum a. Fries, Bab. -St. leafless or with one, rarely more, l. like the radical leaves. L. more or less casio-glaucous, hairy on the margins and under side.-Mlountainous districts. P. VII. VIll.

E. S.

10. H. Lawsoni (Sm.); st. bearing alyout one leaf forked with straight one-headed elongated ped. each subtended by a small leaflike bract, l. lanceolate or clliptical narrowed into a footstalk unequally and slightly toothed: tecth not retroflexed, inv. and ped. greenish-black with black setx and many white-tipped hairs. -E. B. 2083. H. diaphanum $\beta$. Bab.--st. rarcly with more than one leaf which is narrowed gradnally to its base and sessile, simple or 1-3 times forked. L. all pilose or denscly hairy on the margins and beneath, more or less tootlied or denticulate; rootl. numerous; petioles variable in length, usually very villose with long silky hairs. Heads large, solitary. Fl, cream-eoloured.Mountainous districts. P. VIl.

E. S.

11. H. vulgatum (Frics); st. leafy from the base, l. oblonglanceolate narrowed into a footstalk usually coarsely toothed : teeth all pointing upwards, heads corymbose, inv. and ped. white with stellate pubescence with black setx interspersed.- $H$. sylvaticum Sm., E. B. 2031.-St. erect. Barren radieal leafy tufts contemporaneous with the flowers. L. green, stalked, the margins and under side hoary; st.-l. 3 or morc, uppermost nearly or quite sessile.- $\beta$. maculatum (Hook.); l. ovate-lanceolate with strong teeth spotted with purple. $H$. maculatum Sm., E.B. 2121.- $\gamma$. pictum; "l. lanceolate spotted and clonded with purple above. H. pictum Sehleich." Hook.-Woods, banks and walls. P. VIl. VIII.

12. H. Lapeyrousii (Froel. ?) ; st. clothed with hairs leafy, rarlical l. ollong-ovate or oblong-lanceolate with shaggy winged petioles persistent, stem l. sessile clasping ovate taper-pointed, all with small tceth or nearly entire hairy, corymbose heads and upper part of the stem glandular-hairy.-E. B.S. 2916.-St. usually simple, $1-2$ feet high, terminating in a corymb of few large heads; with scattered stellate pubescence intermixcel with the hairs throughout, increasing in quantity upwards and densely eovering the petioles and lower part of the involucre. Stem l. narrowing downwards to a rounded somewhat enlarged truly clasping base. Upper half of the l. often tinged with purple. Involucral scales scarcely at all membranous at thc edges.-Teesdale. Garra Head, Antrim. Mr. D. Moore. P. VIII.

E. I.

13. H. cerinthoides (L.?); st. slightly hairy with few leaves, 
radical 1. oblong-lamceolate with slaggy winged petioles persistent, stem l. ovate-lanceolate or ovate taper-pointed gradnally narrowing quite to the base and half-clasping, all nearly cutire, heals few corymbose.-E. B. 2378. H. longifolium Schleich.?L. much longer and narrower than in the preceding, stem 3 . not at all romnded nor onlarged at the base and only imperfectly clasping.-" "Ilighlands of Scotlaud, not uncominon." Mr. G. Don ; but I suspect some mistake has occurred as it has not been again fonnd, and many of Don's specimens of other plants seem to bave been taken from native roots eultivated in his garden. Was not H. Lawsoni the plant found by him? The specimen in Sin. Herb. agrees with a plant in cultivation named H. cerinthoides in Linglislr and German botanical gardens which is not that of Gonan nor probably of Linn. although the latter may have inelnded it under that name. P. VIII.

14. H. amplexicaule (L.); glandular-hairy throughout, st. leafy, radieal 1. elliptical-oblong with small teeth narrowed into a winged petiole, stem 1. cordate acute sessile clasping lower toothed upper entirc, heads corymbose.-E. B. S. 2690.-Remarkable for having its stem, leaves and involucres viscid with glandular hairs. Sten $1-2$ feet high. Heads few. Fr. ribbed, not furrowed.-Clova Mountains and Cleish Castle. P. VII.-S.

*** Prenanthoidex. Stem leafy. Radical leaves withered or quite decayed at the time of flowering. Teeth of the corolla bearing jointed hairs externally.

15. $H$. denticulatum (Sm.); st. erect leafy panicled above, peduncles and involucres glandular-hairy, l, elliptic-laneeolate denticulate, lower l. tapering into a footstalk upper sessile ovate. -E. B. 2122.-St. 3 feet high, leafy throughout. Heads small numerous. Nearly allied to the next but with much more numerous black-based hairs and fewer setæ on the ped. and inv.; the cultivated plant is more like the next in this respect.-Subalpine glens in Scotland, rare. P. VII. VIII.

S.

16. H. prenanthoides (Vill.); st, erect leafy simple, peduncles and involucres glandular-hairy, involucres of few scales and nearly simple, 1. all sessile clasping denticulate, lower $l$. narrowed above the base, upper ovate, lowest much narrowed downwards, radical evanescent, $f r$. smooth slightly ribbed.-E. B. 2235.-St. 2-3 feet high, leafy thronghout. Heals small, numerous; inv. of searcely more than one row of equal scales and a row of very much smaller ones at the base, clothed with many setæ and a few black-based hairs. Radical l. stalked? This does not exactly agree with the plant of Villars which has quite entire leaves.River-sides in S. and the north of E. P. VIII. 
**** Sabandex. Stem leafy. Radical leaves withered or quite decayed at the time of flowering. Teeth of the corolla glabrous externally.

17. H. inuloides (Tausch!); st. erect leafy, peduncles and involucres stellate-pubescent, involucres of numerous imbricated scales : lowermost lax aurl rather distant, 1 . all sessilc the lowermost much uarrowed dowuwards, intermediate narrowed above their base, uppermost ovate-lanceolate, radical evanescent, $f r$. rough. - St. $2-4$ feet high, leafy throughont, hairy. Heals larger than those of $H$. prenanthoides; involucre of much more numerous seales, which decrease gradually in length, the lowermost descendiug on to the peduncle, slightly hairy and scarecly at all glandular; peduncles without hairs or glands. Fr. slightly ribbed. L. not clasping. My specimens agree well with those of Tausch $(P l$. Sel. Boh.).-Highland woods, Scotland. Cumberland and Teesdale. Mr. Borrer. P. VIII.

E. S.

18. H. boreale (Fries); st. erect scabrous leafy subcorymbose above, l. ovate-lanceolate or lanceolate toothed lower ones narrowed into a short petiole, upper $l$. subsessile with a rounded or cordate base, radical evanescent, ped. thickened under the head and with several seales, involucral scales adpressed in about 3 rows.-H. sabaudum Sm., E. B. 349.-St. 1-3 feet ligh, hairy or hispid below. Upper l, with a rounderl base. Corymb irregular. Ped. and base of inv. hoary with stellate pubescence and long hairs interspersed; seales with a slightly hispid keel, nearly uniform in colour, turning black in drying. Fr. dark brown or nearly black.--Or (H. sabaudum Bab.) st. often hairy throughout. Upper l. with a cordate base. Ped. and base of the invol. usually with many long hairs and fine but thin stellate pubescence; margins of scales slightly paler. Fr. usually red.-The true $H$. sabaudum is a very different plant with broad leaves, larger heads with an obtuse almost umbilicate base, ped. not thickened and beariug rarely more than one scale beneath the head. It inhabits the south of Europe.-Thickets and banks. P. VIII. IX.

E. S.

19. H. tridentatum (Fries); st. crect scabrous leafy shightly branched and panicled above, l. narrowed at both ends ovate-lanceolate or lanceolate coarsely toothed in the midlle, lowermost stalked evanescent, upper subsessile, involucral scales attenuated with pale margins, - H. rigidum Bab., Koch ed. 2, Fries Mant. ii. 48.-St. 2 feet high, stout, brauching slightly in the upper half, scabrous, somewhat hairy. Base of the involncre and slightly thickened scaly upper part of the perluncle loary with stellate pubescence : scales more attenuated and less regular than in $H$. boreale much overtopping the unopencd flowers, " their tips afterwards patulous." L. with a few (3) strong triangular or lanceolate 
teeth at about the middle, more or less hairy beneath. F'r. rough. - $\beta$. angustifolium; st. slenter, l. lanceolate with 2 or 3 lincarlanccolate teeth on each side.-Walls and banks. P. VI.Vill.

E. S. ?

20. H. rigidum (l'ries!); st. erect smooth leafy simple corymbose, l. narrowed at both ends ovate-laneeolate, npper l. lanceolate or lincar-lanceolate finely toothed subsessile, lowermost evanescent, involucral scales smooth adpressed with pale margins. $-H$. rigillum $\gamma$. Bab. H. lavigatum $\mathbf{F r}$. Mant. ii. 49. H. lanceolatum 'Tausch!, Vill.?-St. l-2 ft. high, subdivided at the summit only, or rarely, with 1 or 2 simple branches above the middle. Lorrermost stem leaves often closely placed so as to seem a radical cluster. Upper part of the peil. with a few scales, thickened upwards and as well as the base of the inv. more or less hoary with stellate pubeseence. Inv.-scales nearly glabrous.- $\beta$. pictum; 1. narrower spotted and clouded with purple above.-Mountainous districts. N. Wales. N. of England. P. VI. VII. E.

21. H. umbellatum (L.); st. erect nearly simple leafy corymbose above, $l$. oblong-lanceolate or linear uniform toothed or entire, lower l. narrowed into a dilated petiole, upper sessile, radical evanescent, involucral scales with recurved points uniform in colour.-E. B. 1771.-St. $2-3$ feet high, leafy throughout, hairy or glabrous, upper l. narrowing giadually to the base. Fr. dark brown.- $\beta$. Taylori; st. creet simple shightly downy, l. lanceolate, lower l. attenuated below, upper with a somewhat rounded base.-St. 3-4 feet high, stout, erect, with a terminal corymb of rather large heads. Upper part of the stem, peduncles and involucre hoary with stellate pubescence but without hairs.Thickets. $\beta$. Kenmare, Kerry. Dr. Taylor. P. VIII. IX.

\section{Anomalous Genus. Order AMBROSIACEF Link.}

\section{Xanthium Linn.}

*? 1. X. strumarium (L.) ; st. without spines, lower l. heartshaped 3 -lobed at the base eoarsely dentate, beaks of the fr. 2 straight. - E. B. 2544.-Involuere of the fr. oval, downy.-Rieh waste land, searcely naturalized. A. VIII. IX.

\section{Order XLVII. CAMPANULACEA.}

Cal. superior 5 -fid or entire. Cor. monopetalous, inserted on the ealyx, 5-lobed, regular or irregular. Stam. inserted with the cor. and alternate with its lobes; anth. distinct or cohering, 2-eelled, opening longitudinally. Fr. dry, capsular, opening by lateral fissures or valves at the apex, many-seeded. Embryo straight in the axis of fleshy albumen. 
Tribe I. LOBELIE E. Odd segment of the calyx anterior. Cor. irregular. Antl. collering. Style glabrous with a fringe of hairs below the stigma.

1. Lobelia. Cal. 5-fid. Cor. irregular, tube split to the base on the upper side, limb 2-lipped 5-parted. Anth. 5, coliering. Stigma blunt, surrounded by a cupshaped fringe. Caps. 2-3-celled, opening at the end by $2-3$ valves.

Tr. II. CAMPANULEAE. Odd segment of the calyx posterior. Cor. regular. Antl. usually free. Style pubescent.

2. JAsione. Cal. 5-fid. Cor. rotate with 5 long linear segments. Anth. cohering at their base. Style hairy, bifid. Caps. 2-celled, opening by a large somewhat valvular pore at the end.

3. Phyteuma. Cal. 5-parted. Cor. rotate with 5 long linear segments. Anth. free; filaments dilated at the base. Style hairy, 2-3-fid. Caps. 2-3-celled, bursting at the sides.

4. Campanula. Cal. 5-parted. Cor. mostly bellshaped with 5 broad and shallow segments. Anth. free ; filaments dilated at the base. Stigma 3-5-fil. Caps. not elongated, 3-5-celled, opening by lateral pores outside the segments of the calyx.

5. Specularia. Cor. rotate. Caps. linear-oblong, prismatical, opening by lateral pores between the calyeine segments. Otherwise like Campanula.

6. WAHLENBERGia. Cajs. half superior, 3-eelled, opening by $3-5$ valves 'within the calycine segments. Otherwise like Campanula.

\section{Tribe I. Lobeliea.}

\section{Lobelia Linn.}

1. L. Dortmanna (L.); 1. linear entire of 2 longitudinal cells, st. simple nearly naked.-E. B. 140.-L. blunt, $1-2$ in. long. St. 12-18 in. ligh. l'l. light blue, distant, in a simple raeeme, slightly raised above the water, the rest of the plant submersed. - Lakes with a gravelly bottom. P. VII.

2. L. urens (L.) ; st. nearly upright, lower l, obovate or oblong slightly toothed, upper lanceolate serrate, fl. in long terminal raccmes.-E. B. 953.-St. 12-18 in. high, leafy, branehed, angular, roughish. Racemes ereet, simple, lax. Fl. light blue.Bushy plaees in Devonshire, very rare. P. VIII. IX. E. 


\section{Tribe II. Campanulea.}

\section{Jasione Limn. Sheep's Scabious.}

1. J. montana (L.) ; root simple, l. bluntish oblong wavy, $f$. stalkel.-F. B. 882. - St. several from the crown of the root, 6 in. to 2 fect long, simple or brancherl, pilose, leafy below, bare aut usually glabrous above. Fl. small, in terminal bracteaterl heads. Bracts glabrous or hairy. Calyx-segments linear-sctaccons, glabrous. Cor. light blue.-Dry places. B. VII.

\section{Phyteuma Linn. Rampions.}

1. P. orbiculare ( $\mathbf{L}$.); heads of fl.globose of fr. oblong, l. crenate-serrate, lowermost cordate-ovate stalked, upper ones linearlanceolate sessile, outer bracts ovate-lanceolate attenuated, stignins 3.-F. B. 142.-St. 12-18 in. high, cach with 1 terminal had of bluc flowers.-Chalky downs. P. VII.

E.

2. P. spicatum (L.); heads of fl. oblong of fr. elongated cylindrical, lower l. cordate-ovate somewhat donbly serrate stalked, upper l. lincar-lanceolate sessile, bracts linear, stigmas 2.-E.B.S. 2598.-St. ' -2 feet high, cach with a solitary terminal head of cream-colourel flowers. Spike of fruit often 2-3 in. long.Woods and thickets about Waldron, Sussex.

P. VII.-E.

\section{Campanula Linn.}

* Caps. sessile, erect, pores at the base.

1. C. glomerata (L.); 1. minutely crenate-serrate lowermost stalked ovate-lanceolate generally cordate at the base, upper 1 . half clasping sessile ovate acute, $f$. sessile in terminal and axillary clusters.-E. B. 90.-St. 6-18 in. high. Bracts ovate-acuminate, shorter than the large erect flowers. Cal. hoary with lanceolate segments. Cor. funnel-shaped, large, deep blue, downy. L. often hoary beneath.-Dry pastures on limestone. P. VII. VIII. Clustered Bell-flower. E. S. ** Caps. stalked, nodding, pores at the base.

2. C. latifolia $(\mathrm{L}$.$) ; l. ovate-lanceolate acuminate doubly ser-$ rate hairy lower ones stalked, upper l. nearly sessile, $\mathrm{fl}$. racemose, peduncles l-flowered, cal.-segments lanceolate acuminate glabrous finely serrate, st. erect slightly angular.-E. B. 302. St. 72. 3. - St. 3-4 feet high, simple, leafy. Cor. very large, deep blue, glabrous, hairy within.-Woods and thickets in the nortl. P. VII. VIII. Giant Bell-flower.

3. C. Trachelium (L.) ; l. coarsely double serrate hispid lower ones cordate with long stalks, upper l. nearly sessile ovate or lanceolate-acuminate, fl. racemose, peduncles 2-3-flowered, cal.-segments triangular-lanceolate entire ereet, st. erect angular. 
-E. B. 12.-St. $2-3$ feet ligh, mostly simple, leafy. Cor. truly bellshaper, large, decp blue.-Hedges and thickets chiefly in the south. P. VIII. VIII. Nettle-leaved Bell-flower.

4. C. rapunculoides (L.); l. unequally crenate-serrate scabrous lower ones cordate with long stalks, upper l. sessile lanceolate, $f l$. racemose unilateral, peduncles l-fiowered, cal.-segments linearlanceolate entire at length reflexed, st. erect slightly angular, root crecping. - E. B. 1369.-St. 2 feet high, simple, leafy. Cor. pale blue.-Woods and hedges, very rare. P. VII. VIII. E. S.

5. C. rotundifolia (L.); radical l. cordate or reniform shorter than their stalks, stem l. linear the lower ones lanccolate, fl. 1 or more racemose, cor. turbinate-campanulate.-E. B. 866.-St. 6-12 in. high. Radical l. soon vanishing. Cor. blue. Cal.segments linear-subulate-Dry and hilly places. P. VII. VIII. Hairbell.

*** Caps. stalked, erect, pores immediately below the calycine segments.

6. C. persicifolia (L.); l. smootl slightly serrate, radical l. obovate narrowed into a petiole, stem 1. linear-lanceolate sessile, raceme few-flowered, cal.-segments lanceolate-E. B. S.2773.St. $1-2$ feet high. L. long, narrow, with very narrow serratures. Fl. very large, often solitary. Cal.-segments entire.-"Woods neal Cullen." A very doubtful native. P. VII. S. ?

7. C. Rapunculus (L.); 1. crenate, radical 1. elliptic-lanceolate narrowed into a petiole, stem 1 . linear-lanceolate, panicle erect racemose, cal.-segments subulate.-E. B. 283.-St. 3 feet high, angular, rough. Fl. small, pale blue. Cal.-segments entire.Sandy soil in the south. P. VII. VIII. Rampions. E.

8. C. patula (L.); l. crenate, radical l. oblong-elliptical narrowed into a petiole, stem l. linear-lanceolate, panicles lax, $f$. on long stalks erect, cal.-segments toothed at the base subulate.E. B. 42.-St. 2 feet ligh, terminating in a very loose spreading panicle. Fl. blue, funnelshaped, open.-Hedges and thickets. B. VII. VIII.

E.

\section{Specularia Heist.}

1. S. hybrida (A. DC.); st. simple or branched, l. slightly crenate wavy oblong sessile, lower l. spathulate, cal. scabrous : segments lanceolate longer than the cor. shorter than the ovary.Campanula Sin., E. B. 375.-St. 6-12 in. high, rough with rigid minute hairs. Fl. few, terminal, solitary, small.-Corn-fields. A. V1.-IX.

\section{Wahlenbergia Schrad.}

1. W. hederacea (Reich.); l. roundish-cordate angularly 5-lobed 
stalked alternate, st. filiform prostrate, peduncles solitary, "seeds punctate."-Campanula Sm., E. B. 73.-St. branched and creeping to a great extent. Peduncles longer than the leaves. Fl. pale blue, at first noddling, afterwarls ereet. Cal.-segmeuts subulate. Caps. nearly globose.-Damp peaty places in the south and west. P. VII. VIII. Ioy-leaved Bell-flower.

\section{Order XLVIII, ERICACEA.}

Cal. 4-5-parted, persistent. Cor. monopetalous, 4-5-parted, usually regnlar aud marcescent. Stam. 8-10. Anth. 2-celled, opening by pores and often appendaged. Ovary surrounded by a disk or seales, free or adliering to the corolla. Fr. eapsular or baccatc with several cells, many-seeded.

Tribe I. ARBUTEA. Fr. baccate, fleshy. Anth. 2-celled. Disk liypogynous.

1. Arbutus. Cal. 5-parted. Cor. globose or ovate-campanulate with a small contracted 5 -cleft reflexed border. Stam. 10 with flattened filaments. Anth. compressed, with 2 pores at the apex, fixed at the back beneath the apex and there furnished with 2 reflexed awns. Berry globose, granular; cells 5, many-seeded.

2. Arctostaphylos. Fr. with 5 l-seeded cells, not granular externally. Otherwise like Arbutus.

Tr. II. ERICEAE. Fr. capsular, dry. Anth. 2-celled. Disk lypogynous. Testa close.

3. Andromeda. Caps. dry, of 5 cells and 5 valves. Otherwise like Arbutus.

4. Calluna. Cal. 4-parted, membranous, coloured, longer than the 4-cleft campanulate corolla, surrounded by 4 green . bracts. Stam. 8, with dilated filaments. Caps. 4-celled; dissepiments adhering to the axis; valves opening at the dissepiments and separate from them.

5. Erica. Cal. 4-parted. Cor. eampanulate or ovate often ventricose, 4-toothed. Stam. 8. Caps. 4-celled; valves opening between the dissepiments and carrying a part with them.

6. Phy llo doce. Cal. 5-parted. Cor. ovate with a contracted 5-toothed mouth. Stam. 10, included; filaments slender, longer than the anthers; cells short, truncate, opening by pores at the apex. Stigma peltate with 5 tubercles. Caps. 5 -celled with 5 valves opening at the dissepiments. 
7. Da всеста. Cal. 4-cleft. Cor. ovate, ventricose, limb 4toothed. Stam. 8, included; filaments flattened shorter than the linear anthers which are sagittate below; cells loosened and opening by oblique pores at the apex. Stigma simple truncate. Caps. 4-eelled with 4 valves opening at the dissepiments.

8. Azalea. Cal. 5-parted. Cor. campanulate, 5-eleft. Stam. 5 , equal, shorter than the corolla; antlı. roundish; cells opening by a longitudinal fissure. Stigma capitate. Caps. 2 -3-celled with 2 or 3 bifid valves whose inflexed edges form the double partitions.

Tr. 1II. VACCINEA. Fr. baccate, fleshy. Anth. 2-celled. Disk epigynous.

9. Vaccinium. Cal. entire or 4-5-toothed or lobed. Cor. 4-5-eleft or toothed. Stam. 8-10; anth. oblong, bifid at the summit. Berry globose, crowned by the persistent limb of the calyx, 4-5-celled, many-seeded.

Tr. IV. PYROLE $E^{1}$. Fr. capsular, dry. Secds witl a loose testa. Disk 0. Anth. opening by pores.

10. Pyrola. Cal. 5-parted. Col. of 5 petals. Stam. 10 ; anth. inverted, with 2 cells each opening by a round pore at the base. Style 5-lobed. Caps. 5-celled, 5-valved, opening near the base, margins of the valves conneeted by a web.

11. Moneses. Cal. 5-parted. Cor. of 5 petals connected below. Stam. 10; antll. inverted with 2 cells each furnished with a tubular horn opening at the end. Stigma 5-parted, radiant. Caps. 5-celled, 5-valved, "opening from the summit" with eonneeted margins.

Tr. V. MONOTROPEA. Fr. capsular, dry. Seeds with a loose testa. Disk 0. Anth. opening by a transverse fissure.

12. Monotropa. Cal. 4-5-parted. Cor. of 4-5 petals, each with a hooded nectariferous base. Stam. 8-10. Anth. kidney-shaped, l-celled, 2-valved. Stigma peltate. Caps. 5 -celled, 5-valved, many-seeded.

\section{Tribe I. Arbutea.}

\section{Arbutus Linn.}

1. A. Unedo (L.); bark rough, l. elliptic-laneeolate serrated coriaccous glabrous, paniclc terminal nodiling, pedicels glabrous. -E. B. 2377 . - An evergreen tree. Fr. whitish, pendulous. Fr. red.-Killarney, where it is truly wild. T. IX. X.

${ }^{1}$ Combined with Droseracea by Coss. and Germ. (Fl. Par. 66) under the name of Roridulece. 


\section{Arctostapliyos Adans.}

1. A. alpina (Spr.); procumbent, $l$. wrinkled serrated deciduous, clusters terminal.-Arbutus Sm., E. B. 2030. St. 6. 8.St. wooly, trailing, long. L. obovate, reticulated. Fl. white, hairy abont the montl. lerry smootl, black.-Mountainons leatls in the north. Sh. V.

S.

2. A. Uva-ursi (Spr.); jrocumbent, l. obovate entire shining evergrecn, clisters terminal.-Arbutus Sin., E. B. 714. St.6.8. -St. woody, trailing, long. L. obtuse, quite entire. Fl. rosecoloured, smootl. Berry globose, scarlet.-Dry stony alpine heaths. Sl. VI.

\section{Tribe II. Ericea.}

\section{Andromeda Linn.}

1. A. polifolia (L.); 1. alternate lanceolate with revolute margins glaucous beneath, fl. subumbellate terminal.-E. B. 713 . - St. slender, woody, prostrate below. Fl. drooping, ovate, pink. L. evergreen, acute. Peduncles 2 or 3 times as long as the flowers, not as in E. B.-Peat bogs. Sh. V.-IX.

\section{Calluna Salisb.}

1. C. vulgaris (Salisb.).-E. B. 1013.-A low tufted shrub with small sessile closely imbricated keeled leaves arranged in 4 rows, each 1 . having 2 small spurs at the base and nearly or quite smooth. Fl. small, shortly stalked, drooping, rose-coloured or white.- $\beta$. tomentosa; 1. hoary.-Dry heatlss. Sh. VI.-VIII. Common Heath. Ling.

\section{Erica Linn.}

* Cor. globose or urceolate, stam. included, filaments capillary, stigma peltate. ERICA D. Don.

1. E. Tetralix (L.); $l .4$ in a whorl lanceolate or linear ciliated downy above and on the midrib beneath: margins revolute, fl. capitate, sep. linear downy ciliated, antl. awned, ovary downy.E. B. 1014.-St. branched below, often in a determinate manner about the middle, simple in the upper part, densely leafy below, the whorls more distant towards the top and usually leaving a leafless space next to the flowers. Young l. always downy above, old 1. sometimes glabrous. Sep. downy and mealy. Fl. rosecoloured. Style usually included.-Boggy heaths. Sh. VII. VIII. Cross-leaved Heath.

2. E. Mackaiana (Bab.); $l .4$ in a whorl ovate ciliated the midrib beneath and upper surface glabrous : margins revolute, $\mathrm{fl}$. capitate, sep ovate-lanceolate glabrous, anth. awned, ovary gla- 
brous.-E. B. S. 2900.-St. irregnlarly branehed throughout, particularly above, dienscly and equally leafy quite up to the flowers. L. and sepals quite without down, l. mealy beneath: midrib bare, sep. with a sinall portion of meal ncar the apex beneath otherwise quite barc. Fl. purplish. Style protruded.Between Roundstone and Cliften, Cunnamara. Sll. VIII. IX. Mackay's Heath.

3. E. cinerea (L.); $l .3$ in a whorl linear-lanecolate aeute keeled beneath with a central furrow glabrous, $f$. in dense whorled racemes, sep. lincar-lanceolate smooth acute keeled, anth. awned, ovary glabrous. - E. B. 1015.-St. with numerous upright branches. L. Hat above, minntely serrulate. Fl. resldish-purple.-Dry heaths. Sh. VII. VIII. Fine-leaved Heath.

4. E. ciliaris (L.); $l .4$ in a whorl ovate ciliated the margins revolute, $f$. in terminal unilateral racemes, anth. without awns, mouth of the cor. oblique.-E. B. S. 2618.-St. long, straggling, each terminatiug in a long raceme of large oblong purple flowers and producing numcrous short barren branches. Style protruded. -Ileaths. Warcham, Dorset. Carclew, Cornwall. Said to have been found in Cunnamara, I. Sh. VII. VIII.

** Cor. campanulate or shortly tubular, stam. exserted, filaments flattened, style capitate. Gypsocallis D. Don.

5. E. mediterranea (L.?); l. 4 in a whorl linear glabrous flat above convex with a central furrow beneath, decurrent line from the l. reaching but not extending beyond the next whorl, fl. axillary drooping racemose, cor. cylindrical-urceolate twice as long as the coloured calyx, anth, without awns opening throughout nearly their whole length.-E. B. S. 2774.-St. $2-5$ feet ligh, with numerous, upright rigid branches terminating in leafy racemes of flesh-coloured Howers but afterwarls prolonged. L. numerous crecto-patent. Bracts above the middle of the pedicels. Stam. and style slightly exserterl, style afterwards elongated. Germen glabrous.-Our plant differs from $E$. carnea, to which it is referred by Bentham (DC. Prod. vii. 614.), by its 1 . having a longitudinal furrow and not keel on the back, the decurrent ridge from their base not extending beyoul the next whorl (in $E$. carnea it reaches the second), the anthers much shorter and their pores much longer in proportion, and the eor. of a different slape. I am unable to deteet any distinction between our plant and a beautiful specimen of $E$. mediterranea from Portugal (IFelw. Iter Lusit. 31.). The name is bad; the plant being, it is said, confined to the Atlantie coast.-Mountain hogs in the west of Mayo and Galway. Urrisbeg; Curraau Achil; Burrishoole Lake; \&c. Sh. IV.

6. E. vagans (L.); 1. 4-5 in a whorl linear glabrous, $\mathbf{t}$. axil- 
lary erowded, cor. short campanulate, sep. small ovate ol,tuse, anth. ovnte of 2 distinct cells gibbous nt the base.-E. B. 3.St. 1-2 feet high, copionsly brancherl. H. usually collected in large numbers considerably below the top of the branches, cor. resl or white. Antli. dark purple. Germen glabrous.-Westeru parts of Cornwall. Coast of Waterford. Sh. VII. VIII. Cornish Heath.

E. I.

\section{Pinllodoce Salisb.}

1. P. corulea; 1. linear denticulated, ped. glandular-hairy, calyeine segments lameeolate acute, anth. 3 times shorter than the glabrons filaments.-Menziesia Sm., E. B. 2469.-St. 4-5 in. ligh, determinately branched, naked below, densely hairy above. Ped. terminal, aggregate, simple. Fl. large, pale, bluish-red.Sow of Athol, Perthshire; nearly if not quite extirpated by an Edinburgh nursery-man. Sh. V'I. VII.

\section{Dabecia D. Don.}

1.D. polifolia (D. Dou).-Menziesia Sm., E.B.35.-St. bushy, 1-2 fect loug, ultimately decumbent. L. ovate or elliptical, Hat, with revolnte margins, white and cottony beneath. I'l. large, purple, sometimes white, drooping, on short stalks, in terminal simple unilateral elusters. Anth. very large.-Cimnamara. Sh. VIII. Cunnamara or St. Dabeoc's Heath.

\section{Azalea Linn.}

I. A. procumbens (L.).-E. B. 865. Loiseleuria Desv., DC. The original Azalea of Linnæus and only speeies.-St. woody, spreading, procumbent. L. small, opposite, revolute. Fl. small, on simple stalks, terminal, aggregated.-Summits of the highland mountains. Sh. V. VI.

[LEDUM palustre is not known as a British plant.]

\section{Tribe III. Vaccinea.}

9. Vaccinium $\operatorname{Limn}$.

* Anthers with 2 dorsal horns.

1. V. Myrtillus (L.); l. ovate serrated glabrous deeiduous, $f$. solitary, st. acutely angular.-E. B. 456.-St. woorly, abont a toot high, brauching. Fl. greenish, tinged with red, nodding. Berries black.-Stony woods and heaths. Sh. V. Bilberry.

2. V. uliginosum (L.); l. obovate entire glaucous and veined beneath deciduous, fl. aggregate, st. rounded.-E. B. 581. St. 12. -St. woody. Fl. flesh-eoloured, norlding. Berries blaek.Mountain bogs. Sh. V. Bog Wortleberry. 


\section{** Anthers without horns on the back.}

3. V. Vitis-idea (L.) ; l. obovate dotted beneath persistent: margins revolute and somewhat crenate, $\mathrm{fl}$. racemose terminal, cor. campanulate.-E. B. 598,-St, woody, 6-8 in. high, straggling. L. like those of box, dark green above. Fl. pink, 4-cleft. Berries red.-Mountain heaths. Sll. VI. VII. Red Wortleberry. Cowberry.

4. V. Oxycoccos (L.); l. ovate entire persistent with revolute margins glaucous beneuth, $\mathrm{fl}$. terminal on long simple peduncles, cor. rotate with reflexed segments.-E. B. 319. Oxycoccus palustris DC.-St. procumbent, filiforn, rooting. L. smalI. F'l. bright rose-colour. Cor. dceply divided, remarkably reflexed. Berries crimsou.-Wet bogs. Sh. Vl. VII. Cranberry.

[V.macrocarpum (Ait.); l. oblong with flat margins, fl. lateral on long simple perluncles; has been found in Loughton Bog, Mould, Flintshire. It has probably been sown there. Phytol. ii. 44I.]

\section{Tribe IV. Pyrolea.}

\section{Pyrola Linn.}

I. $P$. rotundifolia $($ L.) ; l. nearly round entire or slightly crenate, fl. racemose, cal.-segments lanceolate acute, stam. ascending style much longer bent down and curved upwards at the end, stigma annular with 5 erect blunt points.-E.B.2I3.-Fl. white, rather numerous, expanded. Style longer than the petals. Stam. all turned upwards. L. numerous.-In a plant found on the coast of Lancashire by Mr. Kenyon the cal.-segments are shorter and broader and the st. has more numerous bracts.- $[P$. chlorantha (Sw.) differs by having its cal.-segments as broad as long and antlı. with long tubular pores.]-Damp bushy places and reedy marshes. P. VIII.

E. S.

2. P. media (Sw.) ; l. nearly round or roundish-oval slightly crenatc, fl. racemose, cal.-segments ovate acutc, stam. regularly inflexed style longer nearly straight declining, stigma annular with 5 erect points. - E. B. 1945.-Fl. milk-white, tinged with pink, rather numerous, less expanded than in the prcceding. Style projecting a little beyond the corolla, always nearly straight. Stam. all regularly incurved round the germen. L. numerous. -Woods in the north. P. VII. VIII.

3. P. minor (L.); l. roundish-oval crenate, fl. racemose, cal.segments ovate-triangular acute, stam. regularly inflexed style the same length straight, stigma without a ring 5 -lobed pointless. - E. B. 2543 and I58 (bad). St. 13. I2.-Fl. pale pink, numerons, on very short pedicels, nearly closed. Style very short, included. Stam. all equally inflexed. L. numerous.-Mossy woods and thickets. P. VII. 
4. P. secunda (L.); l. ovatc acute serratcil, $f$. in a secund raceme, cal.-segunents triangular rounded notehed, stam. regularly incurved style long straight, stigma 5-lobed without a ring or points.-W.B.517. St. 13. 13.-Fl. white, drooping, oval-oblong. nearly closed. Style very long, exserted. L. numerous,-Mossy alpine woorls. l'. V'Il.

\section{Moneses Salisb.}

1. M. grandiflora (Salisb.).-Pyrola Sm., E. B. 146.-L. few, roundisl,, serruted. Fl. solitary, terninal, large, drooping, white, opeu, nearly an inch broal. Stam. shorter than the pet. and closcly arlpressed to theur. Stigmas very large.-Alpine woods, rare. P. VI. VII. S.

\section{Tribe V. Monotropece.}

\section{Monotropa Linn.}

1. M. Hypopitys (L.); fl. in a drooping cluster, lateral ones with 8 terminal with 10 stamens, fr. erect, bracts and fl. glabrous externally.-E. B. 69.-Inner side of the pet., filaments, germen and style glabrous (Hypopitys glabra Bernh., DC.), or hairy (H. multiflora Scop., DC.).-Plant $6-8$ in. high, succulent, simple, clothed with ovate scales, termiuating in a short cluster, dingy yellow, at length turning nearly black. 11. with large scaly bracts. Not parasitical. (Phytol. i. 341.) Clusters sometimes erect.-Woods. P. VII. VIİI. Yellow Bird's-nest.

\section{Order XLIX. ILICINEE.}

Sep. inferior, 4-6, imbricated. Cor. regular, 4-6-parted, imbricate. Stam. inserted into the base of the corolla and alternate with its lobes. Disk 0 . Orary $2-6$-celled; ovules solitary, pendulous, with a cupshaped fimiculus. Fr. fleshy, not bursting; scerls stony, $2-6$.

1. Ilex. Cal. 4-5-fil, persistent. Cor. rotate, 4-5-fid. Stam. 4-5, inserted upou the corolla. Stigmas 4-5, nearly sessile. Fr. Heshy, containing $4-5$ l-seeded nuts.

\section{ILEX Linn. Holly.}

1. I. Aquifolium (L.); l. ovate acute spinous wavy shining, peduncles axillary short many-flowered, fl. somewhat umbellate. -E. B. 496. St.7. 4.-A sinall tree. L. evergreen, often quite entire on the upper branches, elged with strong spiuous teeth and terminated by a spine on the lower ones. Fl. white. Berries scarlet.-Woods and helges. T. VI.-VIII. 


\section{Orter L. OLEACEF.}

Cal. monosepalous, divided, persistent. Cor. with 4-8 divisions, rarely 0 , valvate. Stam. 2. Ovary free, 2 -cclled; ovules in pairs, pendulous. Stigma entire or bifid. Fr. a berry, drupe or capsule, often 1-seeded. Albumen dense or none.

1. Ligustrum. Fr. fleshy, a berry containing 2 membranous 1-seeded nuts. Cal. cupshaped with 4 minute teeth. Cor. fuunelshaped, limb 4-cleft spreading. Stam. 2.

2. Fraxinus. Fr. dry, a pentulous samara of 1 or 2 singleseeded cells, Cal. 0 or 4 -cleft. Cor. 0.-Fl, sometimes without stamens.

\section{Ligustrum Limn. Privet.}

1. L. vulgare (L.); l. elliptic-lanceolate entire glabrous, panicles terminal compound dense.-E. B. 764. St. 14. 1.-A bushy shrub, $6-8$ feet high, with straight smooth branches and opposite leaves. Fl. white. Beries globosc, black, rarely yellow. -Thickets in the sonth of England. Sh. VI. VII.

E.

\section{Fraxinus Limn. Ash.}

1. F. excelsior (L.); 1. pinnate with $4-8$ pairs of nearly sessile ovate-lanceolate acmminate serrate lcaflcts, cal. wanting. -E. B. 1692. St. 44. 7.-A handsome tree. Fl. appearing before the l., in axillary clusters. $\beta$. heterophyllus (Hook.), l. simple and pinnate.-E. B. 2476.-Woods and hedges.

\section{Order LI. APOCYNE E.}

Cal. in 4 or 5 persistent divisions. Cor. regular, $4-5$-lobed, deciduous, contorted. Stam. 5, filaments distinct. Anth. 2celled, pollen granular. Ovaries 2, 1-celled; or 1 of 2 cells. Stigma 1. Seed with fleshy albumen.

1. VINCA. Cor. salvershaped; tube long with 5 angles at the mouth, closed with sprealing hairs and the connivent stamens; limb flat, 5-lobed. Styles 5. Stigma capitate with a ring at its basc. Fr. of 2 erect elongated follicles.

\section{VINCA Linn. Periwinkle.}

1. V. minor (L.) ; st. procumbent, l. lanceolate-elliptical, their margins as well as those of the small lanceolate calyx-segments glabrous. - E. B. 917.- St. prostrate, rooting, flowering branches erect. Fl. smaller than those of the next, blue, rarely white.Woods and thickets. P. V. VI. Lesser Periwinkle.-E. S.? I. ? 
*2. V. major (L.); st. somewhat ascending, I. ovate acute or subcordate, their margins as well as those of the clongate-subulate ealyx-segments ciliated.-E. B.514.-St. at fir'st ascending, afterwarls prostrate and rooting, flowering shoots erect. lil. large, purplish-bluc.-Hedges and thiekets, naturalized. P. IV. V. Greater Periwinkle.

E. S.? I.?

\section{Order LII. GENTIANACE $A$.}

Cal. inferior, persistent. Cor, regular, 4-8-fid, hypogynous, marcescent ; xstivation imbricate-twisted. Stam. inserted on the cor., as many as the segments. Ovary of 2 carpels with the edges slightly inflexed or meeting. Caps. or berry many-seeded, generally 2 -valved.

Subord. I. GENTIANEA. Astivation of the corolla twisterl. L. opposite.

* Style deciduous.

Tribe I. CHLOREAE. Corolla rotate.

1. Chlora. Cal. 8-parted. Cor. nearly rotate, 8-parted. Stam. 8. Style 1. Stigma 2-4-eleft. Caps. 1-celled, placentas on the inflexed margins of the valves.

Tr. II. ERITHR EEA. Corolla funnelshaped.

2. Erythrasa. Cal. 5-fid. Cor. funnelshaped, limb short 5-fil. Staul. 5. Anth. erect, at length spirally twisted. Style simple, stigmas 2. Caps. imperfeetly 2-celled from the inflexed margins of the valves.

3. Crcendra. Cal. 4-lobed, tubular. Cor. funnel-shaped, limb short 4-fid. Stam. 4. Anth. erect, not twisted. Stigma eapitate, undivided. Caps. 1- or imperfectly 2-celled.

** Style persistent or stigma sessile.

Tr. III. SWERTIRE. Style often wanting, stigma persistent.

4. Gentrana. Cal.4-5-cleft. Cor. funnel-or salver-shaped, limb 4-5-cleft. Stam. 4-5. Stigmas 2. Caps. 1-eelled, seeds on the inflexed margins of the valves.

Subord, II. MENYANTHIDEF. Nistivation of the corolla induplicate. L. alternate.

5. Vrllarsia. Cal. 5-parted. Cor. rotate; limb 5-parted, smooth on the disk, bearded or sealy at the base. Stam. 5 . Stigma with 2 toothed lobes. Caps. 1-celled with sutural placentas, 2-valved (in our plant), not bursting. 
6. Menyanthes. Cal. 5-parted. Cor. funnelshaped; limb 5-parted, bearded intcrnally. Stam. 5. Stigma capitate. Caps. I-celled, 2-valved, " valves bearing the sceds in their axis."

\section{Suborder I. Gentianea. Tribe I. Chlorea.}

\section{Cinlora Limn. Ycllow-wort.}

I. C. perfoliata (L.); lowermost I. elliptic-oblong narrowed below, stem l. broadly perfoliate.-E. B. 60.-St. 12-I8 in. high, simple. Stem l. triangular-ovate, connected by thcir whole brealdth iu rather distant pairs, glaucons. Panicle forked, manyflowered. Cal. divided to its base into linear-subulate segments. Cor. briglit yellow. Stigmas yellow.-Dry calcareous hills. A. VII.-IX.

E. I.

Tribe II. Erythrace.

\section{Erythrasa Renealm.}

I. E. pulchella (Fries); st. erect inuch branched acutely quadrangular, I. ovate the uppermost oblong-lanccolate, fl. all stalked axillary and tcrminal, cal. rather shorter than the tube of the opening corolla, lobes of the cor. clliptic-oblong obtuse-E. B. 458. E, ramosissima Griseb.-St. sometimes quite simple, $\mathrm{l}$ in. higlı and single-flowered; at otleer times very much branched, even from the base, $6-8$ in. high, with very numerous flowers. Radical l. very few. Inflorescence dicliotomously divided, the lateral $f$. distant from the floral leaves. The length of the tube must be observed exactly at the time when the flower is about to expand.-Sandy ground. A. VII.-IX.

2. E. Centaurium (Pcrs.); st, erect branched above quadrangular, l. elliptic-obloug the upper ones acute, fl. nearly sessile corymbosely panicled, cal. not half as long as the tube of the opening corolla, lobes of the cor. oval.-E. B. 417.-St. 6-I8 in. higl, usually simple below. Panicles of $\mathrm{fl}$. lax. Lateral $f$. apparently staiked but sessile between the small floral leaves. Radical l. numerous.-Dry pastures. A. VII. VIII. Common Centaury.

3. E. latifolia (Sm.); st. short branched from the base quadrangular, 1. broadly elliptical obtuse, $f$. in dense forked tufts sessile, cal. rather shorter than the tube of the opening corolla, lobes of the cor. lanccolate.-E. B. S. 27 I9.-St. thick, 2-3 in. high, sometimes taller and branched, usually dividing into 3 main branches. Fl. densely aggregated. Radical l. very large, with 5-7 ribs, numerous. "Cor.-lobes sometimes oval."Mr.Watson. -Near the sea-slore. A. VI.-VIII.

E. I. 
4. E. linarifolia (Pers.); st. simple solitary or several from the crown of the root, l. oblong-linear obtuse ninrowed below, radical 1 . crowded spathulate, $f$. sessile densely corymbose, calyx as long as the tube of the opening corolla, bobs of the cor. oval obtıse.-E. littoralis sm., E. B. 2305. - St. 2-6 in. high, solitary or sevcral, simple, with scabrous angles. Inflorescence usially trichotomous, dense, branches somctimes clongated. Radieal 1 . only slightly larger than those of the stem, numerous.Santly sea-shores. A. VII. VIII.

\section{Cicendia Allans.}

1. C. filiformis (Reich.); cal. half tubular adpressed to the subglobose tube of the eorolla, lobes ovate acute, st. threadsliaped forked, fl. solitary on long stalks.-Eracum Sin., E. B. 235. Microcala Griseb),-St. very shender, 1-4 in. high. Radical 1. lincar-lanceolate, stem 1. subulate, all sessile. Fl. ycllow. Caps. with the edges of the valves uot inflexed.-Damp sandy places. A. VII. VIII.

E. I.

\section{Tribe III. Swertia.}

\section{Gentiana Linn.}

1. G. Amarella (L.); cor. salvershaped 5-cleft bearded in the throat, cal.-segments 5 nearly equal linear-linceolate, 1. sessite ovate-lanceolate; radical 1. obovate.-E. B. 2336.-Very variable in size and in the number of the fowers, 3-12 in. high, ereet. St. square, much branched. Fl. pale purple.-Grisebach distinguishes $G$. germanica from this by its acuninate calyx lobes, obconical tube of the corolla, and stalked capsules. G. Amarella possesses, according to that author, obtuse ealyx lobes, a cylindrical tube to the corolla, and scssile capsules. IIe refers to both plants as being natives of Britain. Koch gives the former ovate st.-l. from a broal base; and the latter laneeolate or hinear-lanceolate st.-l. from a broad base and fl. of half the size. See Trans. Bot. Soc. Edin. i. 59. and Phyt. i. 381.-Diy calcareous fiekts. A. VIII. IX.

2. G. campestris (L.); cor. salvershaped 4-cleft bearded in the throat, cal.-segments 4, 2 outer ones very large ovate, l. ellipticoblong.-E. B. 237.-St. 3-10 in. high. Fl. blue, tube of the corolla slightly thicker upwards. Caps. nerty sessile. Upjer l. and sepals pointed.-Dry limestone hills. A. VIII. IX.

3. G. nivalis (L.) ; cor. salvershaped 5-cleft with minnte intermediate bifil segments, throat naked, cal. cylindrical with 5 keeled angles, l. ovate lowermost broadly elliptical.-E. B. 896 . -St. erect, slightly branched, 2 or 3 in. high. Fl. bright blue. - Summits of highland mountains, very rare. A. VIII. S. 
4. G. verna (I.); cor. salvershaped 5-cleft with small intermediate bifid segments, throat naked, cal. with prominent angles and sharp teeth, 1 . ovate lower ones erowded, st. caspitose singleflowered with 1 or 2 pairs of leaves, $-E .3 .4933$. St. 40. 12.St. prostrate, rosting, cach terminating iu a roselike tuft of 1 . and producing a single short flowering shoot. Fl. rather large, vivid blue.-Barren limestone distriets. Teesdale, Durhan. Burrin and betwcen Gort and Galway, Clare. P. IV. E. I.

5. G. Pneumonant he (L.); cor. bellshaped 5-cleft, throat naked, cal. cntire with liaear obtuse segments, fl. mostly solitary slightly stalked, l. linear obtuse.-E. B.20.-St. 4-10 in. high, leafy, simple, erect or ascending. ll. very large, deep blue with 5 greenish bands down the middle of cach segment.-Moist turfy heatlis. A. VIII. IX.

\section{[G. acaulis (L.) E. B. 15.94. is not a native.]}

[SIVERTIA veremis (L.), known from our plants of this Order by the 2 curious fringed glands at the base of each segment of the cor. $(E, B .1441$.$) , is said to have been formerly$ found in Wales.]

\section{Suborder II. Menyanthideæ.}

j. Villarsia Vent.

1. Ir. nymphaciades (Vent.); 1. opposite heartshaped floating wary at the edges, pedincles aggregate l-flowered, cor. ciliated. -E. B. 217. St. 13. 4. Limnanthemum Griseb., Koch.-Floating. St. long, round, branclied. L. resembling those of $N y m p h a a$ alba but much smoller. Fl. yellow. Caps. sometimes 3-valved. -Still places in rivers, rare. P. VII. VIII. E.

\section{Menyantues Limn.}

1. M. trifoliata (L.).-E. B. 495. St.8.-L. ternate. Leaflets equal, obovate, wayy. Clusters stalker, each opposite to a leaf, many-flow'ered. (Cor. flesh-coloured, densely bearded. St. ascending, round, letify,-Boggy places. P. V.-Vil. Buckbean.

\section{Orde: LIII. POLEMONIACEF.}

Cal. inferior, 5-parted, persistent. Cor. hypogynous, regular, 5-lobed. Stam. 5, unequal, on the tube of the corolla. Ovary 3-celled. Stignas 3-fid. Caps. 3-celled, 3-valved, valves separating at the axis.

1. Polemoniun. Cal. 5-fid. Cor. rotate, with a short tube and 5-lobed linıb, throat nearly closed by the dilated bases of the filament:i.-G. F. G. Gam. i. 62. 


\section{Poingonium Limn.}

1. P. coruleum (L.); st. angrular, l. glabrous pimmate, leaflets ovate-lanceolate pointed, panicle dowuy glandular,-E. B. 14. -St. I - 2 fect ligh, simple, lollow. L. alternate, leaflets numerous. F'l. muureus, somewhat drooping, loright blue or white. -Buslyy hilly places, rare. P'. VII. Blue Jacob's Ladder.

\section{Order LIV. CONVOLVULACEA.}

Cal. inferior, 5-partel, persistent, imbrieated, often unequal. Cor. hypogymous, regular, plaited, deciluous. Stam. 5, from near the base of the corolla. Ovary of $2-4$ cells, few-seeded, surrouuded by an anmular hypogynous disk. Style 1, rarely 2. Caps. with the valves scparating from the erges of the dissepiments or bursting transversely.

\section{* IVith leaves and cotyledons.}

1. Convolvulus. Cor. bellshaped, with 5 prominent plaits and 5 shallow lobes. Style simple, stigmas 2. Caps. 2-4celled, cells 2-secded.-G. I. G. Gam. i. 63, 64.

\section{** Without leaves or cotyledons.}

2. Cuscuta. Cal. 4-5-cleft. Cor. roumdish-urceolate or bellshaped, 4-5-parted, with as many scales alternating with the segments at the base within. Stam. 4-5. Styles 2, rarely 1. Caps. bursting transversely, 2-celled, 4-seeded. -G. F. G. Gam. i. 65.

\section{Convolvulus Linn.}

1. C. arvensis (L.); l. arrowshaped with acute lobes, peduncles mostly 1 -flowered, bracts minute distant from the flower. $-E$. $B$. 312.-St. numerous, angular, twining or prostrate, leafy, branchel. Peduncles sometimes 2 -flowered. Cor. beautifully variegated with pink and white. Roots descending remarkably deep. Plant glabrous or ( $\beta$. hirtus $K o c h$ ) st. and l. downy. - Fields and herlges. P. VI.-VIII. Small Bindweed.

2. C. Sepium (L.) ; l. arrowshaped with truncate lobes, peduncles I-flowered square, bracts large cordate close to the flower. -E. B. 313. Calystegia R. Br.-St. twining, many fect long, with large rather distant leaves. Fl. solitary, axillary, large, white, rarely pink. Bracts quite inclosing the calyx. Fr. imperfectly 2-celled through the shortness of the dissepiment.Hedges and thickets. P. VII. VIII. Great Bindweed.

3. C. Soldanella (L.); l. reniform slightly angular fleshy, peduncles 1 -flowered with 4 membranous angles, bracts ovate close to the flower.-E. B. 314 . Calystegia R. Br.-St. short, pro- 
cumbent. Fl. large, solitary, axillary, very handsome, pink with yellow bands. Bracts rather shorter than the ealyx.-Sandy seashores. P. VI.-VIII. Sea-side Bindweed.

\section{Cuscuta Limn. Dodder.}

I. C. europaa (L.); clusters of $\mathrm{Al}$. bracteated sessile, tube of the eor. at first eylindrical afterwards ventricose, scales adpressed to the inside of the tube bitid distant below with rounded spaees, cal. much shorter than the corolla.-E. B. 378.-St. threadshaped, branehuig, reddish. Fl, in rather large elusters, yellowish.-Parasitical upon herbaceous plants. A. VIII. IX. Greater Dodder.

I.

†2. C. Epilinum (Weilie); elusters of $\mathrm{fl}$. bracteated sessile, tube of the eor. ventricose, scales adpressed fimbriated distant below with rounded spaces, cal. with fleshy segments deltoid below nearly as long as the tube of the corolla.-E.B.S.2850. C. densiflora Soy. Willm.-St. sleuder, nearly simple, pale green. Fl. in rather small distant elusters, whitish. Seales bifid with $4-8$ fimbrix on each lobe. Ventrieose tube of the eor, with 5 longitudinal protuberanees; segments ventrieose. Styles at first erect, soon bowing outwards the stigmas eonverging.-Parasitical upon flax and very injurious to the erop. A. Vill. Flax Dodder.

3. C. Epithymum (Murr.); elusters of fl. bracteated sessile, tube of the eor. cylindrical, scules concerging as long as the tube of the cor. fimbriated and rounded at the end approximate below with narrow acute spaces, eal. bcllshaped shorter than the tube of the corolla.-E. B. 55.-St. slender, red. Fl, small, with a reddish thin eal. and white cor. with spreading orate-aeute segments. Sep. broad, ovatc-apieulate, longer than their tube. Anth. blunt or notched at the end. Lower part of the corona adpressed throughout; seales broarl.-Par'asitieal upon small shrubby plants. A. VII.-IX. Lesser Dodder.

E. S.

†4. C. Trifolii (Bab.); elusters of fl. bractented sessile, tube of the eor. (ylindrical, scales converging half as long as the tube of the cor. fimbriated and rounded at the end distant below with rounded spaces, eal. narrowed below as long as the tube of the eor.-E. B. S. 2898.-St. slender, branching, redlish-yellow. Fl. small, white. Cal. fleshy, usually tipped with red; sep. laneeolate, about as long as their tube. Anth. apieulate. Conneeting membrane of the eorona not adpressed but forming euplike spaces between itself and the eor.; scales narrow.-Parasitical upon elover ehiefly. A. VII.-IX. Clover Dodder. E.

\section{Order L $\mathbf{T}$. BORAGINEA.}

Cal. inferior, 4-5-parted, persistent. Cor. hypogynous, re- 
gular. Stam. 5, inserted on the corollis. Ovary 4-parted, 4seeded, orules pendulons. Style simple. lir. separating in 4 nutlike or' 2 bilocular portions. Scenls without albunen.

'T'ribe 1. CYNOGLOSSEAE. Nuts 4, aftixed to the persistent base of the style.

1. Aspinugo. Cal. 5-cleft with alternate smaller teeth, enlarged and compressed in fruit. Cor. fumnelshaped witl rounded scales in the throat. Stam. ineluded, filaments short. Nuts verrucose, compressed, attached by their narrow side, covered by the compressed calyx,-G. F. G. Gam. ii. 53 .

[2. Ecrinospermum. Cal. in 5 decp segments. Cor. salvershaped with rounded scales in the throat. Stam. ineluded, subsessile. Nuts triquetrous with muricated margins, attached by their inner edge.-G. F. G. Gam. ii. 54.]

3. Cynoglossum. Cal. 5-eleft. Cor. funnelshaped, the mouth closed with promincnt blunt scales. Stam. included ; filaments very short. Nuts roundish-ovate depressed, muricatch, attached by their inner edge.-G. F. G. Gam. ii. 56.

Tr. II. ANCHUSE E. Nuts 4, affixed to an hypogynous disk, with an excavated space surrounded by a tumid ring at their base.

4. Borago. Cal. in 5 decp segments. Cor. rotate; tube very short; throat with short erect cmarginate scales. Stam. exserted; filannents bifid, the inner fork bearing the antlier; anthers linear-lanccolate, eonnivent in the form of a cone.G. F. G. Gam. ii. 69.

5. Ancuusa. Cal. 5-fid. Cor. funnelshaped with a straight tube; throat closed by prominent obtuse seales. Stam. included, subsessile. Nints depressed.-G. F. G. Gam. ii. 61.

6. Lycopsis. Cal. in 5 decp seginents. Tube of the cor. curved ; limb oblique. Otherwise like Anchusa.-G. F. G. Gam. ii. 72.

7. Srmpiytum. Cal. 5-cleft or 5-parted. Cor. cylindricalbellshaped, throat closed by a prominent cone of eomivent lanceolate-subulate scales. Stam. exserted from the tubc but eovered by the scales; filaments short. Nuts ovate.-G.F.G. Gam. ii. 68:

Tr. III. LITHOSPERMEAE. Nuts 4, affixed to an hypogynous disk, their base not excavated but attached by a flat or rather convex surface.

8. Echivм. Cal. in 5 deep segments. Cor. subbellshaped; 
throat dilated, naked; limb irregular. Stam, exserted; filaments very long, unequal. Style bifid. Nuts wrinkled, attached by a flat triangular base.-G. F. G. Gam. ii. 65.

9. Pulmonaria. Cal. tubular, 5-fid. Cor, funnelshaped, its throat naked. Stam. included in the tubc; filaments very short. Style simple. Nuts smooth, attached by their truncate base with a ceutral tubercle.-G. F. G. Gam. ii. 63.

10. Steenhammera. Cal. in 5 decp scgments. Cor. bellshaped, with a short thick cylindrical tube with 5 minute protuberances in its throat. Stam. protruded beyond the throat; filaments elongate. Style simple. Nuts smooth, rather drupaceous attached laterally near their base by a flat surface.-G. F. G. Gam. ii. 64.

11. Litiospermum. Cal. in 5 dcep segments. Cor. funnelshaped its throat naked or with 5 minute scales. Stam. included in the tube; filaments very short. Style simple. Nuts smooth or tubercular, stony, attached by their truncate flat base.-G. F. G. Gam. ii. 61, 62.

12. Myosotis. Cal. 5-parted. Cor. contorted in astivation, salvershaped; throat closed with scales; limb 5-fid, obtuse. Stam. included; filaments very short. Style simple. Nuts smooth, convex externally, keeled within, attached by a minute lateral spot near their base.-Distinguished from all the other gencra of the Order by the contorted æstivation of its corolla.-G. F. G. Gam. ii. 60 .

\section{Tribe I. Cynoglossea.}

\section{Asperugo Linn.}

1. A. procumbens (L.).-E. B. 661.-St. procumbent, angular, rough with short decurved bristles. L. oblong, rough, hispid, lower ones stalked, upper sessile. Fl. small, axillary, solitary, blue, upon short pedumcles. Cal. of the fr. much enlarged.Waste places, rare. A. VI. VII.

E. S.

\section{Echinospermum $S w$.}

[1. E. Lappula (Lehm.); st. branched above, l. lanceolate adpressed-hairy, cor. longer than the calyx, fruit-stalks erect, nuts with a double series of barbed spines on the margins the disk and sides tubercled.-St. 43. 16.-St. and l. covered with adpressed hairs giving them a silky appearance. Closely resembling a Myosotis but belonging to a different tribe.-In one spot, upon shingle, near Southwold, Suff., in very small quantity; possibly introduced, but by what means I cannot conjecture, certainly neither with seed nor amongst ballast.-A. VI.] E. 


\section{Cinoglossum Lim.}

1. C. officinale (L.) ; 1. downy acute, lower l. clliptical contracting into a petiole, upper 1 . lanceolate narrowed below sulbcordate half clasping.-E. B.921.-Cor. dull crimsou, "veiny ; veins disappearing in drying." "Nuts plane in front surrounded by a thickened prominent margin."-Waste ground. B. VI. VII. Hound's-tongue.

2. C. montanum (Lam.); l. slightly hairy acute nearly glabrous and shining above scabrous beneath, inferior oblong narrowed into a long petiole, upper l. lanceolate slightly narrowed below clasping.-C. sylvaticum Sm., E. B. 1642.-Cor. reddish, changing to bluc. L. sometimes very scabrous.- "Road-sides and hedges in slady situations." 13 . VI. VII.

\section{Tribe II. Anchuseœ.}

\section{Borago Linn. Borage.}

$\dagger$ 1. B. officinalis (L.); lower l. obovate obtuse attenuated below, segments of the cor. ovate acute flat spreading.-E. B. 36. -Fl. blue. Stem-l. much narrowed below so as to appear stalked, eared at the basc. Whole plant hispid with tubercled hairs. St. spreading.--On rubbish and in waste places, scarcely a native. B. VI. VII.

\section{Anchusa Linn.}

†1. A. officinalis (L.); l. lanceolate hispid, spikes crowded unilatcral, bracts ovate-lanceolate, calyx-segments bluntish hairy on both siles, scales of the cor. hairy.-E. B. 662.-Fl. dcep purple. Cal.-segments narrow, longer than the tube. St. $1-2$ feet high, rough with deflexed hairs.-Waste ground, rare. P. VI. VII. Common Alkanet.

†2. A. sempervirens (L.); l. ovate, lower l. on long stalks, peduncles axillary each bearing 2 dense spikes with an intermediate flower, cal.-scgments hairy on the outside only, bracts minute lanceolate, scales of the cor. downy.-E. B. 45.-Fl. blue, rather salver- than funnclshaped. Cal.-segments narrow. St. $1 \frac{1}{2}-2$ feet high, rough with spreading somewhat deflexed hairs. -Waste ground ncar ruins, rare. P. V.-VIII.

\section{Lycopsis Linn.}

l. I. arvensis (L.); l. lanceolate erose-dentate very hispid, cal. of fr. bcllshaped erect.-E. B.938.-Fl. small, blue. Whole plant very hispid with strong hairs each rising from a scaly tubercle.-Corn-fields and hedges. A. VI. VII. Bugloss. 


\section{Srmphytum Linn.}

1. S. officinale (L.); l. ovate-lanceolate attenuated below, stem $l$. very decurrent lanceolate, st. winged in the upper part.E. B. 817.-Height $1-2$ feet. Racemes in pairs, drooping. 11. yellowish-white or purple. Cal.-segments somewhat spreading in the purple-flowered variety which is $S$. patens Sibth.Common in damp places. P. V. VI. Comfrey.

2. S. tuberosum (L.); l. orate-oblong attenuated below, stem l. laneeolate, uppermost slightly decurrent, st. scarcely winged ncarly simple.-E. B. 1502.-Fl. yellowish-white, whole plant smaller and slenderer than the preceding. Anth. twice as long as their filaments.-Dain places, rare. P. VI. VII.

[S. asperrimum and $S$. orientale have both been noticed in an apparently wild state in England, but possess no elaims to be considered as natives.]

\section{Tribe III. Lithospermea.}

\section{8. Есніuм Limn.}

1. E. vulgare (L.) ; tubereular-hispid, st. erect simple, l. lanceolate l-ribbed, stem $l$. narrowed below sessile, fl. in short lateral spikes, stam. longer tham the corolla.-E. B. 181.-Lower 1. attenuated into a footstalk. Fl. at first reddish, afterwards bright blue.-Dry places. B. VI. VII. Viper's Bugloss.

2. E. violaceum (L.); pilose-hispid, st. crect branched diffuse, lower branches prostrate, radical l. oblong-ovate stalked, stem $l$. oblong narrowed from a cordate half clasping base with lateral ribs, spikes panicled elongate simple, stam. searcely longer than the corolla.-E. B. S. 2798 . Lyeopsis Ray.-Stam. vcry unequal, 1 short, 2 intermediate, and 2 longer. Fl. violet-blue. Hairs rising from minute tubereles. Root reddish; it stains the paper in the herb. deep violet.-Jersey. B. VI.-IX.

0 .

\section{Pulmonaria Limn.}

1. P. officinalis (L.); l. ovate roundish or cordate, upper 1. oblong. - E. B. 118. - Whole plant more or less hispid. Fl. purple. L. often spotted.-Woods and thickets, rare. P. V. Lungwort. E. S. ?

2. P. angustifolia (L.); 1. all lanceolate.-E. B. 1628.-More pubeseent than the last, but seareely distinguishable as a species. -Woods in IIampshire. P. IV. V.

E.

10. Steenhammera Reich.

1. S. maritima (R.); st. procumbent branched, l. ovate acute 
rough with eallous dots glabrous fleshy glaneous, unts smooth. - Lithospermum Sm., E. B.368.- Fl. in racemes, purplish-bhe. scales in throat of eor. yellow. Nuts elosely converging. L. with a flavour resembling that of oysters. Diflering more in habit, in which " it is sui-generis," than in eharacter from Lithospernum. -Northern sea-shores. P. V. VI.

\section{Lithospermum Linn.}

1. L. officinale (L.); st. erect mueh branehed, 1. lanceolate acrite veined hispid with tubereles and adpressed bristles above hairy beneath, thoat of the eor. with minute seales witlin, nuts suooth.-E. B. 134.-Fl. greenish-yellow. Nuts gray, highly polished, stony, 2 or 3 ripening in eaeh ealyx. Root whitish.This is the only true Lithospermum aeeorting to Spenner, none of the other speeies having a crown of seales in the throat of the corolla.-Dry and stony places. P. VI.-VIII. Gromwell.

2. L. purpureo-caruleum (L.); barreu st. prostrate ereeping the other's erect 2-3-fid above, 1. lanceolate aeute hispid : hairs adpressed tubereular on the upper side, eor. mueh longer than the calyx, nuts smooth.-E. B. 117.-Fl. large, bright blue. Nuts "silvery white, highly polished, slightly rugged," rarely produced.-This speeies and the following have no seales iu the throat of the cor. but merely 5 longitudinal downy folds. They belong to the genus Rhytispermum Link, Spenn.-Thickets on at lintestone soil, rare. P. V.-VII.

E.

3. L. arvense (L.) ; st. ercet branehed, I. lanceolate rather acute hispid with adpressed tubercular hairs on both sides, eor. rather longer than the ealyx, nuts tubercular.-E. B. 123.-Fl. suall, white. Nuts pale brown, polished, wrinkled, pitted, 3 or 4 perfected in eaeh ealyx. Root bright red, eommunicating its colour to paper, \&c.-Corn-fields. A. V.- VII. Corn Gromwell.

\section{Mrosotis Linn.}

* Persistentes.

1. H. palustris (With.); eal. open when in fr. and shorter than the pedieel with straight adpressed bristles : teeth short triangular, limb of the eor. Hat longer than the tube, lobes slightly emarginate, pubescence of the st. spreading.-E.B.1973. St.42.2. -L. bluntish, apieulate. St. angular fiom the prominent decurrent line from the margins of the leaves. Chusters quite leatless. Cor. large, bright blue with a yellow eye. Style about as long as the calyx whieh is divided to about $\frac{1}{3}$ of its length.Valuable observations on this gerus by Mr. Borrer will be found in Hook. Br. Fl. (ed. 3.) and the Suppl. to Eng. Bot.-Ditches 
and watery places. P. VI.-VIII. Great Water Scorpion-grass. Forget-me-not.

2. $M$. repens (Don); cal. open when in fr. and shortel than the perlicel with straight adpressed bristles: teeth narrow lanceolate acutc, limb of the cor. flat longer than tube, lobes slightly emarginate, pubescence of the st. spreading.-E. B. S. 2703. St. 42. 4. M. secunda Murr. North. Fl. 115.-L. rather acute. St. slightly angular. Cluster's usually slightly leafy ( $1-4$ lcaves) below. Cor. pale blue. Style shorter than the cal. which is divided fully half-way down.-Boggy places. P. VI.-VIII.

3. M. caspitosa (Schultz!); cal. open when in fruit shorter than the pedicel with straight adpressed bristles: teeth narrow lanceolate bluntish, limb of the cor. equalling the tube, lobes entire, pubescence of the st. adpressed.-E. B. S. 2661,St. 42. 7. M. lingulata Fries.-L. usually obtuse or cven emarginate. St. round, " with an impresserl decurrent line from the margin of the leaves." Clusters usually slightly leafy bclow. Cor. smaller than in the preceding, bright blue, segments narrower and rounder at the end. Stylc very short, about as long as the tube of the calyx.-Watery places. P. VI.-VIII.

4. M. suaveolens (Kit.) ; cal. attenuated below deeply 5-cleft open when in fruit shorter than the ascending pedicel with straight and a few curved adpressed bristles, limb of the cor. longer than the tube flat, root-7. on long stalks pointed.-St.42.8. not DC. M. rupincola Sm., E. B. 2559. M.alpestris Sm., Borr.-L. oblong-lanceolate, stalks of the lower ones slender. Fl. large, handsome, blue. Style fully half as long as the calyx.-[M. alpestris (Schm.) has blunt roundish or oblong-oval root-leaves and is probably a mountain form of $M$. sylvatica.]-Summits of the Breadalbane mountains. P. VII. VIII.

5. M. sylvatica (Ehrh.) ; cal. rounded below deeply 5-cleft closed when in fruit shorter than the divergent pedicel: tube with sprcading hooked bristles, limb of the cor. longer than-the tube flat, root-l. on short dilated stalks bluntish.-E. B. S. 2630. St. 42. 6.-L. oblong-lanceolate, stalks of the oblong-ovate lower 1. dilaterl. Fl. large, handsome, blue. Style usually as long as the calyx which is divided more than half-way down.-Shady places. P. V. VI.

6. $M$. arvensis (Hoffm.); cal. half 5-clefi closed when in fruit shorter than the divergent pediccl : tube with spreading hooked bristles, $7 \mathrm{mb}$ of the cor. equalling the tube concave, clusters stalked. - E. B. S. 2629. St. 42. 13. M. intermedia Link, Reich., Koch. - L. oblong, acute; lower l. oblong-obovate, obtuse. Fl. small. Style very short.-Cultivated land and thickets. A. VI.-VIII. Field Scorpion-grass. 
** Fugaces.

7. M. collina (IIoffm.); cal. open and ventricose when in fruit. as long as the diverging pedieels : tube with spreading looked bristles, limb of the cor. sliorter than the tube concave, elusters stalked nsually with 1 distant flower, lairs on the l. straight. - E. B. 2558. St. 42. 11. M. hispida Koch.-L. oblong, ol)tuse, lower obovate, with straight silky lairs on both sides. Fl. sinall, blue. Style about half as long as the calyx.-[M, strieta Link, M. arvensis (R.) St. 42. 14. las its eal. closed in fruit with very short pedieels, sessile elusters leafy below, l. with hooked hairs beneath. It is probably a native of Britain and will reward some careful observer.] - Dry banks. A. IV. V.

8. M. versicolor (Elnh.); cal. elosed and oblong when in fruit longer than the aseending pedieels : tube with sprearling hooked bristles, limb of the eor. shorter than the tube concave, elusters stalked.-E. B. 480. (left fig.) St. 42. 12.-L, narrow, oblong, acutish, upper ones frequently opposite. Fl. small, at first pale yellow, afterwards blue. Style elongated.-In a plant inhabiting damp places the $\mathrm{fl}$. are at first white and the eal. is "less deeply divided."-Meadows and banks. A. V. VI.

\section{Order LVI. SOLANACEF.}

Cal. inferior, 5- rarely 4-partel, persistent. Cor. hypogynous, regular or slightly irregular, 5-cleft, decidluous. Stam. inserted on the corolla. Ovary 2-celled. Stigma simple. Pericarp 2-eelled. Seeds numerous. Embryo usually eurved, in fleshy albumen.

1. Solanum. Cor rotate: limb5-eleft, reflexed, plaited, regular. Anth. erect, connivent, opening by 2 pores at the apex. Berry roundish with 2 or more cells.-G. F. G. Gam. i. 58.

2. Atropa. Cor. bellshaped with a short tube and 5 equal lobes. Stam. distant above. Berry globose, 2-celled.G. F. G. Gam. i. 60.

3. Hyoscyanus. Cor. funnelshaped with a short tube and 5 unequal obtuse lobes. Anth. bursting longitudinally. Stigma eapitate. Caps. 2-celled, ventricose below, furrowed, opening tranversely by a convex lid.-G. F. G. Gam. i. 54.

4. Datura. Cor. funnelshaped, angular, plaited, 5-lobed. Cal. deciduous. Anth. bursting longitudinally. Stigma 2-loberl. Caps. 4-valved, with 2 partially bipartite cells.G. F. G. Gam. i. 53.

5. Verbascum. Cor, rotate: limb spreading, 5-eleft, unequal or irregular. Stam. 5, unequal, 2 or more hairy at the 
base. Anth. transversely or obliquely adnate, by confluence l-celled. Caps. 2-celled, 2-valved, the valves slightly bifid. - G. F. G. Gain. i.

\section{Solanum Limn.}

I. S. nigrum (L.); st. herbaceous with tuberched angles, l. ovate obtuscly dentate or wavy, fl. drooping, hairs incurred upwards. -E. B. 566. St. I. 4.-Umbel from the intermediate spaces between the leaves. L. attenuated below. Fr.-stalks thickened upwards. Berries globular, black, or rarely grcen, when ripe. St. a foot or more high.- $\beta$.? miniatum; angles of the st. with prominent tubercles, 1. sinuate-dentate. Closcly allied to this species but differs by its more deeply toothed l. which are less attenuated bclow, its patent (?) pubcscence and red berries. S. miniatum Bernh.?, R. I. f. 1327.?-Waste ground. $\beta$. Jersey. A. VII.-X. Black Nightshade.

2. S. Dulcamara (L.) ; st. shrubby zigzag, 1. corlate-ovate, upper l. auriculate-hastate, fl. drooping.-E.B.565. St. 18.3.Fl. purple with 2 grcen spots at the base of cach segment. Berries ovate, red. St. climbing to the height of $12-14$ feet, ncarly round, almost glabrous throughout.- $\beta$. tomentosum (Koch); st. and 1 . downy with patent hairs. $-\gamma$. marinum; branches of the present year and l. fleshy and usually clothed with hairs incurved upwarels, st. angular prostrate diffuse much branched, l. all (?) cordate not hastate. S. lignosum seu Dulcamara marina Ray 265. It appears to have a more deeply divided cal. with rounded blunt segments. Is it not a distinct species?- $a$. and $\beta$. woods and hedges, common. $\gamma \cdot$ pebbly sea-beach. Renville, Cunnamara, Galway. Lizard Point, Cornwall. Shoreham, Sussex, (glabrous). Mr. Borrer. Sh. VI. VII. Woody Nightshade. Bitter sweet.

\section{Aтropa Limn. Deadly Nightshade. Dwale.}

I. A. Belladonna (L.); st. herbaccous, l. broadly ovate cntire, fl. solitary axillary on short stalks.-E. B. 592. St. 3. 5.-Fl. lurid, purple, drooping. Bcrry violet-black, highly poisonous.Waste places, less common than formcrly. P. VI.-VIII.

\section{Hroscramus Linn.}

1. H. niger (L.); l. oblong pinnatifid or sinuate sessile and subamplexicaule, lower l. stalked, fl. nearly sessile axillary unilatcral.-E. B. 591. St. 3. 4.-Fl. lurid yellow, with dark veins, drooping. Fr. erect. Whole herbage downy, glandular, viscid, foetid. $\quad$ B. pallidus (Koch); fl. without dark veins.-Waste places, preferring a chalky soil. $\beta$. Esher, Surrey. Mr. H. C. Watson. A. or B. V.-VII. Henbane. 


\section{Datura Limn.}

†1. D. Stramonium (I.) ; l. ovate nnequally simmate-dentate glabrous, capss. erect spinose. - F. B. 549.-Fl. white, large, ereet. Fr. densely spinose. Caps. with 4 dissepiments below of which only 2 reach to the summit.-Waste ground, rare. A. VI. VII. Thoru-apple.

I. S.? I.?

\section{Verbascum Limn. \\ * Leaves strongly decurrent.}

1. V. Thapsus (L.?); l. ovate-oblong crenate densely woolly on botl sides all dlecurrent, st. simple, spike dense, pedicels shorter than the ealyx, eor. rotate: segments oblong obtuse, filaments woolly : 2 longer nearly glabrous, anth. all nearly equal. -E. B. 549. V. Schraderi Koch.-St. $4-5$ feet ligh. Fl. about twice as long as the calyx. Filaments with white wool, the 2 glabrous ones about 4 times as long as their slightly decurrent anthers.-Waste ground. B. VII. VIII. Great Mullein.

2. V. thapsiforme (Sclur.); "l. deenrrent crenulate woolly; upper ones acuminate, raceme spiked, segments of the cor. unequal obovate, 2 of the anth. oblong." Fries.-V. Thapsus Koel. -Fl. much larger than those of $V$. Thapsus, about 4 times as long as the calyx. "The 2 glabrous filaments scarcely twice as long as their greatly decurrent anthers." Koch.-Kent. Dr. Lindley. B. VII. VIII.

E.

** Leaves not decurrent, flowers in clusters.

$\dagger$ Flowers yellow, hairs on the filaments white.

3. V. Lychnitis (L.); $l$. crenate nearly glabrous above woolly and powdcry beneath, lower l. elliptic-oblong wedgeshaped below stalkell, "pper l. sessile ovate-acuminate with a rounded base, st. angular panieled above with ascending branches, stam. equal, filaments all with white hairs.-E. B. 58.-Fl. on short stalks, small, numerous, cream-coloured.-Roal-sides and waste places, preferring ehalk. B. VII. VIII. White Mullein.

E.

4. V. floccosum (W. and K.); l. obseurely crenate elothed with mealy deciduous wool on both sides, lower l. oblong-elliptical attenulated into a stalk, upper l. sessile aeuminate, st. terete pranicled alove with patent branches, stam. nearly equal scarlet with white hairs.-V. pulverulentum Sm., E. B. 487.-Fl. on very short stalks, which, as well as the ealyx, are densely covered with wool, bright yellow. Cal.-teeth often glabrous.-In V. pulverulentum (Vill.), of which Schreber saw authentie speeimens, the stem l. are subsessile ovate-oblong rather aeute unequally and doubly serrate, the upper surface of all the leaves only shightly woolly, the wool is not deciluous as in our plant, and the st. and branches are angular.- Road-sides in Norf. and Suff. ; and Den of Cullen, Scotland. B. VII. Hoary Mullein.

E.S. 
计 Flowers yellow, hairs on the filaments purple.

5. V. nigrum (L.); l. doubly crenate nearly glabrous above subpubescent bencath, lower l. cordate or ovate-oblong with long stalks, upper l. cordate-ovate nearly sessile, st. angular, raceme elongated, pedicels twice as long as the calyx, stan. equal with purple hairs. - E. B. 59.-Fl. in clusters on a nearly simple long spike, small, bright yellow.- $\beta$. tomentosum (Bab.); 1. subpubescent above woolly beneatl, fl. smaller. $-\gamma$. nigro-lychnitis; lower l. ovatc-oblong or lanceolate attenuated into a stalk subpubescent above downy beneath.-Banks and way-sides. $\beta$. Alderney. $\gamma$. Sussex. P. VII. VIII. Dark Mullein. E. S.

\section{*** Leaves all decurrent, flowers solitary or in pairs.}

6. V. Blattaria (L.); l. crenate glabrous, lower l. ovate-oblong obtuse sinuate at the base attenuated, upper l. oblong or subcordate semianplexicaule, pedicels solitary nearly twice as long as the bract, stam. and anth. unequal.-E. B. 393.-Panicle glandular pilose. Fl, yellow. Filaments with purple hairs, the 2 longer hairy only on the inside.-On gravelly banks, rarc. B. VIII. Moth Mullein.

E.

7. V.virgatum (With.); l. doubly serrate slightly glandularhairy, lower l. oblong-lanceolate sublyrate lobate-crenate-serrate the base attenuated, upper l. oblong acuminatc semiamplexicaule, pedicels $1-5$ together shorter than the bracts, stam. nearly equal. -E. B. 550.-Panicle glandular-pilose. Fl. yellow. Filaments with purple hairs, 2 rather longer and hairy only within.-On gravelly banks, rare. B. VIII.

E. I.

\section{Order LVII. OROBANCIIEA.}

Cal. variously divided, persistent. Cor. irregular, usually 2lipped, imbricate. Stam. on the cor. 4, didynamous. Ovary in a fleshy disk, 1-celled, with 2 or more parietal placentas. Stigma 2-lobed. Fr. capsular, 2-valved, many-seeded.

1. Orobanche. Cal. 4-cleft or of 2 usually bifid sepals. Cor. ringent, 4-5-cleft, deciduous, its base persistent. Bracts 1-3.-G. F. G. Gam. i. 49, 50.

2. Lathria. Cor. 2-lipped, the upper lip galeate, deciduous, entire. Otherwise like Orobanche.-G. F. G. Gam. i. 51 .

\section{Orobanche Linn. Broom-rape.}

* Sepals 2, entire or bifid, separate or connected below in front. Bract 1.

1. O. rapum (Thuill.); sep. 2-nerved equally bifid nearly as long as the tube of the corolla, cor. bellshaped ventricose at the 
base in front arenate, lips wavy obsoletely denticulated (not fringed), upper lip, helmetshaped scarcely emarginate: sides patent, mildlle lobe of the lower lip much longer than the lateral lobes, stam. inserted at the base of the cor. glabrous bclow, their upper part and the style glandular-pubescent.-E. B. 421 . R. I. f. 900 and 923. O. major (L.) Sm., but Fries states that that syn. belongs to O. elatior.-Stigma distantly bilobed, yellow. Anth. white when dry. For a full deseription from fresh specimens see Leight. Fl. Shrop. 302.-Parasitical upon Broom, Furze and other slurnbby leguminons plants. P. VI. VII. Greater Broom-rape.

2. O. rubra (Sm.); sep. l-nerved lanceolate subulate-attennated longer than the tube of the cor. undivided, cor. bellshaped arcnate glandular-pubescent externally and the upper lip internally, lips acutely denticulated and crisped, upper lip emarginate : sides patent, lobes of the lower lip nearly equal intermediate lobe rather longer, stam. inserted near to the base of the corolla slightly pilose within below, their apex and the npper part of the style slightly glandnlar-pilose.-E. B. 1786 (bad). R. I.f. 885. Probably O. epithymum DC., Koch, Fries (Mant. iii. 59), but there are some discrepancies in the descriptions. - Stigma approximately 2-lobed, pale red. Anth. fuscons when dry. Sep. with a second faint nerve near their anterior margin and, in the dry plant, therc is the appearance of several more. L. few. Sweetscented.-Description drawn from fresh Cornish specimens.Parasitical npon Thymus Serpyllum. P. VII. VIII.

3. O. caryoplyyllacea (Sm.); sep. many-nervell lanceolate equally bifid shorter than the tmbe of the cor. distinct or combined in front, cor. tubular-bellshaped curved on the back, lips spreading, upper one 2-lobed : lobes porrect, lobes of the lower lip nearly equal rounded wavy, stam. inserted above the base of the cor. hairy within below, above together with the style glandular-pilose.-E. B. S. 2639. O. Galii Dnby, Koch.-Stigma purplish-black, approximately lobed. Anth. fuscous, yellow when dry. Sep. with crisped glandnlar liairs externally, each lobe with 1 strong nerve and several slender ones. Cor. similarly hairy on both sides.-Described from fresh Kentish specimens. - On Galium Mollugo in Kent. P. VII.

4. O. elatior (Sntt.); sep. many-nerved equally bifid as long as the tube of the cor. connected in front, cor. curved tubular slightly compressed above, upperlip 2-lobed toothed: lobes inflexed, lower lip of 3 nearly equal acnte lobes toothed, stam. inserterl above the base of the cor. glandnlar-hairy in the lower half within.-E. B. 568. O. major (L.) Fries.-Stigma bilober yellow. Upper lip of the cor. nsnally with an elevated point between the lobes. Cor. glandnlar externally. The stam. sometimes have a 
few hairs on their upper half. Anth. whitish when dry. Stem 2-3 feet high. - Parasitical upon Centaurea Scabiosa, rare. P.? VI.

5. O. Hedera (Duby); sep. 1-nerved ovate below suddenly contracted into 1 or 2 subulate points nearly or quite as long as the tube of the cor., cor. tubular arcuate : lips denticulated wary, upper one bilobed porrect, lobes of the lower lip nearly equal the middle one longest, stam. inserted ncar to the base of the cor. glabrous with a few scattered hairs on their lower part, style glabrous with a few hairs on the upper part, stigma searcely biloberl.-O. barbata R., Bab., not Poir., according to Koch (Syn. ed. 2. 618.), E. B. S. 2859.-Lobes of the stigma attached together by at least $\frac{1}{3}$ of their circumfercnce, yellow. Anth. fuscous, rather paler when dry. St. purplish.-In speaking of this plant, which he is not prepared to arlmit, Sir W. J. Hooker justly observes that the l3ritish specics "need a careful revision with the aid of living specimens."-Parasitical upon Ivy. P.VII. E. I.

6. O. minor (Sutt.); sep. many-nerved ovate below suddenly contracted into 1 or 2 subulatc points as long or longer than the tube of the cor., cor. tubular arcnate: lips obtusely clenticulated wavy, upper lip bilobed porrect, lobes of the lower lip equal, stam. inserted below the niddle of the cor. glabrons with a fer scattered hairs below, style glabrous with a line of distaut hairs on its anterior side, stigma bilobed.-E. B. 422.-Stigma approximately lobed: lobes only just touching at one point, purple. Anth, yellow when dry.-Parasitical chiefly upon Trifolium pratense. $\Lambda$.? VI. VII.

7. O. amethystea (Thuill.); sep. many-nerved ovate below suddenly contracted into 1 or 2 subulate points, cor. tubular curved immediately from the base otherwise straight: lips unequally acutely denticulate wavy, upper lip hooded porrect notched, lobes of lower lip unequal middle one larger, stam. inscrted in the curvature of the cor. glabrous with many liairs at the base within, stigma lilobed.-At7. Fl. Par.t. 19. E. O. Eryngii Duby.-Lobes of stig. "divaricate, purple." (Hore. Phytol. ii. 239.) - "Parasitical upon Daucus maritimus." Whitsand Bay, Cornwall. A.? VII.

** Sep. 4 or 5 , connected below. Bracts 3. PhelipeA Desf.

8. O. arenaria (Bork.); cal. of $5 \mathrm{sep}$. tubular with triangularsubulate tceth shorter than the tube of the cor., cor. tubular slightly enrved in front, the middle of the tube compressed on the back, throat slightly inflated externally glandular, lobes of the lips obtuse with reflexed margins, lower lip hainy within, suture of the anth. lairy.-Atl. Fl. Par.t. 19. L.-Stigma scarcely 2-lobed, style pale yellow (?), glandular. Filaments glabrous with a few 
hairs at their base. Lateral bracts linear-subulate, intermediate limecolate attenuated above. St., scales, ancl cal. glaudularpubsesent. - Parasitieal upon Achillad Millefoliun? in the Chammel Islands. P. VII. VIII.

O.

9. O. ecrulea (Vill.); cal. of 5 sep. tubular with lanecolate nente tecth shorter than the tube of the cor., cor. tubular curved in front, middle of the tube compressed, lobes of the lips acute witl reflexed margins, lower lip liairy within, anth. glabrous.L. B. 423. Atl. Fl. Par. t. 19. K.-Dtig. scarcely 2-lobed, white. St., seales, bracts, cal., and cor. glandular-pubescent. - Grassy pastures. IIcrts. Norf. Isle of Wight. P. VII. E.

I0. O. ramosa (L.); cal. of 4 scp. tubular with triangular ovate aeuminate teeth, antl. glabrous, st. usually branehed.-E. $B$, 181.-I have not scen living specimens.-The genus Pheliprea of some author's is distinguished from the true species of Orobanche by its tubular tribracteate cal. and caps. bursting at the top not the side.-Parasitical upon IIemp. Very rare. A. VIII. IX.-E.

\section{Lathrea Linn.}

1. L. squamaria (L.); st. simple, fl. pendulous secund, lower lip of the cor. 3-cleft.-E. B. 50. G. E. Smith S. Kent. t. 3.Bracts ovate or lanceolate. Style straight or curved. Upper lip nearly cutire, or bifid.-Woods and thickets, parasitical npon Hazels, \&c. P. IV. V.

\section{Order LVIII. SCROPHULARINEÆ.}

Cal. 4-5-cleft, persistent. Cor. irregular or 2-lipped or personate, imbricate. Stam. on the cor., usually 4, didynamous. Orary free, 2-celled. Style simple; stigma 2-lobed. Fr. capsular, 2-celled; placenta central.

\section{* Stanens 4, didynamous.}

1. Digitalis. Cal. in 5 deep segments. Cor. bellshaped, oblique, 4-5-fid.-G. F. G. Gam. i. 33.

2. Antirrhinum. Cal. 5-parted. Cor. personate, gibbous at the base (no distinct spur); lower lip 3-fid with a prominent palate closing the mouth. Caps. opening by 2 or 3 pores at the top, 2-celled.-G. F. G. Gam. i. 32.

3. Linaria. Cal. 5-parted. Cor.personate, spurred; lower lip 3-fid, with a prominent palate closing the month. Caps. with valves or teeth at the top, 2-celled.-G. F. G. Gam. i. 31.

4. Scrophularia. Cal.5-lobed (in S. vernalis 5-cleft). Cor. 
globose; limb minute, of 2 short lips, upper 2-lobed, lower 3-loberl. Often the rudiment of a fifth stamen. Caps. opeuing by 2 valves witl their margins inflexed, 2 -celled.G. F. G. Gam. i. 29.

5. Limosella. Cal. 5-cleft. Cor. 5-fid, bellshaped, equal. Caps. globose, 2 -valved, placenta central, free or connected with a short dissepiment below, I-celled.-G. F. G. Gam.i.37.

6. Melampyrum. Cal. tubular, 4-toothed. Cor. ringent; upper lip compressed laterally with reflexed margins; lower furrowed, 3-fid. Caps. oblong, obliquely acuminate, compressed. Seeds I-2 in each cell, smooth.-G. F. G. Gam.i.47.

「Mı mulus. Cal. prismatical, 5 -toothed. Cor, ringent ; upper lip folled back at the sides. Seerls numerous.]

7. Pedicularis. Cal. inflated, 5-toothed. Cor. ringent; upper lip compressed laterally ; lower plane, 3-lobed. Caps. compressed, acute. Seeds numerous, angular.-G.F.G.Gam. i. 45 .

8. Rurnantuus. Cal. inflated, 4-toothed. Cor. ringent; upper lip compressed laterally; lower plane, 3-lobed. Caps. compressed, obtuse. Seeds numerous, compressed, with an orbicular margin.-Alecterolophus (Hall.) G. F. G. Gam.i.46.

9. Bartsia. Cal. bellshaped, 4-fid. Cor. tubular, ringent. Caps. pointed, cells many-seeded. Seeds compressed at the hilum and with winged ribs on the back (large).-G. F. G. Gam.i. 43.

10. Eufragia. Cal. tubular, 4-cleft. Cor. tubular, 2-lipped. Caps. pointed, cells many-seeded. Seeds slightly angular, very minute, crenate-ribbed, hilum basal.

I1. Eupirasia. Cal. tubular or bellshaped, 4-fid or 4-toothed. Cor. tubular, 2-lipped. Caps. obtuse or emarginate, cells many-seeded. Seeds rather angular, longitudinally ribbed, hilum subapical.-G. F. G. Gam. i. 42.

I2. Sinthorpia. Cal. in 5 deep spreading segments. Cor. rotate, irregularly 5-cleft. Caps. compressed, orbicular, 2 -seedcd, 2-valved.

$$
\text { ** Stamens } 2 .
$$

13. Veronica. Cal. 4-5-parted. Cor. rotate, unequally 4-lobed, lower lohe the smallest. Caps. compressed, 2cellerl.-G. F. G. Gam. i. 38. 


\section{Digitalis Linn.}

1. D. purpurea $\left(\mathbf{L}_{\text {. }}\right)$; 1. ovate-lanceolate crenate downy beneath, lower 1 . attenuated into a footstalk, scp. ovate-oblong acute 3-nerved downy, cor. obtuse glabrous exterually, upper lip scarcely cloven, segments of the lower lip ovate rounded.-E. $B$. 1297. St. 11.-L. often crenate-dentate or -scruate. Fl. sometimes white or flesh-coloured. St. 3-4 feet high.-IIedge-banks and woods. P. VI.-VIII. Foxglove.

\section{Antirrhinum $\operatorname{Linn}$.}

*1. A. majus (L.) ; 1. lanceolate opposite or alternate glabrous, f. racemose, sep. ovate obtuse much slorter than the cor., upper lip bifid. $-E$. B. I 29.-IIeight $1-2$ feet. Cor. $\mathbf{I} \frac{1}{2}$ in. long, purplish-red or white.-OId walls and chalk eliffs. P. VII.-IX. Great Snapdragon.

2. A. Orontium (L.); 1. linear-lanceolate opposite or alternate, fl. loosely spiked distant, sep. linear longer than the corolla.E. B. 1155. St. 27.-About a foot high. Fl. purple.-Dry sandy and gravelly fields. A. VII. VIII.

E. I.

\section{Linaria Mill.}

*I. I. Cymbaluria (Mill.); l. roundish-heartshaped 5-lobed glabrous, st. procumbent.-Antirrhinum Sm., E. B.502. St. 70. 10.-Stems slender, rooting. Fl. solitary, axillary, upon long stalks, pale blue.-Old walls V.-X. Ivy-leaved Toadflax.

2. L. Elatine (Mill.); l. ovate-hastate, lower l. ovate, spur straight, peduncles glabrous, st. procumbent.-Antirrhinum Sin., E. B. 692. St. 70. 1I.-Fl. solitary, axillary, npon long slender stalks, sinall, yellow, with the upper lip purple.-Gravelly and chalky corn-fields. A. VII.-IX.

E. I.

3. L. spuria (Mill.); l. roundish-ovate entire, spur curved upwards, peduncles hairy, st. procumbent.-Antirrh. Sm., E.B. 69I. St.70. 12.-Fl. similar to the last but larger. L. with here and there a small tooth.--In both this species and the preceding some of the fl. are often regular with 5 spurs or partially so with 2, 3, or 4.-Gravelly and sandy corn-fields. A. VII.-IX. E.

4. L. minor (Desf.) ; l. linear-lanceolate obtuse glandular-pubescent mostly alternate, $f$. solitary axillary, peduncles 3 times as long as the calyx, segments of the upper lip diverging, seeds oblong sulcate.-Antirrhinum Sm., E. B. 20I4. St. 70. I5.Fl. small, with the tube, upper lip, and spur of the cor. purplish, lower lip yellowish. St. erect, 4-10 in. high, branched, glandular-pubeseent.-Sandy fields, A. VI.-VIII. 
5. L. Pelisseriana (Mill.); glabrous, l. linear the lower ternate or quaternate upper alternate, sterile branehes radieal prostrate with ternate laneeolate or ovate $1 .$, fl. rucemose, pelluncles as long as the braets, scpals linear acute twiee as long as the eapsule, seeds diseoilat with a fimbriated wing smooth externally tubereular within,-E. B. S. 28:32.-Fl. purple with darker veins. St. one or more from each root, ereet, about a foot high. Caps. bilobed.-Jersey, A. V1.

[*6. L. supina (Desf.); glabrous, raehis ped. and sep. glandular-hairy, l. linear blint mostly whorled, sep. linear-spathulate shorter than the caps. or spur, seeds smooth discoidal with an orbicular striated margin.-L. maritima DC. Icon. Gull. I2.l'. eapitate-racemose, yellow, throat and spur witl slender purple lines, Style entire. Plant a few inches high, much branched at the base. L. narrow with inflexed points. - Catslown Quarries, Plymouth, "a true native." Mr. I. W. N. Keys. A. VII. VIII.]

E.

7. L. repens (Ait.); glabrous, 1. linear seattered or partly whorled, fl. raeemose, sep. lanceolate as long as the spur but shorter than the caps., seeds angular with transverse elevated lines. -E.B.1253. L. striata DC., Koch, R. I. t. 423._-"Fl. bluislı." St. ereet, branched, leafy, $1-1 \frac{1}{2}$ foot high, slender. Seeds much smaller than those of $L$. vulgaris or $L$. italica.-Caleareous soils, partieularly near the sea, rare. P. VII.-IX.

[8. L. purpurea (Mill.); glabrous, l. linear-laneeolate seattered, lower 1. irregularly in fours, fl. narrowly racemose, sep. linear shorter than the eaps. and long ineurved spur, seeds angular witl a network of elevated lines,-Fl. purple or yellow with the lips purple; spur two or three times longer than the perl. which is usually shorter than the braet. St. ereet, leafy.-Old walls, an eseape from gardens. P. VII. VIII.]

E.

9. L. italica (Trev.); glabrous, $l$. scattered linear-lanesolate, fl. raeemose, sep. lanceolate-oblong aeuminate slorter than the eaps. or spur, secds tubercular-scabrous with a smooth orbicular margin.-R. I. t. 421. L. genistifolia DC., not Mill. A. Bauhinii Gaud. See Lond. Journ. Bot. i. 79.-Fl. yellow, intermediate in size between those of $L$. repens and $L$. vulgaris. St. ereet, branelıed, leafy. Quite glabrons.-Banks. Shirley near Southampton. Wr.H. C. Watson. P. VIII. IX. E. I.

[L. sepium (Allman in Proe. R. I. Acad. Jun. 12, 1843) having its sep. laneeolate, seeds with three prominent smooth wings and $\mathrm{fl}$. with purple lines, (found by the river Bandon, Co. Cork, Dr. Allmon; aud near Penryn, Cornwall, Mr. Wratson) is seareely more than a variety of $\dot{L}_{\text {. }}$ italice unless the additional wing to the seeds should prove constant.] 
10. L. vulgaris (Mill.); glabrons, rachis and peluncles glandular-liniry, l. lincar-lanceolate scattered crowded, fl. racemose imbricated, sep. ovate acute glabrous shorter than the caps. or spur, secds tubercular-scabrous with a smooth orbicular nurgin. -E. B. 65. St. 18. 13.--Fl. yellow, large. St. erect, 2 feet high, as well as the l. glabrous. Common and partial flowerstalks occasionally glabrous.-The var. Peloria with 5 spurs and an cqual and regular cor. is sometimes, though rarely, found. E. B. 260.-Hedges on a gravelly soil. P. VI. VII. Yellow Toadflax.

\section{Scrophularia Limn.}

[The abortive fiftl stamen (staminodium), which usually appears under the form of a scale on the inner side of the upper lip of the cor., supplies a valuable distinctive character in this genus.]

1. S. nodosa (L.); l. ovate acute subcordate glabrons doubly and acutely serrate: lower serratures largest, st. acutely 4 -angular, cymes lax, scp. roundish-ovate with a narrow membranous margin, staminodium transversely oblong slightly emarginate.E. B. 1544. St. 23. 14.-Root tuberous, thiek, hnotty. St. $2-3$ feet high. Bracts small, lanceolate, acute. Fl. greenish-purple, lurid, sometimes milk-white. Caps. orate.-Moist liedges and thickets. P. VI. VII. Knotted Figwort.

2. S. Ehrharti (C. A. Stev.); l. ovatc-lanceolatc acute subcordate glabrous sharply serrate: lower serratures smaller, st. and petioles winged, cymes lax few $(4-8)$-flowered, scp). roundish with a broad membranous margin, staminodium bifid with diverging lobes.-Stev. A. N. H. v. t. I. E. B.S. 2875 . S. aquatica St. 23. 15.-St. tall. Bracts leaflike, lanceolatc, acute. Fl. dark purple. Caps. subglobose, obtuse.- Wet places. Cramond Bridge, Edinburgh. Berwick. Dr. P. Maclngan. Preston. Mr. Gilbertson. Wilmingdon, Suss. Mr. Jenner. Primrose Hill, London. Mr. Sowerby. P. VIII. IX. E. S.

3. S. aquatica (L.!); $l$. corlate-oblong rounded-obtuse glabrous crenate-serrate, st. and petioles winged, cymes dense corymbose many (8-15)-flowered, sep. roundish obtuse with a broad membranous margin, staminodium roundish-reniform entire.E. B.854. Stev. l. c. t. 1. S. Balbisii Horn., Koch.-St. $2-5$ feet high. Bracts linear, obtuse. Fl. dark purple, occasionally milkwhite. Caps, ovate, pointed.-In wet places. P. VII. VIII.

4. S. Scorodonia (L.); l. cordate-triangular with large double teeth downy on both sides, st. bluntly quadrangular downy, cymes lax few-flowered, sep. roundish downy with a membranous nargin, staminodium roundish entire.-E. B. 2209.-St. 2-3 feet higl. Bracts leaflike, lower exactly like the leaves. Fl. purple. 
Caps. ovate, acute. - In moist places. West of Cornwall. Tralee, Kerry. Jersey. P. VII. E. I.

5. S. vernalis (L.); l. downy eordate-aeute doubly serrate, st. wingel hairy, cymes axillary corymbose with leaflike bracts, sep. oblong with a recurvesl apex, staminodium $0,-E . B .567$. St. 23. I6.-St. about 2 feet high. Fl. yellow, inflated, their mouth much contracted. Caps. ovate, acute. Differing greatly from the other species and closely allied in appearance to some of the $\mathrm{Cal}$ ceolarias as is well observed by Sir J. E. Smith.-Waste places, rare. P. IV. V.

E. S.

\section{Limoselda Limn. Mudwort.}

1. L. aquatica (L.) ; l. laneeolate spathulate on long stalks, ped. axillary crowded shorter than the petioles. $-E . B$. 357. St. 30. 15.-St. 0, except the naked scions. Fl. small, white, or rose-coloured. Caps. minute, ovate.-Muddy places where water has stagnated. A. VII.-IX. E. S.

\section{Melampyrum Linn.}

1. M. cristatum (L.); spikes densely imbricated 4-sided, bracts heartshaped aeuminate pectinate-dentate lower ones with a long leaflike recurred point.-E. B. 41.-Bracts rosc-coloured at the base. Fl. yellow, tinged with purple. L. linear-laneeolate, aeute, entire, with dark netted veins beneath.-Woods and thickets in the eastern counties. A. VII. Crested Cow-wheat. E.

2. M. arvense (L.); spikes lax conical, bracts ovate-lanceolateattenuated pinnatifid with subulate segments and with a few large glandular elevated points beneath, cal. hispid as long as the tube of the cor. with elongate-laneeolate-attenuated teeth from an ovate base, cor. closed.-E. B. 53 (bad).-Bracts purple-rosecolour. Fl. yellow variegated with rose-colour and purple. L. linear-lanceolate, acute, rough-cilged, slightly downy on both sides, cntire.-Corn-fields and dry banks in Norf. and the Isle of Wight. A. VII. Purple Cow-wheat.

3. M. pratense (L.); fl. axillary secund in distant pairs, upper bracts lanccolate with 1 or 2 teeth at the base, cor. 4 times as long as the glabrous calyx closed: lower lip protruded.-E.B. I13. -Teeth and tube of the cal. about equal in length. L. lanceolate, entire, glabrous. Fl. large, pale yellow. - $\beta$. montanum; smaller in all its parts, bracts quite entire, l. linear-lanceolate lispid, the 2 lowest obovate-lanceolate blunt, st. with an alternate hairy line. M. montanum Johnst. Fl. Berw. Is it distinct?$\gamma$. latifolium; bracts with diverging and declining teeth at the base, 1 . hispid ovate-lanceolate, upper l. broadly eordate-ovateattenuate, st. with an alternate hairy line. Is it distinet?- 
Woods and thickets. $\beta$. Montains. $\gamma$. lanks of the Wye below Mommoutli. Mr. Borrer. A. VI.-VIII.

4. M. sylvaticum (I.); fl. axillary sceund in distant pairs, bracts all entire linear-lanccolate, cor. alont twice as long as the glabrous calyx open : lips equal in length.-E. B. 804.-'Teeth of the cal. longer than the tubc. L. lincar-lanceolate, cntire. Fl. small, half the size of the last, deep yellow.-Alpine woods. A. VII.

[Mimulus luteus (Willd.); l. roundish ovatc nerved, lower ones stalked, uppernost clasping, st. creeping; fl. yellow; a native of $A$ merica, is naturalized in many boggy places. P. VI.-IX.]

\section{Pedicularis Linn.}

1. P. palustris (L.); st. solitary erect branched throughout, 1. pinnatifid: segments oblong blunt lobed, cal. ovate pubescent 2-lobed: lobes inciso-lentate crisped.-E. B. 399.-Upper lip of the cor. with a short truncate beak with a triangular tooth on each sidc. 1'l. large, crimson. St. 12-18 in. high, angular, with alternate branches. Crown of the root with a whorl of ovate-acute scalcs.-Marshy and boggy places. A.? V.-VII. Marsh Louse-wort. Red Rattle.

2. P. sylvatica (L.); st. branched at the base erect, branches long spreading prostratc, l. pimnatifid: scgments ovate lobed, cal. oblong glabrous irregularly 5-lobed : upper lobe lanceolate, other lobes with 3 leaflike divisions. - E. B. 400. St. 13. 14.-Upper lip of the cor. as in the last. Fl. large, rose-colour. Summit of the ped. with a loose membranous cuticle inclosing the base of the calyx as observel by Dr. Bromfield. Primary st. erect, often very short, branches prostratc. Crown of the root with a whorl of ovate-lauceolate crenatc undivided reflcxed leaves.- Wet heathy and rather hilly pastures. A.? V.-VIII.

\section{Rhinanthus Linn.}

1. R. Crista-galli (L.); l. oblong-lanceolate serrate, fl. in lax spikes, cal. glabrous, lobes of the upper lip of the cor. short roundish, bracts ovate inciso-serrate, sceds with a membranous border.-E. B. 657.R.I.! f. 974.-Lateral lobes of the upper lip of the cor. very blunt, shorter than broad, bluish. Bracts green throughout, nectary ovate. St. $1-2$ fcet high.-Meadows and pastures. A. VI. Tellow Rattle.

2. R. major (Ehrh.) ; l. linear-lanceolate serrate, fl. in crowded spikes, cal. glabrous, lobes of the upper lip of the cor. oblong, bracts with an attenuated point inciso-serrate.-Lateral lobes of the upper lip of the cor. longer than broad, purplc; the central 
part truncate. Anth. very villose. Bracts yellowish with green points. - a. platypterus (Fies); seed not twice as broad as its wing. R. major Koch. R. I. f.975.- $\beta$. stenopterus (Fries); seed quite twice as broad as its wing. R. major Bab. ed. 1. E. B. S. 2737. $-\gamma$. apterus (Fries); seed not winged but romded and longitudinally rbbed or furrowed on the back. R. Reichenbachii Drej. -Cultivated land. a. Hastings. Mr. Borrer. $\beta$. North of England and Scotland. $\gamma$. Arbroath, S. Mr. IT. F. L. Carnegie. A. VII. VIII.

E. S.

\section{Bartsia Limn.}

1. B. alpina (L.) ; 1. opposite ovate slightly clasping bluntly serrate.-E. B. 361. St. 17. 15.-St. square, 4-8 in. high, simple. Root creeping. Fl. forming a short dense leafy spike, purplish-blue, downy. Cal. purplish, viseid. Antl. hairy.Alpine pastures, rare. P. VI. VII.

\section{Eufragia Griseb.}

I. E. viscosa (Benth.); l. opposite, upper 1. alternate ovatelanccolate sessile aeutely-serrate.-E. B. 1045. Bartsia Sm.-L. sometimes lincar-lanceolate. St. round, 3-12 in. high, simple. Root fibrous. Fl. distant, axillary, upper ones crowded, yellow. Anth. hairy. St., I., and cal. viscid.-Damp places in the west of England, south-west of Scotland, and south of Ireland. A. VII.-IX.

\section{Euphrasia Linn.}

1. E. officinalis (L.) ; l. ovate or ohlong-lanceolate nearly sessile serrate ( $3-5$ teeth on each side), cor.glabrous, lobes of the lower lip enarginate, of the upper lip patent sinuatc-dentate, anth. unequally mucronate hairy.-E.B. $1416,-$ St. $1-8$ in. high. Fl. axillary, solitary, sessile, crowded towards the ends of the branches. A peculiarly variable plant of which it is next to impossible to define the rarieties. Fries "pro tempore" distinguishes 2 species-1. E. officinatis (I.); l. ovate, floral-l. eordatetriangular or -ovate;-2. E. gracitis (Frics); l. oblong-lanceolate, floral-1, witl a wedgeshaped base;-No. 1 is common in Britain; No. 2 is less generally distributed, it inhabits mountain sides and elcrated heaths and is more slender and elegant than No. 1. -'The caps. varies in shape, the upper lip of the cor. in tootling, and the whole plant except the cor. in pubescence.-Pastures, woods, heatlss. $\Lambda$. VII. VIII. Eye-bright.

2. . . Odontites (L.) ; l. narrowed from the base opposite linearlanceolate remotely serrate, floral-1. longer than tlie fl., cor. pubescent, lobes of the lower lip oblong-obtuse, anth. with 2 equal points liairy.-Bartsia Sm., E. B. 1415.-St. about a foot high, 
mueh branched. Fl. numerous, pink, in leafy unilateral spikes. -Corn-fields and waste places. $\Lambda$. VII. V'IIII.

\section{Sinthorpia Linn.}

1. S. europea (L.).-E. B. 649.-An clegant trailing plant with slender filifor'm creeping stems, and alternate long-stalked roundish renifor'n leaves with a few large crenations. Fl. very small, axillary, solitary, on short stalks, pimkish, inconspicuons.-Damp shady places in the south and south-west. P. VI.-IX. E. I.

\section{Veronica Limn.}

\section{* Racemes axillary. (Root perennial.)}

1. I. scutellata (L.); l. linear-lanceolate acutc sessile minutely denticulatel, racemes alternatc, fruitstalks reflexel, caps. of i flattish orbicular lobes, st. ereet.-E. B. 782. St. 58. 3.-Root stoloniferous. St. weak, elongated. Fl. pale flesh-coloured, with darkicr lines. Scp. small, lanceolate, acute, shorter than the capsulc.-B.pubescens (Koch); st. hairy. V. Parmularia "Poit." -In boggy places. $\beta$. "Shropshire." Leighton. "North of Scotland." Murray. White-moor Pond, Surrey. IIudswell Moor, York. Mr. J. Ward. P. VI.-VIII.

2. V. Anagallis (L.); l. lanceolate serrated acute sessile, racemcs opposite, fruitstalks spreading, caps. elliptical slightly notched, st. erect.-E. B.781.-Root stoloniferous. St. thick, hollow, varying much in height. I'l. pale blue. Sep. lanceolate, longer than the capsule. Racemes sometimes clotherl with glandular hairs. Whole plant usually glabrous.-In stagnant water. P. VI.-VIII. Water Speedweil.

3. I. Beccabunga (L.); l. stalked elliptical obtuse crenateserrate, racemes opposite, fruitstalks spreading, caps, roundish tumid slightly notched, $s t$. procumbent at the base rooting.- $E$. $B$. 655. St. 12. 1.-Fl. bright blue. Whole plant glabrous.- $\beta$. limosa; bracts longer than the pediccls, fl. pink or flesh-coloured. $V$. limosa Lej.-Ditches and strcans. $\beta$. Dalkeith Park near Edimburgh. Prof. Balfour. P. V.-VIII. Brooklime.

4. V. Chamadrys (L.); l. nearly sessile cordate-ovate incisoserrate, racemes opposite, finitstalks ascending, caps. flat obcordate deeply notched ciliated shorter than the cal., st. bifariously hairy ascending.-E. B. 623. St. 58. 6.-Fl. large, numerous, haudsome, blue. Sep. lanceolatc, acute-IIedgc-banks. P.V. VI. Germander Speedwell.

5. I. montana (L.); l. stalked broadly ovate serrate, fruitstalks ascending, caps. orbicular notehed their margins crenulated and ciliated longer than the cal,, st, diffuse hairy all round pro- 
cumbent.-E. B. 766. St. 5R.5.-Fl. few, pale bluc. Caps. very large, quite flat. Sep. ovate-lanceolate, acute.-Woods and thrickets. P. V. VI.

6. V. officinalis (L.); 1. shortly stalked clliptical serrate, racemes dense many-flowered, fruitstalks crect, caps. obcordate truncate obtusely notched longer than the cal., st. prostrate creeping liairy.-E. B. 765 . St. 58.4.-Racemes crect, much longer than the leaves. "Caps. not always notched." Mr. Watson.- $\beta . g l a-$ bra; st., 1., and calyx smootli. $V$. Allionii (Vill.) is a very different plant with olicordate acutely notehed capsules and thick rigid leaves. $-\gamma$. ? hirsuta (Ilook.); l.ovate-lanceolate, caps. abrupt undiviuled. $V$. hirsnta IIopk., E. B. S. 2673. Much smaller than the true $V$. officinalis. I have not seen wild specimens.Dry banks and heatlss. $\beta$. Mountains. $\gamma$. Dry heatl, Carrick, Ayrshire. P. VI.-VIII. Common Speedwell.

\section{** Racemes terminal, tube of the cor. longer than its own diameter.}

7. V. spicata (L.); l. ovate or lanceolatc crenate-scrrate entire at the end, lower l. obtusc stalked, raceme spiked elongate dense, bracts longer than the pediccls, caps. orate cmarginate with a rery long style.-Sit. erect, brancling at the base. Spike nearly always solitary. Fl. blue.-a. vulgaris; lower l. oblong with it werlgeshaped base. E. B. 2.- $\beta$. hybrida; lower l. ovate with a rounded or slightly cordatc base. 'Two or three times as large as var. a. V.hybrida (L.) E. B.673.-Rare. a. On chalky heaths near Newmarket and Bury. $\beta$. On limestone cliffs. P. VII. VIII. Spiked Speedwell.

*** Racemes terminal, tube of the cor. very short.

$$
\dagger \text { Seeds flat. }
$$

8. V. fruticulosa (L.) ; l. elliptical or lanccolate obtuse subcrcnate, lower 1 . smaller, racene glandular-pubescent few-flowered (many-flowered Sm.), caps. elliptical abrupt: valves bifid.-E.B. 1028. St. 56. 1.-Fl. flesh-coloured. I have not seen native specimens.-Ben Cruachan. Dr. Halker. Ben Lawers. Dr. R. Brown. P. VII.

9. V. saxatilis (L.); l. elliptical serrate at about the middle, lower l. smaller, raceme pubescent with crisped hairs not glandular few-flowerel, caps. ovate-attenuated: valves bifid.-E. B. 1027. St. 56. 2.-Fl. bright blue. St. decumbent, woody.-Exposed alpine roeks. P. VII.

I0. V. alpina (L.); l. elliptical or ovate dentate or entire, lower I. smaller, raceme hairy with patent hairs not glandular fewflowered, caps.oblong-obovate emarginate erowned with the very 
short persistent style.-F. B. 484. St. 56. 3.-Fl. bright blue. St. simple, execpt at the base, $4-6$ in. high. Hairs jointed.Summits of highland momitains. l'. VII. VIII.

11. V. serpyllifolia (L.); l. ovatc or clliptical slightly crenate, lower l. smaller and rounder, raceme elongate many-flowered, caps. obcordate broader than long erowned with the long persistent style.-L. B. 1075. St. 58. 1.-Fl. whitish with blue veins. St. rooting bclow, afterwards erect. $-\beta$. humifusa (Sm.); stems quite prostrate, raccmes shorter. V. humifusa Dicks.--Roadsides and damp places. $\beta$. Ilighland mountains. P. V.-VII.

12. V.arvensis (L.); l. corlate-ovate crenate, lowcr l. stalked, uppermost 1 . lanceolatc entirc resembling bracts longer than the flowers, raceme slightly spiked many-flowered lax, pedicels very short, caps. obcordate broader than long compressed ciliated on the kecl.-E. B. 734. St. 58. 11.-St. ascending, sometimes a foot long, prostrate below; or not 2 in., when the spike commences close to the root. Fl. pale blue. Caps. smooth, "with rounderl lobes which arc longer than the style. Seeds $12-14$. Sep. lanceolate, unequal.-Gravelly and sandy places. A. IV.VII.

13. V. verna (L.); l. pinnatifid, lower l. stalked ovate serrate, upper 1. lanceolate entire resembling bracts, raceme slightly spiked many-flowered lax, pedicels very slort, caps. obcordatc compressed ciliated on the keel.-E. B. 25. St. 13. 1.-St, crect, 1-3 in. high, simple, or branched in the lower part. Caps. smooth or downy, with roumded lobes. Style very short. Seeds 12-14. Sep. linear-lanceolate, unequal.-Sandy lieaths ncar Bury, Thetford and Mildenhall, Suff. A. V.

E.

$\dagger+$ Seeds concave.

14. V. triphyllos (L.); l. fungered, lower l. ovate entire or dentate stalked, raceme slightly spiked lax many-flowered, pedicels longer than the caly $x$, caps. obcordate compressed smooth ciliated on the keel.-E. B. 26. St. 8. 1.-St. ercet with spreading branches, 4-5 in. high. Fl. deep blue. Pedicels usually longer than the leaves. Sep. oblong, obtuse. Known by its spreading st., deeply fingercd l., and dark blue flowers.-Sandy fields. Bury and Mildenlıall, Suff. Acomb near York. Mr. O. A. Moore. A. IV.

**** Flowers axillary, solitary; seeds concave.

15. V.agrestis (L.) ; l. all stalked cordate-ovate inciso-scrrate, sep. oblong obtuse, stam. inserted at the very bottom of the cor., caps. of 2 turgil kceled lobes, seeds about 6 in a cell.-E. B.S. 2603. St. 58. 14. R. I. f. 440.-St. procumbent. Caps. sometimes hairy all over, at others ciliated on the kcel. L. usually longer than the peduncles. Lower part of the cor. white. $-[\dot{V}$. 
opaca (Fries) with spathulatc sep. and fewer sceds is probably british. Koch says that its stamens are inserted much higher up) the cor. than in either of its allies.] - Ficlds and waste places. A. IV.-IX. Green field Speedwell.

16. I. polita (Mries); 1. all stalked cordatc-ovate inciso-serrate, sep. broadly ovate acute, stam. inserted at the very bottom of the cor., caps. of 2 turgid lobes, seeds $8-10$ in a cell.-E. $B$. 783. St. 58. 16. R. I. f. 404. 405.-St. procumbent. Caps, with short dense pubescence, rarely glabrous. L. usually shorter than the peduncles. Fl. wholly bluc. $-\beta$. grandiflora; cor. as large as that of $V$. Buxbaumii.-Fields and waste places. $\beta$. Berwickshire, and near Cambridge and Bury St. Elmouds. A. IV.-IX. Gray field Speedwell.

*17. V. Buxbaumii (Ten.); 1. all stalked cordatc-ovate incisoserrate, sep. lanceolate acute, stam. from the bottom of the cor., caps. of 2 divaricated lobes compressed upwards and sharply keeled, seeds about 8 in a eell.-E. B. S. 2769 . St. 56. 5. R. I. 430. 431.-St. long, procumbent. L. shorter than the peduncles. Fl. twice the size of those of the preceding, as large as those of $V$.Chamadrys, blue.-In fields and cultivated land in many places. A. IV.-IX.

I8. $V$. hederifolia (L.); l. with 5-7 large toothlike lobes all stalked, scp. corlate ciliated, caps. of 2 turgid lobes, seeds 2 in each cell.-E. B. 784. St. 56.6.-St. procumbent, fl. pale blue. -Fields and banks. A. IV.-VI. Ivy-leaved Speedwell.

\section{Order LIX. LABIAT 曆.}

Cal. tubular, regular or 2-lipperl, persisteut. Cor. 2-lipped, upper lip entire or bifid, lower 3-cleft. Stam. 4, didynamous, rarely 2. Ovary free, 4-lobed. Style 1, from the base of the lobes; stigma bifid. Fr. in $1-4$ small nutlike portions.

Tribe I. MENTHOIDE E. Cor. bellshaped, nearly regular. Stam. distaut, straight.

1. Mentha. Cor. 4-fid, tube very short. Cal. equal, 5toothed. Stam. 4, anth.-cells parallel.-G. F. G. Gam. ii. 5. 6 .

2. Lycopus. Cor. 4-fid, scarcely longer than the equal btoother calyx. Stam.2, anther-cells parallel or ultimately divergent, 2 upper stam. 0 or rudimentary, or rarely perfect. -G. F. G. Gam. ii. 7 . 
Tr. II. MONARDEA, Cor. 2-lipped. Stam, 2, fertile, parallel umder the mper lip of the corolla.

3. Salíia. 'T'wo upler stam. wanting or melimentary; conneetive filiform, elongate, with 2 diverging branclies, one bearing a perfect ecll the other barren. Cor. ringent. Cal. tubular, 2-lipped.-G. F. G. Gaun. ii. 8.

Tr. III. SATUREINEA. Cor. 2-lipped. Stam. 4, distant ; cells of antl. separate, divergent ; connective dilated.

4. Origanim. Stam. divergent, comnective subtriangular. Upler lip of cor. straight, nearly fiat; lower patent, 3-fid. Cal. with 5 equal teeth and $10-13$ nerves; throat hairy. Spikes 4-sided, resembling eatkins, imbricated with bracts. -G. F. G. Gam. ii. 14.

5. Trivuus. Apices of stam. patent. Anth.-cells at first nearly parallel, afterwards divergent; connective subtriangular. Upper lip of cor. straight, nearly flat; lower patent, 3-fid. Cal. 2-lipped and 10-13-nerved; throat hairy. Fl. whorled, axillary or spiked-G. F. G. Gam. ï.16.

6. Calamintila. Apices of stam. connivent under the upper lip of the corolla. Anth.-cells at length divergent; connective subtriangular. Upper lip of cor. straight, nearly flat; lower patent, 3-fid. Cal. 2-lipped.-G. F. G.Gam.ii.12.13.

Tr. IV. MELISSINEA. Cor. 2-lipped. Stam. distant ; anth.cells connected above.

7. Melissa. Apices of stan. connivent under the upper lip of the cor. Anth.-cells divcrgent. Upper lip of cor. concave; lower patent, 3-ficl. Cal. 2-lipped; upper lip flat, with 3 teeth, the lateral teeth foldted at their midrib.G. F. G. Gam. ii. 11.

Tr. V. SCUTELLARIEAE. Stam. approximating, parallel under the upper lip of the cor. Cal. 2-lipped, closed in fruit.

8. Scutellaria. Apices of the stam. incurved. Filaments simple. Anth. of the 2 longer and inferior stam. 1-celled, of the shorter and superior 2 -celled. Cor. 2-lipped, upper lip concave. Cal. ultimately closed and compressed; lips cntire, upper one with a concave scale on its back.-G. F. G. Gam. ii. 22 .

9. Prunella. Two inferior stam. longest. Filaments bifid, one branch barren. Anth, all 2-celled. Cor. ringent; upper lip concave, entire. Cal. ultimately closed and compressed ; upper lip flat, truncate, 3-toothed; lower bifid.-G.F.G.Gam. ii. 21 . 
Tr. V1. NEPETEXE. Stam. approximating, parallel under the upper lip of the cor., 2 inferior shortest. Cal. tubular.

10. Nepeta. Anth.-cells diverging. Cor. ringent; upper lip flat, straight emargiuate or bifid. Cal. 5-toothed.-G.F.G. Gam. ii. 23. 24.

'l'r. VII. STACHYDEAE. Stam. approximating, parallel under the upper lip of the cor., 2 inferior longest. Cal. tubular or hellshaped, spreading in fruit.

* Stamens longer than the tube of the corolla.

11. Mecitris. Anth. approaching in pairs and forming a cross, bursting longitudinally. Upper lip of the cor. flat, entire, straight ; lower hip with 3 rounded nearly equal lobes. Cal. membranous, bellshaped, ample, variously lobed.G. F. G. Gam. ii. 27.

12. Lamium. Anth. approaching in pairs; cells diverging, bursting longitudinally. Upper lip of the cor. arched; lateral lobes of the lower lip minute toothlike or obsolete rarely elongated. Cal. bellshaped, 5-toothed; teeth ncarly equal. - Galeobdolon (Huds.) has the lateral lobes of the lower lip of the cor. nearly equal to the middle one and all of them acute.-G. F. G. Gam. ii. 28. 29.

13. Leonurus. Anth. approaching; cells nearly parallel, bursting longitudinally. Upper lip of cor. nearly flat, lower with 3 obtuse lobes. Cal. tubular, 5-toothed, 2 lower teeth rather the longest. Nuts flatly truncate--G. F. G. Gam. ii. 30 .

14. Galeopsis. Anth. approaching in pairs; cells opposite, bursting by 2 valves transversely. Upper lip of cor. arched, lower lip 3-lobed with 2 teetl on its upper side, lobes unequal. Cal. tubular, 5-toothed; teetl equal or 2 upper oncs longest. Nuts rounded at the end.-G. F. G. Gam. ii. 32 .

15. Stachys. Anth. approaching in pairs; cells diverging, bursting longitudinally. Upper lip of cor. concave, lower of 3 unequal tobes. Cal. tubular-bellshaped with 5 equal teeth. Nuts obtuse and convex at the end.-G. F.G.Gam. ii. 33. 34 .

16. Ballota. Anth. approximating in pairs; cells diverging, bursting longitudinally. Upper lip of the cor. erect, conrave; lower 3-lobed, midrle lobe cordate. Cal. funnelshaped with 5 equal teeth. Nuts convex and rounded at the end.-G. F. G. Gam. ii. 40. 
** Stamens included in the tube of the corolla.

17. Marrebrum. Stam. included within the tube of the corolla. Anther-cells diverging, bursting longitudiually. Upper lip of eor. straiglit, ereet, flattish, cloven; lower 3lobel, middle lobe the largest. Cal. tubular; tectl nearly equal or 2 longer. Nuts flatly truncate.-G. F. G. Gam. ii. 38 .

Tr. VIII. ADJUGOIDE E. Cor. with the upper lip very short or split decply bifid and appearing as if wanting.

18. Teucrium. Stam. parallel, protruding betwecu the deeply divided lobes of the upper lip of the cor., inferior longest; cells bursting longitudinally. Cor. with the upper lip deeply bifid: lobes elongate; lower lip 3-lobed. Cal. tubular, 5toothed, tecth equal or the upper one larger.-G.F.G. Gam. ii. 45,46 .

19. AJuga. Stam. parallel, protruding far beyond the upper lip of the cor., inferior longest; cells bursting longitudinally. Cor. with the upper lip very short, 2-lobed ; lower 3-lobed, much longer than the upper. Cal. ovate-bellshaped, nearly equally 5-cleft.-G. F. G. Gam. ii. 47.48.

\section{Tribe I. Menthoidea.}

\section{Mentha Linn.}

* Throat of the calyx naked.

1. M. rotandifolia (L.); $l$. sessile elliptic-obtuse crenate-serrate wrinkled shaggy beneath, spikes linear-cylindrical dense, bracts lanceolate, "fr.-cal. not contracted at the mouth." -E.B. 446. Sole Menth. 3.-Viscid. Whorls of spike nearly all close together. Scent acrid.-Waste places, rare. P. VIII. IX. Roundleaved Mint.

E. I.

2. M. sylvestris (L.); l. subsessile ovate or lanceolate serrate hoary beneath, spikes linear-cylindrical dense, bracts subulate, "fr.-cal. contracted at the mouth."-E. B. 686. Sole 1. and 2.Whorls of spike nearly all close together. Scent sweet.- $a$. L. lanceolate, acute, rather narrowed below.- $\beta$. velutina; l. elliptical-cordate. M. velutina Lej. M. rotundifolia Sole 4.- $\gamma_{\text {. crispa }}$; 1. deeply eut and crisped. E. B. S. 2785.-Waste ground in damp places. $\beta$. Norfolk. Arran and Killin. S. $\gamma$. Langley Ford. Nortlumberland. P. VIII. IX. Horse Mint.

E. S.

3. M. viridis (L.); l. glabrous sessile lanceolate acute serrate, spikes lax cylindrical, bracts subulate--E. B. 2424. Sole 5.- 
Cor. glabrous. Whorls of the spike rather distant. L. glandular below.- $\beta$. crispa (Benth.).--In marshy places, rare. $\beta$. Glen Farg, Perthshire. Hooker. P. VIII. Spear Mint.

4. M. pratensis (Solc); l. nearly sessile ovate-lanceolate acute serrate, floral $l$. similar the smaller ones longer than the whorls, whorls distant subglobose, pedicels glabrous, cal. bellshaped: teeth lairy,-Sole 17. M. gentilis. Sole 15. E. B.449. M. gracilis Sm.-St. and l. usually glabrous. L. paler beneath, glandular. Cal. glandular.-Marshy places, rare. P. VIII. IX.

E.

5. M. piperita (L.) ; l. stalked ovate-lanceolate or oblong scrrated, upper l. smaller, bracts lanceolate, spikes lax short obtuse interrupted below, cal. tubular glabrous below with lanccolatc subulate tceth.-E. B. 687.-St. and l. nearly glabrous or hairy on the nerves beneath. Cal. glandular.- $\beta$. sylvestris (Sole); l. ovate rounded and almost heartshaped below, spikes elongated. Sole 24. -Wet places, rare. P. VII. VIII. Pepper Mint.

6. I. aquatica (L.); l. stalked orate serrate rounded or slightly cordate below, uppermost $l$. like bracts and shorter than the whorls, whorls few subglobose capitate the uppermost terminal, cal. tubular with triangular subulate teeth hairy as well as the pedicel.-M. hirsuta Sm., E. B. 447.-Cal. glandular. Inflorescence capitate, determinate. $\mathrm{Fl}$. in terminal and axillary stalked clusters rather than whorls.--M. citrita Ehrh. M. odorata Sole 9. E. B. 1025. is a glabrous variety of this species.-In wet places. P. VII. VIII. Capitute liint.

7. M. sativa (L.); l. stalked ovate or elliptical serrate, upper ones similar but smaller all longer than the whorls, whorls all distant dense, cal. tubular or bellshaped : teeth triangular-lanceolate acuminate.-Inflorescence whorled, indeterminate. Uppermost leaves often barren.-a. vulguris; cal. and pedicels hairy. M. sativa Sm., E. B. 448. - $\beta$. rubra; pedicels and lower part of the calyx glabrous, st. slightly branched reddish, whole plant nearly glabrous. M. rubra Sn., E.B. 1413.- $\gamma$. gentilis; pedicels and lower part of the cal. glabrous : teeth shortcr triangular, whole plant nearly glabrous, st. much branched green, 1. all of nearly the samc size. $M$. gentilis $\mathrm{Sm}$. The characters of this variety closely approach $M$. arvensis. $-\delta$.? acutifolia; pedicels and cal. hairy all over, 1 . ovate-lanceolate tapering at each cnd. $H$. acutifolia Sm., E. B. 2415. It is probable that this plant is correctly referred here. A specimen from near Scttle, Yorkshire (Mr. S. H. Haslam), only differs from Snith's plant by haring glabrous pedicels. - Var, $a, \beta$, and $\gamma$ are closely connected by intermediate forms. - Wet places. $\delta$. Banks of the Medway, but not found for many years. P. VII. VIII. Whorled hairy Wint.

8. $M$. arcensis (L.); $l$. stalked orate or elliptical serrate, 
"1per l, similar and equally large, whorls distant, cal. bellshaped : tecth trimgnlar as broad as long.- Lufloreseence indeterminate. -a. vulgaris; 1. narrowed below. M. arvensis Sin., L. B. 2119. - $\beta$. agrestis; 1 . somewhat cordate below, npper ones nearly sessile. 11. agrestis Sm., E. B.2120.-In eorn-fields. P. VII. -IX. Corn Mint.

** Throat of the calyx closed with hairs. Pulegium Opit\%.

9. M. Pulegium (L.) ; l. stalked elliptieal obtuse slightly erenate all similar, whorls all distant globose many-flowered, cal. tubular hispid elosed witl hairs in the throat.-E. B. 1026. Sole 23. - st. prostrate. 'The smallest of our speeies and remarkably differeut in labit.-Wet plaees. P. Vlll. IX. Pennyroyal.

\section{Lycopus Linn.}

I. L. europaus (L.); 1. stalked ovate-oblong sinuate-dentate or pinnatifid, sterile stam. wanting, nuts within the tube of the ealyx.-E. B. II05.-L. glabrous or pubeseent. Bentham says (Lab. 186.) of this, "stolonibus nullis," but the English plant eertainly prodnees runners. [L. exaltatus is distinguished by having 2 barren stamens and mueh longer seerls.]-Banks of streams and ditehes. P. VII. VIII. Gypsy-wort.

\section{Tribe II. Monardea.}

\section{SAldia Linn.}

1. S. verbenaca (L.); l. oblong obtuse eordate below sinuate and erenate or dentate stalked, upper $l$. short broad cordate sessile elasping, braets eordate acuminate, tube of the cor. as long as the calyx.-E. B. 154.-Varies with the 1. ineiso-dentate. Remarkable for its enlarged very broad sessile upper leaves.-Dry gravelly banks. P. V. VI. English Clary.

2. S. clandestina (L.); l. oblong eordate below sinuate-dentate or iuciso-dentate stalked, upper l. oblong acute sessile seareely eordate or elasping, braets eordate aeuminate, tube of the cor. longer than the calyx.-Probably distinet from the preeeding but rery diffieult to distinguish on paper. See Benth. Lab. 241.Dry gravelly banks, rare. Lizard Point, Cornwall. P. VII. F.

3. S. pratensis (L.) ; l. oblong-ovate eordate below erenatedentate stalked, upper l. small sessile laneeolate aeute, brarts eordate aenminate, eor. thriee as long as the ealyx.-E. B. I53. -Distinguished from both the preeeding speeies by its large flowers.-Near Cobham, Kent. "Oxfordshire." P. VII. E. 


\section{Tribe III. Satureinea.}

\section{Origanum Linn.}

1. O. vulgare (L.) ; l. stalked broadly ovate obtuse, bracts ovate longer than the cal., heads of fl. roundish panicled crowded. - E. B. 1143. St. 3. 13. - Bracts usually piuple. L. often slightly toothed.-Dry uncultivated places. P. VIII. Marjoram.

\section{Thymus Linn.}

1. T. Serpyllum (L.?) ; fl. whorled or capitate, l. ovate or oblong more or less attcnuated into a short petiole flat fringed with long liair's, floral l. similar, upper lip of the cor, emarginate ovate 4-angular, upper lip of the cal. with short ovate-lanceolate lower with subulate ciliated teeth.-E. B. 1514. T. Chamædrys Fries. -L. nearly glabrous, or densely hairy. St. procumbent, woody, bifariously hairy.-Dry licaths. P. VI.-VIII. Wild Thyme.

\section{Calamintha Moench.}

* Fl. in whorls of 2 dichotomous cymes.

1. C. Nepeta (Clairv.); l. ovate serrated pale bencath shortly stalked, cal. subcampanulate obscurely 2-lipped: teeth shortly ciliated all nearly the same shape the upper ones slightly shorter, nuts roundish, cymes dichotomous many-tlowered.- $E$. B. 1414. St.70.3. Thymus Sm. Melissa Benth.-Hairs in the throat of the cal. protruded.-Dry banks, rare. P. VII. VIII. Lesser Calamint.

2. C. officinalis (Moench); l. broadly ovate slightly serrated green on both sides on longish stalks, cal. tubular ventricose in front distinctly 2-lipped: teeth with long cilia those of the upper lip triangular of the lower twice as long and subulate, nuts roundish, lower lip of the cor. with distant segments the middle one longest, cymes scarcely dichotomous few-flowered.-E. $B$. 1676. Thymus Calamintha Sm.-Hairs in the throat of the cal. included. Larger in all its parts than the preceding.-Dry banks, rare. P. VII.-IX. Common Calamint. E. I.

3. C. sylvatica (Bromf.); 1. broadly ovate sharply serrate, cal. tubular distinctly 2-lipped: teeth with long cilia those of the upper lip patent or reflexed, lower lip of the cor. with overlapping segments all nearly equally long, cymes many-flowered stalked.E. B. S. 2897.--IIairs in the throat of the cal. few, included. Root slightly creeping. L. large. Cymes mostly on long stalks. Cal.-teeth tinged with purple. Cor. very large, tube much protruded, middle lobe of lower lip short and broad.- Isle of Wight. P. VIII.-X. 
** Whorls of 6 simple separate peduncles. Acinos Mocnch.

4. C. Acinos (Clairv.); l. ovate subscrrate acute with revolute unargins, cal. tubular gibbous below distinctly 2-lipped: upper with short triangular teeth lower with subulate tectl all converging in fruit. - E. B. 411. St. 70.5. Thymus Sm. Acinos Ilook. Melissa Benth,-St. 6-8 in. long.-Dry gravelly places. A.? VII. VIII. Basil Thyme.

\section{*** Fl. in dense axillary whorls. Bracts forming a kind of involucre. Clinopodium Linn.}

5. C. Clinopodium (Spemu.); l. ovate obtuse rounded below slightly crenate, whorls equal many-flowered, bracts setaceous as long as the calyx,-E. B. 1401. Clinopodium vulgare Sm. Melissa Bentl..-St. 1-1 $\frac{1}{2}$ foot high. Fl. purple in 2 or 3 dense whorls, the uppermost terminal.-Dry bushy places. P. VII. VIII. Wild Basil.

\section{Tribe IV. Melissinea.}

\section{Melissa Linn.}

*1. M. officinalis (L.); l. ovate crenate-serrate acute paler beneath, cal. subcampanulate slightly ventricose in front distinctly 2-lipped, upper lip flat truncate with 3 short broad teeth, lower with 2 lanceolate teeth.-St. 11.-St. 2 feet high. Fl. in axillary secund whorls.-Naturalized in the south. Balm. E. I.

\section{Tribe V. Scutellariece.}

\section{Scutellaria Linn.}

1. S. galericulata (L.); l. shortly stalked all oblong-lanceolate cordate below crenate-serrate, $\mathrm{fl}$. axillary opposite secund, calyx without glands.-E. B. 523.-Cor. large, blue. St. 6-12 in. high, stout. Distinguished from $S$. hastifolia by wanting the glandular hairs on the calyx, although that part is downy, and the different shape of the leaves. This genus has a curved elongated support (earpophore) to its nuts.-Banks of rivers and ditches. P. VII. VIII. Common Skull-cap.

2. S. minor (L.); l. shortly stalked, lower l. broadly ovate, intermediate ovate-lanceolate with the base cordate, upper $\mathrm{l}$. lanceolate with a rounded base, $\mathrm{fl}$. axillary opposite secund, cal. pubescent.-E. B. 524.-Cor. small. St. 4-8 in. high, slender. - Moist lieaths and boggy places. P. VII. - IX. Lesser Skull-cap. 


\section{Prunella Limn. Self-heal.}

1. P. vulgaris (L.); l. stalked oblong-ovate obtnse, upper lip of the cal. witl short truncate mueronate teeth, lower lip with ovatc-lanceolate mucronate teeth, longer stam. with a straight spinous tooth at their apex.-E. B. 961.-L. nearly entire or slightly toothed; on continental specincns they are sometimes pinnatificl. Fl. blue, rarely white, whorled, crowded into a dense spike, with 2 broad obcordate acuminate bracts under eaeh whorl. Cal. reddish-purple.-In damp pastures. P. VII. VIII. E. S.

\section{Tribe VI. Nepetea.}

\section{NePeta Linn.}

1. N. Cataria (L.); l. stalked eorlate arute inciso-serrate whitish-pubescent beneath, whorls dense many-flowered rather stalked spiked, nuts smooth and glabrous--E. B. 137.-Fl. white. St. 2-3 feet high, downy or mealy. Stam. at length curved outwards. - Waste places. P.VII.VIII. Cat-mint. E. I.

2. N. Glechoma (Benth.); 1. cordate-reniform crenate, whorls axillary stalked secund 3-4-flowered, cal.-teeth ovate aristate, nuts oblong with impressed dots.-E. B. 853. Glechoma hederacea Sm.-St. procumbent, creeping. Anth. in pairs forming a cross.- $\beta$. hirsuta; cal.-teeth elongate linear-lanceolate. G. hirsuta "W. and K.," Reich.-IIedges and thickets. $\beta$. Seotland. P. IV.-VI. Ground-ivy.

\section{Tribe VII. Stachydea.}

\section{Melittis Limn.}

1. M. Melissophyllum (L.).-E. B. 577 and 636.-L. oblongovate or slightly cordate. Upper lip of the eal. with 2 or 3 teeth. Fl. purple with a white margin or variegated in different ways, large.-St. 1-2 feet high. M. grandiflora (Sm.) is only a slight variety.-Woods in the south. P. V. VI. Bastard Balm. E.

\section{Lamium Linn.}

1. L. amplexicaule (L.) ; 1, roundisl-cordate obtusely incisocrenate, lower oncs stalked, upper sessile and clasping, cal.-teeth longer than their tube (green) at length connivent, lateral lobes of the lower lip of the cor. toothless, nuts obovate oblong.-E. B. 770. R. I. f. 373.-Nuts small, three times as long as broal, with a small triangular oblique terminal space. Tube of the cor. much longer than the calyx, slender, naked within; oceasionally the lateral lobes of the lower lip have 3 minute teeth. In damp weather the cor. does not always expand but still the 
anth. are fertile and fr. is produced.-Sandy and chalky ficlds. A. V.-VIII. Henbit.

2. L. intermedium (lines); l. obtusely inciso-crenate, lower ones stalked, upper reniform-cordate uppermost sessile reniformcordate, cal.-teeth longer than their tube hispid always spreading, tube of the cor. witl a faint hairy ring within, lateral lobes of the lower lip with a small tooth terminal lobe transversely quadrate or oval and emarginate, nuts oblong.- R. I. f. 964.- Nuts twice the size of those of the preceding, as broad as but longer than those of the following, with a large triangular terminal rather oblique space. Tube of the cor. equal, cylindrical, straight. Cal.-teeth usually purple, rigid.-Common in Scotland. Sligo, Ireland. A. VI.- IX.

S.I.

3. I. incisum (Willd.); 1. cordate obtuse inciso-serrate stalked, upper ones crowded, cal.-tecth as long or longer than their tube always spreading, tube of the cor. naked within, lateral lobes of the lower lip with a strong tooth, nuts oblong.-E. B. 19:33.Varies with the l. cordate or wedgeshaped below, and the st. few slender and elongated or numerous thick and short. 'Tube of the cor. equal, cylindrical, straight, sometimes with a faint ring of hairs within.-Cultivated and waste ground. A. IV.-VI.

4. L. purpureum (L.); l. cordate crenate-serrate stalked the upper ones crowded, cal.-teetl as long as their tube always spreading, tube of the cor. with a ring of hairs within, lateral lobes of the lower lip with 2 teeth, nuts oblong.-E. B. 769.Cor. pale purple, lip spotted with red; tube usually slightly curved and narrowed below. Nut about twice as long as broad. A form of this plant witl more deeply cut leaves is often taken for L. incisum.-Waste and cultivated ground. A. V.-VIII. Red Dead-nettle.

5. L. album (L.); 1. cordate-ovate acuminate deeply serrate stalked, cal.-teeth as long as the tube all separated by acute angles: upper one distant from the others, lateral lobes of the lower lip of the cor. with $1-3$ teeth, tube as long as the calyx with an oblique ring of hairs within.-E. B. 768. St. 8.-St. 12-18 in. high. Fl. large, white. The separation of one tooth from the others in the calyx of this species is remarkable.Waste ground. P. V. VI. White Dead-nettle.

†6. L. maculatum (L.); 1. cordate-ovate acuminate deeply serrate stalkerl, cal--teeth longer than their tube 3 upper oncs separated from the other 2 by broad obtuse angles, lateral lobes of the lower lip of the cor. with 1 tooth, tube longer than the calyx with a transverse ring of hairs within.-E. B. 2550.-St. 12-18 in. high. Fl. purple. L. marked with white cordate-ovate ( $L$. 
maeulatum R. Icon. t. 215.), or green triangular-cordate (L. lævigatum $R$. Icon. t. 216.).--lifeshire and Clova. P. VI.-VIII.

E.? S.

7. L. Galeobdolon (Crantz); l. ovate acuminate truneate below coarsely serrate stalked, upper 1 . lanceolate attenuated below, lielmet of the cor. clongated entire, lower lip in 3 entire nearly equal lobes.-E. B. 787. Galeobdolon luteum Sm. G. montanum Reich.!-Fl. yellow. St. 12-18 in. high. G. luteum Reich.! differs from this by having the 1 . all ovate-aeuminate and the lower ones simply crenate with a minute apiculus. I have not seen this in Britain, in our plant the lower l. are coarsely and even doubly serrate.-Woods and thiekets. P. V. VI. Archangel.

\section{LeONurus Linn.}

1. L. Cardiaca (L.); lower 1. palmately 5-fid inciso-dentate, upper ones 3-lobed entire wedgeshaped bclow, tube of the cor. with an oblique ring, helmet nearly flat, lip spreading the middle lobe entire.-E. B. 286. St. 9. 2.-St. 3 feet high. Cor. hairy externally, purple. Fl. in erowded whorls. Cal.-teeth sharp.Hedges and waste places, rare. P. VIII. Motherwort.

\section{Galeopsis Linn.}

1. G. ochroleuca (Lam.); st. softly pubeseent with deflexed hairs not thickened below the joints, l. ovate-lanceolate serrated soft and downy on both sides, upper l. ovate, eal. glandular shaggy, upper lip of the cor. deeply notched.-E. B.2353. St. 62.5. G. villosa Sm.-Cor. large, pale yellow. St. 10-12 in. high. - Sandy eorn-fields, rare. A. VII. VIII.

2. G. Ladanum (L.) ; st. softly pubeseent with deflexed hairs not thickened below the joints, 1 . laneeolate or ovate-lanceolate serrated or nearly entire downy on both sides, cal. shaggy with adpressed hairs and a few glandular hairs intermixed, upper lip of the cor. slightly notched.-E. B. 884. St. 62. 3.-Cor. purple variegated with erimson and white, shaggy externally. St. about a foot high. When the $\mathrm{fl}$. are half the usual size it is G. intermedia Vill., R.! G. parviflora Lam.-B. canescens (Koclı); l. narrow nearly entire, bracts often reflexed at the end, eal. and upper part of st. clothed with patent hairs but not glandular. G. canescens Sehult., M. Beib.-In gravelly and sandy distriets. $\beta$. near Soutliampton on shingles. A. VIII. IX. Red Hempnettle.

3. G. Tetrahit (L.); st. hispid thickened below the joints, l. oblong-ovate acuminate serrate, cal. tubular teeth and tube nearly equal, tube of the cor. as long as the cal., upper lip ovate.-E. $B$. 207. St. 62.6.-Tube of the cor. slender, slightly inflated. Fl. 
purplish, varicgated or whitc. Cal.-tecth twice as long as the tube, which is shorter but quite as broal and more strongly ribbel than in the next sjecies, rather inflated below the moutl. Nuts wholly greeu, the oblique top longitudinally marked with veins all spriuging from the wholly acute imner angle of the nut. L. slightly pubescent above. Fl. large; middle lobe of lower lip of cor. subquadrate, flat, crenulate, obtuse or slightly emarginate. - $\beta$. bifida ; middle lobe of lower lip of cor. oblong entire emarginate: margins at length revolutc. G. bifida Boenn.?, Fries?, St. 62. 7.? A morc slcuder plant with paler l. and smaller fl. which are said to be differeutly marked.-Woods and cultivated ground. A. VII.-IX. Common Hemp-nettle.

4. G. versicolor (Curt.); st. hispid thickened below the joiuts, 1. obloug-ovate acuminate serrate, cal. bellshaped teeth shorter than the tube, tube of the cor. much longer than the cal., upper lip roundish-oral.-E. B. 667 . St. 62.8 .-Tube of the cor, inflated above. Fl. very large, yellow, with usually a broad purple spot upon the lower lip. Cal,-tecth shorter than the tube. Nuts with the oblique summit dark browu, inner angle rouuded off almost to the base. Difficult to distinguislı upon paper from $G$. Tetrahit.-Cultivated ground. A. VII. VIII.

\section{STachys Linn.}

1. S. Betonica (Benth.); erect, lower l. orate-oblong with a cordate base crenate obtuse with long stalks, upper l. oblonglanceolate serrate acute sessile, bracts linear-lanceolate as long as the cal., whorls many-flowered condensed iuto an oblong slightly interrupted spike, cal. nearly glabrous, stam. shorter than the lip.-Betonica officinalis Sm., E. B. 1142.-Whorls sometimes scparated considerably. Tube of the cor. exserted. The English plant does not exactly agree with either of those described by Reichenbach having the subulate-spinous cal.-teeth of $B$. officinalis! and the round crenate not emarginate lower lip of B. hirta!. From the examiuation of authentic specimens I am led to fear that the forms of the cor. represented on his plates are exaggerated.-Woods and thickets. P. VII. VIII. Betony.

2. S. germanica (L.); whorls many-flowered, st. ercet woolly. 1. oblong-ovate or orate-lanceolate with a cordate base crenateserrate stalked, upper l. lanceolate acute sessile, all densely silky. cal. silky: teeth acute mucronate spioose, bracts equalling the calyx.-E. B. 829.-Fl. purple. [S. polystachia (Ten.!) only differs by having more truly crenate $1 . ;$ S. germanica of Ten.: and of $\dot{R}$. ! is a less woolly plant with more distant whorls and less spinous cal.-teeth.] —Chalky soil in Oxfordshire and Belfordshire. P. VII. Downy Woundwort. 
3. S. sylvatica (L.); whorls 6-8-flowered, st, erect, $l$. cordateovate scirate with long petioles, florul l. linear entire, cal,-tceth lanccolate very acute, bracts minute.-E. B. 416.-Cal.-teeth rather spinons. Pctioles and l. nearly equal. Fl, purple. "Nuts smootl.," L. clothed with scattered adpresserl hairs or densely silky on both sides, - Woorls and thickets. P. VII. VIII. Hedge Woundwort.

4. S. palustris (L.); whorls 6-I0-flowered, st. crect, l. linearor ovate-lanceolate subcordate below acute crenate-serrate nearly sessile, cal.-teeth lanceolate very acute, bracts minute.-E. $B$. 1675. St. 18. 10.-Cal.-teeth rather spinous. Lower 1. with very short stalks, uppermost sessile. Fl. dull purple. Nuts very minutely dotted.- $\beta$. ambigua; 1 . stalked ovate-lanceolate cordate below serrate. Petioles half as long as the leaves. $S$. ambigua Sm.-River-sides and damp places. P. VII. VIII. IIarsh Woundwort.

5. S. arvensis (L.); whorls 4-6-flowered, st. decumbent or ascending, $l$, ovate-cordate obtuse crenate stalked, floral $l$. ovateoblong sessile acute, cal.-teeth lanceolate-aristate, cor. scarcely longer than the cal., hracts minute-E. B. 1154,-Fl. purple. Nuts covered with minute dots and scattered tubercles.-Cornfields. A. VIII. IX.

*6. S. annua (L.); whorls 4-6-flowered, st. ercet, lower l. ovate-oblong obtuse crenate-serrate stalked, floral l. lanceolate acute, cal.-teeth lanceolate very acute, tube of the cor. longer than the cal., bracts minute.-E. B. S. 2669.-Fl. yellowish. Nuts minutely rough.-Near Gadshill, Kent. A. VIII. IX.-E.

\section{Ballota Linn. Horehound.}

I. B. fotida (Lam.); l. ovate crenate-serrate acute, bracts linear subulate, cal.-tubc funnelshaped, cal.-teeth broadly ovate short suddenly acuminate mucronate carinate-reflexed.- E. B.46. R. I. f. I04l !,-St. 2-3 feet high. I'l. purple or white$\beta$. borealis (R.); cal.-teeth with very short points, whole plant including the cor. covered with thick down.-Waste places. B. St. Vincent's rocks, Bristol. Mr. Borrer. P. VII. VIII.

2. B. ruderalis (Fries); l. ovate crenatc-serrate, bracts lincarsubulate, cal.-tube narrow and elongatc, cal.-teeth ovate gradually acuminate aristate erect-patent.-R. I. f. 1039 !- - St. 2-3 fect high. Il. purple or white. Fries, Lcighton, Drejer and others consider these 2 plants quite distinct.-Waste places, rare. P. VII. VIII.

\section{Marrubium Limn.}

1. M. vulgare (L.); st. erect hoary, l. ovate and attenuated 
into a petiole or roundish-cordate crenate loary rough, whorls many-flowered, eal.-tectl 10 sululate recurvo-patent woolly below their upuer half glabrous. $-E . B .410$. - St. 1-2 feet high with mumerous whorls of small flowers. My Scottish specimen has the l. ratlier dentate than crenate.- $\beta$. apulum; l. roundishcordate iensely woolly. W. apulum Ten.-Waste places, "frequent." P. VIII. IX. White Horehound.

\section{Tribe VIII. Adjugoidea.}

\section{Teucrium Linn.}

1. T. Scorodonia (L.); st. ercet, l. oblong-ovate with the base cordate crenate-serrate green on both siles, racemes lateral and terminal one-sided, floral $\mathrm{l}$. ovate acute rather longer than the pedicels, upper lip of the cal. undivided ovate, lower with 4 teeth, tube of the cor. exserted.-E, B. ]543. - St. 1-2 feet high. L. wrinkled. Fl, yellowish. - $\beta$. dentatum; l, oblong truncate below or slightly cordate coarsely deutate : teeth unequal and often alternately smaller. - Woods and shady places. $\beta$. by the roadside near Beaumaris. P. VII. VIII. Wood Sage.

2. T. Scordium (L.); st. procumbent below, $l$. sessile oblong dentate green on both sides, floral l. similar, whorls 2 -6-flowered axillary distant, cal.-teeth short equal.-E. B. 828.-More or less hairy or woolly. L. attenuated or broad or even cordate below. Fl. purple.- $T$. scordioides is only a state of this caused by situation. (Phytol. ii. I29.) - Wet places, rare. P. VII. VIII. E. I.

3. T. Chamadrys (I.) ; st. ascending, 1. ovate inciso-crenate wedgeshaped and entire below green on botl sides, floral l. similar smaller nearly entire, whorls racemose 6-flowered, cal.-tectl lanceolate nearly equal.-E. B. $680 .-$ St. much branched, lower part woody. Fl. purplish with darker lines. The lower floral l. exactly resemble the stem l. but become gradually smaller.Ruined walls and dry banks, rare. P. V'II.

[T. regium (Schreb.) is said to have beeu found on the Blorenge near Abergavenny by Mr. E. Y. Steele. I fear some mistake has occurred. A. N.H.v. 377.]

[T. Botrys (L.) ; l. bipinnatifid-laciniate, floral l.similar, whorls 2-6-flowered ; was found at the "back of Box Hill, Surrey" by Ir. T. Ingall. (Pliytol. i. 1086.) It deserves further inquiry.]

\section{AJUGA Linn.}

1. A. reptans (L.); fl. whorled, st. solitary witl creeping scions, 1 , ovate or obovate entire or crenulated stalked, stem $\mathrm{l}$. sessile.-E.B. 489.-Lower whorls distant, upper ones spicate. 
Tube of the cor. witl a ring of hairs within. Fl. blue, rarely white.-Wet places. P. V. VI. Common Bugle.

2. A pyramidalis (L.); fl. whorled, most or all of the whorls spiked, st. solitary without scions, l. ovate-oblong entire or crenulated, radical 1 . attenmated below, stem 1. sessile upper ones longer than the fl.-E. B. 1270.-Tube of the cor. with a ring of hairs within. Fl. bluish-purple. Whorls crowded in a pyranidal and tetragonal form. Plant often hairy.-Highland pastures, very rare. P. V. VI.

3. A. alpina (L.) ; fl. whorled, whorls distinet, st. solitary "without scions" (Sm.) "stoloniferous" (Fries), 1. ovate-lanccolate obtuse dentate-serrate stalked, floral l. 3-lobed the uppermost entire.-E. B. 477.-L. all nearly of the same size. Whorls all distant. Lip 3-lobed, central lobe entire.-Nountains, very rare. Durham aul Derbyshire. Sm. "Cave Hill, Belfast. Mr. J.W. Nurphy." IIooker. P. VII. E. I.

4. A. Chamapitys (Schreb.); fl. solitary, axillary, st. much branched spreading, l. deeply trifid: segments linear entire, floral 1. similar longer than the flowers.-E. B. 77.-Hairy. Lowest 1. much broaiter and toothed rather than 3-lobed. Fl. yellow with dark spots. St. reddish-purple.-Sandy and chalky fields in Kent, Essex, Surrey. A. V.-VII. Ground Pine. E.

\section{Order LX. VERBENACEA.}

Cal. tubular persistent. Cor. irregular, tubular. Stam. didynamous, sometimes 2. Ovary 2-4-celled; style 1; stigma bifil. Fr. a capsule or berry, with $2-4$ nucules more or less adhering.

1. Verbena. Cal. 5-fid. Cor. inregular, 5-lobed, slightly 2-lipped. Stam. included, 4, didynamous, or 2. Capsule dividing into 4 nuts.-G. F. G. Gam.ii. 50 .

\section{Verbena Linn.}

1. V. officinalis (L.); st. erect solitary, l. ovate-oblong, trifid or laciniate-multifid rough, spikes filiform somewhat panicled.E. B. 767. St. 3.-St. rather hispid, $1-2$ feet high. L. lobed and serrate. Spikes long, sleuder, with small distant pale purple flowers.-Waste ground. A. or P. VII. VIII. Vervain.

\section{Order LXI. LENTIBULARIACEA.}

Cal. permanent, inferior, divided. Cor. irregular, 2-lipped, spurred. Stam. 2. Ovary free, 1-cclled of 2 earpels. Stigma 
bilabiate : inferior lip subobsoletc. Caps. 1-celled; placenta frec central.

1. Pinguicula, Cal. 2-lipped, lower of 1 bific, upper of 3 scgments. Cor. ringent, spurred.-G. F. G. Gam. i. 24.

2. Utricularia. Cal. 2-leaved, equal. Cor. personate, spurred.-G. F. G. Gam. i. 25.

\section{Pinguicula Linn. Butterwort.}

1. P. vulgaris (L.); spur subulate shorter than the limb of the col. whose segments arc very unequal oblong-obovate rounded separated entire.-E. B. 70.-L. all radical, flesliy, covered with minute erystalline points, pale green; when the plant is gathered they curve backwards so as to hide the root. Fl. purple. Caps. ovate, acute.-Bogs. P. V. VI.

2.? P.grandiflora (Lain.); spur subulate often notched as long as the veined limb of the cor. whose segments are very unequal broadly obovate rounded contiguous "the middle one of the lower lip notelied." -E. B.2184.- Iuch larger than P. vulgaris. Fl. very large, deep purple. Caps. oval, rounded at the end. Length of the spur variable.-Kerry and Cork. P. V. VI.

3. P. alpina (L.); spur conical shorter than the unequal limb of the cor. and curved upwards, "caps. acuminate," scape glabrous. -E.B.S.2747.-Fl. small, yellowish, spur remarkably short and conical.-Bogs in Skye; and Black Isle, Ross. P. VI.

4. P. lusitanica (L.); spur cylindrical obtuse deciuved shorter than the nearly equal limb of the cor., caps. globose, scape downy. -E.B. 145.-Fl. small, pale, yellowish, spur short and cylindrical. [P. villosa, distinguished from this by its acute spur and obconical capsule, may be expected in the north of Scotland.] Bogs in the western parts of the country. P. VII.

\section{Utrricularia Linn.}

1. U. vulgaris (L.); spur conical, upper lip of the cor. as long as the palate, "anth. connate," l. pinnate-multifid, bladders upon the leaves.-E. B. 253.-Fl. bright yellow, rather large. St. floating in the water. $[U$.neglecta (Lem.) differs by having the upper lip nearly 3 times as long as the palate, anth. free, morc distant 1 . and bladders on both stem and leaves. It is probably a native.]-P. VI.-VIII. Greater Bladderwort.

2. U. intermedia (Hayne); spur conical, upper lip twice as long as the palate, 1. 3-parted : segments linear dichotomous, bladders separate from the leaves.-E. B. 2489.-Fl. paler and with a much longer lip than in the preceding. Bladders on separate 
stalks from the leaves. Increasing by buds at the end of the shoots and scldom flowering.-Ditehes and pits, rare. P. VIII.

3. U. minor (L.) ; spur very short obtuse, upper lip as long as the palate, lower lip ovate with reflexed sides, l. dichotomously multific, blatklers upon the leaves.- $E$. B. 254.- Scarcely any spur. Fl. small. "Scp. subrotund, acuminate." Plant much smaller than either of the others. [U.Bremii (IIcer) is a rather stronger plant with an "orbicular flat lower lip) and subrotund subreniform minutely apiculate scp." It is probably a native.] -Ditches and pits. P. VI.-VIII. Smaller Bladderwort.

\section{Order I.XII. PRIMULACEA.}

Cal. 4-5-cleft, permanent, inferior. Cor. regular, 4-5-ficl. Stam. upon the cor., opposite to its segments. Ovary free, 1celled, with a free central placenta. Style 1. Stigma capitate. Fr. a capsule. Seeds peltate; cmbryo transverse in fleshy albumen.

1. Prinula. Cal. tubular, 5-fid. Cor. salvershaped, tube cylindrical 11 to the insertion of the stamens. Stam. 5, inserted and included in the tube of the cor. Caps. manysecded, 5-valved witl 10 tecth.-G. F. G. Gam. i. 8.

2. Hotтonia. Cal. 5-parted, divided ahmost to its base. Seeds with the hilım close to one end. Otherwise like Primula.-G. F. G. Gam. i. 22.

3. Cyclamen. Cal. bellshaped, half 5-cleft. Cor. with a short bellshaped tube and 5-partite reflexed limb. Stam. 5, inserted at the bottom on the tube of the cor., included. Caps. many-secled, opening with 5 teeth.-G. F. G. Gam. i. 10.

4. Lysimachia. Cal. 5-parted. Cor. rotate, searcely any tube, limb 5-parted. Stam. 5, at the base of the cor. Caps. with 5 valves (in $L$. nemorum sometimes 2 -valved or indehiscent, in L. thyrsiftora few-seeded).-G. F. G. Gam. i. 14. 15. 16 .

5. Anagallis. Cal. 5-parted. Cor. rotate, tube none, limb 5-parted. Stam. 5, at the base of the cor. Caps. manyseeded, opening all round transversely.-G. F. G. Gam. i. 20. 21.

6. Centunculus. Cal. 4-parted. Cor. with a subglobose inflated tube and patent 4-parted limb. Stam. 4, inserted in the throat of the cor. Caps. many-seeded, opening all round transversely.-G. F. G. Gam. i. 19. 
-Trimstalis, Cal.7-parted. Cor. rotate, 7-parted, tube none. Stan. 7, inscrterl at the base of the cor. Caps. manysceded, opening witl 5 revolute fugaeious valves. Seeds invested with a reticulated tunic.-G. F. G. Gam. i. 17.

8. Glaux. Cal. bellshaped, 5-parted, coloured. Cor. none. Stam. 5, inscrted at the base of the calyx. Caps. few-secded (about 10), opening with 5 valves.-G. F. G. Gam. i. 12.

9. Samolus. Cal.5-parted its tube adhering to the lower half of the germen, persistent. Cor. salvershaped, tube short, limb 5-parted with interposed converging scales. Stam. 5, inserted near to the base of the tube of the cor. Caps. $\frac{1}{2}$ inferior, many-seeded, opening with reflexed teeth.-G. F.G. Gam. i. 23.

\section{Primula Linn.}

1. P. vulgaris (Huds.); l.oblong-ovate wrinkled crenate, scapes single-flowered, cal. tubular : teeth linear-lanceolate attenuated very acute, limb. of the cor. flat with a circle of scalelike folds at the slightly contracted mouth.-E. B. 4. St.14.6. P. acaulis (Jacq.) Koch.-L. narrowing gradually into the footstalks. Scape and cal. villose. Cal.-teeth long. Segments of the cor. cordate. - $\beta$. caulescens; l. slightly contraeted below, scape umbellate, cal.-teetl lanceolate acute, $\mathrm{fl}$. erect. This is often mistaken for P. elatior.-Woods and thickets. P. IV.V. Prinirose.

2. P. elatior (Jacq.); l. ovate contracted below wrinkled denticulate, seapes umbellate many-Howercd, cal. tubular: teeth lanceolate acute, limb of the cor. concare : segments corlate oblong, tube not crowned nor eontracted at the mouth.--E. B.513.? St. 14.5.-Cal.-teeth very long and acute. Segments of the corolla so narrowly cordate as to be almost square. Fl. nodding. Fr. ereet. I believe this to be a truly distinct species, identical with the eontinental plaut. It is known from P.veris by its cal. and cor.; from $P$. vulgaris by its leaves, nodding fl., and almost square eor.-scgments. Limb of the cor. rarely flat.-See Phyt. i. 232 and 1001 . - Woods and meadows in the eastern eounties. P. IV. V. Oxlip.

E.

3. P. veris (L.); l. ovate contracted below wrinkled erenate, scapes umbellate many-flowered, cal.bellshaped: teeth short ovate, limb of the cor. concave with a circle of scalelike folds at the slightly contracted mouth.-E. B.5. St. 14. 4. P. officinalis (Jacq.) Koch.-Scapes and cal. tomentose. Cal. teeth $\frac{1}{3}$ of the length of the tube, terminating in an obtuse or slightly acute angle. Cor.-segments corrlate.-It is probable that lybrids are formed between this aud P.vulgaris, in England, which are mistaken for $P$. elatior, but they are almost unknown on the Continent.-Meadows and pastures. P. IV. Y. Cowslip. Paigle. 
4. P. farinosa (L.); l. obovate-lanccolate mealy, cal. oblongovate: teeth linear, limb of the cor. flat: segments obcordate rounded below distant as loug as the tube.-E. B. 6. St. 14.Fl. pale lilac with a yellow centre. "Colour of the cor. and breadth of segments very variable." Gcrmen obovate. Stigma capitate.-North of England and south of Scotland. P. VI. VII. Bird's-eye Primrose.

E. S.

5. P. scotica (IIook.); l. obovate-lanceolate mealy, cal. swollen: teeth short ovate obtuse, limb of the cor. flat: segments broadly obcordate approximate half the length of the tubc.-E.B.S. 2608. - Ialf as large as the preceding. Fl. bluish-purple witl a yellow centre. "Germen globose. Stigina with 5 points."-Sandy heaths of the north of Scotland. P. VII.

\section{Hottonia Linn. Water-violet.}

I. H. palustris (L.) ; fl. whorled stalked upon a long solitary cylindrical common ped., cor. longer than the calyx, l. pectiuated. -E. B. 364.-L. submerged crowded. Fl. rising above the water, purple and yellow. Style longer than the cal., stam. inscrted in the tube, anth. and filaments about equal in length; or style shorter than the cal., stam. inserted at the top of the tube, filaments 3 or 4 times as long as the anthers. The former of the varietics is apparently barren. The nearly terminal hilum separates this plant from its allies, in all of which it is placerl towards the middle of the secd. The tops of the valves of the caps. remain connected.-Ponds and ditehes. P. V. VI.

E. I.

\section{Cyclamen Linn.}

1. C. hederifolium (Willd.); I. cordate angular crenate, throat of the cor. with 5 teeth, $-E$. B. 548.-Stem a large depressed tuber. L. appearing to be radical. Fl. nearly white, upon long stalks which roll up after flowering and bury the germen.-Sandhurst near Cranbrook, Kent. P. X. (IV. Hook.) E.

\section{Lysimachia Linn.}

1. L. thyrsiflora (L.) ; racemes axillary stalked dense, I. opposite lanceolate.-E. B. 176. Naumburgia R.-Fl. small very numerous. Cor. divided almost to the base into narrow pet. often separated by a minute tooth, yellow and as well as the cal. spotted witl orange. Stam. combined below iuto a short ring. -Marshes in the north. P. VI. VII. E. S.

2. L. vulgaris (L.); st. erect, panicles compound terminal and axillary, $l$. ovate or ovate-lanceolate nearly sessile opposite or 3 or 4 in a whorl, pet. entire with glabrous edges, stam. 5 combined for half their length.-E. B. 761 .- St. $2-3$ feet high. L. rariable in size, shape and pubescence. Panicle much branched or 
uearly simple (L. punctata Hook. not $I_{\text {.. }}$. . - Sides of rivers and pools. P. VII.

†3. L. ciliata (L.); st. ereet, ped. axillary opposite or whorled racenose, $l$. opposite or 4 in a few of the uppermost whorls ovatelanceolate subcordate with ciliated stalks, pet. roundish crenate obtusc cuspidatc, filaments 10 free 5 sterile.-Fl. yellow. Ped. nodding at the end. St. 3 fect high.?-Near Serbergham, Cumb. Ir.W. Backhouse. P. VII.

E.

4. L. Nummularia (L.) ; st. prostrate creeping, fl. solitary axillary, sep. orate acute, filaments glandular connected at the base, 1. opposite rouudish cordate shortly stalked.-E. B. 528.-Pedumcles shorter than the leares. Fl, occasionally in pairs.Damp places. P. VI. VII. Money Wort.

5. L. nemorum (L.) ; st. prostrate, fl. axillary solitary, sep. linear-lanceolate, filaments smooth distinct, l. opposite ovate acute shortly stalked.-E. B. 527. Ephemerum R.-Peduncles longer than the l. Caps. 5-valved but usually dividing longitudinally into 2 parts, sometimes indehiscent. Stam. distinct.-Woods and dainp shady places. P. VI.-VIII.

\section{Anagallis Linn.}

1. A. arvensis (L.) ; st. procumbent or erect, fl. axillary soltary, l. opposite sessile ovate or ovate-oblong.-Cor. rotate. Pet. shightly longer than the cal., crenate. Filaments distinct.a. vera; st. mostly procumbent, pet. fringed with minute glandular hairs (usually scarlet), l. ovate. A. arvensis Sm., E. B.529. Fl. sometimes flesh-coloured (A. carnea Schrank), wholly white or white with a pink eye.- $\beta$. carulea; st. mostly erect, pet. without glandular hairs (usually blue), 1 . ovate-oblong. A. carulea Sm., E. B. 1823.-Probably distinct, as Mr. Borrer also thinks : he suspects that each varies with red or blue flowers.-Cornfields. A. VI. VII. Scarlet Pimpernel.

2. A. tenella (L.) ; st. procumbent creeping, fl. axillary solitary, 1. opposite stalked roundish, cor. funnelshaped, pet. much longer than the calyx entire, filaments connected below.-E. B. 530. Irasekia R.-This plant differs so much in habit from the rest of the genus as almost to deserve generic distinction, but the characters upon which Irasekia is founded do not appear to me to be of sufficient consequence.-Spongy bogs. P. VII. VIII. Bog Pimpernel.

\section{Centunculus Linn.}

1. C. minimus (L.); l. ovate alternate acute, fl. nearly sessile, cor. without glands at the base.-E. B. 531.-Usually very minute. St. usually prostrate. Cor. pale rose-colour.-Damp sandy and gravelly places. A. VI. VII. Bastard Pimpernel. 


\section{Trientalis Linn.}

1. T. europaa (L.) ; oblong-obovate obtuse--E. B. 15.-St. $4-6$ in. high, with the l. mostly collected at the top. Fl. on slender peduncles, white with a yellow ring. Parts of the $\mathrm{fl}$. and fr. varying from 7 to 9 in cach whorl. Valves of the caps. soon falling off.-North of E.; highlands of S. P. VI.

\section{GLaUx Linn.}

1. G. maritima (L.).-E. B. 13.-St. mostly procumbent. L. opposite, ovate, glabrous. Fl. axillary, scssile, pink, with obtuse segments. Distinguished from all the other plants of this Order by its want of pet.-Sca-shores and salt marshes. P. Vl. -VllI.

\section{Samolus Linn.}

1. S. Valerandi (L.); l. obovate or roundish blunt, upper 1. blunt with a point, racemes many-flowered ultimately elongated, caps. snbglobose.-E. B. 703.-Distinguished from all the other genera of the Order by its cal. adhering to the germen and from all but Soldanella by liaving a crown to the corolla.-Damp watery places. P. VII. VIII. Brook-weed.

\section{Order LXIII. PLUMBAGINEF.}

Cal. 5-cleft, persistent, inferior, plicate. Cor. regular, 5-fid or nearly 5-petalons. Stam. 5, liypogynous, or adnate to the base of the pet. Ovary free, of 5 carpels, l-celled, l-seeded; ovule 1 , pendulous by an umbilical cord arising from the bottom of the cell. Styles 5. Fr. a utricle. Seed inverted. Embryo in the axis of farinaceous albumen. Radicle superior.

1. Statice. Fl. spiked. Cal. searious above. Cor. 5-parted. Caps. not bursting.--G. F. G. Gam. i. 4.

2. Armeria. Fl. in a head with an inverted cylindrical sheatl. Caps. not bursting.-G. F. G. Gam. i. 3.

\section{Statice Linn.}

1. S. Limonium (L.); 1. elliptic-oblong stalked mucronate 1-ribbed strongly nerved, scape branched above the mildle, branches much divided corymbose curved outwards, ultimate subdivisions short unilateral ascending densely flowered, cal.-segments entire acute with intermediate tecth, outer bracts pointed small. -E. B. 102. S. Behen Drej--Panicle very much subdivided, truly corymbose, its principal branclies curving horizontally or downwarls, ultimate subdivisions very short and quite covered with closely-placed subimbricate flowers. Several of the lower 
bracts often eupty, inner ones white at the membranous margin. -Muddy salt inarshes. P. VII. VIII. Sea Lavender.

2. S. rariflora (1)rej.!); l. oblong-lanceolate stalked mueronate I-ribbed faintly nerved, seape branclied from below the midlle, branches divided panicled ascending or incurved, ultimate subdivisions elongated with unilateral rather distant fl, cal.-segments acute denticulate with intermediate tceth, outer bracts large. - E. B. S. 2917. S. bahusiensis Fries. S. Lim. $\gamma . S m .-$ Quite different in habit from the preceding. Panicle mueh less divided, not eorymbose, branches all ascending, ultimate ones much lengtheneil. Fl. considerably separated, not at all imbrieated, solitary or in pairs. Bracts obtuse or aeute, margins tinged with pink. Pet. notched or entirc.-Near the sea. England ; coast of Galloway, S.; Waterford and Galway, I. P. VII. VIII.

3. S. spathulata (Desf.); l. spathulate narrowed into a broadly winged stalk mucronate belind the point 3-ribbed below, scape branched from below the iniddle, branches divided panicled aseending, ultimate subdivisions elongated with closely-placed 2ranked $f$., cal.-segments blunt entire without intermediate teeth. -S. binervosa E. B. S. 2663.-Rocky shores. P. VII. VIII.

4. S. reticulata (L.); l. spatlulate narrowed into a flat stalk mucronate behind the point "3-ribbed below," scape panieled almost from the base with numerous slender zigzag repeatedly divided branches of which the lower are barren, $\mathrm{fl}$. in small sceund terminal dense spikes, cal.-segments acute denticulate.-E. B.328. -L. very small. St. remarkably divided and interlaeing.Salt marshes. Norfolk. P. VII.

E.

\section{Armeria Willd.}

I. A. plantaginea (Willd.); l. linear-lanceolate 3-5-nerved, scape glabrous minutely tubercular, outer involucral braets cuspidate, intermediate obtuse mucronate, inner broadly obtuse, cal.-segments acuminate-aristatc.-A, alliacea R. I. t. 966.-Pet. not $\frac{1}{2}$ as long as the villose-striate tube of the calyx.-Jersey. P. VI. VII.

O.

2. A. maritima (Willd.); l. linear blunt I-nerved, scape downy, involucral bracts very obtuse I-3 outer ones mucronate, cal.segments aeute. - Statice Armeria Sm., E. B. 226.- L. very narrow, glabrous or downy. Pet. as long as the uniformly hairy tube of the ealyx. $-\beta$. alpina; 1 . broader, pet. $\frac{1}{2}$ as long as the villose-striate tube of the calyx. This character deserves examination.-Sea-shore. $\beta$. mountain-tops. P. VII. VIII. Thrift. 


\section{Order LXIV. PLANTAGINEA.}

Cal. 4 - (rarcly 5-) parted, persistent, imbricate, inferior. Cor. 4-parted, regular, scarious. Stain. 4, hypogynous, or at the base of the tube, altcrnate with the segments of the cor.; filaments at first doubled inwards. Ovary free, of 1 carpel, 1 -celled, or with a central compressed 2-4-rvinged placenta and thus 2-4-celled. Ovules 1, 2, or indefinite. Style 1. Caps. opening transversely. Sceds peltate or erect. Radicle inferior.

1. Plantago. Cal. 4-cleft. Cor. with an ovatc tube and 4-parted reflexed limb. Caps. bursting trausversely, 2-4celled, 2-4-secded.-G. F. G. Gam. i. 2.

2. Litrorella. Monœcious. Male fl. stalked; scp. 4 ; tube of the cor. cylindrical, limb 4-parted; filaments very long. Fem. fl. sessile; sep. 3 ; cor. oblong, narrowed at both ends; style long; caps. 1-seeded.-G. F. G. Gam. i. 1.

\section{Plantago Iinn.}

1. P. Coronopus (L.); l. lincal pinnatifid or dentate, scape round, spike slender, bracts subulate from an ovate base erect, midrib of the lateral sep. with a ciliated membranous wing, placenta 4-winged with 1 seed in each cell.-E. B. 892. - Tube of the cor. glabrous, not downy as stated by Koch. Rxtremely variable in size and amount of pubescence, sometimes woolly and at other times nearly glabrous. L. varying in width, nearly entire or even doubly pinnatifid. Spikes slender and $1 \frac{1}{2}$ in. long, or spherical with 2-6 flowcrs. - Gravelly and sandy places near the sea and inland. A.? VI. VlI. Buck's-horn Plantain.

2. P. maritima (L.); l. linear grooved fleshy convex on the back, scape roumd, spike cylindrical, bracts ovate acuminate, sep. not winged, caps. 2-seeded, tube of the cor. pubescent.-E. B. 175. -L. usually woolly at their base, sometimes nearly flat and broal or lincar, toothed or quite cntire, glabrous or hairy ; 3 nerved: nerves equidistant. Scape glabrous or hairy. Iu a curious Cornish variety the 1 . are only $1-2$ lives in length and semicylindrical, the scapes very short and the spikes sometimes with only 3 or 4 flowers. - Sea-coast and also on lofty mountains. P. VI.-IX.

3. P. lanceolata (L.) ; l. lanceolate attemuated at both ends 5-nerved, scape furrowed, spike ovate or oblong-cylindrical, bracts ovate acute or cuspidate, 2 lateral scp. keeled, caps. 2celled: cells 1-seeded, tube of the cor. glabrous.-E. B. 507.L. nearly glabrous, lanceolate. Spike ovatc.- $\beta$. elata; l. elongate-lanceolate, spike very long cylindrical, scape often 2 feet 
high and leaves $1 \frac{1}{2}$ foot long. This is not the truc $P$. altissima $(\mathrm{L}$. according to Koch (Syn. ed. 2. 686.). I liave therefore changed the name of the variety. $-\gamma$. spherostachya (W. and G.); 1 . linear-lanceolate 3-nerved, spike globose, scapes $2-3$ times as long as the l. tercte or slightly sulcatc. Root producing long lateral fibres, neck clotlied with dense wool. Seape and l. with silky adpressed hairs. $a$. and $\beta$. in meadows and pastures, $\gamma$. sauly places. P. VI. VII. Ribwort Plantain.

4. P. media (L.); l. elliptical with short broad stalks pubescent, scapc terete, spike cylindrical, bracts ovate-acuminate, sep. not keeled, eaps. 2-eclled: cells I-seeded, tulse of the cor. glabrous.-E. B. 1559.-L. nsually lying flat on the ground.Meadows and pastures. P. VI.-IX.

5. P. major (L.); 1. broadly ovate on longislı channeled stalks, scapes terete, spike clongate, bracts ovate-obtuse keeled about as long as the cal., sep. with a prominent dorsal nerve, caps. 2-celled : cells many-seeded.-E. B. I558.-L. ascending. Seeds abont $8 .-\beta$. microstachya (Koch); scape weak shorter than the 3-nerved 1., spike few-flowered: fl. (scarcely more than 6) lax. Scapes sometimes shorter than the petioles. Root fibrous, slender. Shuttl. in Mag. Zool. Bot. ü. 23. - Fields and waste places. $\beta$. in turf-bogs, Cunnamara, Ireland. Mr. Shuttleworth. P. VI.-VIII. Great Plantain.

\section{Littorella Linn.}

I. L. lacustris (L.).-E. B. 468.-Fl. white. Stalks of the male f. I-2 in. long. L. all radical, linear.-Mnrgins of lakes. P. VI. VII.

\section{Subdivision IV. MONOCHLAMYDEE.}

With a single perianth only, that is the cal. and cor. not distinguishable, or none.

\section{Order LXV. AMARANTHACEÆ.}

Perianth 3-5-parted, scarious, persistent. Stam. hypogynous. Ovary free, I-celled; ovule I or several, suspended from a frec central funiculus. Style I or 0. Stigma simple or compound. Seeds lentiform. Emblyo curved round central farinaceous albumen.-L. without stipules or sheaths.

I. Amaranthus. Fl. monocious. Perianth 3-5-parted. Stam. 3-5. Styles 3. Caps. 1-celled, 1-seeded, bursting transversely. 


\section{Amarantues Linn.}

*1. A. Blitum (L.) ; H. 3-fid 3-androus, clusters small lateral the npper ones in a small naked spike, st. diffuse glabrous.E. B. 2.21.2.-Dhughills and waste places near towns, a very doubtful native. A. V'1II.

\section{Order LXII. CHENOPODIACEA.}

Perianth 5-parted, persistent. Stam. from the base of the perianth. Ovary free or eohering with the tube of the perianth ; orule 1, attacheil-to the base of the cell. Styles divided, or rarely l. Fr. not bursting, dry, membranous, included in the perianth which often beeomes enlarged or fleshy. Embryo curved round farinaceous albumen, or spiral, or doubled together withont albumen; radicle next the hilım.-I, without stipules or sheatls.s.

Tribe I. SALSOLEA. Fl, uniform, perfect. Secds withont albumen. Embryo spiral. St, continuous.

1. Scнoв eria. Perianth 5-parted, without appendages. Stam. 5 , springing from the reeptacle. Stigmas 2-3. Periearp membranous. Seed horizontal; testa crustaceous.-Bracteated.-G. F'. G. Honochl. 62.

2. Salsola. Pcrianth 5-parted: segments ultimately with a transverse dorsal appendnge. Stam. 5, springing from an hypogynons ring. Styles 2. Pericarp nembranous. Seed lorizontal; testa membranous. - Bracteated.-G. F. G. Monoehl. 61 .

Tr. II. CHENOPODEA. Fl. uniform, perfect. Seeds with albumen. Lmbryo curved round the eircumference of the seed. St. continuous.

3. Cirexopodium. Periantl 3-5-partel, persistent, unaltered. Stam. 5, springing from the receptacle. Stigmas 2-3. Pericarp tlin, free. Testa crustaceous. Seed vertical or horizontal.-Withont bracts.-G. F. G. Monochl. 56.

4. Beta. Perianth 5-parted, persistent. Stam. 5, springing from a fleshy ring. Styles 2-3. Pericarp immersed and adhering to the tube of the perianth. Seed horizontal, attached laterally. Testa membranous.-G. F, G, Monochl.67.

Tr. III. SALICORNEAE. Fl. nniform, perfeet. Seeds and embryo as in Tr. II. St. jointel.

5. Salicornia. Perianth fleshy, tumid, undivided, imbedded in an excavation of the rachis. Stam. $1-2$. Style very 
short, stigma bificl. Periear'p membranous. Seed vertical, eovered by the persistent periantlı.-G. 1*, G. Monochl. 68 .

Tr. IV. ATRIPIICEAE. Fl. monocions, rarely perfect. Seels and embryo as in Tr. II. St. continuous.

6. АткіPLex. Perigone of 2 more or less conneeted parts. Stiguns 2. Pericarp membranous, free. Testa crustaceous. Seed vertieal, attaehed by a lateral hilum either near the base or by means of an elongated funiculus in the middle of the side; radicle basal. Stam. 5.-G. F. G. Monoehl. 63.

7. Halimus. Perigone of 2 parts connected to the extremity, 3-dentate, wedgeshaped below. Stigmas 2. Pericarp very thin, ultimately adhering to the tube of the perigone. Testa membranous. Seed vertieal, pendulous from an elongated funienlus, radiele terminal. Stam. 5.-G. F. G. Monoehl. 64 .

Tribe I. Salsolea.

\section{Schoberia C. A. Meyer.}

1. S. fruticosa (Mey.); st. erect shrubby, l. obtuse semieylindrieal, styles 3 , seeds smooth and shining.-E. B. 635 . Salsola Sm. Chenopodium Hlook.-St. 2-3 feet high, with numerous ereet leafy branches and axillary flowers.-On the south and east coasts, rare. P. VII. VIII.

2. S. maritima (Mey.); st. herbaceous, l. acute semieylindrical, styles 2, seeds reticulate-striate shining.-E. B. 633.-Chenopodium Sin.-St. ereet or procumbent with numerous spreading branehes.-Sea-shore. A. VII.-IX.

\section{SALSOLA Linn.}

1. S. Kali(L.); minutely hairy, st. diffuse, l. subulate spinous rough, fl. axillary solitary, segments of the enlarged perianth eartilaginous as long as their patent rather coloured roundish wings.-E. B. 634.-St. angular, rigid, much branehed.-Sandy sea-shores. A. VII.

\section{Tribe II. Chenopodea.}

3. Chenopodium Linn.

* Perianth enveloping the fruit, seed horizontal.

+ Leaves undivided.

1. C. olidum (Curt.); l. ovate-rhomboidal entire mealy, fl. in leafless dense racemes, seed horizontal shining slightly rough (very small), st. diffuse--E.B. 1034. St. 75.14.-Whole herbage 
covered with a greasy pulverulent foctid substanee.-Waste places by roal-sides. $A$. VIII. IX.

2. C.polyspermum (L.); l. ovate-elliptical sessile, fl. in axillary leaffess cymose racemes, sceds horizontal shining minutely punetulate oltuse at the margins.-E. B. 1480 and l481. Leight.t. 5. St.75.12 and 13.-Racemes more or less cymose or spicatc. St. erect or procumbent. L. acute or oltuse. C. acutifolium and C. polyspernium are so completely connected by intermediate forms that it is useless to attempt to distinguish them even as varieties.-Damp waste places. $\Lambda$. VIII. IX.

\section{t† Leaves toothed angled or loberl.}

3. C. urbicum (L.); l. triangular sinuatc-dentate or nearly entire their base contracted into the petiole, spikes erect nearly leafless eompound, seeds horizontal very minutely rough obtuse at the margin. - L. with short triangular teeth. $-\beta$. intermedium (Koch); l, with large acute teeth. E. B. 717.-Kocl has proved by eultivation that these are only varieties.-Near Oxford. Sm. Fl. $\mathrm{Br} . \quad \beta$. Waste places. $\Lambda$. VIIII.

4. C. album (L.); l. rhomboid-ovate sinuate-dentate entire below, upper ones lanceolate nearly entire, fl. in compound branched nearly leafless racemes, seeds horizontal smooth and shining obtusely keeled at the margin.-E. B. 1723. St.75.6.Axillary racemes spicate lense, 1. mealy. - $\beta$. viride (Sm.); racemes cymose much interrupted elongated, 1 . green often quite entire. C. viride, L. St.75.7.-Waste places. A. VII. VIII.

5. C.ficifolium (Sm.); l. unequally 3-lobed from a wedgeshaped hase: lobes ascending, intermediate lobe elongate oblong-lanceolate dentate obtuse, upper l. linear-lanceolatc entire, fl. in erect nearly leafless cymose racemes, seeds horizontal excavato-punctate shining obtuse and not keeled at the margin.-E. B. 1724. St.75. 10.- Seeds smaller than those of C. album.-Waste ground, rare. A. VIII. IX.

6. C. murale (L.); l. rhomboid-ovate unequally and sharply toothed entire below, $\mathrm{fl}$. in divaricately-branched leafless cymes, seeds horizontal elevato-punctate opaque acutely keeled at the margin.-E. B. 1722. St. 75. 5.-Waste ground near towns and villages. A. VIII.

7. C. hybridum (L.); l. subcordate angulate-dentate aeuminate: teeth large distant, $\mathrm{fl}$. in aggregated panicled leafless cymes, seed horizontal excavato-punctate opaque obtuse and not keeled at the margin.-E. B. 1919. St. 75. 2.-Seeds very large. L. with $2-4$ large teeth on each side. - Cultivated fields and waste places, rare. A. VIII. 
** Perianth not covering the fruit, seed vertical.

\section{$\dagger$ Stigmas short.}

8. C. rubrum (L.) ; l. rhomboid irregularly toothed and sinnated entire below, fl. in erect compound dense leafy spikes, seeds very minute smooth shining obtuse and slightly keeled at the edge. - H. B. 1721.- St. erect, often a foot high. Pericarp very loose. seerl vertical or horizontal in the terminal fl. Fl. generally incouplete. Cal, 4- rarely 5-cleft. Stam. 1 or 2. Mr. Leighton has seut une a variety with much more triangular l., shorter spikes and larger seeds, grown in his garden from seel obtained near London. - Waste places, particularly salt marshes. A. VIII. I.X.

9. C. botryoides (Sm.); l. triangular somewhat tootled, $\mathrm{fl}$, in compound deuse leafy spikes, seeds very minute smooth shining ucutely keeled at the edge.-E.B.2247.-St. prostrate, sprearling, 4-5 in. long. Periearp loose. Seerls vertieal.-Moist sandy places near the sea. Cornw., Suff., Northumb. A. IX.

10. C. glaucum (L.); l. oblong sinuate-dentate, fl. in ereet ncally simple leafless spikes, seeds very minute reticulate-rugose acutely keeled at the margin.-E. B, 1454, St. 75. 1.-St. spreading, often prostrate. Seeds reddish, vertical or horizontal.-Waste ground, particularly on a sandy soil. A. IX.

†† Stigmas elongated.

II. C. Bonus-Henricus (L.); l. triangular-hastate entire, fl. in compound leafless spikes, seeds vertical smooth and shining.E. B. I033. St. 74. 13.-St. a foot high. L. large, dark green, used instead of Spinage.-Waste places near villages, common. P. VIII.

\section{Beta Linn.}

I. B. maritima (L.); st. prostrate, 1. cuneate-ovate, spikes elongate simple leafy, bracts lanceolate longer than the 2 -flowered clusters, segments of the perianth with entire kcels.-E. B. 285 . -Root thick, theshy. St. 6-12 in. long, prostrate below, afterwards ascending.-Sea-shore. P. VII.-IX. Sea Beet.

\section{Tribe III. Salicornea.}

\section{Salicornia Linn.}

I. S. herbacea (L.); herbaceous, divisions of the st. compressed rather thickened upwards notehed, spikes cylindrical tapering.E. B. 4I5.-St. usually erect, branched, $3-12$ in. high. Fl. 3 to each division, placed in a triangle. Stam. 1 or $2 .-\beta$. procumbens; st. procumbent. E. B. 2475.-Muddy sea-shores. A. VIII. IX. Jointed Glasswort. 
2. S. radicans $(\mathrm{Sm}$.$) ; divisions of the st. compressed deeply$ notched scarcely thickened, spikes oblong obtusc.-E. B. 1691 . S. fruticosa Sm. (not L.), E. B. 2467.-St. procumbent or asrending, rooting. Fl. in a triangle. Muddy sea-shores. P. VIII. IX. Creeping Glasswort.

\section{Tribe IV. Atriplicece.}

\section{Atriplex Linn.}

* Polygamous; fem. fl. bipartite to the base, seed vertical; perfect fl. 3-5-parted, seed liorizontal.

[*1. A. nitens (Rebent.); st. erect, 1. triangular-cordate-hastate sinuate-dentate shining above glaucous beneath, upper 1 . clongatetriangular, perigone of the fr. ovate-acuminate cntire separate to the base.-A large coarse plant, probably introduced by accident. - Sea-shore near Ryde, Isle of Wight. Dr. Bromfield. A. VIII. IX.]

** Moncecious; fem. fl. bipartite.

2. A. littoralis (L.); st. crect, l. linear-lanceolate entire or rarely toothed, perigone of the fr. ovate-rhomboid acute toothed tubercled on the back spreading.-E. B. 708. St. 79. 12.-Distinguished from the next by the form of its open perigone, and 1 . usually entire.-Sea-coast. A. VII.-IX.

3. A. marina (L.); st. erect, l. ovate-lanceolate irregularly toothed or rarely entirc, perigone of the fr. obcordate-triangular obtuse toothed tubercled on the back closed.-St.80.1.-Distinrruished by its toothed 1 . and form of closed perigone. These 2 never have lobed l. like the succeeding species.-Sea-coast. A. VII.-IX.

4. A. angustifolia (Sm. !); st. erect or prostrate, l. lanceolate entire, the lower 1 . with 2 ascending lobes from a wedgeshaped base, perigone of the fr. rhomboidal acute entire with ascending prominent acute lateral angles smooth on the back and longer than the fr. and collected into nearly simple interrupted spikes, seeds smooth and shining.-E. B. 1774. A. patula Wahl., Koch, St. 79.5.-Spikes wandlike with distant clusters of fl., valves of the perigone of the fr. reticulated.-Common. A. VII.-X.

5. A. erecta (Huds.); st. mostly erect with ascending branches, lower l. ovate-oblong with 2 ascending lobes from a wedgeshaped base irregularly sinuate-dentate, upper 1 . lanceolate entire, perigone of the fr. rhomboidal denticulate acute more or less muricated on the back and scarcely longer than the fr. and collected in branched dense many-flowered spikes, secds smooth and shining. —E. B. 2223.! Koch in St.79.6.-Distinguished by its l., com- 
pound denscly-flowered spikes and sunooth shining seeds.-Common upon cuittivated land. A. VII.-X.

6. A. prostrata (Bouch.?); st. procumbent with procumbent branches, 1. opposite, louer $l$. hastate-triangular with 2 horizontally spreaching lobes slightly toothed or entire, intermediate with 2 ascending lobes from a wedgeshaped base, uppermost l. small lanceolate entirc, perigone of the fr. cordate-triangular slightly toothed or entire scarcely longer than the fr. collected into interrupted slightly branched spikes, seeds smooth and shining.A. oppositifolia Koch in St. 79.9.-Whe most marked distinetive characters of this plant, with which I am but slightly acquainted, appear to be the curious 1 ., the perigones, and the fl. in separate clustcrs. It may possibly be a maritime form of $A$. patula.Sea-coast, rare. A. VIII. IX.

7. A. patula (L.!); st. mostly erect with ascending branches, lower l. ovate-hastate with 2 horizontally spreading lobes denticulate, upper 1 . lanceolate nearly entire, perigone of the fr. triangular-rhomboidal nearly cntire slightly muricated on the back longer thin the fr. and collected into nearly simple interrupted spikes, seeds opaque rough.-E. B.936.! A. latifolia Koch in St. 79. 7.-Cultivated and waste ground, common. A. VI.-X.

[8. A. microsperma (W. and K.); st. erect or ascending with ascending branches, 1. opposite, lower 1. ovate-lanceolate with 2 horizontally spreading lobes denticulate, upper l. lanceolatesubulate hastate entire, perigone of the fr. ovate-triangular acutish entire rough on the back slightly longer than the fr. collected in a branched densely-flowered panicle, secds smooth and shining.W. and K. Pl. rar. Hung. t. 250, A. ruderalis Koch in St. 79.8. -Distinguished from all the others by the form of its perigone in conjunction with its 1 . and panicle. - Waste ground near Bath, but I fear accidentally introduced. A. VII.-IX.] E.

9. A. deltoidea (Bab.); st. erect with ascending branches, $l$. opposite all hastate-triangular with 2 descending lobes unequally dentate or sinuate-dentate, perigone of the fr. ovate-triangular dentate muricated on the back rather longer than the fr. collected into a many-flowered branched dense panicle, seeds smooth shining.-E. B. S. 2860 . A. longipes Drej.-Cultivated and waste land, in many places. A. VII.-X.

E.

10. A. rosea (L.?); st. spreading procumbent or ascending with spreading branches, $l$. mealy ovate-triangular somewhat 3-lobed unequally sinuate-dentate, upper 1 . lanceolate dentate and 3-lobed at the base or nearly entire, perigone of the fr. rhomboidal-acute toothed with 2 irregular rows of tubercles on the back, clusters axillary and terminal few-flowered, sceds minutely tubercularrugose.-E. B. S. 2880 . A. crassifolia " C. A. Mey." Fries.- 
Probably two species are confounded under this name. See Fries Summa. 1. 201.-Sea-shore, common. A. VII.-IX.

11. A. laciniata (L.); st. spreading procumbent with spreading branches, $l$. triangular-rhomboidal laciniated mealy beneath, spike of male $f$. dense naked, fertile $\mathrm{fl}$. axillary, perigones of the fr. rhomboidal-3-lobed with the lateral lobes truncate the back 3-ribbel the 2 lateral ribs often terminating in tubercles, seeds rough opaquc.- $E . B .165$.- The form of the perigone is the nost remarkable character of this plant.--Sea-shore. A. VII. - IX.

\section{HaLimus $T^{\prime} a l l r$.}

1. H. pedunculatus (Wallr.); st. herbaceous wavy branched, 1. obovate entire attenuated below, upper l. narrower, perigone of fr. on a long stalk inversely wedgeshaped with 2 large lateral and one small intermediate lobe.-E. B. 232. Koch in St.80.5. Atriplex Sm.-Muddy salt marshes near the east and south coasts, very rare. A. VíII. IX.

2. H. portulacoides (Wallr.); st. woody, l. obovate-lanceolate entire attenuated below, perigone of the fr. inversely triangular rounded below and shortly stalked with 3 equal lobes above and muricated on the lower part of the back.-E.B.261. Koch in St. 80. 4. Atriplex Sm.-Common on the sea-shore. P. VIII.-X. Sea Purslane.

\section{Order LXVII. POLYGONACEA.}

Perianth 3-, 5-, or 6-parted, imbricate. Stam. definite from the base of the perianth. Ovary $l$, free, with $l$ erect ovule. Styles and stigmas several. Fr. not bursting, a nut, naked or covered by the cnlarged perianth. Embryo inverted, usually on one side of farinaceous albumen; radicle remote from the hilum. -Stipules usually cohering in the shape of oclirex.

1. Rumex. Perianth 6-parted: the interior seginents (pet.) large, connivent. Stam. 6, disposed in pairs. Styles 3 . Nut 1-seeded, triquetrous, covered by thic enlarged inner segments of the perianth, embryo lateral.-G.F.G. Monochl.54.

2. Oxyria. Perianth 4-parted: 2 interior segments larger. Stam. 6. Stigmas 2. Nut l-secded, compressed with a membranous wing, larger than the persistent segments of the perianth, cmbryo central.-G. F.G. Monochl. 55 .

3. Polygonum. Perianth 5-parted. Stam. 5-8. Styles 2-3. Nut 1-seeded, trigonous or compressed; embryo lateral, incurved; cotyledons not contorted.-G. F. G. Monochl. 52 . 
4. Fagopyum. Periantl 5-parted. Stam. 8. Styles 3. Nut I-sceded, trigonous; embryo central; cotyledons large, foliaceous contorto-plicate-G. F. G. Monoch1. 53.

\section{Rumex Linn.}

* Fl.perfect. Herbage not acid. Lapathum Tourn. Docks.

1. R. maritimus (L.); enlarged pet. rlomboidal narrow, each with a linceolate entire point a prominent narrow oblong tubercle and 2 setaceous leeth upon each side as long as the pet., whorls crowded many-flowered leafy, l. linear-lanecolate-E. B. 725. -Nut very small with elliptieal faces. $\Lambda$ valuable set of fig. of the pet. of this genus will be found in Leight. Fl. Shrop.Marshes principally near the sea. P. VII. VIII.

2. R. palustris (Sm.); enlarged pet. ovate-oblong, cacl with a lanceolate entire point a prominent narrow oblong tuberele and 3 setaceous teeth upon each side shorter than the pet., whorls distant many-flowered leafy, l. linear-lanceolate attenuated below. -E. B. I932.- Nut 3 times as large as that of $R$. maritimus, with ovate faces. The teeth are too short in the E. B. figure. Koch says that therc are only 2 teeth, I find 3.-Marshy places, rare. P. VII.-IX.

3. R. conglomeratus (Murr.); enlarged pet. linear-oblong obtuse, each bearing a large tubercle and entire or obscurely toothed at the base, whorls distant leafy, l. oblong pointed, lower l. cordate or ronnded at the base.-E.B.724.R. acutus Sm. See Prim. Fl. Sarn. p. 85. R. glomeratus R. I. f. 552,-Nut ovate, acute. Enlarged pet. broadest near the base, the sides nearly parallel.Wet places. P. VI.-VIII.

4. R. sanguineus (L.); enlarged pet.narrowly oblong obtuse entire only one bearing a tubercle, whorls distant leafless, l. ovatelanceolate, lower l. cordate or rounded at the base.-E. B. I533. -Nut ovate-elliptical, acute. Enlarged pet. broadest above their middle. A very few of the lower whorls often each aceompanied by a small leaf. Veins of the l. bright red.- $\beta$. viridis (Sm.); veins of thel.green. R. viridis Sibth. R. Nemolapathum Ehrh.-Woody places, rare. $\beta$. Woods and road-sides, more frequent. P. VII.

5. R. pulcher (L.); enlarged pet. triangular-ovate reticulated with raised nerves toothed below one principally tubercled, lower l. fiddleshaped or cordate-oblong obtuse, upper l. lanceolate acute, st. procumbent, branches spreading.-E. B. 1576.-St. straggling. Whorls distant, leafy. Nuts ovate, aeute.-Dry waste places. P. VIII. IX. Fiddle Dock.

6. R.obtusifolius (L.); enlarged pet.ovate-or oblong-triangular obtuse toothed below prolonged above into an oblong orligulate entire point one prineipally tubereled, lower l. cordate-ovate obtuse, 
upper l. oblong or lanceolate.-E. B. 1999.-Ieight 2-3 feet. Whorls distant, leafless. Nut elliptical, acute. Distinguished by its obtuse radical $l$. and the prolonged often ligulate point of the petals.-Pastures and waste ground. P. VII.-IX.

7. $R$. pratensis (M. and K.); enlarged pet. unequal cordate dilated and toothed at the base with a small entire triangular point one principally tubercled, l. oblong-lanceolate acute, lower 1. slightly cordate below.-E. B. S. 2757.-Whorls approximated but not crowded, mostly leafless. "Nut elliptical." One of the enlarged pet. larger than the others, sometimes all 3 are equally tubercled.-Marshy places, rare. P. VII.

8. R. crispus (L.); enlarged pet. cordate entire or crenulated one principally tubercled, l. lanceolate acute wavy crisped.-E. $B$. 1998.-Height 2-3 feet. Nut elliptical. Enlarged pet. equal, sometimes all equally tubercled.-Road-sides, fields, \&c. P. VI.-VIII. Curled Dock.

9. R. aquaticus (L.?); enlarged pet. broadly cordate membranous entire or wavy without tubercles, l. lanceolate, lower $\mathrm{l}$. somewhat cordate with petioles "flat and margined above."E. B. S. 2698. R. domesticus Hartm., Fries, Koch.-Height 3-4 feet. L. very large. Whorls crowded, mostly leafless, forming a large dense lobed panicle. Nut elliptical, acute. A very handsome plant.-Damp places in the north, preferring those liable to be flooded. Extending from York to the Butt of the Lewis. P. VII. VIII.

E.S.

10. R. Hydrolapathum (Huds.); enlarged pet. ovate-triangular nearly entire all tubercled, $l$. lanceolate acute tapering below into a petiole which is flat and not margined above.-E. B. 2104. -St. 3-5 feet high. L. often more than a foot long. Whorls crowded, mostly leafless. Nut elliptical.-Ditches and riversides. P. VII. VIII. Great Water Dock.

*11. R.alpinus (L.); enlarged pet. cordate-ovate membranous entire or denticulated without tubercles, $l$. roundish-cordate obtuse with channeled petioles, upper l.ovate.-E. B.S. 2694.-Whorls crowded, mostly leafless. Nut elliptical, acute.-Hellensburgh. Glen Luss. Dollar. Derbyshire. Formerly cultivated. P. VII. Monk's Rhubarb.

E. S.

** Fl. diccious. Herbage acid. Acetosella Tourn. Sorrels.

12. $R$. acetosa (L.); enlarged pet. roundish-cordate entire membranous with a very minute tubercle at the base, sep. reflexed, l. oblong sagittate, stipules laciniate-dentate.- $R$. Pseudo-acetosa Bert., E. B. 127.?-Height $1-2$ feet. Whorls leafless. Nut elliptical with acute angles. I noticed a very fleshy variety amongst rocks near the sea at Zennor, Cornwall.-Smith describes under this name the $R$. acetosa (Bert.), R. hispanicus ("Munting," 
Koch) which is occasionally cultivated, it has ovate cularged pet. each with an oblong green gland extending through more than laalf its lengtl..-Hearlows and pastures. P. V. VI.

13. R. Acetosella (L.); petals scarcely enlarged ovate not tubercled, sep. ascending, l. lamccolate-hastatc or lincar with entire lobes, stipules torn. - E. B. 1674 . - Height 6-10 in. Whorls leatless. L. very variable in breadtl. - Dry gravelly places. I'. V.-VII. Sheep's Sorrel.

[R. scutatus (L.) whieh has hastatc-ovate slightly fiddleshaped 1. lias been found "naturalized" at Craigmillar Castle near Edinburgh by Mr. E. Young, and elsewhere.]

\section{Oxyria Hill.}

1. O. reniformis (Iook.).-E.B. 910.-St. 8-10 in. high, usually leafless. L. radical, reniform, slightly notehed at the end with the nerves radiating from the insertion of the long footstalk. Pedicels thickening upwards, jointed in the middle. The permanent pet. not at all enlarged.-Lofty mountains. P. VII. VIII. Mountain Sorrel.

\section{Polygonum Linn.}

* Stem simple, bearing one spike. Ochrea cylindrical, truncate. Root a rhizoma. Cotyledons accumbent. Nut triquetrous. Stam. 8. Styles 3. Bistorta.

1. P. Bistorta (L.); spike dense, l. ovate subcordate, radical 1. with winged footstalks, stam. half as long again as the perianth, nut triquetrous its faces ovate smooth.-E. B. 509.-St. $1-1 \frac{1}{2}$ foot high. Root large. Fl. flesh-coloured.-Moist meadows. P. VI. Snakeweed.

2. P. viviparum (L.) ; spike lax bulbiferous bearing $\mathrm{fl}$. on its upper part, 1. linear-lanceolate vith revolute margins, lower 1. elliptical with wingless footstalks, stam. twice as long as the perianth, nut triquetrous its faces ovate-lanceolate smooth and shining. $-E$. B. $669 .-$ Height $4-8$ in. Spike slender, the fl. on the lower part replaced by small red bulbs. Fl. flesh-coloured, sometimes very few in number.-Mountain pastures. P. VI. VII.

** Ochrea cylindrical, truncate. Root fibrous. Cotyledons accumbent. Nut compressed or triquetrous. Stam.4-8. Styles 2-3. $\quad \mathrm{Fl}$. spiked, rarely capitate.-Fl. purple or white. L. without or with a central dark spot. Persicaria.

3. P. amphibium (L.); spike dense ovate-cylindrical, l. stalked ovate oblong (floating) or oblong-lanceolate or narrow-lanceolate rough at the margins, ochreæ membranous narrow, nut compressed smooth shining, stam. 5, root creeping.-E. B. 436.- 
St. long wheu floating. Spikes generally solitary and terminal. Fl. rose-coloured. Very variable in the form of its leaves aecorching to its habitation.-Floating or growing upon mud or on boggy ground. P. VII. VIII.

4. P. lapathifolium (L.); spikes oblong cylindrical dense, l. oblong-lanceolate or ovate attenuated at both cnds glandular bencath, ochrea narrow not fringed the upper ones shortly fringed, peduncles and perianth glandular-scabrous, nut compressed its faces rounchish acuminate both hollowed smooth shining scarcely covered by the perianth, styles distinct at length divergent and reflexed, stam. 8.-E. B. 1382.-a. pallidum; 1. all oblong-lanceolate wavy, spikes axillary or terminal solitary, bracts auricled glandular, joints of the st. scarcely thickened. P. lapathifolium R. I. f. 688. P. pallidum With., Fries.- $\beta$. nodosum; lower 1. ovate or clliptical cren, spikes usually 2 together, bracts auricled glabrous, joints of the st. tumid. $P$. nodosum R. I. f. 689, Fries.-The varieties appear to be quitc connected by intermediate forms. According to Fries, var. $a$. lias the veins of its perianth arcuated and recurved at the end, and $v a r . \beta$. has them branched and converging at the end, but I have not becu able to examine this character sufficiently to give an opinion upon it. Height I-2 fcet. Fl. pale. St. sometimes spotted and l. hoary. -Waste and damp places. A. VII. VIII.

5. P. laxum (R.); spikes elongated slender, 1. lanceolate much attenuated at both ends wavy glandular beneath, ochrea lax shortly fringed the floral ones horned, ped. and perianths glandular-scabrous, nut compressed its faces roundish acuminate both hollowed shining a quarter shorter than the perianth, styles connected below at length divergent and reflexed.-E. B. S. 2822. $R$. I. f. 685.-Smaller than the preceding. St. often prostrate. Spikes slender and interrupted (the typical form); or spikes thicker and continuous (represented in E. B.S.), and l. white and woolly beneath.-Damp gravelly places. A. VII.-X. E.

6. P. Persicaria (L.); spikes compact ovate-oblong cylindrical, l. lanceolate plane minutcly tubercled, ochrea lax strongly fringed, ped. and perianths smooth, nut compressed and gibbous on one side or trigonous: faces rounchish acuminate smooth scarcely covered by the perianth, styles connected half-way up at length patent.-E. B. 756. - St. I -2 feet high. L. more or less covered with hairs on both sides, sometimes woolly on the under side when it is $P$. incanum of authors. Ped. sometimes shightly hairy, never glandular.-Waste and damp ground. A. VI.-X.

7. P. mite (Schrank); spikes erect filiform interrupted, 1. lanceolate slightly wary, ochrea lax funnelshaped pilose strongly fringed without glands, perianths without glands, nut (large) compressed its faces roughish ovate acute rather shining convex, 
stam. 5, styles conuceted half-way щ) "arrect." E. B. S. 286\%. - St. 1-3 feet high, often much branched. Ochrea all fringed. spikes thickening upwarls.-Wet places. A. VIII. IX. L.

8. P. Ilydropiper (L.); spikes drooping filiform interrupted, 1. lanceolate wavy, ochrea ventricose glabrous fringed glandular, perianths glandular, nut (large) compressed its faces ovate acutc mose-punctate opaque convex, styles 2 nearly distinct.-E. B. 989.—St. I-3 feet high. Upper ochrea funnelshaped, scarcely fringed. Nut romder than in P. mite. Spikes sometimes erect. - Wet places. $\Lambda$. VIlI. IX.

9. P. minus (Huds.); spikes erect filiform slender lax, 1. linearlanceolate plane, ochrea close pilose fringed without glands, perianths without glands, nut (small) compressed its faces ovate acute smooth shining convex, styles connected for at least $\frac{1}{2}$ their length.-E. B. 1043.-St. procumbent, diffuse. Spikes ascending. Much smaller than the preceding. Ochrex all fringed. Fl. and fr. only half the sizc of those of $P$. Hydropiper, $-\beta$. erectum (Bab.); st. erect, l. narrower.-Wet gravelly places. A. IX.

*** Oclarece 2-lobed. Root fibrous. Cotyledons incumbent. Nut triquetrous. Stam. 8. Styles 3. Fl. axillary. Avicularia.

10. $P$. aviculare (L.); $f, 1-3$ together axillary, l. lanceolate or elliptical plane stalked, ochrece lanceolate acute with few distant simple nerves at length torn, nut triquetrous striated with raised points opaque about as long as the perianth.-E. B. 1252. -L. usually blunt soinetimes acute. The varieties are innumerable. Fl. cither very distant and scattered, or so much collected as almost to form a leafy spike. St. erect or procumbent. A form with very short internodes and leaves, small $\mathrm{fl}$. and much branched stems occurs on the sandy coasts of the south of England; another ( $P$. littorale Link) with more numerous fl., fleshy elongated st. and $\mathrm{l}$. is found on the sea-shore. A corn-field plant with long slightly branched st. having very long internodes, scattered $\mathrm{fl}$., long and much torn ochrex, and linear-lanceolate acute 1, is possibly $P$. virgatum Loisel.-Waste places. A. V.-IX, Knot-grass.

1I. P. Raii (Bab.); fl. I-3 together axillary, l. elliptic-lanceolate, ochrea lanceolate acute with few distant simple nerves at length torn, nut triquetrous smooth shining longer than the perianth.-E. B. S. 2805. P. Roberti Loisel.?, Hook. P. dubium Deak.-St. long, straggling, prostrate. "L. plane, bending towards the stem." Wats. Resembling $P$. aviculare in habit, but $P$. muritimum in fruit. Filaments broader at the base. A variety with smaller $\mathrm{l}$. and $\mathrm{fl}$. occurs in the Channel Islands. P. Roberti 
(Lois.) is probably $P$. aviculare var. littorale.-Sandy sca-shores. A.? VIII. IX.

12. P. maritimum (L.) ; fl. I-3 together axillary, l. ellipticallanceolate coriaceous, ochrece lanceolate with numerous branched nerves at length torn, nut triquetrous smooth shining longer than the periantl.-E. B. S. 2804.-St. procumbent, quite woolly helow, often much buried. "L. convex ahove, revolute at the edge, diverging from the stem." Wats. Filaments hroader at the hase. I suspect that several of Dr. Deakin's (Florig. ii. 577.) stations for this plant, and also Killiney Bay quoted by IIooker, belong to $P$. Raii.-On the sands of the sea-shore near Christchurch Head and in the Channel Islands. P. VIII. IX.-E.

**** Ochrea semicylindrical. Root fibrous. Cotyledons accumbent, nut triquetrous. Stam. 8. Styles 3. Fl.racemose. Tinaria.

13. P. Convolvulns (L.); st. twining angular, 1. triangularcordatc, segments of perianth bluntly keeled, nut triquetrous opaque striated with minute points.-E. B. 941.-St. climbing or prostrate, much sliorter than in the next species. The perianth is sometimes winged, when the plant is often taken for $P$. dumetorum.-Cultivated and waste land. A. VII. VIII.

14. P. dumetorum (L.); st. twining striated, l.triangular-cordate, segments of perianth winged, nut triquetrous very smooth and shining.-E. B.S.281 I.-St. climbing to the height of 4 or 5 feet.-Thickets in the south. A. VII.

E.

4. Fagopyrum Gaert. Buck-wheat.

*I. F. esculentum (Moench); st. erect without prickles, fl. in cymose panicles, stam. 8, l. cordate-sagittate acute, nut triquetrous acute with entire angles.-E. B. 1044. Polygonum Fagopyrum Sm.-Naturalized in many places, being often sown as food for game. A. VII. VIII.

E.S.

\section{Order LXVIII. ELAAGNEÆ.}

Mostly diœecious. Perianth tubular; limb 2-4-toothed, in male $\mathrm{fl}$. 4-parted. Stam. 3 or more, inserted on the throat. Anth. 2-celled, nearly sessile, bursting on the inner side longitudinally. Ovary free, l-celled, with 1 erect ovule. Fr. crustaceous, inclosed within the fleshy perigone. Albumen thin and flesliy. Radicle inferior.

1. IIıроорнав. Diœeious. Fl. with ovate scaly hracts. Male. Perianth of 2 leaves adhering by their points. Stam. 4 with very short filaments. Female. Perigone tubular, 
cloven at the summit. Style short. Stigma clongatc. Nut 1-seeded, clothed with the large coloured berrylike perigone. -G. F. G. Monochl. 44.

\section{Hrppophä̈ Linn. Sea Buckthorn.}

1. H. rhamnoides (L.).-E. B. 425.-A thorny shrub with linear-lanceolate silvery lcaves. Fl. appearing with the young leaves. Fr. orange. II eight $4-6$ fect.-Sandy spots and cliffs of the south-east and cast coasts. Sh. V.

E.

\section{Order LXIX. THYMELEA.}

Perianth tubular, inferior, often coloured, limb 4- rarely 5-cleft. Stan. definite, in the orifice of the tube. Anth. 2-celled, bursting longitudinally. Ovary free, 1-cellet, with 1 pendulous ovule. Fr. a mint or drupe. Albunnen 0 or thin and tleshy. Radicle superior.

1. Daphne. Perianth 4-fid, deciduous. Berry fleshy, 1-seeded. Stam. 8, shorter than the perianth, inserted in the tube in 2 rows.-G. F. G. Monochl. 46.

\section{Daphe Linn.}

1. D. Mezereum (L.); fl. subternate lateral sessile, tube hairy, segments ovate acute.-E. B. 1381. St.8.-Fl. purple, appearing before the lanceolate 1 . which are attenuated below. Berries red. A small shrub.- - ln woods, rare. Sh. 111. Mezereon. E. S.

2. D. Laureola (L.); racemes axillary of about 5 glabrous drooping bracteated fl., l. lanceolate attenuated below glabrous evergreen.- $E$. B. 119.-A small shrub, $1-3$ feet high, slightly brancherl, naked below. Fl. yellowish-green, funnelshaped. Berries bluish-black.-Woods and thickets. Sh. II.-IV.-E. S.

\section{Order LXX. SANTALACEÆ.}

Perianth adnate to the ovary; limb 3-5-fil ; xstivation valvate. Stam. 4-5, opposite to and inserted at the base of the segments. Ovary 1-celled; ovules $2-4$, pendulous from near the apex of a central placenta. Style 1. Fr. drupaceous, l-seeded. Embryo in the axis of fleshy albumen.

1. Thesium. Perianth 4-5-cleft, top- or funnelshaped, persistent. Stam. 5, with a fasciclc of hairs at their base. Style 1. Stigma simple. Nut drupaceous, crowned with the persistent perianth.-G. F. G. Monochl. 48.

\section{Thesium Limn.}

1. T. humifusum (DC.); st. procumbent or ascending racemose, 
racemes branehed or simple, fl.-stalks as long or longer than the H., $f r$.-stalks patent, angles of fr.-stalks and edges of bracts and upper $l$. denticulatc-scabrous, fi. oval-oblong, l. 1-nerved linear. -T. linoplyllum Sm., E. B. 247.- "Plant always parasitical." Mitten. Root woody. St. nearly always procumbent. L. very slender; nerves usually obscurc. Middle bract in the lower part of the racemes longer than the flowers. Tube of perianth very short, open, funnelshaped; segments triangular, spreading, with a tooth on each side. Fr. oval, longer than the persistent perianth which is usually only inflexed at the end, strongly ribbed and slightly reticulated.-Chalky and limestone (oolite) hills. P. VI. VII.

[T. intermedium (Schrad.); st. more ereet panicled, paniele pyramidal, the lowest branches longest, 1. linear-lanceolate 3nerved; is said to be a native of Britain, but all the specimens which I have seen belong to T. humifusum.]

2. T. humile (Vahl); racemes spiked, fl. nearly sessile, fr. strongly ribbed and retieulated sessile crowned with the very short inflexed perianth, $l$. flesly linear l-nerved,-R. Icon. f. 947. -Fr. 4 or 5 times as long as the persistent inflexed perianth. Middle bract much longer than the flowers.-I gathered 2 specimens of this plant somewhere near Dawlish in Devonshire, in 1829. P. VII. VIII.

\section{Order LXXI. ARISTOLOCHIACEA.}

Perianth adnate to the ovary below, tubular above, with a lobed dilated usually irregular limb. Stam. 6-12, epigynous. Ovary 3-6-celled. Style simple; stigma radiant. Fr. manyseeded. Secd with a minute embryo at the base of fleshy albumen.

1. Aristolochia. Perianth tubular, swelling at the base; mouth dilated on one side. Anth. 6, adnate to the short eolumnar style under the 6-lobed stigma. Caps. 6-eelled.G. F. G. Monoehl. 50.

2. Asarum. Perianth bellshaped, single, 3-fid. Stam. 12, inserted at the base of the style. Anth. attached to the middle of the filaments. Stigma 6-lobed. Caps. 6-celled. -G. F. G. Monochl. 51.

\section{Aristolochia Linn. Birthwort.}

* 1. A. Clematitis (L.) ; root ereeping, st. erect simple, l. cordate stalked glabrous, th. aggregate--E. B. 398. St. 6. 16.-Fl. pale yellow.-Naturalized near old ruins. P. VII. VIII. E. 


\section{Asarum Limn. Asarabacea.}

1. A. europaum (L.); l. reniforn oltuse binate.-E. B. 1083. St. 2. 7. - St. short, with '2 leaves, between which there is a solitary dooping dull green $\mathrm{fl}$.; segments of the perianth ovate and incurved. Filanents extending beyoud the anthers. Woods in the north, rare. 1 . V.

E. S.

\section{Order LXXII. EMPETREF.}

Diceeious. Periantl of hypogynous scales imbricated in several rows. Stam. equal in number to the inner row and alternate with them, free. Ovary free, on a fleshy disk, 3-6-eelled. Ornles solitary, aseeuding. Style 1. Stigma radiant. Fr. fleshy with bony eells. Embryo in the axis of fleslyy albumen. Radicle inferior.

I. Enpetrum. Cal. 3-partel. Pet. 3. Stam. 3 in the male $\mathrm{fl}$. Style short, stigma dilated peltate with $6-9$ rays. Berry globose, l-eelled. Seeds 6-9.-G. F. G. Monoehl.42.

\section{Empetrum Linn. Crowberry.}

1. E. nigrum (L.); procumbent, l. linear-oblong their margins mecting in a white line beneath,-E. B. 526.-A small procumbent leafy heathlike shrub. Fl. axillary, small, purple. Stigma with 9 rays. Berries black.-Mountain heaths. Sh. V.

\section{Order LXXIII. EUPHORBIACEF.}

Fl. usually monocious. Perianth lobed or 0 . Male flowers of 1 or more stamens. Anth. 2-celled. Fern. fl. of 1 superior 2-3-celled ovary. Styles 2-3. Stigina eompound or simple. Caps. opening with elasticity; cells $2-3$, with 1 or 2 suspended seeds in each. Embryo in fleshy albumen. Radicle superior.

1. Buxus. Fl. monceious. Male. Cal. 3-parted. Pet. 2. Stam. 4. Fem. Cal. 4-parted. Pet. 3. Caps, with 3 horns, 3-celled, 6-seerled.-G. F. G. Monochl. 41.

2. Euphorisa. Fl. incomplete, collceted into monocious heads consisting of 1 female and numerous male flowers. Involucre campanulate, with 5 divisions and 5 alternate glands. Males naked consisting of a single stamen upon a pedicel, intermixed with scales and surrounding the female. Fem. a single pistil. Styles 3. Stigmas bifirl. Caps. 3-celled, bursting at the back. Seeds solitary, pendulous.-G. F. G. Monochl. 36.

3. Mercurialis. Fl. diceious or monocious. Perianth 
3-parted. Male. Stam. 9-16. Fem. Style short, forked. Caps. 2-celled. Cells 1-sceded, bursting at the back.-G. F. G. Monochl. 40.

\section{Buxus Linn. Box.}

1. B. sempervirens (L.); l. ovate-oblong coriaceous shining above, petioles eiliated, anth. ovate-sagittate.-E.B. 1341.-A small bushy tree of $10-12$ fect in height.-Dry chalky hills, rare. T. IV.-VI.

\section{Euphorbia Linn. Spurge.}

* Leaves with stipules.

1. E. Peplis (L.); st. procumbent branched, heads axillary solitary, caps. kcelcd, seeds smooth, l. opposite stalked halfheartshaped nearly entire glabrous.-E. B. 2002. R. 4753.St. usually much tinged with purple, glaucous. The only British species which has stipules.-Loose sand of the southern seacoast. A. VIl.-IX.

E. I.

** Stipules 0 in this and all the following sections. Involucral glands witlout membranous processes, roundish or transversely oval.

\section{+ Seeds nettcd.}

2. E. Helioscopia (I.); umbel 5-fid then 3-fid and 2-fid, bracts and 1 . membranous obovate-wedgeshaped serrated upwards, caps. smooth glabrous, seeds netted rugose.-E. B. 883. R. 4754.Waste and cultivated ground. A, VI.-IX. Sun Spurge.

\section{t† Seeds smooth.}

3. E. stricta (Koch); umbel 3-5-fid then 3-fid and bifid, general and first partial bracts and l. oblong clasping narrowed above their base, other bracts broadly cordate blunt with a minute apiculus, inv.-glands oval (?), caps. with prominent cylindrical tubercles, seeds smooth oval brown and shining, funiculus cordate.-St. erect, 2-3 ft. high, much branched. Inv., caps., and seeds small. Tubercles on the caps. cylindrical but short. - Woods below the Wind Cliff and near Tintern, Monmouthshire. A. VII. VIII.

4. E. platyphylla (Koch); umbel 3-5-fid then 3-fid and bifid, general bracts ovate-oblong, partial ones all cordate acute or roundish, $l$. obovate-oblong gradually narrowed to the cordate base, inv.-glands oval, caps. with depressed tubercles, seeds obovate brown and shining, funiculus nearly reniform.-E. stricta Sm., E. B. 333 (starved).-Plant smaller than the preceding, erect, slightly branched. Inv., caps., and seeds twice as large. L. larger, not pinched above the base. Partial bracts usually 
eordate, but sometimes narrowed to the base.-Corn-fields. $\Lambda$. VI.-VIII.

5. E. hiberna (L.); umbel about 5-ficl, lraets and l. ovate or elliptical cntire obtuse, invol.-glands reniform, eaps. murieated glabrons, sceds obovate smooth somewliat shining brownish.E. B. 1337. R. 4767.-Height l-2 feet. L. broad, nsually pilose bencatl._-Sontl of Ireland and Devon. P. VI. E. I.

6. E. palustris (L.); umbel irregnlar about 5-fid then 3-fid and 2-fid, bracts all elliptical glabrous, 1. broadly lanceolate minutely serrate slightly hairy, invol.-glands transversely oval, caps. warted hairy, secds obovate minutely punetate smooth.-E.B.S. 2787. E. pilosa L.-St. 2-4 feet high, leafy throughont, annual.-The form with glabrons l., the original $E$. palustris (L.), has not been foumd in Britain. See Forst. in Linn. Trans, xvii. 536.- In shady places near Bath where it was noticed by Lobel before the year 1576 . P. V. VI.

E.

*7. E. coralloides (L.); umbel 5-fid then 3-fid and 2-fid, bracts ovate-oblong the tertiary ones ovate all hairy, l. lanceolate minutely serrate woolly, invol.-glands transversely oval, caps. nearly smooth woolly, seeds obovate mimntely punctate and with faint retieulate bands.-E. B. S. 2837 .-IIeight $2-3$ feet. Usually naked below.-Slinfold, Sussex. Supposed to have been introdueed by the late Mr. Manningham. B.? V. VI.

*** Involucral glands triangular-lunate or with 2 horns.

\section{† Seeds smootl. Bracts connate.}

8. E. amygdaloides (L.); umbel 5- or many-fid then 2-fid, bracts rounded connate, $\mathrm{l}$. ovate-lanceolate hairy beneath entire, invol.-glands lunate with 2 horns, caps. with very minute tubereles glabrous, seeds roundish-ovate smootl. $-E . B .256 . R$. 4799. E. sylvatica L.-St. $2-3$ feet high, leafy, purple below, biennial. Invol.-glands ycllow.-Woods and thickets. P. III. IV. Wood Spurge.

E. I.

[E. Characias (L.) E. B. 442. has no claim to be considered as a native.]

†† Seeds smooth. Braets separate.

[9. E. Cyparissias (L.); umbel many-fid then 2-fid, bracts cordate acute, $l$. linear entire glabrous, invol.-glands lunate, eaps. "nearly smooth, seeds obovate smooth."-E.B.840. R.4793.Known by its narrow truly linear leaves.-A very doubtful native. Woods. P. VI. VII.]

E.

10. E. Esula (L.); umbel many-fid then 2-fid, bracts eordatc obtuse mueronate, l. lanceolate or linear-lanceolate glabrous denticulate, invol.-glands with 2 horns, "eaps. seabrous, seeds obovate smooth."-E. B. 1399. R. 4791.-St. 12-18 in. high, 
leafy, with a few axillary leafy branches without flowers. Root crecping.-Woods, rarc. P. VII.

E. S.

11. E. Paralias (L.); umbel usually 5 -fid then 2 -fid, bracts rather'reniform, l. coriaceous elliptic-oblong, invol.-glands 5 lunate with short points, caps. wrinkled, seeds sinooth.-E. B. 195. R. 4789.-Root wooly, tough. Flowering st. about a foot high, barren stems shorter numerous. L. closely imbricated.-Sandy sea-coast. P. VIII. IX. Sea Spurge.

t†† Seeds rough, tubercled or pitted. Leaves alternate, seattered.

12. E. portlandica (L.); umbels 5-fid then 2-fid, bracts broadly rhomboidal acuminate, $l$. obovate or obovate-lanceolate obtuse somewhat apiculate, invol.-glands 4 linate with long horns, caps. rough at the angles, seeds pitted and netted.-E. B. 441 . R. 4787.-Glaucous, smooth. Scarcely a foot high. L. spreading. Secds netted with white. Funiculus conical, hooded.Sandy sea-coast. P. VII.-IX.

13. E. Peplus (L.); umbel trifid then forked, bracts ovate obtuse mucronate, l. broadly-ovate subemarginate stalked, lower 1. suborbicular, invol.-glands 4 lunate with long horns, caps. smooth with thickened rugose keels, sceds oval pitted.-E. B. 959. R. 4773.-Light green, smooth, erect, $6-10$ in. high. I do not find the intermediate smaller dots on the seeds mentioned by Reichenbach; with us they are arranged, beginning from the back, $4,3,1$, or $3,2,1$, with rarely 1 or more intermediate.-A common weed. A. VII. VIII. Petty Spurge.

14. E. exigua (L.); umbel trifid then forked, bracts lanceolate acute uncqual below, $l$. linear obtuse with a mucro or acute, invol.-glands rounded with 2 horns, caps. smooth with slightly thickencl and tubercular angles, sceds angular wrinkled.-E. $B$. 1336. R. 4777.-Height 3-6 in., usually branched at the base. -Corn-fields. A. VI.-VIII.

\section{**** Seeds rough. Leaves opposite.}

15. E. Lathyris (L.); umbel 3-4-fid then 2-fid, bracts oblong-ovate attenuated acute, 1 . linear-oblong sessile, upper l. cordate at the base, glands of the involucre lunate with blunt horns, caps. smooth with a dorsal line.-E. B. 2255, R.4783.-St. solitary, 2-3 fect high, purplish. L. numerous, in 4 rows.- Truly wild in a few stony and rocky woods, wherc it appears for 2 or 3 vears after the bushes have becn cut. Also naturalized in cultivated ground. B. VI. VII. Caper Spurge.

\section{Mercurialis Linn. Mercury.}

1. M. perennis (L.); st. simple, l. stalked oblong-lanceolate 
rough, femalc fl. on long common stalks, root crecping.-E. $B$. 1872. R. 4804.-St. abont a foot high, usually uaked below.Woods and thickets. P. IV. V.

2. M. annua (L.); st. branched, l. stalked ovate or ovateoblong smootl, femalc fl. nearly sessile, root fibrous.-E. B. 559 . R. 4801 . St. 29. 16.-Ileight 6-12 in. Bright green. Much branched.- $\beta$. ambigua (Bab.); 1. lanccolate, fl. whorled male and female intermixed. M. ambigua (Linn. fil.) E. B. S. 2816. R. 4802.- Waste and cultivated land. $\beta$. Jersey. Isle of Wight. Dr. Bromfield. A. VIIl. IX.

\section{Order LXXIV. URTICACEA.}

Fl. monøecious, diøecious, or perfect. Perianth inferior $4-3$ -6-parted, imbricate, or entire in the female flowers. Stam. indcfinitc, frce, inserted at the base of the perianth and opposite to its lobes. Ovary free, 1-2-celled; ovules solitary. Stigmas 1-2. Fr. not bursting.

Tribe I. URTICEAE. Ovary 1-celled, seed erect, embryo straight.

1. Parietaria. Fl. polygamous, surrounded by an involucre. Perigone bellshaped, 4-parted. Stam. 4. Style filiform.G. F. G. Monochl. 29.

2. Urtica. Fl. monœeious or diøecious. Males in loose racemes; perianth 4-parted; stam. 4. Females in capitate racemes ; perigone 2-parted; stigma sessile.-G. F. G. Monochl. 28.

Tr. II. CANNABINEAE. Ovary 1-celled, ovule pendulous (?), embryo curved or spiral.

3. Humulus. Fl. diøcious. Males with the perianth 5parted; stam. 5 . Females with the perigone scalelike, open, hilden by the scales of an oval catkin; stigmas 2, elongated. -G. F. G. Monochl. 31.

Tr. IIl. ULMEE. Ovary 2-celled, seed pendulous, embryo straight.

4. Ulmus. Fl. perfect. Perianth bellshaped, 4-5-cleft, persistent. Stam. 5. Styles 2. Caps. compressed, winged all round.-G. F. G. Monochl. 34 .

\section{Tribe I. Urticea.}

1. Parietaria Linn. Wall Pelletory.

1. P. erecta (Koch); l. oblong-oval attenuated at both ends 
triplinerved, perianth "bellshaped equalling the stamens."-St. mostly erect and simple. Inv. of two 3-lobed segments : each with $3 \mathrm{fl}$. on its disk, a female $\mathrm{H}$. between them, and two small simple segments alternating with them ; each lateral lobe of each segment bearing a pair of small leaves on its face with the lateral fl. between them.-Old walls. P. VI.-IX.

2. P. diffusa (Koch); l. oval acute at both ends triplinerved, perianth of staminiferous $\mathrm{fl}$. ultimately elongated and twice as long as the stam.-P. officinalis Sm., E. B.879.-St. prostrate or ascending, diffuse, branched. Inv. of two 3-lobed segments : each l-flowered, a fem. fl. betwcen them, and one outer simple lobe in front. Perianth of the perfect $f$. elongated and red as the seed ripens.-Is this structure of the inv. constant?-Old walls. P. VII.-IX.

\section{Urtica Linn. Nettle.}

$\dagger$ 1. U. pilulifera (L.) ; $l$. opposite ovate or cordate acuminate coarsely toothed, stipules oblong-ovate, clusters of fr. globose stalked, secds tubercled.-E. B. 148.-About towns and villages in the east of England. A. VI.-VIII. Roman Nettle. E. I.

†2. U. Dodartii (L.); $l$. opposite ovate or ovate-lanceolate nearly entire, stipules lanceolate, clusters of fr. globose stalked, seeds smooth.- In the east of England, rare. Copford, Essex. Upwell, Norf. Wisbeach, Cambr. A. VI.-VIII. E.

3. U. urens (L.); l. opposite elliptical serrate, spikes axillary nearly simple two together shorter than the petiole, seeds smooth opaque.-E. B. 1236.-Common weed. A. VI.-IX. Small Nettle.

4. U. dioica (L.); 1. opposite cordate serrate, spikes axillary panicled longer than the petioles, seeds smooth opaque.-E. $B$. 1750 . - The form of the $\mathrm{l}$. is variable, being usually cordate but in $\beta$. angustifolia (W. and G.) ovate-lanceolate rounded but not cordate at the base-Common. P. VI.-IX. Great Nettle.

\section{Tribe II. Cannabinere.}

\section{Humulus Linn. Hop.}

1. H. Lupulus (L.).-E. B. 427.-Well known from its long climbing stems, opposite rough $3-5$-lobed serrated leaves, and remarkable catkins. - Truly wild in many parts of England although extensively cultivated. P. VII.

\section{Tribe III. Ulmea.}

4. Ulyus Linn. Elm.

1. U. campestris (L.); "l. rhomboid-ovate acuminate wedge- 
shaped and oblique at the base always scabrous ahove donbly and irregularly serrated downy beneath : serratures incurved, branches wiry slightly corky, when young light brown and pubescent, fr. oblong deeply cloven naked." Lindl.-E. B. 1886.Ileight $60-80$ feet. IIabit tall and upright. l'r. oblong-wedgesliaped or nearly obovate.-See Loudon's Arboretum Brit. for a very full account of the varieties of this and the other species.Southern parts of England. T. IV. V. Small-leaved Elm.

2. U. suberosa (Ehrh.); " $l$. nearly orbicular acute obliqnely cordatc at the base sharply regularly and doubly serrated always scabrous above pubescent bencath lairy in the axils, hranches spreading bright brown winged with corky excrescences, when young very liairy, fr. nearly round deeply cloven naked." Lindl. -E.B. 2161.-IIeight $60-80$ or 100 fect. More spreading than the preceding. Leighton says that the edges of the perianth are smooth, I find them to be ciliated in specimens from $\mathrm{Mr}$. Borrer. Fr. with a sinus reaching to the seed.-Common. T. III.

*3. U. major $(\mathrm{Sm}$.$) ; "l. ovate-acuminate very obliquc at the$ base sharply doubly and regularly scrrated always scabrous above pubescent bencatli with dense tufts of white hairs in the axils, branches spreading light brown winged with corky excrescences, when young nearly smooth, fr. obovate slightly cloven naked." Lindl.-E.B. 2542.- "Height $50-70$ feet." Fr. with a small rounded sinus not reaching half-way to the seed.-lledges. Introduced from Holland? 'T. III. Dutch Elm.

4. U. carpinifolia (Lindl.); "I. ovate-acuminate coriaceous strongly veined simply crenate scrrate slightly oblique and cordate at the base shining but rather scabrous above smooth beneath, branches bright brown nearly smooth, fr.....-Four miles from Stratford-on-Avon on the road to Alcester. T." Lindl.

E.

5. U. glabra (Mill.); "l. ovate-lanceolate doubly and evenly crenate-serrate cuneate and sblique at the base becoming quite smooth above smooth or glandular beneath with a few hairs in the axils, branches light brown smooth wiry weeping, fr. obovate deeply cloven naked." Lindl.-E. B. 2245.-Height 60-80 feet. Fr. smaller than in the other species, cloven down to the seed. Branches spreading, rather drooping. - " $\beta$. glandulosa; l. very glandular beneath. $\gamma$. latifolia; 1 . oblong acute very broad." Lindl.-Woods and hedges; $\beta$. near Ludlow. Lindl. $\gamma$. West Hatch, Essex. Mr. E. Forster. T. III.

6. U. stricta (Lindl.); "l. obovate cuspidate cuncatc at the base evenly and nearly doubly crenate-serrate strongly veined coriaceous very smooth and slining above smooth beneath with hairy axils, branches bright brown smooth rigid erect very compact, fr....... - . parvifolia; l. muclı smaller less oblique at 
the base finely and regularly crenate acuminate rather than cuspidate." Lindl.-Devon anil Cornwall. T. Cornish Elm. E.

7. U.montana (Sm.); "1. obovate euspidate doubly and coarsely serrate cuncate and nearly equal at the base always exceedingly scabrous above cvenly downy beneath, branches not corky cinereous smooth, fr. rhomboid-oblong searcely cloven naked." Lindl. -E. B. 1887.-IIeight 50_60 fect. Spircading. L. very large. -Woods and hedges. T. III. IV. Wych Elm.

[Probably all our Elns belong to only 2 species-U. campestris which produces scions; and $U$. montana which does not. Nos. 1, 2, 3, and 6 belong in that case to the former, and 5 and 7 to the latter.]

\section{Order LXXV. AMENTACEA.}

Fl. monœcious or diœcious, rarely perfect. Barren fl. capitate or in eatkins; sometimes with a membranous perianth. Fertile fi. clustered, solitary or in eatkins. Ovary usually simple. Stigmas 1 or more. Fruit as many as the ovaries, bony or membranaceous. Albumen usually wanting. Embryo straight or curved, plain. Radicle mostly superior.-Young leaves with stipules.

Tribe I. SALICINEAE. Fl. all in catkins. Fr. naked, 2-valved, 1-celled, many-seeded. Sceds erect, comose.

1. Salix. Catkins consisting of imbricated scales. Stam. 1-5. Fr. a 1-celled follicle with $1-2$ glands at its base. Perianth 0.-G. F. G. Monochl. 15.

2. Populus. Catkins with lacerated scales. Stam. 8-30, from a little oblique cupshaped perianth. Fr. almost 2-celled, with a cupshaped perigone.-G. F. G. Monochl. 16.

Tr. II. MIRICEAE. Fl. all in catkins. Fr. drupaceous, surrounded by the scales of the ovary become fleshy and adherent.

3. Myrica. Catkins with concave scales. Stam. 4-8. Drupe 1-celled, 1-seeded. Perianth 0.-G. F. G. Monochl. 26.

Tr. III. BETULINEAE. Fl. all in catkins. Fr. naked, inde. hiscent, membranous, 2-celled with solitary ovules. Seeds pendulous, not comose.

4. Betula. Seales of the barren catkins ternate, the middle one bearing the stamens. Perianth 0 . Scales of the fertile catkin 3-lobed, 3-flowered, membranous, deciduous. Styles 2. Ovary compressed. Fr. with a membranous margin, 1-seeded.-G. F. G. Monochl. 18.

5. Alvus. Scales of the barren catkins 3-lobed, 3-flowered. 
Perianth 4-parted. Scales of the fertile catkin ovate, 2flowerel, coriaceous, persistent. Styles 2. Ovary compressed. lir. not winged, 2-celled.-G. 1'. G. Monochl. 18.

Tr. IV. CUPULIFERA. Male fl. in a eatkin. Fem. solitary or aggregated or spiked. Perigone aduate to the ovary, with a deuticulated limb, sometimes evanescent, surrounded by a eoriaecous involucre.

6. FAgus. Barren fl, in a globose catkiu. Perianth 5- or 6ficl. Stam. $10-15$. Fertile fl. 2 togetlier within a 4-lobed prickly involncre. Stigmas 3. Ovaries 3-cormered and 3cellerl. Nut by abortion 1-2-seeded.-G. F. G. Monochl. 24.

7. Castanea. Barren $t$. in a long cylindrical eatkin. Pcrianth (i-parted. Stam. 10-20. Fertile fl. 3 within a 4 lobed nuricated involucre. Stigmas 6 . Ovary 5-8-celled. Nut I-eelled with 1-3 seeds.-G. 1. G. Monoch]. 25.

8. Quercus. Barten catkin long, pendulous, lax. Stam. 5-10. Perianth 5-7-cleft. Fertile fl. solitary with a eupshaped scaly involucre. Stigmas 3 . Ovary 3-celled. Nut 1-celled, 1-seeded, surrounded at the base by the enlarged eupshaped involucre.-G. F. G. Monochl. 23.

9. Conylus. Barren eatkin long, pendulous, eylindrical. Seales 3-lobed, middle lobe eovering the 2 lateral lobes. Stam. 8. Antl. 1-celled. Periantlı 0. Fertile fl. several, surrounded by a scaly involucre. Styles 2. Nut 1-sceded, inclosed in the enlarged eoriaccous laciniated involucre.G. F. G. Monochl. 22 .

10. Carpinus. Barren catkin long, cylindrieal. Seales roundish. Stam. 8-14. Fertile fl. in a lax catkin. Scales large, leafy, 3-lobed, 2-flowered. Styles 2. Nut ovate, 1-seeded.G. F. G. Monoehl. 20.

\section{Tribe I. Saliciner.}

\section{SAlix Linn.'}

\section{Pedunculate laterales.}

Catkins on a leafy stalk, lateral, coctancous.

* Scales of the catkins deciduous. Trees.

i. Pentandra (Borr.). Stam. more than 3. L. glossy, glabrous.

\section{S. pentandra (L.); 1. ovate-elliptieal or ovate-laneeolate}

1 I have ventured to place some plants as varieties which are considered as distinct by my able friend Mr. Borrer, but I do so with much hesitation, being very imperfeetly acquainted with many of them. 
acuminatc glandular-scrrate, "stip. ovate-oblong straight equal," stam. 5 or more, caps. ovate-attenuated glabrous, pedicel twice as long as the gland, style sloort, stig. bificl.-E. B. 1805.-Height 18-20 feet. Top of the petioles glandular. Foliage fragrant.River-sides in the north. T. V. VI. Bay-leaved Willow.

2. S. cuspidata (Schultz); l. oblong-lanccolate acuminate glandular-serrate, "stip. half cordate oblique, stam. 3 or 4 ," caps. ovate attemuate glabrous, "pedicel 3 or 4 times as long as the gland," style short, stig. emarginatc.—Loudon's Arboretum 1439. S. Meyeriana Willd.-1leight 20-30 feet. Top of the petioles glandlular. Stip. soon falling off in this and the preceding species.-Near Shrewsbury. Rev. W. A. Leighton. 'T. VI. E.

ii. Fragiles (Borr.). Stam. 2. L. glabrous. Trees.

3. S. decipiens (Hoffm.); l. lanceolate pointed serrate, floral l. somcwhat obovate recurved often bluntish, "germens tapering stalked glabrous, style longer than the cloven stigmas." $-E$. B. 1937. - Ileight 30 - 40 feet. Branches smootl, highly polished, reddish-brown; young shoots often crimson.-Damp meadows and osier-grounds. 'T. V.

4. S. fragilis (L.); l. ovate-lanceolate acute scrrate, floral l. similar, "germens stalked oblong-ovate glabrous, style short, stigm. bifid."-E. B. 1807 . Loud. 1444.-11eight $80-90$ feet. Branches round, very smootl, brown, brittle in the spring. Wood without valuc.-Marshy ground. T. IV. V. Crack Willow.

5. S. Russelliana (Sm.); $l$. lanceolate tapering at both ends, floral l. similar, germ. stalked lanceolatc aeuminate glabrous, style as long as the bifid stigmas.-E. B. 1808. Loud. 1445.-Height 80 - 90 feet. Branches polished, round, smootl. L. gradually attenuated, very glaucous beneath. Wood and bark highly valuable.-Marshy woods. T. IV. V. Bedford Willow.

iii. Albœ. (Borr.). Stam. 2. L. hairy with adpressed silky hairs when young. Catkins lax. Trees.

6. S. alba (L.); l. elliptic-lanceolate glamdular-serrate acute silky on both siles when young, germ. nearly sessile ovate-acuminate glabrous, style short, stigmas thick recurved bifid.-E. B. 2430. Loud. 1447.- Height 50-80 fect. Branches silky.-

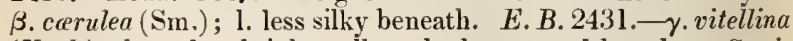
(Koch); branches bright yellow, l. shorter and broader. S. vitellina Sm., Borr.-Wet places. T. V. White Willow.

** Scales of the catkins persistent.

iv. Triandra (Borr.). Stam. 3. L. lanceolate approaching to ovate, glabrous. Catkins lax. Osiers, naturally trees.

7. S. undulata (Ehrh.); 1. lanceolate much acuminate serrate 
ghabrous execpt when young, germ. stalked ovate acuminate, pedicel twice as long as the gland, style elongate, stig. bifid, scales very shaggy. - S. lanceolata Sm., E. B. 1436. Iİeight 12-15 feet. L. sometimes mululated, often quite silky when young. Stip. laalf cordate acuminate. Germ. glabrous (sometimes downy in foreign specimens).-By streams. T. IV. V.

8. S. triandra (L.); l. oblong-lanccolate acute serrated glabrous, germen stalked oblong-ovate glabrous, stigm. nearly sessile, scales glabrous.-E. B. 1435.-IIcight 20-30 feet. Germen not furrowed. L. narowing down to the stalk, somewhat paler beneath; or (S. triandra Curt.) lanceolate wavy paler and glaucous beneath. $-\beta$. Hoffimanniana; $\mathrm{l}$. somewhat romded below ovate-lanceolate, stip. larger, scales shaggy towards their base. S. Hoffmanniana Su., E. B. S. 2620.-W Wet woods and osiergrounds. 'I. $\mathrm{V}$.

9. S. amygdalina (Sm.); l. oblong-ovate acute rounded below scriated glabrous, germen stalked ovate tumid furrowed glabrous, stigm. nearly sessile, scales glabrous, young shoots furrowed.E. B. I936.-IIeight 20-30 feet. Scales usually slightly hairy below.-By water. T. IV. V.

E. S.

[S. petiolaris (Sin.) E. B. 1147. is stated by Lindley not to be a European plant and is therefore omitted.]

\section{Sessiles laterales.}

Catkins lateral, scssile, without leaves or with two or three small leaves or leaflike bracts at the base, stalk sometimes elongated in fruit so as to resemble a leafy shoot but deciduous with the catkin.

v. Purpurea (Koch, Borr.). Filament I with a 4-celled anther, or forked with 2 anthers each of 2 eclls. Anth. purple, ultimately black. Catkins bracteated at the base; scales dark or purple at the end.

I0. S. purpurea (L.); 1. lanceolate broader upwards acuminate attcnuated below finely serrate glabrous, germ. ovate very downy sessile, style very short, stiym. ovate, anth. 1, stip. 0."a. S. purpurea (Sm.); decumbent, twigs purple, fertile catkins very conpact. E. B. 1388.- $\beta$. S. Woollgariana (Borr.); erect, twigs ycliowish-gray, 1 . cuneatc-lanceolate glaucous beneath, stiguris obtuse. E. B.S. 2651.- . S. ramulosa (Borr.); erect, twigs pale yellowish, l. oblong-lanceolate paler beneath, stigmas sessile bifid. - $\delta$. S. Lambertiana (Sm.); erect, twigs purplishglaucous, l. oblong-linear-lanccolate shightly narrowed and somewhat rounded below, stigmas ovate emarginate." E. B. I359.Marshes and river-banks. T. III. IV. 
11. S. Helix (L.); 1, oblong-lanceolate broader upwards acuminate attenuated below finely and slightly serrate glabrous, "germ. oblong-ovate very pubescent sessile, style short, stigmas almost linear emarginate," anth. 1, stip. 0.-E.B. 1343.-Height $10-12$ feet. Twigs pale yellowish or tinged with purple, polisherl. "Style nearly as long as the stigmas." Closely allied to $S$. Lambertiana, but that is stated to have "ovate-cmarginate stigmas."-Wet places. 'T. III. IV. Rose Willow.

12. S. rubra (1Iuds.); l. lincar-lanceolate acuminate glabrous green on both sides, germ. oblong-ovate very pubescent, style elongated, stigmas ovate undivided, anth. 2: filaments combined below, stip. linear.-E. B. 1145.-Height 10-20 fect. Twigs usually tawny. L. like those of $S$. viminalis but without the white pubescence.-Low meadows. T. IV. V.

13. S. Forbyana (Sm.); l. lanceolate-oblong scrrated glabrous, style nearly as long as the linear divided stigmas, anth. 1, stip. linear-lanceolate.-E. B. 1344.--Height 5-8 feet. Twigs grayisli-yellow. L. rather paler and somewhat glaucous beneath. I an unacquainted with this plant.-Wet meadows. Sh. IV.

vi. Viminales (Borr.). Stam. 2. Antl. permanently yellow. Catkins bracteated at the base; scales discoloured at the end. Stalks of the caps. 0, or shorter than the gland. Pubescence of the 1. silky.

14. S. viminalis (L.); l. linear or linear-lanceolate obscurely crenate white silky and shining beneath, stip. small sublanceolate, capsule very shortly stalked lanceolate-subulate, style elongated, stigmas undivided.-E. B. 1898.-Ieight 10-20 feet. Branches wandlike, long, slender. Gland longer than the stalk of the germen.- $\beta$. intricata (Leefe); l. broader, germen shorter and broader, style very short, stigmas from the first cloven reHexed and entangled. $-\gamma$. stipularis (Leefe); l. lanceolate, stip). linear-lanceolate denticulate or semicordate-acuminate, stigmas elongated.-Mr. Leefe gives several other forms which show how difficult it is to define the species of Salix.-Wet places. Sh. IV. V. Common Osier.

15. S. stipularis (Sm.); 1. lanceolate very obscurely crenate white and downy bencath, stip. half cordate acute, caps. ovate nearly sessile, style very short ( $\mathrm{Sm}$.) elongate (Hook.), stigmas linear undivided.-E. B. 1214 . - Height $10-20$ feet with upright brittle reddish-brown twigs. - Wet places. Sh. III.

16. S. Smithiana (Willd.); l. elongate-lanceolate obscurely crenate white with satiny pubescence beneath, stip. small narrow acute, caps. stalked lanceolate-subulate, pedicel as long as the glant, style elongate, stigmas long lincar mostly entire.-E. $B$. 
1509. - Twigs ereet, somewhat downy, brittle.-Wet plaees. Slı. IV. V.

17. S. rugosa (Sm.); 1. elongate-laneeolate seareely crenate greenish-white and rather silky beneath, stip. half cordute aente, caps. stalked lanecolate-subulate, pedieel about as loug as the gland, style moderate, stigmas linear broad undivided.-S. holosericea (Hook.) not IVilld.-Wet plaees. Sh. IV. V. E.

18. S. ferruginea (Anl.); 1. elongate-laneeolate undulatedentieulate greenish-white and rather silky beneath, stip. half ovate or reniform, eaps. stalked laneeolate-sulbulate, pedieel about is long as the gland, style elongate, stigmas linear-oblong undivided.-E. B.S. 2665.-Height $12-15$ feet. Bushy. This and the 2 preeeding are very elosely allied and probably ought to be combined. The stipules appear to be variable.-Wet plaees. Sh. IV. V.

E. S.

vii. Caprea (Koeh). Stam. 2. Anth. permanently yellow. Catkins braeteated at the base; seales diseoloured at the end. Stalks of the caps. at least twice as long as the gland. Trees shrubs with an exposed trunk.

\section{A. Cinerea Borr., Fries.}

No glands at the base of the stipules. Borr.

19. S. acuminata (Sm.); l. laneeolate-oblong pointed finely toothed glaueous and downy beneath, stip. half eordate, germen ovate tapering, style conspicuous, stigmas ovate undivided, buds downy.-E. B. 1434. Loud. 1464.-Height 25-30 feet.-Damp woods and herges. Sh. or T. IV.

20. S. cinerea (L.); 1. elliptie- or laneeolate-obovate pointed subserrate downy beneatl, stip. half eordate, germen laneeolatesubulate, style very short, stigmas simple or bifid, buds downy.E. B. 1897.-Height 20-30 feet.-a. S. cinerea (Sm.); l. obovate-laneeolate rather thiek somewhat misty beneath, stip. half eorlate aeute, style very short thiek. E. B. 1897.- $\beta$. S. aquatica (Sm.); l. obovate-elliptieal thinner downy and rather glaueous beneatl, stip. reniform, style obsolete. E. B. 1437.- - . S. oleifolia (Sm.); l. obovate-laneeolate rather rigid downy and rather glaueous beneath, stip. small rounded. E. B. 1402.Very variable and I think these 3 form only 1 speeies.-Wet plaees. T. or Sh. III. IV. Sallow.

21. S. aurita (L.); l. obovate repando-dentate reeurvo-apienlate wrinkled more or less downy above pubeseent beneath, stip. roundish or reniform large stalked, germens laneeolate-subulate, style very short, stig. generally entire, buds glabrous or slightly downy-E. B. 1487 . - Height $3-4$ feet. L. very rugged, margins deflexed, point hooked.-Damp woods. Sh. IV.V. 
22. S. Caprea (L.); l. ovate or elliptical flat acute crenateserrate wary at the inargins decp green with a downy nidrib whitish above and cottony beneath, stip. subreniform, germens lanceolate-subnlate, style very short, buds glabrous.-E. B. 1488. - A small tree, 15-30 feet high. Catkins very thick, blunt. L. large and broad.-Woods and lickges in dryish places. T. IV. V. Great Sallow.

23. S. sphacelata (Sm.); 1. elliptic-obovate even veiny cntire or slightly serrate downy on both sides discoloured at the point, stip. half cordate toothed crect, germens stalked ovatc-lanceolate, stigmas notched longer than the style.-E. B. 2333.-With this I am unacquainted.-T. IV. V.

S.

\section{B. Nigricantes Borr.}

Glands at the base of the stijules. Borr.-This section forms the S. niyricans of Fries and Koch. I must confess myself unable to distinguish the species satisfactorily and have compiled the characters from those given by Smith and Borrer.

24. S. cotinifolia (Sm.); I. roundish-clliptical pointed obsoletely toothed slightly downy above glaucous and downy beneath, stip. rounded or ovate, germens ovate-laneeolate silky, style elongate deeply bitid, stigmas notched.-E. B. 1403.- $\Lambda$ low shrub, ipuright. L. rectangularly reticulated bencath. Young shoots downy--Norfolk. Glenlice and Forfar. Sh. IV. V. E. S.

25. S. hirta (Sm.); 1. elliptic-heartshaped pointed finely toothed downy on both siles, stip. half heartshaped flat toothed nearly glabrous, germens......, style shortly bifid, stigmas emarginate.-E.B. 1404.-A small trce. Young shoots and petioles with white cottony hair.-Norfolk. Castle Eken, Durham. 'I. IV. V.

26. S. wigricans (Sm.); l. clliptic-lanceolate acute crenate glabrous with a downy midrib (even when young) glaucous with a few hairs beneall, sitip. large obliquely cordate serrated smooth, germ. laneeolate dowmy, style longer than the stigmas. $-E$. $B$. 12133.-A bushy slurub. Bunch of young leaves tipped with a tuft of deciluous down. Young shoots downy.-Wrongay fen, Norf. Shohden Court, IIereford. Sh. IV.

27. S. Forsteriana (Sm.); l. elliptic-obovate acute notehed and very slightly downy except upon the midrib where it is dense glaicous beneath, stip. rounded recurved vaulted, germ. awlshaped silky, style as long as the blunt emarginate stigmas.-E. B.2344. -1 small tree. Youmg sloots minutely downy. Germens crowded. Catkins clongated.-Breadalbanc Mountains. New('astle-upon-Tyne. 'T. V. VI.

E. S. 
28. S. rupestris (Doun); l. obovate acute serrated flat even silky on both sides, stip. sinall ovate hairy, germens awlshaped silky, style as long as the blunt undivided stigmas. - E. B. $2: 342$. - I trailing or depressed shrub. Young shoots minutely downy. "Germens silky or naked." Borr. - Blanchland, Northmnib. Rocks of Craigalleaeh and Mael Ghyrdy, Perthshire. Sh. V. lis.s.

29). S. propinqua (Borr.); 1. elliptical obsenrely crenate nearly flat, nearly naked on both sides pale green beneath, stip. small vaulted glandulose, germens silky towards the point, style longer than the notehed stignas. - E. B. S. 2729.-An npright shrub. Young shoots finely downy. Veins of the l. slightly sunken.Locality mukuown. Sh.

30. S. petraa (And.); l. oblong serrated keeled reticulated hairy and glancous beneath, stip. large half cordate flattish with a few glands, germens naked wrinkled towards the point, style divided longer than the bifid stigmas.-E. B. S. 2725.-Shrub 6-15 feet high. Young shoots densely hairy. L. ultimately nearly losing their glaucons tint. - Brearlalbane Mountains. Sl. $\dot{V}$.

31. S. Andersoniana (Sm.); 1. elliptic-oblong aeute finely noteherl upper ones downy on both sides and rather glaucous beneath, stip. small lialf ovate erect flat at length vaulted glandulose, floral l. almost as long as the eatkin when in flower, germens naked, style divided longer than the diverging stigmas.E. B. 2343. - A bushy shrub.-Breadalbane Mountains. Neweastle-upon-Tyne. Sh. V. VI.

E. S.

32. S. damascena (Forbes); 1. ovate or rhomboidal finely notehed upper ones silky not at all glaucous beneath, stip. haif heartshaped vaulted glanilulose, floral 1 . shorter than the flowering eatkin, yermens naked, style divided longer than the diverging stigmas.-E. B. S. 2709.-An upright shrub very nearly allied to the last. Young shoots hairy.-South of Seotlanil. Sl. IV.

33. S. tenuifolia (L.); l. elliptical or oblong flat with a reeurvel point erenate reticnlated with sunken veins slightly hairy glaucous beneath, stip. half heartshaped or ovate, germens anil their stalk naked, style a little longer than the short cloven stigmas. -E. B. S. $2795 .-A$ mueh branched spreading slirub, eonnecting the Nigricantes and Bicolores.-Kirkby Lonsdale briclge. Sh. V.

E.

\section{Hastata Borr.}

Low shrubs with broad 1 . and very silky catkins.

34. S. hastata (L.); 1. broadly elliptical wary thin and erackling quite glabrous glaueous beneath, stip. unequally heart- 
shaped longer than the petioles, germens subnlate glabrous, style elongated, scales shaggy. - S. malifolia Sm., E. B. 1617.-A tall shrub with crooked brittle twigs. L. shortly acuminated, narrowed towards the base.-Sands of Barric near Dundlee. Norfolk? Sh. V. S. E.?

35. S. lanata (L.); l. broadly oval pointed cntire shaggy beneath, stip. oval, germens conical glabrous, catkins terminal or placed just below the ends of the branches and above the leafluds scssile, fertile ones bracteated.-E. B. S. 2624.-A low and very beantiful shrub.-Glen Dole and Glen Callater, Clova Mountains. Sh. V.

S.

\section{Bicolores Borr.}

This section corresponds nearly with the $S$. bicolor of Koch, and it must be confessed that the species are very closely allied and might probably be reduced in number advantageously by a person who was thoroughly acquainted with them.

36. S. laurina (Sin.); l. elliptic-oblong acute obsoletely crenate naked except when young dark green above glaucous beneatl, stip. pointed glandulose, germens and stalk silky.-S. bicolor Sm., E. B. 1806.-Twigs wandlike, purple. Stalk of the caps. as long or longer than the blunt scale. $-\beta$. S. tenuior(Borr.); 1. obovate-lanceolate, catkins shortcr and more slender lax, stalks of the caps. shorter than the oblong scalcs, style longer than the ovate stigmas. E. B. S. 2650.-Twigs paler and leaves more spreading.-Woods and thickets. $\beta$. Killin. Sh. IV. V.

37. S. radicans $(\mathrm{Sm}$.$) ; 1. oblong- or elliptic-lanceolate acute$ with wavy serratures naked glancous beneath, stip. small lunate glandulose, germens (and stalks?) silky.-S. phylicifolia Sm., E. B. 1958.-A low shrub with spreading decumbent branches. -Breadalbane Mountains. Sh. V.

38. S. Borreriana (Sm.); l. lanceolate tapering to both ends with shallow serratures naked glaucous beneath, stip. small obliquely lanceolate glandulose, germens on long stalks naked.E. B. S. 2619.-A nuch branched shrub with ash-coloured shoots. L. very different from those of S. radicans, serratures shallow and nearly even.-Glen Nevis and Brcadalbane. Sh. IV.

S.

39. S. tetrapla (Walk.); l. lanceolate tapcring at both ends unequally serrated nearly naked glaucous beneath, stip. small half heartshapel, germens naked: their summits and stalks silky. -E. B. S. 2702.-An upright shrub with straight spreading twigs. L. very acute--Breadalbane. Sh. V.

40. S. Davalliana (Sm.); 1. obovate-lanceolate very acutely pointed obscurely toothed naked somewhat glaucous beneath, 
stip. very minute, germens and stalks silky.-E. B. S. 2701.-A bushy slumb with aseending branches.-Scotland. Sh. V. S.

41. S. laxiflora (Borr.); l. broadly obovate very slightly toothed narrowed to the base naked rather glaneous beneath : upper ones acute, stip. small concave, lower purt of the germens and stalks naked.-E. B. S. 2749,-A treelike shrub.-Killin. Sh. V.

42. S. Weigelliana (Willd.); l. roundish or elliptieal with a short point obsoletely erenate naked, stip. small, germens and stalks silky.-E. B. S. 2656.-An upright slurub.- $\beta$. S. nitens (And.); l. ovate or elliptieal aente slightly scriate. E. B.S. 2655.-Mountainous places. $\beta$. Seotland and Teestale. Sh. IV.

E. S.

43. S. Croweana (Sm.); l. elliptieal pointed obsoletely serrate naked green and shining above glaueous beneath, stip. half lieartshaped, germens silky (Sm.) glabrous (Borr.).-E. B. 1146.A bushy slirub. Stam. combined below.-Swampy plaees. Sh. V. VI.

44. S. bicolor (Ehrh.); l. elliptical pointed obsoletely serrate slightly laairy green and slining above glaueous beneath, stip. creseent-shaped serratel, germens......, filaments slightly bearded at the base.-S. tenuifolia Sm., E. B.2186.-A bushy spreading shrub.-Glen Lyon. Ettriek. Sh. IV.

45. S. phillyreifolia (Borr.); 1. elliptic-laneeolate aeute at each end strongly serrate naked glaueous beneath, stip. small, germens and stalks naked.-E. B. S. 2660,-An upright mueh branehed shrub.-Highlands of Inverness and Perth. Sh. IV.

46. S. Dicksoniana (Sm.); l. elliptic acute slightly toothed glabrous glaucous beneath, young branehes very glabrous, eatkins ovate slort ereet, germens ovate silky, stigmas nearly sessile.E. B. 1390.-Seotland. Sh. IV.

viii. Fusca. Stam. 2. Anth. fuscous-yellow when empty. Catkins braeteated at the base; seales discoloured at the enil. Stalks of the eaps. very rarely not longer than the gland. Shrubs with a subterranean creeping trunk.

\section{A. Rosmarinifolia (Borr.). Small erect shrubs.}

47. S. rosmarinifolia (L.); 1. linear-laneeolate silky beneath quite entire or remotely glandular-toothed, stip. lanceolate, germens silky lanceolate-aeuminate, scales short hairy, "style about as long as the linear-divided stigmas." - E. B. 1365.-A slender" upright shrub, 3 feet high. Catkins very short, at first drooping. Whole plant beeoming nearly black in drying. Style short. - "Several parts of the north." Sm. Sh. IV. 
18. S. angustifolia (Wulf.?); 1. linear-laneeolate silky beneatl when young afterwards nearly glabrous remotely glandulartoothed, stip. very minute (on strong radical slioots lanccolate with the l. ovate Sm.), germens densely silky ovate-acuminate, scales very villose and nearly as long as the young germens, style as long as the erect lanceolate entire stigmas. - S. Arbuscula Sm., E. B. 1366. not Koch, Fries. - I shrub abont a foot high. L. very much attenuated at both ends, except on the radical shoots mentioned by Sm. which I hare not seen,-Clova. Dumfries. Sh. IV.

S.

49. S. Doniana (Sm.); 1. lanceolate or obovate-lanceolate acute slightly serrate livid with scattered silky hairs beneath, stip. linear, germens rery silky ovate-oblong longer than the bearded oblongorate scale, style very short, stigmas short emarginate.-E. B. S. 2599. - Shrub about 6 feet high. "Stam. moualelphous, anth. ultimately lutco-fuscous not black." Closely allied to the Purpurea.-Scotland. Sh. V.

\section{B. Fusca (Borr.). Small procumbent shrubs.}

50). S. fusea (L.?); 1. elliptical or elliptic-lanceolate acute entire or minutely glandular-scrrate glaucous and silky beneath, germens lanceolate silky, style molerate, stigmas ovate bifid.a. vulgaris; 1. elliptic-lanceolate with a straight point, st. depressed with short upright branclies. S. repens Sin., E. B. 183. - $\beta$. fusc $a$; 1. oblong-oval straight, st. decumbent below then ereet unuch branchel. S. fusca Sm., E. B. 1960.- - . prostrata; 1. clliptic-oblong with a twisted point, st. prostrate with elongated straight branches. S. prostrata Sm., E. B. 1959.- - . ascendens; l. elliptical with a recurred point, st. recumbent with long somewhat ascending branches. S. ascendens Sm., E. B. 1962. S. parrifolia Sm., E. B. 1961.-є. incubacen; l. elliptic-oblong with a twistel point, stip. stalked orate acute. $S$. incubacea L., E. B. S. $2600 .-\zeta$. argentea; 1 broally elliptical with a twisted point, stip. stalked oval. S. aryentea Sm., E.B. 1364.-Heaths at v'arious elevations. Sh. III, IV.

\section{Anbbigua Borr.}

51. S. ambigua (Ehrh.); l. oval obovate or lanceolate slightly toothed with a recurrerl point somewhat rugose above soft and silky beneath, stip. stalked half ovate acute, germens lanceolatesubulate silky, style very short, stigmas short at length cloven. - E. B. S. 2733.-A snill decumbent shrub. - $\beta$. major; l. oborate very silky on both sides.- $-\gamma$. spathulata; l. obovate morlerately hairy or silky, style somewhat elongated.- $\delta$. undulata; 1. ovate-lanceolate.-Gravelly heatlıs. Sh. V. 
ix. Arbuscnle. Stan. 2. Antli. yellow or brown when empty. Catkins subsessile bracteated at the base; seales discoloured at the cull. Stalks of the capsules 0 or shorter than the gland. Shrubs with an exposed trunk.

\section{A. Vacciniifolia Borr.}

52. S. Arbuscula (L., Fries, Koch) ; l. lanceolate-ovate or ovate glabrous smooth glaucous and opaque beneath finely serrated, gerinens oblong-ovate silky, stigmas bifid.-I believe that the following 4 plants are forms of one species. $-a$. S. carinata (Sm.); l. ovate finely toothed minutely veinerl folded into a keel, catkins cylindrical with rounded hairy scales. E. B. 1363.$\beta$. S. prunifolia (Sm.); l. broadly ovate toothed smooth on both sides, st. crect much branched. E.B.1361.- $\gamma$. S. venulosa (Sm.); 1. ovate toothed naked reticulated with prominent veins above, st. erect much branched. E. B. 1362.- $\delta$. S. vacciniifolia (Sm.); 1. lanceolate-ovate serrated smooth and even above silky beneath, st. decuinbent. E. B. 2341.-Highlauds. Sh. IV.-VI. S.

\section{B. Glauce Borr.}

53. S. arenaria (L.); 1. lanceolate or elliptical subacuminate entire cottony or silky beneath with erisped hairs wrinkled above and when young downy, germens ovate-lanceolate silky, stigmas lincar.-S. Lapponum L., Fries, Koch.-I follow Koch in redncing 3 of Smith's species to one.-a. S. arenaria (L.); I. ovate-lanceolate reticulated and somewhat downy above veined and woolly beneath, style as long as the sessile woolly germen, stigmas linear. E. B. 1809. Germen with a long slender reddish style.- - $\beta$. S. Stuartiana (Sm.); l. ovate-lanceolate shaggy above densely silky almost cottony beneath, style as long as the almost sessile woolly germen, stigmas capillary deeply divided.

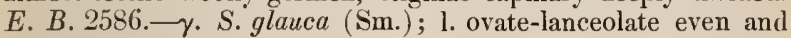
nearly smooth above woolly and snow-white beneath, germens sessile woolly, style very short with thick ovate stigmas. $E . B$. 1810. Germen blunter. Style elongating and the stigmas becoming linear and deeply cloven as the fruit ripens. S. glauca L., Wahl., Koch, has subterminal catkins with very long leafy stalks and belongs to the next section.-Breadalbane and Clova Mountains. Sh. VI. VII.

\section{Pedunculate terminales.}

Catkins on long leafy persistent shoots from the terminal or subterminal buds. Chamely $x$ Fries.

x. Myrsinites (Borr.). Catkins at the extremity of the terminal shoot, or of those from the last but one or two of the buds, but in such a manner as to appear to be an elongation of the branch. Small bushy plants.

54. S. Myrsinites (L.); l. elliptical or lanceolate serrate shining o 5 
often hairy with prominent veins, germens subsessile ovate-subulate downy, style elongate.-S. Myrsinites $\beta$. Sm. - St. mueh branehing. L. resembling those of Betula nana.- $\beta$. ? S. betulifolia (Forst.); l. elliptical serrate nearly smooth, eatkins short, style short, stigmas eloven. S. Myrsinites Sm., E. B. 1360.IIighlands. $\beta$. a doubtful native. Borrer. Sh. VI.

S. I.

55. S. procumbens (Forbes); l. oval minutely serrated bright green and shining on both sides, catkins elongated cylindrical, germens subsessile ovate-lanceolate downy, style short deeply eloven, stigmas bifid.-E. B. S. 2753. - Seales of the eatkin nearly black, longer and more hairy than in S. Myrsinites. A low proeumbent mueh branehed slirub.-Highlands. Sh. VI.

56. S. retusa (L.) ; l. ovate-oblong at length glabrous opaque beneath, eatkins oblong of few flowers, germens ovate-conieal obtuse glabrous or pilose, pedicel twice as long as the gland, style elongate, stigmas bifid linear.--Seales of the eatkin yellowish-green. L. shortly stalked. An altogether procumbent, mueh branehed shrub.-Fries (Mant. i. 76.) states that "beautiful specimens of the var. serpyllifolia collecterl by Mr. Winch in Breadalbane are in Hornemann's Herbarium." It is not to be found in Mr. Winelı's IIerbarium.-Sh. VII.

xi. Herbacer. Catkins exactly terminal upon a shoot from the terminal bud.-A. Reticulate Borr.

57. S. reticulata $(\mathbf{L}$.$) ; l$. nearly orbieular-elliptical very obtuse entire reticulated with veins and glaucous beneath, germens sessile oblong-ovate downy, style short, stigmas bifid.-E. B. 1908.A proeumbent mueh branched shrub. Catkins opposite to the terminal leaf, separated from it by a bud, upon long peduncles.Lofty mountains. Sh. VI.

E. S.

\section{B. Herbaceæ Borr.}

58. S. herbacea (L.); $l$. orbieular or oval obtuse or retuse serrate shining glabrons retieulated with veins, germens subsessile ovate-conical glabrous, style short, stigmas bifid.-E. B. 1907. - $A$ very minute herblike slurub; the stems extend far amongst loose stones on the tops of mountains. Edges and veins of 1 . lairy.-Alpine situations. Sh. VI.

\section{Populus Linn.}

1. P. alba (L.); l. roundish-eordate angularly toothed eottony and snowy-white beneath, l. of the young slioots eordate palmately 5 -lobed, stig. 4. - E. B. 1618.-A large tree with suekers. L. generally lobed, seales of the eatkins notehed at the end.Damp woods. T. IV. White Poplar. Abele. 
2. P. canescens (Sin.); 1. rouudish angularly toothed cottony and white bencath, 1 , of the young shoots cordate-ovate undiviled, stig. 8.-E. B. 1619.- 1 large tree with suekers. L. not lobed execpt oecasionally the youngest. Seales of the eatkins deeply cut at the end.-Damp woods. T. IV. Gray Poplar. E.

3. P. tremula (L.); l. nearly rouud acute serrate glabrous on both sides, young l. slightly downy, stig. 4 erect auricled in pairs. -E. B. 1909.-A ratlier large tree, produeing numerous suckers. Perluncles rertieally eompressed. Seales of the eatkins deeply pahıately cut. Stig. ercet, eaeh pair furnished with a eommon descending wavy lobe.-Woods. T. III. IV. Aspen.

4. P. nigra (L.); l. triangular aeuminate serrate glabrous, "catkins lax eylindrieal, stig. 4 simple spreading."-E.B. 1910. -1 large trec withont suekers. L. remarkably triangular. Young shoots glabrons. Seales of the eatkins palmately cut smootl. Damp' plaees, river-banks. T. III. Black Poplar.

\section{Tribe II. Myricea.}

\section{Mrrica Linn.}

1. M. Gale (L.); 1. laneeolate broader upwards serrate, st. shrubby.-E. B. 562.-Height 3-4 feet. Bushy. Catkins sessile, ereet. Fr. with resinous glands. L. fragrant when bruised.Bogs. Sh. V. Sweet Gale. Bog Myrtle.

\section{Tribe III. Betulinea.}

\section{Betula Linn. Birch.}

1. B. alba (L.); l.rhomboid-triangular doubly serrate abruptly acuminate, seales of the fem. catkins 3-lobed: lateral lobes deflexed, $f r$, obovate-elliptical shorter than the rounded membranous margin.-E. B. 2198 (upper fig.). B. alba Koeh. B. verrucosa Fries!-L. usually glabrous, often eovered with resinous spots above, always having a manifest tendency to a rhomboidal form. Young shoots mostly with resinous tubereles. Stip. ovate-laneeolate, aeute, thriee as long as broad, eireinatc; sides not deflexed. Buds conical. Readily distinguished from the following by its leaves. Young twigs often very long and pendulous.Rather eommon. T. IV. V. White Birch.

2. B. glutinosa (Fries!); l. cordate-ovate unequally serrate acute, seales of the fem. catkins 3-lobed : lateral lobes ascending, fr. broadly obovate as long as the rounded membranous margin.E. B. 2198 (lower fig.). B. pubescens Koch.-L. usually glabrous always more or less ovate. Stip. ovate, blunt, twice as long as broal; sides deflexed. Buds ovate. Not so elegant a tree as the preceding and often little more than a bush. Twigs some- 
times pendulous. - $\beta$. pubescens $(\mathbf{F r}$.); l. peduncles and young twigs downy. B. pubescens Ehrh,-Common. T.IV.V. Common Birch.

[Although thinking that the above plants are really distinct, I am unable to draw up good paper characters for them. The leares on the older and, if possible, the upper branches should be examined as they vary in form on the lower and younger ones. Fries says that the wood of $B$. glutinosa is soft and bad whilst that of $\dot{B}$. alba is hard and excellent.]

3. B. nana (L.) ; l. orbicular crenate glabrous : crenations obtuse, scales of the fem. catkin digitate-trifid divided almost to their base: lobes equal, fr. orbicular with a very narrow membranous margin.-E. B. 2326.?-A small procumbent shrub with minute leaves and little catkins. B. nuna Fries!, Reich.!, Tausch!- $\beta$. Linnai; scales of the fem. catkins 3-lobed divided through only half their length, fr. elliptical with a narrow membranons margin. B. nana Linn.! llerb. Exactly resembling var. $a$. except in the structure of the fructification. Probably a distinct species.-Turfy places in the highlands. $a$. Ben Lawcrs. B. commou. Sh. V. Dwarf Birch.

\section{Alvus Tourn. Alder.}

1. A. glutinosa (Gacrt.); 1. roundish obtuse wavy serrated glutinous rather abrupt with a wedgeshaped base, axils of the veins bencath downy.-E. B. 1508. St. 29. 15.-Trunk and branches crooked. Male eatkins long and pendent; fem. ones short, ovate or oblong, very persistent. A moderately large tree. - $\beta$. incis $\alpha$; leaves deeply cut. - Wet places and river-banks. $\beta$. Galloway. S. Dr. Balfour. T. III.

\section{Tribe IV. Cupulifera.}

6. Fagus Linn. Beech.

1. F. sylvatica (L.); l. ovate glabrous obsoletely dentate ciliate on the edges. - E. B. 1846. - I large tree.-Woods, particularly on chalky soils. T. III. IV.

\section{Castanea Tourn. Chestmut.}

†1. C. vulgaris (Lam.); 1. oblong-lanceolate acuminate mucronate-serrate glabrous on each side.-Fagus Sm., E. B. 886.-Ileight 50-80 feet. A magnificent tree.-A doubtful native, often planted. T. V. Sweet Chestnut.

E.

\section{Quercus Limn. Oak.}

1. Q. Robur (L.); "young branches glabrous, l. on short footstalks cuueately oblong pinnatifid slightly pubescent beneath, 
lobes oblong rounded with deep narrow somewhat aente simuses, bases biamriculate equal, fem. catkins on long peduneles, fi: ob. long."-E. B. 1342. Martyn Rust. 10.-Woods. 'T'. IV. V. Common Oak

2. Q. intermedia (D. Don); "young branches glabrous, l, on long footstalks cuneately oblong slightly pimmatifid glancous and eopionsly clothed with fine stary pubescence beneath, lobes short rounded sinnses shallow spreading obtuse, base obtuse uncqual, fem. catkins on very short pedmeles, fi' oblong."-Mart. 11 .IIlly woods. 'T. IV. V. Intermediate Oak. Norwood Oak.

3. Q. sessiliftora (Salisb.); "young branehes pubeseent, l. on long footstalks oblong pinnatifid glabrons beneath, lobes ovateoblong obtuse simuses rather deep forming a somewhat acute angle, base unequal obtuse or frequently more or less attennated, fem. catkins sessile, fr. orate."-E. B. 1815. Mart. 12.-Hilly woods. T. IV. V. Sessile-fruited Oak. Durmast Oak.

[1 have thought it advisable to adopt the eharaeters of our supposed three oaks as given by the lamented Prof. Don in Leighton's Shropshire Flora and must refer to that cxeellent work for a detailcd aeeount of them. See also a highly valuable paper by Dr. Greville in Trans. Bot. Soc. Edin. i. 69.]

\section{Coryuus Linn. Hazel.}

1. C. Avellana (L.); stip. oblong obtuse, 1. ronndish-cordate aeuminate, involucre of the ovoid fr' eampanulate spreading torn at the margin.-E. B.723.-A shrubby tree. Yonng twigs hairy and glandnlar. L. downy beneath. Male eatkins long, pendulous. Fem. fl. in ovate buds. Stigmas bright erimson.-Hedges and copses. Sh. III. IV. Hazel Nut.

\section{Carpinus Linn. Hornbeam.}

1. C. Betulus (L.); seales of the fruit 3-parted: segments lanceolate the middle one longest. $-E$. B. 2032.-A small tree. L. ovate, aente, plaited when young, deeply and sharply donbly serrate.-Damp clayey woods and hedges. T. V.

\section{Subclass II. GYMNOGENS.}

\section{Seeds quite naked.}

\section{Order LXXVI. CONIFERA.}

Fl. monocious or diøcious. Barren fl. of one or more monadelphous stamens, eolleeted in a deeiduous eatkin about a eommon axis. Anth. of 2 or more lobes bursting outwards, often 
terminated by a scalclike crest. Fertile fl. usually in cones sometimes solitary. Ovary spread open in the shape of a seale and placed in the axil of a membranous bract in the solitary fl. apparently wanting. Ovules naked, in pairs on the face of the ovary and inverted, or (in the solitary fl.) ercet. Fr. a cone, or solitary naked seed. Testa hard crustaceous. Embryo in the axis of fleshy albumen. Radicle next the apex. Ligncous tissue marked with circular disks.

Tribe 1. TAXINEAE. Male fl, in catkins. Fem. fl. solitary, naked or bracteated.

1. TAxus. Catkins of male fl. oval, scaly below, flowering at the top. Stam. numerous. Anth. peltate, 4-6-celled. Fem. fl. scaly bclow. Style 0. Ovule surrounded at the base by a ring which becomes a fleshy cupslaped disk surrounding the secd.-G. F. G. Monochl. 14.

Tr. II. CUPRESSINE E. Malc fl. in catkins. Anth. 4-7, inserted on the edge of the subpeltate scales. Fem. fl. few in a small eatkin. Ovules pointing from the axis.

2. Juniperus. Anth. 4-7, 1-celled, inserted on the lower crlge of the scales. Scales of the fem. catkin imbricated, lower ones barren. Ovules 3 , surrounded by a 3-fid fleshy involucre formed of the 3 uppermost connate scales of the catkin.-G. F. G. Monochl. 12.

Tr. 111. ABIETINEA. Fl. in catkins. Anth. 2, 1-celled, adnate to the undcrside of the scales. Fem. fl. a flat scalelike open ovary in the axil of a membranous scale. Orules in pairs on the inner face of the ovary, pointing towards the axis.

3. Pinus. Male catkins crowded, racemose. Seales of the cone (carpels) thickened and angular at the end. Seeds with a crustaceous coat, winged.-G. F, G. Monochl. 6.

\section{Tribe I. Taxinea.}

\section{Taxus Linn. Yew.}

1. T. baccata (L.) ; 1. 2-ranked crowded linear acute, fl. axillary sessile. - E. B. 746.-A low trce, trunk often attaining a very considerable bulk. Hr. roundish.- $\beta$. fastigiata; l. scattered, fr. oblong, branches fastigiate.-Mountainous woods and limestone cliffs. $\beta$. North of Ireland. T. III. 1V. Yew. $\beta$. Irish Yew.

Tribe II. Cupressinca.

2. Juniperus Limn.

l. J. communis (L.); l. 3 in each whorl spreading linear-sub- 
ulate mucronate keeled longer than the ripe fiuit.-E. B. 1100 . - l'ruticose, ercet. It with a broal flat sliallow cliaunel above, the kecl beneatlı witl a sleuder furrow. Berries blaek, tinged with blue, about half the length of the leaves.-Dry lills, especially on a calcareous soil. Sl.. V. Juniper.

2. J. nana (Willl.); I. 3 in each whorl ineurved linear-lanceolate mueronate kecled equalling the ripe fruit.-E. B. S. 2743. - I prostrate shrub with longer berries and shorter leaves than the last.-Mountaius. Sh. V.

\section{Tribe III. Abietinea.}

\section{Pinvs Limn.}

1. P. sylvestris (L.); l. in pairs, young eones stalked recurverl ovate-eonical, wing thrice as long as the seed.-E. B. 2460.-A lofty tree. Cones referred by the late Prof. Don to P. Mughus (a variety of this species) have been found at eonsiderable depths in the Irish bogs.-IIighlands. T. V. VI. Scotch Fir. 


\section{Class II. MONOCOTYLEDONES.}

Stems destitute of medullary rays, consisting of cellular tissue amongst which the vaseular tissue is mixed in bundles, increasing by the addition of new matter at the centre. Leares mostly altcrnate and shcathing with parallel simple reins comnected by sinaller transicrse ones. Cotyledon one, or if more they are alternate.

\section{Subclass I. DICTYOGENS.}

Lcaves net-reined, deciduous. Root with the wood in a solid concentric circle.

\section{Order LXXVII. TRILLIACEN.}

Perianth inferior, 6- or 8-parted ; in 2 whorls ; outer whorl or calyx herbaceous ; inner or corolla coloured, or in our plant herbaceous. Stam. 6-10. Anth. linear; filament subulate. Ovary superior, 3-5-celled. Ovules indefinite in two rows. Styles as many as the cells, distinct; stigmas inconspicuous. Hr. succulent, not bursting. Seeds with a leathery skin. Embryo minute, in fleshy albumen.

1. PAris. Perianth subherbaceous, 8-parted, 4 inner leares narrower than the others. Stam.8-10. Anth. fixed to the middle of the subulate filament.-G. F. G. Monocot.ii. 58 .

\section{Paris Linn.}

1. P. quarlifolia (L.); 1. usually 4 in a whorl.-E. B. 7.-St. about a foot high, springing from the extrenity of a long rhizoma, usually with 4, occasionally from 3-6 l. at its summit. Fl. solitary, terminal. Sep. lanceolate. Pct. subulate. Styles 4. Berry 4-celled; cells with 4-8 seeds. No root leares. See Loud. Mag. Nat, Hist.v. 429.-Damp woods. P. V. Herb Paris.

\section{Order LXXVIII. TAMEA.}

Perianth superior, petaloid 6-parted. Stam. 6, inserted into 
the base of the segments of the perianth. Anth. bursting inwards. Ovary inferior, 3-cellerl. Ovnles 2 in each cell, erect. Strle 1. Stigmas "3, reflexed. Fr, baceate, not bursting. Embryo minute, quite inclosed in the albumen.

1. Tamus. P'rianth bellshaped, limb 6-parted. Male with 6 stamens. Fem. with the perigone adhering to the ovary and persistent. Stam, very short, abortive.

\section{Tamus Limn. Black Bryony.}

I. T. communis (L.); l. undivided cordate acute.-E. B.91.Dioccions. Root large, thick, fleshy. St. very long, twining. Racemes axillary, on long stalks. H. yellowish-green, regular, small. Berry red.-licdges and thickets. P. V. VI.

\section{Subclass II. ENDOGENS.}

Leares parallel-reined, persistent. Root resembling the stem internally.

\section{Subdivision I. FLORID E.}

Floral envelopes whorled.

\section{Order IXXIX. IIYDROCHARIDEE.}

Sep. 3, herbaceous. Pet. 3, regular, coloured. Stam. cpigynous. Ovary solitary, inferior; placentas parietal, sometimes projceting into the centre of the ovary. Stigmas 3-6. liv. dry, or succulent, not bursting, 1- or spuriously many-celled. Seeds numerous. Albumen 0 . Embryo straight, cylindrical. Radicle at the opposite end from the liliun.

1. IIrprocharis. Diocious, Cal. 3-parted. Pet. 3. Male with 9-12 stamens in 3 rows surrounding 3 abortive styles. Fem. with 3 abortive filaments and 3 fleshy scales surrounding the 6 deeply bifid styles. Caps. inferior, 6-celled, manyseeded.

2. Stratiotes. Diocious. Cal. 3-parted. Pet. 3. Male with 12 or more stamens surrounded by numerous abortive ones. Fen. with 6 deeply bifid styles. Berry inferior, 6celled, many-seeded.

\section{IIvdrocharis Linn. Frog-bit.}

1. H. Morsus-rana (L.).-E. B. 808. St. 44. 16. R. 112.Floating. Creeping. L. stalked, roundish-reniform, entire. Fl. white, delicate, springing from a pellucid membranous sheath. 
Sceds covercd with beautiful prominent spirally twisted cells. - Ponds and ditches. P. VII. VIII.

\section{Stratiotes Lim. Water Soldier.}

1. S. aloides (I.); l. swordshaper-triangular ciliate-spinous. -E. B. 379. R. 111.-Creeping extensivcly in the mud. L. mumerous rigid like those of an aloe. Stalk compressed, 5 or 6 in. high with 2 l. near its summit. Fl. white, delicate. The plant rises to the surface of the water to flower and sinks again afterwards.-Ditches in the east of England; naturalized in Scotland. P. VII.

E.

\section{Order LXXX. ORCHIDEA.}

Sep. 3, usually coloured. Pet. 3, 2 abovc, 1 below (lip) frequently lobed and spurred and unlike the others. Stam. 3, united in a central column, 2 lateral abortive, or (in Cypripedium) the middle one abortive. Pollen powdery or adhering in masses. Ovary l-celled, inferior, with 3 parietal placentas. Style forming part of the column with the stam.; stigma a viscid space in foont of the column. Caps. 3-valved. Seeds very numerous, minute. Testa loose, reticulated.

Tribe I. OPHRYDINEA. Pollen-masses in divisible lobes which are indefinite in number and waxy. Anthers wholly adnate.

* Cells of the anther with a rostellate process between their bases.

1. Orchis. Perianth ringent, hooded. Lip 3-lobed, spurred. Glands of the stalks of the pollen-masses in a common pouch.

2. Grmadenia. Glands of the pollen-masses without a pouch. Otherwise like Orchis.

3. Aceras. Lip without a spur. Otherwise like Orchis.

* Cells of the anther without any process between their bases.

4. Habenaria. Perianth ringent, hooded. Lip 3-lobed or entire, spurred. Glands of the stalks of the pollen-masses exserted, naked.

5. Ophrys. Perianth patent. Lip variously lobed, without a spur. Glands of the staks of the pollen-masses each in a distinet pouch.

6. Iferuinium. Perianth bellshaped, segments all erect. Lip 3-lobed, tumid bencath at the base, without a spur. Glands of the staks of the pollen-masses exserted, naked. 
'I'. 11. LIMODORE $K$. Pollen-masses granular: granules in only a slight state of coliesion. Antliers free.

\section{* Stiyma rostellated.}

7. Goonvera. Periauth ringent. Lip sacente at the base, entire, iuchulerl. Stigma subcordate. Rostellum ereet, bipartite, with a large squarish appendage between its slender segments.

8. Sprrantines. Periantl ringent. Lip channeled, elawed, fringed. Stigma roundish. Rostellum straight, bifid with an elongate linear appendage between its points.

9. Listera. Perianth ringent. Lip deflexed, 2-lobed. Stigma transverse. Rostellum elongated, entire, acute, with a minute glolose appendage at its somewhat reflexed apex. Columu very short.

10. Neotria. Perianth hooded. Lip deflexed, 2-lobed, saeeate at the base. Stigma transverse. Rostellum flat, broad, prominent, entire, without an appendage. Column elongated.

11. Eprpactis. Perianth patent. Lip interrupted, the basal division concave, terminal one larger with 2 projeeting plates at its base above. Stigma nearly square. Rostellum short, terminated by a globose appendage. Antl. terminal, ereet, sessile, 2-eelled : cells without septa. Column short. Germen straight, on a twisted stalk.

\section{** Stigma without a rostellum.}

12. Cephalanthera. Perianth converging (in C. rubra spreading). Lip interrupted, the basal division saceate, jointed to the recurved terminal one. Stigma transverse. Rostellum 0 . Anth. terminal, ereet, moveable, shortly and thiekly stalked, 2-eelled : eells with imperfect septa. Column elongated. Germen sessile, twisted.

Tr. III. MALAXIDE $A$. Pollen eohering in granules or masses whieh are definite in number and at length waxy and confluent. Anther free.

13. Corallorriza. Perianth converging. Lip with 2 prominent longitudinal ridges at the base, 3 -lober, lateral lobes small, middle lobe large slightly emarginate. Spur short or obsolete. Stigma triangular. Rostellum obsolete but with a large globose appendage. Anth. terminal, 2-eelled, opening transversely. Column elongated. Germen slightly stalked, straight.

14. Malaxis. Perianth patent. Lip posterior, ereet, entire, similar to the pet., smaller than the sepals. Spur 0. Stigma rhomboidal. Rostellum short, entire, acute. Anth. terminal, 
continuous with the short column ont of the apex of which it appears as if it were excavated, with 2 imperfect cells. Pollen-masses comnected at their apex. Germen upon a twisted stalk.

15. Sturmia. Perianth patent. Lip anterior, erect or oblique, entire, dilated, much larger than the sepals. Spur 0. Stigma roundish. Rostellım obsolete, but with an appendage consisting of 2 tubercles. Anth. terminal, deciduous, moveable like a lid, with 2 distinct cells. Column elongated. Germen on a twisted stalk.

Tr. IV. CIPRIPEDIE E. Intermediate anther barren petaloil, 2 lateral anthers perfect.

16. Cypripediun. Perianth patent. Lip ventricose, inflaterl. Coluun trifid above, the lateral lobes bearing stamens, middle lobe sterile dilaterl. Two lower (lateral) sepals combined. Germen straight.

\section{Tribe I. Ophrydinea.}

\section{Orchis $\operatorname{Linn}$.}

* Glands of the pollen-masses separate, lip erect in astivation.

$\dagger$ Bracts 1-nerved, tubers undivided.

+ Lip 3-lobed, lobes broad and short.

1. O. Morio (L.) ; lip 3-lobed crenulate : inidlle lobe truncateemarginate, spur ascending subclavate rather shorter than the germen, sep. and pet. ohtuse connivent, anth. obovate rather acute. -E. B. 2059.- St. 6-12 in. ligh. L. lanceolate, lower spreading, upper adpressed. Fl. few, in a lax spike, purple; sep. (rarely patent) and pet. marked witl green veins, converging so as to form a sort of helmet; lip pale in the middle, spotted with purple. Fl. sometimes white.-Meadows and pastures. P. V. VI. Greenwinged Meadow Orchis.

E. I.

2. O. mascula (L.) ; lip 3-lobed crenate : middle lobe emarginate with a central tooth, spur ascending cylindrical rather longer than the germen, sep. acute: 2 outer reflexed upwards, pet. converging, antl. obcordatc apiculate.-E. B. 631.-St. a foot high. L. mostly radical, elliptic-lanceolate, usually spotted with purple. Fl. in a lax spike, purple; centre of the lip whitish at the base, spotted and downy. Sep. and pet. without veins.-Woods and pastures. P. VI. Early purple Orchis.

† Lip 3-lobed, central lobe dilated bifid and often with an intermediate tooth.

3. O. fusca (Jacq.) ; lip pinnately 4-lobed with raised rough 
red points, basal lobes lineat-oblong, terminal lobes broader and shorter with an intermediate tooth; spur about $\frac{1}{2}$ as long as the gernen, sep. (onnivent into an ovate helmet inelnding the pet., bracts minute.-E.B. 16. St.41. I.3.-St. I-2 ft. higl. L. ovateoblong obtuse. I'l. in a lather dense spike; helmet dark purple, varicegated; lip paler.-C Clalky bushy hills in Kent. I'. V. E.

4. O. militaris (L.); lip pinnately 4-lobed with raised rough red points, basal lobes linear, terminal lobes broader and shorter witl an intermediate tooth, spur abont $\frac{1}{2}$ as long as the germen, sep). comnivent into an ovate-lanceolate lielnet including the pet., bracts minnte.-E. B. S. 2675.- Sinaller than the preceding. Helmet ash-coloured or pale purple. Lip purple, white in the midlle, spotted, witl a linear space between the pairs of lobes.('halkỵ liills in Berks., Oxf., Bueks., and near Tring, Herts. I?. V.

E.

5. O. macra (Lindl.); lip pinnately 4-lobed, lobes all long narrow I-nerved linear witl an intermediate setaceous tooth, spur $\frac{1}{2}$ us long as the germen, sep. counivent into an ovate-lauceolate helmet including the pet., bracts minute.-O. teplirosanthos Bich., E. B. 1873. Fl. Lond. n. s. t. 82. " not Vill."-More slender than the preceding. Helmet dark purplish. Lip remarkable for its very slender segments, dark purple with or without small rongh raised points; a linear space between the pairs of lobes which are about cqual in length.- Koch refers this to $O$. militaris not to O. Simia which he considers the same as $O$. tephrosanthos Vill.-Chalky hills in Berks., Oxf., and Kent. P. V.

E.

6. O. ustulata (L.); lip pinnately 4-lobed, lobes linear-oblong, spur $\frac{1}{3}$ the length of the germen, scp. connivent into a roundish helmet including the pet., bracts elongate- $-E . B$. 18. St. 12.St. 4-6 in. high. L. lanceolate, acute, Spike oblong, dense. I'l. small, numerous. Helmet dark purple. Pet, linear-lanceolate, obtuse. Lip white with purple spots-Caleareous hills. P. VI.

E.

† Bracts with 3 or more nerves, tubers undivided.

7. O. laxiflora (Lam.); lip 3-lobed, lateral lobes rounded and cremulated in front longer than the trumeate slightly emarginate intermediate lobe, spur shorter than the germen eylindrieal emarginate, 2 lateral sep. reflexed upwards, pet. connivent, antl. obcordate apiculate.-E. B. S. 2828. - St. $1-2$ fect high, round, angular and rough upwards. L. lanceolate or linear-lanceolate. liracts 3-5-nervel. Spike elongate, lax. Fl, bright purple.Wet meadows and bogs in Jersey and Guernsey. P. V. VI. O.

†† Bracts with 3 or more nerves, tubers palmate.

S. O. maculata (L.); lip 3-lobed flat erenate, spur subulate 
shorter than the germen, 3 sep. patent, pet. eonnivent, st. solid. -E. B. 632.--St. about a foot high. L. usually spotted with purple, lower obtuse or rarely acute, upper linear-lanceolate resembling the bracts. Spike ovate, afterwards elongated; lower bracts longer than the germen, upper equalling it. Fl. pale purple, more or less streaked with purple. Lateral nerres of bracts inconspicuous. Middle sep. with a flat acute point. Lip usually flat, deeply 3-lobed, lateral lobes rounderl, middle lobe longer and narrower. Damp pastures and heaths. P. V. VI. Spotted palmate Oichis.

9. O. latifolia (L.) ; lip obscurely 3-lobed: sides reflexed crenate, spur subulate shorter than the germen, two latcral sep. patent, pet. comnivent, st. hollow.-About a foot ligh. L. seldom spotted. Braets longer than the fl. Midllle sep, usually hoorled at the end.-The following forms arc considered as specics by many authors and deserve attention.-a.mojalis; l.spreading oblong obtuse, upper l. laneeolate acute, lower bracts longer than flowers. O. mejalis R. I. t. 565.! O. latifolia Koch, Fries, Sm.!- $\beta$. incarnata ; l. erect approaching the st. lanceolate attenuated hooded at the end not spotted, all the braets usually longer than the flowers. O. angustifolia W. and G. O. latifolia R. I. t. 564.! E. B. 2308. O. incarnata (L.) Fries, Koch. $\rightarrow \gamma$. Traunsteineri; l. erceto-patent linear-lanceolate narrowed from the base, upper l. linear erect, lower bracts equalling the fl. upper ones shorter. O. Traunsteineri Koch. O. angustifolia R. I. t. 818 ! Fries.-Marshes and damp meadows. P. VI. Marsh Orchis.

** Glands of the pollen-masses united, lip erect in astivation. Avacamptis Rich.

10. O. pyramidalis (L.); lip with 3 equal lobes and 2 tubercles at the base above, lohes oblong truneate, mildlle lobe sometimes emarginate, spur filiform longer than the gernen, lateral sep. ovate-lancedate acute sprearling, bracts 3-nerved, tubers undivided.-E. B. 110.-St. I2-18 in. high. L. linear-lanceolate, acute. - Spike pyramidal, aftcrwards cylindrical. Fl. rosepuple, sometimes white.-Chalky pastures. P. VII. Pyramidal Orchis.

*** Glands of the pollen-masses united, lip spiral in astivation. IIma ntogloss d a spr.

11. O. hircina (Scop.); lip 3-parted dlowny, segments linear, midlle one very long twisted, lateral much shorter wavy, spur very short. $-E: B .34 .-$ A most singular plant, 2-3 feet high. "Cal. grcen, spotted with dull purple internally." Lip purplish white and spotted at the base.-Bushy chalk hills in Kent and Surrey, very rare. I. V. Lizard Orchis. 


\section{Granadinia $R, B r$.}

1. G. conopsea (R. 13r.) ; lip 3-lobed, lobes equal cutire obtuse, lateral sep. sprealing, spmir filiform twice as long as the germen, tubers palnate.-Orchis sm., E. B. 10.-St. a foot high. L. lincar-lanceolate. Spike crlindrical elongatel. l,racts 3-nerved. Fl. rosc-purple, fragrant. l'ollen-cells open in front and bclow, stopper below by oblong glutinous ralves to the broater ends of which the glands of the pollen-masses are attached. These valves are quite distinet from the stigma.-Hilly pastures. P. VI. VII.

2. G. albida (Rich.) ; lip 3-lobed, lobes unequal cntire, midlle lohe longest and broarlest, sep. and lateral pet. connivent, spur much shorter than the germen, tubers clustered.-Habenaria R. B1. Orchis Sin., E. B. 505. Peristylus Lindl.-St. 6-12 in. high. L. oblong, obtuse, upper lanceolate acute. Spikc clongatcl, cylindrical, dense. liracts 3-nerverl. Fl. small, yellowishwhite, fragrant.-Mountain pastures. P. VI. VII.

\section{Aceras $R, B r$.}

1. A. anthropophora (R. Br.); lip 3-parted, scgments linearfiliform, midlle one bifid and often with an intermediate tooth. -E. B. 29.-Tubers ovate. Height 8-12 in. Spike long, lax. - grecnish-yellow. Sep. orate, acute, connivent, margined with purple, including the lincar-lanceolate obtuse petals. - Dry chalky places. P. VI.

\section{Habenaria $R$. Br.}

* Spur very short, usually inflated. Cecloglossum Hartm., Koch, Fries.

1. H. viridis (R. Br.); spur 2-lobed, lip linear flat 3-pointed middle point the shortest.-Orchis Sin., E. B. 94. R. I.f. 8I3. Peristylus Lindl.-Lip with 3 tubercles at its base, 1 central, 2 lateral. Stigma oblong, slightly emarginate above. Glands of the pollen-masses connecterl by an elevated transverse line. Sep. and pet. connivent. Tubers palmate. Fl. green, lip browner. St. 6-8 in. high.-Pastmes, P. VI. VII. Frog Orchis.

\section{** Spur slender. Platianthera Rich., Koch, Fries, Lindl.}

2. H. bifolia (R. Br.); spur twice as long as the germen, lip linear entire, pet. connivent obtuse, anth.oblong truncate : pollenmasses parallel.-E. B. S. 2806. R. I. f. 1143.-About a foot high. Radical 1. usually 2, elliptical. Stem 1. small, lanceolate, resembling the bracts. Spike slenter. Fl. white. Central line between the cells of the antl. a furrow in front and a keel behind. Stigma truncatc, emarginate with pointed lobes. - - Heathy places. P. VI. VII. Lesser Butterfly Orchis. 
3. H. chlorantha (Balb.); spur twiee as long as the germen, lip linear enture, pet. connivent obtuse, anth. truneate twice as broad at its base as at is top: pollen-masses ascending obliquely converging upuards.-Orchis bifolia Sm., E. B.22. R. I. f. 1145. -Usually taller and stouter that the preeeding. Spike usually lax but sometimes dense. Fl. larger. Central line between the cells of the anth. a prominent ridge in front and a groove behind. Stigma very broad slightly pointed in the middle.-See Linn. Trans. xvii. 462. and Am. Nat. Hist. i. 374.-Moist woods and thickets. P. V. VI. Great Butterfly Orchis.

\section{OpHrys Linn.}

1. O. apifera (IIuls.); lip tumid 5-lobed, 2 lower lobes prominent and with a lairy base, 2 internediate reflexed truneate, terminal acute elongated reflexed, anth. with a hooked point, pet. oblong bluntish downy.-E. B.383. R. I. f. 1159.-A bout a foot ligh. Fl. few, large, rather distant. Sep. whitish, tinged with purple. Lip velvety, brown variegated witl yellow.-On ehalky and ealcareous soils. P. VI. VII. Bee Orchis.

2. O. arachnites (Reichard); lip somewhat tumid entire or with 4 slallow inflexed marginal lobes and a terminal inflexed flat rather heartshaped appendage, antli. with a straight or hooked point, pet. deltoid downy.-E. B. S. 2596. O. fuciflora $R$. I. f. $1162-1165$. - Sep. pinkish. Lip velvety, dark purple, variegated with vellow: appendage green, never reflexed.-Chalk downs near Folkstone and Sittingbourne, Kent. P. IV.-VI. Late Spider Orchis.

3. O. aranifera (Huds.); lip iumid obseurely 3-lobed: middle lobe large emarginate without an appendage, anth. aeute, pet. linear glabrous.-E. B. 65. R. I. f. 1154-1156.-Smaller than the two preeding and with fewer flowers. Sep. green. Pet. green, quite glabrous. Lip deep brown, hairy, with paler or yellowish glabrous lines often resembling the Greek letter II, entire at the end or notched with a eentral point.- $\beta$. fucifera (IIook.); lip usually undivided often with a gland in the noteh, pet. seabrous. O. fucifera sm., E. B. S. 2649 .-Chalky plaees. $\beta$. Kent and Sussex. P.IV. V. Spider Orchis.

E.

4. O. muscifera (Huds.); lip oblong trifid with a broad pale spot in the centre : middle lobe elongated bifid, anth. short obtuse, pet. filiform.-E. B. 64. R. I. f. 1146. St. 40. 15.-Slender, about a foot ligh. Sep. green. Lip brownish-purple, eentral spot subquadrate bluish. Pet. very narrow, prirple.-Damp ealeareous thickets and pastures. I'. V. VI. Fly Orchis. E. I.

\section{Herminum $R$. $B r$.}

1. H. Monorchis (R. Br.); lip 3-lobed: eentral lobe longest, 
jet, with a lobe ou cach side. - E. B. 71.-Tubers very unequal mul distant. L. nsually 2. St. about ( $\mathrm{i}$ in. high. Sep. ovate, rrecnish. Spike deuse, slender.-Calcareous soil in the soutl. P. VI. V'II. Musk Orchis.

\section{Tribe II. Limodorea.}

\section{GoOdyera $\boldsymbol{R} . \mathbf{B r}$.}

1. G. repens (R. 13r.); l. radical ovate stalked reticulated, sep. pet. and lip orate-lanceolate.-E. B. 289.-St. $6-8 \mathrm{in}$. high, bearing linear adpressed bracts. Root erecping. Whole upper part of the plant covered witl minute stalked glands. L. reticulited with brown.-lir forests of the north. P.VIII. $S$.

\section{SPIRAnthes Rich.}

1. S. autumnalis (Rich.); tubcrs ovate-oblong thick, radical l. ovate-oblong, stem l. like bracts, spike dense.-E. B.54l. St. 12. Neottia Sm.-St. 4-6 in. high. Spike spiral. Fl. greenishwhite. Column and operculum acute with an obtuse ovate nembranous process between them on each side.-Dry chalky and gravelly places. P. VIII. IX. Fragrant Lady's Tresses.-F. I.

2. S. restivalis (Rich.); tubers elongated cylindrical, radical 1. oblong-lauceolate, stem 1. narrowly lauceolate, spike lax.E. B. S. 2817. R. Icon. f. 337.-Spike spiral. Fl. with a larger lip. Column and operculum acute with the intermediate processes lanceolate acute.-Bog betweeu Lyudhurst and Christchurch in the New Forest. St. Owen's Pond, Jersey. P. VII. VIII. E.

3. S. cernua (Rich.); tuberselongate-cylindrical, radical l. linearlanceolate, stem l. triangular-lanceolate, bracts shorter than the H., spike dense 3-rauked, sep. and pet. equal obtuse adliering together, lip blunt spathulate--Neottia gemmipara Sm., E. B. S. 386 (imperfect). Linn. Trans. xix. t. 32.-A true Spiranthes. See full description from fresh specimens in Linn. Trans. Spike about $1 \frac{1}{2}$ in. long. Fl. fragrant.-Castleton Bearhaven, Co. Cork. P. VIII. IX.

\section{Listera $R . B r$.}

1. L. ovata (R. Br.) ; 1. 2 opposite ovate, lip bifid, columu with a crest which includes the anther.-E.B. 154S. St. 29. I4. -St. about a foot high. Spike elongated, very lax. Fl. small, greenisl. L. large.-Woods and pastures. P. V. VI. Twayblade.

2. L. cordata (R. 13r.); 1. 2 opposite cordate, lip 4-lober, column without a crest.-E. B. 358.- Height $3-5$ in. St. 
slender. Fl. very small, in a lax spike, greenish. Lip with 2 basal and 2 terminal linear lobes. Turfy mountainous moors in the north. P. VI.-VIII.

\section{Neotta Limn.}

I. N. Nidus-avis (Rich.).-E. B. 48. Listera Hook., Sin.Whole plant pale reddish-brown. Root formed of numcrous short thick fleshy fibres from the extremities of which the young plants are produeed. See Leight. F7. Shrop. 43-1. St. a foot high, with sheathing brown seales. L. none. Spikes dense, cylindrical, many-flowered. Lip linear-oblong witl 2 sprearling lobes.This is the original Neottia of Linnæus. Act. Ups. 1740. p. 33. $\rightarrow$ Shady woods. P.? VI. Bird's-nest.

\section{Epipactis Rich.}

1. E. latifolia (All.); l. broally ovate longer than the internokes, upper l. ovatc-oblong, lower bracts longer than the $\mathrm{H}$., terminal division of the lip entire roundish-cordate obtuse with a sinall recurved point shorter than the broadly ovate sep. and pet. "its keel not crenatc above."-E. B. 269.-L. ovate, very broad, the very uppermost sometimes lanceolate-attenuated; lowermost leafless shcaths close. Lower bracts leaflike, lanceolate, attemuated. Il. green with the lip purple, sometimes all purple. Peduncle shorter than the downy germen. Lobe of the lip broader than long, erenate.-Mountainous woots. P. VII. VIII.

2. E. media (Fries); l. ovate-oblong the upper ones lanceolate acute, lower bracts longer than the $\mathrm{fl}$. and fr., terminal division of the lip entire triangular-cordate acute as long as the lanceolate sep. and pet. its keel "erenate above."-R. i. f. 1141, 1142,Narrower anc more elongate in all its parts than $E$. latifolia. Only the very lowest l. ovate, intermediate lanccolate, upper l. lanceolate-attenuated and merging gradually into the linear-lanceolate bracts; sheaths funnelshaped, Fl. "green tinged with purple." Peduncle shorter than the downy germen. Lobe of the lip longer than broad erenate.- $\beta$. purpurata ; l. ovate-lanceolate the upper ones narrower, terminal division of the lip shorter than the ovate-lanceolate sep. and pet. its keel plieate-crenate above. E. purpurata Sm., E. B. S. 2775. Fl. "yellow-green tinged with pink." St. and 1 . much tingerl with purple. Peduncle shorter than the downygermen. Lobe of the lip longer than broad, cntire, exactly like that of $E$. media but with a more attenuated point.-Woods. Salop. Matlock. Abberly, Wors. ß. Woburn. Reigate. Crawley, suss. P. VIII. E.

3. E. ovalis (Bab.); l. ovate-oblong acute the upper ones lanceolate, 1 or 2 lowest bracts longer than the fl. but shorter than the fr., terminal division of the lip transversely oval acute as long 
as the ovate ante sep. and pet. its keel plieate-erenate above.E. B. S. 2884 . Helleborine \&e. No. 2. Ray. 383.-L. smull; slentlss funnelshaped, rather close. liracts all mueh smaller than even the upermost laaf. Fl. varying from a dark yellow to blackish-red, perhucle shorter than the downy germen. Lobe of the lower lip tramsversely oval, crenate, with a small acute point and an elevated folded and tubereularly crenate triangular keel nbove. St. 6-18 in. high.-Giggleswick and other plaees on the sides of mountains near Settle, Yorkshire. P. VII. F.

4. E. palustris (Sw.); l. lancenlate, bracts shorter than the somewhat arooping fl., terminal division of the hip roundish obtuse crenate as long as the perianth.-E. B. 270.-St. 12-18 in. high. Cal. purplish-green, pet. and lip white tinged with purple.-Moist places, not rare. P. VII. VIIII.

\section{Cephalanthera Rich.}

1. C. grandiflora (Bab.); l. ovate or ovate-laneeolate pointerl, bracts longer than the glabrous germen, lip obtuse inchuded.E. B. 271. "S. grandiflora Linn." Sn. C. paltens Koch.-Fl. white, lip marked with several clevated longitudinal lines.-In dense woods, usually on a caleareous soil. P. VI. E. I.

2. C. ensifolia (Rieh.); 1. lanceolate pointed, bracts much shorter than the glabrous germen, lip obtuse ineluded.-E. B. 494. -Fl. white, lip with several elevated white lines and a yellow spot in front.-Mountainous woods, rare. P. V. VI.

3. C. rubra (Rich.); l. lanceolate acute, bracts longer than the downy germen, lip aeute as long as the pet.-E. B. 437. Epipactis Sm.-Fl. purple, lip white with a purple margin, marked with numerous wavy longitudinal lines.-Mountainous wools, very rare. "Bank sloping to the south on IIampton Commou, Gloneestershire." $\mathrm{Sm}$. P. VI. VII.

1..

\section{Tribe III. Malaxidea.}

\section{Corallorhiza IIall.}

1. C. innata (R. Br.); spur obsolete or wanting. - E. B. 1547 . - Root of thick fleshy much branehed fibres. Spike of few yellowish flowers. Sep. and pet. lanceolate, acute. Lip oblong, white, with a few purple spots. - Boggy woods, rare. P. VII._-S.

\section{Malaxis $S w$.}

l. M.paludosa (Sw.); st. with $3-5$ oval eoneave leaves, lip coneave aeute. - E. B. $72 .-$ St. $1-4$ in. high. Sep. orate, P 2 
spreading, 2 of them turning upwards. Lip above, ereet, its base surrouting the eolumn. L. fringed at the end with bulbous gemmx. Forming a small bulbous hybernaeulım.-This rurious plant and the following rather grow upon the moss as epiphytes than amongst it.-Spongy bogs. P. VIII. IX.

\section{Sturuia Reich.}

1. S. Loeselii (R.); 1. oblong-lanceolate, st. triangular, lip obovate longer than the petals.-Malaxis Sm., E. B. 47. Liparis Rieh., Hook., Lindl.-St. 6-10 in. ligh. Fl. 6-12, in a lax spike, yellowish. Sep. laneeolate. Pet. linear. IIybernaculum large, ovate, inelosed in the whitish sheaths of the deeaverl leaves. An epiphyte?-Liparis is not admissible as a generic uame in botany, having been previously used for a geuus of insects, and at a still earlier date for one of fish. See $R$. Icon. iv. 1). 39. Steph. Syst. Cat. Ins. ii. 50. Cuv. Règ. Anim. (ed. 1829) ii. 346. Sturmia has been employed several times in botany but always superseded. I follow Koch iu adopting it here.Spongy bogs in Norf., Suff., and Camb., very rare. P. VI.-E.

\section{Tribe IV. Cypripediea.}

\section{Cypripedium Lim.}

3. C. Calceolus (L.); st. leafy, middle lobe of the eolumu nearly ovate obtuse deflexed, lip slightly eompressed shorter than the ealyx--E. B. 1.-St. 12-18 in. higle, downy, bearing 3 or 4 large ovate pointed leaves. Fl. usially solitary, sometimes 2, large; sep. 1-1 $\frac{1}{2}$ in. long, dark brown; pet. dark brown, rather narrower than the sep.; lip $1 \mathrm{in}$. long, inflated, yellow, reticulated with darker veins,-Dense woods in the north, very rare. P. V. VI. Lady's Slipper.

E.

\section{Order LXXXI. IRIDEA.}

Perianth tubular, 6-parted, petaloid, iu 2 often unequal rows. Stam. 3, epigynous, opposite the outer segments of the perianth. Anth. bursting outwards. Ovary inferior, 3-eelled. Style 1. Stigmas 3, dilated, ofteu petaloid. Caps. 3-celled, 3-valverl, valves bearing the dissepiments in the middle. Seeds numerous. Embryo eyhindrical, inelosed in horny or fleshy albumen. Radiele pointing towards the hilum.

1. Sisyrixchium. Periantl 6-eleft, superior: segurents nearly equal, patent. Stiguas 3 , involute, filform. Filaments eonnate below. 
2. lnIs. Periantl 6-cleft, superior: alternate segments reHexed. Stigma is-proted, petaloid, eovering the stanens.

3. Trichonema. P'erianth regulir', 6-cleft: segments sprealing. Stigmas 3 , bifid : lobes slender.

4. Crocus. Perimth regular, funnelshaped with a long tube: linb bellshaped. Stigina 3-fid or 3-parted : lobes widening upwards.

\section{Sisyrinchudi Limn.}

1. S. anceps (Lam.); scape 2-edged nearly simple nearly leafless, spath about 4 -flowered "longer than the flowers," segments of perianth emmginate mucronate.-Redoute Lil. v. 282.-St. ubout I foot high. L. grasslike. Spath with lanceolate valves, shorter than the $\mathrm{H}$. in my Irish specimen. Periantl blue; segments narrowed below. - In a wood near Woodford, Galwav. Mr. Jas. Lynam. P. VII.

\section{IRIS $\operatorname{Linn}$.}

1. I. Pseud-acorus (L.) ; l. swordshaped, st. romul, perianth beardless, its inncr segments narrower and shorter than the stigmas.-E. B.578. - Fl. yellow.- " $\beta$. citrina; fl. smaller, segments of the perianth narrower, the inner ones more acutc, st. taller. Fl. paler." Hook.-Wet places. $\beta$. Ayrshire. P. V1. VII. Yellow Flaq.

2. I. futidissima (L.); l. swordshaped, st. eompressed, periantl beardless, its inner segments about as long as the stigmas. -E. B. 596.-IIcrb green, not glaucous, yielding an unpleasant smell when bruised. Fl. lead-coloured or bluish.-Woods and thickets in the west and soutli-west. P. VI. VII.

[*I. tuberosa (L.); l. tetragonal, segments of the periantl acutc, l'oots tuberous. Near Penzanee and Cork.-E. B. S. 2818.]

\section{Trichonema Ker.}

l. T. Columnce (R.); scape l-flowered usually solitary slightly nodding, l. filiform compressed furrowed recurved, spath longer than the tube of the cor., style shorter than the stam., stigmas bifid.-E. B. 254\%. T. Bulbocodium Sm.-A small bulbous plant not more than 4 in. high. Fl. pale purple or violet, yellow in the lower part within.-Sandy places. Dawlish Warren, Devon. Jersey and Guernsey. P. III. IV.

E.

\section{Crocus Linn.}

* Scapes enveloped in a tubular sheath.

* 1. C. vernus (Willd.); l. and fl. at the same time, spath simple, throat of the eor. fringed with hairs, stigma shortly 3-tid: 
lobes erect wedgeshaped jagged at the end, bulb clothed with slender anastomosing fibres.-E. B. 344.-Fl. riolet-purple.Near Nottingham; and Mcndlam, Suff.-A native of the mountains of ccutral Europe, never descending into the plains of France or Germany. Gay.-P. III.

[2. C. sativus (L.); l. succeeding the fl., spath double, throat bearded, stigma in 3 deep linear divisions drooping, bulb clothed witl slender anastomosing fibres.-E. B. 343.-Fl. purple. L. usully appearing just before the fl. fades.-Formerly cultivated near Saffiron Walden, not even naturalized.-Found wilkl only near Ascoli in the Abrnzzi, Italy. Gay.-P. IX. Saffron.] E.

3. C. nudiflorus (Sm.); l. succeeding the fl., spath simple, scapes with a tubular sheath (?), stigma in 3 deeply laciniated divisions erect, bulb with a membranous coat.-E. B. 491.-L. appearing in December. Fl. purple. Stigmas only a little higher than the anthers.- $\beta$. speciosus; stigmas rising considerably above the anthers. C. speciosus Ilook., E. B. S. 2752. not Bieb.-Meadows. Between Nottingham Castlc and the Trent. $\beta$. Warwick; Warrington; IIalifax.-A native of the west of Europe. Gay.-P. IX.

$$
\text { ** Scapes naked. }
$$

[4. C. biflorus (Mill.); l. and fl. at the same time, spath double, stigma longer than the stam. ercet deeply trifid : divisions truncate and slightly notched at the cad, bulb with a membranous coat.-E. B. S.2645. C. prrecox Haw. C. minimus IIook.-Fl. pale lilac with yellow and purple stripes.-In the park (site of old garlen) Barton, Suff. Not indigenous. P. III.] E.

[5. C. aureus (Sib.); l. and fl. together, spath simple, stigma shorter than the stam. shortly 3-fid: segments truncate or slightly notched at the end, bulb coated with compact fibres.-E. B. S. 2646.-Fl, yellow.-With the preceding. P. III.] E.

\section{Order LXXXII. AMARYLLIDEAs.}

Stam. 6. Anth. bursting inwards. Otherwise like IRIDE $E$.

1. Narcissus. Perianth 6-parted, spreading, with equal segments, and a bellshaped crown within. Stam. alternately shorter, within the crown.

2. Levcojum. Perianth 6-parted, bellshaped, the segments all equal and thickened at their points. Stam. equal.

3. Galan'rues. Periantl 6-parted, 3 external segments spreading, 3 interior shorter erect emarginate. Stam. equal, subulate. 


\section{Narcissus Linn.}

*1. N. biflorus (Curt.); 1. linear obtuse "acutely" (Sm.) "oltusely" (Koch) keeled, seape compressed 2-edged striated "Howered, crown very short eoncave crenate at the pale margin. - E. B. $276 .-$ Pet. of a pale sulplur-colour, border of the short crown white.-Sandy fields in the south. P. IV. V. L. l.

*2. N. poeticus (L.); 1. linear obtusc obtusely keeled, scapc compressed 2-elged mostly l-flowered, crown very short concave crenate at the red margin.-E. B. 275.-Fl. white with a vellow erown margined with red. Heathy opeu fields on a sandy soil. Norf., Kent. P. V.

3. N. Psendo-narcissus (L.); l. linear obtuse not kecled, scape 2 -edged 1-flowered, crown bellshaped crisped at the margin and crenate as lour as the perianth.-E. B. 17.-Fl. large, ycllow, pedicel within the seape short.-Woods and thickets. P. III. IV. Daffodil.

\section{Levcouva Limn. Snowflake.}

†1. L. astivum (L.); spath many-flowercd, style thickened upwards.-E. B. 621 - - Bulbous. Height $2-2 \frac{1}{2}$ feet. Fl. white, with the tips greenish, droopiug. L. broadly linear, keeled. Scape 2-cilecel. Spath usually as long as the flowers.-Wet mearlows. P. V. Summer Snowflake.

\section{Galanthus Limu. Snowdrop.}

1. G. nivalis (L.).-F. B. 19.-Fl. white with the inner segments greenish, droopiug. Scape l-flowered. L. 2, keeled, broadly linear, glaueous. Bulbous.-Thickets and damp fields. P. 11. III.

E. S.

\section{Order LXXXIII. ASPARAGEE.}

Perianth inferior, petaloid, 6-parted or 4-8-parted. Stan. 6 or $4-8$, inserted into the receptaele or on the perianth. Anth. bursting inwards. Ovary superior, 3-celled. Ovules 1 or many in each eell. Styles $1-3$. Fr. suceulent, not burstiug. - In this and the two following Orders I follow Koch, who appears to have paid great attention to them. He states that the testa varies amongst the species of the same genus.

1. Asparagus. Perianth 6-parted, bellshaped, tubular below. Stam. 6. Ovary 3-celled, cells with 2 ovules. Style 1. Stigmas 3, reflexed.-Fl. by abortion diceious.-G. F. G. Monocot. ii. 57.

2. Convallaria. Perianth bellshaped or tubular, 6-parted 
or 6-toothed. Ovary 3-celled, cells with 2 ovules. Stigma obtuse, trigonous. Berry with l-scerled cells.-G. F. G. Monocot. ii. 60. 61 .

3. Maranthemum. Perianth 4-parted, segments horizontally patent or reflexed. Stam. 4. Style I. Stigma olstuse. Berry '2-celled, cells I-seeded.-G. I'. G. Monoeot. ii. 62.

4. Ruscus. Periantl 6-parted to the base. Male with the filaments commected into a tube on the top of which the 3 anth. are placerl. Fem. the same but the anthers barren. Style 1. Stigma capitate. Berry 3-celled, cells 2-sceded. -G. F. G. Monocot. ii. 64.

\section{Asparagus Linn.}

1. A. afficinalis (L.); st. herbaceous mostly erect without spines brancherl, 1. fasciculated terete flexible setaceous, "limb of the perianth twice as long as the tube."- E. B. 339.--Root (recping. Stems numerous, scaly, erect, or rarely procumbent, rarely more than a foot high (in cultivation 3 fect). - Wild state of the garden Asparagus. Sea-coast, rare. Kynance Cove, Cornwall. Callar Point, Pemb. Gosford Links, Scotl. P. ViII.

\section{Convallaria linn.}

* Flowers cylindrical-tubular, white with green tips.

1. C. verticillata (L.); l. linear-lanceolate whorled, st. erect angnlar.-E. B. 128. - St. 2 feet high. L. 3-5 in a whorl. Berries rerl.-Woods. Den of Rechip near Dunkeld, and Craighall, Perthshire. Sinalesmouth, N. Tyne, Northumberland. Mr. Storey. P. VI.

E. S.

2. C. Polygonatum (L.); l. ovatc-oblong half clasping glabrous aiternate, st. angular, peduncles I-2-flowered, filaments

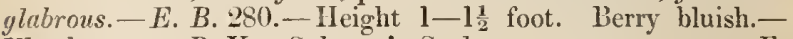
Woods, rare. P. V. Solomon's Seal.

3. C. multiflora (L.) ; l. ovate-oblong half clasping glabrous alternate, st, round, peduncles I- or many-flowered, filaments downy.-E. B. 279.-Height 2 feet. Berry bluish.-Woods. P. V. Solomon's Seal.

E. S.

\section{** Flowers bellshaped, wholly white.}

4. C. majalis (L.); scape semicylindrical naked, fl. racemose nodding, 1. 2 ovate-lancer hate radical. $-E$. B. 1035. St. 14.10. - About a foot ligh. Fl. pure white globose-bellshaperl, fragrant.-Woorls and thickets. P. V. Lily of the Valley. E.S. 


\section{Mannthemum /V̈̈ggers.}

*? 1. M. bifolium (DC.); st. witls 2 alteruate stalked triangularcordate leaves.-Ger. Herb. p. 409.-Convallaria L., St. 13.6. - st. 6-8 in. high. Root filiform. I. very decply cordate. Racene terminal, resembling a spike. lil. sinall, scgments reflexed. "Merry vellow witl brown spots."- Woods. Howick, Northumb. (now eradieated). Mr. R. Embleton. Kenwood, Mildlesex. Mr. E. Edwards. "It groweth in Lancashire in Diugley Wood, 6 miles from Preston Anldirnesse, and in Harwood near Blackeburne likewise." Gerard. P. V.

\section{Ruscus Limn.}

1. R. aculeatus (L.); l. ovate attenuated very acute rigil bearing the fl. npon the milldle of their upjer surface, fl. solitary rarely 2 together subtended by a flat subulate scarious 1 -uerved bract. - E. B. 560. St. 41.16.-Folinge cvergrecu. Fl. very minnte. The apparent $\mathrm{l}$. are flatteued shoots.-Bushy places and woods. Sl. III. IV. Butcher's Broom.

\section{Order LXXXIV. LILIACEA.}

Perianth inferior, petaloid, 6-parted. Stam. 6, inserted into the receptacle or on the perianth. Anth. bursting inwards. Ovary superior, 3-celled. Ovules many iu cach cell. Style 1. stigmas 3 or 1 . Fr. dry, capsular, bursting with 3 valres bearing the dissepiment on their middle.-Roots bulbous.

Tribe I. TULIPEAE. Lcaves of the perianth distinct. Cells of the caps. many-seeded. Secds flat (in Lloydia angular), placed closely one above another; testa pale or fuscous, not crustaceous.

1. Tulipa. Perianth of 6 leaves withont nectaries. Style 0 . Stigna 3-lobed. Seeds flat.-G. F. G. Mouocot. ii. 36 .

2. Fritillaria. Perianth of 6 leaves with a nectariferous depression at the base of each. Style 3-fid at the apex. Sects flat.-G. F. G. Monocot. ii. 39.

[3. Lilium. Perianth of 6 lcaves, spreading or reflexed, with a longitudinal nectariferous furrow at the base of cach. Style undivided. Stigma capitate. Seeds flat.]-G. F. G. Monocot. ii. 40.

4. Lloydia. Perianth of 6 patent leaves, witl a transverse nectariferous fold near the base of each. Stam. inserted at the base of the perianth. Anth. erect, attached by their bases. Style filiform. Stigma trigonous. Seeds angular above, flat beneath.-G. F. G. Monocot. ii. 38. 
Tr. II. ASPHODELEA. Leaves of the perianth distinct. ('ells of the caps. few-scerled. Secds rarious in form, usually witl a black crustaceons testa.

5. Ornitiogalum. Perianth of 6 patent leaves. Stam. inserted upon the receptacle and allhering only slightly to the perianth. Anth. incumbeut, attached by their backs.-Fl. white or yellow, never blue.-G. F. G. Monocot. ii, 48. 49.

6. GAGEA. Perianth of 6 patent leaves. Stam. alhering to the base of the pcrianth. Anth. erect, attached by their bases. - Fl. corymbose or umbellate,-G. F. G. Monocot. ii. 37 .

7. Scilla. Perianth of 6 patent leaves. Stam. inserted on the base of the perianth. Anth. incumbent.-Fl. racemed, never white or yellow.-G. F. G. Monocot. ii. 46.

8. Allium. Perianth of 6 leares, rather spreading. Stam. inserted at the base of the perianth. Anth. incumbent.Fl. umbellate. Spatha of I or 2 leaves.-G. F. G. Monoeot. ii. $50.5 \mathrm{I}$.

Tr. III. HEMEROCALLIDEAE. Leares of the perianth combined below. Cells of the caps. few-seeded. Seeds various in form, testa (in our plants) black.

9. Agraphis. Perianth tubular-bellshaped of 6 comirent leares with reflexed points, combined below. Stam. inserted helow the middle of the perianth, filaments deeurrent.G. F. G. Monocot. ii. 45 .

10. Muscari. Perianth globose or subcylindrical, narrowed at the mouth, 6-toothed. Stam. inserted at about the middle of the tube, filaments not deeurrent.-G.F.G.Monocot. ii. 41 .

\section{Tribe I. Tulipere.}

\section{Tulipa Linn. Tulip.}

†1. T. sylvestris (L.); st. I-flowered glabrous, f. at first drooping, inncr segments of perianth and base of the stamens bearderl. - E. B. 63. St. 29. 11.-Fl. yellow, rarely produced in a wild state.-Chalk-pits in the eastern counties. Several places in Scotland. P. IV. Wild Tulip.

E. S.

\section{Fritillaria Linn. Fritillary.}

I. F. Meleagris (L.); st. single-flowercd leafy, l. all alternate linear-lanceolate.-E. B. 622. St. 18.4.-About a foot high. Fl. flesh-coloured with numerous dark spots, sometimes white. -Meadors and pastures in the east and south. P. V. E. 


\section{LILIUM Linn.}

[*1. I. Martagon (L.); 1. whorled elliptic-lanccolate, st. pubescent-seabrous, th. nodeling, perianth reflexed.-E. B. S. 2799 . - Ileight l-1 1 foot. Il. violet-flesh-coloured with dark purple spots.-Copse's. P'. V1. VI1. Turk's-cap Lily.

E.

\section{Luordia Salisb.}

I. L. serotina (K.).-E. B.793. St.28.2. Anthericum Sm.11 (eight 5 or 6 in. L. senicylindrical, filiform. St. and l. springing separately from the root. St. bearing several short leaves dilated and sheatling at their base. Fl. white with reddish lines intemally.-Iigher parts of the Welsh mountains, very rare. P. VI.

\section{Tribe II. Asphodelea.}

\section{Ornithogalum Linn.}

*1. O. umbellatum (L.); ff. corymhose, peduneles longer than the linear-laneeolate bracts, filaments lanceolate simple, 1. linear glabrous. $-E$. B. 130.-L. linear and longer than the stem, or filiform aud slorter than it. Ifeight 8-12 in. Fl. white with a broad green longitudinal band externally.-Meadows and pastures. P. V. Common Star of Bethlehem.

E. :.

2. O. pyrenaicum (L.); fl. iu an elongated raceme, perluncles at first spreading afterwards erect, bracts lanccolate-acuminate, filanents dilated bclow with an elongated point, 1. fugacious linear groovel. - E. B. 499.--St. leafless, $2-3$ feet high. Raceme very long. Fl. greenish-white, segments of the periantl variable in breadth. L. withering before the stalk appear's, rarely contemporaneous. This is more correetly $O$. narbonense (L.), but the plants do not appear distinguishable.-Woods. Extremely common near Bath. Sussex. Bedfordshire. P. VI. Spiked Star of Bethlehem. E.

*3. O. nutans (L.); fl. few in a lax nodding raceme, peduncles shorter than the bracts, filaments fiat membranous trifid: the lateral poiuts acute midclle one very short bearing the anther, 1 . linear-lanceolate.-E. B. 1997. Albucea R.-Height 9-12 in. Fl. large, whitc, greenish externally. - Fields and orehards, rave. P. IV. V.

\section{Gagea Salisb.}

1. G. lutea (Ker.); radieal 1. usually solitary linear-laneeolate flat, bracts 2 opposite, peduncles umbellatc simple glabrous, segments of the perianth oblong obtusc, bulb ovate solitary.E. B. 21. Ornithogalum L.-St. about 6 in. high, shorter than 
the leaves. Bracts lanceolate, 1 of them often longer than the yellow flowers.-Woods and thickets, rarc. P. III. IV. E. S.

\section{Scilla Limn.}

I. S. autumnalis (L.); l. linear numcrous, raceme slightly corymbose, peduncles asecnling, bracts $0 .-E . B .78$.-Height 4-6 in. Fl. purplish-blue with a green line down the back, in perfection before the l. appear.-Diy pastures in the south anl west. P. VIII. Autumnal Squill.

2. S. verna (Iuds.); 1. linear channeled hooded at the end munerous, raceme few-flowered corymbose, bracts lanceolate as long or longer than the peduucles.-E. B. 23.-Height $4-5$ in. l'l. bluc. L. as long or longer than the stalk. -Western and northern coasts. P. IV. V. Vernal Squill.

[3. S. bifolia (L.) ; 1. linear-lanceolate usually only 2 , raceme lax slightly corymbose, ped. erect, bracts 0.-E. B. 24. - Said to grow in the west of England. P. IV.]

E.

\section{Allium Linn.}

* Root bulbous. Stam. alternately broader and 3-pointed, the intermediate point bearing an anther, the others filiform and barren. Porrum Tourn.

*1. A. Ampeloprasum (L.); st. leafy below, l. flat keeled, spath elongated, umbel globose compact, stann. exserted, 3 inner oncs 3-pointerl: anther-bearing point as long as the common filament, bulb compound of few (2-4) divisions.-E. B. 1656. -Bulb with large off'sets within its coats. St. 4-6 feet high. L. losig, linear. Spath calyptriform, parting at the base and falling off in one piece before the $\mathrm{fl}$. open; horn $\mathrm{l}-2 \mathrm{in}$. long. Fl. pale purple, the keel of the outer subemarginate segments greeuish and roughish. Gcrmen rather globose, nectarial projections at about the middle, lower spaces slightly excavated. Hear-bulbs rare, when present small, the size of peas.-Cliff's on the Steep rolmes Island in the Severn (remains of former cultivation, Borr.). Indigenous on cliffs in Guernsey. P. VIII. E.

2. A. Brabingtonii (Borr.); st. leafy below, l. flat acutely keeled, spath long pointed, umbel loose irregular with hemispherical bulbs, stam. exserted, 3 inner ones 3-pointed : antherbearing point rather shorter than the common filament with an incurced apex when young, bulb compound of few (2) divisions. -E. B. S. 2906. A. Halleri Bab. not G. Don.-St. 4-6 feet high. L. long, limear, broak. Ileads largc, with numcrous bulbs about as large as a hazel-nut. Spath usually deciduous in two pieces or persistent; horn $1-2$ in. long. Fl. pale reddish purple, rather few, more conical than in the preceding, only 
slightly opening; the outer segments with a green keel, ovateol)fong, with (allous points, the ederes and back rough with minute ulheid points: inner segments slightly emarginate and without

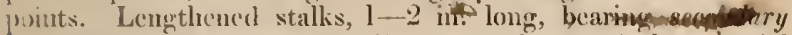
heads are usually present. Germen rather conical, nectarial projections below the middle, lower paces rather decply exca-

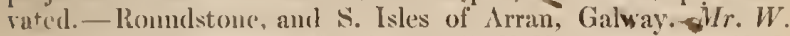
Inac Calla. Conwall. Mr. Eagle. .P. VIII.

E. I.

3. A. Scorodoprasum (1..!); st. leafy below, l. flat, shenths 2-edged, spath sliort and broal with a short point, umbel globose with numerous splerical bulbs, stam. included or equalling the periantl, 3 inner ones 3-pointed: anther-bearing point shorter than the common filanent and the barren points, bulb with numeroms pupple offsets.-E. B. S. 2905. A. arenarium L.!, Sill.-St. 2-3 feet high. L. with scabrous margins. Heads small. Spath with a very short point. Fl. few, purple; the segments all with a minute apieulus, the outer with the eiges aril keel rongh. IIead-bulbs very small, deep purple.-A. Scorodoprasum (Sm. Herb.), so named by Davall, is A. Babingtonii. -Sandy woods and fields in the north. P. VI. VII. E. S.?

4. A. vineale (L.); st. leafy below, l. terete hollow slightly \& elianneled above, spath l-valved short with a slender elongated point, mubel globose with numerous bulbs, stanı. exserted, 3 inner ones 3-pointed : anther-bearing point equalling the common filament and half as long as the barren points.-E. B. 1974. R. Icon. t. 404 . 1. arenarium Fries. - St. 2 feet high. L. faded at the time of flowering. IIeads with few pale rose-coloured 11. with green keels and long stalks. Head-bulbs small oval acute greenish. - $\beta$. compactum; umbel without $\mathrm{t}$., head-bulbs terminating in a leaflike point. A. compactum "Thuil."-Waste ground and dry fields. P. VII. Crow Garlick.

5. A. sphcerocephalum (L.); st. leafy below, l. suheylindrieal channeled above smooth hollow, spath 2-valved short, umbel globose uithout bulbs, stam. twiee as long as the periauth, 3 inner ones 3-pointed : anther-bearing point as long as the common filament longer thun the barren points, bulb aceompanied by stalked offsets.-E. B. S. 2813.-St. 1-2 fect high. L. usually faded hefore the time of flowering. Ileads with numerous rose-eoloured or purple fl. with the keels darker and rough. A. descendens (L.) scarcely differs._- Sands in Jersey. P. VII.

0.

** Root bulbous. Stam. all simple, not 3-pointed, connected at the base. Spath 2-valved, 1 valve with a long point.

6. A. oleraceum (L.); st. leafy below, 1. ehanneled above 
rilsbed beneath, spath with 1 of the points very long, umbel witl lulbs, stan. simple equalling or shorter than the perianth.E. B. 488.- Height $1-2$ feet. L. (of the Bristol plant) thick. fleshy, solid, nearly flat but slightly and broadly channeled above, with 4 ribs beneath. Segments of perianth obtuse.- $\beta$. complanatum (Fries); stan. simple shorter than the perianth, l. of equal thickness thronghout, the margins curved upwards so as to make then appear to be chamneled, with numerons ribs on both sides. Perhaps a distinct species. A. carinatum Sm., E. B. 1658.Borders of fields. $\beta$. Mountains in the north. P.VII.VIII. E. S.

[A. flexum (W. and K.) and A. carinatum (L.) are distinguished from the preceding by their protruded stamens.]

\section{*** Root bulbous. Stam. all simple and distinct. Spath 2-valved, short.}

7. A. Schanoprasum (L.); st. naked or with one leaf, l. terete or slightly flattened above hollow subulate, spath orate pointed about ats long as the flowers, umbel nany-flowered globose without bulbs, stam. simple about half the length of the lanceolate segments of the perianth.-E. B. 2441.-St. about 6 in. high. L. straight with even strix. Pet. lanceolate. Barren bulbs with 2 leaves. Style "much shorter than the young germen." Fl. pink. Bulbs forning dense tufts. $-\beta$. arcuatum; 1 . curved and bent downwards with crenulated strix, pet. lanceolate-attenuate, barren bulbs single-leaved, style longer than the young germen. A. sibiricum Willd.? Height 6 in. to 2 feet. Heads large. This plant has retained its characters for several years in Mr. Borrer's garden and is probably (as considered by him) a distinet species. - Meadows and pastures in mountainous situations. $\beta$. Rocks and cliff's near the sea in Cornwall. Tintagel. Rev. R. T. Bree. Between Kynance Cove and Mullion. P. VI. VII. Chives. E. S.

\section{**** Root bulbous. Stam. all simple. Leaves flat.}

8. A. ursimum (L.); st. naked triangular, l. all radical stalked ovate-lanceolate, spath '2-valved ovate, umbel level-topped lax without bulbs, stam. simple.-E. B. 122.-Bulb slender, oblong. L. few, broad, smooth, bright green. Stalk 1 , as tall or taller than the leaves. Fl, white. Smelling strongly of garlick when bruised.-Damp woods and hedges. P. V. VI. Ramsons.

[A. ambigurm (Sm.) which has broadly linear attenuated leaves, umbels few-flowered and with a few bulbs, spath 3-4-valved, and stam. about half the length of the perianth, has been found near Rochester and on Eye Castle Iill, Suff., but has no just claims to be eonsidered as a native. E. B.S. 2803.] 


\section{Tribe III. Hemerocallidec.}

\section{Arikaphis Link.}

1. A. nutans (Link); 1. lincar, raceme nodding, fl. bellshaped cvlintrieal, apex of the sep. recolute, brats $2 .-E . B .377 . K . I$. f. 1125. Seilla Sm. II yeinthus Hook.-Scape about a foot high. Fl. blue, rarely white. Stam. united to the perianth half-way 11). L. shorter than the seape. Not agreeing with either of the genera to which it is usually referred, therefore better separated from them.- I Foods and thickets. P. V. English Blue-bell.

\section{Muscari Tourn. Grape Hyacinth.}

†1. M. racemosum (Mill.); fl. orate nodding erowded upper ones nearly sessile abortive, l. linear flaccid reeurved.-Hyacinthus Sm., E. B. 1931.-Seape about a foot high. Fl. dark blue. -Sandy fields. Very plentiful near Pakenham, Suffolk. P. V.

E. S.

\section{Order LXXXY. COLCHICACEAs.}

Perianth inferior, 6-7-parted. Stam. 6, inserted into the receptacle or on the perianth. Anth. bursting ontwards. Ovaries superior, 1 of 3 eells, or 3 of 1 cell more or less eonnected. Ovules numerous. Styles 1-3. Fr. bursting inwards of 3 separate 1-eelled follieles, or more or less combined into a 3 -celled septicidal capsule.

1. Colcin icur. Perianth fummelshaped with a very long tube ; limb 6-parted, petaloid. Caps. 3, connected throughout, 1-celled, opening at the inner edge, many-secded.-G.F.G. Monoeot. ii. 34.

2. Tofieldia. Periantl 6-leaved. Anth. bursting longitudinally. Caps. 3, conneeted to above the middle, 1-cellerl, opening at the inner edge, many-seeded.-G. F. G. Monocot. ii. 31 .

\section{Colchicum Linn. Meadow Saffron.}

1. C. autumnale (L.); 1. flat lanceolate ereet.-E. B. 133.Root large, tuberous. L. a foot long and often an ineb broarl, dark green, smooth. Fl. several, bright purple, radical, witl very long tubes, the germen remaining under ground and appearing in the spring with the leaves.-Meadows. P. IX. X.

\section{Tofieldia IIuds.}

1. T. palustris (Huds.); pedicels naked at the top but with a 3-lobed braet at the base.-E. B.536 (not good). T. borealis 
Wahl., Koch, Gaud., Reich., Hoppe in St. 78. 8.-St. 4-8 in. hingh. L. swordshaped, about 2 in. long, in 2 -rankerl radieal tufts. I'l. in a slort dense spike, at first sessile, afterwards slightly stalked, with a bract at the base of the stalk but none under the perianth. This is the true plant of Hudson, and therefore his name must be retained.-Mountain bogs. P. VII.

\section{Order LXXXVI. ERIOCAULACEF.}

Fl. eapitate, unisexual. Perianth glumaeeous, 2-6-parterl. Stan. 2-6, if in two rows the inner row most developed. Anth. 2-celled. Ovary superior 2-3-eelled. Ovules solitary, penlulous. Dehiscence of caps. loenlieidal. Seeds eoated with wings or rows of hairs. Eimbryo lentieular, on the outside of farinaceous albmenen, at the extremity remote from the hilum.

1. Eriocaulon. Fl. in a eompaet scaly hear. Barren fl. in the eentre. Perianth 4-6i-fid, the inner segments uniter nearly to the summit. Stam. 4-6. Fertile fl. in the circumferenee. Perigone deeply 4-parted. Stigmas 2-3. Caps. 2-3-lobed, 2 -3-celled : eells 1 -seeded.

\section{Eriocaulon Linn.}

1. E. septangulare (With.); seapes striated longer than the eellular eompressed subulate glabrous l., fl. 4-eleft hairy at the extremities as well as the scares, stam. 4, eaps. 2-eelled. Hook. -E. B. 733. Hook. Fl. Lond. t. 52.-St. varying in height aeeording to the depth of the water, usually with 6 or 8 rarely 7 or 10 angles, each corresponding with a bundle of vessels surrounding a eentral bundle. Fertile fl. 4-parted nearly to the base, 2 lateral divisions keeled compressed obtuse fringed black. Laelı fl. with a broad blunt black scale in front shorter and broader than the flower. Roots of numerous white jointed fibres.Peaty lakes and pools in Skye and a few of the neighbouring islands; and in Cumamara. P. VIII.

S. I.

\section{Order LXXXVII. JUNCACEA.}

Perianth more or less glumaecous, 6-parted. Stam. 6, inserted into the base of the segments, or 3 opposite to the outer series. Anth. 2-eelled. Ovary l-3-eelled, superior. Ovules 1, 3, or many in each eell. Style 1, stigmas usually 3. Fr. eapsular, 3-valved, loculieidal, sometimes not bursting. Embryo subcylindrical, very minute, within firm albumen, near the hilum.

1. Narthecium. Perianth partly coloured, of 6 linear-lanceolate persistent leaves. Filaments woolly. Style undivided. 
Stigma sinple obtnse. Caps. pyramilal, 3-celled, 3-valved. Placenta extending only a short distunce up the inner edge of the dissepiment. Seeds with a long filiform appendaye at each end.-Referred to Jiliacea by Koch.-G. F. G. Monocot. ii. 30 .

2. Juncus. Perianth glumaceous, 6-leaved. Filaments glabrous. Style undivided. Stigmas 3, filiform. Caps. 3celled, 3-valved. Seeds attached to the inner edge of the dissepiments.-G. F. G. Monocot. ii. 29.

3. Luzura. Caps. I-celled, 3-valved, without dissepiments. Seeds :3, at the base of the eell. Otherwise like Juncus.G. F. G. Monocot. ii. 30 .

\section{Nartuecrum Ituds. Bog Asphodel.}

1. N. ossifragum (Huds.); 1. linear-swordshaped, pedicels with 1 bract at the base and another above their middle, perianth longer than the stanr. and considerably shorter than the eaps.E. B. 535. St. 78. 3.-St. 6-8 in. high, slightly leafy, decumbent and rooting below. L. mostly in radical 2-ranked tufts, half the height of the stem. Cluster continuous. Fl. bright yellow. Occasionally a proliferous spike occurs.-The seeds separate this genus from its allies.-Turfy bogs. P. VI. VII.

\section{Juncus Limn. Rush.}

* Barren and fertile stems subulate with leafy sheaths below. L. long, resembling the stems, or reduced to a mucro. Seeds with a loose testa forming a sack at each end (appendaged).

1. J. maritimus (Sm.); st. naked, 1. rartical terete sharppointed, panicle compound erect, segments of perianth equal lanceolate acute as long as the elliptical mucronate capsule.E. B. 1725. St.71.7.-St. erect, 1-2 feet ligh. Panicle elongated, lax.-Salt marshes, but not very eommon. P. VII. VIII.

2. J. acutus (L.); st. naked, l. radical terete sharp-pointed, panicle very compound mostly compact, segments of perianth equal half the length of the roundish ovate caps.: 3 inner ones obtuse with a membranous border.--E. B. 1614. St.71.6.-St. erect, rigid, witl a very sharp rigid point, $3-6$ feet high. Paniele dense, corymbose. Fr. twiee as large as that of the preceding. - Sands on the sea-coast, rare. P. VII. VIII.

E. I.

** Barren and fertile stems subulate with sheaths at their bases which are either leafless or with rudimentary leaves. Seeds with a close testa (not appendaged).

3. J. effusus (L.); st. naked faintly striated soft, pith conti- 
uuous, panicle congloinerate or diffinse, caps, obovate retuse not "piculate-E. B. 836. Leers Herb. t. xiii. 2.-1leight I-2 feet. L. altogether wanting or rednced to minute slender filaments at the top of sheathing scales. Panicle diffuse, branched. Stam. 3. - . compactus (Leight.); panicle more or less dense globosc.Narshy gromud. $\beta$. Near Lath. P. V11. Soft Rush.

4. J. conglomeratus (L.); st. naked faintly striated soft, pith continuous, panicle conglomerate or liffuse, caps. obovate retuse "piculate.-E. B. 835. St. 71. 3.--Height 1-2 fect. L. none or reduced to minute slender filaments at the top of the sheatling sceales. Panicle globosc, dense. Stam. 3.- - B.effusus (Leight.); panicle more or less effuse.-Marshy ground. P. VII. Common Rush.

5. J. glaucus (Sibth.); st. naked deeply striated rigid, pith interrupted, panicle loose much branched erect, segments of periantl lanceolate-subulate rather longer than the elliptic-oblong mucronate capsule.-E. B. 665. St.71.5. J.inflexus Leers t. xiii. 3.-Distinguished by its ascending diffuse panicle, longer black fi., rigid attenuated glaucous st., dark sheaths, and 6 stan. L. none or reduced to minute slender filaments at the top of the scales. Wet places. P. VII. Hard Rush.

6. J. diffusus (IIoppe); st. naked finely striated rigid, pith continuous, panicle loose much branched erect, segments of perianth lanceolate-subulate longer than the obovate-obtuse mucronate capsule.-Hoppe in St. 77. 10.-Very similar to the prceeding but caps. much sinaller. St. green. Stam. 6.-In wet places, rare? Kincardine, N.B. Mr. Sonder. Hertingfordbury, Herts. Rev. H. H. Coleman. P. VII. VIII.

7. J. balticus (Willd.); st. naked very faintly striated rigid, pith continuous, panicle erect slightly branched, segments of perianth ovate-lanceolate acute, caps. eiliptical scarcely trigonous obtuse mucronate-E. B. S. 2621. St. 71.2.-Root creeping widely. L. none or reduced to very ninute points at the top of the sheathing scales.-Distinguished from $J$, arcticus by its rounded not trigonous enjsiles, and from $J$. glaucus by its extensively creeping root, scarcely striated st. and continuous pitl. - Sandy and wet sea-coasts. P. VII.

8. J.filiformis (L.); st. naked filiforn faintly striated, panicle simple of few (about 7) fl. placed near the middle of the st., seg-

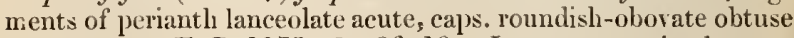
mucronate. - E. B. 1175. St. 36, 10.-L. none or as in the preceding plants. Distinguishel by its remarkably slender st. of about a foot in height, upon which the small panicles are placed very low, and the roundish capsules.-Stony margins of lakes in the north. P. VII,

E. S. 
*** No barren stems. Flowers capitate or solitary and terminal. Seeds appendayed.

9. J. custaneus ( $\mathrm{Sm}_{0}$ ) ; st. bearing 2-3 channcled 1., heads terminul solitary or $2 \geq$ or 3 , segrments of perianth elliptic-lanceolate acute lialf as long as the ovate-oblong pointed trigonal capsules, root creeping.-E. B. 900. St.71. 14.-St. 8-12 in. high. Root with lax rumners. Caps. chocolate-coloured. Filaments about twice as long as the anthers.-Mieaceons monntain bogs at a great clevation, lare. P. VII. VIII.

10. J. triglumis (L.); st. naked round, l. radical subulate channeled, head solitary terminal of $1-3$ creet $t$. usually as long as the membranous bract, seginents of the perianth elliptical-oblong obtusc rather shorter than the ovate-oblong obtuse-mucronate ca1s.s, root cespitose.-E. B. 899. St. 28.3.-Root scarcely creeping. St. several from one root, $3-6$ in. high, perfectly round. Caps. chestnut-coloured. Filaments many times longer than the anthers.-Boggy places on mountains. P. VII. VIIÎ. E. S.

11. J. biglumis (L.) ; st. naked channeled on one side, 1. radical subulate compressed (not channeled), head solitary terminal of 2 nuilateral $\mathrm{H}$. one of which is stalker usually shorter than the leafy bract, segments of perianth oblong-obtuse rather shorter than the turbinate retuse caps., root fibrous.-E. B. 898.-St. $2-4 \mathrm{in}$. high, seldom more than 1 from cach root. Caps. light brown with purple margins. Anthers short.-Boggy spots on monntains, rare. P. VIII.

12. J. trifidus (L.); st. with I leaf on its upper part, the basal sheaths awned: upper one with a short 1., head terminal of I-3 H. with two setaceous leaflike bracts, scgments of perianth acnte shorter than the rounded elliptical beaked caps., root creeping.E. B. 1482. St. 71. 12.-St. crowded, erect, slender, $2-6$ in. high. Oceasionally the stem-l. is wanting and sometimes it has a second head in its axil. Remarkable for its long setaceous bracts. Perianth and caps. dark brown.-Damp rocky places on mountains. P. VII. VIIII.

**** No barren stems. Flowers in a terminal head or 2 heads one above the other, or in panicled heads. Seeds not appendaged.

I3. J. capitatus (Weigel); st. naked erect simple, l. radical filiform, head terminal mostly solitary shorter than the setaceous bract, segments of the perianth ovate-lanceolate acuminate-aristate twice as long as the truncate apiculate caps., stam.3.-E.B.S. 2641.- Plant $1-4$ in. high. L. half as long as the stems. Heads large, of 3-6 sessile flowers.-Sandy ground in Guernsey and Jersey. A. VI. VII.

O. 
14. J. obtusiflorus (Ehrh.); st. 2-leaved and as well as the internally jointed $l$. terete, panicle repeatedly compound spreading divaricated, segments of perianth equal obtuse as long as the ovate acute trigonous capsule.-E. B. 2144. St. 77. 12.-Erect, 2-3 fect high. St. and l. not compressed. Segments of perianth pale, often tinged with purple, quite blunt or with a small inflexed point.-Marshes, rather rare. P. VII.-IX.

15. J. acutiflorus (Ehrh.); st. 3-4-leaved and as well as the intcrnally jointed $l$. subcompressed, panicle compound pyramidal, segments of perianth acuminate-aristate inner ones longest all rather shorter than the narrow-ovate acuminate rostrate triquetrous capsule.-E. B. 2:38. J. sylvaticus Hoppe in St. 78. 1, Koch.St. crect, $1 \frac{1}{2}-2$ feet high. L. slightly compressed. Clusters 5-6-flowered. Caps. pale brown.-Boggy places. P.VI.-VIII.

16. J. lamprocarpus (Ehrh.); st.3-6-leaved and as well as the internally jointed $l$. compressed, panicle repeatedly compound erect forked, segments of perianth equal acute the inner ones obtuse all shorter than the ovate attenuated mucronate triquetrous capsule.-E. B. 2143. St. 71. 16.-St. crect, 12-18 in. high. L. compressed, with numerous iuternal divisions. Clusters 4-8flowered. Caps. dark brown.-Boggy places. P. VII. VIII.

[J. alpinus (Vill.), having an acutc dorsal angle to the sheaths of its leares and blunt segments to its perianth which are mucronate below their summit ;-also J. atratus (Krock.), having " more deeply striated leaves" than either of the 2 preceding species and the imner segments of the perianth about as long as the capsule; will probably be found in Britain.]

17. J.nigritellus (D. Don); st.3-4-leaved and together with the internally jointed $l$.nearly cylindrical, panicle slightly eompound erect, seyments of perianth nearly equal (3 inner rather longer and broader) acute shorter than the linear-oblong trigonous rostrate capsule.-E. B. S. 2643. not Koch, Kunth.-St. erect, (i-12 in. high. L. scarcely at all compressed. Clusters of more numerous fl. than in the preceliug. Caps. brown, at lengtl black aud glossy, more abruptly poiuted than iu J. lamprocarpus. - Boggy places in the north. "P. VII. VIII.

18. J. supinus (Moeneh); st. filiform, l. setaceous slightly channeled and faintly jointed internally, panicle nearly simple clougated with few distant clusters, segments of the perianth equal acute ( 3 inner rather obtuse) nearly as long as the elliptical very obtuse mucronate capsule, anth. as long as their filaments.E. B. 801. St. I3. 8. J.uliginosus and J. subverticillatus Sin.Extremely variable in size and the direction of its stems, sometimes ereet, at others prostrate and rooting at every joint, or floating. Caps, very obtuse, pale brown. lil. often viviparous. 
"Stan. 3." Anth. linear-oblong, as long as their filanents.Ilople figures (St.78.2.) a plaut closely allied to this but differine in linving 6 stant., and filaments nearly twice as long as their elliptical suth., under the name of J. nigritellus (1). Dom) which it is not; 1)on's plaut being most nearly allied to J. lamprocarpus. Hoppe's plant, which I possess from the bogs of Cumnamara, is perhaps justly referred to $J$. supinus by Koch.-Bogery aud wet places. I'. V1.-V'III.

***** No barren sterns. Flowers solitary, remote or corymbose and forming a terminal panicle. Seeds not appendaged.

19. J. squarrosus (L.); st. naked simple, l. linear channeled radical, panicle terminal compound with cymose branches, segments of perianth ovate-lanceolate acute or rather obtuse as long as the olorate obtuse inncronate capsule, anth. 4 times as long as their filaments.-E. B. 933. St. 36. 11.-St. erect, 6-I2 in. high. L. numerous, somewhat spreading, rigid, half as long as the steu. Caps. pale brown, shining.-Wet heatls and moors. P. VI. VII.

20. J. compressus (Jacq.); st. with 1 leaf in the middle, l. linear channeled, pannicle terminal compound subcymose usually shorter than the bract, segments of perianth oval-oblong obtuse shorter than the shortly mucronate capsule.-E. B.934. St. 36. 13.-St. slender, erect, round and leafy below, naked and compressed above. Floral bracts usually pale. "Style half the length of the ovary." Anth. oblong, about as long as the filaments.-Damp places. P. VI.-VIIII.

21. J. Gerardi (Lois.); st. with l or more leares, l. linear channeled, panicle terminal compound subcymose usually longer than the bract, segments of perianth oval-oblong obtuse about as long as the oval-oblong strongly mucronate capsule.-J. ccenosus Bich., Sm., E. B. S. 2680. St. 71. 8.-Similar to the preeeding. St. trigonous in its upper part. Floral bracts usually shining brown. "Style as long as the ovary." Anth. elongate, at least twice as long as the filaments.-Salt marshes. P. VI.-VIII. Mud Rush.

22. J. tenuis (Willd.); "st. above shortly dichotomous panicled, l. linear-setaccous grooved, fl. solitary approximate mostly sessile, caps. nearly spherical shorter than the very acuminated leares of the perianth." Hooker.-E. B.2174. J. Gesneri Sm.Distinguished from the following by its capsule. Sinith states that the true $J$. tenuis (Willd., Pursh) differs essentially by having a cymose not racemose panicle. I am not acquainted with the Seottish plant.- "By a rivulet in marsiny ground, among the mountaius of Clova. Near the summits." Mr. G. Don. P. VII. 
23. J. bufonius (L.); st. leafy dichotomous, I. setaeeons, ff. solitary unilateral scattered mostly sessile, segments of the perianth unequal lanceolate-acmminate longer thin the oblong obtuse capsule.-E. B. 802. St. 36. 12.-St. 4 - 8 in. high, usually with only 1 leaf on the slender stems.- $\beta$. fasciculatus (Koch); st. shorter $(2-3 \mathrm{in}$. high) and thicker, $\mathrm{H}$. 2 or 3 together.-Marsly and wet places. A. Vil. V1ll. Toad Rush.

[J. pygmaus (Thuil.), which has a pyramidal caps. and closely resembles $J$. bufonius $\beta$, will probably be found in Britain.]

\section{Luzula Cand.}

1. L. sylvatica (Bieh.); 1. linear-lanceolate hairy, panicle subcymose doubly compound, peduncles clongated, clusters about 3flowered, segments of perianth bristle-pointed as long as the ovate-mueronate capsule, filaments very slort, seed minutely tubercled at the end.--E. B. 737. St. 36. 14. L. maxima DC:, Koeh. Juncus sylvaticus IIuds.-Undergromnd st. woody. St. 12-18 in. highl. L. broad, shining, striated with hairy edges. Panicle much longer than the leafy bracts.-Shady plaees. P. IV.-VI. Great Woodrush.

[*L. nivea (DC.); 1. linear hairy, panicle decompound patent overtopped by the bract, ped. mostly 4-flowered, segments of perianth aeute longer than the caps., anth, almost sessile.-Fl. whitish._Bromball Woods, Dunfermline, S. Dr. Dewar. It was planted there by a gardener. Dr. Balfour.]

2. L. Forsteri (DC.) ; l. linear hairy, panicle subcymose only slightly branched, peduncles 1 -flowered erect with both fl. and fr., filaments about as long as the anth., caps. acute, seeds with a straight blunt crest.-E. B. 1293. St. 77. 2.-St. slender, about a foot high.-Thickets, xather rare. P. V. E.

3. L. pilosa (Willd.); l. lanceolate lairy, panicle subcymose only slightly branched, peduncles 1 -flowered reflexed after flowering, filaments about half as long as the antl., caps. blunt, seeds with a fulcate crest.-E. B. 736. St.77. 3. - St. slender, 6-12 in. high.-Thickets. P. V.

4. L. campestris (Willd.); I. linear hairy, panicle of 3 or 4 ovate dense sessile or stalked clusters, segments of perianth lanceolate-acuminate, filaments much shorter than the unthers, caps. obtuse apiculate, seeds nearly globular with a basal appendage. -E. B. 672. St. 77.5.-St. 4-6 in. high. Anth. linear, about 6 times as long as the filaments.-Pastures and dry places. P. IV. V.

5. L. multiflora (Lej.); I. linear hairy, panicle of numerous ovate dense sessile or stalked clusters, segments of perianth narrowly-laneeolate strongly acuminate, filaments about as long as 
the anthers, caps. obtuse apiculate, seeds nearly twice as long as broad with a basal appendage.-L. B.S.2718. St.77.7. L. conyesta sm. - st. 8-20 in. high. Wilanents more than half as long as the rather short small anth. and of ten equalling them. Panicle with the clusters nearly all stalked, or ( $\beta$. congesta, L. congestu, L.j., L. campestris $\beta$. Hlook.) contracted into a romiled lobed liead.-Moorish and turfy places. P. VI.

6. L. spicata (DC.); 1. narrow slightly channeled hairy, panicle an oblong lobed nodding spike, chusters shorter than their luacts, segments of periantl narrow acuminate bristle-pointed, filancuts half as long as the anthers, caps. obtuse apicnlate, seeds oblong with a rery slight basal appendage.-E. B. 1176.-St. 3-12 in. lighl. L. short, slender. Spike $\frac{1}{2}-\mathrm{l}$ in. long, nodding. Partial bracts taperiug, bristle-pointed.-Highland mountains. l'. VII.

7. L. arcuata (IIook.) ; l. clianneled slightly haiı, panicle subumbellate of few 3-5-flowered clusters on long drooping peduncles, scgments of pcrianth broadly-lanceolate bristle-pointed, filaments equalling the anthers, caps. roundish-ovate, scels oblong obtuse or apiculate scarcely appendaged below.-E. B. S. 2688. - St. slender $2-5$ in. long. L. short, curved, narrowly liuear. lanicle of $3-5$ sinall clusters, l nearly sessile, the others on long deflexed stalks.- Highest summits of the Cairngorum and sutherland mountains. P. VII. VIII.

\section{Order LXXXVIII. ALISMACEE.}

Perianth frce, 6-partel, coloured. Stam. 6--9 or more. Ovaries 3-6 or numerons. Styles and stigmas the same. Fruit not bursting, l- or many-seeded. Enbbryo straight or curved, albumen 0 .

\section{Suborder 1. ALISMOIDEE.}

Three inner segments of the perianth petaloid. Seeds $1-2 \mathrm{in}$ cach cell, erect or ascending. Placenta sutural. Embryo cylindrical, doubled upon itsclf, radicle next the hilum.

1. Alisira. Fl. perfect. Cal. of 3 leaves. Pet. 3. Stam. 6. Carp. unmerous, l-secded, not bursting.-G. F. G. Monocot. ii. 25.

2. Actinocarpus. Fl. perfect. Cal. of 3 leaves. Pet. 3. Stam. 6. Carp. 6-8, 2-seeded, combined at the base and spreading in a radiant manner.

3. Sagittaria. Fl. monœcious. Cal. 3-leavell. Pet. 3. Male fl. with numerous stam. Femalc fl. witl numerons 
1-seeded compressed earpels upon a globose receptacle.G. 1'. G. Monoeot. ii. 26.

\section{Suborder II. BUTOMEA.}

Three inner segments of the perianth petaloid. Sceds numerons, minute. Placenta ramified over the inner surface of each folliele. Embiro straight or eurved, radicle next the hilum.

4. Butonus. Perianth 6-parted, coloured, resembling a corolla. Stann. 9, 3 interior. Follieles 6 , eonnected below, bursting inwards.-G. F. G. Monoeot. ii. 27.

\section{Suborder III. JUNCAGINEA.}

Perianth uniform, herbaceous, or 0 . Seeds 1-2, creet, approximated at the base. Embryo straight, radiele at the opposite end from the hilum, plumule coming through a lateral eleft in the embryo.

5. Scineuchzeria. Perianth of 6 leaves. Stam. 6 , with slender filaments. Ovaries "with 2 orules." Style 0. Stigma adnate to the ovary, downy. Fruit eompressed, inflated, diverging, 1- " or 2-" sceded.-G. F. G. Monoeot. ii, 24 .

6. Triglochin. Perianth of deeiduous leaves. Stam. 6, anth. almost sessile. Ovaries 3-6, with single ovules. Style 0. Stigmas feathery. Car'). attached to an angular axis from which they at length separate at the base.-G. F. G. Monoeot. ii. 23.

\section{Suborder I. Alismoidea.}

\section{Alisma Linn.}

1. A. Plantago (L.) ; fl.-stalk panieled with whorled compound branches, earp. rounded at the end not awned with 1 or 2 strixe on the back, fr. depressed obtusely trigonous, 1 . eordateovate or laneeolate.-E. B. 837. R. vii. t. 5\%.-L. all radieal, on long stalks. Flower-stalk $2-3$ feet high. Fl. pale roseeolour.- $\beta$. lanceolatum (Sm.); 1. laneeolate attenuated below. A. lmerolata With.-By water. P. VII. VIII. Great II'aterplantain.

2. A. natans (L.); st. floating and rooting leafy, peduncles simple frol: the joints of the stem, carp. "obiquely acuminated striated in a ghobose head," Hoating l. stalked obloug obtuse, radieal l. (leafless petioles) linear-tapering sessile.-E. B. 775. R. vii. t. 54 . - St. slender, floating, the few lowest joints rooting at the bot- 
tom of the water. Fl. rather large, white with a yellow spot.Lnkes, rure. P. VIII.

3. A. romunculoides (1.); fl.-stallis umbellate, carp. acute with 5 angles collereted into a globose squarrose head, l. linear-lanceolate neute.-E. B. 3326. R. vii. t. 55.-- L. all radical, on long stalks. l'lower-stalks from in few in. to 2 fect lighl, terminating in a simple nmbel or 2 umbellate whorls of simple peduncles. Fl. pale purple.- $\beta$. repen.s (Sm.); plant depressed, umbels rooting and proliferons, tl. larger. A. repens (1)av.) E. B. S. 2722. -Turfy bogs. $\beta$. Margins of lakes in Wales and Scotland. $P$. VI. VII. Lesser II ater-plantain.

\section{Actinocarius $R$. Br.}

1. A. Damasonium (R. Br.); stallis with $1-3$ whorls of $\mathrm{fl}$., carj. sulbulate compressed opening longitndinally, l. cordatcoblong.-E. B. 1615. Alisma Sm. Damasonium stellatum Kunth. -L. all radical, floating, on long stalks. Pet. white. Carp. large, with 2 stalked scerls, 1 from the luwer angle erect, the other from the upper horizontal.-Ponds and ditches, rare, P. VI. VII.-E.

\section{Sagittaria Limn. Arrowhead.}

1. S. sagittifolia (L.) ; 1. arrowshaped with lanccolatc straight lobes, fl.-stalk simple, fl. whorled.-E. B. 84. R. vii. t. 53.Stoloniferous; eacli runncr ending in a tuber. L. remarkably arrowshaperl, rising above the water. Submersed petioles without a limb. Fl. white.-Ditehes and rivers. P. VIII. E. I.

\section{Suborder II. Butomea.}

4. Butomus Limn. Flowering-rush.

1. B. umbellatus (L.).-E. B. 651. R. vii. t. $58 .-A$ beautiful plant. Flower-stalk radical, 2-3 feet high, longer than the leaves, bearing an irregular nany-flowered simple umbel with scarious bracts and a membranous 3-lcaved involucre. Fl. rosecoloured. L. all radical, linear, triangular.-Rivers and ponds. P. VI. VII.

\section{Suborder III. Juncaginea.}

\section{Scheuchzeria Limo.}

1. S. palustris (L.).-E. B. 1801. St. 78. 4.-St. $6-8$ in. high, erect. L. distichous, few, altcrnate, semicylindrical, obtuse, with a minute pore on the upper sile at the apex. Raceme terminal of about 5 greenish flowers. Caps, about 3, mueh inflated. 
- Sphagnous parts of bogs. Lakely Car, Boroughbridge; 'Thome Moor, Doncaster, Yorkshire. Bomere, Shropshire. Methvin, Perthshirc. P. VII.

E. S.

\section{Triglochin Linn.}

1. T. maritimum (L.) ; fr. ovate of 6 combinel capsules.E. B. 255. R. vii. t. 52. St.78. 5.-I. all radical, lincar. Fl. in a lax simple spike or raceme, greenish. Fr. with 6 angles and constricted below the stigm., or without angles or constriction.Salt marshes. P. VII. VIII.

2. T. palustre (L.); fr. linear angular of 3 eombined capsules. -E. B. 366. R. vii. t. 5 l.- Taller than the preceding but closely resembling it. Stoloniferous.-Marshy plaees. P. VI. VII.

\section{Order LXXXIX. AROIDEE.}

Fl. mostly unisexual, arranged upon a spadix. Perianth 3-4or 6-parted or 0. Stam. numerous or definite and oppositc to the segments of the perianth. Anth. bursting ontwards. Ovaries free, solitary or numerous, 1-3-celled, 1- or many-seeded. Stigmas 1 or 2. Fr. not bursting, suceulent or dry. Embryo in the axis of fleshy albumen.-The eharacters of this and the preeeding Order appear to require revision and probably a new arrangement of the genera.

\section{Suborder I. TYPIIINEA.}

Fl. numerous, with a perianth. Stam. 3. Antlı, wedgeshaped, ereet. Filaments long, slender.

1. Tүрна. Sterile and fertile spikes cylindrical. Stam. surrounded with setæe. Anth. 3 together on one filament. Ovary surrounded with setæ, at length stalked.

2. Sparganium. Fl, in dense globose heads, each with a single 3-leaved perianth. Fruit dry, sessile.

\section{Suborder II. ARINEA.}

Fl. numerous. Anth. 1-2- or many-celled, ovate. Filaments very short.

3. Acorus. Spath 0. Perianth 6-leaved, inferior, persistent. Stam. 6, filiform.

4. Arum. Spath of 1 leaf, eonvolute at the base. Perianth 0 . Male fl. of 1 sessile 2-celled anther. Female fl. lowermost on the spadix, of a solitary pistil. Fr. sueeulent. 


\section{Suborder III. LEMNE.}

Periantlı 0. Fl. 2, monocious, in a membranous spath.

5. Lemna. Spatl 2-flowered, uncmbranous, urecolate. Male fl. of 2 stamens. Fr. ntrieular, indehiscent.-Fronds withont distinct stem or leaves. Fl. from just beneath the margin of the frond.

\section{Suborder I. Typhinea.}

\section{Typha Linn.}

I. T. latifolia (L.); l. linear nearly flat, sterilc and fertile catkins contiguous. - E. B. 1455. -St. 6-7 fcet high. L. overtopping the inflorescence, very broad. Catkins very long. Style longer than the sctae; stig. oblique, linear-subulate rounded below.-[ln T. Shuttleworthii (Koch) the stig. does not protrude beyond the setx.]-Ponds and lakes. P. VI. VII. Great Reed. mace.

2. T. angustifolia (L.); l. linear channeled below, sterile and fertile catkins a little separated from each other.-E. B. 1456.St. 5-6 fect ligh, much slendercr than in the preceding. L. very narrow, overtopping the inflorescence. Catkins very long, slender, separated by an interval of about an inch. Style longer than the setæ; stig. elongate, filiform.-Lakes and ponds. P. VI. VI1. Lesser Reed-mace.

[3. T. minor (Sm.); 1. linear-setaceous overtopped by the distant catkins.-E. B. 1457.-Reported to have been found on IHounslow Heath. Dillenius. P. VII.]

E

\section{Sparganium Linn.}

1. S. ramosum (Huds.); l. triangular at the base with concave sides, st. branched, stigma linear.-E. B. 744.-About 2 feet high. L. long. Fl. in spherical heads.-Ditches. P. VII. Branched Bur-reed.

2. S. simplex (Huds.); l. triangular at the base with flat sides, st. simple, stigma linear.-E. B. 745.-About I foot high. St. not branched but the lower heads of $\mathrm{fl}$. are stalked.-Ditches. P. VII. Simple Bur-reed.

3. S. natans (L.) ; l. floating flat, st. simple, stigma oblong-E. B. 273.-St. often very long, floating. L. very long, pellucid. IIeads of $\mathrm{fl}$. few, barren head usually solitary.-Lakes and, ditches. I'. VII. VIII. 


\section{Suborder II. Arinea.}

\section{Acorus Limn.}

1. A. Calamus (L.); seape with a long leafy prolongation beyond the spadix. $-E . B .356 .-5$ t. $5-6$ feet ligh, resembling the 1., cnsiform, flattened. Spadix completely covered by the flowers, 2-3 in. long, lateral. St. and l. swect-scented when crushed.-In water, rare; more common in Norf. and Suff. P. VI. Sweet-flag.

E. S.

\section{Arum Linn.}

1. A. maculatum (L.); l. all radical hastate-sagittate green or spotted with purple, spadix clubshaped straight obtuse shorter than the spatli.-E. B. 1298.--Root tuberous. L. with branching veins. Spath large. Spadix with ovaries at the base; above them whorls of antli.; above these a few filaments, probably abortive ovaries; elub naked. Berries scarlet, remaining after the rest of the plant has disappeared.-IIedge-banks and tliekets. P. IV. V. Cuckow-pint.

\section{Suborder III. Lemnea.}

\section{Lemna Linn. Duckweed.}

1. L. trisulca (L.); fronds thin pellucid elliptic-lanceolate tailed at one end serrated at the other, roots solitary.-E. B. 926 . $R$. vii. 19.-Roots tipped with a sheath. Fronds half an in. long, proliferous at right angles. "Filaments reeurved, filiform." Schleid. Plants truly annual, producing gemmae which survive the winter as in the other species.-Stagnant water. A. VI.

2. L. minor (L.); fronds obovate compressed opaque, roots solitary.-E. B. 1095. R. vii. 15.-Fronds $1-2$ lines long, nearly that beneath, of a compact texture. "Filaments recurved, filiform." Schleid.-Stagnant water. A. VI. VII.

3. L. polyrrhiza (L.); fronds roundish-obovate compressed, loots numerous clustered.-E. B. 2458. R. vii. 17. Spirodela Schleid., Endl.-Fronds half an in. long, green above, purple beneath. "Filaments narrowed below." Schleid.-Stagnant water. A. Fl. have not been seen in Britain.

4. L. gibba (L.); fronds obovate nearly flat above hemispheri$c a l$ and spongy beneath, roots solitary.-E. B. 1233. R. vii. 16 . Telmatophace Schleid., Endl.-Fronds l-2 lines long, remarkably giblous and cellular beneath. "Filaments reeurved, dilated in the midlle." Schleid. See an excellent account of the germination of this plant, by Mr. Wilson, in Bot. Misc. i. 145. t. 42.Stagnant water. A. VI.-VIII. 


\section{Order XC. POTAMOGETONE.}

l. perfect or misexual. Periantl inferior, 4-parted, or 0. Stam. definite, hypogynous. Ovaries 4 , or 1 , distinct, each with l ovule. lir. a dinpe or mut, not bursting, l-seederl. Sieed peudulous. Albumen 0. Embryo straight or eurved, with a lateral eleft.

1. Potamogeton. Fl. perfect. Perianth 4-parted. Anth. 4 , sessile, opposite to the divisions of the perianth. Ovaries 4, styles 0. Drupes 4, sessile.

2. Rupria. Fl. perfect. Periantl 0. Stam. 2, the eells eonsiderably separated, filanents very short sealelike. Ovaries 4, styles 0 . Nuts 4 , with long stalks.

3. Zannicheldia. Fl. imperfect. Male fl. with 1 stan. and no perianth. Fem. fl. with a bellshaped pcrianth, persistent style, peltate stigma. Nuts $3-5$ or more, very shortly stalked.

4. Zostera. Stam. and pistils inserted in 2 rows upon one side of a spadix. Spath linear, terminating in a leafy point. 11. nakerl. Anth. 1. Ovary 1, style 1, stigmas 2.

\section{Potamogeton Linn. Pondweed.}

* L. alternate, upper l. floating and sometimes opposite, stipules free.

1. P. natans (L.); l. all stalked, upper eoriaeeous floating orate or elliptical, lower l. linear or lanceolate or setaceous, petioles plano-concave above, $f r$. (large) rounded on the back when fresh keeled when dry, peduncles equal.-E. B. 1822. R. vii. t. 50.A creeping rhizoma at the bottom of the water. Lowermost 1 . often quite setaceous; upper l. nnore or less cordate at the base, when pressed flat a ridge is formed on each side of the base. Fr. 2 lines long.-Ponds, ditches, and slow streams. P. VI. VII.

2. P. oblongus (Viv.); l. all stalked, upper eoriaeeous floating oblong-elliptical, lower l. linear-lanceolate, petioles plano-concave above, $f r$. minute obtuse and rounded on the back, peduncles equal.-E. B. S. 2849.-St. creeping below. Lower 1. often very narrow. Fr. not exceeding 1 line in length, rounded on the back when fresh and having 3 faint ridges when dry.-Ditches, small streams, ponils. P. VII.

3. P. plantagineus (Ducr.); l. all stalked membranous and pellucid blunt entire, upper elliptieal, lower l. oblong, petioles planoeoneave above, $f r$. minute rounded on the back when fiesh acutely keeled when dry, peduneles equal.-E. B. S. 2848. R. vii. t. 45. -St. creeping below, branehed, sometimes throwing out long 
scions from its upper axils. L. all beautifully transparent and netted with veins, the upper often nearly sessile and nearly orbicular, sometimes slightly cuspidate. Fr. not excecding 1 line in length.-Stagnant peaty watcr. P. VI. VII.

4. P. rufescens (Schrad.); submersed l. lanceolate narrowed at both ends subsessile membranous pellucid entire not apiculate, floating l. subcoriaceous obovate obtuse narrowed into a short petiole, stip. withont wings, fr. acntely keeled, peduncles equal. -E. B. 1286. R. vii. t. 32. P. Aluitans Sm.-St. simple. Upper 1. alone slightly coriaceous, often tinged with purple, longer than their stalks; submcrsed 1. all nearly, if not quite, sessile, with ehainlike reticulations near the midrib. Sep. "transversely oval." - [P. spathulatus (Schr.) differs from this by having long stalks to all its leaves and the upper oncs truly coriaceous. Is it a native?]-Ditches and slow streams. P. VII.

5. P. lanceolatus (Sm.); submersed l. lanceolate sessile narrowed at both ends entire not apiculate, floating 1 . subcoriaceous elliptic-lanceolate stalked, stip. linear-lanceolate acute uppermost broader, fr......, peduncles equal.-E. B. 1985 . not $R$. P. nigrescens Fries? - St. very slender, slightly branched, floating l. not always present, submerscd l. with chainlike reticulatious near the midrib. Uppermost stip. apparently with 2 stronger dorsal ribs. Fr. unknown.--Streams, rarc. Rivulet between Bodafon and Lligwy, Anglesca. Angus. Kincardineshire. Elgin. P. VII. VIII.

E. S.

6. P. heterophyllus (Schreb.); submersed l. lanceolate narrowed at both ends sessile denticulate and apiculate, floating l. subcoriaccous elliptical stalked, stip. broadly lanceolate obtuse with 2 stout prominent ribs, lower ones linear-lanceolate, $f r$. obtuse on the back, peduncles swelling upwards.-E. B. 12R5. R. vii. t. 4143. P. gramineus Fries, Koch. - St. much branched below. Lower stip. without the two strong ribs and equally nerved, upper. ones widely spreading. Dry fr. slightly marked with 3 ridges on the back.-[P. nitens (Weber) has the submersed l. rounded and clasping at the base and the floating l. more coriaceous.]-Ponds and ditches. P.VI. VII.

\section{** L. all submersed, membranous, lanceolate or broader ;} stipules free.

7. P. lucens (L.) ; l. pellucid oval lanccolate stalked denticulate and apiculate, stip. winged, fr. "obtuse on the back and slightly keeled when fresh," peduncles swelling upwards, spikes cylindrical densely flowered.-E. B. 376. R, vii. t. 36.-Combined by some authors with $P$. heterophyllus, but appears to be sufficiently distinct. All the stipules have two prominent wings on their back and are longer and narrower in proportion. Spikes 
long, about equalling the peduncles. Aecording to Mr. W. Wilson " ovate-lanceolate moderately acute coriaceous l." sometines occur, but 1 suspect the existence of another species. $-\Lambda$ variety is ocersioually found with the limb of the 1 . much reduced in size and the nidrib prominent and reseubling a long spine, whieh is, according to Koch, the $P$. acuminatus Schum. - Common in deepish water. P. VI.

8. $P$. longifolius (Gay); $l$. pellueid elongate-lanceolate narrowed below entire apieulate, stip. winged, fi......, peduncles very long swclliug upwards, spikes with few subvertieillate distant flowers.-E. B. S. 2847. - St. long, slender. L. distant, quite entire, nearly sessile with very short stalks. Stipules green, laneeolate, with 2 narrow wings on the back. Peduncles $6-8$ in. long and much thicker than the stem, suddenly contraeting at the spike which is about an inch long and has the fl. rather more decidedly whorled than they are represented in E.B.S. Fr. unknown.-Deep water. Lough Corrib, Galway. Mr. J. Ball. P. VIII.

9. P. prcelongus (Wulf.); l. pellueid elongate-oblong halfclasping obtuse and hooded at the end entire, stip. not winged, fr. rounded on the back when fresh keeled when dry, peduncles very long equal, spikes many-flowered.-E. B. S. 2858. R. vii. t. $3 \dot{3}$. -St. long, growing in deep water and forming dense masses of foliage just below the surface. Peduncles $6-12$ in. long. Spikes 1-2 in. long.-Rirers and ditches, rare. P. VI.

10. P. perfoliatus (L.); st. round, l. pellucid cordate-ovate clasping serrulate plane, fr. rounded on the baek when fresh, keeled when dry, peduncles equal.-E, $B .168$. $R$. vii. t. 29.St. long, slightly branched. Peduncles rather thick and short. Spikes short.-Lakes and streams. P. VII.

II. P. crispus (L.); st. compressed, l. pellucid linear-oblong obtuse sessile serrulate wavy, fr. with a long beak keeled on the back when dry, peduncles equal. $-E$. B. 1012. $R$. vii. t. $29-30$. - St. much branched. Peduncles elongated. Spikes few-flowered. Beak as long as the nut. L. usually crisped at the edges, oceasionally plane when it is $P$. serratum Huds.-Ditches and strearns. P. VI.

*** L. all submersed, alternate, linear ; stipules free.

12. P. zosterøfolius (Sehum.); st. flattened, $l$. linear-aeuminate with 3 principal ribs and numerous close parallel intermediate nerves occupying the whole surface, spikes cylindrical upon long peduncles, sep. transversely oval, fi: obovate kecled, style terminal.-E. B. S. 2685. R. vii. t. 27. P. cuspidatus Sm., P. compressus Fries, Koch.-Peduneles $2-4$ in. long. Spikes 
I0-15-flowercd. L. suddenly acuminate or apiculate.-Rivers and lakes. P. VI.

E. S.

13. P. acutifolius (Link); st. flattencd, l. linear-aenminatc with 3 principal ribs and numerous elose parallel intermediate veins oecupying the whole surface, spikes ovate about as long as the short pedunele, sep. rhomboidal, fr. reniform keeled, style faeial. -E. B. S. 2609. R. vii. t. 26.-Peduncles very short. Spikes 4-6-fiowered. L. gradually acuminate. Styles a continuation of the straight inner edge of the fr.-Marsh ditehes in Sussex and IIertfordshire. P. VI.

E.

14. P. gramineus (L.?, Sm.); st. slightly eompressed with rounded edges, I. linear 3-nerved, spikes ovate dense eontinuous about as long as the short ped., sep. rhomboidal, fr. obovate keeled.-E. B. 2253. P. obtusifolius Koch, $R$. vii. t. 25. - St. slender, mueh branehed. Peduneles very short. L. rounded off to a slight point at the end, with oblong reticulations next the midrib but wanting the numerous parallel nerves of the two preeeding speeies.-Ponds and ditches, rare. P. VI. VII.

I5. P. compressus (L.); st. slightly eompressed, $l$. linear 5 -nerved suddenly apieulate, spikes short lax 2 or 3 times shorter than their compressed elavate ped., sep. transversely oval, fr. obliquely elliptical obtusely kecled.-E. B.418. R. vii.t. 24. not Fries, Koeh.-Lateral nerves nearer together and nearer to the margin of the l. than to the midrib, no intermediate veins.Resembling the preceding rather than the following.-Ditches. P. VI. VII.

I6. P. pusillus (L.); st. slightly compressed, I. linear 3-nerved, spikes short rather lax 2 or 3 times shorter than their ped., $f r$. obliquely elliptical obtusely keeled.-E. B.2I5.-St. slender. L. narrow, rather aeute without intermediate parallel veins, the lateral nerves equidistant between the midrib and margin. Ped. seareely eompressed, not thiekened.- $[P$. triehodes (C. and S.), $R$. vii. t. 2l., is elosely allied to this but has linear-setaeeous I-nerved l., interrupted spikes and semieireular eompressed acutely keeled fr.; also $P$. rutilus (Wolfg., Fries) with 3-nerved attenuate-cuspidate 1. , semiterete st., and oblong-elliptieal fr. without a keel; also $P$. graeilis (Fries) with I-nerved attenuateeuspidate 1., terete st., and globose-elliptieal fr. without a keel.] -Ponds and ditehes. P. VI.

**** L. all submersed, alternate, linear, sheathing.

I7. P.zosteraceus (Fries?); l. linear aeuminate 3-ncrved with eonnecting veins, spikes interrupted, fr. (large) roundish-obovate rounded on the baek with a prominent keel when dry.-Fries (Summa. 216.), R. vii. t. 20 ? (1. 5-nerved).--Lateral nerves of 1. sub- 
marginal.- Species 17,18 and 19) are very closely allied, but may be casily distinguished by attenching to the characters derived from the fruit. 'Ilie present species approaches the preceling by its leares. Its fro are 2 lines long with a somewhat facial style and a prominent roumled keel when dry, but no lateral ridges.-In the Serpentine, Iyde Park, lonklon. Dr. J. A. Power. P. VII. E.

1․ P. pectinatus (L.); l. linear-setaceous 1 -nerved with transverse veins, spikes interrupted, $f r$. (large) roundly obovate rounded on the back with two lateral ridges but no keel when dry. -E. B. 3233? $R$. vii.t. 19.-L. narrower and more gradually acute than in the preceding. lir. 2 lines long with a somewhat facial style, their back rounded and prominent with a ridge on ench side lunt no true keel when dry. Fries and Koch deseribe the fr. as keeled, which ean searcely be correctly sail of our plant which agrees well with Reichenbach's figure.-Ponds, searce. Jerscy. Surrey. P. VI.

E.

19. P. filiformis (Nolte!); l. linear-setaceous 1-nerved with transverse veins, spikes greatly interrupted, $f r$. (smaller) obovate rugose rounded on the back uithout keel or ridges when dry.$P$. marinus Fries, Koch, $R$. vii.t. 18,-L. like those of the precerling but longer. Fr. smaller and rounded on the back without keel or ridges. Whorls very distant on the spikes. Peduncles very long.-Rare. Forfarshire and Berwickshire. P. VI. VII. E.? S.

[A plant found at Bath and Sandwich closely resembles P. trichodes (R. vii. t. 2l.) but has adnate stip. and transverse veins in its leaves. Its dry fi. is scmi-obovate, compressed, with 3 (?) obscure keels on the back. Probably a new species but I am not sufficiently acquainted with it to describe it.]

***** L. all opposite, submersed; stipules none.

20. P. densus (L.); l, all opposite pellucid clasping ellipticallanceolate or lanceolate, spikes shortly stalked ultimately reflexed. -E. B. 397. R. vii.t. 28.-L. crowded, rather recurved. Spike 4-flowered.-Ditches. P. VI.

\section{Ruppia Linn.}

1. R. maritima (L.); cells of the anthers oblong. $-R$. vii.t. 26. -Whole plant stronger than the next. $L$. very narrowly linear. Sheaths large inflated. Nut ovate, obliquely erect.-Salt marshes. Newhaven, Suss. Mr. Borrer. Guernsey. P. VII. VIII. O.

2. R. rostellata (Koch); cells of the anthers nearly round.$E . B .136$ ? R. vii. t. 25.-Whole plant very slender, L. rather filiform than linear. Sheaths small, close. Nut obliquely ascendiug, less so than in continental specimens.- Salt marshes. P. VII. VIII. 


\section{Zannichellia Linn.}

1. Z. palustris (L.); style at least half as long as the nut.E. B. 1844. R. vii. t. 16.-Floating. L. slender, opposite, filiform. Fl. axillary, sessile. Anth. 2-4-eelled. Stigma generally notelied at the margin. Nuts very shortly stalked.- $-\beta$. pedunculata; cluster of fr. stalked, nuts with elongated stalks. Z. pedunculata R.- [Z. polycarpa (Nolte) is distimguished by its very short style scarcely a sixth of the length of the nut.]-Stagnant water. A. or P. V.-VIlI. Horned Pondweed.

\section{Zostera Linn.}

1. Z. nana (Roth); 1. linear 1-nerved, ped. filiform, nuts smooth. $-R$. vii. 2.-Plant small, scarcely 3 in. long. L. slender. Pcd. quite as long as the inflated oblong-lanceolate spaths. I have seen no native spccimens.- On the castem coast? Dover. Mr. W. Sonder. P.? VII. VIII.

E.

2. Z. angustifolia (R.); l. lincar 1-3-nerved, ped. thickened upwards, nuts striated. $-R$. vii. 3.-Plant many times larger than Z. nana. L. broad. Ped. slender, quite as long as the linear spaths, each having a bifid linear bract at its base.-Seashore. P.? VIII. IX.

3. Z. marina (L.) ; l. linear 3-5-7-nerved, ped. short thick, nuts striated.-E. B. 467. R. vii, 4.-Plant very long. L. broad. Ped. stout, shorter than the linear spaths. Bracts 0?-Seashore. P.? VII. VIII.

[These plants are well deserving of study.]

\section{Subdivision II. GLUMACE E.}

Floral envelopes imbricated.

\section{Order XCI. CYPERACEA.}

Fl. perfect or unisexual, cach with a scale or glume imbricated on a eommon axis. Perigone 0, or rarely membranous. Stam. hypogynous, definite. Antli. erect, fixed by the base, entire at the apex. Ovary l-celled, often surrounded by bristles. Style simple, trifid or bifid. Embryo inelosed within the base of the albumen.-L, with entire sheaths'.

1 For figures of the genera of this Order see Gen. Fl. Germ. Monocotyl. vol. 2. 
Tribe I. CYPEREAE. l'. perfect. Glunes 2-ranked.

1, Cypfrus. Spikelets 2-ranked. Ghumes of l valve, numerous, keeled, nearly all with flowers. Bristles 0. Perigone 0 .

2. Scurcesus. Spikelets 2-ranked, 2-4-flowered. Glumes 6-9, lower ones sinaller, empty. Bristles few or 0.

Tr. II. SCIRPEAE. Nl. perfect. Glumes imbricated on all siles. Perigone 0.

3. Cladium. Spikelets 1-2-flowercl. Glumes 5 or 6 , the lower ones empty and smaller. Bristles 0 . Nut with a thick fleshy coat, tipped with the slender base of the style.

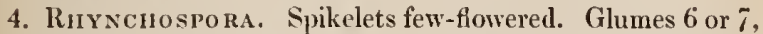
lower ones empty or smaller. Bristles about 6 . Nut compressed convex on both sides crowned with the dilated base of the style.

5. Eleocharis. Glumes fertile, lowermost larger, 1 or 2 of the lowest cmpty. Bristles $3-6$. Nut compressed, crowned with the persistent dilated base of the style.

6. Scirpus. Glumes fertile, nearly equal, or lowermost larger, 1 or 2 of the lowest empty. Bristles about 6 or 0 . Nut plano-convex or trigonous, tipped with the filiform not dilated base of the style.

7. Blysuus. Glumes fertile, outermost the largest and empty. Bristles 3-6. Style not thickened at the base, persistent. Nut plano-convex, tipped with the not-dilated base of the stylc. Spikelets bracteated, alternate, forming a close distichous compound terminal spike.

8. Eriophorum. Glumes fertile, nearly equal, lowcrmost sometimes empty. Bristles ultimately much longer than the glumes and accompanying the fr., silky. Nut trigonous.

Tr. III. ELYNEE. Fl. diclinous. Perigone 0 or formed of 1 or 2 scales.

9. Kobresia. Spikes aggregate. Lower fl. fem., perigone of 1 scalc inclosing the germen and covered by the glume. Upper fl. male, without any perianth.

Tr. IV. CARICEAE. Fl. diclinous. Nut completely inclosed in the urceolate perigone.

10. CAREX. Fl, in imbricated spikes, each corered by a glume. Female $\mathrm{fl}$. with a single urceolate persistent perigone, 1 style and $2-3$ stigmas. Male $f$. of 3 stam., without a perianth. 


\section{Tribe I. Cyperea.}

\section{Cyperus Lim.}

I. C. longus (L.); spikelets lincar-lanceolate in ereet twiee compound umbels, peduncles of partial umbels crect unequal, stigmas 3, root creeping.-E. B. 1309. St. 52. 10.-St. triangular, 2-3 feet high. Umbel very large unequal, its stalks triangular and closely slicathed at the basc, its base with 2 or 3 long leaves. Glumes brownish-red, with green keels and pale margins.-Soutl of Eingland, rare. P. VIII. IX.

E.

2. C. fuscus (L.); spikclets linear-lanceolate in small roundish hearls at the extrcmities of the branches, glumes sprearling, stigmas 3, root fibrous.-E. B. S. 26:66. St. 52.5.-1 small nearly prostrate plant. Stems numerous, $2-5$ in. long. Heads with 3 unequal 1. at the base. Glumes fuscous, with green keels.Little Chelsea, Hiddlesex. Peat-pond, Shalford Common, Godalming, Surrcy, Mr, J.D. Salmon. Jersey. P.VIII. IX. E.

\section{SCHOENUS Limn.}

1. S. nigricans (I.); st. round naked, spikelets 5-10 collected into a terminal roumdish head overtopped by the lower bract, glumes scabrous at the keel.-E. B. 1121. St.40.9.Root of strong black fillres. St. $8-12 \mathrm{in}$. high, clothed at the base with blackish-lorown smooth shining scales some of which terminate in setaceous ereet leaves which are shorter than the stem. Bristles variable in number, short, rough with upward spines. Stigmas 3 . Antll. terminating in a point. Glumes dark-brown or blaek,-Turfy bogs. P. VI.

\section{Tribe II. Scirpea.}

\section{Cladium Pat. Br.}

1. C. Mariscus (R. Br.); panicles lateral and terminal repeatedly compouml, spikelets capitate, st. roundish leafy smooth, 1. rough on the margins and keel.-E. B.950.-Root creeping. St. 3-4 feet high. L. very long, rigid, narrowed and triquetrous towards the end, the margins and keel with fine but very acute serratures. Fl, in cacli spikelet $1-3$, but usially only one nut is prodnced.-Bogs and fens, rare except in Cambridgeshire. P. VII. Common Sedge.

\section{Rhynchospora $V a h l$.}

1. R. alba (Vahl); spikelets in a compaet corymb about as long as the outer bracts, stam. 2 , bristles with deflexed teeth, 
base of the strle withont tecth.-E. B. 985. St.40.7.-Root slightly creeping. St. (i-12 in. high. L. namowly linear. Spikelets whitish. Iristles 9-12. Hilaments slender.- $\beta$. sordida; spikelets brownish, in small oval rhusters often overtopped by the outer bracts. - 'ruify bogss. P. VII.

2. R. fusca (Sm.); spikclets in an oval head considerably shorter than the onter bracts, stam. 3, bristles with ascending teeth, base of the style with erect teetli.-E. B. 1575. St. 40. 6. -Root ereeping extensively. St. (i-s in. high. L. nearly filiform. Spikelets brown. Iiristles 6 . Filaments dilated.-13ogrs, rare. South-west of Eingland. Ireland. P. VII. VIII. E. I.

\section{Eleocharis $R . B r$.}

1. E. palustris (R. Br.); spikes teminal solitary oblong, ghmmes rather acute: lowest $\frac{1}{2}$ surrounding the spike, stigmas 2 , nut obovate obtuse plano-convex with loninded margins smootl crowned with the broadly-ovate base of the style and shorter than the 4 bristles, base of the st. clathed with membranous obtusely-truncate sheaths.-E. B. 131. St.9. R. viii. 704.-Lxtensively creeping. Sheaths almost transversely-truncate with a very obtuse point on one side.-Wet and marsliy places. P. VI.

2. E. uniglumis (Link); spikes terminal solitary oblong, glumes rather acute: lowest almost surrounding the spike, stiginas 2, nut obovate obtuse rather compressel with rounded margins smooth erowned with the conical base of the style and sloorter than the bristles, base of the st. clothed with transverselytruncate sheaths. - $R$. viii. 703.-Extensively crecping. - Wet sandy places. Aberdeen. Dr. Dickie. Barvas, Isle of Lewis. P. VI. VII.

3. E. multicaulis (Sm.); spikes terminal solitary oblong, glumes obtnse, stigmas 3 , nut acutely triquetrous smooth crownel with the broal triquetrous base of the style as long as the 6 bristles, base of the st. clothed with obliquely truncate rather acute sheaths. -E.B.1187. St.78.11. R.viii.702.-Slightly creeping. Sheaths truneate so as to form a rather acute point on one side.-Marshy places. P. VII.

4. E. acicularis (Sm.); spike terminal solitary ovate, glumes obtuse, stigrmas 3, nut obovate-oblong compressed longitudinally ribbed and transwersely striated crowned with the turbinate base of the strle, bristles short deciduous. - E. B. 749. St. 10. R. viii. 695.--Root fibrous with slender runners. St. nımerous, slcuder, erect, 3-4 in. ligh. Spikes very small.-In damp places upon heaths. P.?, A. (Koch) VII. VIII. 


\section{Scrrpus Linn.}

* Bristles 6. Spikes numerous.

† St. triangular; paniele leafy.

1. S. maritimus (L.); spikes stalked or sessile in a dense terminal eluster, bracts several lenflike, glumes bifid with an intermediate point : segments acute, nut obovate trigonous smooth. -E. B.542. St. 13.3. R. viii. $726.727 .728 .-5 t .1-3$ feet high, leafy. Spikes large, sometimes solitary. Stigmas 3, or rarely 2. - Salt marshes. P. VII.

2. S. sylvaticus (L.); spikes clustered in a large cymose very compound terminal panicle : clusters stalked and sessile, general braets several leaflike, glumes obtuse with a minute apienlus, nut obovate obtnsely trigonous. $-E . B .919$. St.36.8. R. viii.731. -St. 2-3 feet high. Spikes very numerous, small, greenish, ovate. L. broad, flat. Stigmas 3.- [S. radicans (Schk.), spikes all stalked, scions long and rooting, will probably be found.] Damp woods and banks. P. VII.

\section{†† Stem triangular; paniele naked.}

3. S. carinatus (Sm.); st. round bclow obtusely trigonous upwards, spikes in a small cymose paniele, glumes emarginate mucronate slightly punctate-scabrous and pilose fringed, nut "convex on the baek smooth." -E. B.1983(1809). S. Duvalii St.36.2. (1814), Koch, R. viii. 724.-Roth (Enum.) refers bis S. trigonus to $S$. triqueter, and his $S$. triqueter to $S$. Rothii.-St. $2-4$ feet high, convex between the angles, with 1 or 2 long sheaths at the base, the upper sheath in all my speeimens terminates in a leaf of 3 or $4 \mathrm{in.long}$; most authors deseribe the plant as leafless. Lower bract much longer than the paniele. Stigmas 2.-By rivers, near London and in Sussex. P. VI. VII.

E.

4. S. triqueter (L.); st. acutely triquetrous throughout, spikes in a small cymose paniele, glumes emarginate mueronate glabrous fringed: lobes rounded olutuse, nut "roundish-olovate planoconvex smooth." -E. B. 1694. St.36.3. R. viii. 719.-St. 3-4 feet high, flat or coneave between the angles, with 1 or 2 long sheaths at the base the upper one terminating in a very short broal triquetrons leaf. Lower braet long and rigid, resembling a prolongation of the stem. Spikclets small, stalked and sessile. "Anth. with a short beardless point." Stigmas 2.-Muddy banks of the Thames near London; and the Arm, Sussex. P. VIII.

5. S. Rothii (IIoppe); st. acutely triquetrous throughout, spikelets few sessile, glumes bifid mucionate smooth : lobes acute, nut roundisli-oborate plano-convex smooth.-S. pungens (Vahl) E. B. S. 2s19. R. viii. 717.718. St.36.4. S. tenuifolius DC. 
S. triqueter $\beta$. Sm.-St. from a few inches to $1 \frac{1}{2}$ foot high, sleneler, with several sheatlss at the base terminating in long narrow keeled leaves. Lower bract very long and rigid, resembling a prolongation of the stem. Spikelets large, ovate, obtuse, all sessile. Antlı. witl a subulate fringed point. Stigmits 2.-St. Ouen's Pond, Jersey. P. VI. VII.

\section{†† Stem terete.}

6. S. lacustris (L.) ; st. round, spikes in a terminal twice eompound panick, glumes emarginate mucronate glabrous fringed, unt obtusely trigonous obovate, stignas 3.-E. B.666. St.36. I. $R$. viii. 722.-St. 4-6 feet high, naked, with 1 or 2 long sheaths at the base. Anth. bearded at the end. Panicle terminal, the bract sometimes resembles a continuation of the stem. Sometimes the sheaths bear long nearly flat floating leaves.-Rivers and ponds. P. VI. VII. Bull Rush.

7. S. Tabernamontani (Gm.); st. round, spikes in a terminal compound panicle, glumes emarginate mucronate punctate-scabrous fringed, nut compresserl roundish-oblong smooth, stigmas 2 . -R. viii. 723. S. glaucus Sm., E. B. 2321.-St. 2 fect high, with 1 or 2 long leafless shcaths at the base. Anth. not bearderl. Panicle smaller than in the preceling. Lower bract short. Fr. convex on one side.-Rivers and ponds. P. VI. VII.

**Bristles 4-6. Spikes solitary, terminal. Baeothryon Dietr.

8. S. caspitosus (L.) ; st. round striated with imbrieated leafless acute seales and sheaths with short subulate $l$. below, spikes terminal solitary ovate few-flowered, glmmes ovate membranous pointed, 2 outer ones as long as the spike inclosing it and teruinating in long rigid leaflike points, nut obovate oblong mucronate smooth, bristles longer than the nut with a few ereet teeth near the tip.-E. B. I029. St.10. R. viii. 710.-St. 3-6 in. long, numerous, erect, many of them barren. Bristles 6.-Barren turfy heaths. P. VI.-VIII.

9. S. pauciflorus (Lightf.); st. round striated with a few thin narrow leafless scales and one tight abrupt leafless sheath below, spikes terminal solitary ovate few-flowered, glumes ovate keeled membranons at their edges, 2 outer ones obtuse shorter than the spike and inclosing it, nut obovate mueronate reticulate-striate, bristles shorter than the nut with deflexed teeth.-E. B. 1122. St. 10. R. viii. 707.708.-St. 3-10 in. long, numerous ereet many of them barren. Bristles 6.-Boggy moors and heaths. P. VI.-VIII.

10. S. parvulus (R. and S.); st. round with one close-pressed leafless sheath, $l$. filiform acute radical slightly dilated at the base aud elasping the st., spikes terminal solitary oval few-flowered, 
glumes ovate obtuse kecled membranous, 2 outer ones rather longer, nut obovate-oblong imueronate smooth, bristles twice as long as the mut with deflexed teeth throughout. - St. 85. I. R. viii. 706. Eleocharis Hook. S. lumilis Wallr-ZRoot fibrons with capillary seious. St. about an inch lighl, several from the same root. St. and 1. with 2 or 3 longitudinal fibres and more or less perfect transverse lines. Bristles $4-6$. - On a mud-flat near Lymington, Ilants. Rev. G. E. Smith. It is fearel that the station is now destroyed. A. VII.

\section{*** Bristles 0.-† Spikes solitary. Eleogiton Link.}

I1. S. fluitans (L.) ; st. floating branched leafy, l. fascieulate, fl.-stalks alternate with a sheathing $l$. at the basc, spikes terminal solitary ovate few-flowered, glumes obtuse kecled membranous at their edges, 2 outer ones larger shorter than the spike and inclosing it, nut obovate, bristles 0, stigmas 2.-E. B. 216. St.85.2. $R$, viii. 705.-St. rooting from the lower joints and spreading to a great extent in a zigzag manner.-Ditches and ponds. $P$. VI. VII.

\section{†† Spikes I-3. Isolepis R. Br.}

12. S. setaceus (L.); st. terete leafy at the basc, spikes terminal, lower bract elongatel so as to resemble a short continuation of the st., glumes olstuse mucronate, nut trigonous obovate longitudinally ribbed and transversely striated, bristles 0 , stigmas 3.-E. B. 1693. St. 10. R. viii. 711.712.-St. tufted, slender, 3-6 in. high. Spikes small, sessile, considerably slorter than the lower bract. Glumes brown with whitish margins and a green keel.-Wet sandy and gravelly places. P.? VII.

13. S. Savii (S. and M.); st. terete leafy at the base, lower bract shorter or slightly longer than the terminal spikes, glumes obtuse submucronate, nut subglobose rough with slightly elevated points, bristles 0 , stigmas 3.-E. B. S. 2782. R. viii. 714.Closely resembling $S$. setaceus. Spikes varying considerably in lengtli, sometimes $\frac{1}{4}$ in. long. Glumes scarcely mucronate, greenish, usually with a brown spot on the upper part of eaeh side.- $\beta$. monostachys (IIook.); spike small solitary, braet very short. Isolepis pygmaa Kunth.-In many plaees near the eoast. P.? VII.

†† Spikes numerous, in heads. HoLoschanus Link.

14. S. Holoschœenus (L.); st. round, spikes in dense globular sessile or stalked heads, lower involucral bract ereet long, glumes obovate emarginate mucronate.-E. B. 1612.-St. $3-4$ feet high, round quite up to the cluster. Upper bract patent or ascending; lower very long, with a flat open white channel. Glumes variegated with fuseous and white, pilose. Anth. witl 
an clongated entire point. I cannot identify our plant satisfactorily with either of those figured by Reich. (viii. 736-741).Sandy coast of Somerset and Ievon, rare. P. IX.

\section{Buysuus Panz.}

l. B. compressus (P'anz.) ; st. rather triangular, spikelets $6-8$ flowered, onter glmine shorter than the spikelet, bristles $3-6$ strong persistent with deflexed teeth, l. flat rough on the calges and keel.-Scirpus Sm., E. B. 791. St. 85. 6. R. viii. 693.-St. $6-8 \mathrm{in}$. high. Outer glume of the lowest spikelet with a subulate leaflike point which often overtops the spike. Glumes reddishbrowu, striated. Nut lenticular, shortly stalked, crowned with the long persistent style, shining.--Boggy pastures. P. VI. VII.

E. S.

2. B. rufus (Link); st. round, spikelets 2-4-flowered, outer glume as long as the spikclet, bristles $1-6$ slender deciduous with patent or aseending tceth, l. channcled not keeled smooth.Scirpus Sm., E. B. 1010. St. 85. 7. R. viii. 694.-St. slender. Glumes dark-brown, polished, not striated. Nut ovate with a long beak and very short stalk, opaquc.-Marshes near the sea on the northern and western coasts. P. VII.

\section{Eriopiorum Lim.}

* Bristles 4-6, at length crisped. Spike solitary.

1. E. alpinum (L.); st. triquetrous scabrous, l. very short, spike oblong.-E.B. 311 (excl, the leafy shoot). R. viii. 683.684. St. I0. A A slender elegant plant now lost (?) through the drainage of its place of growth.-MIoss of Restenet, Forfar. Mr. Brown. P. VI.

** Bristles very numerous, not crisped.

+ Spike solitary.

2. E. vaginatum (L.); st. triangular above round below, spike oblong, nut obovate, l. long setaceons, upper sheath inflated leafless.-E. B. 873. St. 10. R. viii. 686.-Bogs and moors. P. V. Hare's-tail Cotton-grass.

[3. E. capitatum (Sm.); "st. entirely round with a swelling sheath, spike roundish, glumes membranous."-E. B.2387.-By a rivulet on Ben Lawers near perpetual snow, once found. $M r$. G. Don. Mr. Don's authentic specimen in Sir W. J. Hooker's Hcrb. resembles $E$. capitatum but the upper part of its st. is triangular. There is no speeimen in Sm. Herb. P. VIII.] S.

十† Spikes more than one.

4. E. polystachion (L.); st. round, peduncles smooth, l. linear 
ehanneled their upper half triangular, nut elliptie-aeuminate or obovate triquetrons.-E. B. 564. St. 10. R. viii. 689. 690. E. angustifolium Sm.-Tall and rather slender. I.triangular througl more than lialf their length. Bristles 3 or 4 times as long as the spikes.-B. elegans; st. and l. very slender. E. gracile Sm., E.B. 2402 , not Koch. In alpine form of this varicty (found in spongy rills on Ben Lawcrs, S.) often has but one nearly sessile spike. $-\gamma$. elatius (Kocli); st. strong tall, 1. 2-3 lines broad the triangular part commencing above the mildlle, bristles about 3 times as long as the spikes. E. polystachion sm. Eng. Fl, i. 67.Bogs. $\beta$. in mountainous distriets. $\gamma$. rather rare, more eommon in Ireland. P. V. VI. Common Cotton-grass.

5. E. latifolium (IIoppe); st. triquetrous in its upper half, peduncles scabrous, l. linear nearly tlat eontracted above the middle into a triangular point, mut obpyriform triquetrous. - St. 10. R. viii. 691. 692. E. pubescens sin., E. B. S. 2633 . E. polystaclion E. B. 56.3? - A tall rather slender plant. L. about 2 lines broad, triquetrous point short. Several of the elegant spikes upon longislı stalks whieh are not downy but seabrous. Bristles 2 or 3 times as long as the spikes.-Bogs, rather rare. P. V. VI.

6. E. gracile (Koeh); st. somewhat triquetrous, peduncles downy, l. narrowly-linear triquetrous, nut oblong-linear triquetrous.-E. B. S. 2886. R. viii. 687.688. E. triquetrum Hoppe, St. 10. 2.-A tall slender plant. Spikes about 4, most of them on downy not sealorous stalks. Glumes with many ribs. Bristles about twiee as long as the spike.-Bogs. Near IIagnalyy, Yorkshire. Mr. Jos. Woods. White-moor Pond near Guildford. MIr. Borrer. P. VI. VII.

E.

\section{Tribe III. Elyneæ.}

\section{Kobresia Willd.}

1. K. caricina (Willd.).-E. B. 1410. Schk. Rrr. 161. R. viii. t. 193.-St. ereet, $6-12$ in. high. L. slender shorter than the stem. Spikes $4-5$, aggregated at the summit of the stem, 6 -8-flowered. There is often an abortive stam. (?) at the base of the nut. Some authors eonsider each $f l$ as a separate spike, and the rudiment as representing a seeond flower. Nees von Esenb. figures 2 seales to the perigone, but I have only seen one. -Moors. Yorkshire. Durham. Perthshire. P. VII. E. S. 


\section{Tribe IV. Caricee.}

\section{Cakex Linn.'}

i. Spike simple, solitary. Stigmas 2.-* Diœcious.

1. C. dioica (L.); fem. spike ovate dense, glumes obtuse, fr. ascending ovate many-nerver angles rough near the summit, nut romulish-oval, st. and l. sinootl, root ereeping. - E. B. 543. Schk. A. 1. H. a. 1. R. $522 .-\Lambda$ bont 6 in. higl. Sometimes the nale spike has a single fruit at its base--Spongy bogs. P. V. VI.

2. C. Davalliana (Sin.); fr. deflexed ovate-lanceolate ribbed angles rough near the sumnit, nut "linear-oblong," st. and margins of the l. rough, root fibrous.-E. B. 2123. Schk. A.2. W.2. II. a. 2. R. 523.--About 6 in. high.-Lansolown near Bath, now lost by drainage. Several other stations have been given, but it is doubtful if they refer to this plant. P. VI. $\quad$ E. S.? I.?

\section{** Androgynous.}

3. C. pulicaris (L.); spike with the upper half barren, fr. remote at length deflexed oblong narrowed at both ends compressed, nut oblong-obovate, glumes deciduous.-E. B. 105l. Schk. A. 3. H. a. 3. R. 524.-St. slender, 6-12 in. or more in height, ereet, smooth. L. slender, ereet, smooth. Fr. dark brown.Bogs. P. VI.

\section{ii. Spike simple, solitary. Stigmas 3 .}

4. C. rupestris (All.); spike with the upper half barren, $f r$. obovate triquetrous with a very short beak adpressed searcely longer than the persistent glumes, "nut obovate acutely triqnetrous." -E. B. S. 2814. H. b. 4. R. 531.-St. 3-6 in. high, acutely triangular, rough upwards. $L$. flat ending in a tortuous rough slender triangular point. Glunes fuscous. Fr. paler. Leighton's fig. appears to have been taken from an immature fruit.-Lofty inountains. Glen Callater and Little Craigindal, Braemar. Inchnadamff, Sutherland. Rev. Churchill Babington. Glen Dole, Clova. Dr. Balfour. P. VII.

5. C. pauciflora (Lightf.); spike with 1 or 2 terminal barren florets, fr. 2-4 lanceolate-subulate terete patent or reflexed longer than the deciduous glumes, nut linear-oblong obtusely trigonous.

1 In the description of the Carices fruit must be understood to mean the nut or true capsule covered by the persistent bottleshaped perigone, and it is to be examined when ripe. See plates in Leighton's $\mathrm{Fl}$. of Shropshire. The glume deseribed is always taken from the fertile spike unless it is otherwise stated. Schk. refers to the plates of Schkuhr's Riedgräser; H. to Hoppe's Caricol. Germ. in Sturm Deutschl. Flora; and $R$. to Reichenbach Ic. Fl. Germ. Cent. viii. 
-E. B. 2041. Schk. A. 4. H. b. 1. R. 526.-St. usually about 5 inche's high, slender. I. 22 or 3, much shorter than the stem. Fr. pale yellow, striated.-Bogs. Seotland. Northumberland. P. II. VII.

E. S.

iii. Spikclets androgynous in a compound continuous or interrupted spike. Stigmas 2.

* Spikelets sterile at the end.- + Root crecping.

6. C. incurva (Lightf.); spilielcts collected into a roundish head, fr. intlated broally ovate acuminate-rostrate, beak smooth obliquely truneate, nut obovate compressed, st. smooth about as long as the leaves.-E. B. 927. Schk. IIh. 95. H. a. 5. R. 533. - Root creeping extensively. St. 2-3 in. high, usually recurved so as to bring the large head down to the ground. Fr. with its beak vccasionally rather scabrous.-Sandy shores of the north. P. VI.

7. C. divisa (Huls.); spikelets collected into a somewhat ovate heal, $f r$. plano-convex ovate many-nerved, beak acutely bifid with finely serrated edges, nut broadly oblong compressed, glumes with an excurrent rib, lowermost bract leatlike, st. roughish at the summit.-E. B. 1096. Schk. R. and Vv. 61.--St, slender, a foot high. Fr. nerved upon both sides. Sjike often interrupted below. - Near the sea on the southern and eastern coasts. P. V. VI.

8. C. intermedia (Good.); spikelets collected into an oblong interrupted spike upper and lower ones fertile intermediate barren, $f r$. ovate-lanceolate nerved narrowly margined bifid with serrated edges above, nut (usually abortivc) clliptical, glumes shorter than the $f r$. acute the midrib not reaching the summit, st. with scabrous angles,-E. B. 2042. Schk. B. 7. H.a. 14. R.552.-Height 1-2 feet. Fr. slightly widened at the base of the beak which is deeply divided on one side. Lowermost bract with a slender leaflike point.-Marshy places. P. V. VI.

9. C. arenaria (L.); spikelets collected into an oblong interrupted spike upper barren lower fertile intermediate barren at the end, $f r$. ovate nerved winged and finely serrate from the middle to the bifid sunmit of the beak, nut bluntly ovate, glumes longer than the fr. acuminate, st. scabrons above.-E. B. Y28. Schk. B. and Dd. 6. H.a. 13.-IIeight 1 foot. Root creeping extensively and binding loose sands. Lowermost bracts with slender leaflike points.-Sandy places. P. VI.

\section{†† Root fibrous.}

10. C. vulpina (L.); spikelets compound collected into a cylindrical crowded spike, fr. ovate-acuminate plano-convex nerved bifid finely serrate above divergent, nut oval compressed tipped 
with a beak slightly thickened "pwards, glumes mucronate shorter them the fruit, st. acoutely triquetrons with seabrons angles, bracts setaceous.-L. B. 307. Schk. C. 10. II. a. 16. R.56-4.-Ileight 2 feet. st. firm; faces concave, I. broul. Fr. palish green. Beak of the nut constricted, its base narrower than the base of the style.-Wet places. P. VI.

11. C. muricatu (L.); spikelets approximate iv an ohloug spike dense or interrujted below, $f r$, ovate-acuminate plano-convex obsoletely nerved bifil finely serrate above divergent, nut ovate compressed its heak extremely short, ghumes mucronate shorter than the fruit, st. smooth with rongh angles.-E. B. 1097. R.561. C. contigua $H$. a. 10.-II cight $1-2$ fect. St. slender. L. narrow. Lowermost spikelets not more than their own length distant from each other. lir. with a broal flat beak with very sharp edges.-Gravelly pastmes. I’. VI.

12. C. divulsa (Good.); spikelets distant the upper ones approximate, $f r$. ovate acute plano-convex obsoletely nerved bifid smooth ascending: beak slightly rough at the edges, nut ovateoblong compressed its beak extremely short, glumes mucronate shorter than the fruit, st. smooth with rough angles above, bracts short setaceous. $-E . B .629$. Schk, Dd. and Ww. 89. H. a. 16. R. $5 \%$ 0.-Height $1-2$ fect. More slender than the preceding. Spikelets gravish, nsually distant, 1 or 2 lowest often lengthened into a short branch. Fr. with a thick green margin slightly rough near the summit.-Moist shady places. P. VI.

13. C. teretiuscula (Good.); spike compound oblong, spikelets densely aggregated, $f r$. ovate-gibbous with $2-5$ central nerves on the convex side : beak bidentate serrulate subtriquetrous strongly winged on the convex side, nut turbinate convex on both sides: beak extremely short, style not thickened at the base, st. trigonous and scabrous above with convex faces.-E. B. 1065. Schk. D. 19. T. 69. H. a. 9. R. 572.-Root forming scattered simple tufts. St. $1-2$ feet high, slender.- $\beta$. Ehrhartiana; root more exspitose, spike elongated, spikelets rather loosely aggregated, nut narrowed from below the middle, st. triquetrous above. C. Ehrhartiana Hoppe!, C. pseudo-paradoxa Gibs. !Boggy meadows, rare. $\beta$. near Manchester. P. VI.

14. C. paradoxa (Willd.); spikes narrowly panicled lower branches rather distant, $f r$. ovate gibbous with numerous short elevated ribs near its base : beak bidentate serrulate with no wing on its convex side, nut rhomboilal constricted below convex on both sides with a short beak, style slightly enlarged at the base, st. trigonous and scabrous in the upper part with convex faces. -E. B.S.2896. Schk. E. 21. H. a. 12. R. 573.-Root densely tufted, crowned with the fibrous remains of decayed leaves. St. 
1-2 feet high, slender.-In a boggy wood at Ladiston near Mullingar. Ireland. Mr. D. Moore. Ascham bog and Heslington field, York. Mr. R. Spruce. P. VII. E. I.

15. C. paniculata (L.); spikes panicled with elongate diverging branches, $f r$. ovate gibbous obscurely many-nerved with a bifid fringed triangular beak winged on its convex side, nut ovate obtuse narrowed below compressed-triquetrous: beak slightly thickened upwards, st. triquetrous with flat faces.-E. B. 1064. Schk. D. 20. Ttt. 163. H. a. 19. R. 574.-Root forming dense elevated crespites. St. stout, 2-3 feet ligh. Panicle usually large and spreading but occasionally reduced to a slender compound (or even simple) spike. Bracts all much shorter than the spike.-Bogs. P. VI.

16. C. Boenninghausiana (Weihe); spikelets sevcral upper ones simple crowded lower distant composed of alternate spicula, fr. laneeolate plano-convex tapering into an almost cntire beak strongly serrated from below the middle (nut obovate-elliptical pointed ?), glumes equalling the fruit, root tufted, lower braet as long as, or longer than the spike.-E. B. S. 2910. H. a. 34. Kunzc Riedy. 22. R. 568. C. Hailstoni Gibs.!-St. 1-2 feet high, triangular with slightly convex faces and rough edges. Inflorescence often a foot long. Rachis straight with 3 rough edges. Glumes ovate, membranous, silvery brown, smooth. Lower spikelets composed of spiculæ disposed alternately in the manner of a spike along the rachis of the spikelet. Bracts, except the lowest, short. L. channeled. "Male fl. at the top of the spikelets." Coleman.-Sussex. Hertfordshire. Edinburghshire. Bamffshire. P. VI.

E. S.

17. C. axillaris (Good.); spikelets scveral upper ones simple erowded lower distant composed of several crowded spicula, fr. ovate-lanceolate plano-convex tapering bifid scrrated above, nut obovate with a beak, glumes shorter than the fruit, root tufted, lower bract as long as, or longer than the spike.-E. B. 993 . H. a. 33. - St. $1-2$ feet high, acutely triangular. Rachis straight with 3 rough angles. Glumes ovatc, membranous, brownish, midrib often rough, extending to the point. Spieulæ of the lower spikelets erowded into the axils of the bracts. Bracts, excent the lower one, short. L. flat. Base of the style slightly thickened. "Male fl. terminal." Coleman.-Marshes, rather rare. P. VI.

\section{** Spikelets sterile at their base.}

18. C. remota (L.); spikelets several all simple upper ones crowded lower distant, fr. ovate-acuminate plano-convex bifid at the end scrrated above, nut elliptical with a beak, glumes shorter than the fr., root tufted, bracts elongated.-E.B.832. Schk. E. 
23. H. a. 35. R. 556.-St. $1-2$ feet high, trigonous with couvex faces. Rachis zigzag, with 2 rough angles in its 11 p'per part. Ghuncs oblong, membranous, greenish-white, midrib smooth usually not reaching the point. Spikelets all simple. Several of the bracts elongated. L. chameled. Base of the style slightly thickencel. Base of st. sometimes prolonged laterally into a thick rooting densely proliferous rhizoma. R. 557.- Ilooker refers C. tenella (Sm.) to this species. According to Simith it differs by its small spikelets with a terminal sterile $f$., and $f r$. equally convex on both sides. Schknlur refers his C. gracilis and C. tenella to C. loliacea (L.) which has the lowermost fl. sterile and ribbed fruit. It should be looked for "in a wood by the Lisk, Angusshirc."-Damp places. P. VI.

19. C. elongata (L.); spikelets numerous oblong approximate, fr. patent oblong-acuminate plano-convex with many ribs on both sides: beak almost entire with rough edges, nut linear-oblong tapering below beak very short style persistent, glumes shorter than the fruit, bracts none or one very short. $-E$. B. 1920. Schk. E. 25 . H. a. 32 . R. 565 . - St. $1-2$ feet high, triquetrous. Glumes ovate, dark brown with a green keel and whitish edges, obtuse sometimes apiculate. Upper spikelets erowderl, lower lax, the interval between them not exceeding their own length. - IIarshes, rarc. P. VI.

E. I.

20. C. stellulata (Good.); spikelets about 4 roundish rather distant, fr. patent broally ovate acuminate plano-convex striated : beak bifid with serrated edges, nut ovate obtuse tapering below, glumes shorter than the fruit.-E. B. 806. Schk. C. 14. H. a. 28. R. 560.-St. $6-12$ in. high, triquetrous, nearly smooth, lowermost spikelet often with a short bract. Glumes ovate, inembranous, reddish with a green kecl and white edges. Fr. greenish.-Boggy meadows. P. V. VI.

21. C. curta (Good.); spikelets $4-6$ elliptical approximate, fr. erect ovate acute plano-convex faintly striated: beak short emarginate not split rough at the edges, nut elliptical : beak very short style persistent, ghumes ovate shorter than the fruit.E. B. 1386. Schk. C. 13 . C. cancscens H. a. 31. R. 546.-St. a foot high, triquetrous, smooth except at the top. Lowermost spikelet often with a setaceous bract. Glumes membranous, whitish with a green keel, blunt, apiculate. Fr. whitish.-Bogs, rare. P. VI.

22. C. Persoonii (Sieber); spikelets $4-8$ ovate or oblong approximate, fr. erect ocate plano-convex faintly striate : beak short split to its base on one side rough at the edges, ghumes ovate shorter than the fruit.-R.547. C. Gebhardi H. a. 30. not Schk. C. curta $\beta$. alpicola $W a h l$., $B a b$.-St. 6-12 in. high, triquetrous, smooth except at the top. Lowermost spikelet often with a 
sctaceous braet. Glumes membianous, brown with a white margin.-Alpine places. Ben Wyvis. Ben Lawers. Loch na Gar. P. VII. VIII.

23. C. leporina (L.!); spikelets $3-4$ roundish-elliptical contiguous, fr. crect elliptical acuminate plano-convex narrowed below nearly entire at the point with smooth erlges, "nut elliptieal tipped with the persistent style," glumes ovate nearly as long as the fruit. - E. B. S. 2815 . C. leporina Linn. F7. Lap. not Fl. Suec. C. lagopina $W$ all., H. a. 24, R. 543.-St. $4-8$ in. ligh, smooth, triangular. Glumes reddish with the margins paler. Fr. yellow. - On the south side of Loch na Gar. Dr. Dickie. P. VIII.

S.

24. C. ovalis (Good.); spikelets about 6 oval contiguous, fr. erect ovate-attenuate plano-convex narrowed below bifid at the point with membranous margins serrulate above, nut elliptical with a short eylindrical beak terminating in the persistent style, glumes lanceolate as long as the fruit.-E. B.306. Schk. B. S. C. leporina $H$. a. 22, R. 554.- St. 1-2 feet high, triangular, smooth or roughish above. Glumes lanceolate, acute, brown with a paler membranous margin. Fr. yellowish.-Marshy meadows. P. VII.

iv. Terminal spike androgynous, sterile $\mathrm{fl}$. at the base. Stigmas 3.

25. C. Vahlii (Schk.); spikes 1-4 roundish or oblong contiguous nearly sessile, $f r$, obovate triquetrous scabrous above with a short notched beak longer than the ovate rather acute glumes, nut obovate triquetrous blunt with a short cylindrical beak, braet scarcely overtopping the spikes, st. triangular rough towards the summit.-E. B. S. 2666. Schk. Gg. 94. and Ppl. 154. R. 588.St. 6-12 in. high, erect. Glumes brown or black.-Glen Callater and Glen Phu, Clova. P. VII.

S.

26. C. Buxbaumii (Wahl.); spikes $3-4$ oblong sessile eontiguous, the lowest shortly stalked rather distant, fr. oval obtuse compressed (ultimately trigonous) bidentate subseabrous above shorter at the base of the spike than the cuspidate glumes, nut obovate trigonous blunt apiculate, lower bract leaflike.-E. B.S. 2885. H. b. 11. Schk. X. and Gg. 76. R. 589.-St. $1-2$ feet high, triquetrous, rough. Sheaths of the l. connected by netlike filaments. Glumes nearly black with a green keel prolonged into a cuspidate point. Fr. glaucous-green.-Dr. Boott has shown that this is the true $C$. canescens ( $\mathbf{L}$.) but it is surely better not to change the name by which it is universally known.-Island near Toom bridge in Lough Neagh. P. VI.

27. C. atrata (L.); spikes 3-4 ovate-oblong shortly stalked eontiguous ultimately drooping, the lowest rather distant and 
with a longer stalk, $f r$, elliptical-triquetrous with a short terete slightly noiched beak broader but not longer than the acute glumes, nut elliptical triquetrous blunt apiculate, lower bract leaflike.-

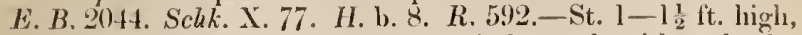
triangular, nsually smootl. Glumes dark purple with a sleniler palc nindrib. Fr. yellowisl. $-\Delta$ p pine rocks. P. VI. VII. L. S.

\section{v. Terminal spikes barren, 1 or 2 . Stigmas 2.}

28. C. vulgaris (1'rics); spikes ercet, barren 1 or 2 , fertile 3-4 subsessilc cylindrical, bracts with short auricles leaflike, fr. elliptical plano-convex with many nerves below and a short entire beak, nut roundish very blunt with a short slender beak, st. acutely triangular rough towards the top,-C. cespitosa Sm., E. B. 1507 . C. Goodenovii Gay.-St. about a foot high. $L$. slender, not keeled; sheaths not filamentous. Bracts without sheaths. Spikes near together, short. Glumes shorter than fr., jurple; kecl slender, pale green. Fruit greenish or with a purple tinge. Nut rather broader than long.-Marshes. P. V. VI.

29. C. caspitosa (L.); spikes erect near together, barren 1 , fertilc subsessile oblong, bracts with long auricles lowest alone slender leaflike short, fr. elliptical acute lenticular not nerved rather patent with a short entire beak, sheaths of 1 . with a slight web.-R. 582. C. pacifica Drcj.-Caspitose. St. slender, acntely triangular. Spikes close together. Leaflike bract usually solitary; auricles long and narrow. Glumes lanceolate, dark purple; keel rather paler.-“Britain. Dr. Greville." Fries. P. V. ?

30. C. rigida (Good.); spikes erect, barren 1, fertile oval or shortly cylindrical dense subsessile, lower bract leaflike, $f r$. elliptical doubly convex without nerves with a very short entire beak, nut roundish blunt with a slender beak, st. acutely triangular rough towards the top, $l$. with deflexed edges.-E. $B$. 2047. H. a. 40. R. 578.-Stoloniferous. St. 6 in. to a foot or more high. L. broad, flat, keeled, rigid. Bracts without sheaths. Spikes near together, short, rarely narrowed and laxly-flowered below. Glumes about as long as the fr., purple with a green keel. Nut rather longer than broad.-In wet and stony places on mountains. P. VI. VII.

31. C. aquatilis (Wahl.); spikes erect, barren 1 or more, fertile 3 or 4 elongated narrowed below lower ones stalked, bracts leaflike erect overtopping the stem, fr. elliptical lenticular without nerves broader than the glumes: beak very short entire, nut oblong narrowed below with a short slender beak, st. trigonous smooth.-E. B. S. 2758.-Tufted (stoloniferous Fries). St. 1-4 ft. high, with convex faces and obtuse angles. L. narrow; sheaths not filamentous. Spikes rather distant. Glumes usually 
short, always mueh narrower than the yellowish-green fr., reddish-purple with a pale midrib.-Alpine table-lands of the Clora mountains and in the valley by the bridge at Clova. P. VII. S.

32. C. stricta (Gool.): spikes ereet, barren 1 or more, fertile subsessile elongate-eylindrieal, braets aurieled lowermost leaflike short, fr. oblong-elliptical acute compressed on both sides nerved closely imbrieated with a short entire beak, nut roundish oborate blunt with a short leak, sheaths of 1 . eomeeted by filamentous network.-E. B.914. R. 583.-Densely erespitose. St. 2-3 ft. high, aeutely triangular. L. short. Glumes laneeolate, acute, equalling or shorter than the fr., narrow, dark purple; keel green. Fr. in 8 or 9 regular rows.-Marshes. P. VI.

33.? C. Gibsoni (Bab.); spikes ereet, barren 1, fertile 2-4 oblong narrowed downwards slightly stalked, braets with short auricles leaflike, $f r$. lanceolate acute with many nerves not reaehing the summit and a short entire beak, nut broadly obovate very blunt with a short thick beak, st. aentely triangular or triquetrous rough towards the top.- $A$. N. H. xi. t. 5.-Creeping. St. 6-8 in. high. I. flat, not keeled : sheaths not filamentous. Lowest braet often overtopping the stem. Spikes lax below. Glumes $\frac{1}{3}$ shorter than the fr., oblong, blunt, purplish-brown with a broad green band up the midrib; on the barren spike paler, obovate-laneeolate. Perigone nearly twice as long as the nut, gradually narrowed from below the middle to the top. Nut rather broader than long.-This very remarkable plant may, as seems generally suspeeterl, be an abnormal form of some speeies (perhaps C. acuta as suggested by Dr. Boott), but after a eareful re-examination of it I am unable to refer it to any one.- Hebden Bridge, Yorkshire; said to be now lost by drainage. Mr. S. Gibson. P. VI.

E.

34. C. acuta (L.); barren spikes $1-3$, fertile 3 or 4 slender crlindrieal-aeuminate ereet in fruit, lowermost braet leaflike often surpassing the stem, with elongate auricles, fr. oblong lentieular nerved bieonvex with a short entire beak, nut roundishoborate with a short slender beak, glumes aeute.- E. B. 580 . Schk. Ee. Ff. 92. H. a. 44.-St. 2-3 feet high, acutely angular, rough. L. broad and flat, sheaths not filamentous. Glumes narrow-laneeolate aeute, on the male spikes spathulate-laneeolate, purple with a green keel. Fr. pale. Fertile spikes usually with a few barren $\mathrm{fl}$. at the end, nodding when in flower.-Wet places. P. VI.

35. C. saxatitis $\left(\mathrm{I}_{0}\right.$ ) ; barren spikes 1 (rarely 2 ), fertile 1 or 2 roundish-ovate lower one stalked braeteated sheathless ereet, $f r$. ovate nerveless inflated: beak short notched, "nut roundish mucronate," stigmas $2-3$, glumes bluntish.-C. pulla Good. E. B. 
2045. Schk. Ce, 88. -St. 6-8 in. high. Glumes dark pumple tipped witl white, midrib dark purple. Fr. dirk purple, paler at the base, longer than the glumes, stalked.-Dr. Boott has ascertained from the Limn. and lianks. II(r), that this is the plant of Limneus, thus confirming the opinion of Sinith and solander whieh is doubted by Gay.-I I et parts of the ligher Seottish mountains. P. VI.

36. C. Grahami (Boott); barren spikes 1 or 2 slender acute, fertile 2 or 3 ovate obtuse lower one stalked bracteated sheatlless, fr. oblong-ovate nerved inflated narrowed into a short bifid beak, nut......, "stigmas 2," glumes acute.-St. $1-2 \mathrm{ft}$. high. Glumes fuscous witl the tip and midrib pale. Fr. pale or darkish brown, nearly twice as long as the glume, with several strong ribs on eaeh side. Nut abortive in all the specimens whieh I have seen.-Glen Plu, Clova, Forfarshire. P. VII.

vi. Terminal spike barren solitary. Stigmas 3 .

\section{* Fruit glabrous.}

$\dagger$ Fertile spikes short, mostly ereet.

37. C. flava (L.); fertile spikes roundish-oval subsessile lower one with a nearly ineluded stalk, braets leafike with slort sheaths, glumes obtuse, fr. ovate intlated ribbed smootl witl an ereet or deflexed rough-edged bifid beak, nut obovate trigonous punctate-scabrous, st. bluntly-trigonous smooth.-E. B. 1294. Schk. II. 36. H. b. 22. R. 654.-St. 6-12 in. high. L. broad. Barren spike cylindrical, obtuse : glumes obtuse. Fertile spikes usually near together, sometimes distant : glumes with a green midrib slightly rough and often exeurrent at the end. Beak of the fr. eurved down wards. - $\beta$. OEder $i$; spikes very near together, fr. with a short straight beak, C. Cderi E. B. 1773. H. b. 23.-Wet plaees. P. V. VI.

[C. Mairii (C. and G.!), whieh has glumes with a seabrous beak, fr. obsoletely nerved gradually narrowed into a setoseeiliated beak, is likely to oeeur.]

38. C. fulva (Good.); fertile spikes oblong-oval distant with exserted stalks, bracts leaflike with elongated sheaths, glumes aeute not mueronate, fr. ovate triquetrous ribbed smooth with a straight rough-edged bifid beak, nut obovate trigonous nearly smooth, st. acutely triangular rough-edged.-E.B. 1295.? R. 620 . -St. about a foot high. Barren spike spindleshaped, acute: glumes obtuse. Lowest braet frequently, but not always, reaehing up to the barren spike. Root sometimes ereeping.- $\beta$. Hornschuchiana; fertile spikes oblong on longer stalks more distant, fr. more inflated and more strongly ribbed, st. bluntly triangular 
smooth exeept sometimes near the top, lowest braet longer than its own spike. C. speirostacliya Sm., E. B.S.2770. C. Hornseluchiana H. b. 40., Koch. R. 62l.-Boggy places. $\beta$. Peaty bogs, eliefly on mountains. P. VI.

39. C. extensa (Gool.); fertile spikes oblong near together subsessile lower one rather clistant with a short included stalk, braets very long leaflike, glumes mucronate, fr, ovate triquetrous ribbel narrowed below with a straight smooth-edged bifid beak, nut oblong-elliptical narrowed at both ends triangular smooth.E. B. 83i3. Schk. V. Xx. 72. H. b. 32. R. 655.-St, usually curved, 8-12 in. high, bluntly triangular, smooth. Barren spike nearly sessile, blunt, its glumes blunt. L. and bracts very narrow, convolute, long.-Marshes, chiefly near the sea. P. VI.

40. C. pallescens (L.); fertile spikes ovate or oblong witl pxserted stalks approximate, bracts leaflike, glumes mucronate, fr. ovate-oblong convex on both sides striated obtuse : beak 0 , nut linear-elliptical narrowed at both ends trigonous.-E. B. 2185. Schk. Kk.99. H. b. 44. R. 617.-St. slender, acutely triangular, rough above, $1-1 \frac{1}{2}$ foot high. Spikes obtuse, pale green, the barren one sessile darker.-Marshy places. P. VI.

41. C. punctata (Gaud.); fertile spikes erect cylindrical with slightly exserted peduncles particularly the lowest, liracts witlr sheaths, glumes ovate shortly awned, fr. ovate tumid obsoletely ribbed pellucidly punctate with a linear bidentate smooth beak, nut ovate-rhomboidal narrowed at both ends triangular rough.H. b. 37. Kunze Riedg. 6. R.619.-St. smooth, 1-2 feet high, slender. Spikes distant or the upper ones approximating; peduncles usually slightly, the lowest often greatly exserted, lough ; lowest spike frequently very distant. Glumes pale red with a broad green longitudinal dorsal band. Fr. pale, nut brown. Barren spike with blunt glumes.-Marshy places near the sea. Banks of the Menai near Bangor. Guemsey. P. VI. F.

42. C. distans (L.); fertile spikes remote erect oblong, peduncles mostly shorter than the slieaths of the bracts, glumes mucronate, fr. ovate triquetrous equally ribbed pellucidly punctate smooth rough at the edges of the bifid narrow beak: inner edges of the notch serrulate, nut triquetrous roughish oblongelliptical attenuated at both ends,-E.B.1234. Schk. T.68. H.b. 42. R. 622.-St. smooth, seldom exceeding a foot high, slender. Spikes distant, short; upper peduncles quite inelosed; lower half exserted. Glumes brownish. Fr. greenish-brown. Nut yellowish. Barren spike cylindrical, clavate, with blunt glumes.-Marshy places near the sea, sometimes inland on dry ground. P. V.

43. C. binervis (Sm.); fertile spikes remote the upper ones approximating eylindrical their peduneles mostly ineluded the 
lower elongated with exserted peduneles, braets with slieathing bases, ghumes mueronate, fr. ovate triquetrous with 2 principal green submarginal ribs on the outer surface, beak broad bifid rongh at the edges, nut obovate attenuated below roughish.-E.B. 1235. Schk. Rir. 160. H. b. 39. R. 624.-St. triangular, smootl, $1-3$ or 4 feet lighl. Spikes often very distant; perluneles of the npper ones frequently quite ineluded, never much exserted, of the lower often greatly exserted. Glumes dark purple, with a greenish-yellow midrib. Fr. brown or deeply tinged with purple, with 2 prominent ribs always green; nit brown. Barren spike with brown glumes.-Dry lieaths and moors. P. V1. VII.

44. C. lavigata (Sm.); fertile spikes remote cylindrical their perluneles more or less exserterl, braets with sheathing bases, glumes aente, $f r$. ovate-attenuated striated with a long deeply bifid beak with glabrous edges, nut subpyriform attenuated below triangular smootl, $-E, B, 1387$. Schk. Bbb. 116. and Sss. 162. H. b. 38. R. 623. - St. smooth, 2-3 feet ligh. Spikes distant, ereet or drooping. Glumes often aeute on the barren spike, always so on the others, purple with a paler dorsal longitudinal banil. Fr. green; not yellowish. L. broad.-Marshes and wet thickets, rather rare. P. VI.

45. C. panicea (L.); fertile spikes remote subeylindrieal with distant $f$. on exserted stalks, braets leaflike sheathing, glumes rather acute, $f r$. ovate-subglobose inflated with a short terete truncate beak, nut obovate-oblong bluntly trigonous with a eylindrieal beak.-E. B. I505. Schk. Ll. 100. H. b. 33.-St. I-2 feet high, ereet, smooth. Fertile spikes about 2. Glumes oblong, more or less aeute, dark brown with a green keel and membranous pale margins. Lowermost braet about as long as its spike, the rest shorter, sheaths elose-Marshy places. P. VI.

46. C. vaginata (Tausch!); fertile spikes remote with distant fl. on exserted stalks, braets sheathing seareely leaflike, glumes bluntisl, fr. ovate triquetrous glabrous with a short terete smooth very obliquely truncate and emarginate beak, nut elliptical triangular "with a beak slightly thickened upwards."-H. b. 17. Kunze Riedg. 15. C.phceostachya Sm., E. B. S. 2731.-St. 5-6 in. high, sinooth. Fertile spikes 1-2. Glumes bluntish. Bracts with funnelshaped sheaths.-Dr. Boott refers C. Meilichoferi (Sm.) to this speeies and it is probable that he is eorreet, although Smith expressly says that the $\mathrm{fr}$, is rough-edged. I have never seen speeimens, but judging from the fig. (E. B. 2293.) and deseription it appears not to be the plant of Schk. Mmmm. 198. nor H. b. 52,-Highland mountains. P. VII.

47. C. depauperata (Good.); fertile spikes ereet remote with 3 or $4 \mathrm{fl}$. and exserted stalks, braets sheathing leaflike, glumes acute, $f r$, large nearly globose with a long bifid beak witl rough 
edges, mut elliptical trigonons with bluntish angles.-E. $B$. 1098. Schk. 11. 50.-St. l-2 feet high, bluntly triangular, smooth. Glumes of the barren spike blunt. Known by its very large and few fr. with numerous ribs. Spikes very distant.Dry woods, very rare. P. VI.

E. S. ?

†十 Fertile spikes short drooping.

48. C. capillaris (L.); fertile spikes upon long stalks half included few-flowered lax, one bract sheathing several flowerstalks, glumes obtnse, fr. oblong triangular turgiil narrowed below terminating in a slender membranous beak, nut obovate triquetrous blunt with a short beak.-E. B. 2069. Schk. 0.56. H. b. 53. R. 600.-St. very slender, $2-6$ in. high, smooth. Peduncles rough, several usually inclosed in one sheath. Glumes short, broad, obtuse, nidrib not reaching the summit, shorter than the small smooth brown fruit. Nit pale. Root tufted.-Teesdale and Scottish highlands. P. VI.

E. S.

49. C. rariflora (Sm.); fertile spikes 2 or 3 upon long stalks oblong few-flowered lax, bracts with very short sheaths, glumes very broad obtuse as long as the fr., fr. oblong attcnuated at both ends with 3 blunt angles and depressed sides beak extremely short entire, nut roundish-oblong.- $-E$. B. 2516.-St. $6-8$ in. high, smooth. Root creeping. Peduncles solitary. Glumes very broad and blunt, folded round the fr., dark brown, midrib pale terminating in a minute apiculus. Fr. pale, faintly nerved; nut darker.-Boggy summits of the lighlaud mountains, rare. P. VI.

S.

50. C. limosa (L.); fertile spikes 1 or 2 upon very long stalks ovate densely-flowered with occasionally a few barren $f$. at their summit, bracts auricled slender strongly kecled, glumes ovate mucronate, $f r$. roundish-obovate compressed strongly ribbed with a very short entire beak, nut obovate bluntly trigonous with a beak, l. narrow linear complicately-channeled rough at the edges throughout.-E. B.2043. Schk. X. 78. H. b. 49. R. 592.-St. a foot high. L. and bracts very slender. Ghımes purple, with a green keel, about as long as the pale fr. which is broadest above the middle. Nut pale. Root creeping.-Spongy bogs. P. V1.

51. C. irrigua ("Sm.,"IIartm.) ; fertile spikes 2 or 3 upon long stalks oblong densely-flowered with occasionally a few barren fl. at their base, bracts auricled leaflike rather broad nearly flat, glumes ovate-lanceolatc atteunated acute, fr. roundish-ovate compressed faintly ribbed with a very short entire beak, nut elliptical triangular with a bcak, $l$. linear flat smooth at the edges except near the apex.-E, B. S.2895. H. b. 48, R. 593.-St. a foot or more in height. $L$. and bracts 2 or 3 times as broad as in the preceding. Glumes wholly purple, usnally longer than the pale 
fr. which is broalest below the middle. Nut pale. Root erecping.-Spongy bogs. Muekle Moss, Nortluunb. 'Terregles, Dunfiries. Benima near Loch Lomonl.-P. VI. E. S.

52. C. ustulata (Walll.); fertile spikes 2 or 3 upon short stalks ovate densely-flowerel, lracts scarcely leaflike or sheathing, ghmes ovate acute, $f r$. elliptical compressed rough-edged with a cloven beak, unt clliptical triangnlar on a long stalk, root fibrous. - L. B. 2044. Schk. Y. 82. H. b. 47. R. 615.-St. 3-4 feet higl. L. very short, broad. Glumes dark purple with a slender pale midrib. Fr. dark purple paler below. Nut fuscous. I have seen no specimens.-Ben Lawers, Mr. G. Don. P. VII. S.

†十 Fertile spikes elongated.

53. C. strigosa (IInds.); fertile spikes about 4 distant rather drooping slender lower ones with exserted stalks, bracts leatlike sheathing, fr. oblong-lanceolate narrowed at botl ends triangular nerved with an obliquely truncate mouth, nut elliptical triangular puuctured, l. broad.-E. B. 994. Schk. N. 53.-St. 2 feet high. Slicaths covering nearly the whole length of the peduncles. Spikes laxly-flowered. Glumes elliptic-lanceolate, diaphanous, greenish down the back.-Groves and thickets, rarc. P. V. VI,

54. C. sylvatica (Huds.); fertile spikes about 4 distant slightly drooping linear with long half-exscrted stalks, bracts leaflike sheathing, fr. elliptical triangular obscurely nerved narrowed into a long cloven smootl beak, nut obovate-elliptical triangular, l. narrower than in the precelling.-E. B.995. Schk. Ll. 101. H. b. 55. R. 603.-St. about 2 feet high, smooth. Sheatlis scarecly eovering half the length of the peduncles. Glumes ovate, acute, diaphanous with a green kecl.-Damp woods. P. V.

55. C. pendula (IIuds.); fertile spikes about 5 distant drooping cylindrical very long denscly-flowered, bracts leaflike lower oues with sheaths equalling the flowerstalks upper searcely sheathing, fr. elliptical subtriquetrous tumid with a short trigonous emarginate beak, nut elliptical narrowed at both ends triangular.-E. B.2315. Schk. Q.60. R.604. Huds.(1762). C. Agcstachys Ehrh. H. b. 57. C. maxima Scop). (1772).-St. 3-6 feet high, rough at the angles above. Fertile spikes often 3 or 4 in. long, the upper ones frequently with barren fl. at the summit. Glumes ovate, mucronate, brown with a green keel. Fr. green, eiliated at the mouth.-Damp woods. P. V.

56. C. Pseudo-cyperus (L.); fertile spikes about 5 drooping cylindrical densely-flowered upon long stalks, bracts lcatlike scarcely sheathing, glumes setaceous scabrous dilated at the base, fr. ovate-lanceolate ribbed much attenuated into a deeply bifid. beak, nut elliptieal triangular, st. with acute rough angles.- 
F. B. 242. Schk. Mm. 102. H. b. 56.-St. $2-3$ feet high. Fertile spikes $1 \frac{1}{2}-2$ in. long.-Damp places, rare. P. VI. E.I.

$$
\text { ** Fruit downy or hairy. }
$$

57. C. pracox (Jacq.); fertile spikes 1--3 oblong-ovate near together sessile, bracts clasping the lowest leaflike and slightly sheathing, glumes broadly ovate-acuminate, fr. ovate-rhomboidal trigonous with an entire mouth, nut obovate narrowed below trigonous: base of the style surrounded by a prominent ring, root creeping.-E. B. 1099. Schk. F. 27. H. b. 24.-St. 3-1: in. high. Lowernost spike sometimes slightly stalked.-Dry places. P. IV. V.

58. C. montana (L.); fertile spikes $1-3$ ovate near together sessile, bracts small membranous the lowest with an awlshaped point, fr. narrowed below oblong-obovate trigonous with a short notched beak, nut oblong narrowed below with a pyramidal beak, root fibrous.-Schk. F. 29. H. b. 21.-St. about a span long, slender. L. narrow. Glumes very dark; midrib narrowly yellowish. Fr. luairy, its beak purple.-Ncar Tonbridge Wells. Mr. W. Mitten. P. VI. VII.

E.

59. C. pilulifera (L.); fertile spikes abont 3 roundish near together sessile, bracts small lowest scarcely leaflike awlshaped not sheathing, glumes broadly-ovate mucronate, $f r$. stalked subglobose witl a short bifid beak, nut subglobose subtrigonous narrowed below, root fibrous.-E. B. 885. Schk. 1. 39. H. b. 20. R. 632.-St. 6-12 in. long, slender, at length decumbent. Base of the style enlarged.-Wet heaths. P. V.

60. C. tomentosa (L.); fertile spikes 1 or 2 nearly sessile $c y$ lindrical obtuse, lowermost bract lenflike with a very short sheath, glumes broadly ovate acute, fr. obovate subtrigonous scarcely beaked slightly emaryinate, nut obtuse trigonous narrowed below witl a short beak constricted at its base, root creeping.-E. B. 2046. Schk. F. 28. H. b. 28. - St. a foot bigh, with 3 sharp angles, rough upwards, erect. Beak of nut slightly swclling upwards. Fr. with copious white down, mouth rery broad.-Water-meadows at Merston Measy, Wilts. P. VI.

E.

61. C. humilis ("Leyss."); fertile spikes 2 or 3 remote about 3-flowered inclosed in the membranous sheathing leafless bracts, fr. obovate subtrigonous narrowed below with an entire oblique mouth, "nut obovate triangular with a short beak."- $H$. b. 15 . C. clandestina Good. E. B. 2l24. Schk. K. 43. R. 595.-St. about $2 \mathrm{in}$. high, erect, conccaled amongst the leaves. Bracts large, wholly membranous, nearly hiding the fertile spoikes. L. all radical, linear, channeled, rough. $-C$. humilis is much the older name.--Limestone hills in Wilts and Somerset. P. IV. 
62. C. digitata (I.); fertile spikes 2 or 3 distant linear erect lax, bracts membranons sheathing obliquely truncate lowermost with a setaceous leaflike point, $f r$. obovate triquetrons narrowed below, with a short nearly entire beak, " nut elliptic-oblong triingular shortly-stalked and shortly-beaked."-E. B. 615. Schk. H. 38. H. b. 14.-St. $6-8 \mathrm{in}$. high, ereet, sheathed at the base, leatless, taller than the flat radical leaves.-Woods on limestone, rare. $P . I V, V$.

li.

vii. 'Terminal spikes barren, 2 or more; stigmas 3 .

* Fruit downy.

63. C. glauca (Scop.); barren spikes 1 or more, fertile 2 or is at leugth drooping cylindrical densely flowered with long stalks, bracts leatlike scarcely sheathing, glumes ovate acute, fr. obtuse elliptical slightly downy entire at the small point, nut roundishovate triangular.-H. b. 67. Schk. O. P.57. R.648. C. recurva IIuds. E. B. 1506.-Root ereeping. St. a foot or more in height. Barreu spikes very variable in number. Fertile spikes often with barren $\mathrm{fl}$. at the summit.- $\beta$. Micheliana (Sm.) differs only by having quite blunt glumes and smaller fruit. E. B. $2236 .-\gamma$. stictocarpa; fertile spikes ovate, fr. obovate dotted. C. stictocarpa Sm., E. B. S.2772.-Wet places. P. VI.

64. C. filiformis (L.); barren spikes 2 , fertile 3 or 4 remote erect sessile oblong, bracts leaflike lowermost slightly sheathing, glumes oblong-ovate cuspidate and ciliated at the point, $f r$. oblong-ovate narrowed upwards into an obliquely truncate beak ending in 2 lateral points, nut narrowly elliptical attenuated at both ends triquetrous, l. slender channeled.-E. B.904. Schk. K. 45. H. b. 31. R. 643.-St. 2 feet high. L. with filamentons sheaths below.-Boggy meadows. P. V.

65. C. hirta (L.); barren spikes 2 or 3 , fertile 2 or 3 remote erect oblong-cylindrical stalked, bracts leaflike the lower with long sheaths nearly equalling the peduncles, glumes elliptic-lanceolate with long slender ciliated points, fr. oblong-ovate narrowed upwards into a deeply divided beak, nut obovate narrowed below triquetrous, l. flat hairy.-E. B. 685. Schk. Uu. 108. H. b. 58 . - St. $1 \frac{1}{2}-2$ feet high, leafy. L. and sheaths shaggy, rarely glabrous. Fr. tawny. Occasionally the spikes are compound.Wet places. P. IV.

\section{** Fruit glabrous.}

66. C. hordeiformis (Wahl.); barren spikes 2 , fertile 3 oblong remote with short exserted stalks, bracts overtopping the spikes long leaflike flat sheathing, $f r$. large ovate plano-convex scabrous winged ciliate-serrate narrowed into a long bifil beak, nut oblongobovate trigonous with a long slender beak. -Schk. Ddd. 121. 
C. secalina Sin. not Willd.-Fr, very large, twice as long as the glumes. I have not seen native specimens.-Small valley about three miles west of Panmure, Forfar. Mr. G. Don. P. Vl.-S.

67. C. ampullacea (Good.); fertile spikes 2 or 3 remote cylindrical erect stalked, bracts leaflike witlout sheatlıs, fr. subglobose inflated with a long narrow bifid beak, "nut obovate triquetrous," st. smooth obtusely angled.-E. B. 780. Schk. 'T't. 107. H. b. 65. R. 659.-St. 1-2 feet high, with rounded faces and 3 slight angles. L. glaucous, channcled.-Very wet bogs. P. VI.

68. C. vesicaria (L.); fertile spikes 2 or 3 remote cylindrical, bracts leafike without sheaths, $f r$. ovate-conical infiated narrowing gradually into a subulate bifid beak, " nut elliptical triquetrous," st. with acute angles.-E. B. 779. Schk. Ss. 106. H. b. 64. R. 658.- St. 2 feet high, with flat faces and 3 strongly marked angles. L. rather broad, green. $-\beta$ ? involuta ; l. narrow folded into a $\frac{1}{2}$ cylinder, midrib of fem. glumes terminating in an apiculus, fr. narrower. Probably distinet.-Wet bogs. $\beta$. Hale Moss, Manchester. Mr. J. Sidebotham. Congleton, Chesh. Mr. E. Hilson. P. V.

69. C. paludosa (Good.); glumes of the barren spikes obtuse, fertile spikes cylindrical obtuse, bracts leafike without sheaths, fr. oblong-oborate compressed with a short bifid beak, "nut roundish-obovate triquetrous."-E. B. 807. Schk. Oo. 103.St. 2-3 feet highl, angles rough. L. broal. - Wet places. P. V.

70. C. riparia (Curt.); glumes of the barren spikes acute, fertile spikes acute cylindrical, bracts leaflike without sheaths, fi. oblong-ovate convex on both sides narrowed into a short broad cloven beak, "nut pyriform trigonous."-E. B. 579. Schk. Qq. and Rr. 105. H. b. 66.- St. 3 feet high, angles rough. L. broader than in the preceding.-Wet places. P. V.

\section{Order XCII. GRAMINEA.}

Fl. perfect or unisexual, 1,2 or more seated on a common axis which is contained vithin an involucre of 1 or 2 valves (ghumes) or rarely wanting, the whole forming a locusta or spikelet. Each fl. of 1 or 2 seales (pales) of which the outer or lower is simple and usually keeled, the inner witl 2 nerves or keels. Hypogynous scales 2, 3, or none. Stam. hypogynous, 1-6. Anth. versatile, notehed at both ends. Orary 1-celled. Styles usually 2, rarcly 1 or 3 . Embryo on the outside of the albumen and at its base.-L. with split sheaths ${ }^{1}$.

1 Nearly all the genera of this Order are beautifully figured in the Gen. Fl. Germ. Monocotyl. vol. i. 
Tribe 1. PANICE:AE. Spikelets dorsally compressed, 1-flowered or with $\mathrm{l} \mathrm{fl}$. ancl an inferior rudinent resembling a third ghlume or a neuter flower. Glumes 2, uneçual, the lower often very small. Styles clongated. Stigmas feathery.

1. Digitaria. Spikes fingered. Spikelets in 2 rows on one side of a flattened riehis, unarmed, l-flowered with an inferior rudiment. Glumes 2, lower very small, npper 3nerved. Sterile fl. of one 5-7-nerved pale, resembling the upper glume and equalling the flower.

2. Hemnocnuox. Spikes eompound, seeund in the whole and in each part. Spikelets on one side of a flattened raehis, 2-flowered, inferior fl. rudimentary. Glumes 2, lower small, 3-nerved, upper as long as the fl. 5-nerved mueronate. Outer pale of the sterile fl. resembling and equalling the upper glume.

3. Setaria. Spike cylindrical, eompound. Spikelets surrounded by an involucre of bristles, 2-flowered, inferior $\mathrm{fl}$. rudimentary. Glumes 2, lower small 3-nerved, upper as long as the fl. many-nerved. Sterile fl. of 1 pale resembling the upjer glume.

Tr. II. PHALARIDEA. Spikelets laterally compressed, 1flowered, with l or 2 or more below resembling the glumes. Styles long. Stigmas filiform, protruded from the summit of the spikelet.

4. Phaldris. Glumes 2, navieular, earinate, membranaceous, nearly equal, longer than the Hower. Pales eoriaecons, unequal, elosely investing the fruit. Rudimentary fl. 1-2, each eonsisting of a single scale.

5. Anthoxanthum. Glumes 2, unequal, membranous, lower small 1-nerved, upper longer than the fl. 3-nerved. Pales searious. Stam.2. Rudimentary fl. 2, each eonsisting of a single notched seale awned on the back.

6. Ilizrochlok. Glumes 2, nearly equal, membranous, about as long as the flowers. Fl. $3 ; 2$ lower male, 3-androus, upper pale with 2 keels; upper herm., 2-androus, upper pale with 1 keel.

Tr. III. PHLEINEAE. Spikelets laterally compressed, 1flowered or' with a superior rudiment. Glumes nearly equal. Styles and stigmas as in 'Tr. II. Infloreseence a spikelike paniele.

7. PHLEum. Glumes parallel at the midrib truneate with a terminal seta or aeute. Fl. 1. Pales 2, meinbranous, lower 3 -nerved obtuse, without awns, or with a minute central point. 
8. Alopecurus. Glumes membranous, acute (in A. geniculatus blunt). Fl. 1. Pale 1, scarious, 5-nerved, awned on the back, the margins usually connected below. "Styles usually combined,"

9. KNa PPIA. Inflorescence a somewhat 1 -sided raceme. Glumes not keeled, blunt. Fl. 1. Pale l, searious, very hairy, obtuse, not awned.

Tr. IV. AGROSTIDEA. Spikelets and glumes as in Tr. III. Stigmas sessile or nearly so. Inflorescence panicled.-Glumes very unequal in Apera.

10. Gastridium. Glumes membranous, acute, unarmed, ventricose at the base, much longer than the flower. Fl. l. Pales 2, membranous; lower truncate or toothed at the end, with or without a dorsal awn.

11. Polypogon. Glumes searious, nearly equal, each furnished with a long seta from just below the emarginate summit. Pales shorter than the glumes, outer usually awned from below the summit.

12. Milium. Glumes membranous, nearly equal, unarmed. Pales 2, nearly equal, unarmed, about as long as the glumes, hardening on the fruit. Spikelets convex on the back, or shightly dorsally compressed.

13. Agrostis. Glumes membranous acute, unarmed, the upper one smaller. Pales unequal, scarious, with or without a dorsal awn, shorter than the glumes. Seed free.-In $A$. canina the inner pale is wanting.

14. Apera. Spikelets with the rudiment (pedicel) of a superior floret. Lower and lesser glume l-nerved; upper and larger 3-nerved, about as long as the lower pale. Otherwise like Agrostis.

[Tr. V. STIPACE E. Spikelets in an equal panicle, 1-flowered, without any rudiment. Outer pale convolute and hardened upon but not attached to the fruit, the extremity rolled up and jointed to a long awn.]

[15. Strpa. Florets stalked. Pales coriacous, the inner entire. Awn evidently jointed to the pale, kneed and twisted.]

Tr. VI. ARUNDINEAE. Spikelets laterally compressed, 1flowered, or with a superior rudiment, or many-flowered. Fl. enveloped in long (short in Psamma) silky hairs. Styles and stigmas various. "Awn, when present, not twisted."

16. Arundo. Glumes nearly equal, the lower rather the longer. 
Floret l, with or witlout the superior rudiment of another reduced to a pedicel. Outer pale awned. l'anicle diffuse. Styles short. Stigmas feathery.

17. Psamma. Ghunes nearly cqual, the lower ratler the shorter. l'loret 1, with a superior rudiment of another. Outer pale with a short awn. Panicle spikelike. Styles short. Stigmas featliery.

18. Prragimes. Glumes unequal, the lower mueh smaller. Florets 2-6, unamed, the lower ones imperfect. Paniele diffuse. Styles elongate. Stigmas plumose.

Tr. VII. CHLORIDEAE. Spikelets laterally compressed, 1Howered in our plants and sometimes with a superior rudiment, placed in 2 rows on one side of a flattened rachis.

19. Crnodon. Spikes fingered, 1-flowered with a superior rudiment. Glumes nearly equal, patent. Pales equal, outer boatshaped compressed embracing the inner. Styles long, distinet. Stignas feathery, protruding below the summit of the floret.

20. Spartina. Spikes upright, in a raceme, 1-flowered. Glumes unequal, the upper long and aeuminate. Pales unequal, outer boatshaped eompressed retuse. Styles elongated, united half-way up. Stigmas filiform, protruding at the summit of the floret.

'Tr. VIII. ORIZE E. Spikelets laterally eompressed, I-flowered. Glumes wanting in ou plant.

21. Leersia. Pales 2, compressed, keeled, awnless; lower mueh broader. Stigmas protruding from the side of the florets. Nut inclosed in the pales.

Tr. 1X. SESLERIEAE. Spikelets laterally eompressed, with 2 or more fl., without hairs. Styles 0 or very short. Stigmas very long, filiform, protruded from the summit of the florets.

22. Sesteria. Paniele spiked; spilielets sessile, tiled all round. Glumes 2-6-flowered, nearly or quite as long as the spikelet. Outer pale keeled, membranous; with a scarions margin, ending in 3 or 5 points, dorsal rib evaneseent.

Tr. X. AVENINEAE. Spikelets with 2 or more florets (except in Lagurus), upjer often barren. Glumes as long (or nearly) as the spikelet. Fl. usually surrounded by stiffhairs. Awn twisted and kneed (wanting in our Triodia).

23. Lagurus, Panicle spiked. Glumes 1-flowered, searious, ending in a long fringed seta. Outer pale ending in 2 long setx and with a dorsal genieulated twisted awn. 
24. Arra. Paniele lax. Glumes 2-flowcred, with or without the rulliment of a third (which is sometimes perfected in A. caspitosa). Outer pale terete on the back with or without very faint lateral nerves, awned. Awn ilorsal, kneed (in A. cospitosa straight). Ovary glabrous. Fr. not crested.

25. Corynephorus. Awn clubshaped, straight, jointed in the middle, the upper portion clavate, a tuft of liairs at the joint. Otherwise like Aira.

26. Trisetur. Spikelets crowled. Glumes 2-6-flowered. Outer pale keeled with faint lateral nerves, ending in 2 aeute teetl, awned. Awn dorsal, kneed and twisted. Ovary glabrous. Fr. neither crested nor furrowed.

27. Avena. Glumes 2- or more-flowered. Outer pale with lateral nerves, awned, ending in 2 points. Awn dorsal, kneed and twisted. Ovary hairy at the top. Fr. crested and furrowed.

28. Arritenatherum. Glumes 2-flowered with a rudiment, lower ft. male with a long dorsal kneed and twisted awn, upper with a short straight awn. Pales lierbaceous, ending in 2 points. Ovary hairy at the top. Fr.....

29. Houcus. Glumes 2-flowered, lower perfect awnless (or very rarely awned), upper usually male with a dorsal awn. Pales hardening on the fruit.

30. Triodia. Glumes 2-3-flowered. Outer pale rather eoriaeeous, smooth, rounded on the back, bifid with an intermediate broad point sometimes becoming the base of a kneed awn.

Tr. XI. FESTUCINEAE. Spikelets with 2 or more fowers, upper often barren. Glumes shorter than the lowest flower. Styles very short. Stigmas protruded from the base of the Hower.

31. Koeleria. Glumes unequal, upper one with 2 or 3 ribs, shorter than the compressed $2-5$-flowered spikelet. Outer pale nerved, keeled, acuminate (or with a straight subapicular seta). Seed loose. Styles terminal.

32. Melica. Glumes nearly equal, with lateral ribs, nearly as long as the ovate spikelet of 1 or 2 flowers rounded on the baek and a elublike rudiment of 1 or 2 more. Pales hardening on the loose fruit. Styles terminal.

33. Molinia. Glumes unequal, without lateral ribs, shorter than the laneeolate spikelet of 2 or 3 semieylindrieal flowers and a subulate rudiment of another. Pales hardening on the loose fruit. Styles terminal. 
3. Catabrosa. Glumes unequal, very short, rounded or trumeate, without lateral ribs, much shorter than the spikelet. Flower's usually 2, rounded on the back, distant. Onter pale menloranous, with 3 parallel ribs ending in teetl which do not quite extend to the summit and are eounected by the searious nargin. Styles terminal.-The upper glume has 2 very short faint lateral nerves. Awn 0.

35. Pos. Glumes rather unequal. Outer pale with 3 or 5 parallel nerves, membrauous below, searious at the tip, compressed, keeled, unarmed. Styles terminal.

36. Glyceria. Glumes unequal, submembranous. Outer pale with 5-7 strong prominent distiuet and parallel ribs aml a scarious margin, subcylindrical, unarmed. Styles teriuinal.

37. S̈clerochloA. Glumes unequal, menbranous. Outer pale with 5 faint but distinct and parallel nerves, nembranous, cylindrical below, unarmed, often keeled at the tip or with a very minute mucro. Styles terminal.

38. BrizA. Glumes nearly equal, broad, 3-ribbed. Fl. 3-8, densely imbricated in a short distichous spikelct. Onter pale navicular, heartshaped, obtuse, rounderl on the back, inarmed. Glumes and pales membranous with a scarious margin. Styles terminal. "Fr. free." (Woods.)-Outer pale with $7-9$ faint nerves.

39. Cynosurus. Glumes nearly equal, scarious, with a strong keel, with 1 or more flowers. Outer palc rounded on the back with a terminal seta. Each spikelet with a pectinated bract (abortive spicula) at its base. Panicle spicate, l-sided.

40. Dactylis. Glumes uuequal, herbaceous, many-flowered, the larger keeled. Outer pale compressed, keeled, 5-nerved, the dorsal nerve fringed and excurrent just below the summit forming a short seta. Spikelets crowded, subsecund.

41. Festuca. Glumes unequal, herbaccous, many-flowered. Outer pale rounded on the back, very acutc, or with the dorsal nerve excurrent at or just below the apex (if clongated usually called an awn), lateral nerves slightly converging and vanishing below the apex. Inner pale minutely ciliated on the ribs. Styles terminal.-Rachis with acute angles. Sheaths of the leaves divided to the base.

42. Bromus. Glumes uncqual, herbaceous, many-flowered, lower 1-nerved, upper 3-5-nerved. Fl. lanceolate, compressed. Outer pale with a long seta (usually) founded on 3 nerves from below the tip. Styles below the summit of the fruit, lateral.-Sheaths of the l. divided half-way down. 
43. Serrafalcus. Glumes unequal, herbaeeous, manyflowered, lower 3-5-nerved, upper 7-9-nerved. Fl. oblong, turgid. Outer pale with a short seta (usually) founded on 3 nerves from bclow the tip. Styles below the summit of the fruit, lateral.-Sheatlis of the 1. scarcely divided halfway down. Spikelets narrower upwards.

44. Brachy podium. Glumes unequal, many-flowered. Outer pale rounder on the back setigerous at the summit, lateral nerves slightly converging not vanishing upwards. Inner pale fringed on the ribs with rigid seta. Styles terminal.-The unequal glumes alone distinguish this from Triticum.

Tr. XII. HORDEINE E. Spikelets solitary or 2 or 3 together, sessile on opposite sides of a chameled and toothed raehis. (Lateral spikelets often stalked in Hordeum.) Otherwise like Tr. XI.

45. Triticum. Glumes opposite, nearly equal, inany-flowered, embracing the flowers. Spikelets solitary.

46. Lolium. Glume solitary, or that next the rachis sinall, with 3 or more flowers. Spikelets placed edgewise on the rachis, solitary.

47. Elymus. Glumes 2, both on the same side of the spikelet, without awns or setæ, with 2 or more perfeet flowers. Spikelets 2 or 3 together.

48. Hordeum. Glumes 2, terminating in long setæ, with 1 perfect flower and a stalklike rudiment next the common rachis. Spikelets in threes, often partially barren.

Tr. XIII. ROTTBOELLIINEA. Spikelets of one perfeet flower placed edgewise on the rachis.

49. Nardus. Spikelets in 2 rows on one side of the rachis, of one flower. Glumes 0. Outer pale keeled, tapering into a subulate point. Stigmas elongate, filiform, protruded at the apex of the flower.

50. Lepturus. Spikelets solitary, imbedded alternately on opposite sides of the rachis, of 1 flower and a superior rudiment. Glumes $1-2$ opposite to the rachis, cartilaginous, covering the flower. Pales scarious. Stigmas feathery.

\section{Tribe I. Panicea.}

\section{Digitaria Scop.}

[1. D. sanguinalis (Scop.); l. and sheaths hairy, fl. oblonglanceolate glabrous with downy margins (?). $-E . B .849 . R$. i. 
1407. P. 70.-St. ascending, a foot long.-Not a true native; occasionally found in ficlds. $\Lambda$. VIII.]

E.

2. D. humifusa (Pers.); l. and sheaths glabrous, fl. elliptical downy witl glabrous nerves. - E. B. S. 2613. P. 71.-St. mostly procuubent, $4-8$ in. long. Spikes usually 3 or 4 , springing from nearly the same point. Spikelets in pairs, one on a longer stalk than the otler.-Sandy fields, rare. A. VII. VIII. E.

\section{Ecringciroa Pal. de Beauv.}

* 1. E. Crus-galli (Beauv.); spikes alternate or opposite, spikelets near together, upper glume and sterile floret awned or mucronate hispid, rachis lispid.-E. B. 876. P. 67. R. 14I2. Panicum Sm. Oplismenus Kunth._A strong con'se grass; found oceasionally on cultivated land.-Near London. A. VII. E.

\section{Setaria Pal. de Beauv.}

*1. S. viridis (Beauv.); panicle spikelike, involucral bristles with erect tecth, pales smooth.-Panicum Sm., E. B. 875. $R$. 1467. P.68. - Fields near London and Norwich. A.VII.VIII.-E.

*2. S. verticillata (Beauv.); panicle spikelike, involucral bristles with reflexed teeth, pales smooth.-Panicum Sm., E. B. 874. R. 1465. P.69.-Fields near London and Norvich. A. VII. VIII.

*3. S. glauca (Beauv.); panicle spikelike, involucral bristles with erect teeth, pales transversely rugose.- $R$. 1466.-Wevbridge, Surrey. Mr. Borrer. A. IX.

\section{Tribe II. Phalaridec.}

\section{Phalaris Linn.}

*1. P. canariensis (L.); panicle ovate resembling a spike, glumes winged on the keel, wing entire, rudimentary fl. 2 half as long as the fertile fl., pales pilose.-E. B. I310. R. 1492. P. 9.-St. 1-2 feet high, terminating in a compact compound panicle. Glumes large, pale yellow variegated with green lines and remarkably winged at the back.- Scarcely naturalized. A.VII. Canary-grass.

2. $P$. arundinacea (L.); panicle upright with spreading branches, fl. clustered, glumes not winged, rudimentary fl. 1 or 2 small liairy-E. B. 402. P. 9. Baldingera R. 1494.-St. 4-5 feet high, from a creeping root. Panicle $3-4$ in. long. Glumes keeled.- $\beta$. picta; l, variegated with white lines.-By water. P. VI. VII. 


\section{Anthoxanthum Lim.}

1. A. odoratum (L.); panicle spikelike oblong eompound, glumes about as long as tlie awns.-E. B. 647. R. 1722-1724. P. 8.- Shout a foot ligh.-Very common in pastures. P. V.VI. Sweet Vernal-grass.

\section{Hierochloe Gmel.}

1. H. borealis (R. and S.); panicle divarieate, pediccls glabrous, fl. without awns,-E. B. S. 2641. R. 1728. P. 31.-About a foot high.-In a narrow mountain vallcy called Glen Kella [or Cally, near the spittle of Glen Shee. Mr. Wilson], Forfarshire. IIr. G. Don. P. VII. (V. VI. Sm.)

\section{Tribe III. Phleinea.}

\section{Phleun Limn. Cat's-tail-grass.}

1. P. asperum (Jacq.); panicle eylindrieal, glumes wedgeshaped truncate swelling upwards rough.-E. B. 1077. St.26.5. P. 79. R. 1487.- St. often branched, clothed with leaves almost up to the paniele. Outer pale entire not awned.-Dry open fields, rare. A. VII.

E.

2. P. Boelumeri (Wibel.); panicle cylindrical, glumes linearlanceolate obliquely truncate mueronate scabrous.-E. B. 459 . P. 80. R. 1488. - St. leafy below, the upper half naked, aceompanied by sterile leafy shoots. Outer pale entire, not awned.Dry chalky fields, rarc. P. VII.

E.

3. P. Michelii (All.); panicle nearly cylindrieal, glumes lanceolate acuminate.-E. B. 2265. R. 1489. P. 7.-St. aceompanied by sterile leafy shoots. Glumes ciliated throughout their whole length. Outer pale entire, more than lialf as long as the glume.-Very rare. On the rocky parts of the Clova mountains. Mr. G. Don. P. VII. VIII.

S.

4. $P$. arenarium (L.); panicle oblong somewhat narrowed below, glumes lanceolate acuminate-E. B.222. R.1482. St.29.1. $P .7$. - St. varying greatly in height. Sheaths inflated. Glumes ciliated in the upper half only. Outer palc notched at the summit, $\frac{1}{3}$ the length of the glumes. "Stig. very short." - Sandy places near the sea. $\Lambda$. VI.

5. P. pratense (L.); panicle cylindrical, glumes oblong truncate ciliated on the back bearing a seta of less than half their length.-E. B. 1076. R. 1483. P. 77 and 78.-Root slightly creeping in dry places rather tubcrous (P.nodosum L.). Panicle 1-5 in. long. Awns sometimes longer. Outer pale jagged at the summit.-Meadows and pastures. P. VI. Timothy-grass. 
6. P. commutatum (Gaul.); panicle ovate-oblong, ghnmes truneate glabrous ciliated ou the back bearing a scabrons not ciliated seta of $\begin{gathered}3 \\ 4\end{gathered}$ their length, sheath of the mper l. inflated $3 \mathrm{or}^{4} 4$ tines as long as its leaf, upper ligule very short and obtuse. $-P$. alpinum Sim., not Linn. E. B. 519 (ball). P. 6.- Root somewhat creeping. St. $6-12 \mathrm{in}$. high. Panicle not excecding an in. in length.- Well distingnished by shnttleworth ( $\mathrm{Hag}$. Zool. Bot. ii.12.) from the true $P$. alpinum (Linn.!), which lias a longer panicle, ghumes bening a ciliated seta, the upper sheath scarcely inflated and only twice as long as its leaf, and the uppermost ligule oblong and acute.-Wet alpine moors at an eleration of $2500-3500$ feet. P. VII.

\section{Alopecurus Lim. Fox-tail-grass.}

1. A. pratensis (L.); st. erect smooth, panicle cylindrical obtuse, glumes acute eomected below ciliated downy, pale cqualling the glumes, awn projecting more than half its own length beyond the pale, upper l. about as long as its sheath.-E. B. 759. St.8.1. R. 1479 . P. 4.-Root fibrous, scarcely ereeping. St. $1-3$ feet high. Upper sheath slightly inflated. Ligule short, obtuse. Spike 1-3 in. long, branclies 4-(i-flowerel. Anth. yellow. Styles combined.-Rich pastures. P. IV.-VI.

2. A. alpinus (Sm.); st. erect smooth, panicle oblong, glumes acute connected below laairy, palc equalling the glumes, awn projecting $\frac{1}{3}$ of its length beyond the pale, upper 1 . shorter than its sheath.-E. B. 1126. P. 4.-Root somewhat creeping. St. decumbent at the base, then erect, 9-12 in. ligh. Ligule short, obtuse. Uppermost l. usually (not always) short and broad, $\frac{1}{3}$ of the length of its inflated sheatll. Awn from about the midcle of pale, sometimes wanting. Styles combined. Spike not exceeding an inch long, silky branches $4-6$-flowercd.-On mountains at an elevation of 2500-3500 feet. Loch na Gar. Ben Lawers. Clova. P. VII.

S.

3. A. geniculatus (L.); st. ascending bent at the joints smooth, panicle cylindrical, glumes obtuse connected below eiliated rather longer than the pale, awn from near the base of the pale and projecting half its length beyond it, anth. linear, upper l. as long as its sheath.-E. B. 1250. R. 1477. P. 5.-Root fibrous. St. about a foot long, branehing at the lower joints which are generally (in dry places) oral and fleshy. Upper sheath inflated. Ligule oblong. Glumes membranous at the top except the midrib. Pale when lairl open oblong, obtuse, slightly notched. Anth. ultimately violet-yellow. Styles mostly combined. Spikes $1-2$ in. long. -Wet places. P. VI. VII.

4. A. fulvus (Sm.); st. aseending bent at the joints smootl, panicle cylindrical, glumes conneeted below ciliated rather shorter 
than the pale, awn from just below the middle of the pale and scarcely extending beyond it, anth. short and broad, upper l. as long as its sheath,-E, B. 1467. P. 5. - St. 1-2 feet long, procumbent below. Lignle oblong. Spikes 2-3 in. long. Anth. at first white, afterwards orange-coloured.-Wet margins of ponds. P. VI.-IX.

E. S.

5. A. bulbosus (L.); st. ereet smooth, paniele cylindrical aeuminate, glumes distinct abruptly acute downy longcr than the pale, awn from near the base of the pale and projecting half its length beyond it.-E. B. 1249.-Root fibrous. St. 1 foot high, the lowermost joint forming an ovate fleshy tuber. Upper sheath inflatel, longer than its leaf. Ligule oblong. Pale when laid open trumcate emarginate with a small tooth in the middlc. Styles combined. Panicles about an in. long, less decidedly racemose than in our other species, pedicels usually l-flowered.Salt marslies in the south, rare. P.VI.

E. S.

6. A. agrestis (L.); st. ereet scabrous upwards, panicle tapering slender, glumes acute connected below nearly glabrous, awn from near the base of the pale and projecting half its length beyond it.-E. B. 848. R. 1473. P. 3.-St. 1-2 feet high, slender. Sheaths roughish, upper one longer than its leaf. Ligule prominent, obtuse. Glumes glabrous but with a row of fine short cilia on the back. Styles combined.-A very troublesome weed. A. VII.

E. S. ?

\section{Knappia Sm.}

I. K. agrostidea (Sm.).-E. B. I127. P. 73. Sturmia minima Hoppe in St. 7. 1. Chamagrostis Koch. Mibora verna $R .1405$. - An elegant but very small grass. Root small, fibrous. St. numerous. L. short, rough. Spikes slender; spikelets 5-10, sessile, from one side of the rachis, but still rather alternate. Pale shorter than the glumes, liairy, truneate, ragged. Mibora (Adans.) is the oldest nanc, but I have thought it better to follow Sinitl._-Sandy maritime pastures, rare. A. III.-V. E.

\section{Tribe IV. Agrostidea.}

\section{I0. Gastridum Pal. de Beauv.}

1. G. lendigerum (Gaud.); glumes laneeolate acuminate, outer pale awned, awn rather longer than the glumes.-E. B. 1107. P. 86. R. 1418.-St. 3-12 in. high. L. roughish at the edges. Ligule oblong. Panicle close, almost spiked, lobed. Glumes remarkably ventricose and shining at the base. Pales very small. -Wet places near the sea, rare. A. VII. 


\section{Polypogon Desf.}

1. P. monspeliensis (Desf.); seta more than twice as long as the rather obtuse glumes.-E. B. 1704. P. 11.-Root fibrous. St. 1-1! foot high. Paniele dense, lobed, pale, silky, often 2 in. long. Glumes lincar, hairy. 1 most beautiful grass.-Salt marshes. A. VI. VII.

L. S.

2. P. littoralis $(\mathrm{S} n$.) ; setxe equalling the acutc glnmes. $-\boldsymbol{E} . B$. 1251. P. 81.-Root somcwhat ereeping. St. about a foot high. Panicle close, lobed, purplish. Glumes lincar-lauceolate.-Muddy salt marshes, rare. P. VI. VII.

\section{Milium Linn.}

1. M. effusum (L.); panicle diffisc, pales acute, st. smooth, 1. lanceolate-linear.-E.B. $1106 . R$. 1456. P. 17.-Root fibrous with scions. St. $3-4$ feet high. Branches of the panicle long, in distant alternate tufts, in flower horizontal, afterwards deflexcil. -Damp shady woods. P. VI.

\section{Agrostrs Linn. Bent-grass.}

1. A. setacea (Curt.); panicle close oblong, branches and pedicels scabrous, glumes unequal acute: outer withont lateral ribs, outer pale erose at the top 4-ribbed: lateral ribs terminating in short setx, awn from the base of the pale and twice its length, $l$. setaceous, sheaths rough, ligule oblong acute.-E. B. 1188. P. 83.-Root tufted. L. short, involute, almost eapillary. Branches of the panicle short. Midrib of outer glume scabrous iu its upper half, slightly excurrent at the apex. Inuer pale very minute with a tuft of hairs at its base; outer erose at the top.Dry heaths in the south-west. P. VII.

E.

2. A. canina (L.); panicle spreading when in flower otherwise close, branches and pedicels scabrous, glumes unequal acute: outer without lateral ribs, outer pale erose at the top 4-ribbed, awn from below the midlle and longer than the pale, lower $l$. setaceous tufted, stem l. narrow, sheaths smooth, ligule oblong acute.-E. B. 1856. P. 15.-Root creeping and tufted with trailing leafy shoots. St. decumbent below, then erect. L. narrow; radical involute. Branches of the panicle long, slender. Fl. tinged with purple or green. Outer glume not erose at the top; midrib scabrous from rather below the middle. Inner pale 0 , or very minute. The awn is sometimes very short or rarely absent. - Peaty heaths. P. VII. VIII.

3. A. vnlgaris (With.); panicle spreading during and after flowering, glumes nearly equal : outer toothed on the upper part of the keel, ligule short truncate.-E. B. 1671. P. 12. 13.-St. long, ascending or deeumbent below and rooting at the joints, 
often producing long prostrate seions. Sheaths mostly smooth. Fl. rarely awned. - 3 . pumila; exspitose, st. 2-3 in. high, $\mathrm{fl}$. often awned nsually infested with smut.-Rather dry places. P. VII.

4. A. alba (I.) ; panicle compact after flowering, glumes nearly equal: outer toothed throughout its keel, ligule elongate acute.E. B. 1189. P. 13. 14.-St. ereet. Sheaths roughish. Paniele spreading when in flower, afterwards elosc. Florets sometimes though rarely awned.- $\beta$. stolonifera; with long prostratc seions. E. B. 1532. - $\gamma$. maritima; st. procumbent, rooting at the joints, paniele small lobed.-Fields, \&e. $\gamma$. Sea-sands. P. VII.

\section{Apera Adans.}

1. A. Spica-venti (Beauv.); panielc spreading, awn 3 or 4 times as long as the pale, anth. linear-oblong.-R. 1421. Agrostis Sm., E. B. 951. Anemagrostis (Triu.) P. 17.-St. 1-2 feet high. Paniele very light and elegant. Rudiment of the seeond fl. a small perlieel with a tuft of hair on each side, at the base of the inuer pale.-Sandy fields, rare. $\Lambda$. VI. VII.

E. S.

\section{Tribe V. Stipacee.}

\section{Stipa Limn. Feather-grass.}

[1. S. pennata (L.); awn very long twisted feathery its base glabrous. - E. B. $1356 .-\Lambda$ beautiful plant with remarkably long awns, common in gardens.-On roeks in Long Sleadale 6 miles north of Kendal, Westm. Dillenius. P. VI.] E.

\section{Tribe VI. Arundinca.}

\section{Arundo Linn.}

1. A. Calamagrostis (L.); paniele loose ereet, awn very short from the bottom of the notch at the top of the outer pale and searcely extending beyond it, hairs longer than the pales, no rudimentary fl.-E. B. 2159. P. 84. Calamagrostis lanceolata Koch. -St. slender, 3-4 feet high.-W Wet plaees, rare. P. VII. E.

2. A. Epigejos (L.); paniele rather close lobed, awn from about the middle of the outer pale, hairs longer than the pales, no rudimentary fl.-E. B. 403. P. 16. Calamagrostis, Hook.-St. 3-5 feet high.- " $\beta$. glauca (Fries); more slcuder, 1. narrower, paniele effise."-Damp sharly plaees. $\beta$. Near St. Ives, Hunts. Rev. W. W. Newbould. P. VII.

3. A. stricta (Sehrad.); panicle elose, glumes lanceolate rough on the kecl one (at least) 3-nerved, outer pale nearly as long as the inner glume deeply notched at the top longer than the hairs, 
awn from below the middle of the pale and scareely extending beyoud it straight, rudiment of a second fl. present, l. of the barren shoots slender.-E. B. 2160.-Cal. stricta and lapponica Bab.-St. erect, 2-3 ft. high. I. broak; those of the barren shoots much narrower. Upyermost lignle short, blunt; longer and acute in the Lish plant. Fl. tinged with purplish-hlue.The Irish plant, usually naned $A$. lapponica, has shorter branches to its panicle than the English and Scotch plants, but that will not afford a eoustant charaeter. Its longer and sharper ligule is more worthy of attention. Its glumes seem of exactly the same shape as those of $A$. stricta from whieh I am unable to distinguish it. A.lapponica (Walıl.) has l-nerved glunes, a bent awn, and hairs as long as the pale.-Bogs. Formerly found near Forfar. Oakmere, Cheshire. Rev. G. E. Smith. Lough Neagh, Antrim. P. VI. VII.

\section{Psama Pal. de Beauv.}

1. P. arenaria (R. and S.); panicle eylindrieal narrowed upwards, glunes and pales linear-laneeolate acute, hairs $\frac{1}{3}$ of the length of the pales.-Arundo Sn., E. B. 520. Ammophila $R$. 1434. P. 8. - St. erect, stiff, $2-3$ feet high. L. rigid, involute, acute, glaueous.-The name of Ammophila was given to a genus of Hymenopterous insects by Kirby in 1798. - Sandy sea-shore, binding the shifting sands. P. VII. Sea-reed. IIarram.

\section{Phragmites Trin. Reed.}

1. P. communis (Trin.); panicle diffuse, spikelets $3-5$-flowered, fl. longer than the glumes.-Arundo Sm., E. B. 401. R. 1729. Par. 29. - St. 5 - 6 feet high, ereet. Paniele large, purplish. L. flat, broad.-Dr. Bromfield mentions (Phyt. i. 146.) a state with prostrate stems $20-40$ feet long; found on the south eoast of the Isle of Wight.-Marshes. P. VIII.

\section{Tribe VII. Chloridea.}

\section{Cynodon Rich.}

1. C. Dactylon (Pers.); spikes 3-5 digitate, pales smooth, 1. downy beneath, seions prostrate $-E$. B. 850. P. 72. R. 1404. -Creeping. Scions long, branehed. Flowering st. 4-6 in. high terminating in a single eluster of spreading inany-flowered slender spikes. Spikelets purplish. L. on the barren shoots flat, spreading.-Sandy shores. Dorset. Deron. Cornwall. P. VIII.

20. Spartina Schreb.

E.

1. S. stricta (Roth); l. artieulated to their sheaths shorter than the spikes, spikes $2-3$, raehis seareely extending beyond 
the last spikelet, outer glume hairy.-E. B. 380, R. 1401.-St. $1-2$ feet high. L. narrowing to the base where they easily separate from their slieatlis. Spikes pressed elose together. A remarkably rigid plant.-Muddy salt marshes. P. VIII.

E.

2. S. alterniflora (Loiscl); l. eontinuous with their sheaths as long or longer than the spikes, spikes numerous, raehis produced beyond the spikelets and flexuose, outer glune glabrous. -E. B. S. 2812. P.75.-St. 2-3 feet high. L. broadest at the base and not separating from their sheaths more easily than at any other part. Spikes pressed close together.-Mud-flats in the river Itehen at Southampton. P. VIII.

E.

\section{Tribe VIII. Oryzea.}

\section{Leersia Soland.}

I. L. oryzoides (Sw.); panicle patent with wary branehes, spikelets 3-androus lialf-oval ciliated on the back.-E. B. S. 2908. R. I495.-Creeping. St. I-2 ft. high, "never proeumbent and rooting at the joints as erroneously stated in E. B. S." Borrer. L. broad, rough-edged ; uppermost horizontal at the flowering season. Panicle rarely, if ever, protruded in this country, mostly inclosed in the sheath of the uppermost leaf.-Ditches in Henfield Level, Suss.' Mr. Borrer. P. IX.

E.

\section{Tribe IX. Sesleriea.}

\section{Sesleria Scop.}

1. S. crerulea (Scop.); raceme ovate slightly I-sided, outer pale terminating in 4 teeth : the dorsal rib rough with a short excurrent point, l. abrupt with a minute rough point.-E.B. 1613. R. 1510. P. 27.--Roots tufted. St. $6-12 \mathrm{in.}$ high. Raeeme about half an in. long, bluish-purple. Styles combined. Stigmas very long, linear, at first combined almost to the summit, afterwards separate.-Mountains. Banks of the Sliannon, I.-P.IV.V.

\section{Tribe X. Aveninere.}

23. Lagurus Linn.

1. L. ovatus (L.).-E. B. I334. P. 88. R. 1415.-St. 4-I2 in. high. L. broall, lanceolate. Spikes orate, soft.-Sandy places in Guernsey. A. VI. VII. 


\section{Arra Iinn.}

* Outer pale truncate, jagged. Nut free, not furrowed on the back.

$\dagger$ Awn straight. Descuampsia lieanv.

1. A. caspitosa (L.); paniele spreading, 1. that, glumes slight7y rougl at the midrith, awn from below the middle of the pate and scarcely extending beyond its smmmit.-DE. B. 1453, R. 16821686. P. 23.-Root tufted. St. $1-3$ feet high. L. rigid, roughish, their margins involute when dry. Branches of the panicle rough. Onter pale with 4 nerves in addition to that which terminates in the rough awn. Rudiment of the third $\mathrm{fl}$. often scarcely, if at all, distinguishable, or, in other cases, lialf the lengtli of the 1 pper $\mathrm{tl}$. and somewhat clavate. $-\beta$. brevifolia (Par.); ralieal l. short, sheaths and st. smootl, paniele small. $P .106$. Often taken for $A$. alpina.-Meadows, thickets, \&e. $\beta$. Mountain tops. l'. VII.

+十 Am bent, twisted at the base.

2. A. alpina (L.); paniele elose, l. mostly involute, glumes smooth on midrib, awn from above the middle of the pale and seareely extending beyond its summit.-E. B. 2102. P. 23.Height $6-12$ in. L. narrow, rigid, ronghish on the upper surfaee. Branehes of the panicle quite or nearly smooth, lower onts lax, upper erect. Fl. often viviparous.-Tops of highland mountains. P. VIII.

3. A. flexuosa (L.); panicle spreading triply forked with wavy branclies, l. very narrow subsetaceous, awn from near the base of the pate and extending consilerably beyond its summit, pedieel of the second $f$. less than $\frac{1}{4}$ of its length, ligule truneate, $-E$. B. 1519. R. 1678-1679. P. 107.-St. erect, slender, about a foot high. L. solid, nearly terete. Upper sleaths rough from above downwards. Outer pale notched at the summit.-Heathy places. P. VII.

** Outer pale bifid. Nut adnate to the pales, "furrowed cn the back." Arropsis Fries.

4. A. caryophyllen (L.); pauicle spreading triply forked, glumes rouuded at the base, awn from below the middle of the pale and exteuding considerably beyond its attenuated deeply bifid point. -E. B. 812. R. 1676. P.24. Avena Koch.—St. 6-12 in. high. L. short and narrow. Sheaths roughish from below upwards. Spikelets very small, romded below, chiefly collected at the ends of the branches; no rudiment of a third floret.-Dry gravelly places. A. VI.

5. A. precox (L.); panicle spikelike oblong, glumes scarcely rounded at the base, awn from below the middle usually near the base of the pale and extending eonsiderably beyond its attenuated 
deeply bifid point.-E. B. 1296. R. 1675. P. 25. Avena Ǩoch. - Ileight 1-6 in. l'anicle close, oval or oblong. No rudiment of a thind floret. L. very narrow. Often with difficulty distinguished from the preceding.-Dry and sandy places. $\Lambda$. IV. V.

\section{Corynephorus Pal. de.Beauv.}

1. C. canescens (Beaur.); panicle rather dense elongated, glumes longer than the fl. acuminate, awn from near the base of the pale, l. setaceous.-R. 1190. Aira Sm., E. B. 1190. P. 110. -St. tufted, slender, 6-8 in. high. L. numerous. Panicle close, spreading when in full bloom. Spikelets variegated witlı purple and white. Anth. dark purple. Lower portion of the awn dark yellow, straight, cylindrical, longitudinally striated and slightly twisted; upper part clavate, white tinged with purple.-Sandy coasts of Norf., Suff., and Jersey. A. VI. VII.

\section{Trisetum Pers.}

1. T. flavescens (Beauv.); panicle much branched diffuse equal, glumes rery uncqual about 3-flowered.-P. 54. Avena Sm., E. B. 952. R. 1694-1696.-St. about a foot high. Radical 1. and sheaths lairy. Ligule very short, obtuse. spikclets yellowish. Upper glume oblong-lanceolate acuminate. Floral axis hairy, hairs short.-Fields. P. VII.

\section{Avena Linn.}

* Upper glume 5-9-nerved. Spikelets ultimately pendulous.

1. A. fatua (L.); panicle erect, spikelets about 3-flowered drooping, $f$. shorter than the glumes hairy at the base, outer palc bifid at the end.-E. B.2221. P.27.- Height 3 feet. Fl. with long fulvous hairs at their base by which it may be distinguished from A. sativa, the cultivated Oat.-Corn-fields. A. FII. Wild Oat.

2. A. strigosa (Schreb.); panicle sccund, spikelets of about $2 \mathrm{fl}$. drooping, fl. as long as the glumes, outer pale ending in 2 long straight bristles.-E. B. 1266. P. 26.-Ieight 3 feet. Tory like A. sativa but readily distinguished by the bristles at the eud of the fi.-Corn-fields. A. VII.

\section{** Upper glume 3-nerved. Spikelets erect.}

3. A. pratensis (L.); panicle crect with simple or slightly divided loranches, $f$ l. erect $3-6$ longer than the glumes, l. scabrous. - E. B. 1204. P. 52.- H cight nearly 2 feet. St. usually nearly round. L. usually short, narrow, acute. Branches of the panicle generally simple bearing only one spikelct.- $\beta$. longifolia (Par.); l. much longer. $-\gamma$. alpina; st. often compressed and shcaths carinate, branches of the panicle often bearing scveral 
spikelets, spikelet with more numerous fl., inner pale less acnte, 1. broader. 1 believe that uone of these cliaracters are permanent. F. B.2141. P. 53.-A. planiculmis of Ilooker (E. B. S. 2684.) appears to me to bclong to this species, differing in its greatly compressed st., strongly keeled slieatlis and more branched panicle.-Dry pasturés and mountainons places. P. VI.

4. A. pubescens (L.); panicle erect ncarly simple, fl. erect 2 or 3 , searecly longer than the glumes, lower $l$. and sheaths hairy. - E. B. 1640. R. 1700 . P. 53.-Height $1-2$ feet.Chalky and limestone districts. P. VII.

\section{Arruenatherum Pal. de Beaur.}

1. A. avenaceum (Bcanv.); l. flat.-Holcus Sm., E. B. 813. R. 1715-1717. P. 25.-I Icight 2-3 fect. Root fibrous. Joints of the st. glabrous sometimes downy. $-\beta$. nodosum; base of the st. witl swollen knobs, joints downy. A. bulbosum Lindl. P. 26. I find this plant preserving its characters on rich as well as barren soil.-Hedges and pastures. P. VI. Oat-grass.

\section{Holcus Linn.}

1. H. lanatus (L.); upper glume obtuse apiculate, awn smooth cxecpt for a short distance from the tip. $-E . B .1169 . \quad R .1718$. P. 21.-IIcight I-2 feet. Sheaths downy. Inflorescence panicled, often pinkish. Lower fl. awnless. Awn at length curred likc a fish-hook and inclurled within the glumes, quite smooth or slightly rough at the point. Root fibrous.-Meadows and pastures. P. VII.

2. H. mollis (L.); upper glume acute, awn rough throughout its whole length.-E. B. I170. R. I721. P. 21, 22.-Height I -3 fcet. Sheaths nearly smooth. Inflorescence not so compact as in the preceding, whitish. Lower fl. awnless. Awn at length bent at an angle, protruding beyond the glumes. Root crceping. Sometimes the lower $\mathrm{fl}$. has an awn, and rarely the upper is perfect. Ocensionally the spikelets are much smaller and the plant only 12-18 in. high.-Thickets or open places on a light soil. P. VII.

\section{Triodia $R . B r$.}

1. T. decumbens (Beauv.); panicle racemose, spikelets few oval, $f$. about 4 scarcely extending beyond the glumes without awns.-E. B. 792. R. 1572. P. 30.-St. 6-I2 in. high. L. flat. Sheaths rather hairy. Ligule reduced to a tuft of hairs. Spikclets few, $1-7$. Glumes smooth, coriaceous, hiding the fl. Outer palc terminating in 3 points, 5 -ribbed, hairy at the base.-Mountain pastures. P. VII. 


\section{Tribe XI. Festucinece.}

\section{Koneria Pers.}

1. K. cristata (Pers.); panicle eompaet spikelike interupted below, outcr pale acute 3-ribbed, l. narrow rough at the edges ciliatcl.-Aira Sm., E. B.648. R. 1669. P. 19.-Root crowned with the undivided sheaths of the old leaves. St. 6-18 in. high, downy particularly in the upper part. L. rongh and ciliated at the edges, otherwise glabrous; or together with the sheaths villose. Glumes and pales glabrous or downy; glumes minutely toothed at the keel; outer pale minutely toothed on the midrib. Sometimes the l. become convolute when dry. In dry plaees the l. are much shorter than the st., in damper places elongated and oftcu nearly equalling the stem.-Dry pastures. A large form on damp ledges on Ben Bulben. I. P. VI. VII.

\section{Melica Linn.}

1. M. uniflora (Retz.); panicle branchel slightly drooping, spikelets erect with 1 perfect glabrous $f$., 1 . flat, ligule short obtuse with a slcnder acuminate lobe on one side. $-E . B .1058$. R. 1576. P. 18. Shady and roeky woods. P. VI.

2. M. nutans (L.); panicle a ncarly simple lax seeund raceme, spikelets pendulous with 2 perfect glabrous $\mathrm{fl.}, \mathrm{l}$. flat, ligule short obtuse.-E. B. 1059. R. 1577. P. 18.-Damp shady woods. P. V. VI.

\section{Molinia Schrank.}

I. M. carulea (Hoench); panicle crect elongate narrow, spikelets 1 -3-fl., outer pale 3 - (rarely 5-) nerved awnless, upper part of the st. naked.-E. B. 750. R. 1606. P. 20.-St. $1-2$ feet high. L. long, lincar, attenuated. $-\beta$. depauperata; spikclets I-fl. few, outer prale often but not constantly 5 -nerved. M. depauperata Lindl., P. 19.- Wet heaths. $\beta$. $\Lambda$ lpine situations. P. VII. VIII.

\section{Catabrosa Pal. de Beauv.}

1. C. aquatica (Presl); panicle equal with half-whorls of patent branches, l. broally linear obtuse.-E. B. 1557. P. 20.Crceping. St. long, procumbent or floating below. L. flat, broad. Branches of the paniele springing in threes or fives from alternate siles of the rachis. Spikelets usually 2- (sometimes 3-5-) flowered. Ghumcs very thin, often tinged with purple. 1. dlistant.- $\beta$. minor; st. $2-3$ in. high, spikelets mostly 1flowered.--Pouds and ditehes. $\beta$. Wet sands. P. VI. VII. 


\section{I'OA Linn.}

\section{* Root fibrous; no stolons.}

+ Lower branches of the panicle solitary or in pairs. Dorsal and marginal nerves of the onter pale lairy.

1. P. bulbosa (L.); panicle elose erect, spikelets ovate of 3 or 4 acnte webled fi., outer pale with 3 silky nerves, upper sheath below the middle of the st. much longer than its leaf, ligule pomincent acute.-E. B. 1071. P. 89. R. 1619.-Root fibrous. Base of the st. swollen and resconbling a bulb. L. with a narrow white serrated margin. The st. soon wither and the bulbs lie loose upon the sand until the antumn, when they again fix themselves. - Sandy sea-shores of the south aud east. P.IV. V. L.

2. P. annua (L.); panicle spreading erect with a triangular outline, spikclets ovate-oblong of 5 or 6 free $\mathrm{fl}$, outer pale with 5 nerves all more or less silky, upper sheath longer than its leaf, ligule oblong acute.-E.B.1141. P.40,41. R. 1621.-Root tibrous. St. ascending or prostrate. L. flaccid, often wary, broad. Branches of the panicle patent or divarieated.-3. supina; onter pale glabrous or with a very few hairs on the midrib, branches of the panicle erect-patent, l. narrow.-Very common. 1. III. - X.

3. P. minor (Gaud.); panicle oblong subovate, spikelets of 3 or 4 webbed fl., outer pale with 5 nerves the dorsal and marginal hairy, upper sheath longer than its leaf which is folded and slightly incurved but tapering at the summit, uppermost joint covered, npper ligule loug acute, lower ones short rather blunt.- $P$. flexuosa Sm., E. B. 1123.? not of others.-Root fibrous. St. 6-8 in. high. Fl. often viviparous.-Lofty mountains. Loch-na-Gar. Prof. Balfour. "Beu Nevis." Sim. P. VII. VIII.

4. P. laxa (Haenke!); pauicle lax slightly drooping, spikelets oblong-orate of 3 free $\mathrm{fl}$., outer pale with 3 hairy nerves, upper sheath longer than its leaf which is flat and taper-pointed, uppermost joint covered, ligules all long acute.-P. 38.- Root fibrous. St. 6-12 in. high. Fl. often viviparons; sometimes, it is said, slightly webbed. This seems certainly the Bohemian plant but most of my Swiss specimens appear to be $P$. minor. Perhaps they are not truly distinct.-Lofty mountains. Ben Nevis. Dr. Parnell. Loch-na-Gar. Prof. Bälfour. P. VII. VIII.

5. P. alpina (L.); panicle erect sprcading when in flower, spikelets ovate of 3 or 4 free fl., outer pale with 3 hairy nerves. upper sheath longer than its leaf which is folded and rounded behind the summit, uppermost joiut exposed, ligule long pointed. -E. B. 1003. P. 37 and 94.--Root fibrons, tufterl. St. 6-12 
in. high, basal slicaths common to it and the tuft of leaves. Fl. often viviparous.-Lofty mountains. P. VI. VIl.

6. P. montana (Par.); panicle erect close slender, spikelets few lanceolate-ovate of 2 or 3 free fl., outer pale with 5 nerves the dorsal and marginal hairy, upper sheath not longer than its leaf, uppermost joint at about the middle of the stem, ligule prominent obtuse.-P. 39.--Root creeping. St. 12-18 in. high. Joints 4 or 5 , the highest rather above than below the middle of the stem; in my rather imperfect specimen the upper one is exposed. Panicle with long branches bearing 1 or 2 spikelets. Lowest $f l$. not longer than the large glume.-Ben Lawers (3600) ft.). Dr. Greville. P. VI.

7. P. casia (Sm.); panicle ereet slender, spikelets ovate of $2-5$ acute free $\mathrm{H}$., outer pale with 5 nerves the dorsal and marginal hairy, upper sheath not longer than its leaf, uppermost joint near to the base of the stem, ligule short obtuse.-Root fibrous. St. 6-12 in. high. Lowest fl. longer than the large glume.- $a$. cesia; spikclets of 4 or $5 \mathrm{fl}$., panicle rather spreading.

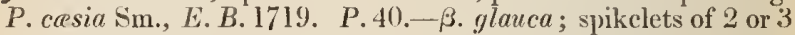
fl. panicle rather close, l. broader. P. glauca Sm., E. B. 1720. - Mountains. a. Ben Lawers. Clova. ß3. Snowdon. Ben Nevis. P. VII.

E. S.

Hower branches of the panicle in fives or 2 or 3 together. Dorsal and marginal nerves of the outer pale hairy.

8. P. nemoralis (L.); paniele rather drooping slender, spikelets ovate-lanceolate of 3 or 4 webbed $\mathrm{fl}$., outcr pale with 5 nerves the dorsal and marginal hairy, upper sheath not longer than its leaf, uppermost joint at about the middlc of the st. exposed, ligule extremely short truncate-E. B. 1265. P. 36.--Root shightly creeping. St. slender, $1-2$ feet high. Sheaths smooth. - $\beta$. angustifolia; st. and panicle very slender, l. long and narrow, uppermost joint near the panicle, spikelcts few 1-2-flowered.- $\gamma$. glauca; st. slender, panicle with many long-stalked spikelets, plant glaucous.-Shady places. $\gamma$. Mountains. F. VI. V11.

9. P. Parnellii (Bab.); panicle ereet large rather close oblong, spikelets ovate of 2 or 3 acute free $f$., outer pale with 5 nerves the dorsal and marginal hairy, upper sheath usually longer than its leaf, upper joint at about the middle of the st. cxposed, ligule very short truncate.-E. B. S.2916. P.93.-St. aseending, $1 \mathrm{ft}$. or more high, compressed; joints 5 or 6 , uppermost not above the middle of the stem. Ligule 6 times as broad as long, but longer than that of $P$. nemoralis to which this is perhaps too nearly allied. Oeeasionally there is a slight traee of a web to 
the florets.-IIigh Foree and other parts of Upper Teesdale. P. V'Il.

10. P. Balfourii (Par.); panicle ereet rather spreading, spikelets ovate of $3 \mathrm{or} 4$ webbed H., outer pale with 5 nerves the dorsal and marginal hiny, upper sheath about as long as its leaf, upper two-thirds of the stem without joints, ligule prominent obtuse.P. (66. E. B. S. 2918 - -Root creeping. St. 3-15 in. high; joints about 3 , eoncealed by the sheaths, uppermost within the lower third of the stem. (In speeimens from Cheviot and Ingleborongh the uppermost joint is exposed and placed slightly higher.) Lower fl. as long as the larger glume.-Tops of mountains. Ingleborongh, Yorkshire. Mr.J. Backhouse, Jun. Cheviot, Northmmb. Perth aml Forfarshire. P. VII. E.s.

tit Lower branehes of the paniele subverticillate. Dorsal nerve of the outer pale hairy; narginal glabrous.

11. P. trixialis (L.); panicle liffuse, spikelets ovate of 2 or 3 aeute webbed $\mathrm{A}$., outer pale with 5 nerves, upper sheath much longer than its leaf, ligule acute long. $-E$. B. 1072. P. 35.Root tufted. St. 1-2 ft. high. Sheaths slightly rough. $-\beta$. parviflora (Par.); spikelets small 1-2-flowered, plant sleurler.Moist and shady plaees. P. VI.

\section{** Root creeping by long stolons.}

12. P. pratensis (L.); panicle diffuse, spikelets ovate of 3 or 4 webbed fl., outer pale with 5 prominent nerves the dorsal and marginal hainy, upper sheath mueh longer than its leaf, ligule prominent obtuse.-E. B. 1073. P.31-34.-Very variable in size. St. and sheaths nearly always smooth. Fl. strongly webbed.- $\beta$. subcarulea; spikelets broader, l. broad and short, up)per l. compressed romded at the end behind. E. B. 1004.$\gamma$. angustifolia; spikelets small, l. slender long, lower l. involute. - Common. P. VI. VII.

13. P. compressa (L.); panicle rather unilateral spreading when in flower otherwise close, spikelets ovate or oblong-ovate of $5-7$ obtuse slightly webbel fl., outer pale with 3 hairy nerves, upper sheath about as long as its leaf, uppermost joint at about the middle of the stem, ligule short obtuse,-E. B.365. P. 37.$S t$. decumbent at the base, then ereet, very nueh compressed. $1-1 \frac{1}{2} \mathrm{ft}$. high. Outer pale with no intermediate nerves. $-\beta$. subcompressa; outer pale distinctly 5 -nerved, intermediate nerves glabrous. P. subeompressa $P .90$. This differs in look from $P$. compressa, but is, I fear, searcely distinet from it.-Dry situations. P. VII.

14. P. polynoda (Par.); panicke ereet ovate-lanceolate, spikelets ovate or ovate-lanceolate of 4 or 5 not webbed fl., outer pale 
with 5 nerves the dorsal and marginal hairy, ıpper sheath not longer than its leaf, uppermost joint above the middle of the stem, ligule prominent obtuse.-P. 91.-St. decumbent at the basc, then ereet, compressed, I- $1 \frac{1}{2} \mathrm{ft}$. high ; joints 7 or 8 , the second at about the midlle of the stem. L. acute. Panicle with short branches. Lowest $\mathrm{H}$. not longer than the large ghme.- $\beta$. denticulata (Par.) ; midrib of outer palc not hairy but denticnlated throughout, ligule shorter, often one convoluted hair at the base of the A. P. 92.-Dry stony places. P. VI. VII. E. S.

\section{Glyceria $R$. $\boldsymbol{B r}$.}

I. G.aquatica (Sm.); paniclc ercet repcatedly branched sprcading, "rachis semiterete," branches scabrous, spikclets lincar-oblong of $5-10 \mathrm{H}$., outer pale obtuse, l. smooth with slightly compressed sheaths.-E. B. 1315. P. 44.-Root crecping. St. 3-6 feet high, smooth, slightly compressed. Sheaths very long. L. long, rough on the elges and keel. Ligule short. Panicle large. Branches angular, slender, branched. Outcr pale with the central nerve cxtending to the summit. - Watery places. P. VII.

2. G. fluitans (R. Br.); panicle secund shightly branched very long, branches nearly simple roughish, spikclets linear of 7-12 fl. alpresscd, fl. lanccolate-oblong acute, outer pale nearly thrice as long as broad, sheaths compressed.-P. 95.-St. ascending, ronting below, or floating, slightly rough below the joints. L. pale green, acute. Ligule elongate. Panicle remarkably elongated, often nearly simple; branches withont callosities, ascending, lowermost nsually in pairs. Spikelets adpressed, Outcr pale with a triangular central point. Anthers about 5 times as long as broad, purple, palc yellow when empty.-Stagnant water and wet places. P. VI.-IX.

3. G. plicata (Fries); panicle compound, branches compound nearly smooth erect when in flower divaricate with fruit, spikclets lincar of $7-20 \mathrm{fl}$., $\mathrm{fl}$. oval-oblong blunt, outer pale twice as long as broad, sheaths compressed.- $R$. vii. 79. G. fluitans Sm., E.B.1520. P.45.-Resembling G. Aluitans. St. smooth. L. glaucons, bluntish, "plicate when young." Ligule shorter. Panicle much branched; branches with callosities at the base, lowermost about in fives. Outer pale with 3 nearly equal teeth at the end. Anth. about 3 times as long as broad, cream-coloured, fuscous when empty. - Stagnant water and wet places. P. VI.-IX.

\section{Scherochloa Pal. de Beauv.}

* Glumes with 3 ribs.

1. S. maritima (Lindll.); paniçc branched : lowermost branches in pairs, or simple, branches ultimately erect, spikelets lincar ad- 
pressed 4-8-flowered, rachis terete, outer pale obluse apiculate: midrit not reaching to the apex, root stoloniferous.-Glyceria sin., E. B. 1140 . R. 1611, 1612. P. 42.-Root fiblous with rooting or aseending seions. L. involute; the central ridge on their upper surface strongly marked, the others faint. Anth. abont 6 times as long as broal. Onter pale with involute margins. Ligule bluntish.- $\beta$. hispida (Par.); st. eompressed, rachis furrowed on one side and as well as the branches of the paniele rough. $P .99$. -Sca-coast, in damp places. P. VI. VII.

2. S. distans (13ab.); panicle branched, branches clongated ultimately spreading or deflexed lowermost in fours or fives, spikelets linear 3 -6-flowered, rachis semiterete rather flat on onc sirle, outer pale obtuse: midrib not reaching to the apex, root fibrous. -Glyceria Sm., E. B.9\$6. R. 1609. P. 41.-Root fibrous, without rooting scions. St, decumbent below. L. flat, short, with 8-10 equally prominent ridges upon their upper surface. Ligule short anl trumeate. Margins of the outer pale not involute. Spikelets and $\mathrm{H}$. half the size of those of the preeeding.3. obtusa (Par.); panicle more compound, spikclets abont 7-flowered, outer pale truncate and broader, ligule shorter. P.96 and 97. -Sandy sea-shores. $\beta$. Leicestershire. P. VI._-VIII.

3. S. Borreri (Bab.); panicle branched, branches ultimately erect-patent lowermost gencrally in fours, spikelets linear 4-7H., rachis terete, outer pale with a rigid apiculus formed by the extremity of the dorsal nerve, root cxspitose.-Glyeeria $E . B$. S. 2797 (1837). P.98. G. remota Fries (1839).-St. 6-12 in. high. L. short, Hat, with very long sheaths. Ligule short, truneate. Margins of the outer pale not involute. Spikelets and $\mathrm{fl}$. half the size of those of $S$. maritima and S. procumbens. Branches of the panicle short, scarcely elongated after flowering, hispid.Murdy salt marshes. P. III.

E.

4. S. procumbens (Beauv.); panicle ovate-lanceolate compact distichous rigid, spikelets linear-lanceolate of about $4 \mathrm{fl}$., rachis angular, outer pale obtuse with an apiculns formerl by the extremity of the clorsal nerve, root fibrous.-Glyceria Sm., E. B. 532. R. 1517. P. 42.-St. procumbent, (rarely when growing in water erect, ) rigid. L. flat, with inflated sheaths. Panicle about 2 in. long, with very short rigid branches sprearling in 2 rows. Fl. large.-Salt marshes. A. VII. VIII.

\section{** Glumes with only one ril.}

5. S. rigida (Link); panicle laneeolate rigid distichous, spikelets linear acute of $7-10 \mathrm{fl}$., outer pale obtuse with a mucro, upper glume reaching to the base of the third fl., root fibrous.Glyceria Sm., E. B. 1371. R. 1518. P.43.--St. slender, wiry, 
ercet. L. ncarly fiat, acute. Panicle $1-2$ in. long, nearly simple. Outcr pale obsoletely nerved. Fl. small.-Dry places. A. VI.

6. S. loliacea (Woods); panicle racemose narrow rigid secund, spikelets oblong of 8-12 $\mathrm{fl}$, outer pale obtuse with a mucro, npper glume reaching to the base of the fourth fl., root fibrous. -Triticum Sm., E. B. 221. R. 1370. P.43.-St. stout, slightly curved, asecnding. L. flat, convolute when dry. Spikelets usually solitary, altcrnate, all dirceted to one side; footstalks very short and stout. Marginal nerve of the outer pale broad and strong. Very different in appearance from the preceling but difficult to distinguish on paper.- Sandy sca-coast. A. VI. VII.

\section{Briza Linn.}

1. B. minor (L.); spikelets triangular of about 7 fl., glumes longer than the lowermost $f$., panicle diffuse, ligule elongate lanceolate acite.-E. B. 1316. R. I663. P.101.-St. very slender, about 1 foot high. Spikelets palc grecn. Outer pale roundishcordate cartilaginous and very gibbous in the middle of the back. -Dry and sandy fields in the extreme south. $\Lambda$. VII. E.

2. B. media (L.) ; spikclets broally ovate of about $5 \mathrm{fl}$., glumes shorter than the lowermost $f$., panicle diffuse, ligule truncate very short.-E. B. 340. R. 1665. P.30.-St. slender, erect, $1-1 \frac{1}{2}$ foot high. Panicle light and elegant, with slender branches. Spikelets nsually purplish. L. lincar-acuminate. Outer pale oblong, cartilaginous, but not gibbons on the back.-I found a form of this plant near Bath with the ligule elongate and obtuse. -Pastmres. P. VI. Quaking-grass.

\section{Cynosurus Linn.}

1. C. cristatus (L.); raceme spikelike linear, fl. with a very short awn.-E. B.316. R. 1351. P.28.-Well marked by its unilateral spike and curious crested appendage to the spikelets.-Pastures. P. VIII. Crested Dog's-tail-grass.

2. C. echinatus (L.); raceme contracterl close ovate, fl. with awns about as long as the pales.-E. B. 1333. R. 1349, 1350. P. 28 and 129.-St. erect, $1-2$ feet high. Seales of the appendage with long points. - Sandy places in the extreme south, very rare. Guernsey and Jersey. A. VII.

\section{Dactylis Linn.}

1. D. glomerata (L.); panicle distantly bianched, branches bearing ovate cluster's of spikelets, st. erect, l. linear flat with scabrous margins, root cespitose not creeping. $-E . B .335 . R$. 1523. P. 29.-A coarse well-known grass. Paniclc usually with long spreading or divaricated branches cach bearing an ovatc 
cluster of spikelets; sometimes the branches are wanting, and then the whole inflorescence consists of one of these clusters.Mealows. P. V1. VIl. Cock's-foot-grass.

\section{Festuca $\operatorname{Lin} n$. \\ * Root leaves very narrow.}

1. F. uniglumis (Sol.); raceme 2-ranked sccund, lower glume very minute, $\mathrm{fl}$. compressed keeled shorter thian their awns.E. B. 1430. P. 112. R. 1526, 1527.-St. 6-12 in. high, erect, leafy nearly to the top. Raceme close. Lower glume usually scarcely listinguishable.-Sandy sea-shores. A. II. E. I.

2. F. bromoides (L.); panicle secund, glumes very uncqual, fl. terete shorter than thcir awns scabrous. - St. 6-18 im. high, more or less leafy. Lower glume always shorter than the upper, often very small. $-a$, bromoides; flowering panicle erect-patent. E. B. 1411. Lower branches of the panicle often equalling half its lengtlı.- $\beta$. Myurus ; flowering panicle narrow spikelike nodding at the end. F. Myurus Sm., E. B. 1412. not Linn. Lower branches of the panicle always very short.-Dry waste places. 1.? VI. VII.

3. F. ovina (L.); panicle close subsecund, spikelets of about $6 \mathrm{fl}$. mostly with awns of half their length, $l$. all involute-set 1 ceous, ligule bilobed, root fibrous cespitose.-E. B. 585. P. 56, 57.- Very variable. L. short, slightly curved, tufted. Root crespitose, not truly creeping. Fl. with short awns, glabrous, or glumes and outer pales hairy.- $\beta$. vivipara; spikelet converted into a leafy shoot. E. B. $1355 .-\gamma$. tenuifolia; l. very long setaceous, $\mathrm{tl}$. without awns, sometimes viviparous. $-\delta$. duriuscula ; flowering panicle pyramidal: branches almost divaricated, lowermost sheath pubescent, stem l. at first flat. F. duriuscula Fries. -Dry hilly pastures. $\beta$. and $\gamma$. on mountains. P. VI. Sheep's Fescue-grass.

4. F. rubra (L.); panicle close'subsecund, spikelets of about 6 awned $\mathrm{H}$., 1 . involute-setaceous, stem 1 . flat, higule bilobed, root stoloniferous, suckers terminating in erect shoots with distichous leaves.-E. B. 2056. R. 1557. F. duriuscula P.58, 59, 60, $\mathrm{Sm}$. (in part).- Root truly creeping. Fl. with short awns, glabrous, hairy, or villose. L. variable in length and breadth and the $f$. in size.-Common in dry sandy, rarely in wet, places. P. VI.

** Root leaves broad and flat. Bucetum Par.

5. F. sylvatica (Vill.); panicle erect diffuse much-branched: branches rough, spikelets of $3-5$ awnless acute $f$., outer pale scabrous witl 3 prominent ribs, dorsal rib serrated throughout, 
1. lanceolate-linear with seabrous margins, ligule elongaterl, root tufted.-R. 1562. Pon P. 44 and 100. F. Calamaria Sin., E. B. 1005.- Root searcely crecping. St. 2-4 feet high, covered at the base with imbricated broal acute leafless sheaths. L. very long, broad, roughish on both sides, the uppermost l. smaller than the other's. Outer pale very acute, the midrib extending nearly to the apex or slightly beyond it. Ovary pilose at the top.3. decidua (Sm.) ; 1. narrow er, fl. about 2. E. B. 2266.-Woods in mountainons distriets. P. VII.

6. F. gigantea (Vill.); panicle drooping branched, spikelets of about 5 awned fl., outer pale 5-ribbed, the dorsal rib nearly smooth not extending to the apex but terminating in a scabrous awn twice as long as the pale, l. lincar-laneeolate.-E. B. 1820. Bucetum P. 47.-St. 3-4 feet high. L. very long, broad, roughish on both sides, except near the base on the under side. Ligule short, unequal, auricled. Outer pale roughish, nembranous, often bifid at the apex, thus searcely agreeing with the genus. Top of the ovary glabrous. Styles terminal.- $\beta$. triflora (Sm.); paniele smaller and more erect, spikelets seattered of about 3 fowers. E. B. 1918.-Moist woods and thickets. P. VII.

7. F. arundinacen (Schreb.); panicle diffuse patent, branches mostly in pairs each bearing 2 or more spikelets divaricated after flowering, spikelets very numerous of $5-6 \mathrm{fl}$., outer pale 5 -ribbed: dorsal rib terminating at or just below the apex and forming a short awn, l. lineur-laneeolate.-F. elatior Sm., E. B. 1593. P. 46 and 47. - It seems probable that this plant was improperly combined with the next in my lst edition. I am indebted to Mr. Watson for pointing out the charaeter derived from the remarkably divarieated branehes of the fiuit-paniele.-Banks. P. VI. VII.

8. F. pratensis (Huds.); panicle elose, branches in pairs one liearing a single spikelet the other several never divaricated, spikelets of 5-10 $\mathrm{fl}$, outer pale 5-ribbed : dorsal rib terminating at or just below the apex or forming a very short awn, 1. linear-lanceolate. - E. B. 1592. P. 46.-Brauches of the panicle ascending, not divaricated after flowering; one of each pair nearly alway's reduced to a single spikelet. Iu this and the precediug the outer pale is obtuse or acute according as the midrib is or is not attaehed up to the summit.- $\beta$. loliacea; spikelets solitary alternate, lower ones stalked, upper sessile. This var. is distinguished from Glyceria fluitans, to which it bears much resemblance, by its very short ligule, 3-ribbed upper glume and 5-libbed outer pale. F. loliacea Sm., E. B. 18:1. P. 45, 113 and 114.- Wet meadows. P. VI. VII. 


\section{Bronus Linn.1}

* Spikelets broader upwards when in flower.

1. B. erectus (IIuds.); panicle erect, spikiklets lanceolate, tl. remote subcylindrieal, outer pale indistinctly 7-nerved $\frac{1}{3}$ longer than the smaller glume aml longer than its awn, root l. very narrow ciliated.-W. B. 47 l. R. 1604. P.51.-St. 2-3 feet ligh, erect. Upper l. broader than the other's, shcaths somewhat hairy, the hairs pointing upwarls. - $\beta$. nillosus; outer pale hairy.-On diy sandy and chalky soil. P. VI. VII.

2. B. asper (L.); panicle drooping, pedunckes long slightly ly'anched, spikelets lanceolate, fl. remote linear-lanceolate, outer pale hairy 5-7-ribbed twice as long as the smaller glume and longer than its awn, l. broad hairy.-E.B. 1172 . R. 1603. P.51. -St. 4-5 fect high. L. bruad, flat, the lower ones broadest, sheaths with hairs pointing downwards. - Damp woods and thickets. A. or B. VII.

\section{** Spikelets always broader upwards.}

3. B. sterilis (L.); panicle drooping, peduncles long slightly branched, fl. remote linear-lanccolate, outer pale glabrous shorter than its awn with 7 distinct equidistant ribs, l. pubescent.-E. B. 1030. R. 1583. P. 50.-IIeight $1-2$ feet. L. broad, flat.-Waste places. $\Lambda$. VI.

4. B. diandrus (Curt.); panicle erect scarcely branched, peduncles short, spikelets lanceolate, fl. linear remote subcylindrical, outer pale 7-ribbel twice as long as the smaller glume and about as long as its awn.-E. B. 1006 . R. 1584. P.50. B. madritensis Linn.-St. 6-12 in. high, glabrous. Rachis and pedicels scabrous. Remarkable for its erect panicle. $-\beta$. rigidus (Bab.); panicle compact, pedicels very short, upper part of the st., pedicels, rachis and glumes pubescent. B. rigidus (Roth) $R$. 1586.Dry sandy places, rare. $\beta$. Channel Islands. A. VI. VII. E. S.

5. B. maximus (Desf.); panicle erect lax at length nodding slightly branched, peduncles elongated after flowering, spikelets downy, outer pale 7-ribbed about laalf as long as its awn.E. B.S. 2820. P.115. (Parnell's figure represents the styles as terminal, not so the beautiful plate in E.B.S.)-Height 1-2 feet. A most beautiful grass.-Sandy places. Channel Islands. A. VII.

0 .

\section{Serrafalcus Parlatore 2}

1. S. secalinus; panicle loose drooping in fr. slightly com-

1 Synonymons with the genus Schedonorus of Fries.

2 Corresponds to the genus Bromus of Fries. 
pound, simple peduncles about equalling the oblong glabrous spikelets, $\mathrm{fl}$. at first loosely imbricated afterwards distinct about as long as the straight awn, onter pale not overlapping the next fl., l. hairy with nearly smooth sheatlis.-Bromus Sm., E. B. 1171. P. 49, 121 and 122.-In fr. the $\mathrm{fl}$. are quite separate and the spikelets pendulous. Summit of the larger glume half-way between its base and the summit of the second fl. on the same side. Outer pale not twice as long as broal, longer than the inner, 7-ribberl.- $\beta$. velutinus (Koch); panicle nearly simple, $\mathrm{fl}$. larger downy. P. 123. B. velutinus Sm., E. B. 1884.?-Cornfields. $\beta$. Between Edinburgh and Newhaven. Sm. A.? VI. VIl.

2. S. commutatus; panicle loose slightly drooping compound, simple perluncles equalling or longer than the oblong-lanceolate spikelets, fl. loosely imbricated about as long as the straight awn, l. and sheaths hairy.-Bromus Schrad. P. 124. B. pratensis Sm., E. B. 920.-Outer pale only slightly overlapping that of the next $\mathrm{fl}$. at the base when in fruit. Summit of the larger glume half-way between its base and the summit of the second $f$. on the same side. Outer pale twice as long as hroad, longer than the inner, glabrous or domny, 7-ribbed.-B. multiflorus (Par.); fl. more numerous, summit of the large glume rather more than half-way between its base and the summit of the second floret. P. $125,-$ Common. A.? VI. VII.

3. S. mollis (Parl.); paniclc close erect compound or simple, spikelets ovatc somewhat compressed pubescent, fl. closely imbricated about as long as the straight awn, midrib of the glumes and pales not scabrous, 1 . and sheaths liairy or downy.-Bromus Sm., E. B. 1078. P. 116.-Summit of the larger glume half-way between its base and the summit of the third fl. on the same side, or a little longer (var. ovalis Par. 117, when the spikelets are short and oval), or almost half-way to the summit of the fourth floret (var. pratensis Par. 118, when the spikelets are longer). Outer pale longer than the inncr. Simple peduncles not longer than the spikelets.- $\beta$. velutinus; panicle quite simple, peduncles very short, spikelets and 1 . densely pubescent.-Common. $\beta$. Sandy ground in Devon and Coruwall. A.? V. VI.

4. S. racemosus (Parl.); panicle close or elongated erect usually simple, spikelets orate somewhat compressed glossy, fi. closely imbricated about as long as the straight awn, midrib of the glumes and pales scabrous towards the top, l. and sheaths slightly hairy.-Bromus Sm., E. B. 1079. P. 119.-Summit of the larger glume half-way between its base and the summit of the thirr fi. on the same side. Simple ped. not longer than the spikelets. Outer pale longer than the inner.- $\beta$. arenarius; panicle nearly or quite simple, pell. very short.-See Dr. Parnell's account of these species (Brit. Grasses) and Mr. Watson's 
paper (Lond. Journ. Bot, i. 82.).-Common. $\beta$. Sandy ground in the soutl. A. VI.

[S. arvensis (Godron); panicle spreading erect compound, spikelets linear-lanceolate, pales equal in length: outer 7-ribbed with 2 prominent ribs near each margin, anth. 4 times as long as broad.-E. B. 1984. P. 126.--Sumnit of larger glume lialf-way to summit of the second $\mathrm{fl}$. on the same side.-IIas been found near Southampton, on the Durham coast, and near IIebden Bridge in Yorkshine. Accidentally introdueed. A. VII. VIII.]

[S. patulus; panicle spreading compound at first crect, spikelets lanceolate, pales unequal 7-9-ribbed : 2 lateral ribs prominent, anth. twice as long as broad.-P. 127.-Aecidentally introduced. Yorkshire. A. VI.]

[S. squarrosus; panicle drooping simple, spikelets ovatelanceolate subeompressed, fl. nearly glabrous imbricated conpressed, awn divaricating, l. pubescent.-E. B. 1885. P. I18.Said to have been found in Somcrsct and Sussex, probably introdueed with corn sced. A. VI. VII.]

\section{Brachypodum Pal. de Beauv.}

1. B. sylvaticum (R. and S.); spike drooping, spikelets (at first) terete alternate distichous, awns of the upper $\mathrm{H}$. Tonger than their pales, 1. that lincar-lanceolate flaccid, root fibrous.-E. B. 729 . P. 61.-St. usually solitary or 2 or 3 from the same root, creet, 1-2 feet high. Sheaths and inner side of the l. hairy. Ligule short, blunt, notched or torn. Pales hairy.-Woods and hedges. P. VII.

E. I.?

2. B. pinnatum (Beauv.); spike erect, spikelets (at first) terete alternate distichous, awns of the upper fl. shorter than their pales, I. flat linear-lauceolate rigid, root creeping. - E. B.730. P. 132I:37. B. gracile $R$. 1374.-St. several, erect, I-2 feet high. Pales seabrous or hairy. Ligule short, truncate.- $\beta$. cespitosum; l. very narrow and involute, st. very numerous, spikelets small smooth.-On dry limestone soil. $\beta$. near Bath. P. VII.

\section{Tribe XII. Hordeinea.}

\section{Triticum Linn.}

I. T. caninum (Huds.); spikelets 4-5-flowered, glumes 3-ribbed with a short terminal seta, outer palc 5-ribbed shorter than its rough awn, axis and edges of the rachis lispid, l. flat rough on both sides, root fibrous. - E. B. I372. P. 62. Agropyrum R. I318.-Banks. P. VII. 
2. T. repens (I.); spikelets 4-8-flowered, glumes acute 5-7-ribhed, onter pale acute, axis scabrous, rachis with rough angles, l. flat roughish or hairy above, root creeping.-E. B.909. P.62. R. 1384-1388.- Hairs on the inner surface of the 1 . in a single row upon each ridge. The outer pale often has an awn whieh is never more than half its length. Rachis glabrous or downy but always with small aseending rigid bristles on its angles. - $\beta$. littorale (13ab.); spike distichous, spikelets laneeolate, raehis nearly or quite smooth glabrous, $\mathrm{fl}$. awned, edges of $\mathrm{l}$. involute. -Common. B. Sea-shores. P. VII. Couch-yrass.

3. T. junceum (L.) ; spikelets 4-6-flowered, glumes obtuse 6-11-ribbed, outer pale obtuse, axis smooth or slightly downy, rachis smooth, l. involute finely and closely downy above, root creeping.-E. B.814. R.1394. P.63.-Spikelets distant. Raehis easily separating at the joints.- $\beta$. ? scabrum (Bab.); spikelets approximate, axis lowny, raehis slightly rough at the angles, $l$. scabrous above with very numerous aeute points. Probably a distinet speeies, but 1 eannot ilentify it with the plants of eontinental authors, and leave it for future examination.-Sandy sea-shores. $\beta$. Vazon Bay, Guernsey; St. Brelade, Jersey. Rev. W. W. Newbould. P. V1I. V111.

4. T. cristatum (Sehreb.); spikelets 4-5-flowered closely imbricated, ghumes with a terminal awn, outer pale with an awn about as long as itself, raehis and axis slightly downy, l. hairy above, st. rough. - E. B. 226\%. R. 1382. P. 61.- Known from our other speeies by its short elosely imbrieated spike.- "On steep banks and roeks by the sea-side between Arbroath and Montrose." Mr. G. Don. Now lost? P. VII.

\section{Lolium Linn.}

1. L. perenne (L.); spikelets $6-8$-flowered, glume equalling the lowermost floret, outer pale usually awnless, root produeing leafy barren shoots: margins of young $l$. simply folded.-E. $B$. 315. R. 1346. P. 65.-St. 1-1 $\frac{1}{2}$ foot high, usually bent at the lower joints. Whole plant rather dark green.- $\beta$. aristatum; outer pale with a long awn.- $\gamma$. tenue; spikelets few-flowered, l. slender. I. tenue L.-Sometimes the spikelets beeome eonverted into branches; oeeasionally the raehis is so mueh shortened as to form a broad ovate elose distiehous spike.-Common. P. VI. Rye-grass.

*2. L. italicum (A. Braun); spikelets 9-14-flowered, outer pale with a long awn, root with leafy barren shoots: margins of the young l. involute.-L. perenne (several varieties) P. 138141. "L. multiflorum (Lam.)" Koch, Bab.-St. numerous, straight, in close tufts, $1 \frac{1}{2}-3$ feet high. Number of $\mathrm{fl}$. variable. Whole plant, especially the spikelets, paler in eolour than the 
preeediug. Ligule short, abrupt.-It seems probable that L. multiflormm (Gand.) Koch, R. 1345, is confonnded with this in Britain; it has no barren shoots and is aunual. Does $P$. 140 represent this plant? ls it not a var. of $L$. italicum? - In eultivated fichls. A. or P. VI. Italian Rye-grass.

3. L. temulentum (1.) ; spikelets about ( $j$-flowered equalling or shorter than the glume, outer pale as long as its awn.-E.B.I I24. P. 142.-St. erect. Root without barren shoots. Ligule short. Inner glume usually present, often bificl.- $\beta$. arvense; fl. 4-5 without or with short awns. L. arnense Witl. E. B. I125.-Cultivated fields. A. V1.-V111. Darnel.

[L. linicola (Sond.) Koch; outer glume about $\frac{1}{2}$ as long as the spikelet and longer than the lowest floret, no barren slioots.L. arvense R. 1337-1339, not With.-"Field near Catteriek 13ridge, Yorkshire." Mr.J.IVard. Probably not a native. A. VII.]

\section{Elymus Limn.}

1. E. arenarius (L.); spike upright elose, raelis flat not winged, glumes laneeolate downy not longer than the spikelets.-E. $B$. I672. R. 1360, 1361. P. 64.-Closely resembling Psamma arenaria, but readily distinguished by its struetmre and by the broad 1. and short ligule. St. 3-4 feet high.-Sandy sea-shores. 1'. VII.

2. E. geniculatus (Curt.); spike lax bent downwards, raehis winged, glumes awlshaped glabrous longer than the spikelets.E. B. 1586. P. 131.-St. 3-4 feet high. Spike I-2 feet long, remarkably bent downwards at the seeond or third spikelet.-In a salt marsh near Gravesend. Mr. Dickson. P. VII. E.

\section{Hordeum Linn. Barley.}

1. H. sylvaticum (Huds.); glumes all awlshaped not ciliated rough, lateral $\mathrm{fl}$. perfect, middle $\mathrm{fl}$. often barren, outer pale with an awn of twiee its length.-P. 130. Elymus europaus Linn., Sn., E. B. 1317. R. 1359.-Closely resembling H. pratense. Middle $\mathrm{fl}$., if barren, with shorter glumes which have their edges involute so as to appear setaeeous. The spikelets have a seeond fi. oecasionally. - Woods and thiekets on a ealcareous soil. P. VII. VIII.

E.

2. H. pratense (Iuds.); glumes all setaceous not ciliated rough, lateral $\mathrm{fl}$. imperfeet, outer pale of the fertile middle $\mathrm{fl}$. with su awn of about its length.-E. B. 409. R. 1363. P. 11.Gilumes of the lateral fl. shorter.-Damp meadows. A. VII.

3. H. nurinum (L.); glumes of the middle spikelet linearlaneeolate ciliated, of the lateral ones setaeeous rough, lateral $\mathrm{fl}$. imperfeet.-E. B. 1971. R. 1362. P. 10.-Awn longer than the 
outer pale. $-\beta$. arenarium (Bab.); lower part of the st. buried, lengthened and rooting, thus appearing to have a creeping root. -Waste places. $\beta$. Sands on the sea-shore. A. VI. VII.

4. H. maritimum (Wither.); glumes scabrous, inner one of the lateral fl. half-ovate, the rest setaceous, lateral fl. imperfect.E. B. 1205. R. 1364. P. 10.-The smallest species.-Sandy pastures near the sea. A.VI.

\section{Tribe XIII. Rottboelliinea.}

\section{Nardus Limn. Mat-grass.}

1. N. stricta (L.).-E. B. 290. R. 1733. P. 2.-St. and l. erect, slender, rigid. Height 5-8 in. Spike close. Outer pale with a short rough awn, coriaceons, often purplish ; inner membranous.-Moors and heaths. P.VII.

\section{LePTURUS $R . B r$.}

1. L. incurvatus (Trin.); spike eylindrical-subulate, glumes 2 equalling or slightly longer than the flowers.-Rottboellia Sin., E. B. 760. P. 2. L. filiformis R.?-St. 2-6 in. long. Spike long, curved when dry.- $\beta$. filiformis ; spikes much more slender filiform searcely at all curvel. I. filiformis (Trin.?), Par. 3.Sandy salt marshes. A. VII. 


\section{FLOWERLESS PLANTS.}

Substance of the plant wholly of ccllular tissuc (excepting in the Subclass Ductulosce which has a few ducts). No woody fibre. No true flowers with stamens and pistils. No distinct embryo or cotyledons.

\section{Class III.}

\section{CRYPTOGAMEA DUCTULOSAE.}

Plants with a few ducts amongst the cellular tissue, but, according to Arnott, no tracheæ ${ }^{1}$.

\section{Order XCIII. EQUISETACEA.}

Leafless branched plants with a striated fistular stem, articulations sheathed at the base. Sporules surrounded by elastic clavate filaments and inclosed in thecx arising from the peltate seales of terminal cones.-Vernation straight. Cuticle abounding in silex. Only one genus.

\section{Equisetum Linn. Horse-tail.}

* Fertile stems mostly unbranched and succulent; barren stems with whorled branches.

1. E. arvense (L.); sterile st. with few furrows slightly scabrous, branches rough with 3 or 4 simple angles, fertile st. simple with few lax distant sheaths.-E. B. 2020. N. 77.- Sterile st. numerous, procumbent or ascending, with numerous whorls of numerous roughish usually simple branches having 3- or 4-toothed sheaths, each tooth long and acute with $\mathrm{l}$ rib extending to its

1 Those who desire to obtain an intimate acquaintance with the British Ductulose are referred to Newman's History of Britisk Ferns, ed. 2. which is quoted (N.) in these pages. 
end; general outline attenuateu upwards. Fertile st. short, with few $(4-5)$ sheaths. Sterile and fertile st. always distinet.Damp meadows. l'. IV.

2. F. umbrosum (Willd.); sterite st. with about 20 strix very scabrous with prominent points particulurly above, branehes simple with 3 or 4 simple angles, fertile st. simple with numerous erowded deeply toother sheatlis.-N. 63. E. Drummondii Ilook., E. B.S. 2777. - Sterile st. I-1 $\frac{1}{2} \mathrm{ft}$. high, nearly naked below, with numerous whorls of slender branehes in the upper part laving 3- or 4-toothed sheatls, each tooth blunt with one rib vanishing upwards; general outline remarkably olstuse at the top. Branehed fertile st. with larger sheaths and whorls of about 6 branehes; simple fertile st. short (4-6 in.), with numerous loose and still larger yellowish-white sheaths with blaek prominent ribs upwards and $12-20$ tecth.-Wet places, rare. P. IV.

3. E. Telmateia (Ehrh.); sterile st. nearly smooth with about 30 stria and branelies, branches rough doubly-angular simple, fertile st. simple with munerous crowled large deeply tootherl sheaths. - N. 67. E. fluviatile Sm., E. B. 2022.-Sterile st. 3-6 ft. high ; oceasionally bearing a small terminal catkin ; furnished from top to bottom with whorls of slender branehes whieh have 4 angles eaeh with a longitudinal furrow, and 4-toothed sheaths each tooth with 2 denticulated ribs. Fertile st. stont 1 foot or nore in height witl numerous pale brown sheaths with $30-40$ tecth ; eatkin large.-Wet places. P. IV.

\section{** Sterile and fertile stems similar, simple or branched.}

4. E. sylvaticum (L.); sterile and fertile st. with about I2 furrows and numerous whorls of slender compound spreading or deflexed branches, slieaths lax ending in 3 or 4 blunt lobes.E. B. 1874. N. 59.-St. 12-18 in. high. Slicaths of the branches with 3 long acute teeth each having a rib extending to its end. Fertile st. occasionally simple. Catkin blunt. General outline of sterile st. pyramilal, of fertile abrupt.-Wet shady places. P. IV. V.

5. E. fimosum (L.); st. smooth with many stight furrows, teeth of the sheaths short rigid aeute, branches ercet simple whorled often abortive.-E. B. 999.-Usually growing in water. St. about $2 \mathrm{ft}$. high, very smootb, simple below. Sheaths rather short. Catkin blunt.- a. limosum; teeth of the slieaths not furrowed, sheaths of the branches green with minute black tips to the roundbacked ribs, branches often wanting. E. limosum Fries.- $\beta$. $f u$ viatile; st. more deeply furrowed, teeth of the sheaths sloort dark brown acute : rib furrowed on the back. E. fluviatile (L.) Fries. -In stagnant water. [ $\beta$. Reported to be a native.] P.VI. VII. 
6. E. palustre (L.); st. with 6-8 deep furrows branched thoughout, sheaths loose pale with acute wedgeshaped teeth tipped with brown and membranons at the edges.-E. B. 20121. N. 4:3, 47 and 49.-St. slightly rough. Catkin blunt. Sheatlıs of the colour of the st. or paler; teeth brown with nearly transparcut unirgius, ril, furrowed on the back. Branches nsually barren, or ( $\beta$. polystachion) each terminating in a catkin. Oecalsionally ( $\gamma$. nudum 1)C.) the angles and tecth are fewer and the st. nearly or quite simple aud dwarf.-Spougy bogs. $\gamma$. Sauly places. P. VI. VII.

7. E. hyemale (L.); st. simple very rough with $14-20$ slender furrows, sheaths close whitish but the top and bottom black, teeth slender black deciduous.-E. B. 915. N. 17.-St. 1-2 ft. high, simple. Catkin with an apiculus. Sheaths widlest at then top, at first green with a black erenate rim after the tecth have falleu, then cutirely black and ultimately pale in the middle and black above and below,-Damp banks and wooks. P. VII. VIII.

8. E. Mackuii (Newm.); st. simple or very slightly branched very rough with 8-12 furrows, sheaths close ultimately wholly black, teeth slender persistent.-N. 24. E. elongatum Hook. not Willd. E. trachyodon (Braun) Koch?-St. 1-3 feet high, simple or with solitary distant branches. Catkins with an apiculus. Sheaths quitc cylindrical, pale green with a black band beneatl the tecth but ultimately wholly black. 'Tecth much more persistent than in the preceding, usually black.-Mr. Newman lias shown (Phyt. i. 306.) that this is not the E. elongatum (Willd.), the European form of which is the same as E. ramosissimum (Desf.) and E. ramosum (Schleich.) Koch.-Mountain glens. P. VII. VIII.

9. E. variegatum (Weber and Mohr); st. simple or very slightly branched very rough with 4-10 furrows, sheaths slightiy enlarged upwards green below black above, teetl obtuse cach tipped with a deciduous bristle. - N. 31.-St. about a foot ligh, erect, usually simple except at the base. Lowcr half of the shcatlis green likc the stem, upper part black ; teeth persistent, ovate, black in the centre, with a white membranous margin. Catkin apiculate. $-\beta$. arenarium; st. procumbent, usually more siender, teeth of the sheaths wedgeshaped. E. variegatum Sm.,

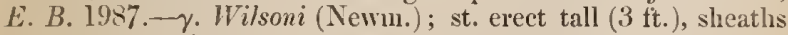
with a black ring at the summit: tecth short obtuse. N. 39.Wet places, $o r$ in water, chiefly in mountainous districts. $\beta$. sandy places near the sca. $\gamma$ " in a ditch at Mucruss, Killarney." $M r$. II. IVilson. P. VII. VIII. 


\section{Order XCIV. FILICES.}

Leafy plants with a rhizoma or trunk. L. or fronds with a circinate vernation (Tribc VIII. excepted), simple or divided. Frnctification springing from the reins on the under side or at the edge of the 1 . and consisting of 1-celled thecx stalked aud with an elastic ring or sessile and without a ring.

\section{* Thece with an elastic marginal ring.}

\section{Suborder I. POLYPODIACEA. .}

Thecre in clusters on the back of the frond, opening transversely; ring vertical, usually incomplete.

Tribe I. POLYPODIEAE. Sori nearly circular, without an indusium, seatcd upon the back of the lateral veins.

1. Aluosorus. Sori circular, at length confluent, concealed by the reflexed margin of the frond.

2. Polypodium. Sori circular, naked; margin of the frond flat not reflexerl.

3. Woodsia. Sori circular with an inferior involucre duvided at the edges into numerous capillary segments.

Tr. II. ASPIDIE $A$. Sori nearly circular, covered by an indusium, seated upon the back of the lateral veins.

4. Lastrea. Indusium reniform, attached by the sinus. Veins distinct after leaving the unidrib, not uniting with those of the adjoining lobe.

5. Polystichum. Indusium circular, attached by the centre. Veins distinct after leaving the midrib.

6. Cystopteris. Indisium attached by its broad hooded base under the sori, with a lengthened fringed free extremity at first covering the thecæ.

Tr. III. ASPLENIEAE. Sori oblong or linear, covered by an indusium opening longitudinally on one side, placed on the side of the lateral veins.

7. Atruyrum. Sori oblong-reniform. Indusium opening towards the central ncrve or midrib, margin fringed.

8. Asplenium. Sori elongate straight. Indusium opening towards the central nerve or midrib, nearly flat.

9. Scolopendrivn. Sori elongate straight, 2 together. Indusia of each pair opening towards each other. 
10. Cetreracr. Lateral reins anastomosing, sori attached to their middle on the sirle nest the midrib, except in the lowest. Indusinm (?) a narrow nearly ercet membrane on the back of the vein. Whole back of the frond covered with claffy scales.

Tr. IV. ADIANTARIA. Theca covered by a marginal or suburargiual elongated part of the frond, or by a scparated portion of the cuticle resembling an indusium.

11. Buechnum. Thece in a continuous line parallel to the midrib upon a longitudinal anastomosing part of the transverse veins, and covered by a continnous scarions indusium.

12. PTERIS. Thece in a continuous marginal line covered by a contimuons indusium formed of the reflexcd margin.

13. Adrantum. Sori marginal, oblong or roundish, covered by distinct reflexed portions of the margin of the frond.

\section{Suborder II. HYAIENOPHYLLACEA.}

Thecæ opening irregularly ; ring oblique, excentric, transverse, complete; receptacle terminating a vein at the margin of the frond.

Tr. V. HYMENOPHYLLEAE.

14. Trichomanes. Theca on an elongated filiform receptacle within a cupshaped involucre of the same texture with the frond.

15. Hymenophyllum. Thece on a narrow subclavate receptacle within a two-valved involucre of the same texture with the frond.

\section{** Thece without an elastic ring.}

Suborder III. OSMUNDACEA.

Vernation circinate. Rachis woody. Thecæ regularly 2-valved, stalked, in clusters at the extremity of the frond.

TI. VI. OSMUNDEAE.

16. Osmunda. Thecre clustered, arranged in a branched spike terminating the frond. 


\section{Suborder IY. OPIIIOGLOSSACEA.}

Vernation straight. Rachis succulent. Theere rcgularly 2valved, sessile, in clusters on a separate branch of the frond.

Tr. VII. OPHIOGLOSSEAE.

17. Вотвусничм. Thece distinet, disposed in a compound spike attached to a pinnate or bipinnate frond.

18. Ophioglossum. Thece comate, disposed in a simple distichous spike attached to an undivided frond.

\section{Suborder I. Polypodiacea. Tribe I. Polypodiea.}

\section{Allosorus Bernh.}

1. A. crispus (Bernh.); barren fronds 2-3-pinnate : leaflets wedgeshaped or linear-oblong often bifid at the end, leaflets of the fertile fronds oblong.- N. 103. Pteris Sm., E. B. 1160. Cryptogramma R. Br., Hook.-Fertile frond nearly triangular. Veins altcrnatc, often forked and cach branch terminating in a sorus which is totally without an indusium but concealed by the reflexed margins of the leatlet. Height 6-12 in. St. slender, very brittle.-Stony places on mountains, occasionally on old walls. P. VII. Rock Brakes.

\section{Polypodicm Limn.}

1. P. vulgare (L.); fronds deeply pinnatifid: lobes linearoblong somewhat serrated all parallcl upper ones gradually smaller.-E. B. 1149. N. 111.-Rhizoma brown, densely scaly, ereeping. Fronds strapshaped. Sori large, on the upper part of the frond. Lateral veins of the pinnæ with 4 branches of which the lowest terminates in a sorus. Pinnæ oecasionally bifid at the cnd, sometimes deeply scrrate or cven ( $P$. cambricum L.) doubly pinnatifid.-On shady banks, walls and old trees. P.VIII. -X. Common Polypody.

2. P.? Phegopteris (L.); fronds pinnate : pinnæ linear-lanceolate united at the base pinnatifid with linear-oblong blunt lobes, lowest pair of pinnce turned downwards and forwards the rest upwards, sori marginal.-E. B. 22:24. N. 115.-Rhizoma nearly black, wiry, slightly scaly, creeping extensively. Fronds triangular. Pimmæ very acute, pointing upwards, rather hairy, connected by their whole width with the rachis; the lowest pair quite distinct, with a minute stalk, standing forwards and pointing from the others. Lateral veins of the lobes simple, extending to the margin.- Roth ( Fl. Germ. iii. 73.) found an evanescent 
indusimm, which no other person appears to have seen, and therefore referred this and the following to Polystichum. Newman places them in Lastrea.-Damp places, loving the spray of waterfalls. P'. VII.-IX.

3. P.? Dryopteris (L.); fronds ternate glabrous divisions pinnate, pimnx pimnatific obtuse tlic uppermost nearly entire, sori marginal.-12. B. 616. N. 1:233.-Rhizoma black, wiry, creeping, slightly sealy. Stalk slender, brittle. 'The three divisions of the frond loosely spreading, the middle one rather the largest. Vernation resembling 3 little balls on wires. Not at all glandular.Sharly momtainous places. P. VI. VII.

4. P.? calcareum (Sm.); fronds triangular subternate glandular-mealy: lower branches pinnate, pinna pinnatificl obtuse the uppermost nearly entire, sori marginal. $-E, B .1525 . \quad$ N. 131. P. Robertianum (Hoffm.) Koch.- Very different in habit from the preceding and always covered with very minute stalked glands giving a mealy character to the surface. Frond not so decidedly 3 -fid, the lower branches being much smaller in proportion to the midlle one; all the 3 erect, rigid.-On exposed mountain heaths ol woods in limestone distriets. P. VII. VIII.

E.

\section{Woodsia R. Br.}

1. W. ilvensis (R. Br.); frond lanceolate or oblong pinnate hairy beneath. - N. 134 and $147 .-$ Our plants appear to me to form only one species althongh they present 3 different appearances, viz.- - a. ilvensis; fronds lanceolate, pinnæ oblong deeply lobed or pinnatifid blunt, lobes ovate crenate. $W$. ilvensis E. B.S. 2616. In the continental plant the pinnæ are narrowed from the base and rather acutc.- $\beta$. gracilis; frond linear-lanceolate, pinnæe triangular pinnatifid, lobes $5-9$ oval entire or the lowest crenate. W.hyperborea E. B. 2023, Tausch! Pol.hyp.ß.gracileWahl.—y. alpina; fronds oblong, pinnæ triangular-oval lobed, lobes 3-5 rounded very blunt. Pol.hyperboreum Wahl. 'Acrost. alpinum Bolt. 42.-A very small plant ; fronds $1-3 \mathrm{in}$. long, hairy and scaly. Rhizoma tufted.-Exposed alpine rocks, very rare. a. Glyder-Fawr, N. Wales. Faicon Clints, Teesdale, Durham. $\beta$. Ben Lawers. Mr. Dickson! $\gamma$. Ben Lawers. Mr. W. Wilson! I have not scen the plant from Clogwyn y Garnedd nor Clova. P. VII.

E. S.

\section{Tribe II. Aspidiece.}

\section{Lastrea Presl.}

1. L. Thelypteris (Presl); fronds pinnate, pinnæ linear-lanceolate pimatifid slightly downy but without glands: lobes oblong with revolute elges, sori submarginal.-Aspidium Sm. N. 183.- 
Earlier fronds barren, later fertile, lanccolate, 2 or 3 lowest pairs of pinne decreasing in size. Lobes blunt entire, at first sight they appear acute on the fertile fionds from the revolute inargins; lateral vcins alternatc forked extending to the edge. Sori at length conflucnt, midway between the midrib and edge. Rhizoua creepiug widely.-Marslyy and boggy plaees, rather rare. P. VII. VIII. Mïarsh Fern.

2. L. Oreopteris (Presl); fronds pinnate, pinnæe linear-lanceolate pinnatifid glandular bencath gradually decreasing from about the middle of the frond to near the root: lobes oblong, flat, sori marginal. - Aspidium Sm., E. B. 1019. N. 187.Fronds remarkably narrowed downwards, rising in a circle from a tuftel rhizoma, fragrant when bruised from the numerous glands on their under surface. Lobes blunt, cntire : lateral veins simple or forked. Height $2-3$ fcet. The indusium is often searcely distinguishable when the plant has all the appearance of a Polypodium.-Mountain heaths. P. VII. Sweet Mountain Fern.

3. L. Filix-mas (Presl); fronds bipinnate, pimnules obtuse and serrated, sori near the central nerve, lateral nerves forked.-Aspidium Sm., E. B. 1458. N. 198.- Fronds only slightly narrowed downwards and the lowest leaflet of considerable size, rising in a eirele from the tufted rlizona. Pinnules usually a little combined at the base. Stipes and rachis nearly glabrous, yellow, or densely elothed with purple scales. Indusium very persistent. Ilcight 3-4 feet.- Sori confined to the base of the pinnules in a dwarf variety $1 \mathrm{ft}$. high ( $\beta$. abbreviatum DC.) from Cumberland and Yorkshire. Mr. Pinder; and Wyck, Gloueestershiue.Woods and banks. P. VI. VII. Male F'ern.

4. L. cristata (Prest); fionds linear almost doubly pinnate, pinna short triangular-oblong piunatifid, pinnules serrated the lowermost lobed and almost pinuatifid, lateral nerves of the lobes with several branches.-Aspidium Sm., E. B. 2125. N.203.Fronds long and narrow, quite ereet, broad at the base, from a tufted rhizoma. Stipes very long, with scattered large brown blunt scales. Latcral nerves with numcrous branches iu the Holt plant, fewer in that from Oxton. Height about 2 feet.Bogs and boggy heaths. Holt, and Fritton-broad, Norf. Near Lynn, Suff. Oxton bogs, Notts. P. Vill.

5. L. rigida (Presl); fronds triangular-lanceolate bipinnate glandular, pinnulcs oblong blunt lobed and scrate, segments 2-5-toothed not spinulose, lateral nerves 3-fid, indusium persistent fringed.-Aspidium Hook., E. B. S. 2724. N. 191.Fronds erect, lanceolate with the lower pinne rather short and triangular; or triangular with the lower pinna elongated; upper pinnæ narrow; all pinuate. Pinnules truneate below with a 
narrow attachment. Stipes short, sealy. Corered with minute stalkerl glands. IIeight I-2 feet,--Ingleborough, Arnside Knot, and near settle. P. VII. VIII.

I.

6. I. spinulosa (PresI); fronds lincar-lanceolate bipinnate, pinnules oblong inciso-pimnatifid, seyments scrrate spinose-nucronate, indusium persistent without marginal stalkel glauds, stipes clothed with broad roundish concolorous scales.-Aspidium Sm., L. spinosa N. 209.-Fronds uearly erect; the lowest piuna equalling those that follow. (See A.N.H. xv. 322.)-Marsly places and wet woods. P. VIII. IX.

7. I. dilatata (PresI); frond orate-lanceolate bipinuate, pinunles pinnate or pinnatifid, segments serrate spinose-mucronate, indusium with uarginal stalked glands, stipes clothed with long pointed scales with a dark centre and diaphanous margin.Aspidium Sin., L. nultiflora N. 215. - Fronds arehed, often drooping, convex; the lowest pinnæ shorter than the following. Fronds of young or starred plants often deltoid, of older and perfect ones ncver.-Woods, banks, \&e. P. VIII. IX.

8. L. Fonisecii; frond triangular bipinnate, pinnules pinnate or pinnatifid, scgments serrate spinose-mucronate, indusium jagged at the edge, stipes clothed with long narrow laciniated concolorous scales.-Nephrodium Fonisecii Lowe! L. recurva N. 225.-Froul elongate-triangular concave above; the lower pinna much the largest. A smaller plant than the two preeeding.-Damp places. P. VIII. IX.

\section{Polystichum Roth.}

1. P. Lonchitis (Roth); fronds rigid linear simply pinnate, pinnæ uot lobed serrate spinous their base auricled above oblique below.-N. 163. Aspidium Sm., E. B. 797. Stipes very short. Fronds narrow very rigid and leathery. Pinuæ overlapping and twisted (most in the Irish, much less so in the Welsh plant), lower ones usually anrieled both above and below.-Young and simply pinnate frouds of the next species are often distinguished from this with difficulty.-Alpine rocks. P. VII.

2. $P$. aculeatum (Roth); fronds rigid linear or lanceolate bipinmate, pinuules obliquely decurrent acute--N. I69. Aspidium aculeatum and $A$. lobatum Sm.-Stipes usually short. First upper pinnule of each pinna longer than the others, its lower side (next the main rachis) usually nearly straight, its upper acutely auricled and forming an acute angle with the lower and with the partial rachis at the point of attacliment. In young plants the pinne are serrate or pinnatifid or with one or more piunules distinct. A few of the lowest pinnules are often slightly stalked but very differeutly from those of $P$. angulare. $-A$. lob $a$ - 
tum (Sm.) is a form having the pinna less divided than in the type of the speeies and the fromls linear-laneeolate and more rigid.-Iledge-banks. P. VII. VIII.

3.? P. angulare (Newn.); fronds lax drooping laneeolate, pinnules truncate below distinetly stalked bluntish, - N. 173. Aspidium Sm., E. B. S. 2776. - Stipes usually elongated. First npper pinmule seareely longer than the others, its lower side rounded below, its upper with a large bluntish auriele and forming an obtuse angle with the lower at the summit of the short stalk whieh is nearly at right-angles with the partial rachis.-I have endeavoured to point out differenees between this plant and the preeeding but an far from eertain that they are constant.Sheltered wood and liedge-banks. I’. VII. VIIII.

\section{Cystopteris Bernh.}

1. C. fragilis (Beruh.); frond laneeolate bipinnate, pinna ovate-laneeolate, pinnules ovate or ovate-laneeolate toothed or pinnatifid.-N. 149.-Remarkably variable, three forms may be distinguished, but they are connected by intermediate speeimens. - a. dentata; pinnules ovate obtuse pointless bluntly toothed or rarely pinnatifid not deeurrent. Cystea dentata Sm., E. B. 1588 ? "Pinnæ of young fronds reflexed, drooping, convex; sori more marginal" than in the following. $-\beta$. fragitis; pinnules ovate acute pinnatifid eut and serrated, slightly decurrent. E. B.1587. A much more divided plant. Sori more central. $-\gamma$. angustata; pinnules linear-laneeolate deeply and aeutely pinnatifid or slightly toothed at the margin, ultimate subdivisions oblong or linear not dilated rounded or ovate sometimes notehed at the end. Known by its very narrow and usually distant subdivisions. C. angustata Sm.-These plants are exeellently illustrated in Mr. Newman's work, to whose figures I must refer, as it is seareely possible to describe their differenees.-Common. $\alpha$. "Scotland." Newm. I find what I consider as the same in Teesdale. $\beta$. Roeks and walls. $\gamma$. Craven, and N. Wales. P. VII.

[2. C.alpina (Desv.); frond laneeolate bipinnate, pinnæ ovate, pinnules ovate deeply pinnatifid with broadly and shortly linear segments partly eloven and slightly toothed at the end.- N. 157. $E$. B. 163.-Fronds very much divided but eompact and elose. -On a wall at Low Layton, Essex, where it is still oecasionally found. Not a true native. P. VII.]

3. C. montana (Link); fronds triangular bipinnate, pinnules of lower pinnæ pinnate: lobes pinnatifid with notelied segments. $-N$. 15\%.-Fronds resembling those of $P$. ealeareum in shape, very finely divided. Lower pair of pinna mueh the largest; their lower larger than their upper pinnules. $-A$ t the station of 
Sax. rivularis on Ben Iawers, Perthshire. Mr. W. IVilson. P. VIII.?

[Onoclea sensibilis is naturalized in one spot near Warrington.]

\section{Tribe III. Aspleniea.}

\section{Athyrium Roth.}

1. A. Filix-foemina (Roth); frond lanceolate pinnate, pinna linear acute regularly pinnate, pinutes linear-oblong deeply serrate or pinnatifid.-E. B. 1459 (bad), and $A$. irriguum Sm., $E$. $B$. 2I99. N. 237.-Fronds $1-3$ or even 4 fect high. Midrib of the pinnules wavy; lateral veins forkel, the anterior branch bearing at about its middle the kidneysliaped sorus which at lengtlı becomes nearly round.- $a$. incisum; fronds drooping broally lanceolate, pimules not connected flat pinnatificl, lobes tootherl. A. Filix-fomina Rotl., P. incisum IIoffm. Dark grcen. Sori distinct. - $\beta$. molle; fronds scmi-erect ovate-lanceolate, pinnules connected by the wing of the mirlrib that toothed. A, molle Roth. Light green. Sori distinct. Less divided than $a .-\gamma$. convexum (Bab.); fronds semi-erect linear, pinnules not connected narrow convex with deflexed margins toothed blunt. A.rhceticum Roth. Pale green. Sori confluent.-It is highly probable that these are distinet species.-Wet shady situations. P. VI. VII.

[2. A. fontanum (Presl); frond linear-lanceolate bipinnate, pinnæ oblong-ovate, pinnules obovate-cuneate with few deep sharp teeth. - E. B. 2024.-This plant does not associate well witl the genus.-Formerly on Amersham church, Bucks. Found by Hudson "above Wybourn in Westmoreland." P.] E. ?

\section{ASPLENIUM Linn.}

* Ultimate subdivisions with a distinct midvein. Asplenium Newm.

I. A. lanceolatum (Huds.); fronds lanceolate doubly pinnate, pinnules ovate deeply and slarply toothed or lobed, sori short nearly marginal.-E. B.240. N.249.-Fronds sometimes nearly linear and simply pinnate, always narrowed at the base. Sori short oblong, ultimately rather confluent into roundish masses. -Rocks and walls, ratlier rare. P. VI.-IX.

E.

2. A. Adiantum-nigrum (L.); fronds triangular attenuatel twice or thrice pinnate, pinnæe and pinnules triangular sharply toothed, sori elongated central.-E. B. 1950. N. 255.- Sori 2 or 3 times as long as in the preceding, placed near the midrib and ultimately confluent in oblong masses often covering the whole under surface of the pinnule.-Rocks and walls. P. VI.-IX. Black Spleenwort. 
3. A. Trichomanes (L.); frond linear pinnate, pinnæ roundishovate crenate stalked, nerves forked below the sori.-E. B. 576 . N. 2\$5.-Rachis black. A curious variety is occasionally found with its pinna deeply but irregularly pinnatifid with hinear notched segments.-Rocks and walls. P. V.-X. Common Spleenwort.

4. A. viride (Huls.); frond linear pinnate, pinnæ roundishovate or rhomboidal erenate stalked, nerves simple or forked beyond the sori.-E. B. 2257. N. 281. Rachis green. Sori at length conflucnt.-Rocks on mountains. P. VI.-X.

5. A. marinum (L.); frond linear simply pinnate, pinnæ stalked ovate or oblong serrate unequal and wedgeshaped at the base.E. B. 392. N. 275.-Varying greatly in size. Sori not confluent. - Maritime rocks. P. VI.-X.

** Ultimate subdivisions without a distinct midvein. Amesium Newm.

6. A. Ruta-muraria (L.); fronds bipinnate, pinnules rhomboidwedgeshaped notehed or toothed at the end, indusium jagged.E. B. 150. N. 261.-Fronds 3-4 in. long.-Rocks and old walls, P. V.-IX. Wall Rue.

7. A.germanicum (Weiss.) ; fronds simply and alternately pinnate, pinnules narrow-wedgeshaped the lowermost temate, indusium entire at the edge.-N. 265. A. alternifolium Sm., E. B. 2258. - Fronds 3-4 in. long.-Rocks, very rare. P.VI.-IX. -S.

8. A. septentrionale (IIull); fronds 2- or 3-cleft, segments clongate-lanceolate bifid.-E. B. 1017. N. 269.-Segments of the fronds very narrow, narrowing gradually downwards, with 1 or 2 short bifid lateral teeth, and bifid at the end.-Dry clefts of rocks, rare. P. VI.-X.

E. S.

\section{Scolopendrium $\boldsymbol{S} m$.}

1. S. vulgare (Sym.); frond oblong strapshaped smooth simple with a cordate base, stipes shaggy.-E. B. 1150. Phyllitis Scolopendrium N. 289.-Fronds $1-2$ feet long, acute, often crisped towards the end and occasionally the end is multifid.Danmp and sharly places. P. VII. VIII. Hart's-tongue.

\section{Ceeterach Willd.}

1. C. Officinarum (Willd.); fronds pimnatifid covered beneatl with dense scales, pinnx alternate or opposite obtuse sessile.Notolepum Ceterach N. 293. Scolopendrium Ceterach Sm., E. B. 1244. - Fronds 3-6 in. long, green and smooth above, wholly covered by very numcrous scales beneath, amongst which the thecæ are almost hidden.--Old walls and rocks. P. IV.-X. 


\section{Tribe IV. Adiantaria.}

\section{BLECHNUM $\operatorname{Linn}$.}

1. B. horeale (Sw.); barren fronds pectinate-pinnatifid with broadly-linear ratler obtuse pinne, fertile frond pinnate: pinnex lineur acute.-E. 13. 1159. Lomaria Spicant N.89.-Each lateral nerve of the fertile pinme extending half-way to the margin and then turning at right angles and proeeeding up the pinna until it reaelies the uext nerve. Thece attached in a continuous row to the longitudinal portions of the combined lateral nerves. Rather a Blechnum than Lomaria. Stony and heatlyy plaees. P. VII.

\section{PTERis Linn.}

1. P. aquilina (L.); fronds tripartite, branehes bipinnate, pinmules linear-lanceolate the lower ones pinnatificl, segments oblong obtuse.-E. B. 1679. N. 93. Eupteris Newm. (Phytol. ii. 278). - Fronds anmual, $1-5$ feet high, rery much divided with spreading branches. Theca attached to the marginal vein, lying upon a fine membranc and corered by the membranous continuation of the epidermis. A transverse section of the stipes presents a figure resembling the imperial eagle.-Woods and heaths. P. VII. Brakes or Brachen.

\section{Adiantum Linn. Maiden-hair.}

1. A. Capillus-Veneris (L.); frond iregular, branches aud roundish-wedgeshaped lobed thin pinnules alternate, lobes of the fertile pinnules terminated by a transversely linear-oblong reHexed lobe covering several roundish sori, sterile lobes serrated.-E. B. 1564 . $^{\text {N. }}$ 83. - Rhizoma blackish, shaggy. Fronds 6-12 in. high. Stipes and rachis slender, nearly blaek. Pinnules not jointed to the partial stalks.-Damp roeks near the sea. P. V.-IX.

\section{Subord. II. Hymenophyllacea. Tr. V. Hymenophylleæ.}

\section{Trichomanis Linn.}

1. T. radicans ( $\mathrm{Sw}$.) ; fronds 3 or 4 times pinnatifid glabrous, segments uniform linear, involueres solitary in the axils of the upper segments, seta at first included ultimately very prominent. - E. B. 1417. T. speciosum Willd., N. 305.-The frond in fact consists of hard wiry branehed ribs each furnished throughout with a rather membranous wing. Rhizoma black, downy, very long. Fronds rather triangular, very much divided, $4-8$ in. long.- - Inrolucres scarcely winged. $-\beta$. Andrewsii (Newm.); fronds lanceolate, involueres winged. N.315.-Our plant is a form of T. radi- 
cans, Hook. Sp. Fil. i. 125.-Tery damp shady places. Rare. Formerly at Bellbank, Iorkshire, from whence I liave an old specimen exactly like Bolton's figure t. 30 . South and southwest of lreland. P. IX. X.

E. I.

\section{Hymexopiytoum $S m$.}

1. H. tunbridgense (Sm.); fronds pinnatc, pinnæ distichous, segments linear undivided or bifid spinosely-serrate, involucre compressed spinosely serrate, rachis broadly winged.-E. B. 162. N. 32l.- Slender and delicate. Rhizoma very long, threadshaped. Pinna, rachis and involucres in the same plane. Valves of the involuere adpressed throughout the greater part of their length, slightly gibbous at the base.-Amongst moss in damp and shady places. P. V'11.

2. H. Wilsoni (Ilook.); fronds pinnate, pinnæ recurved, segments linear undivided or bifid spinosely-scrrate, involucre inflated entire, raclis slightly bordered.-E. B. S. 2686.-Resernbling the preceding, but the pinnx curve backwards and the involucres forwards. Valves of the involucre convex or gibbous throughout, touching only by their elges which are quite entire. -Amongst moss in damp and shady places. P. VII.

\section{Suborder III. Osmundacea. Tribe VI. Osmundea.}

\section{Osmunda Linn.}

1. O. regalis $(\mathrm{L}$.$) ; fronds bipinnate, pinnules oblong nearly$ entire dilated and slightly auricled at the base, clusters panicled terminal.--E. B. 209. N. 331.-Fronds erect or drooping, ] -8 feet ligh. Panicle of fruit bipinnate--Boggy places. P. VII.IX. Flowering-fern.

\section{Subord. IV. Ophioglossacea. Tr. VII. Ophioglossea.}

\section{Botrychum $S w$.}

1. B. Lunaria $\left(\mathrm{Sw}_{\mathrm{.}}\right)$; frond pinnate solitary, pinnæ lunate or fanshaped notched or crenate.-E. B. 318. N. 137.-Height 3-6 in. Pinnæ sometimes deeply notehed, occasionally bearing a few thecæ. Fronds usually solitary, but sometimes there are two on the same stalk.-Pastures. P. VI. V1l. Moon-wort.

\section{Ophioglossum Linn. Adder's-tongue.}

l. O.vulgatum (L.); frond orate obtuse.-E.B. 108. N.349. -Ileight 4-12 in., erect. Spike clubshaped, usually rather longer than the frond, sometimes rery long.-Pastures. V.VI. 


\section{Order XCV. MARSILEACEA.}

Crecping plants witl alternate erect leaves liaving a circinate vernation. Fructification consisting of globular nearly sessile coriaceous bodies with $3 \mathrm{ol}^{4} 4$ cells and containing sacs including either other bodies that germinate or loose gramules.

1. Pilularia. Involucres solitary, nearly sessile, globose, coriaccons, 4-celled. Cells containing bodies of 2 kinds, granules and membranes containing minute grains.

\section{Pilularia Linn. Pillwort.}

1. P.globulifera (L.).-E. B. 521. N.393.-Rhizoma slender elongated, erecping, producing leaves and roots at regular intervals. L. very slender, crect. Involucres (sporocarps) slightly stalked, axillary, nearly spherical, hairy.-Margins of ponds and lakes. P.

\section{Order XCVI. LYCOPODIACEAE.}

Leafy plants with simple imbricated leares; or stemless with erect subulate leaves. Fructitication of axillary sessile thecæ with 2 or 3 valves and no ring, including minute powdery matter or sporules.

\section{* Capsules not opening.}

1. Isomtes, Fructification inclosed within the swollen base of the leaves. Sporules of two kinds attached to filiform receptacles.

$$
\text { ** Capsules bursting. }
$$

2. Lycopodrum. Caps. 1-celled, 2-valved, containing powder; or 3-valved, containing $1-4$ granules.

\section{Isoetes Linn. Quillwort.}

1. I. lacustris (L.); 1. subulate roundish-quadrangular with 4 longitudinal jointed tubes.-E. B. 1084. Hook. Lond. t. 131. N. 381. R. vii. t. 1.-Rhizoma a blunt tuber. L. slender, broad and flat at the base but clsewhere between cylindrical and quadrangular. There is still some doubt about the internal structure of the capsules. - Bottom of lakes and ponds in hilly districts. P.

\section{Lycopodium Linn.}

* Caps, all 1-celled. Sporules like powder. Lycopodium Koch.

1. L. clavatum (L.); l, scattered incurved with a filamentous point, spikes stalked 2 or 3 together cylindrical, scales ovatetriangular membranous finely inciso-serrate--E. B. 224. N. 353. 
-St. prostrate, many feet long. Spikes on long stalks, pale yellow. larly disposed in whorls. - Ileatlss. P. VII. VIII. Common Clubmoss.

2. L. annotinum (L.); l. scattered laneeolate mucronate sermlate, spikes sessile solitary terminal, scales roundish with an attenuated point inembranous and jagged.-E. B. 1727. N.361. -St. prostrate, long. IBranches ratlier long, erect, each year's growth marked by a spot where the leaves are adpressed. Spikes cylindrical, greenish-yellow, not persistent as supposed by Smith. - Stony mountains. Rare on Glyder Fawr, Caernarvonshire. Common in the Ilighlands. P. VIIII.

E. S.

3. L. alpinum (L.); $l$. in four rows imlricated acute keeled entire, spikes sessile solitary terminal, scales ovate-lanceolate flat, branches erect elustered forked level-topperl-E. B. 234. N. 365.-St. prostrate, long. Fertile branches usually twice dichotomons, each division ending in a short eylindrical yellowishgreen spike rather thicker than the branch.-Lilevated mountains. P. VIII. Savin-leaved Club-moss.

4. $L$. Selago (L.); $l$, in eight rows crowded uniform linearlanceolate ncuminate, capss. not spiked but in the axils of the common leaves, st. ereet forked level-topped--E.B. 233. N.375. -St. short, erect or slightly decumbent, densely leafy. No separate spikes. At the cxtremity of the stems a few curious viviparons buds may usually be found; they are well illustrated by Mr. Newman (p. 378). Oecasionally the stems in sheltered situations become much elongated.-Heaths, ehiefly on mountains. P. VI.-VIII. Fir Club-moss.

5. L. inundatum (L.); l. seattered linear acute turned upwards, spikes terminal sessile leafy solitary upon short crect branches. -E. B. 239. N. 369.- St. short, prostrate, rooting. Branches few, simple, short, erect, fertile.-Boggy heaths. P. VIII. IX.

** Caps. of two kinds. Selaginella (Spring) Koch.

6. L. selaginoides (L.); l. scattered lanceolate ciliated, spikes terminal solitary sessile leafy upon short erect branches.-E. $B$. 1148. N.371. Selaginella spinulosa Koch.-St. prostrate, much branched, rooting, slender. Flowering branches simple, short, erect. In addition to the 2-valved theca which oceur in all our speeies, this plant produees others which are 3-valved and eontain 2-4 large grains.-Boggy spots ehiefly in monntainous places. P. Vîl. 


\title{
ALPHABETICAL INDEX
}

\author{
OF \\ THE ORDERS AND GENERA.
}

** The names in italies are synonyms.

Acer, 62.

Aceras, 311.

Acerince, 62 .

Achillea, 172.

Achyrophorus, 188. Acinos, 247.

Aconitum, 10.

Acorus, 340 .

Actæa, 10.

Actinocarpus, 337 .

Adiantum, 415.

Adonis, 4 .

Adoxa, 149.

Egopodium, 138.

.Ethusa, 141.

Agraphis, 32\%.

Igrimonia, 92.

Agropyrum, 399.

Agrostemma, 47.

Agrostis, 381 .

Agroslis, 382.

Aira, 385 .

Aira, 386, 388 .

Airopsis, 385 .

Ajuga, 253.

Albucea, 323.

Alchemilla, 92.

.lisma, 336.

Alisma, 337 .

Alismacex, 335 .

Alliaria, 24 .

Allium, 324.

Allosorus, 408.

Alnus, 300 .

Alopecurus, 379.

Alsinanthe, 50 .

Alsine, 49.

Alsinex, 41.

Althea, 58.

Alyssum, 26.

Alyssum, 26.
Amaranthacer, 263.

Amaranthus, 264.

Amaryllidex, 318.

Anibrosiacce, 166.

Amentacese, 286.

Amesium, 414.

Ammophila, 383.

Aracamptis, 310.

Anacyclus, 172.

Anagallis, 259.

Anchusa, 219.

Andromeda, 205.

Androscmum, 60.

Anemagroslis, 382.

Anemone, 4.

Angelica, 143.

Antennaria, 17\%.

Antlemis, 170.

Anthericum, 323.

Anthoxanthum, 378.

Anthriseus, 146.

Anthyllis, 80 .

Antirrhinum, 231.

Antirrhinum, 231.

Apargia, 188, 189.

Apera, 382.

Aphanes, 93.

Apium, 136.

Apocyneæ, 210.

Aquilegia, 9.

Arabis, 21.

Aracium, 193.

Araliaceæ, 148.

Arbutus, 204.

Arbutus, 205.

Archangelica, 143.

Arctium, 182.

Arctostaphylos, 205.

Arenaria, 51.

Arenaria, 49, 50, 51 .

Aristolochia, 278.
Aristolochiaceæ, 278.

Armeria, 261.

Armoracia, 27.

Arnoseris, 187.

Aroidex, 338.

Arrhenatherum, 387.

Artemisia, 174 .

Arthrolobium, 86.

Arum, 340.

Arundo, 382.

Arundo, 383.

Asarum, 279.

Asparagex, 319.

Asparagus, 320.

Asperugo, 218.

Asperula, 152.

Aspidium, 409, 410.

Asplenium, 413.

Aster, 168.

Astragalus, 81 .

Astrantia, 136.

Athamanta, 142.

Athyrium, 413.

Atriplex, 268.

Atriplex, 270.

Atropa, 224.

Avena, 386.

Avena, 385, 386.

Azalea, 207.

Baëothryon, 351.

Baldingera, 377.

Ballota, 252.

Balsaminex, 67 .

Barbarea, 20.

Barkhausia, 191.

Bartsia, 236.

Bartsia, 236.

Batrachium, 5.

Bellis, 168.

Berberideæ, 10.

Berberis, 10. 
Berula, 139.

Beta, 267.

Betonica, 251.

Betula, 299.

Bidens, 170 .

Blechnum, 415.

Blysmus, 353.

Boragineæ, 216.

Borago, 219.

Botrychium, 416.

Brachypodium, 399.

Brassica, 24.

Brassica, 25.

Breea, 184.

Briza, 394.

Bromus, 397.

Bromus, 398.

Bryonia, 119.

Bucetum, 395.

Buffonia, 47.

Bunium, 138.

Bupleurum, 139.

Butomus, 337.

Buxus, 280.

Cakile, 32.

Calamagrostis, 382.

Calamintha, 246 .

Callitriche, 118.

Calluna, 205.

Caltha, 8.

Calycifloræ, 68.

Camelina, 28.

Campanula, 201.

Campanula, 202, 203.

Campanulacex, 199.

Caprifoliaceæ, 150.

Capsella, 31 .

Cardamine, 22.

Carduus, 183.

Carduss, 186.

Carex, 355.

Carlina, 180.

Carpinus, 301.

Carum, 138.

Carum, 138.

Caryophyllex, 40.

Castanea, 300 .

Catabrosa, 388.

Caucalis, 145.

Celastrinex, 68.

Centaurea, 181.

Centranthus, 157.
Centunculus, 259.

Ceplialanthera, 315 .

Cerastium, 54 .

Cerastium, 52, 54 .

Cerasus, 90.

Ceratophyllcx, 113.

Ceratophyllum, 113.

Ceterach, 414.

Chærophyllum, 147.

Charophyllum, 146.

Chamienerion, 114.

Chamagrostis, 380.

Cheiranthus, 19.

Chelidonium, 13.

Chenopodiacex, 264.

Chenopodium, 265.

Chenopodium, 265.

Cherleria, 50.

Chlora, 212.

Chrysanthemum, 173.

Chrysocoma, 169.

Chrysospleniun, 130.

Cicendia, 213.

Cichorium, 187.

Cicuta, 136.

Cineraria, 178.

Circæa, 116.

Cirsium, 184.

Cistineæ, 33.

Cistus, 34.

Cladium, 348.

Clematis, 3 .

Clinopodium, 246.

Cnicus, 184.

Cnidium, 142.

Cochlearia, 27.

Cochlearia, 28.

Coeloglossum, 311.

Colchicaceæ, 327.

Colchicum, 327.

Comarum, 95.

Compositx, 160.

Coniferæ, 301.

Conium, 147 .

Conringia, 23, 24.

Convallaria, 320 .

Convallaria, 321.

Convolvulacex, 215.

Convolvulus, 215.

Conyza, 169.

Corallorhiza, 315.

Coreopsis, 170.
Coriandrum, 148.

Cornce, 149.

Cornus, 149.

Corollifloræ, 150.

Corrigiola, 120.

Corydalis, 14.

Corylus, 301.

Corynephorus, 386 .

Cotoneaster, 111.

Cotylcdon, 124.

Crambe, 32.

Crassulaceæ, 112.

Cratægus, 111.

Crepis, 191.

Crithmum, 143.

Crocus, 317.

Cruciferæ, 15.

Cryptogameæ, 403.

Cryptogramma, 408.

Cucubalus, 44.

Cucurbitaceæ, 119.

Cuscuta, 2] 6.

Cyclamen, 258.

Cynodon, 383.

Cynoglossum, 219.

Cynosurus, 394 .

Cyperaceæ, 346.

Cyperus, 348.

Cypripedium, 316 .

Cystea, 412.

Cystopteris, 412.

Cytisus, 73.

Dabøcia, 207.

Dactylis, 394 .

Damasonium, 337.

Daphne, 277.

Datura, 225.

Daucus, 144.

Delphinium, 10.

Dentaria, 22.

Deschampsia , 385.

Dianthus, 42.

Dichodon, 52.

Dicotyledones, 1.

Dictyogens, 304 .

Digitalis, 231.

Digitaria, 376.

Diotis, 173 .

Diplotaxis, 26.

Dipsaceæ, 158.

Dipsacus, 159.

Doronicum, 177. 
Draba, 27.

Drosera, 37.

Druseracex, 37 .

Dryas, 91.

Dilctulosac, 403.

Echiuochloa, 377.

Echinoplıora, 147.

Echinospermum, 218.

Echium, 220.

Elataguce, 276.

Elatinc, 40.

Elatince, 40.

Eleocharis, 349.

Eleocharis, 352.

Eleogiton, 352.

Elodes, 62.

Elyrnus, 401.

Elymus, 401.

Enpetrex, 279.

Empetrum, 279.

Endogens, 305.

Ephemerum, 259.

Epilobium, 114.

Epimedium, 11.

Epipactis, 314.

Epipactis, 315.

Equisetacer, 403.

Equisetum, 403.

Eranthis, 9.

Erica, 205.

Ericace 203.

Erigeron, 168.

Eriocaulacex, 328.

Eriocaulon, 328.

Eriopliorum, 353.

Erodium, 65.

Erucastrum, 26.

Ervum, 81.

Eryngium, 136.

Erysimum, 24.

Erytliriea, 212.

Eufragia, 236.

Euonymus, 69.

Eupatorium, 167.

Euphorbia, 280.

Euphorbiaceæ, 279.

Euphrasia, 236.

Eupteris, 415.

Exacum, 213.

Exogens, 1.

Fagopyrum, 276.

Fagus, 300 .
Fagus, 300.

Farselia, 26.

Fedia, 157, 158.

Festuea, 395.

Filago, 175.

Filices, 406.

Floridie, 305 .

Foniculum, 142.

Fragaria, 96.

Frankenia, 40.

Frankeniaceæ, 39 .

Fraxiıus, 210.

Fritillaria, 322.

Fumaria, 14.

Fumariacea, 14.

Gagea, 323.

Galantlıus, 319.

Galeobdolon, 250.

Galeopsis, 250.

Galium, 153.

Gastridium, 380 .

Gelista, 72 .

Gentiana, 213.

Gcutianaceæ, 211.

Geraniaceæ, 62.

Geranium, 63.

Geum, 91.

Glaucium, 13.

Glaux, 260.

Glechoma, 248.

Glumacex, 346.

Glyceria, 392.

Glyceria, 393.

Gnaphalimn, 176.

Gnaphalium, 175, 177.

Goodyera, 313.

Graminex, 370 .

Grossularicæ, 125.

Gymnadenia, 311 .

Gymnogens, 301 .

Gypsocallis, 206.

Habenaria, 311.

Haliantleus, 49.

Halimus, 270.

Haloragere, 117 .

Haloscias, 142.

Hedera, 149.

Helianthemum, 33.

Helleborus, 9.

IIehninthia, 190.

Helosciadium, 127.

Heracleum, 144.
Ilerminium, 312.

IIeruiaria, 120.

IIesperis, 23.

Itieracium, 194.

Hieracium, 193.

llicrochloc, 379 .

IIimantoglossum, 310 .

Hippocrepis, 86 .

llippophaë, 277.

llippuris, 118.

IIolcus, 387.

Holcus, 387.

Holoschonus, 352.

Ilolosteum, 51.

Honckenya, 49.

llordeum, 401.

liottonia, 258.

II umulus, 284.

liutchinsia, 29.

Hyacinthus, 327.

IIylrocharideæ, 305 .

IIydrocharis, 305 .

Hydrocotyle, 135.

Hymciophyllum, 416.

IIyoseyamus, 224.

Hypericineæ, 59.

IIypericum, 59 .

Hy pochœris, 187.

IIypochoris, 188.

Hypopitys, 209.

Iberis, 29.

Ilex, 209.

Ilicinex, 209.

Illccebrum, 121.

Impatiens, 67.

Inula, 169.

Inula, 169, 170.

Iridex, 316 .

Iris, 317.

Isatis, 31 .

Isnardia, 116.

Isoetes, 417.

Isolepis, 352 .

Jasione, 201.

Juncaceæ, 328.

Juncus, 329 .

Junipcrus, 302.

Knappia, 380.

Knautia, 159.

Kobresia, 354.

Kœleria, 388.

Koniga, 26. 
Labiatæ, 240.

I actuca, 190.

Lagurus, 384.

Lamium, 248.

Lappa, 183.

Lapsana, 187.

Lapsana, 187.

Larbrea, 54.

Lastrea, 409.

Latluræa, 229.

Lathyrns, 84 .

Lavatera, 58.

Ledum, 207.

Leersia, 384.

Leguminosæ, 70 .

Lemna, 340.

Lentibulariaccx, 254.

Leontodon, 188.

Lcontodon, 191.

Leonurus, 250.

Lepidium, 30.

Lepigonum, 49.

Lepturus, 402.

Leucojum, 319.

Libanotis, 142.

Ligusticum, 142.

Ligustrum, 210.

Liliacex, 321.

Lilium, 323.

Limnanthemum, 214.

Limosella, 234.

Linaria, 231.

Linex, 66.

Linnæa, 152.

Linosyris, 169.

Linum, 66.

Liparis, 316.

Listera, 313.

Listera, 314.

Lithospermum, 221.

Lithospermum, 221.

Littorella, 263.

Lloydia, 323.

Lobelia, 200.

Lobularia, 26.

Loiseleuria, 207.

Lolium, 400.

Lomaria, 415 .

Lonicera, 151.

Loranthaceæ, 150.

Lotus, 79.

Luzula, 334 .
Lychnis, 46.

Lycopodiacea, 417.

Lycopodium, 417.

Lycopsis, 219.

Lycopsis, 220.

Lycopus, 245.

Lysimachia, 258.

Lythrariea, 112.

Lythrum, 112.

Maianthemum, 320 .

Malachium, 54 .

Malaxis, 315 .

Malaxis, 316.

Malcolmia, 22.

Malva, 57 .

Malvacce, 56.

Marrubium, 252.

Marsilcacex, 417.

Maruta, 171.

Matricaria, 174.

Matricaria, 174.

Matthiola, 19.

Meconopsis, 13.

Medicago, 74 .

Melampyrum, 234.

Melica, 388.

Melilotus, 75 .

Melissa, 247.

Melissa, 246.

Melittis, 248.

Mentha, 243.

Menvanthes, 214.

Menziesia, 207.

Mercurialis, 282.

Mespilus, 111.

Meum, 143.

Neum, 142.

Mibora, 380 .

Microcala, 213.

Milium, 381.

Mimulus, 235.

Moehringia, 51.

Moenchia, 54 .

Molinia, 388.

Moneses, 209.

Mnochlamydex, 263.

Monocotyledones, 304 .

Monotropa, 209.

Montia, 119.

Mulgedium, 194.

Muscari, 327.

Myosotis, 221.
Myosurus, 4.

Myrica, 299.

Myriophyllum, 117.

Myrrhis, 147.

Myrrlis, 147.

Narcissus, 319.

Nardus, 402.

Nartlecium, 329.

Nasturtium, 19.

Naumburgia, 258.

Neottia, 314.

Neottia, 313.

Nepeta, 248.

Notolepum, 414.

Nuphar, 11.

Nymphæa, 11.

Nymphæacex, 11.

Enanthe, 140.

Enothera, 116.

Oleacex, 210.

Olismenus, 377.

Onagrariæ, 113.

Onobrychis, 87.

Ononis, 73.

Onopordum, 183.

Ophioglossum, 416.

Ophrys, 312.

Oplismenus, 37\%.

Oporinia, 188.

Orchidex, 306 .

Orchis, 308.

Orchis, 311.

Origanum, 246.

Ornithogalum, 323.

Ornithogalum, 323.

Ornithopus, 86.

Orobanche, 226 .

Orobancheæ, 226.

Orobus, 86 .

Orobus, 82.

Osmunda, 416.

Oxalideæ, 68.

Oxalis, 68.

Oxycoccos, 208.

Oxyria, 273.

Oxytropis, 80 .

Pxonia, 10.

Panicum, 377.

Papaver, 12.

Papaveracer, 12.

Parietaria, 283.

Paris, 304. 
Parnassia, 38.

l'aronychiacex, 120.

I'astiunea, 141 .

Pedicularis, 235.

l'cplis, 113.

Peristyles, 311.

Petasites, 167.

Petroselinum, 137.

Peucerlanum, 143.

Phalaris, 377.

Phelipcea, 228.

Phlcum, 378.

Phragmites, 383.

Phyllitis, 414.

Phyllodoee, 207.

Physospernum, 148 .

Phyteuma, 201.

Pieris, 190.

pilularia, 417.

Pimpinella, 138.

Pimpinella, 137.

P'inguieula, 255.

Pinus, 303.

Pisum, 86.

Plantagineæ, 262.

Plantago, 262.

Plalanthera, 311.

Plumbagineæ, 260.

Poa, 389.

Polemoniacex, 214.

Polemonium, 215.

Polycarpon, 121.

Polygala, 38 .

Polygaleæ, 38.

Polygonaeex, 270.

Polygorium, 273.

Polygonum, 276.

Polypodium, 408.

Polypogon, 381.

Polystichum, 411.

Populus, 298.

Portulaceæ, 119.

Potamogetonex, 341.

Potamogeton, 341.

Potentilla, 94.

Poterium, 92.

Prenanthes, 190.

Primula, 257.

Primulacca, 256.

Prunella, 248.

Prunus, 89.

Psamma, 383. l'teris, 415.

Pteris, 408.

l'nlicaria, 169.

Pulmonaria, 220.

l'yrethrum, 173.

Pyrola, 208.

Pyrola, 209.

Pyrus, 111.

Quercus, 300.

Radiola, $6 \pi$.

Ranuneulaceæ, 1.

Ranuneulus, 5.

Raphanus, 32.

Reseda, 33.

liesedaeex, 32 .

Rhamnex, 69.

khamnus, 69.

Rhinanthus, 235.

Rhodiola, 122.

Rhynchospora, 348.

Rhyt ispermum, 221.

Ribes, 125.

Roberlsonia, 126.

Roemeria, 13.

Rosa, 107.

Rosacea, 87.

Rottboellia, 402.

Rubia, 156.

Rubiacex, 152.

Rubus, 96.

Rumex, 271.

Ruppia, 345.

Ruseus, 321.

Sagina, 47.

Sagittaria, 337.

Salieornia, 267.

Salix, 287.

Salsola, 265.

Salsola, 265.

Salvia, 245.

Sambneus, 151.

Samolus, 260.

Sanguisorba, 92.

Sanieula, 135.

Santalaeeæ, 277.

Saponaria, 43.

Sarothamnus, 73 .

Saussurea, 180.

Saxifraga, 126.

Saxifragea, 126.

Seabiosa, 159.

Scandix, 146.
Schedonorus, 397.

Sehcuchzeria, 337 .

Schoberia, 265.

Selıœnus, 318.

Seilla, 324 .

Scilla, 327 .

Seirpus, 350.

Scirpus, 353,

Seleranthus, 121.

Seleroehloa, 392.

Seolopendrium, 414.

Scolopendrium, 414.

Scrophularia, 233.

Scrophularinex, 229.

Scutellaria, 247.

Sedum, 122.

Selaginella, 418.

Selinum, 143.

Sempervivum, 124.

Senebiera, 31 .

Senecio, 178.

Senecio, 178.

Serrafalcus, 397.

Serratula, 186.

Serralula, 180.

Seseli, 142.

Sesleria, 384.

Setaria, 377.

Sherardia, 152.

Sibbaldia, 93.

Sibthorpia, 237.

Silaus, 142.

Sileue, 44.

Silenex, 41.

Silybuin, 186.

Sinapis, 25.

Sinapis, 25, 26.

Sison, 137.

Sison, 137.

Sisymbrium, 23.

Sisymbrium, 24.

Sisyrinchium, 317.

Sium, 139.

Sium, 137, 138.

Smyrnium, 148.

Solanaeeæ, 223.

Solanum, 224.

Solidago, 168.

Sonehus, 193.

Sonchus, 194.

Sparganium, 339.

Spartina, 383. 
Spartium, 73.

Spatularia, 127.

Specularia, 202.

Spergella, 48.

Spergula, 48.

Spergula, 48.

Spiræa, 90.

Spirantlıes, 313.

Spirodela, 340.

Stacliys, 251.

Staphylea, 69.

Statice, 260.

Statice, 261.

Steenlımmera, 220.

Stellaria, 52.

Stipa, 382.

Stratiotes, 306.

Sturuia, 316.

Sturmia, 380.

Subularia, 31.

Swertia, 214.

Sympliytum, 220.

Taniariscinea, 39.

Tamarix, 39.

- Tamea, 304.

Tamus, 305.

Tanacetum, 175.

Taraxacum, 191.

Taxus, 302.

Teesdalia, 29.

Telmatophace, 340.

Teucrium, 253.

Thalamifloræ, 1.
Thalictrum, 3.

'l'hesium, 277.

Thlaspi, 29.

Thlaspi, 31.

Thrincia, 188.

Thymelex, 277.

Thymus, 246.

Thymus, 246.

Thysselinum, 143.

Tilia, 58.

Tiliaceæ, 58.

Tillad, 122.

Tofieldia, 327 .

Tordylium, 144.

Torilis, 145.

Tormentilla, 95.

Tragopogon, 189.

Trichomanes, 415 .

Triclıoncma, 317.

Trientalis, 260.

Trifolium, 75.

Triglochiı, 338 .

Trignnella, 78.

Trilliacea, 304.

Trinia, 137.

Triodia, 387.

Tripolium, 168.

Trisetum, 386.

Triticum, 399.

Triticum, 394.

Trollius, 9.

Tulipa, 322.

Turgenia, 145.
Turritis, 21.

Tussilago, 167.

Tussilago, 167.

Typha, 339.

Ulex, 72.

Ulmus, 284.

Umbelliferæ, 130.

Urtica, 284.

Urticaceæ, 283.

Utricularia, 255.

Vaccinium, 207.

Valcriana, 157.

Valeriana, $15 \%$.

Valerianacea, 156 .

Valerianella, 15\%.

Vella, 27.

Verbascum, 225.

Verbena, 254.

Verbenaceæ, 254.

Veronica, 237.

Viburnum, 151.

Vicia, 81.

Villarsia, 214.

Vinca, 210.

Viola, 35.

Violaceæ, 34.

Viscum, 150.

Wahlenbergia, 202.

Woodsia, 409.

Xantlium, 199.

Zannichellia, 346 .

Zostera, $\mathbf{3 1 6 .}$ 


\section{N DEX}

() F TIE

\section{POPULAR ENGLISII NAMES.}

Abelc, 298.

Aconite, 9.

Adder's tongue, 416.

Alcler, 300.

Alexanders, 148.

Alkanet, 219.

Allemone, 4.

Archangel, 250.

Arrow-head, 337.

Asarabacca, 279.

Ash, 210.

Aspen, 299.

Asphodel, 329.

Avens, 91, 92.

Awlwort, 31 .

Bald-money, 143.

Balm, 247.

Balm, bastard, 248.

Balsam, 67.

Barberry, 10.

Barley, 401.

Basil, 247.

Beech, 300.

Beet, 267.

Bell-flower, 201, 203.

Bent-grass, 381.

Betony, 251.

Bilberry, 207.

Bindweed, 215.

Birch, 299.

Bird-cherry, 90.

Bird's-nest, 314.

Bird's-nest, yellow, 209.

Birthwort, 278.

Bitter-cress, 22.

Bitter-sweet, 224.

Black thorn, 89.

Bladder-nut, 69.

Bladder-wort, 255.

Blue-bell, 327.

Bluc-bottle, 181.
Bog Myrtle, 299.

Borage, 219.

Box, 280.

Bracken, 415.

Brakes, 415.

Brakes, rock, 408.

Brooklime, 237.

Brookweed, 260.

Broom, 73.

Broom-rape, 226.

Bryony, red, 119.

Bryony, black, 305 .

Buckbean, 214.

Buckthorn, 69.

Buck-whcat, 276.

Bugle, 254.

Bugloss, 219.

Bugloss, viper's, 220.

Bullace, 89 .

Bull Rush, 351.

Burdock, 183.

Burnet, 92.

Bur-reed, 339.

Butcher's Broom, 321.

Butter-bur, 167.

Butterwort, 255.

Cabbage, 24.

Calamiut, 246 .

Campion, 45, 46, 47 .

Canary-grass, 377 .

Candy-tuft, 30.

Carrot, 144.

Catchfly, 44.

Catmint, 248.

Cat's-tail-grass, 378 .

Celery, 137.

Centaury, 212.

Clamomile, 171 .

Chamomilc, corı, 171 .

Chamomile, wild, 174.

Charlock, 25.

Charlock, jointed, 32.
Cherry, 90.

Chervil, 146.

Chestrut, 300.

Chickweed, 53.

Chickweed, water, 54 .

Chicory, $18 \%$.

Chives, 326.

Cicely, 147.

Clary, 245.

Cleavers, 156.

Cloud-berry, 107.

Clover, 75.

Club-moss, 418.

Cock's-foot-grass, 395 .

Cole-seed, 25.

Colt's-foot, 167.

Columbine, 9.

Comfrey, 220.

Coriander, 148.

Coralwort, 22.

Coru Cockle, 47.

Corn Marigold, 173.

Coriander, 148.

Cotton-grass, 353,354 .

Cotton-thistle, 183.

Couch-grass, 400.

Cowbane, 136.

Cow-berry, 208.

Cow-parsnep, 144.

Cowslip, 257.

Cow-rwheat, 234.

Crab tree, 111.

Cranberry, 208.

Crane's-bill, 63.

Crosswort, 153.

Crowberry, 279.

Crowfoot, 5, 7, 8.

Cuckow-pint, 340 .

Cudweed, 175.

Currant, 125, 126.

Daffodil, 319.

Daisy, 168. 
Dame's Violet, 23.

Dandelion, 191.

Danewort, I51.

Darnel, 401.

Dcad-nettle, 249.

Deadly Nightshade, 224.

Devil's-bit, 160.

Dewberry, 107.

Dock, 271.

Dodkler, 216.

Dog Rose, 110.

Dog's-tail-grass, 394.

Dog-wood, 149.

Dropwort, 91:

Duckweel, 340.

Dwale, 224.

Dyer's-weel, 73.

Dyer's-woad, 32 .

Elder, 151.

Elecampane, 169.

Elm. 284.

Enchanter's Nightshade, 116.

Evening Primrose, 116.

Eye-bright, 236.

Feather-grass, 382.

Fennel, 142.

Fern, 410.

Fescue-grass, 395 .

Feverfew, 173.

Figwort, 233.

Fir, 303.

Flag, 317.

Flax, 67 .

Fleabane, 168, 170.

Flixweed, 23.

Flowering-fern, 416.

Flowering-rush, 337.

Forget-me-not, 222.

Fools' Parsley, 141.

Fox-glove, 231.

Fox-tail-grass, 379 .

Fritillary, 322 .

Frog-bit, 305.

Fumitory, 14, 15.

Furze, 72.

Gale, 299.

Garlick, 325.

Glasswort, 267, 268.

Glohe-fiower, 9.

Goat's-beard, 189.
Gold-of-pleasure, 28.

Golden Rod, 169.

Gamphire, 169. Lambs' Lettnee, 158.

Golden Saxifrage, 130. Larkspur, 10.

Gooseherry, 125.

Goose-grass, 156.

Gorse, 72.

Gout Weed, 138.

Grape llyacinth, 327 .

Gromwell, 221.

Gromul-ivy, 248.

Ground Pine, 254.

Groundsel, 178.

Guelder-rose, 151.

Gypsy-wort, 245.

Hair-belI, 202.

Ilare's-ear, 140.

Ilart's-tongue, 4 I 4.

Ilawkwced, 194.

IlawtIorn, 111.

Hazel, 30 I.

Ileartsense, 37 .

IIeath, 205, 206, 207 .

Hedge Mustard, 23.

II ellehore, 9.

llemlosk, 148.

Hemp Agrinony, 167.

Hemp-nettle, 250,251.

Henhane, 224.

Henbit, 249.

IIerb Paris, 304.

IIog-weed, 144.

Holly, 209.

Honcysuckie, 152.

IIop, 284.

Horehound, 252.

Horehound, white,253.

Hornbeam, 301.

Horned-poppy, 13.

Horse radish, 28.

Horseshoe Veteh, 86 .

Horse-tail, 403.

Hound's-tongue, 219.

Houseleek, 124.

Ivy, 149.

Jacob's Ladder, 215.

Jack-lyy-the-hedge, 24.

Juniper, 303.

Knapweed, 181, 182.

Knot-grass, 275 .

Lady's Fingers, 80.

Latly's Mantle, 93.
Lettuee, 190.

Lily of the Valley, 320 .

Lime Tree, 58.

Ling, 205.

Live-long, 123.

London Pride, 126.

London Rocket, 23.

Loosestrife, 113.

Louse-wort, 235.

Lovage, 142.

Lucerne, 74.

Lungwort, 220.

Madder, 156.

Maidenhair, 4 I5.

Mallow, 57.

Maple, 62.

Mare's Tail, 118.

Marjoram, 246.

Mlarram, 383.

Marsh Mallow, 58.

Marsh Marigold, 9.

Mat-grass, 402.

Nleadow Rue, 4.

Meadow Saffron, $32 \%$.

Meadow-sweet, 90.

Mledick, 74.

Medlar, 111.

Melilot, 75.

Meremry, 282.

Mezereon, 277.

Milk Thistle, 186.

Milkwort, 38.

Millefoil, 172.

Mint, $243,244$.

Mistletoe, 150.

Money Wort, 259.

Monk's-hood, 10.

Monk's Rhubarb, 272.

Moonwort, 416.

Motherwol't, 250.

Mountain Ash, 112.

Mousetail, 5.

Mudwort, 234.

Mugwort, 175.

Mullein, 225, 226.

Mustard, black, 55 .

Mustard, white, 25.

Needlc Wlin, 73. 
Netele, 284.

Niglitshade, 221.

Nipplewort, 187.

Oak, 300.

Oat, 386 .

()at-grass, 387 .

Orchis, $308,311,312$.

Orpine, 123.

Osier, 290.

Ox-eye, 173.

Ox-lip, 257.

Ox-tonguc, 190.

Paiglc, 257.

Pansy, 37.

Parsley, 137.

Parsley Piert, 93.

Parsnep, 144.

Pasque-flower, 4.

Pea, 86.

Pear tree, 111.

Pearlwort, 47.

Pelletory, 283.

Penny cress, 29.

Penuy-royal, 245.

Penny-wort, 135.

Pcriwinkle, 210.

Plieasant's-eye, 5.

Pig-nut, $138^{\circ}$.

Pilewort, 7 .

Pillwort, 4]7.

Pink, 42, 43.

Pimpernel, 259.

Plantain, 262.

Plowman's Spikenard, 169.

Plum, 90.

Polypody, 408.

Pond-weed, 341,346 .

Poplar, 298, 299.

Poppy, 12.

Primrose, 257.

Privet, 210.

Purslane, water, 113.

Purslane, sea, 270.

Quaking-grass, 394.

Quillwort, 417.

Radish, sea, 32.

Ragwort, 179.

Ragged Robin, 46.

Ranupious, 201, 202.

Ramsons, 326.

Raje, 25.
Raspberry, 96.

Red Rattle, 235.

Reed, 383.

liced-mace, 339 .

Rest-hanow, 73.

Ribwort Plantain, 263.

Rock Brakes, 403.

Rocket, 20.

lock-rose, 34 .

Rose, 107.

Rose-root, 122.

Rowan-trec, 11\%.

Rush, 329.

liye-grass, 400.

Saffron, 318.

Saintfoil, 87.

Sallow, 291, 292.

Salsafy, 189.

Samphire, 143.

Sauce-alone, 24.

Saw-wort, 186.

Scabious, 159.

Scorpion-grass, 222.

Scurvy-grass, 28.

Sea Buckthorn, 277.

Sea Holly, 136.

Sea-kale, 32.

Sea Lavender, 261.

Sea Pea, 86.

Sea-radish, 32.

Sea-reed, 383.

Sea-rocket, 32 .

Sedge, 348.

Selfheal, 248.

Service tree, 111, 112.

Sheep's Scabious, 201.

sheplierd's Needle, 146.

Shepherd's Purse, 31.

Silver Vleed, 94.

Skull-cap, 347.

Slne, 80 .

Snakeweed, 273.

Snapdragon, 231.

Sneezewort, 172.

Suowdrop, 319.

Snowtlake, 319.

Soapwort, 44.

Solomon's Seal, 320 .

Sorrel, 272, 273.

Sorrel, wood, 68 .

Sowthistle, 193.
Spcarwort, 7.

Speedwell, 237, 238, 240.

Spindle-trec, 69 .

Splcenwort, $413,414$.

Spurge, 280.

Spurrey, 48, 49.

Squill, 324.

St. John's-wort, 59.

St. ''atrick's Cabbage, 126.

Star of Bethlehem, 323.

Star-thistle, 182.

Stitchwort, 52, 53 .

Stock, 19.

Strawberry, 96.

Strawberry, barren,95.

Succory, 187.

Sunder, 37.

Sweet Briar, 109.

Swcet-flag, 340.

Sycamore, 62.

Tantarisk, 39.

Tansy, 175 .

Tares, 81 .

Teasel, $] 59$.

Thistle, 183.

Thorn-apple, 225.

Thorow-wax, 140.

Thrift, 261.

Thyme, 246.

Timothy-grass, 378 .

Toad-flax, 231, 233.

Traveller's-joy, 3 .

Tree-mallow, 58.

Tulip, 322.

Turk's-cap Lily, 323.

Turnip, 25.

Tutsan, 60 .

Tway-blade, 313.

Valerian, 157.

Vernal-grass, 378.

Vervain, 254.

Vetch, 82, 81 .

Violet, 35, 36 .

Wall-flower, 19.

W all Pepper, 124.

Wall Rue, 414.

Water Cress, 19.

Water Hemlock, 136.

Water-lily, 11. 
Water Milfoil, 117. White Beam tree, 112. Wood-rush, 334. Water-plantain, 336, Whitethorn, 111. Wood Sage, 253. 337.

Water Soldier, $306 . \quad$ Willow, 288.

Water Starwort, 118. Willow, rose, 290.

Water-violet, 258. Willow Herb, 114.

Wayfaring tree, 151. Woad, 32, 73.

Weld, 33.

Whin, 72.

Woodbine, 152.

Woodruff, 153.

Wormwood, 174.

Wortleberry, 20\%, 208.

Woundwort, 251, 252.

Yarrow, 172.

Yellow Rattle, 235.

Yellow-wort, 212.

Yew, 302.

THE FND.

PRINTED BY R. AND J. E. TAYLOR, RED LION COURT, FLEET STREET. 
By the sume Aullor.

\section{PRIMITIA FLORA SARNICA ;}

OR,

AN OUTLINE OF THE FLORA OF THE CHANNEL,

ISLANDS OF JERSEY, GUERNSEY, ETC.

CONTAINING

A CATAlOGUE OF THF PLAN'TS INDIGENOUS TO THE ISLANDS; WITII OCCASIONAL, OBSERVATIONS UPON THEIR DISTINCTIVE CHARACTERS, AFFINITIES ANI NOMENCLATURF,

$12 m o$, Price 4s.

\section{FLORA BATHONIENSIS;}

OR,

A CATAlogue of THE PLANTS INDIGENous TO THE VICINITY OF BATH.

Second Edition. 12mo, Price 3s.

\section{A SYNOPSIS OF THE BRITISH RUBI.}

svo, Price $2 s$. 


\section{O U T L I N E S}

$\mathrm{Or}^{\mathrm{r}}$

\section{STRUCTURAL AND PHYSIOLOGICAL BOTANY.}

\section{By ARTHUR HENFREY, F.L.S., ETc.}

LECTURER ON BOTANY AT ST. GEORGE'S AND THE MIDDLESEX Hospitals.

With 18 Plates. Fep. 8 vo, 10s. 6d.

"It is not a mere compilatiou, but a careful digest, cvidently prepared by one who is thoroughly conversant with his subject; the topics are admirably arranged and the results succinctly and for the most part very clearly stated. *** We may unhesitatingly recommend this little treatise to the general and especially to the medical student. Compendious as it is we know of no work in the English language which gives so much information upon vegetable anatomy in such small compass, or so well exhibits the present state of knowledge and opinion upon this class of subjects."-Prof. Gray in Silliman's Journal.

"It is not indeed in the minute details of structure alone that Mr. If enfiey has slown himself a master of his subject; his riews of higher matters are lucid and judicious."-Lindley's Gardener's Chronicle.

"The best books are those which make us think,-Mr. Henfrey's is one of these."-Westminster Review. 


\section{O'PHER BOOKS PUBLISIHED BY MR. VAN VOOIS'T.}

ANSTRD (Professor), The Aucient World: or Picturesque Sketches of Creation. Pust $8 \mathrm{vo}, 12 s$.

ANSTE1) (Professor), Gcology: Introductory, Descriptive and Practical. 2 vols. $8 \mathrm{vo}, 2 l .2 s$.

BABINGTON (C. C., M.A., F.L.S.), Manual of British Botany. Sccond Edition, $12 \mathrm{mo}, 10 \mathrm{~s}$.

BAPTISMAL FONTS. A series of 125 Engravings, with Descriptions, 8vo, $1 \ell .1 \mathrm{~s}$.

BELL (Professor), History of British Crustacea, iu Parts, at $2 s .6 d 0^{*}$

BELL (Professor), History of British Quadrupeds, including the Cetaccá. 8\%o, 28s.* BEVAN (Dr.), The Honey Bce. Second Edition. 12mo, 10s. $6 d$.

BLOOMFIELD'S Farmer's Boy and other Poems. Fep. 8vo, 7s. 6d،"

COUCH (Jonathan, F.L.S.), Illustrations of Instinct. Post 8vo, shorlly.

DRUMMOND (Dr.), First Steps to Anatomy. 12mo, 58.

FORBES (Professor), History of British Starfishes, and other Animals of the Class Echinodermata. 8vo, 15s.*

GARNER (Rohert, F.L.S.), Natural History of the County of Stafford. 8vo, 1l. $1 s$.

GOSSE (P. H.), Canadian Naturalist. Post 8vo, 12s.

GOSSE (P. H.), Birds of Jamaica. Post 8vo, 10s.

GRAY'S Elegy, with 33 Illustrations. 8vo, 9s.

GRAY'S Bard, to correspond. $7 s$.

HENFREY (Arthur, F.L.S.), Outlines of Structural and Physiological Botany. Fcp. 8vo, 10s. $6 d$.

HEWITSON (W. C.), Coloured Illustrations of the Eggs of British Birds, with descriptions. 2 vols. 8 vo, $4 l .10 s$.

INSTRUMENTA ECCLESIASTICA. Edited by the Ecclesiological, late Cambridge, Camden Society. ito, $1 l .11$ s. $6 d$.

JENYNS (Rev. Leonard, M.A.), Observations in Natural History, with a Calendar of Periodic Phenomena. Post 8vo, 10s. 6 $d$.

* Of those thus * marked, largr paper copies may he hal. 


\section{BOOKS PUBLISHED BY MR. VAN VOORST.}

JWSSE (bdward, F.L.S.), Angler's Rambles. Post 8vo, 10s. 6d.

JOHNSTON (George, M.D., LL.D.), History of British Zuophytes. Second Edition. 2 vols. $8 \mathrm{vo}, 21.2 \mathrm{~s}, *$

JONES (Professor Rymer), Natural History of Animals. Vol. 1., post 8vo, $12 x$.

KELAART (Dr.), Butany and Topography of Gibraltar and its Neighbourhood. $8 v 0,10 s .6 d$.

MORRIS (John), Catalogue of British Fossils. 8vo, $10 s$.

MOULE (Thomas), Heraldry of Fish. 8vo, $21 s$.

NEWMAN (Edward, F.L.S.), Familiar Introduction to the History of Insects. 8vo, $12 s$.

NFWMAN'S History of British Ferns and Allied Plants. Second Edition. 8vo, ll. $5 s$.

OWEN (Professor), Description of the Skeleton of an Extinct Gigantic Sloth; with Observations on the Megatherioid Quadrupeds in general, 4to, $1 l, 12 s, 6 d$.

OWEN (Professor), History of British Fossil Mammals and Birds. 8vo, $1 l$. 11 s.6d.*

PALEY (F. A., M.A.), Manual of Gothic Architecture. Fcp. 8vo, 6s. 6 d.

SELBY (P. J., F.L.S.), History of British Forest Trees. 8vo, 28s.*

SHARPE'S Windows of the Decorated Period, in Parts, at $2 s .6 d$.

SPRATT (Lieut. R.N.) and Professor Ed. FORBES, Travels in Lycia, \&c. 2 vols. 8 vo, $1 l .16 s$.

THE VICAR OF WAKEFIELD, with 32 Illustrations by William Mulready, R.A. Square $8 \mathrm{vo}, 21 \mathrm{~s}$.

TULK and HENFREY'S Anatomical Manipulation. Fep, 8vo, $9 s$.

WARD (N, B., F.L.S.), On the Growth of Plants in Glazed Cases, 8vo, $3 s$.

WHITE'S Natural History of Sellorne. A new Edition, with Notes by the Rev. Leonard Jenyns, M.A., \&c. 12mo, 7s, $6 d$.

YARRELL (William, F.L.S., F.Z.S.), History of British Fishes. Second Edition. 2 vols. $8 v o, 3 l$. Supplement to the First Edition, 8vo, $7 s .6 d$. Royal $8 v 0,15 s$. Imperial $8 \mathrm{vo}, 22 s$. 6d. Paper on the Growth of the Salmon in Fresh Water, with 6 Coloured Illustrations of the Fish of the natural size. 12s. sewed.

YARRELL'S History of British Birds. Second Edition. 3 vols. 8vo, $4 l .14 s .6 d$. Supplement to the First Edition, 8vo, 2s. $6 d$. Royal 8vo, 5s. Imperial 8vo, 7s. 6 d.

*** Of those thus * marked, large paper copies may be had. 



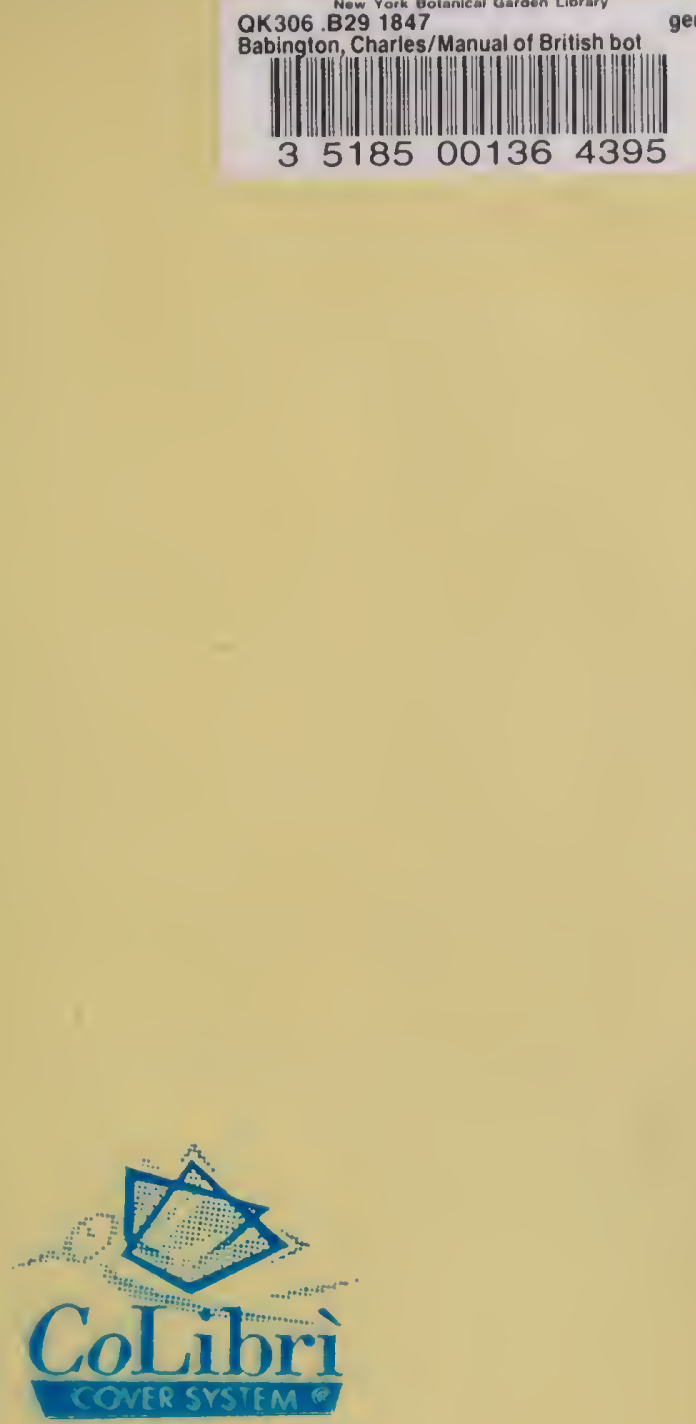

Made in Italy

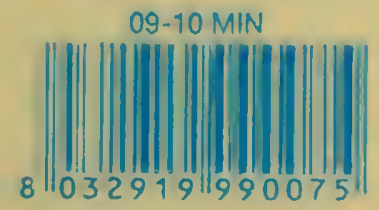

mw.colibrisystem.com 


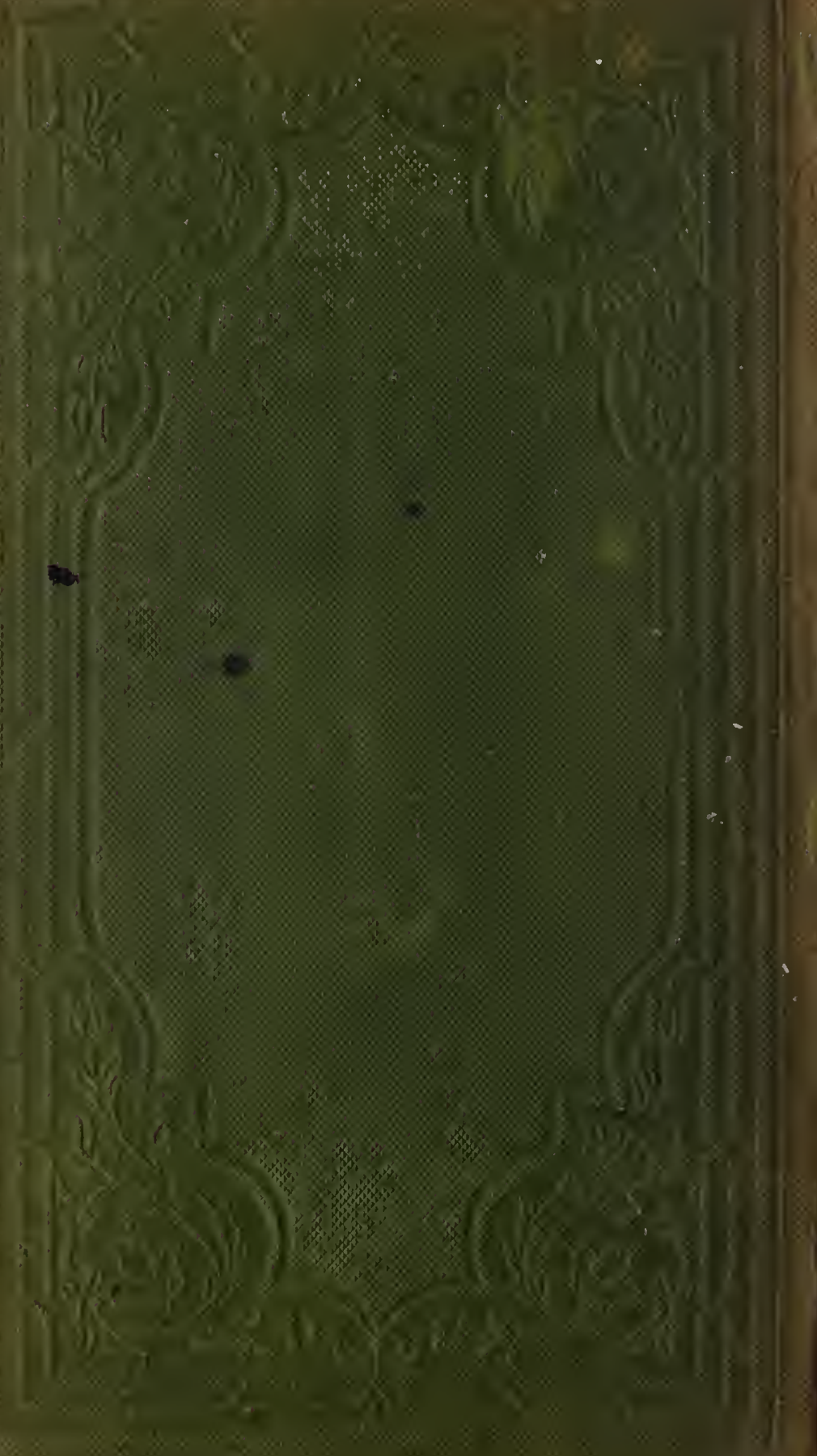

